\title{
Quantum of Silence: Inaction and Jus ad Bellum
}

\section{Citation}

Dustin A. Lewis, Naz K. Modirzadeh \& Gabriella Blum, Quantum of Silence: Inaction and Jus ad Bellum (The Harvard Law School Program on International Law and Armed Conflict (HLS PILAC), 2019).

\section{Published Version}

https://pilac.law.harvard.edu/quantum-of-silence

\section{Permanent link}

http://nrs.harvard.edu/urn-3:HUL.InstRepos:40931878

\section{Terms of Use}

This article was downloaded from Harvard University's DASH repository, and is made available under the terms and conditions applicable to Other Posted Material, as set forth at http:// nrs.harvard.edu/urn-3:HUL.InstRepos:dash.current.terms-of-use\#LAA

\section{Share Your Story}

The Harvard community has made this article openly available.

Please share how this access benefits you. Submit a story.

Accessibility 


\section{QUANTUM OF SILENCE: INACTION AND JUS AD BELLUM}

Dustin A. Lewis, Naz K. Modirzadeh, and Gabriella Blum

AnNex:

hls pilac Catalogue of Communications to the Security

Council of Measures Taken by United Nations Member States in Purported Exercise of the Right of Self-Defense: OCTOBER 24, 1945 THROUGH Degember 31, 2018

\section{9}

Harvard law School Program on International Law and Armed Conflict 


\title{
Quantum of Silence: Inaction and Jus ad Bellum
}

Dustin A. Lewis, Naz K. Modirzadeh, and Gabriella Blum

\section{Annex: HLS PILAC Catalogue of Communications to the Security Council of Measures Taken by United Nations Member States in Purported Exercise of the Right of Self- Defense: October 24, 1945 through December 31, 2018}

\author{
Editor: Dustin A. Lewis \\ Contributors: Lindsay Anne Bailey, Emma Broches, Laura Clark, \\ Sonia Chakrabarty, Thejasa Jayachandran, Daniel Levine-Spound, \\ Sarah Libowsky, Samantha Lint, Yang Liu, Carolina Silva-Portero, \\ Shira Shamir, William Ossoff, Tamsin Parzen, and Shanelle Van
}




\title{
CREDITS
}

\begin{abstract}
About HLS PILAC
The Harvard Law School Program on International Law and Armed Conflict (HLS PILAC) provides a space for research on critical challenges facing the various fields of public international law related to armed conflict, including jus ad bellum, jus in bello (international humanitarian law/the law of armed conflict), international human rights law, international criminal law, and the law of state responsibility. Its mode is critical, independent, and rigorous. HLS PILAC's methodology fuses traditional public international law research with targeted analysis of changing security environments. The Program does not engage in advocacy. While its contributors may express a range of views on contentious legal and policy debates, HLS PILAC does not take institutional positions on these matters.
\end{abstract}

\begin{abstract}
About the Authors
Dustin A. Lewis is a Senior Researcher at HLS PILAC. Naz K. Modirzadeh, the Founding Director of HLS PILAC, is a Professor of Practice at Harvard Law School. And Gabriella Blum, the Faculty Director of HLS PILAC, is the Rita E. Hauser Professor of Human Rights and Humanitarian Law at Harvard Law School.
\end{abstract}

\section{Acknowledgments}

The authors gratefully acknowledge the following people: HLS PILAC Research Assistants Charles Hobbs, Francesco Romani, and Paras Shah, for research and analysis; HLS PILAC Research Assistants Lindsay Anne Bailey, Emma Broches, Laura Clark, Sonia Chakrabarty, Thejasa Jayachandran, Daniel Levine-Spound, Sarah Libowsky, Samantha Lint, Yang Liu, Carolina Silva-Portero, Shira Shamir, William Ossoff, Tamsin Parzen, and Shanelle Van, for contributing to the catalogue contained in the Annex; Jennifer Allison, Bridget J. Reischer, and Caroline Walters of the Harvard Law School (HLS) Library, as well as other members of the HLS Library staff, for research support; participants in the 2017-2019 informal "International Law Lunches" hosted in collaboration with the Permanent Missions to the United Nations in New York of Belgium, Liechtenstein, Mexico, Norway, and Switzerland, for discussion and feedback; Scott Anderson, Ashley Deeks, Mona Khalil, Eliav Lieblich, Marko Milanovic, Tom Ruys, Stephen Townley, and Larissa van den Herik, for feedback on the catalogue; Jessica S. Burniske, for copy-editing; and Thomas Ewing and Elvina Pothelet for translation assistance.

\section{Disclaimers}

HLS PILAC receives generous support from the Swiss Federal Department of Foreign Affairs (FDFA). The views expressed in this paper and annex should not be taken, in any way, to reflect the official opinion of the Swiss FDFA. HLS PILAC is grateful for the support that the Swiss FDFA provides for independent research and analysis. The research undertaken by the authors of this paper and annex was completely independent; the views and opinions reflected in this paper and annex are those solely of the respective authors; and those authors alone are responsible for any errors in this paper and its annex.

\section{License}

Creative Commons Attribution-NonCommercial-ShareAlike 4.0 International license (CC BY-NC-SA 4.0).

\section{Web}

This paper and annex are available free of charge at https://pilac.law.harvard.edu. 


\section{CONTENTS}

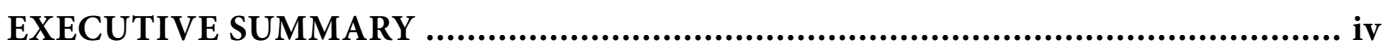

\section{QUANTUM OF SILENCE: INACTION AND JUS AD BELLUM}

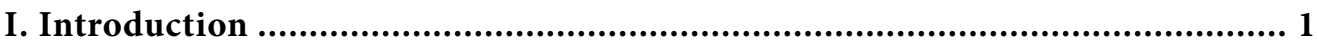

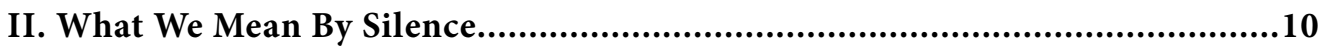

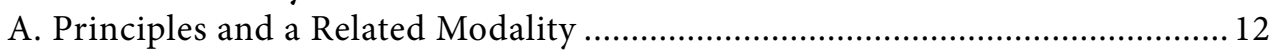

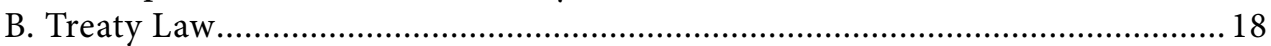

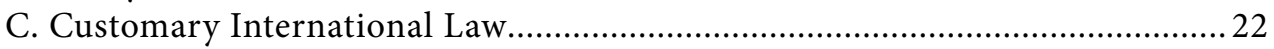

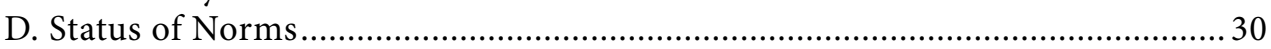

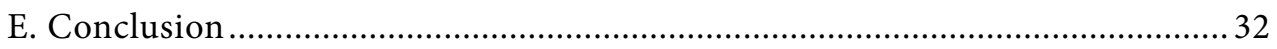

III. Silence in Jus ad Bellum ...........................................................................33

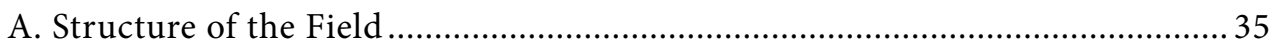

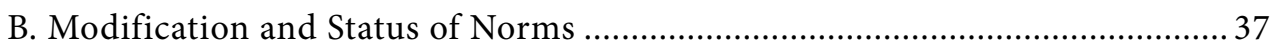

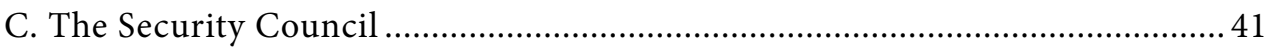

D. Invocations of Silence in International Scholarly Discourse ........................... 70

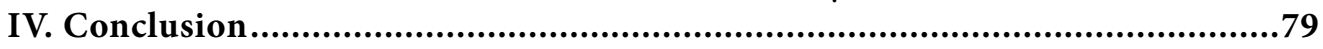

\section{ANNEX: HLS PILAC CATALOGUE OF COMMUNICATIONS TO THE SECURITY COUNCIL OF MEASURES TAKEN BY UNITED NATIONS MEMBER STATES IN PURPORTED EXERCISE OF THE RIGHT OF SELF-DEFENSE: OCTOBER 24, 1945 THROUGH DECEMBER 31, 2018}

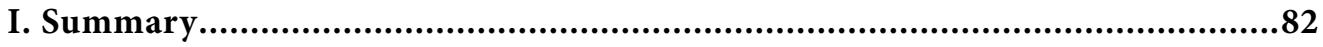

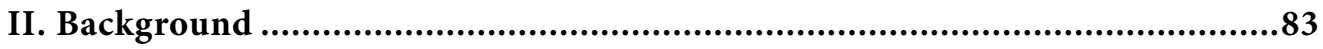

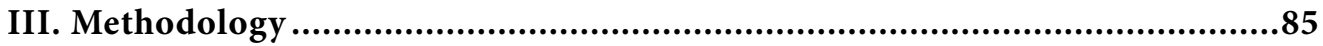

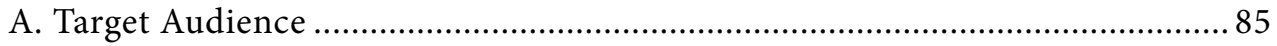

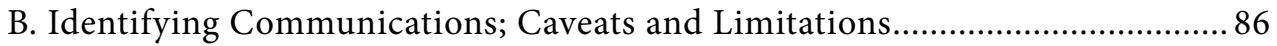

IV. Parameters of the Catalogue ................................................................91

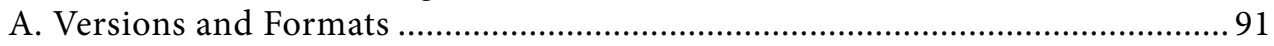

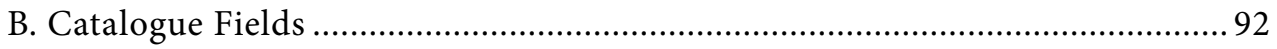

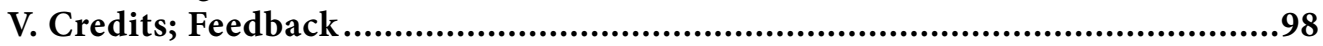

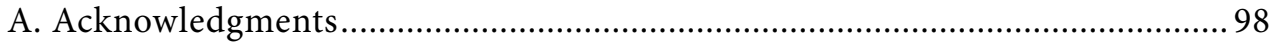

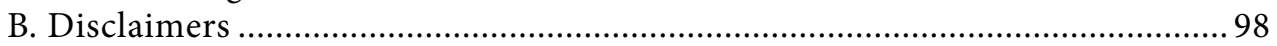

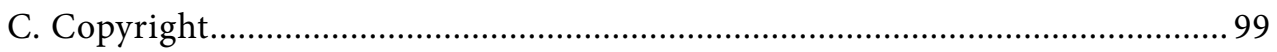

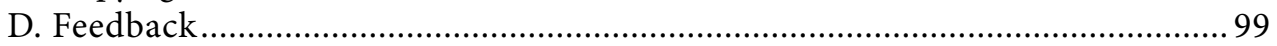

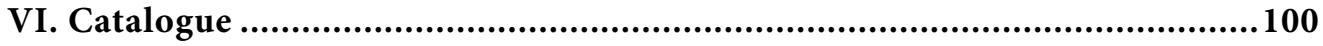




\section{EXECUTIVE SUMMARY}

tates frequently take actions and make statements that implicate international law. But because States do not - and, indeed, could not - express a view on each such act or statement by all other States at all times, silence seems to be the norm, rather than the exception, in international relations.

When States and other international actors do not express their views on a particular incident, issue, or statement that implicates international law, what is the legal significance, if any, of their silence? Does it denote acquiescence, either with the status quo or with a recent potential departure from the status quo? Does it represent a type of unuttered protest, perhaps meant to signify an objection or a lack of agreement? Might their silence have no legal significance at all? Who makes this determination? And who benefits, and who loses, from a finding that a particular silence does or does not yield legal consequences?

Despite certain specific provisions, international law does not offer clear general guidance on what could or should be inferred from apparent silence or inaction. Nevertheless, international actors have long imbued silence with legal significance, at least in some instances. None of these practices has been consistent, however.

In international scholarly discourse, the silence of States and other international actors has been routinely invoked as proof of support for particular legal views. Not least, this practice has been noticeable, and with apparently increasing frequency, in the jus ad bellum field: the legal regulation of the threat or use of force in international relations. Moreover, where scholars in this field invoke silence as legally significant, those invocations are more often than not submitted in favor of relatively wide claims to use force. Of course, academic writings are by no means determinative in discerning what a legal rule is, let alone how it should be interpreted or applied. Still, legal scholarship often informs debates in all fields of law, and international law is no exception.

In this paper, we examine the actual and potential roles of silence as an element of jus ad bellum treaty law and customary international law. By silence, we mean a lack of a publicly discernible response either to conduct reflective of a legal position or to the explicit communication of a legal position. We focus here on the silence of States and the United Nations Security Council as the primary actors who are positioned to shape, interpret, and apply jus ad bellum. We evaluate how silence has been employed by various scholars in making legal arguments in this field, and how silence may have the potential to affect the formation, identification, modification, 
and termination of various doctrines.

We submit that there is no quantum of silence that has clear doctrinal force. We argue that, at least in relation to jus ad bellum, only certain forms of qualified silence - whether of States or of the Security Council - may be capable of contributing to legal effects. We further contend that, due in part to the nature and status of the norms underlying this field, those forms of qualified silence ought not to be lightly presumed. Arguably, there is a strong, if rebuttable, presumption that silence alone does not constitute acceptance of a jus ad bellum claim. Still, States and other international actors should be aware of the possible role that their silence could play in the identification and development of jus ad bellum.

We complement our analysis with an Annex that offers the most comprehensive catalogue to date of communications made by U.N. Member States to the Security Council of measures taken in purported exercise of the right of self-defense. The catalogue records more than 400 communications made since the founding of the United Nations in late October 1945 through 2018. These communications reflect the views of the submitting State(s) on the scope of the right to employ force on the purported basis of self-defense. Notably, U.N. Member States are apparently not made aware of such statements on the use of force as a matter of routine practice. This means that, at least in some instances, States might fail to comment on or otherwise react to other States' positions on the use of force, not as a deliberate choice but for lack of awareness.

If this is correct, two conclusions follow. The first relates to our suggestion that only qualified silence be accorded potential legal significance: if States are unaware of practices or positions forwarded by other States, it is difficult to see how the silence of those unaware States can carry normative value. The other is that especially in the jus ad bellum field, the fact that States are not routinely made aware contemporaneously of self-defense communications made to the Security Council under article 51 of the U.N. Charter is, in our view, a significant concern that ought to be addressed as a matter of priority.

The questions of what silence means as a matter of international law and under what conditions it may and should be relied upon merit closer attention and discussion. Furthermore, States that are concerned about existing jus ad bellum, or about how that law may be developing, may wish to consider the contexts in which they speak out and those in which they remain silent. 
[Page intentionally left blank] 


\title{
QUANTUM OF SILENCE: INACTION AND JUS AD BELLUM
}

\author{
2019 \\ Dustin A. Lewis, Naz K. Modirzadeh, and Gabriella Blum \\ Harvard Law School Program on International Law and Armed Conflict
}

\section{INTRODUCTION}

S

tates frequently take actions and make statements that implicate international law. But because States do not - and, indeed, could not - express a view on each such act or statement by all other States at all times, silence seems to be the norm, rather than the exception, in international relations.

When States and other international actors do not express their views on a particular incident, issue, or statement that implicates international law, what is the legal significance, if any, of their silence? Does it denote acquiescence, either with the status quo or with a recent potential departure from the status quo? Does it represent a type of unuttered protest, perhaps meant to signify an objection or a lack of agreement? Might their silence have no legal significance at all? Who makes this determination? And who benefits, and who loses, from a finding that a particular silence does or does not yield legal consequences? ${ }^{1}$

In some contexts, international law assigns specific legal effects to silence or inaction. For example, under the Vienna Convention on the Law of Treaties (VCLT), merely signing certain treaties - without also ratifying them - is not sufficient to make those instruments binding. ${ }^{2}$ A separate provision in the

1. See Elisabeth Schweiger, Listen closely: what silence can tell us about legal knowledge production, 6 LONDON REV. INT'L L. 391 (2018).

2. See Vienna Convention on the Law of Treaties arts. 11-17, 1155 U.N.T.S. 331 (entry into force Jan. 27, 1980). But see id. at 
VCLT stipulates that a contracting State that fails to explicitly object to a reservation entered by another party within twelve months is considered to have accepted the reservation. ${ }^{3}$ Still another provision of the VCLT foresees the adoption of a treaty at an international conference even if one-third of the States are not present or do not vote. ${ }^{4}$ As an additional example, an article of the United Nations Convention on the Law of the Sea (UNCLOS) contemplates that certain marine-scientific-research projects may proceed unless the coastal State responds to a notification within four months. ${ }^{5}$

Despite these specific provisions, however, international law does not offer clear general guidance on what could or should be inferred from apparent silence or inaction.

Nevertheless, international actors have long imbued silence with legal significance, at least in some instances. ${ }^{6}$ For example, in the jurisprudence of

art. 18 ("A State is obliged to refrain from acts which would defeat the object and purpose of a treaty when: (a) it has signed the treaty or has exchanged instruments constituting the treaty subject to ratification, acceptance or approval, until it shall have made its intention clear not to become a party to the treaty; or (b) it has expressed its consent to be bound by the treaty, pending the entry into force of the treaty and provided that such entry into force is not unduly delayed.") (hereinafter, VCLT). Note that a State that does not contract into a treaty would nevertheless be bound by a rule contained in that treaty at least insofar as that rule is reflective of customary international law.

3. See VCLT art. 20(3)(5) ("For the purposes of paragraphs 2 and 4 and unless the treaty otherwise provides, a reservation is considered to have been accepted by a State if it shall have raised no objection to the reservation by the end of a period of twelve months after it was notified of the reservation or by the date on which it expressed its consent to be bound by the treaty, whichever is later.").

4. See VCLT art. 19(2) ("The adoption of the text of a treaty at an international conference takes place by the vote of two thirds of the States present and voting, unless by the same majority they shall decide to apply a different rule.").

5. See United Nations Convention on the Law of the Sea art. 252, 1833 U.N.T.S. 3 (entry into force Nov. 16, 1994) ("States or competent international organizations may proceed with a marine scientific research project six months after the date upon which the information required pursuant to article 248 was provided to the coastal State unless within four months of the receipt of the communication containing such information the coastal State has informed the State or organization conducting the research that: (a) it has withheld its consent under the provisions of article 246; or (b) the information given by that State or competent international organization regarding the nature or objectives of the project does not conform to the manifestly evident facts; or (c) it requires supplementary information relevant to conditions and the information provided for under articles 248 and 249; or (d) outstanding obligations exist with respect to a previous marine scientific research project carried out by that State or organization, with regard to conditions established in article 249.") (hereinafter, UNCLOS) (cited in Sophia Kopela, The Legal Value of Silence as State Conduct in the Jurisprudence of International Tribunals, 29 AUSTL. Y.B. INT'L L. 87, 90 n.18 (2010)).

6. See, among others, AleXis Marie, Le SilenCe de L'Etat comme Manifestation de SA Volonte (2018); Schweiger, above note 1; Paulina Starski, Silence within the process of normative change and evolution of the prohibition on the use of 
the International Court of Justice (ICJ), acquiescence has led to the enlargement of Norway's maritime claims vis-à-vis the United Kingdom ${ }^{7}$ and a change in the land boundary between Thailand and Cambodia. ${ }^{8}$ In the identification of customary international law, which requires evidence of a general practice accepted as law (opinio juris), under certain conditions silence has been treated as both manifestations of such general practice and proof of States' legal views. ${ }^{9}$

Yet none of these practices has been consistent. Even the ICJ has treated silence differently on different occasions, at times viewing it as legally significant and other times denying it such significance. ${ }^{10}$ Moreover, when the International

force: normative volatility and legislative responsibility, 4 J. USE OF FORCE \& INT'L L. 14 (2017); Kopela, above note 5; David J. Bederman, Acquiescence, Objection and the Death of Customary International Law, 21 DUKE J. COMP. \& INT'L L. 31 (2010); Nuno Sérgio Marques Antunes, Acquiescence, in MaX PlancK EnCyClopedia Of PUblic International LaW (Rüdiger Wolfrum ed., 2006); Gionato Piero Buzzini, Les Comportements Passifs des Etats et Leur Incidence sur la Réglementation de Lemploi de la Force en Droit International Général, in CUSTOMARY INTERNATIONAL LAW ON THE USE OF Force: A Methodological Approach 79-117 (Enzo Cannizzaro \& Paolo Palchetti eds., 2005); Hans Das, Lestoppel et l'acquiescement: assimilations pragmatiques et divergences conceptuelles, 30 REVUE BELGE DE DROIT INT'L 607 (1997); Sir Ian Sinclair, Estoppel and acquiescence, in FIFTY YEARS OF THE INTERNATIONAL COURT OF JUSTICE: ESSAYS IN HONOUR OF SIR ROBERT JENNINGS 104-20 (Vaughan Lowe \& Malgosia Fitzmaurice eds., 1996); Jean Barale, L'acquiescement dans la jurisprudence internationale, 11 ANNUAIRE FRANÇAIS DE DroIt INT'L ANNÉE 389 (1965); I. C. MacGibbon, Customary International Law and Acquiescence, 33 BRIT. Y.B. INT'L L. 115 (1957); I. C. MacGibbon, The Scope of Acquiescence in International Law, 31 BRIT. Y.B. INT'L L. 143 (1954).

In international scholarly discourse, the legal effects, if any, of silence have often been framed as a contest between the purportedly competing theories of "voluntarism" and "objectivism." As summarized by Kopela, "voluntarism argues[ that] the legal effects of silence, that is whether silence is legally relevant, depend upon the intention of the silent state. On the contrary, objectivism asserts to base its conclusions not on the intention of this state, but on the impact of silence as a factual situation upon other states." Kopela, above note 5, at 89 (emphasis added). See also id. at 100 ("Objectivism purports to safeguard the juridical security in international law as expressed in the reliance of states or the international community upon the conduct of a state, whereas voluntarism seeks to preserve the rights and the interests of the silent state, whose will is the legal basis of international law."). Kopela argues that a "third pillar" ought to be added to "voluntarism" and "objectivism" - namely, that of the "jurisprudential perspective." Id. at 89.

7. See Fisheries (U.K. v. Nor.), Judgment, 1951 I.C.J. Reports, 116, 138-39 (Dec. 18) (hereinafter, Fisheries, Judgment). See further below note 44 and the accompanying text.

8. See Temple of Preah Vihear (Camb. v. Thai.), Judgment, 1962 I.C.J. Reports, 6, 23 (June 15) (hereinafter, Temple of Preah Vihear, Judgment). See further below note 41 and the accompanying text.

9. See Part II.

10. Compare, among others, Asylum (Colom. v. Peru), Judgment, 1950 I.C.J. Reports, 266, 277-78 (Nov. 20) (hereinafter, Asylum, Judgment); Fisheries, Judgment, above note 7, at 139; Rights of Nationals of the United States of America in Morocco (Fr. v. U.S.A.), 1952 I.C.J. Reports, 176, 200-201 (Aug. 27) (hereinafter, Rights of U.S. Nationals); Temple of Preah Vihear, Judgment, above note 8, at 23; Military and Paramilitary Activities in and against Nicaragua (Nicar. v. U.S.A.), Jurisdiction 
Law Commission (ILC) recently elaborated the preliminary view that under certain circumstances, silence could be regarded as acquiescence in the areas of subsequent treaty practice and identification of customary international law, several States rejected - expressly - part of those proposals as imposing undue burdens and lacking a basis in international law. ${ }^{11}$ (Ultimately, the ILC did not budge, though the Commission's respective commentaries on those matters do consider some of the concerns raised by States. ${ }^{12}$ )

While it is impossible to construct a general rule on the legal significance of silence in respect of all of the sources of contemporary international law, several scholars have routinely invoked the silence of States and other international actors as proof of support for particular legal views. Not least, this practice has been noticeable, and with apparently increasing frequency, in the jus ad bellum field: the legal regulation of the threat or use of force in international relations. ${ }^{13}$ Moreover, where scholars in this field invoke silence as legally significant, those invocations are more often than not submitted in favor of relatively wide claims to use force. ${ }^{14}$

The stakes for invoking silence in this context are immensely high. This is not only because of the obvious importance of the subject matter itself but also

\footnotetext{
and Admissibility, 1984 I.C.J. Reports, 392, 408-09 (Nov. 26) (hereinafter Military and Paramilitary Activities, Jurisdiction and Admissibility); Sovereignty over Pedra Branca/Pulau Batu Puteh, Middle Rocks and South Ledge (Malay./Sing.), Judgment, 2008 I.C.J. Reports, 12, 50-51 (May 23) (hereinafter, Sovereignty over Pedra Branca/Pulau Batu Puteh, Judgment); with Land and Maritime Boundary between Cameroon and Nigeria (Camer. v. Nig.: Eq. Guin. intervening), Judgment, 2002 I.C.J. Reports, 303, 351, 352-53, 354-55 (Oct. 10) (hereinafter, Land and Maritime Boundary, Judgment); Sovereignty over Pulau Ligitan and Pulau Sipadan (Indo./Malay.), Judgment, 2002 I.C.J. Reports, 625, 650 (Dec. 17) (hereinafter, Sovereignty over Pulau Ligitan, Judgment); Alleged Violations of Sovereign Rights and Maritime Spaces in the Caribbean Sea (Nicar. v. Colom.), Preliminary Objections, 2016 I.C.J. Reports, 3, 25 (Mar. 17) (hereinafter, Caribbean Sea, Preliminary Objections); Question of the Delimitation of the Continental Shelf between Nicaragua and Colombia beyond 200 nautical miles from the Nicaraguan Coast (Nicar. v. Colom.), Preliminary Objections, 2016 I.C.J. Reports, 100, 122 (Mar. 17) (hereinafter, Nicaraguan Coast, Preliminary Objections). For summaries, see below notes $40-43$ and the accompanying text.

11. See Part II.

12. See id.

13. With respect to nomenclature regarding this field, there is a tendency, at least in some of the more recent literature on the subject, to replace the generic term jus ad bellum with that of jus contra bellum. See Claus Kreß, The International Court of Justice and the 'Principle of Non-Use of Force', in THE OXFORD HANDBOOK OF THE USE OF FORCE IN INTERNATIONAL LAW 565 n.18 (Marc Weller ed., 2015) (citing to ROBERT KOLB, IUS CONTRA BELLUM. LE DROIT INTERNATIONAL RELATIF AU MAINTIEN DE LA PAIX INTERNATIONALE (2d ed., 2009) and OLIVIER CORTEN, LE DROIT CONTRE LA GUERRE (2008)).
}

14. See Part III.D. 
because of certain jurisprudential structures of this legal field. Jus ad bellum treaty law is relatively sparse and subject to much debate and contestation. Meanwhile, customary international law on the use of force is often treated, in both theory and practice, as a key means to help resolve legal disputes, fill-in perceived gaps in the law, and further develop doctrine. Yet whether a customary norm has in fact emerged, what its relationship is with the U.N. Charter, and what its precise contours are - all make for their own sets of controversies.

Indeed, recent decades have witnessed voluminous and heated debates over certain key questions regarding the permissible use of force under international law, such as what constitutes an "armed attack"; how to apply jus ad bellum principles of necessity and proportionality; and whether a State may use force preemptively, may engage in "humanitarian intervention," or may undertake unilateral military action against non-state actors in a foreign territory. An array of States, international organizations, courts, scholars, and nongovernmental organizations (NGOs), all relying on the same sources of international law, have often reached remarkably discordant views on these and other pressing jus ad bellum questions.

In many - and perhaps all - of these debates, the purported silence of States and other international actors appears to play a role, whether by inference or by express invocation. Those silences have been deployed, explicitly and implicitly, to ground claims of tacit support for, or opposition to, a particular legal position. At other times, the potential legal significance of silence has been expressly or impliedly disclaimed.

Scholarship provides perhaps the clearest example. For instance, writings on the following military actions (among several others) directly invoke silence as carrying some type of legal significance: ${ }^{15}$

- The military raid in 1976 by Israel in Entebbe, Uganda;

- The military intervention in 1979 by Tanzania in Uganda;

- The airstrikes in 1998 by the United States against al-Qaeda in Afghanistan;

15. See id. 
- The military operations in 1999 and $2007-08$ by Turkey against the Partiya Karkerên Kurdistanê (PKK) in Iraq;

- The military intervention beginning in 2001 by the United States in Afghanistan;

- The military operations in 2002 and 2007 by Russia against Chechen rebels in Georgia; and

- The military operations beginning in 2014 by an international coalition against the self-described Islamic State of Iraq and Syria (ISIS) in Syria.

As it is impossible at this stage to construct a general doctrinal rule on the significance of silence under international law, these instances of invocation of silence in support of legal arguments may or may not be on a sound juridical footing. And, of course, even if valid as a scholarly effort, academic writings are by no means determinative in discerning what a legal rule is, let alone how it should be interpreted or applied.

Still, legal scholarship often informs debates in all fields of law. And international law is no exception. ${ }^{16}$ In fact, the Statute of the ICJ accords the views of prominent international-law writers a particular role in the determination of the rules of law that the Court may rely on in deciding specific disputes. ${ }^{17}$ Indeed, one would be hard-pressed to find legal decisions by international courts that do not reference scholarship. ${ }^{18}$ Moreover, government lawyers, international

16. See, e.g., William Twining, Ward Farnsworth, Stefan Vogenauer, \& Tesón Fernando, The Role of Academics in the Legal System, in THE OXFORD HANDBOOK OF LeGAL STUdies 945 (Mark Tushnet \& Peter Cane eds., 2005) ("It cannot be denied, however, that the many thousands of pages published annually in international law journals have an influence on the actual rules enforced and articulated in the legal arena. Again, that influence cannot be easily quantified, yet this much can be said: scholars sometimes help to make the agenda of important international law issues more concrete and well defined. To be sure, that agenda is ultimately the reflection of the various converging interests and conflicts that governments happen to have. Still, there is no doubt that the systematic scholarly presentation of an issue contributes to the discussion of that issue and the sharpening of the respective positions in non-academic settings. Just as governments shift the object of their concern, so do scholars.").

17. Statute of the International Court of Justice art. 38(1)(d), 3 Bevans 1179 (entry into force Oct. 24, 1945) ("The Court, whose function is to decide in accordance with international law such disputes as are submitted to it, shall apply: ... subject to the provisions of Article $59, \ldots$ the teachings of the most highly qualified publicists of the various nations, as subsidiary means for the determination of rules of law.") (hereinafter, ICJ Statute).

18. For example, with respect to the field of international criminal law, see Nora Stappert, A New Influence of Legal Scholars? 
organizations, and other actors interested in international law routinely review scholarship to inform their legal analyses. Unsurprisingly, reliance on scholars may increase where the identification, interpretation, or application of the law is subject to greater debate and contestation.

And so, while as a normative matter the silence of States or other international actors may or may not be imbued with legal consequences, as a practical matter it often is - and that is particularly so in the field of jus ad bellum.

With these stakes in mind, in this paper we examine the actual and potential roles of silence as an element of jus ad bellum treaty law and customary international law. ${ }^{19}$ By silence, we mean a lack of a publicly discernible response either to conduct reflective of a legal position or to the explicit communication of a legal position. ${ }^{20} \mathrm{We}$ focus here on the silence of States and the United Nations

The Use of Academic Writings at International Criminal Courts and Tribunals, 31 LEIDEN J. INT'L L. 963,979 (2018) (concluding in part that "[b]oth the quantitative data of citations to academic writings and the qualitative interviews with judges and legal officers indicate that scholarly contributions play a more influential role than its formal categorization as a subsidiary means implies. In international criminal law as a subfield in which international courts and tribunals have played a particularly prominent role in the development of legal rules and principles, this room for judicial creativity also seems to have indirectly opened a door for legal scholars to play a more prominent part in the interpretation, and potentially making, of international law.") (citations omitted).

19. On silence in respect of peacetime cyber operations, see Barrie Sander, The Sound of Silence: International Law and the Governance of Peacetime Cyber Operations, in 11TH INTERNATIONAL CONFERENCE ON CYBER CONFLICT: SILENT BATTLE 36181 (Tomáš Minárik, Siim Alatalu, Stefano Biondi, Massimiliano Signoretti, Ihsan Tolga, \& Gábor Visky eds., 2019); on silence in respect of the law of armed conflict, see Sandesh Sivakumaran, Making and Shaping the Law of Armed Conflict, 71 CURRENT LEG. Prob. 119, 152-59 (2018).

20. We do not address other concepts pertaining to silence or inaction in international law, for example in relation to a non liquet that could result from the absence of a legal rule altogether or to the duty of a State to refrain from acquiescing in organized activities within its territory directed towards the commission of organizing, instigating, assisting, or participating in acts of civil strife or terrorist acts in another State when those acts involve a threat or use of force. On non liquet, see Daniel Bodansky, Non Liquet, in MAX Planck ENCYCLOPEDIA OF PUbliC INTERNATIONAL LAW para. 4 (Rüdiger Wolfrum ed., 2006) ("A non liquet could result either from the absence of a legal rule altogether or from a tribunal's inability to determine what the legal rule is, that is, it could signify either that the law is silent or obscure. In the first instance, the non liquet would be ontological in nature; in the latter instance, epistemological. If a new situation arose that international law did not address in any way, the result would be an ontological non liquet. In contrast, if a court were to conclude that it could not ascertain the relevant State practice regarding a particular issue, say, the standard of compensation in expropriation cases, the result would be an epistemological non liquet.") (emphasis added); see also Helen Quane, Silence in International Law, 84 BRIT. Y.B. INT'L L. 240 (2014). On the duty to refrain from acquiescing in certain activities involving threat or use of force, see U.N. General Assembly, resolution 2625(XXV) ("Declaration on Principles of International Law concerning Friendly Relations and Cooperation among States in accordance with the Charter of the United Nations"), A/RES/2625(XXV), Oct. 24, 1970 ("Every State has the duty to refrain from organizing, instigating, assisting or participating in acts of civil strife or terrorist acts in 
Security Council as the primary actors who are positioned to shape, interpret, and apply jus ad bellum. We evaluate how silence has been employed by various scholars in making legal arguments in this field, and how silence may have the potential to affect the formation, identification, modification, and termination of various doctrines. To help demonstrate our argument, we zoom in on the contemporary debate surrounding the resort to military action by States against non-state actors in foreign territory without the consent of the territorial government and without authority from the Security Council. ${ }^{21}$ While far from new, this debate has gained increased attention and heightened relevance since the advent of the "War on Terror" in late 2001, and again with the targeting of ISIS members in Syria beginning in $2014 .^{22}$

To stress, we take no position here on the substantive merits of the various, and often opposing, legal positions elaborated in contemporary jus ad bellum debates, nor even on whether there is any room for debate in the first place. Instead, we take the existence of these debates as a given and focus on the ways in which writers have invoked - and the ways in which other international actors could use - the silence of others as possible proof of tacit support for, or implied rejection of, particular positions. One of our goals is to help raise awareness of silence as an international-law argumentative technique. Another to invite a broader engagement with the question of the significance of silence in the identification and development of international law in general and in the law governing the use of force in particular.

We argue that, at least in relation to jus ad bellum, only certain forms of qualified silence - whether of States or of the Security Council - may be capable of contributing to legal effects. We further contend that, due in part to the nature and status of the norms underlying jus ad bellum, those forms of qualified silence ought not to be lightly presumed. Arguably, there is a strong,

another State or acquiescing in organized activities within its territory directed towards the commission of such acts, when the acts referred to in the present paragraph involve a threat or use of force.").

21. See Part III.C.4.

22. See Schweiger, above note 1; Starski, above note 6. 
if rebuttable, presumption that silence alone does not constitute acceptance of a jus ad bellum claim. Be that as it may, in an era seemingly marked by "normative volatility" in this field, ${ }^{23}$ States and other international actors should be aware of the possible role that their silence could play in the identification and development of jus ad bellum.

We proceed as follows. In Part II, we outline what we mean by silence in the context of international law. In Part III, we evaluate the actual and potential roles of silence in the jus ad bellum field. And in Part IV, we conclude.

We complement our analysis with an $A_{n n e x}{ }^{24}$ that offers the most comprehensive catalogue to date of communications made by U.N. Member States to the Security Council of measures taken in purported exercise of the right of self-defense under article 51 of the U.N. Charter. ${ }^{25}$ The catalogue records more than 400 communications made since the founding of the United Nations in late October 1945 through 2018. These communications reflect the views of the submitting State (or States) on the scope of the right to employ force on the purported basis of self-defense. Notably, U.N. Member States are apparently not made aware of such statements on the use of force as a matter of routine practice. ${ }^{26}$ This means that, at least in some instances, States might fail to comment on or otherwise react to other States' positions on the use of force, not as a deliberate choice but for lack of awareness.

If this is correct, two conclusions follow. The first relates to our suggestion that only qualified silence be accorded potential legal significance: if States are unaware of practices or positions forwarded by other States, it is difficult to see how the silence of those unaware States can carry normative value. The other is

\footnotetext{
23. See Starski, above note 6.

24. See Annex, HLS PILAC Catalogue of Communications to the Security Council of Measures Taken by United Nations Member States in Purported Exercise of the Right of Self-Defense: October 24, 1945 through December 31, 2018 (Dustin A. Lewis ed., 2019).

25. The second sentence of article 51 of the U.N. Charter lays down the following: "Measures taken by Members in the exercise of this right of self-defence shall be immediately reported to the Security Council and shall not in any way affect the authority and responsibility of the Security Council under the present Charter to take at any time such action as it deems necessary in order to maintain or restore international peace and security." Charter of the United Nations art. 51, second sentence, 3 Bevans 1153 (entry into force Oct. 24, 1945) (hereinafter, U.N. Charter).
}

26. See Part III.C.3. 
that especially in the field of jus ad bellum, the fact that States are not routinely made aware contemporaneously of self-defense communications reported to the Security Council under article 51 is, in our view, a significant concern that ought to be addressed as a matter of priority.

Two methodological caveats should be noted here. First, we catalogue and focus on (apparent) ${ }^{27}$ reports of self-defense measures and certain forms of Security Council responses thereto - but without bringing into view the responses of (other) States to those reports. This means that our catalogue gives voice to States that have reported self-defense measures and to the Security Council in response thereto, but not to States that have reacted to such reports. Second, in our review of international-law scholarship, we have covered academic publications in the English and French languages only. Notwithstanding the loss of a broader examination of scholarship in other languages, it is frequently English and French publications that make their way into international judicial decisions and other international legal analyses. It appears that the practice of reliance on silence in the scholarship that we did cover is sufficiently common to suggest that States' silence in the field of jus ad bellum deserves greater attention than it has been accorded so far.

\section{What We MEAN BY SILENCE}

$\mathrm{I}$

n international law, some - but not all - inactions, non-responses, omissions, or other "silences" are capable of producing legal effects. ${ }^{28}$ In some cases, these legal effects are clearly provided for. As noted in the introduction, examples include VCLT provisions concerning the signing but not also ratifying certain

\footnotetext{
27. The reports identified as "article 51 communications" in this paper and in the HLS PILAC catalogue should be considered apparent "article 51 communications" because there has been no authentic and authoritative interpretation under the Charter that each such report does in fact constitute an "article 51 communication." See Annex. On the concept of "authentic" and "authoritative" interpretation, see below note 188 and the accompanying text. For ease of reading, we do not expressly qualify each identified report as "apparent"; however, that qualification should be considered to implicitly attach to each "article 51 communication" identified in this paper and in the HLS PILAC catalogue.

28. See generally IRINA Buga, ModifiCATION OF TREATIES By SUbSEQUENT PRACTICE 63-71, 209 (2018).
} 
treaties; ${ }^{29}$ the failure to object to a reservation functioning as a form of acceptance of that reservation; ${ }^{30}$ and the adoption of a treaty at an international conference even if one-third of the States are not present or do not vote. ${ }^{31}$ Another instance is the UNCLOS provision on proceeding with a marine-scientific-research project unless the coastal State has responded within a certain amount of time. ${ }^{32}$

Yet, in most other cases, international law does not provide clear guidance on what, if any, legal effects follow from State silence. The challenge here lies in no small part in the polysemous nature of silence: ${ }^{33}$ it is necessary to discern which of silence's multiple possible meanings - including tacit agreement, ${ }^{34}$ implied objection, ${ }^{35}$ absence of view, or lack of interest ${ }^{36}$ - operates in respect of a particular situation or issue. As some courts have observed, for example, the mere tolerance of a practice might not constitute acceptance of its legality. ${ }^{37}$

29. See VCLT arts. 11-17. But see id. at art. 18. Note, however, that a State that does not contract into a treaty would nevertheless be bound by a rule contained in that treaty insofar as that rule is reflective of customary international law.

30. See VCLT art. 20(3)(5) ("For the purposes of paragraphs 2 and 4 and unless the treaty otherwise provides, a reservation is considered to have been accepted by a State if it shall have raised no objection to the reservation by the end of a period of twelve months after it was notified of the reservation or by the date on which it expressed its consent to be bound by the treaty, whichever is later.").

31. See VCLT art. 19(2).

32. See UNCLOS art. 252 (cited in Kopela, above note 6, at 90 n.18).

33. See Marques Antunes, above note 6, at para. 19; see also Buzzini, above note 6, at 84-117.

34. See, e.g., UNCLOS art. 252 (cited in Kopela, above note 6, at 90 n.18).

35. For example, in the Asylum case, the ICJ expressed the view that Peru had - by refraining from ratifying the Montevideo Conventions of 1933 and 1939 - "repudiated" a custom concerning diplomatic asylum that was included in those instruments. Asylum, Judgment, above note 10, at 277-78 ("The Court cannot therefore find that the Colombian Government has proved the existence of such a custom. But even if it could be supposed that such a custom existed between certain LatinAmerican States only, it could not be invoked against Peru which, far from having by its attitude adhered to it, has, on the contrary, repudiated it by refraining from ratifying the Montevideo Conventions of 1933 and 1939, which were the first to include a rule concerning the qualification of the offence in matters of diplomatic asylum.") (emphasis added; cited in Kopela, above note 6 , at 90 n.19).

36. See IAN BRownLIE, PRinCiPLeS OF PUblic InTERNATIONAL LAW 8 (6th ed., 2003).

37. See, e.g., Jurisdiction of the European Commission of the Danube, Advisory Opinion, 1927 P.C.I.J. (ser. B) No. 14, at 3637 (Dec. 8) ("In this connection the Court wishes to record that, in the course of arguments submitted on behalf of Roumania, it has been more than once admitted that the European Commission may have exercised certain powers in the contested sector; but that, at the same time, it has been contended that such exercise was based on mere toleration by the territorial State and that toleration could not serve as a basis for the creation of legal rights. [g] In this respect it will suffice to observe that, under the construction of Article 6 of the Definitive Statute adopted by the Court, even if, before the war, an actual exercise 
As noted in the introduction, by "silence" we mean a lack of a publicly discernible response either to conduct reflective of a legal position or to the explicit communication of a legal position. ${ }^{38}$ To help sort the legally relevant wheat from the juridically superfluous chaff, in this part we first briefly describe some underlying principles and a related modality. We then outline more specifically how silence might operate in general in relation to two of the main sources of international law: treaties and custom. Finally, we note why the status of a norm might matter for silence.

\section{A. Principles and a Related Modality}

\section{Acquiescence}

In international-law terms, acquiescence has been said to denote consent conferred from a juridically relevant silence. ${ }^{39}$ The basic notion has arisen in several ICJ proceedings, including in relation to consular rights, ${ }^{40}$ border disputes, ${ }^{41}$ diplomatic

of certain powers by the Commission above Galatz was based on mere toleration, this practice has now been converted into a legal right by Article 6 of the Definitive Statute. It is therefore not necessary to examine whether, in international law, the continued exercise of certain powers might not have converted into a legal right even a situation considered by Roumania as a mere toleration. [ $\mathbf{g}$ ] It cannot be maintained that Article 6 was intended to continue in a state of mere toleration the situation which existed before the war; for toleration implies a negation of right; and, as has already been shown, it would be entirely at variance with the legal system established by the Definitive Statute, if on one sector of the river neither Commission should have any legal powers.").

38. See above note 20 .

39. See Marques Antunes, above note 6, at para. 2. At least in the view of scholar Irina Buga, "[t]he fundamental problem with identifying acquiescence is determining when it actually reflects consent, as opposed to merely action or inaction by States based on various considerations, such as political expediency or simply a lack of occasion to react." BUGA, above note 28 , at 69 (citing to MacGibbon, The Scope of Acquiescence, above note 6, at 172 and to Marcelo G. Kohen, Desuetude and Obsolescence of Treaties, in The Law of Treaties Beyond the Vienna Convention 350 (Enzo Cannizzaro ed., 2011).

40. See Rights of U.S. Nationals, above note 10, at 200-1 (characterizing the situation in which the United States continued after 1937 to exercise consular jurisdiction over all criminal and civil cases in which U.S. nationals were defendants as one that must be regarded as in the nature of a provisional situation acquiesced in by the Moroccan authorities).

41. See Temple of Preah Vihear, Judgment, above note 8, at 23 (finding that the extended absence of a reaction by Thailand in circumstances calling for a reaction - was proof of Thailand's acquiescence to a map depicting the position of the Temple of Préah Vihéar on the Cambodian side of the land-boundary line); Sovereignty over Pedra Branca/Pulau Batu Puteh, Judgment, above note 10, at 50-51 (expressing the view that the absence of a reaction to certain manifestations of the display of sovereignty may amount to acquiescence and that, accordingly, silence may speak, but only if the conduct of the other State calls for a response) (citations omitted); Land and Maritime Boundary, Judgment, above note 10, at 351, 352-53, 354-55 


\section{asylum, ${ }^{42}$ consent to jurisdiction, ${ }^{43}$ and maritime claims. ${ }^{44}$ Based on an analysis of such proceedings as well as practice and doctrine, Nuno Sérgio Marques Antunes}

(considering that where a treaty establishes a determinate boundary, circumstances only exceptionally call for a reaction because preference must be given to the holder of the title, and concluding that Cameroon had not acquiesced in the abandonment of its title); Sovereignty over Pulau Ligitan, Judgment, above note 10, at 650 (finding that the lack of reaction by the British Government to a line on a map cannot, in the circumstances of the case, be deemed to constitute acquiescence in that line; those circumstances included the following: the Explanatory Memorandum and map were "simply forwarded" to the British Government by the Netherlands' diplomatic agent in The Hague (thus, the memorandum and map were never formally transmitted by the Dutch Government to the British Government); the Netherlands' agent had specified that the map had been published in the Official Journal of the Netherlands and formed part of a Report presented to the Second Chamber of the States-General; that agent had added that "the map seems to be the only interesting feature of a document which does not otherwise call for special comment"; and the British Minister in The Hague did not draw the attention of his authorities to the red line drawn on the map among other lines); Caribbean Sea, Preliminary Objections, above note 10, at 25 (expressing the view that the ICJ is unable to read into the absence of any objection on the part of the other parties to the American Treaty on Pacific Settlement (Pact of Bogotá), 30 U.N.T.S. 55 (1948), with respect to that notification an agreement, within the meaning of article 31(3)(b) of the VCLT, regarding Colombia's interpretation of article LVI thereof, and further considering that the absence of any comment by Nicaragua does not amount to acquiescence); Nicaraguan Coast, Preliminary Objections, above note 10, at 122 (same).

42. See Asylum, Judgment, above note 10, at 277-78 (finding that silence by Peru - in the form of the repudiation of a regional custom concerning diplomatic asylum by way of refraining from ratifying instruments in which that custom was reflected precluded a finding of the existence of that custom in respect of Peru).

43. See Military and Paramilitary Activities, Jurisdiction and Admissibility, above note 10, at 408-09 (ruling that Nicaragua had consented to the Court's jurisdiction because Nicaragua had regularly been placed, on multiple official publications, on the list of those States that had recognized the compulsory jurisdiction of the Court - a practice that had been conducted for nearly four decades and that had provided Nicaragua an opportunity of accepting or rejecting that claim).

44. See Fisheries, Judgment, above note 7, at 138-39 ("The United Kingdom Government has argued that the Norwegian system of delimitation was not known to it and that the system therefore lacked the notoriety essential to provide the basis of an historic title enforceable against it. The Court is unable to accept this view. As a coastal State on the North Sea, greatly interested in the fisheries in this area, as a maritime Power traditionally concerned with the law of the sea and concerned particularly to defend the freedom of the seas, the United Kingdom could not have been ignorant of the Decree of 1869 which had at once provoked a request for explanations by the French Government. Nor, knowing of it, could it have been under any misapprehension as to the significance of its terms, which clearly described it as constituting the application of a system. The same observation applies a fortiori to the Decree of 1889 relating to the delimitation of Romsdal and Nordmore which must have appeared to the United Kingdom as a reiterated manifestation of the Norwegian practice. [ $\mathbf{9}$ ] Norway's attitude with regard to the North Sea Fisheries (Police) Convention of 1882 is a further fact which must at once have attracted the attention of Great Britain. There is scarcely any fisheries convention of greater importance to the coastal States of the North Sea or of greater interest to Great Britain. Norway's refusal to adhere to this Convention clearly raised the question of the delimitation of her maritime domain, especially with regard to bays, the question of their delimitation by means of straight lines of which Norway challenged the maximum length adopted in the Convention. Having regard to the fact that a few years before, the delimitation of Sunnmöre by the 1869 Decree had been presented as an application of the Norwegian system, one cannot avoid the conclusion that, from that time on, all the elements of the problem of Norwegian coastal waters had been clearly stated. The steps subsequently taken by Great Britain to secure Norway's adherence to the Convention clearly show that she was aware of and interested in the question. [9] The Court notes that in respect of a situation which could only be strengthened with the passage of time, the United Kingdom Government refrained 
concludes that acquiescence "concerns a consent tacitly conveyed by a State, unilaterally, through silence or inaction, in circumstances such that a response expressing disagreement or objection in relation to the conduct of another State would be called for." ${ }^{45}$ Under that framing, acquiescence cuts a middle path between two dueling maxims: qui tacit consentire videtur (he who keeps silent is held to consent), on the one hand, and qui tacit neque negat, neque utique fatetur (he who keeps silent is held neither to deny nor to accept), on the other hand. Silence will thereby convey consent - according to the following logic of the ICJ in the Temple of Preah Vihear case - only if the condition of si loqui debuisset ac potuisset (if he must and can act) is satisfied:

It has been contended on behalf of Thailand that this communication of the maps by the French authorities [note: the sovereignty of Cambodia was under French protectorate at the relevant time] was, so to speak, ex parte, and that no formal acknowledgment of it was either requested of, or given by, Thailand. In fact, as will be seen presently, an acknowledgment by conduct was undoubtedly made in a very definite way; but even if it were otherwise, it is clear that the circumstances were such as called for some reaction, within a reasonable period, on the part of the Siamese authorities, if they wished to disagree with the map or had any serious question to raise in regard to it. They did not do so, either then or for many years, and thereby must be held to have acquiesced. Qui tacet consentire videtur si loqui debuisset ac potuisset. ${ }^{46}$

It appears that this notion of acquiescence may thus emerge only where all of the following conditions are established: where it refers to facts that are, or ought to be, known by the acquiescing State (notoriety or awareness); where such facts are

from formulating reservations. [ ] The notoriety of the facts, the general toleration of the international community, Great Britain's position in the North Sea, her own interest in the question, and her prolonged abstention would in any case warrant Norway's enforcement of her system against the United Kingdom.") (emphasis added).

45. Marques Antunes, above note 6, at para. 2 (internal cross-references omitted). See also MacGibbon, The Scope of Acquiescence, above note 6, at 143 (stating that "[a]cquiescence, in the accepted dictionary sense of tacit agreement or consent, is essentially a negative concept. In the present article it is used to describe the inaction of a State which is faced with a situation constituting a threat to or infringement of its rights: it is not intended to connote the forms in which a State may signify its consent or approval in a position fashion. Acquiescence thus takes the form of silence or absence of protest in circumstances which generally call for a positive reaction signifying an objection.").

46. Temple of Preah Vihear, Judgment, above note 8, at 23. See also Marques Antunes, above note 6, at para. 19. 
of direct interest for the acquiescing State (interest); when these facts have existed for a significant period (lapse of time) without significant change of context and the meaning conveyed (consistency); and in cases in which the conduct is attributable to a relevant representative of the State (provenance).$^{47}$

\section{Estoppel}

The doctrine of estoppel in international law operates to protect legitimate expectations of a State induced by the conduct of another State. ${ }^{48}$ The basic idea is that "international jurisprudence has a place for some recognition of the principle that a State cannot blow hot and cold-allegans contraria non audiendus est" ${ }^{49}$ (a person making contradictory statements is not to be heard ${ }^{50}$ ). In certain respects, the exact parameters of the doctrine of estoppel - and its relationship with related concepts, including preclusion - remain difficult to draw with precision. ${ }^{51}$ However, the following position concerning the "principle of preclusion" by Judge Spender of the ICJ, in his dissenting opinion in the Temple of Preah Vihear case, might provide useful guidance: ${ }^{52}$

47. See Marques Antunes, above note 6, at para. 21. See also BUGA, above note 28, at 68-70; Gennady M. Danilenko, The Theory of International Customary Law, 31 GERMAN Y.B. INT'L L. 9, 40 (1988) (“Under international law, the conduct of inactive States implies tacit approval of a practice and creates legal consequences only if certain conditions have been fulfilled. In the first place, it is necessary that the practice should directly or indirectly affect the interests and rights of an inactive State because otherwise there would be no ground to expect a protest. Secondly, the inactive State must be aware of the legal claims for which consent is presumed in case of the absence of protest.").

48. Thomas Cottier \& Jörg Paul Müller, Estoppel, in MaX Planck ENCyClopedia of Public InTERnational LaW para. 1 (Rüdiger Wolfrum ed., 2007). See also BUGA, above note 28, at 68-70; I. C. MacGibbon, Estoppel in International Law, 7 INT’L \& COMP. L. Q. 468 (1958).

49. Arnold D. McNair, The Legality of the Occupation of the Ruhr, 5 BRIT. Y.B. INT'L L. 17, 25 (1924).

50. See Charles T. Kotuby, JR. \& Luke A. Sobota, General Principles of LaW and International Due Process: PRINCIPLES AND NORMS APPLICABLE IN TRANSNATIONAL DisPUTES xvii (2017).

51. See, e.g., Delimitation of the Maritime Boundary in the Gulf of Maine Area (Can./U.S.A.), Judgment, 1984 I.C.J. Reports, 246, 305 (Oct. 12) (hereinafter, Gulf of Maine, Judgment) (stating that, "[a]ccording to one view, preclusion is in fact the procedural aspect and estoppel the substantive aspect of the same principle," but expressly not engaging at this point on a "theoretical debate").

52. See Dispute concerning Delimitation of the Maritime Boundary between Bangladesh and Myanmar in the Bay of Bengal (Bang./Myan.), Case No. 16, Judgment of Mar. 14, 2012, ITLOS Rep. 4, 42 ("The Tribunal observes that, in international law, a situation of estoppel exists when a State, by its conduct, has created the appearance of a particular situation and another 
[T] he principle [of preclusion] operates to prevent a State contesting before the Court a situation contrary to a clear and unequivocal representation previously made by it to another State, either expressly or impliedly, on which representation the other State was, in the circumstances, entitled to rely and in fact did rely, and as a result that other State has been prejudiced or the State making it has secured some benefit or advantage for itself. ${ }^{53}$

Under those requirements, it has been said, "[t]he typical effect of the doctrine is that $\ldots$ a representing party is barred-estopped or precluded-from successfully adopting different, subsequent statements on the same issue, without regard to their truth and accuracy." ${ }^{54}$

Acquiescence and estoppel are often considered to be "indubitably ... entangled." 55 Both concepts are, as an ad hoc Chamber of the ICJ assessed (in obiter) in the Gulf of Maine case, "based on different legal reasoning, since acquiescence is equivalent to tacit recognition manifested by unilateral conduct which the other party may interpret as consent, while estoppel is linked to the idea of preclusion." ${ }^{56}$ In accordance with the reasoning of the ICJ in the North Sea Continental Shelf cases, the crucial element concerning estoppel in international law has been said to consist of "[e]vidence that that State has openly relied on a certain situation of fact, and that a change thereof would lead to undue prejudice (or an unjustified benefit for the other State)...." ${ }^{57}$ The first distinction between acquiescence and estoppel thus concerns detrimental reliance: in the words of the

\footnotetext{
State, relying on such conduct in good faith, has acted or abstained from an action to its detriment. The effect of the notion of estoppel is that a State is precluded, by its conduct, from asserting that it did not agree to, or recognize, a certain situation"); see also Cottier \& Müller, above note 48 , at para. 1.

53. Temple of Preah Vihear, Judgment, above note 8, Dissenting Opinion of Sir Percy Spender, at 143-144.

54. Cottier \& Müller, para. 1. Estoppel has thus been said to operate as one of the "concretizations" of good faith and equity in proceedings before international courts and tribunals. See Markus Kotzur, Good Faith (Bona fide), in MAX PLANCK ENCYCLOPEDIA OF PUBLIC INTERNATIONAL LAW para. 24 (Rüdiger Wolfrum ed., 2009).

55. Marques Antunes, above note 6, at para. 24. See Phil C.W. Chan, Acquiescence/Estoppel in International Boundaries: Temple of Preah Vihear Revisited, 3 CHIN. J. INT'L L. 421 (2004); Das, above note 6; Sinclair, above note 6; D. W. Bowett, Estoppel before International Tribunals and Its Relation to Acquiescence, 33 BRIT. Y.B. INT'L L. 176 (1957).

56. Gulf of Maine, Judgment, above note 51, at 305.

57. Marques Antunes, above note 6, at para. 24 .
} 
ICJ Chamber in the Gulf of Maine case (in obiter), "the element of detriment or prejudice caused by a State's change of attitude ... distinguishes estoppel stricto sensu from acquiescence." ${ }^{58}$ The second distinction between the two concepts pertains to consent or lack thereof (again in obiter): "acquiescence signals an expression of consent (albeit tacitly conveyed), whereas for estoppel to arise there is no requirement of consent." ${ }^{\text {59 }}$

\section{Protest}

Silence may also relate to protest, which has been described as "a formal objection by subjects of international law, usually a State, against a conduct or claim purported to be contrary to or unfounded in international law." ${ }^{100}$ The primary "function of a protest is the preservation of rights, or of making it known that the

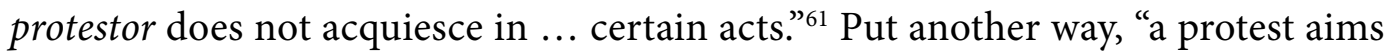
at rebutting any presumption of acquiescence in a particular claim or conduct." ${ }^{62}$ In certain circumstances, it may be difficult to distinguish between a protest in the legal sense and a mere political declaration. ${ }^{63}$

58. Gulf of Maine, Judgment, above note 51, at 305 (citing to North Sea Continental Shelf (Fed. Rep. Ger./Neth.), Judgment, 1969 I.C.J. Reports, 3, 26 (Feb. 20), which states, in relevant part: "Having regard to these considerations of principle, it appears to the Court that only the existence of a situation of estoppel could suffice to lend substance to this contention, - that is to say if the Federal Republic [of Germany] were now precluded from denying the applicability of the conventional régime, by reason of past conduct, declarations, etc., which not only clearly and consistently evinced acceptance of that régime, but also had caused Denmark or the Netherlands, in reliance on such conduct, detrimentally to change position or suffer some prejudice.").

59. Marques Antunes, above note 6, at para. 24.

60. Christophe Eick, Protest, in Max Planck EncyClopedia of PUblic International LaW para. 1 (Rüdiger Wolfrum ed., 2006).

61. Id. at para. 1 (emphasis original); see further id. (explaining that "[a] protest thus has the opposite effect to that of recognition. Its purpose is to prevent a situation from becoming opposable to a subject of international law which protests against it, and may thus deprive it of any legal effect. Used in such a manner, a protest can have an effect on the formation of historical titles such as acquisitive prescription.").

62. Id. at para. 13; see further id. (explaining that "[a] State may want to rely on a protest in order to deny a particular claim based on acquisitive prescription. Protests may also have an effect on the formation of customary international law when constituting evidence of a general practice accepted in law, or, conversely, evidence that there is no such accepted general practice. A protesting State may also seek to exclude the application of a rule of customary international law for its own conduct, assuming the role of persistent objector.").

63. See id. at para. 9. 
By linking protest to a lack of acquiescence, an expectation of protest may yield legal consequences for remaining silent.

\section{B. Treaty Law}

W

ith respect to treaty law, silence and its effects may pertain to, among other things, interpretation, invalidity, fundamental changes in circumstances, and reservations. ${ }^{64}$ Among those areas, the role of silence or inaction in establishing an interpretive agreement of a treaty provision merits particular focus here.

In its work on "Subsequent agreements and subsequent practice in relation to interpretation of treaties," the ILC formulated the following draft conclusion: while " $\mathrm{t}$ ] he number of parties that must actively engage in subsequent practice in order to establish" an interpretive agreement of a treaty provision in the sense of article 31(3)(b) of the VCLT "may vary," "[s] ilence on the part of one or more parties may constitute acceptance of the subsequent practice when the circumstances call for some reaction." ${ }^{65}$ The ILC cited the ICJ's proposition in the Temple of Preah Vihear case that when circumstances clearly call for some reaction within a reasonable period, a State "confronted with a certain subsequent conduct by another party 'must be held to have acquiesced."'66

\footnotetext{
64. See Marques Antunes, above note 6, at para. 14 ("Another important area over which acquiescence may have an impact is that of the sources of law latissimo sensu. With regard to treaties, issues such as interpretation (eg subsequent practice in the application of a treaty), invalidity (eg loss of the right to invoke a ground for invalidity, termination, withdrawal from or suspension of a treaty; error in circumstances such that the State ought to have been on notice of a possible error), and fundamental changes in circumstances are interrelated with the notion of acquiescence and its effects. On another level, treaties may explicitly exclude the operation of acquiescence in relation to certain aspects; or conversely, establish that silence or inaction corresponds to a certain effect (eg acceptance of reservations).").

65. Int'l L. Comm., Draft Conclusions on Subsequent agreements and subsequent practice in relation to the interpretation of treaties, in Report of the International Law Commission, A/73/10, 70th Session, Supp. No. 10, 2018, 15, http://legal.un.org/ilc/reports/2018/english/a_73_10_advance.pdf, permalink: https://perma.cc/24PR-BEHR (draft conclusion 10, para. 2) (emphasis added) (hereinafter, Draft Subsequent Agreement Conclusions).

66. Id. at 79 (citing to Temple of Preah Vihear, Judgment, above note 8). The ILC also cited other ICJ - as well as International Criminal Tribunal for the Former Yugoslavia (ICTY) and World Trade Organization (WTO) - proceedings in support of the general idea that silence, or inaction, may entail legal significance when the circumstances call for a reaction. Id. at 79, n. 430 (citing Oil Platforms (Iran v. U.S.A.), Preliminary Objection, 1996 I.C.J. Reports, 803, 815 (Dec. 12); Military and Paramilitary Activities, Jurisdiction and Admissibility, above note 10, at 410; Prosecutor v. Furundžija, Trial Chamber, Judgment, Case No. IT-95-17/1-T, Dec. 10, 1998, ICTY, paras. 165 et seq. at para. 179; Rantsev v. Cyprus and Russia, No. 25965/04, Jan. 7, 2010,
} 
While the ILC refrained from specifying when precisely "circumstances call for some reaction," the Commission did indicate that "the particular setting in which the States parties interact with each other in respect of the treaty" may have relevance in that regard. ${ }^{67}$ Furthermore, according to the ILC:

The significance of silence also depends on the legal situation to which the subsequent practice by the other party relates and on the claim thereby expressed .... The relevance of silence or inaction for the establishment of an agreement regarding interpretation depends to a large extent on the circumstances of the specific case. Decisions of international courts and tribunals demonstrate that acceptance of a practice by one or more parties by way of silence or inaction is not easily established. ${ }^{68}$

Using cases on boundary delineation to illustrate the difficulty in identifying precise circumstances, the ILC formed the view that "circumstances will only very exceptionally call for a reaction with respect to conduct that runs counter to the delimitation ... [and i]n such situations, there appears to be a strong presumption that silence or inaction does not constitute acceptance of a practice." ${ }^{69}$ Nonetheless, conduct by one party interpreting a treaty does not necessarily require the other party or parties to react. In the Kasikili/Sedudu Island case, the parties charged an expert commission to resolve a factual dispute. ${ }^{70}$ The ICJ determined that a State that failed to react to the expert commission's findings did not automatically signal agreement with those findings or an agreement to end the dispute because "the

ECHR 2010 (extracts), para. 285; cautiously: WTO Appellate Body Report, EC - Chicken Cuts WT/DS269/AB/R and Corr.1, WT/DS286/AB/R and Corr.1, adopted Sept. 27, 2005, para. 272 (hereinafter, WTO, Chicken Cuts); see, also, for a limited holding, Iran-United States Claims Tribunal, Award No. 30-16-3, RayGo Wagner Equipment Company v. Iran Express Terminal Corporation, Iran-United States Claims Tribunal Reports, vol. 2 (1983), 141, at 144; The Question whether the reevaluation of the German Mark in 1961 and 1969 constitutes a case for application of the clause in article 2 (e) of Annex I A of the 1953 Agreement on German External Debts between Belgium, France, Switzerland, the United Kingdom of Great Britain and Northern Ireland and the United States of America on the one hand and the Federal Republic of Germany on the other, May 16, 1980, UNRIAA, vol. XIX, 67-145, 103-104).

67. Draft Subsequent Agreement Conclusions, above note 65, at 79 (emphasis added).

68. Id. at 80 (emphasis added).

69. Id. (emphasis added; citing to Land and Maritime Boundary, Judgment, above note 10, at 351; Frontier Dispute (Bur. Faso/Mali), Judgment, 1986 I.C.J. Reports, 554, 586 (Dec. 22); Case concerning the delimitation of the maritime boundary between Guinea-Bissau and Senegal (Guin.-Bis. v. Sen.), Award, July 31, 1989, XX UNRIAA (Sales No. E/F.93.V.3), 119, 181).

70. Id. at 81 (citing to Kasikili/Sedudu Island (Botsw./Nam.), Judgment, 1999 I.C.J. Reports, 1045, 1089-1091 (Dec. 13)). 
parties had considered the work of the experts as being merely a preparatory step for a separate decision subsequently to be taken at the political level." ${ }^{\prime 1}$ The Court's opinion thus suggested that the conduct's finality might be one factor that States may consider when deciding whether it is or is not warranted to react. Furthermore, reasoning of the Appellate Body of the World Trade Organization (WTO) implies that a party's awareness of the practice may be another factor to consider. For example, the WTO Appellate Body might understand a State's lack of reaction as acceptance of the practice of other treaty parties when "a party that has not engaged in a practice has become or has been made aware of the practice of other parties (for example, by means of notification or by virtue of participation in a forum where it is discussed), but does not react to it."72 Finally, the ILC espoused the position that "[s]ilence by a party shall not be presumed to constitute subsequent practice under article 31 , paragraph $3(b)$, accepting an interpretation of a treaty as expressed in a pronouncement of an expert treaty body." 73

The ILC received comments on an earlier iteration of its subsequentagreements-and-practice draft conclusions from various States, including Australia, ${ }^{74}$ Belarus, ${ }^{75}$ the Czech Republic, ${ }^{76}$ El Salvador, ${ }^{77}$ Germany, ${ }^{78}$ the

71. Id.

72. Id. (citing to WTO, Chicken Cuts, above note 66, at para. 272).

73. The ILC's commentaries explained that draft conclusion 13, paragraph 3, does not create an exception to the general rule that silence can constitute acceptance to subsequent practice when the circumstances call for a reaction, but instead applies the rule to typical cases of expert body pronouncements. Id. at 113.

74. The original information provided by Australia is apparently not available on the ILC website, but that information is provided in a report compiled by the ILC. See Int'l L. Comm., 70th Sess., A/CN.4/712 (Feb. 21, 2018), 23.

75. See information submitted by Belarus,

http://legal.un.org/docs/?path=../ilc/sessions/70/pdfs/russian/sasp_belarus.pdf\&lang=R,

permalink: https://perma.cc/Q3DR-5F84.

76. See information submitted by the Czech Republic,

http://legal.un.org/docs/?path=../ilc/sessions/70/pdfs/english/sasp_czech_republic.pdf\&lang=E,

permalink: https://perma.cc/8RF6-8M2T.

77. See information submitted by El Salvador,

http://legal.un.org/docs/?path=../ilc/sessions/70/pdfs/spanish/sasp_el_salvador.pdf\&lang=S, permalink: https://perma.cc/Y5W3-L49H.

78. See information submitted by Germany,

http://legal.un.org/docs/?path=../ilc/sessions/70/pdfs/english/sasp_germany.pdf\&lang=E, 
Netherlands, ${ }^{79}$ Spain, ${ }^{80}$ Sweden (on behalf of the Nordic countries), ${ }^{81}$ the United Kingdom, ${ }^{82}$ and the United States. ${ }^{83}$

In its comments, Australia emphasized that "the subsequent practice of fewer than all parties to a treaty can only serve as a means of interpretation under very restrictive conditions. This applies in particular to the silence on the part of one or more parties." ${ }^{4}$ The Czech Republic noted its own lack of clarity as to what "silence" means within the context of the draft conclusion and objected to the mention of it. ${ }^{85}$ Belarus also pointed to the need, in its view, for clarification and added that "it should be made abundantly clear that a party that has accepted a practice by way of silence should have been made aware of such practice and its implications for interpretation and should have had the opportunity to contest it." 86

Ultimately, the ILC adopted the position that silence, or inaction, is capable of producing legal effects in relation to the establishment of an interpretive agreement of a treaty provision but only if the circumstances require a reaction. ${ }^{87}$ As noted above, the Commission did not ultimately specify those circumstances.

permalink: https://perma.cc/MHX7-R4HJ.

79. See information submitted by the Netherlands, http://legal.un.org/docs/?path=../ilc/sessions/70/pdfs/english/sasp_netherlands.pdf\&lang=E, permalink: https://perma.cc/9A3B-PZS9.

80. See information submitted by Spain, http://legal.un.org/docs/?path=../ilc/sessions/70/pdfs/spanish/sasp_spain.pdf\&lang=S, permalink: https://perma.cc/Q9JR-3B6E

81. See information submitted by Sweden (on behalf of the Nordic countries), http://legal.un.org/docs/?path=../ilc/sessions/70/pdfs/english/sasp_sweden_nordic.pdf\&lang=E, permalink: https://perma.cc/M4ZZ-86VF.

82. See information submitted by the United Kingdom, http://legal.un.org/docs/?path=../ilc/sessions/70/pdfs/english/sasp_uk.pdf\&lang=E, permalink: https://perma.cc/D9XY-CQX9.

83. See information submitted by the United States, http://legal.un.org/docs/?path=../ilc/sessions/70/pdfs/english/sasp_usa.pdf\&lang=E, permalink: https://perma.cc/J25M-U6CM.

84. Int'l L. Comm., 70th Sess., A/CN.4/712 (Feb. 21, 2018), 23 (emphasis added).

85. Id.

86. Id. (emphasis added).

87. See Draft Subsequent Agreement Conclusions, above note 65, at 15 (draft conclusion 10, para. 2). 
At least based on the proceedings that the ILC cited, the finality of the circumstances and the party's awareness of them might be two factors to consider in that regard. A review of State comments on an early submission of the ILC draft conclusions indicates that those States by and large adopt a relatively restrictive approach to the circumstances under which silence or inaction may establish an interpretive agreement of a treaty provision.

\section{Customary International Law}

Tn general, in the words of the ILC in its work on "Identification of customary international law," "[t]o determine the existence and content of a rule of customary international law, it is necessary to ascertain whether there is a general practice that is accepted as law (opinio juris)." 88 Silence or inaction is capable of pertaining to either or both of the constituent elements of customary international law: (1) a general practice (2) that is accepted as law (opinio juris).

With respect to forms of practice, "[t]he requirement of a general practice, as a constituent element of customary international law, refers primarily to the practice of States that contributes to the formation, or expression, of rules of customary international law." ${ }^{89}$ Yet, in addition, "[i]n certain cases, the practice of international organizations" - such as the United Nations - "also contributes to the formation, or expression, of rules of customary international law." ${ }^{90}$ As formulated in a draft conclusion adopted by the ILC, State practice in the sense of identifying customary international law may "take a wide range of forms. It includes both physical and

\footnotetext{
88. Int'l L. Comm., Draft Conclusions on Identification of customary international law, in Report of the International Law Commission, A/73/10, 70th Session, Supp. No. 10, 2018, http://legal.un.org/ilc/reports/2018/english/a_73_10_advance.pdf, permalink: https://perma.cc/24PR-BEHR (draft conclusion 2) (emphasis added) (hereinafter, Draft CIL Conclusions). In making that assessment, "regard must be had to the overall context, the nature of the rule, and the particular circumstances in which the evidence in question is to be found." Id. (draft conclusion 3, para. 1). According to the "two elements" approach, each of the two constituent elements - (1) a general practice (2) that is accepted as law (opinio juris) - must be separately ascertained based on an assessment of evidence for each. Id. (draft conclusion 3, para. 2).

89. Id. (draft conclusion 4, para. 1). "State practice" as a constituent element of customary international law consists "of conduct of the State, whether in the exercise of its executive, legislative, judicial or other functions." Id. at 120 (draft conclusion 5).

90. Id. at 119 (draft conclusion 4, para. 2).
} 
verbal acts. It may, under certain circumstances, include inaction." ${ }^{11}$

According to the ILC's commentaries on its draft conclusion regarding inaction as a form of State practice, "the words 'under certain circumstances' seek to caution ... that only deliberate abstention from acting may serve such a role: the State in question needs to be conscious of refraining from acting in a given situation, and it cannot simply be assumed that abstention from acting is deliberate." ${ }^{92}$ Examples provided by the ILC of a State so deliberately refraining from action include declining to initiate criminal proceedings against foreign officials, deciding not to protect certain naturalized persons, and abstaining from the use of force..$^{93}$ While the commentaries mention abstaining from the use of force as an example of State inaction, the ILC does not provide a concrete example to (further) illustrate that contention.

The ILC received comments on an early iteration of the draft conclusions on the identification of customary international law from Austria, ${ }^{94}$ Belarus, ${ }^{95}$ China, ${ }^{96}$ the Czech Republic, ${ }^{97}$ Denmark (on behalf of the Nordic countries), ${ }^{98}$

91. Id. at 120 (draft conclusion 6, para. 1) (emphasis added). Moreover, "[t]here is no predetermined hierarchy among the various forms of practice." Id. (draft conclusion 6, para. 3). In assessing a State's practice, account is to be taken of all available practice of that particular State, which is to be assessed as a whole. Id. (draft conclusion 7, para. 1). Where the practice of a particular State varies, the weight to be given to that practice may, depending on the circumstances, be reduced. Id. (draft conclusion 7, para. 2). No particular duration is required, provided that the practice is general. Id. (draft conclusion 8, para. 2).

92. Id. at 133 (emphasis added).

93. Id.

94. See information submitted by Austria, http://legal.un.org/docs/?path=../ilc/sessions/70/pdfs/english/icil_austria.pdf\&lang=E, permalink: https://perma.cc/UY2Z-WDS6.

95. See information submitted by Belarus, http://legal.un.org/docs/?path=../ilc/sessions/70/pdfs/russian/icil_belarus.pdf\&lang=R, permalink: https://perma.cc/2ESE-8D2B.

96. See information submitted by China, http://legal.un.org/docs/?path=../ilc/sessions/70/pdfs/chinese/icil_china.pdf\&lang=C, permalink: https://perma.cc/FGZ5-FBBG.

97. See information submitted by the Czech Republic, http://legal.un.org/docs/?path=../ilc/sessions/70/pdfs/english/icil_czech_republic.pdf\&lang=E, permalink: https://perma.cc/3YEB-6G2M.

98. See information submitted by Denmark (on behalf of the Nordic countries),

http://legal.un.org/docs/?path=../ilc/sessions/70/pdfs/english/icil_denmark.pdf\&lang=E, 
El Salvador, ${ }^{99}$ Israel, ${ }^{100}$ the Netherlands, ${ }^{101}$ New Zealand, ${ }^{102}$ South Korea, ${ }^{103}$ Singapore, ${ }^{104}$ and the United States. ${ }^{105}$

Most of the State comments did not address inaction in relation to practice. Those that did sought to qualify the draft conclusion's reference to inaction with the word "deliberate." Israel, for instance, argued for the change because the distinction is of "sufficient importance to merit specific mention." 106 Israel further called for the draft conclusion to specify "the need for the inaction to stem from a sense of customary legal obligation ... given the unique and complicated nature of inaction as a potential source of customary international law." ${ }^{107}$ Finally in the view of Israel, the sense of customary legal obligation for deliberate inaction should not consider "diplomatic, political, strategic or other

permalink: https://perma.cc/23QW-E95E.

99. See information submitted by El Salvador, http://legal.un.org/docs/?path=../ilc/sessions/70/pdfs/spanish/icil_el_salvador.pdf\&lang=S, permalink: https://perma.cc/YR5E-ZR6N.

100. See information submitted by Israel, http://legal.un.org/docs/?path=../ilc/sessions/70/pdfs/english/icil_israel.pdf\&lang=E, permalink: https://perma.cc/YR5E-ZR6N.

101. See information submitted by the Netherlands, http://legal.un.org/docs/?path=../ilc/sessions/70/pdfs/english/icil_netherlands.pdf\&lang=E, permalink: https://perma.cc/9JTE-4EZP.

102. See information submitted by New Zealand,

http://legal.un.org/docs/?path=../ilc/sessions/70/pdfs/english/icil_new_zealand.pdf\&lang=E, permalink: https://perma.cc/2M4J-F7ER.

103. See information submitted by South Korea,

http://legal.un.org/docs/?path=../ilc/sessions/70/pdfs/english/icil_republic_of_korea.pdf\&lang=E,

permalink: https://perma.cc/HML4-Z5C8.

104. See information submitted by Singapore,

http://legal.un.org/docs/?path=../ilc/sessions/70/pdfs/english/icil_singapore.pdf\&lang=E,

permalink: https://perma.cc/5YWQ-HC47.

105. See information submitted by the United States,

http://legal.un.org/docs/?path=../ilc/sessions/70/pdfs/english/icil_usa.pdf\&lang=E, permalink: https://perma.cc/99VB-MDE5.

106. Int'l L. Comm. 70th Sess., A/CN.4/716 (Feb. 14, 2018), 24 (noting that, "[w]ith regard to the discussion in the draft conclusion as to whether inaction can serve as an indicator of State practice, we would like to see a clarification in the text of the draft conclusion that inaction may be taken into account as practice only when it is deliberate.").

107. Id. (emphasis added). 
non-legal considerations which while deliberate, should not be regarded as State practice for purposes of identifying customary international law." 108 The Netherlands, ${ }^{109}$ New Zealand, ${ }^{110}$ and Singapore ${ }^{111}$ similarly argued for "deliberate" to qualify inaction in the text of the relevant draft conclusion. Singapore also stressed that "determining what constitutes a 'deliberate' abstention will ultimately be a factual exercise dependent on all the circumstances of the case," and to avoid doubt "any inaction, or deliberate abstention from acting, relied upon in identifying a rule of customary international law must be accompanied by opinio juris." 112

The United States emphasized that, in its view, "in order for a State's inaction to 'count' as State practice, it must be shown that the State had full knowledge of the facts and deliberately declined to act." 113 The United States advocated adding language to the draft conclusion that "it is recognized that this deliberate abstention may be difficult to demonstrate and should not be presumed to exist." 114 Finally, the United States suggested removing the example in the commentary on deliberate inaction concerning "abstaining from the threat or use of force" on the basis that "there are so many reasons other than customary international law (including treaty and policy-based reasons) that a State may abstain from threatening or using force that it is unlikely that it could be demonstrated that a State did so out of a belief that it was required by customary international law." 115

Against this backdrop, with respect to practice as a constituent element of

108. Id.

109. Id. at 26. The Netherlands attached "much importance" to this qualification. Id.

110. Id. New Zealand noted its "hesitation" about considering inaction as part of State practice. Id.

111. Id. at 27.

112. Id.

113. Id. at 28 (emphasis added).

114. Id. (emphasis added).

115. Id. (emphasis added). In addition, the United States added that "actual operational conduct is frequently the most probative form of a State's practice." Id. at 29. 
customary international law, intention and deliberateness appear to be factors to consider when evaluating purported inaction. Other factors raised by States to consider include whether a sense of legal obligation - rather than political, diplomatic, strategic, or policy concerns - animated or otherwise sufficiently contributed to a State's inaction. Finally, the degree of factual knowledge was raised in respect of its potential role in discerning whether a State deliberately declined to act.

As for the requirement of evidence of "acceptance as law (opinio juris)," that requirement means that the practice in question must be undertaken not from mere usage or habit ${ }^{116}$ but with a sense of legal right or obligation. ${ }^{117}$ Evidence of such acceptance may take a wide range of forms. ${ }^{118}$ According to an ILC draft conclusion, "failure to react over time to a practice may serve as such evidence, provided that States were in a position to react and the circumstances called for some reaction." 119 The ILC further notes that "[w]here a State has objected to a rule of customary international law while that rule was in the process of formation, the rule is not opposable to the State concerned for so long as it maintains its objection." 120

The ILC commentary espoused the view that tolerance of practice may arise to evidence of opinio juris when both (1) a reaction to the practice was called for and (2) the State was in a position to act. ${ }^{121}$ First, reaction to the practice was said to be called for, in part, when the practice affects - usually unfavorably

116. See Draft CIL Conclusions, above note 88, at 120 (draft conclusion 9, para. 2).

117. Id. (draft conclusion 9, para. 1).

118. Id. (draft conclusion 10, para. 1). Included among the forms identified are public statements made on behalf of States; government legal opinions; diplomatic correspondence; and conduct in connection with resolutions adopted by an international organization. Id. (draft conclusion 10, para. 2).

119. Id. (draft conclusion 10, para. 3) (emphasis added).

120. Id. at 121 (draft conclusion 15, para. 1). The objection must satisfy three criteria - it must be: (i) clearly expressed; (ii) made known to other States; and (iii) maintained persistently. Id. (draft conclusion 15, para. 2). The draft conclusion concerning a "persistent objector" is, however, expressly "without prejudice to any question concerning peremptory norms of general international law (jus cogens).” Id. (draft conclusion 15, para. 3).

121. Id. at $141-42$. 
— the interests or rights of the State failing or refusing to act. ${ }^{122}$ However, as with its conclusions on subsequent practice, the ILC did not provide a concrete example regarding when reaction is called for or when practice affects the rights of the State. The Commission did, however, cite to the Sovereignty over Pedra Branca/Pulau Batu Puteh, Middle Rocks and South Ledge case for the general assertion that " $[\mathrm{t}]$ he absence of reaction may well amount to acquiescence .... That is to say, silence may also speak, but only if the conduct of the other State calls for a response." ${ }^{123}$ Second, a State being in a position to react means, in the view of the ILC, the following:

[T] he State concerned must have had knowledge of the practice (which includes circumstances where, because of the publicity given to the practice, it must be assumed that the State had such knowledge), and that it must have had sufficient time and ability to act. Where a State did not or could not have been expected to know of a certain practice, or has not yet had a reasonable time to respond, inaction cannot be attributed to an acknowledgment that such practice was mandated (or permitted) under customary international law. ${ }^{124}$

In their comments, several States cautioned that the draft conclusions should not read too much into silence or inaction because a range of non-legal factors might inform why a State chooses to react or refrain from reacting to a particular situation. States also emphasized that they may react in a confidential manner away from public view, which could appear to others as inaction but would in fact constitute a response.

For example, according to the Czech Republic:

There could be various reasons why States do not react to practice of other States, even if they could be generally presumed to do so. States may fail or refuse to react simply due to diplomatic and political considerations or because of lack of capacity or lack of direct interest in the relevant concrete conduct of other State (States). Thus, the reasons why States do not react in a specific case may have nothing to do with the legal

122. Id. at 142 .

123. Id. (citing to Sovereignty over Pedra Branca/Pulau Batu Puteh, Judgment, above note 10, at 50-51).

124. Id. (emphasis added). 
assessment of the practice and their (non-)reaction to such practice.

$\cdots$

[M] ore attention [should be] paid[] ... to the differentiation between, on the one hand, failure to react by States which are particularly (specially, directly) interested, concerned and affected by relevant practice of other States and are aware of the legal significance of their reaction or failure to react, and, on the other hand, inaction or failure to react by other States, which may be based on political, practical or other non-legal considerations and which does not stem from the sense of customary legal obligation. ${ }^{125}$

Israel echoed this point, stating that "mere failure to react does not, on its own, constitute practice to begin with: when a State simply refrains from acting, it lacks practice ... only express evidence explaining the State's reasons for refraining from acting can indicate whether it lacks practice vis-à-vis the alleged customary rule or whether it deliberately abstained due to opinio juris and thus had negative practice." 126 To illustrate this point, Israel explained the following:

[W]hen a State fails to protest against another State fishing in its maritime zones ... its failure to react alone does not constitute opinio juris indicating that it views such fishing activity as permissible under international law. It may very well be that the motivation for not protesting and allowing the practice is political or diplomatic, or that the State is in fact protesting the practice but for various reasons only does so in a private and confidential manner. Consequently, silence by the State in these circumstances cannot in itself be seen as opinio juris. ${ }^{127}$

The Netherlands stated that the "rule is not that silence implies acquiescence, but rather that in a particular situation in which it was clear that reaction was called for, no such reaction came." 128 The Netherlands suggested that the draft conclusions should better account for "the role of explanations

125. Int'l L. Comm., 70th Sess., A/CN.4/716 (Feb. 14, 2018), 39 (emphasis added).

126. Id. at 40 (emphasis original).

127. Id.

128. Id. at 41 (emphasis added). 
that States may at a later stage give for certain positions and their possible silence .... [and] that a State does protest but does so in a confidential, or at least not public, manner ... we are of the view that the fact that there is no public reaction to certain conduct cannot be taken as evidence of acceptance as law of that conduct." 129

New Zealand argued that a failure to react to another State's practice cannot assume acquiescence or acceptance of law because " $[t]$ here are many legitimate reasons why a State may not publicly react to, or protest against, the actions of another State. States must balance a range of interests when considering whether and how to respond to the actions of another State, including the maintenance of friendly relations and the effective functioning of international affairs." 130 Moreover, this is particularly true "where a State has not been directly affected by the actions taken or has no other particular interest in them. In other cases, a State may judge it more appropriate to react on a confidential basis." 131

In the view of the United States, a State's failure to act "rarely evidences its views on international law." 132 This is because political or practical reasons such as "to avoid a bilateral irritant, to address domestic political concerns, or other non-legal reasons" - may motivate the State not to act. ${ }^{133}$ The United States sought to clarify that "a State's deliberate inaction must be motivated by legal considerations to reflect opinio juris ... [and] that States frequently choose for political (international or domestic) or other reasons, such as limited government resources, to refrain from engaging in legally permissible acts." 134

In sum, States thus raised several factors - including the rights of the State, knowledge of the practice, timing, and ability to act - that might be relevant in respect of the possibility that silence or acquiescence may contribute to evidence that a general practice was accepted as law (opinio juris). Several States also added

\footnotetext{
129. Id.

130. Id.

131. Id. (emphasis added).

132. Id. at 42 (emphasis added).

133. Id.

134. Id.
} 
that, to entail such relevance, the inaction should derive from a sense of legal obligation or right, rather than non-legal considerations, such as resource constraints, international or domestic political calculations, or diplomatic relations. Finally, States called for caution in this connection because in some contexts States might react in private, and in respect of these instances reactions occur in fact irrespective of whether they are externally visible.

\section{Status of Norms}

The legal effects, if any, of silence or inaction may depend in part on the modalities through which a relevant norm may be formed, modified, or terminated. That assessment may depend, in turn, on the relative status of the norm at issue.

With respect to status, rules of a jus dispositivum character may be distinguished in certain respects from rules of a jus cogens character (the latter as a form of lex superior). ${ }^{135}$ In a nutshell, rules of a jus dispositivum character have been said to consist of those "rules of international law that may be modified, abrogated or derogated from by the agreement of States." 136 At least under the second sentence of article 53 of the VCLT, a jus cogens norm is "a peremptory norm of general international law ... accepted and recognized by the international community of States as a whole as a norm from which no derogation is permitted and which can be modified only by a subsequent norm of general international law having the same character." 137

135. According to scholar Georg Schwarzenberger, jus dispositivum comprises those rules of international "law capable of being modified by contrary consensual engagements." GEORG SCHWARZENBERGER, INTERNATIONAL LAW AND ORDER 5 (1971).

136. Int'l L. Comm., Report of the International Law Commission, A/71/10, 68th Session, Supp. No. 10, 2016, 299. "Most of international law" - at least according to the ILC Study Group on the Fragmentation of International Law — "is dispositive" in this sense. Int'l L. Comm., Conclusions of the work of the Study Group on the Fragmentation of International Law: Difficulties arising from the Diversification and Expansion of International Law, in Report of the Commission to the General Assembly on the work of its fifty-eighth session, Y.B. INT'L L. COMM., vol. II, part two, 2006, A/CN.4/SER.A/2006/Add.l (Part 2), 178. See also Draft Articles on the Law of Treaties with commentaries, Y.B. INT'L L. Comm., 1966, Vol. II, A/CN.4/SER.A/1966/Add.1, 248 (stating, with respect to draft art. 50 [ultimately art. 53] of the VCLT, that "the majority of the general rules of international law do not have" the character of jus cogens, "and States may contract out of them by treaty.").

137. VCLT art. 53, second sentence (emphasis added). Note that that definition, stricto sensu, applies only in respect of the 
The ILC included provisions pertaining to peremptory norms of general international law in its 2001 (Draft) Articles on the Responsibility of States for Internationally Wrongful Acts and its 2011 (Draft) Articles on the Responsibility of International Organizations. ${ }^{138}$ Those sets of provisions contain both an obligation on all States to not recognize legal situations created by violations ${ }^{139}$ (in particular, in the words of those Articles, by any "serious breach" of an obligation arising under a peremptory norm of general international $\operatorname{law}^{140}$ ) and an obligation to cooperate through lawful means to bring such violations to an end. ${ }^{141}$ To the extent a norm is of a peremptory status, the silence of States or an international

VCLT. At least according to André de Hoogh, a "sensible construction" might be found in the proposition that a jus cogens norm ought to be based on a universal rule of customary international law. André de Hoogh, Jus Cogens and the Use of Armed Force, in THE OXFORD HANDBOOK OF THE USE OF FORCE IN INTERNATIONAL LAW 1163 (Marc Weller ed., 2015) (citations omitted). Assuming that that proposition holds, "[t]he determination of the existence of a peremptory norm ... involves a two-stage process: (1) the establishment of a norm of general international law, that is, a universal rule of customary international law; and (2) acceptance and recognition of such a norm as one from which no derogation is permitted." Id. (citations omitted). With respect to prevalence of norms, pursuant to article 103 of the U.N. Charter, "[i]n the event of a conflict between the obligations of the Members of the United Nations under the present Charter and their obligations under any other international agreement, their obligations under the Charter shall prevail." U.N. Charter art. 103. In the two Questions of Interpretation and Application of the 1971 Montreal Convention arising from the Aerial Incident at Lockerbie cases, the ICJ considered that prima facie - at the stage of proceedings on provisional measures - the obligation entailed in article 25 of the Charter extended to the decision contained in Security Council resolution 748 (1992) and that, "in accordance with Article 103 of the Charter, the obligations of the Parties in that respect prevail over their obligations under any other international agreement ...." Questions of Interpretation and Application of the 1971 Montreal Convention arising from the Aerial Incident at Lockerbie (Libya v. U.K.), Provisional Measures, Order of April 14, 1992, 1992 I.C.J. Reports, 3, 15 (Apr. 14); Questions of Interpretation and Application of the 1971 Montreal Convention arising from the Aerial Incident at Lockerbie (Libya v. U.S.A.), Provisional Measures, Order of April 14, 1992, 1992 I.C.J. Reports, 114, 126 (Apr. 14).

138. See, among other provisions, Int'l L. Comm., (Draft) Articles on the Responsibility of States for Internationally Wrongful Acts arts. 40-41, in Report of the International Law Commission, A/56/10, 56th Session, Supp. No. 10, 2001, 29 (hereinafter, (Draft) Articles on State Responsibility); Int'l L. Comm., (Draft) Articles on the Responsibility of International Organizations arts. 41-42, in Report of the International Law Commission, A/66/10, 63rd Session, Supp. No. 10, 2011, 52 (hereinafter, (Draft) I.O. Responsibility Articles).

139. See (Draft) Articles on State Responsibility art. 41(2), above note 138, at 29 ("No State shall recognize as lawful a situation created by a serious breach within the meaning of article 40 , nor render aid or assistance in maintaining that situation."); (Draft) I.O. Responsibility Articles art. 42(2), above note 138, at 62 ("No State or international organization shall recognize as lawful a situation created by a serious breach within the meaning of article 41 , nor render aid or assistance in maintaining that situation.").

140. See (Draft) Articles on State Responsibility art. 40, above note 138, at 29; (Draft) I.O. Responsibility Articles art. 41, above note 138 , at 62 .

141. See (Draft) Articles on State Responsibility art. 41(1), above note 138, at 29; (Draft) I.O. Responsibility Articles art. 42(1), above note 138 , at 62 . 
organization in the face of a violation of that norm may run counter to these provisions of the Articles on the Responsibility of States or International Organizations, respectively - though caution is warranted in making any such finding in light of the polysemous character of silence. ${ }^{142}$

\section{E. Conclusion}

$\mathrm{T}$ various contexts pertaining to the identification and interpretation of international-law sources, silence has been treated as legally significant, though not without dispute.

With respect to treaty law, it appears that silence, or inaction, is capable of producing legal effects in relation to the establishment of an interpretive agreement of a treaty provision if the circumstances require a reaction. The finality of the circumstances and the party's awareness of them might be two factors to consider in that regard. As noted above, a review of States' comments on an early submission of the ILC relevant draft conclusions indicates that, by and large, those States adopted a relatively restrictive approach to the circumstances under which silence or inaction may establish an interpretive agreement of a treaty provision.

With respect to customary international law, it appears that State practice may, under certain circumstances, include inaction. Intention and deliberateness appear to be factors to consider when evaluating such purported inaction, as well as whether a sense of legal obligation (rather than political, diplomatic, strategic, or policy concerns) animated or otherwise sufficiently contributed to the State's inaction. Finally in this connection, the degree of factual knowledge may be raised in respect of its potential role in discerning whether a State deliberately declined to act. Regarding evidence to establish that a general practice is accepted as law (opinio juris), it appears that failure to react over time to a practice may serve as such evidence, provided that States were in a position to react and that the circumstances called for some reaction. In that context, several factors - including the rights of the State, knowledge 
of the practice, timing, and ability to act - might be relevant. Moreover, it appears that to entail such relevance, the silence should derive from a sense of legal obligation or right, rather than non-legal considerations, such as resource constraints, domestic political calculations, or diplomatic relations. Finally, caution has been called for because in some contexts States might react in private, and in respect of these instances reactions occur in fact irrespective of whether they are externally visible.

While silence may in general "speak" in these ways in both treaty law and customary international law, an additional element for consideration is the status of the norm at issue, in particular whether or not it is of a jus cogens character.

\section{SilENCE IN JUS AD BELLUM}

$\mathrm{S}$ ilence may be of particular concern in respect to jus ad bellum. As noted in the introduction, the significance of silence here derives in part from the foundational importance of the subject-matter itself: the prohibition of the threat or use of force in international relations. ${ }^{143}$ In addition, the structure of the legal field - which is made up largely of customary international law alongside a few treaty-law provisions and which is hotly contested and frequently debated - seems to invite a reliance on silence as acquiescence in, or support for, competing legal views. In this context, it should not be surprising that the purported silence or inaction of some international actors has been routinely invoked by several writers as carrying the actual or potential proof of particular interpretations of the relevant U.N. Charter provisions, the existence or interpretation of certain customary rules, or the relationship between the Charter and custom. ${ }^{144}$

For several reasons, the general complexities of imbuing silence with legal significance - as sketched in Part II, above - are amplified in the field of jus ad bellum.

For example, it stands to reason that though political considerations may

143. See U.N. Charter art. 2(4) and related customary rule.

144. See Part III.D. 
motivate silence in numerous areas of international law, those considerations may be especially powerful with regard to the use of force: military alliances, other forms of wartime partnerships, and joint or competing interests in specific regions or elsewhere are all factors that might be motivating silence more (and perhaps much more) than the merits of a given legal position. As a jurisprudential matter, moreover, it is not clear that silence may be a legitimate device with respect to a jus ad bellum norm that is of a jus cogens character. ${ }^{145}$

In addition, while resort to judicial or arbitral resolution of international disputes is the exception rather than the norm in general, it is an especially rare occurrence in disputes implicating jus ad bellum. ${ }^{146}$ With no final juridical decision on the legal arguments, competing legal narratives - including those that rely on silence - appear to have a greater potential to affect the development of the law (and potentially State conduct as well).

Finally, while our focus so far has been on the silence of States, the field of jus ad bellum accords a special role to the U.N. Security Council. As the primary institution entrusted with safeguarding international peace and security, the Security Council plays a tripartite role of (quasi-)legislator, adjudicator, and enforcer in many matters pertaining to use of force. A lack of response - including inaction - by the Council itself, as well as States' lack of reactions in relation to relevant Council conduct, introduce additional layers of silence that might have legal significance. Indeed, at least for some international-law scholars, it does.

In what follows, we elaborate on these various elements that may lend silence particular significance in the jus ad bellum field. We first describe the relevant parts of the structure of the field, and then highlight aspects

145. See Part III.B.

146. But see U.N. Charter art. 33(1) ("The parties to any dispute, the continuance of which is likely to endanger the maintenance of international peace and security, shall, first of all, seek a solution by negotiation, enquiry, mediation, conciliation, arbitration, judicial settlement, resort to regional agencies or arrangements, or other peaceful means of their own choice."). See generally Claus Kreß, The International Court of Justice and the 'Principle of Non-Use of Force', in THE OXFORD HANDBOOK OF THE USE OF FORCE In INTERNATIONAL LAW 561-604 (Marc Weller ed., 2015); Vaios Koutroulis, The Prohibition of the Use of Force in Arbitrations and Fact-Finding Reports, in THE OXFORD HANDBOOK OF THE USE OF FORCE IN INTERNATIONAL LAW 605-26 (Marc Weller ed., 2015); Mark Weisburd, Use of Force: Justiciability and Admissibility, in THE OXFord HANDBOOK OF THE USE OF ForCE IN INTERNATIONAL LAW 329-46 (Marc Weller ed., 2015). 
concerning modification and status of norms. Next, we discuss the role of the Security Council in this area. Finally, we give examples of invocations by scholars of silence in relation to jus ad bellum.

\section{A. Structure of the Field}

Compared to certain other fields, such as the law of armed conflict and treaty provisions. Some of the primary treaty provisions that regulate this field at the international level ${ }^{147}$ are laid down in articles $2(4), 39-42$, and 51 of the U.N. Charter.

Customary international law is often treated as a key means to help resolve legal disputes, fill-in perceived gaps in the law, and further develop the legal framework. ${ }^{148}$ For example, the ICJ has elaborated its views on certain complexities in discerning the relationship between jus ad bellum customary international law and the U.N. Charter. In 1986, for instance, in the Military and Paramilitary Activities in and against Nicaragua case, the ICJ expressed the view that "Article 51 of the Charter is only meaningful on the basis that there is a 'natural' or 'inherent' right of self-defence, and it is hard to see how this can be other than of a customary nature, even if its present content has been confirmed and influenced by the Charter." 149 Furthermore, in that same case, the ICJ also formed the position that "the Charter gave expression in this field to principles already present in customary international law, and that law has in the subsequent four decades developed under the influence of the Charter, to such an extent that a number of rules contained in the Charter

147. We do not address treaty provisions pertaining to the non-use of force that are laid down in regional or bilateral treaties. 148. For its part, the ICJ held in the Military and Paramilitary Activities in and against Nicaragua case that "[ $\mathrm{t}]$ here can be no doubt" that at least certain "issues of the use of force and ... self-defence ... are issues which are regulated both by customary international law and by treaties, in particular the United Nations Charter." Military and Paramilitary Activities in and against Nicaragua (Nicar. v. U.S.A.), Judgment, 1986 I.C.J. Reports, 16, 27 (June 27) (emphasis added) (hereinafter, Military and Paramilitary Activities, Judgment).

149. Id. (referring to the French text ("droit naturel") and to English text ("inherent right") in the first sentence of article 51 of the U.N. Charter) (emphasis added). 
have acquired a status independent of it." ${ }^{150}$

Ultimately, it is in the interaction between treaty law and customary international law - and, where relevant, among other sources as well, such as unilateral acts - that existing jus ad bellum is to be found. ${ }^{151}$

Over the last several decades numerous debates concerning jus ad bellum have generated voluminous and wide-ranging arguments. Several of those debates have addressed such matters as what constitutes an "armed attack" in the sense of the first sentence of article 51 of the U.N. Charter (and its customary counterpart, if any); ${ }^{152}$ how to apply the customary jus ad bellum principles of necessity ${ }^{153}$ and proportionality; ${ }^{154}$ and whether - and, if so, under what conditions - a State may use force preemptively, may engage in "humanitarian intervention," or may undertake military action against non-state actors in a foreign territory absent both consent of the territorial State and authority from the Security Council. ${ }^{155}$ Though relying on the same sources of law, an array of States, international organizations, courts, scholars, and NGOs have often reached remarkably discordant conclusions on these and other pressing jus ad bellum questions.

Of course, not all international actors participate in all of these debates all of the time. It seems that more often than not, States act without other States reacting, or make statements to which other States do not respond. Arguments are leveled but are often not met with either counterarguments or support. The

\footnotetext{
150. Id. at $96-97$.

151. On simultaneous regulation by treaty law and customary international law, see BUGA, above note 28, at 209; Rebecca Crootof, Change Without Consent: How Customary International Law Modifies Treaties, 41 YALE J. INT'L L. 237 (2016); Bing Bing Jia, The Relations between Treaties and Custom, 9 CHINESE J. INT'L L. 81 (2010); Yoram Dinstein, The Interaction Between Customary International Law and Treaties, 32 RECUEIL DES COURS 246 (2007); MARK E. VILLGER, CUSTOMARY INTERNATIONAL LaW AND Treaties: A MANual on the Theory and Practice of the INTERRElation OF SOURCES (2d ed., 1997).

152. See generally TOM RUYs, 'ARMEd ATTACK’ AND ARTICLE 51 OF THE UN CHARTER (2010).

153. See, e.g., Olivier Corten, Necessity, in THE OXford HANDBOOK OF THE UsE OF ForCE IN INTERNATIONAL LAW 861-878 (Marc Weller ed., 2015).

154. See, e.g., Sina Etazazian, The nature of the self-defence proportionality requirement, 3 J. USE OF FORCE \& INT'L L. 1 (2016). 155. See generally Christine Gray, International LaW AND the USE OF ForCE (4th ed., 2018); Yoram Dinstein, WaR, AgGression AND SELF-Defence (6th ed., 2017); Olivier CorTen, The LaW Against WAR (2012).
} 
same seems to hold for speech and other conduct by the ICJ, international organizations, NGOs, and scholars. In short, a formal or even an informal arbitration of these questions is an exceptional occurrence. Indeed, in only a handful of cases has the ICJ ever addressed jus ad bellum arguments - and no other existing court has standing general jurisdiction to do so. ${ }^{156}$ The Security Council more routinely addresses instances of the use of force. Yet, as we discuss below, Security Council practice does not provide a clear answer to these questions.

As for the legal role of silence, rarely, if ever, will a State expressly indicate that it is placing reliance on the silence or inaction of other States or other international actors to ground a legal claim. That lack of acknowledgment, however, does not negate the fact that the silence of States or the Security Council may be playing a role in influencing a State's perception of its legal rights and responsibilities.

Where reliance on silence to make legal arguments is perhaps most common and explicit is in international-law scholarship, which, as we have noted in the introduction, has the capacity, however indirectly, to influence both law and State conduct. (We give examples of the invocation by scholars of silence by States and the U.N. Security Council in subsection D below.)

\section{B. Modification and Status of Norms}

With respect to modification, in general if a norm is of a jus dispositivum
character (and therefore not of a jus cogens character), it may be adjusted - and even terminated - through an operation of regular treaty law or customary international law. ${ }^{157}$ Yet in respect to jus ad bellum, a preliminary question concerns whether or not silence is well-suited to operate in respect to this field at all.

Regarding treaties, in general both subsequent practice in connection with the

156. But see Rome Statute of the International Criminal Court arts. 8 bis, 15 bis-15 ter, 2187 U.N.T.S. 3 (entry into force July 1, 2002) (jurisdiction over the crime of aggression).

157. On the question concerning modification of jus cogens norms, see Dinstein, above note 151, at 397-403. 
treaty $^{158}$ and subsequent customary law ${ }^{159}$ may serve as means of treaty modification. However, with respect to articles 2(4) and 51 of the U.N. Charter in particular, it has been argued that it will be "extremely hard to modify the existing practice as derived from the text" "[g]iven the strong textual presumption against the use of force" in those provisions. ${ }^{160}$

Regarding customary international law, in general the reactions of other States to a purported new position would be a key element to discern relevant attitudes. ${ }^{161}$ It has been argued that it will be necessary to consider "whether the accumulation of apparent breaches denotes that the breach is no longer a breach but instead a signal of an erosion in the law hitherto in effect." 162 That is because "if breaches of a customary rule gain an impetus of their own, and if - over a period of time - numerous other States follow in the footsteps of the pioneering State that first defied an existing custom, the legal situation metamorphoses." 163 Even if States are at variance with each other for an intermediate period, "once the pendulum of communal opinio juris palpably swings in the direction of the new custom, a red line is crossed. From then on, a transformation occurs from one customary legal regime to another." ${ }^{164}$ It is in this way that "[o]ne of the special

158. See BUGA, above note 28 , at 107-194.

159. See id. at $195-235$

160. Jessica Liang, Modifying the UN Charter through Subsequent Practice: Prospects for the Charter's Revitalisation, 81 NORDIC J. INT'L L. 1, 19 (2012) ("Larger changes, especially when consistently attempted, are bound to attract controversy and produce objections. In this regard, the most immediate field of operation under the Charter is that of the use of force. Given the strong textual presumption against the use of force as construed from Article 2(4) and the limited circumstances in which the use of force is permitted under Article 51 and Chapter VII, it will be extremely hard to modify the existing practice as derived from the text.") (citing to Andrea Bianchi, The International Regulation of the Use of Force: The Interpretive Method, 22 LEIDEN J. INT'L L. 651, 665 (2009)).

161. See Olufemi Elias, The Nature of the Subjective Element in Customary International Law, 44 INT'L \& COMP. L. QUART. 501, 509 (1995) (arguing that " $[s]$ ome States initiate a practice, but we do not look to them for opinio juris; rather, we look to the reactions of other States to the new position. If these other States consent to (i.e. agree, acquiesce in, comply with, concur with or permit) this new practice, then there is opinio juris in relation to this new practice.") (citation omitted). See also BUGA, above note 28 .

162. Dinstein, above note 151 , at 322 (emphasis added).

163. Id. at 323.

164. Id. 
characteristics of international law is that violations of law can lead to the formation of new law." 165

It has been argued, however, that where jus cogens norms are concerned, international law might not allow - or, at least, might lay down a strong, if rebuttable, presumption against - the invocation by an acting State of the silence or inaction of a third State to establish the basis for that third State's approval of the acting State's conduct. ${ }^{166}$ That contention is based on the notion that "recourse to acquiescence might not be legally tolerable" "[w]here overarching issues in which the interests of the international order as a whole are in question...." 167 That notion is premised on two linked contentions: first, that the values underlying peremptory norms are of a universal character; and, second, that, partly as a result, the binding nature of those norms is poorly

165. Rosalyn Higgins, International Law and the Avoidance, Containment and Resolution of Disputes: General Course on Public International Law, 230 RECUEIL DES COURS 9, 44 (1991). See further id. (arguing that "this characteristic is more troublesome for those who regard law as rules, and less troublesome for those who regard law as process. But whether one believes that international law consists of rules that have been derived from consent or natural law, or whether one believes international law is a process of decision-making, with appropriate reliance on past trends of decision-making in the light of current context and desired outcomes, there still remains the question of how the 'rules' or the 'trend of decision' changes through time. And in so far as these rules or trends of decision are based on custom, then there is the related question of what legal significance is to be given to practice that is inconsistent with the perceived rules or trend of decision.").

Whether the practice and/or opinions of so-called "specially affected" States may play a (particular) role in relation to the development of customary international law on recourse to force is a subject of debate in international scholarly discourse. See, e.g., RUYS, above note 152, at 38 (inferring from ICJ jurisprudence "that acquiescence matters most when it emanates from States directly concerned with a concrete recourse to force (for instance the State against which self-defence is exercised or neighbouring States) or from a large number of States.") (citing to Buzzini, above note 6, at 85-6, 104). On "specially affected" States, see Kevin Jon Heller, Specially-Affected States and the Formation of Custom, 112 AM. J. INT'L L. 191 (2018). Also, with respect to a so-called "persistent objector," per the ILC, "[w]here a State has objected to a rule of customary international law while that rule was in the process of formation, the rule is not opposable to the State concerned for so long as it maintains its objection." Draft CIL Conclusions, above note 88, at 121 (draft conclusion 15, para. 1). The ILC indicates that that formulation is without prejudice to any question concerning peremptory norms of general international law (jus cogens). Id. (draft conclusion 15, para. 3).

166. Marques Antunes, above note 6, at para. 16 (arguing that "acquiescence is dispensed with, as far as their [that is, jus cogens norms'] binding nature is concerned").

167. Id. at para. 14. With respect to obligations erga omnes, see Bianchi, above note 160, at 663 ("Indeed, silence towards significant events, potentially affecting the interests of all states, remains enigmatic, all the more so when one realizes that nowadays many are the international fora in which states can express themselves. The relevance of acquiescence and the wider significance of the lack of reaction even by those states that are directly affected by such uses of force ought to be carefully analysed in any serious attempt to discern states' opinio juris.") (citations omitted). 
suited to the relational character typically associated with acquiescence, which has been said to usually operate in relation to concrete specific cases. ${ }^{168}$

In this context, recall, also, that - at least under the ILC's (Draft) Articles on Responsibility of States and of International Organizations - in the case of "serious breaches" of peremptory norms of general international law, all States and international organizations are under obligations both to cooperate in bringing those breaches to an end through lawful means ${ }^{169}$ and not to recognize the legal situation created by the violations. ${ }^{170}$ Under these terms, if there is a "serious breach" of a jus ad bellum norm of a jus cogens character, silence might prove a violation of the Articles on the Responsibility of States or International Organizations.

Two points merit emphasis here. First, as noted above, it is not clear what role(s), if any, silence may have in respect of identifying the existence and content of a primary jus ad bellum norm (and possible exceptions thereto). And second, there is a lack of universal agreement as to which existing jus ad bellum norms (and possible exceptions thereto), if any, are of a jus cogens character.

168. Id. For a skeptical view on whether acquiescence in the face of a violation of a peremptory jus ad bellum norm may lead to the establishment of a new or extended right to resort, see Nigel D. White, The Will and Authority of the Security Council after Iraq, 17 LEIDEN J. INT'L L. 645, 663 (2004) ("Furthermore, one should not quickly assume acceptance in the face of rules that are peremptory, such as that prohibiting the threat or use of force in Article 2(4). When practice is apparently violative of a peremptory norm, it is not enough to have acquiescence in the face of the violation in order to establish a new or extended right. It is argued that there needs to be more positive acceptance of the claim, positive proof that states have accepted the modification of the peremptory norm, proof in other words of opinio juris. Arguments about acquiescence seem to assume the emergence of new rights in a legal vacuum, but that is not the case. Brownlie puts this clearly when he states that 'the major distinguishing feature of such [peremptory] rules is their relative indelibility. They are rules of customary law which cannot be set aside by treaty or acquiescence but only by the formation of a subsequent customary rule to contrary effect.") (emphasis added; quoting BROWNLIE, above note 36, at 488).

169. See (Draft) Articles on State Responsibility art. 41(1), above note 138, at 29; (Draft) I.O. Responsibility Articles art. 42(1), above note 138, at 62. With respect to States, see generally Paolo Palchetti, Consequences for Third States as a Result of an Unlawful Use of Force, in THE OXFORD HANDBOOK OF THE USE OF FORCE IN INTERNATIONAL LAW 1224-38 (Marc Weller ed., 2015).

170. See (Draft) Articles on State Responsibility art. 41(2), above note 138, at 29; (Draft) I.O. Responsibility Articles art. 42(2), above note 138 , at 62 . 


\section{The Security Council}

s with States, the silence of the Security Council in principle can "speak." In
several respects, practice relating to and by the Security Council is particularly significant to determinations concerning the legality of uses of force.

As a preliminary matter, there are two competing approaches regarding the silence of the Council itself on jus ad bellum issues.

On one hand, the theoretical contention has been raised that because the Security Council has been characterized as having a responsibility to act to maintain international peace and security, "its silence in the face of an act of armed force across an international border must mean that it has exercised its power in the direction of concluding that the use of force was lawful." ${ }^{171}$ Further, inaction on the part of the Council could, this argument runs, constitute a legally relevant omission that engages the responsibility of the U.N. Organization. ${ }^{172}$

Yet, on the other hand, it has been argued that the procedures of the Council may, in this respect, "make it difficult to read much into Council inaction." ${ }^{173}$ For example, in light of "the veto possibility, inaction may mean that some states deemed the action unlawful but were aware that they could not muster nine affirmative votes, including those of the five permanent members, for a resolution of condemnation." ${ }^{174}$ Along these lines, it has been posited that toleration - in the sense of a lack of a reaction by the Council - falls short of (active) acceptance, and arguably only such acceptance represents a confirmation of legality. ${ }^{175}$ Alternatively, a lack of a response by the Council might mean that some Members of the Council

171. John Quigley, The Afghanistan War and Self-Defense, 37 VALParaiso UnIV. L. ReV. 541, 554 (2003).

172. It has been argued in respect of a different context - namely, whether the Council is bound to respect international law, including human rights, and thus has an obligation, under certain conditions, to act positively and not abstain — that "under the lex lata, passivity of the Council has not given rise to its international legal responsibility." Anne Peters, Article 24, in I THE Charter of the United Nations: A COMmentary 850, marginal note 199 (Bruno Simma, Daniel-Erasmus Khan, Georg Nolte, \& Andreas Paulus eds., Nikolai Wessendorf assistant ed., 3d ed., 2012).

173. Quigley, above note 171, at 554 .

174. Id.

175. Alexander Orakhelashvili, Changing Jus Cogens Through State Practice? The Case of the Prohibition of the Use of Force and its Exceptions, in THE OXFORD HANDBOOK OF THE USE OF FORCE IN INTERNATIONAL LAW 171 (Marc Weller ed., 2015). 
deemed the action lawful but were aware that they could not marshal sufficient votes for a resolution of approval. Either way, it would seem to follow at least from the reasoning of the ICJ in the Namibia advisory opinion concerning U.N. organs (albeit there in relation to the General Assembly, not to the Security Council) that the fact that a particular draft resolution is not adopted by the Council "does not necessarily carry with it the inference that a collective pronouncement is made in a sense opposite to that proposed." 176

In the context of these doctrinal uncertainties, silence in relation to the Security Council merits legal consideration in at least three dimensions.

A first dimension concerns whether, doctrinally, the silence or inaction of the Security Council may affect the interpretation of a relevant provision of the U.N. Charter and/or the identification or development of a rule of customary international law. A second dimension concerns States' communications to the Council under the second sentence of article 51 of the U.N. Charter, and the Council's response - or lack thereof - to those communications. Third, how other States respond or fail to respond to such "article 51 communications" might also be relevant here. Below, we take up these issues in turn. Following that inquiry, we sketch a brief case study on silence of States and the Security Council in relation to military action against non-state actors.

\section{Security Council Conduct}

Articles 24 to 26 of the U.N. Charter lay down the functions and powers of the Security Council. ${ }^{177}$ Several of those functions and powers pertain to jus ad bellum, including the following Charter provisions related to the Security Council: article 39 (concerning a threat to the peace, a breach of the peace, or an act of aggression), ${ }^{178}$

\footnotetext{
176. Legal Consequences of the Continuing Presence of South Africa in Namibia, 1971 I.C.J. Reports, 16, 36 (June 21) (emphasis added) (hereinafter, Namibia, Advisory Opinion). See Alexander Orakhelashvili, above note 175, at 174.

177. See U.N. Charter arts. 24-26.

178. See id. at art. 39 ("The Security Council shall determine the existence of any threat to the peace, breach of the peace, or act of aggression and shall make recommendations, or decide what measures shall be taken in accordance with Articles 41 and 42 , to maintain or restore international peace and security.") (emphasis added).
} 
article 42 (concerning taking action to maintain or restore international peace and security), ${ }^{179}$ and article 51 (concerning taking measures to maintain international peace and security if an armed attack occurs against a Member State). ${ }^{180}$

With respect to treaty law, in its draft conclusions on subsequent agreement and subsequent practice, the ILC expressed the view that the "[p]ractice of an international organization in the application of its constituent instrument may contribute to the interpretation of that instrument when applying articles 31 and 32 [of the VCLT and their customary counterparts]." 181 Thus, "[a]s to subsequent practice, not only the conduct of the member States but also that of the organs set up by the treaty has to be considered." 182 Scholars have noted, for example, that " $[\mathrm{t}]$ he Security Council has also played a role in the law of treaties by encouraging their negotiation, endorsing them, finding them obsolete, and enforcing and interpreting their provisions." 183

It is not clear, however, whether the interpretive powers of the Security Council ought to be considered to be, primarily or otherwise, of a legal nature.

179. See id. at art. 42 ("Should the Security Council consider that measures provided for in Article 41 [that is, measures not involving the use of armed force] would be inadequate or have proved to be inadequate, it may take such action by air, sea, or land forces as may be necessary to maintain or restore international peace and security. Such action may include demonstrations, blockade, and other operations by air, sea, or land forces of Members of the United Nations.") (emphasis added). In the Nuclear Weapons advisory opinion, the ICJ stated that "[a] further lawful use of force" - that is, beyond the recognition in article 51 of the inherent right of individual or collective self-defence if an armed attack occurs - "is envisaged in Article 42, whereby the Security Council may take military enforcement measures in conformity with Chapter VII of the Charter." Legality of the Threat or Use of Nuclear Weapons, Advisory Opinion, I.C.J. Reports 1996, 226, 244 (July 8) (hereinafter, Nuclear Weapons, Advisory Opinion).

180. See id. at art. 51 ("Nothing in the present Charter shall impair the inherent right of individual or collective self-defence if an armed attack occurs against a Member of the United Nations, until the Security Council has taken measures necessary to maintain international peace and security. Measures taken by Members in the exercise of this right of self-defence shall be immediately reported to the Security Council and shall not in any way affect the authority and responsibility of the Security Council under the present Charter to take at any time such action as it deems necessary in order to maintain or restore international peace and security.") (emphasis added).

181. Draft Subsequent Agreement Conclusions, above note 65, at 15 (draft conclusion 12, para. 3) (emphasis added).

182. Stefan Kadelbach, Interpretation of the Charter, in I THE CHARTER OF THE UNITED NATIONS: A COMMENTARY 80, marginal note 18 (Bruno Simma, Daniel-Erasmus Khan, Georg Nolte, \& Andreas Paulus eds., Nikolai Wessendorf assistant ed., 3d ed., 2012) (emphasis added; citing to Namibia, Advisory Opinion, above note 176, at 22).

183. The United Nations and International Law, in I OPPENHEIM'S INTERNATIONAL LAW: UNITED NATIONS 415, marginal note 12.04 (Rosalyn Higgins, Philippa Webb, Dapo Akande, Sandesh Sivakumaran, \& James Sloan eds., 2017) (citations omitted). 
One perspective sees the Council primarily as a political body whose actions may involve an array of (mostly non-legal) motivations and meanings; another perspective views the Council as having a juridical or legislative role as well. ${ }^{184}$ It seems at least arguable that the practice of the Council may carry particular force in terms of interpretation of the Charter when that practice is subsequently (also) generally accepted by Member States and evidences "a general practice of th[e] Organization." 185 The same reasoning would seem to follow if one were to give the Security Council's silence similar legal force: instead of the silence itself, it would be the views of the Member States with regard to that silence as reflecting a general practice of the United Nations (by way of the Security Council as one of the Organization's organs) that would endow the Council's silence with legal meaning. (And, of course, when the Security Council makes a decision, including a decision under its Chapter VII powers and responsibilities, Member States are obliged to accept and carry out that decision. ${ }^{186}$ )

In short, even though it cannot apparently revise the Charter as such, it seems that the Security Council may nonetheless interpret the Charter, ${ }^{187}$ though neither

184. Compare Jan Klabbers, Intervention, Armed Intervention, Armed Attack, Threat to Peace, Act of Aggression, and Threat or Use of Force: What's the Difference?, in THE OXFORD HANDBOOK OF THE USE OF FORCE IN INTERNATIONAL LAW 500 (Marc Weller ed., 2015) ("the Council is a political organ, endowed with a political task, and while its decisions will inevitably be accompanied by legal fall-out, it is not for the Council to assume the role of judicial body or lawmaker.") and Kadelbach, above note 182, at 93, marginal note 56, with Military and Paramilitary Activities, Judgment, above note 148, at 105 (expressing the view, in obiter, that, at least as a matter of the treaty law of the Charter, the Security Council is "empowered to determine the conformity with international law of the measures" reported to the Council where a State is seeking to justify those measures on the basis of self-defense) (emphasis added). It might be accurate to characterize the interpretive powers of the Council as, if not necessarily primarily legal, then at least somewhat legal in nature. That contention might accord with the approach of the ICJ in the Namibia advisory opinion. There, the ICJ formed its interpretation of the term "concurring votes of the permanent members" by relying primarily on the practice of the Council (as the competent organ) in combination with the fact that the Council's practice was then "generally accepted" by Member States and evidences a general practice of the United Nations. See Namibia, Advisory Opinion, above note 176, at 22.

185. See Commentary on the Draft Subsequent Agreement Conclusions, above note 65, at 100.

186. See U.N. Charter arts. 2(5), 2(7), 24(1), 25, 39-51, 103.

187. Peters, Article 24, above note 172, at 828, marginal note 135 (citation omitted); see also The United Nations and International Law, above note 183, at 419, marginal note 12.12 ("The Security Council has the more specific mandate of maintaining peace and security, but it has engaged in influential interpretation of the Charter. It has interpreted and modified Charter provisions on membership and voting. A 'threat to the peace' under Article 39 has evolved to include humanitarian 
authentically (in the sense of coming only from the parties themselves) nor authoritatively (in the sense of flowing from delegated powers). ${ }^{188}$

Regarding the role of the Security Council in shaping customary jus ad bellum, the ILC has suggested, as a general matter, that "[a] resolution adopted by an international organization ... may provide evidence for determining the existence and content of a rule of customary international law, or contribute to its development." ${ }^{189}$ Indeed, "[a] provision in a resolution adopted by an international organization ... may reflect a rule of customary international law if it is established that the provision corresponds to a general practice that is accepted as law (opinio juris)." 190 Yet, "the mere adoption of a resolution (or a series of resolutions) purporting to lay down a rule of customary international law does not create such law: it has to be established that the rule set forth in the resolution does in fact correspond to a general practice that is accepted as law (accompanied by opinio juris)." ${ }^{191}$ Furthermore, while practice attributable to international organizations

crises, and 'armed attack' in Article 51 has been applied to terrorism. Military measures that have been taken under Chapter VII differ from what was originally conceived of in Articles 42, 43, and 47 of the UN Charter. It has established criminal tribunals and compensation commissions, and become engaged in territorial administration.") (citations omitted).

188. See Kadelbach, above note 182, at 89, marginal note 47. The ICJ, in the Certain Expenses of the United Nations (Article 17, paragraph 2, of the Charter) advisory opinion, formulated the following position:

In the legal systems of States, there is often some procedure for determining the validity of even a legislative or governmental act, but no analogous procedure is to be found in the structure of the United Nations. Proposals made during the drafting of the Charter to place the ultimate authority to interpret the Charter in the International Court of Justice were not accepted; .... As anticipated in 1945, therefore, each organ must, in the first place at least, determine its own jurisdiction. If the Security Council, for example, adopts a resolution purportedly for the maintenance of international peace and security and if, in accordance with a mandate or authorization in such resolution, the SecretaryGeneral incurs financial obligations, these amounts must be presumed to constitute 'expenses of the Organization'.

Certain Expenses of the United Nations (Article 17, paragraph 2, of the Charter), Advisory Opinion of July 20, 1962, 1962 I.C.J. Reports, 151, 168 (July 20) (emphasis added). At least in line with that reasoning, the results of a U.N. organ's interpretation are not formally binding on the other organs. Kadelbach, above note 182, at 89, marginal note 47 (citations omitted). It has been argued that "the Security Council is authorized neither to undertake an authentic interpretation nor to amend the Charter. These powers are incumbent on the members as 'masters of the treaty"' Peters, Article 24, above note 172, at 835 , marginal note 155 .

189. Draft CIL Conclusions, above note 88 , at 121 (emphasis added).

190. Id. (draft conclusion 12, para. 3) (emphasis added).

191. Id. at 147. Here, only the practice that is attributed to the Security Council - as an organ of the U.N. Organization - 
themselves "arises most clearly where member States have transferred exclusive competences to the international organization," it is also possible that such practice "may ... arise where member States have not transferred exclusive competences, but have conferred competences upon the international organization that are functionally equivalent to powers exercised by States." ${ }^{192}$ A deployment of military forces - for instance, for peacekeeping - is one of the examples cited by the ILC as practice of an international organization that may contribute to the formation, or expression, of rules of customary international law. ${ }^{193}$ It seems at least arguable that only certain rules of customary international law - namely, those (1) whose subject matter falls within the mandate of the Security Council concerning maintenance (or restoration) of international peace and security, and/or (2) that are addressed specifically to the Council concerning maintenance (or restoration) of international peace and security - might be relevant here. ${ }^{194}$ (And again, this question would be independent of a Member State's obligation to accept and carry out a decision of the Council, including a decision made in a resolution adopted under Chapter VII. ${ }^{195}$ )

\footnotetext{
may be relevant in these ways. See id. at 130. The practice of States acting within or in relation to the Security Council remains attributable to the States concerned (not to the Council itself). See id.; see also id. at 147. For their part, Security Council resolutions (or, at least, decisions) seem to fit within the scope of resolutions capable of producing relevant legal effects. Id. at 147. Yet the ILC cautioned that resolutions "adopted by organs ... with more limited membership [than the U.N. General Assembly, such as, it can be presumed, the Security Council] may also be relevant, but their weight in identifying a rule of customary international law is likely to be less [than organs with full membership]." Id. (emphasis added). In the context of this particular ILC draft conclusion, one dimension of what may be considered relevant "is that [resolutions of organs of international organizations] may reflect the collective expression of the views of such States: when they purport (explicitly or implicitly) to touch upon legal matters, the resolutions may afford an insight into the attitudes of the member States towards such matters." Id. at 147 (emphasis added). As with "treaties, resolutions cannot be a substitute for the task of ascertaining whether there is in fact a general practice that is accepted as law (accompanied by opinio juris)." Id. In any event, the ILC exhorted that caution is required "in assessing the weight of the practice of an international organization as part of a general practice." Id. at 131. As a general rule, "the more directly a practice of an international organization is carried out on behalf of its member States or endorsed by them, and the larger the number of such member States, the greater weight it may have in relation to the formation, or expression, of rules of customary international law." Id. (emphasis added).

192. Id. at 131.

193. Id.

194. Id. That is in part because it might be argued that the only relevant practice of the Security Council is that which forms part of the practice of the U.N. Organization in the latter's international relations - and when accompanied, separately, by indications of opiniones juris of enough States - that gives rise to, or attests to, certain rules of customary international law. Id.
}

195. See above note 186 and the accompanying text. 
In a similar vein to the Council's effects on the interpretation of certain Charter provisions as a matter of treaty law, it might be the case that the Council's statements or actions that could be capable in theory of shaping customary international law are nevertheless not legally determinative in and of themselves. In this context, Professor Olivier Corten raises the prospect that where the Security Council condemns a State by qualifying the State's action as unlawful, that condemnation can be taken into account to clarify the meaning of the prohibition of the use of force, but only if it is combined with the practices and opiniones juris of enough States. ${ }^{196}$ Those opiniones juris may be expressed, for instance, in the debates that take place in Security Council meetings, and must be combined with corresponding State practice. ${ }^{197}$ Corten thus propounds that the Council may contribute - but only to this limited extent - to the emergence, crystallization, or consolidation of a customary rule of general international law. ${ }^{198}$

Having established that certain practice of the Council might be of relevance to the expression, or formation, of customary international law, what is to be made of the Security Council's silence or inaction in this area? No draft conclusion elaborated by the ILC in its relevant workstream has expressly addressed whether - and, if so, how and to what extent - a non-reaction of an international organization (or an organ thereof) may contribute to the

196. See Olivier Corten, La participation du Conseil de sécurité à lélaboration, à la cristallisation ou à la consolidation de règles coutumières, 37 REVUE BELGE DE DROIT INT'L 552, 556 (2004) (“Dans le domaine de l'interdiction du recours à la force, par exemple, le Conseil de sécurité peut condamner un Etat en qualifiant incidemment son action d'illicite, et ce en rejetant ses arguments juridiques. On peut alors se trouver devant un précédent qui, combiné à d’autres, peut être pris en compte pour préciser le sens de la prohibition de l'interdiction du recours à la force dans les relations entre Etats à partir d'une pratique du Conseil de sécurité.") (citations omitted).

197. See id. at 557 (“[L]es nombreux débats qui ont eu lieu en son sein ou dans d’autres cénacles méritentils toute lattention, dans la mesure où ils révèlent des prises de position juridiques très claires en ce domaine.") (citation omitted).

198. See id. at 553 ("Ce n’est que dans une mesure limitée que le Conseil peut prétendre contribuer à lémergence, à la cristallisation ou à la consolidation d'une règle coutumière de droit international général."). Along that line of reasoning, the Security Council has also and separately been characterized as participating in a "law-making exercise" that, among other things, "produces quasi-legislative effects through the mere affirmation and concretization of legal standards, partly through an impact on customary international law." Nico Krisch, Introduction to Chapter VII: The General Framework, in II THE Charter of the United Nations: A COMmentary 1252, marginal note 32 (Bruno Simma, Daniel-Erasmus Khan, Georg Nolte, \& Andreas Paulus eds., Nikolai Wessendorf assistant ed., 3d ed., 2012). 
identification, expression, formation, modification, or termination of customary jus ad bellum.

Four possibilities emerge. The first is to endow the Security Council's purported silence with no legal significance whatsoever, given the political workings and constraints of the institution. Second, with respect to the "practice" element of customary international law, it might be argued that Security Council practice - like State practice - may, under certain circumstances, include inaction. ${ }^{199}$ As with State practice, however, perhaps "only deliberate abstention from acting may serve such a role." 200 Third, with respect to the evidence-of-opinio-juris element of customary international law, it might be argued that failure by the Security Council to react over time to a practice may serve as evidence of acceptance as law (opinio juris), provided that the Council was in a position to react and the circumstances called for some reaction. ${ }^{201}$ And fourth, it might be argued that only certain non-reactions by the Security Council - in particular, those that are combined with the practices and opiniones juris of enough States - may be capable of contributing to the emergence, crystallization, or consolidation of a customary rule of general international law concerning jus ad bellum. ${ }^{202}$

Having sketched how the Security Council might be capable, doctrinally, through its silence or inaction, of contributing to the establishment of an interpretive agreement of a relevant provision of the U.N. Charter and/or to the identification or development of a rule of customary international law, we now turn, in particular, to lack of responses by the Security Council to selfdefense communications reported to it.

199. Draft CIL Conclusions, above note 88, at 120 (draft conclusion 6, para. 1) (with respect to States).

200. Id. at 133 (emphasis added).

201. Id. at 120 (draft conclusion 10, para. 3) (with respect to States).

202. See Olivier Corten, La participation du Conseil de sécurité, above note 196, at 553. In any event, arguably the practice of the Security Council in this area (as in other areas) may not, in itself, be decisive in respect of a particular case. See id. at $556-57$. 


\section{Security Council Responses to Member States' "Article 51 Communications"}

Pursuant to the second sentence of article 51 of the U.N. Charter:

Measures taken by Members in the exercise of this right of self-defence [that is, the inherent right of individual or collective self-defence if an armed attack occurs against a Member of the United Nations] shall be immediately reported to the Security Council and shall not in any way affect the authority and responsibility of the Security Council under the present Charter to take at any time such action as it deems necessary in order to maintain or restore international peace and security. ${ }^{203}$

In relation to that provision, the Security Council is - at least in a conception of the ICJ (though apparently in obiter) - "empowered to determine the conformity with international law of the measures that the [reporting] State is seeking to justify on th[e] basis [of self-defense]." 204

Security Council practice in response to "article 51 communications" ranges significantly. According to the new HLS PILAC catalogue, the most common reaction by far is for the Security Council not to respond to "article 51 communications," at least in a formal sense. Indeed, according to that catalogue of self-defense communications covering the 1945-2018 period, the Security Council responded formally - at least in the sense of a provision in an act of the Council or in a presidential statement - to only about one-tenth of the identified self-defense communications. ${ }^{205}$

Where it does formally respond to such communications, the Security Council often couches its reactions not in legal terminology but rather in more politically oriented terms, such as by expressing its concern. For example, in response to an "article 51 communication" from Armenia, in a Presidential

203. U.N. Charter art. 51, second sentence (emphasis added). On the reporting requirement, see James A. Green, The Article 51 Reporting Requirement for Self-Defense Actions, 55 VIRGINIA J. INT'L L. 563 (2015); D. W. Greig, Self-Defense and the Security Council: What Does Article 51 Require?, 40 InT'L \& COMPARATIVE L. QUARTERLY 366 (1991); Jean Combacau, The Exception of Self-Defense in U.N. Practice, in THE CuRRENT Legal Regulation of THE UsE OF ForCE 9-38 (Antonio Cassese ed., 1986). 204. Military and Paramilitary Activities, Judgment, above note 148, at 105.

205. See Annex. 
Statement the Security Council "expresse[d] its serious concern at the deterioration of relations between the Republic of Armenia and the Azerbaijani Republic and at the tensions between them." ${ }^{206}$ The Statement did not proceed to make any legal evaluation of the Armenian claims.

Condemnations of illegality by the Security Council are relatively rare in this context, but they have occurred. For example, in the 2611th meeting of the Security Council, on October 2nd, 1985, Israel characterized its military action against Palestinian Liberation Organization targets in Tunisia as "a legitimate act of selfdefence." ${ }^{207}$ In operative paragraphs 2 and 3 of resolution 573 (1985), the Council " $[c]$ ondemn[ed] vigorously the act of armed aggression perpetrated by Israel against Tunisian territory in flagrant violation of the Charter of the United Nations, international law and norms of conduct" and "[d]emand[ed] that Israel refrain from perpetrating such acts of aggression or from threatening to do so ...."208

\footnotetext{
206. In response to (among other things) Armenia, S/26328 (Aug. 18, 1993), see U.N. Security Council, Presidential Statement S/26326 (Aug. 18, 1993), at 1 ("The Security Council expresses its serious concern at the deterioration of relations between the Republic of Armenia and the Azerbaijani Republic and at the tensions between them. The Council calls upon the Government of Armenia to use its influence to achieve compliance by the Armenians of the Nagorny Karabakh region of Azerbaijan with Council resolutions 822 (1993) and 853 (1993)."). As another example, in response to (among other things) Croatia, S/1995/647 (Aug. 4, 1995), see U.N. Security Council, Presidential Statement S/PRST/1995/38 (Aug. 4, 1995), at 1 ("The Security Council is deeply concerned at the resumption of hostilities in and around the Republic of Croatia. The Council recalls the statement by its President of 3 August 1995. It strongly deplores the decision by the Croatian Government to launch a broad military offensive, thereby unacceptably escalating the conflict, with the risk of further consequent attacks by whatever party, and demands that all military action cease immediately and that there be full compliance with all Council resolutions including resolution 994 (1995).").
}

207. S/PV.2611 (Oct. 2, 1985), Israel, at 5.

208. U.N. Security Council, resolution 573 (1985), S/RES/573(1985), Oct. 4, 1985, OPs 1-2. See also, in response to (among other things) Israel, S/3525 (Jan. 3, 1956), see U.N. Security Council, resolution 111 (1956), S/RES/111(1956), Jan. 19, 1956, OP 3 ("Condemns the attack of 11 December 1955 [by Israel regular army forces against Syrian regular army forces on Syrian territory] as a flagrant violation of the cease-fire provisions of its resolution of 15 July 1948, of the terms of the General Armistice Agreement between Israel and Syria, and of Israel's obligations under the Charter" (adopted unanimously); in response to (among other things) S/PV.1320 (Nov. 16, 1966), Israel, at 14, see U.N. Security Council, resolution 228 (1966), S/RES/228(1966), Nov. 25, 1966, OP 2 ("Censures Israel for this large-scale military action [that is, 'the grave Israel military action which took place in the southern Hebron area of 13 November 1966'] in violation of the United Nations Charter and of the General Armistice Agreement between Israel and Jordan" (14-0-1)); in respect to (among other things) Israel, S/8470 (Mar. 18, 1968), at 3, U.N. Security Council, resolution 248 (1968), S/RES/248(1968), Mar. 24, 1968, OPs 2-3 ("2. Condemns the military action launched by Israel in flagrant violation of the United Nations Charter and the ceasefire resolutions; 3. Deplores all violent incidents in violation of the cease-fire and declares that such actions of military reprisal and other grave violations of the cease-fire cannot be tolerated and that the Security Council 


\section{It is also relatively rare - but not unknown - for the Security Council to formally respond (in one of the identified ways) to communications of purported self-defense measures taken by a permanent Member of the Council. ${ }^{209}$}

would have to consider further and more effective steps as envisaged in the Charter to ensure against repetition of such acts" (adopted unanimously)); in response to (among other things) Israel, S/9089 (Mar. 17, 1969) and S/PV.1466 (Mar. 27, 1969), Israel, at 8, see U.N. Security Council, resolution 265 (1969), S/RES/265(1969), Apr. 1, 1969, OP 3 ("Condemns the recent premeditated air attacks launched by Israel on Jordanian villages and populated areas in flagrant violation of the United Nations Charter and the cease-fire resolutions, and warns once again that if such attacks were to be repeated the Security Council would have to meet to consider further and more effective steps as envisaged in the Charter to ensure against repetition of such attacks." (11-0-4)); in response to (among other things) S/9387 (Israel, Aug. 12, 1969), see U.N. Security Council, resolution 270 (1969), S/RES/270(1969), Aug. 26, 1969, OP 1 ("Condemns the premeditated air attack by Israel on villages in southern Lebanon in violation of its obligations under the Charter and Security Council resolutions" (adopted without vote)); in response to (among other things) S/PV.1537 (May 12, 1970), Israel, at 4, see U.N. Security Council, resolution 280 (1970), S/RES/280(1970), May 12, 1970, inter alia, OP 2 ("Condemns Israel for its premeditated military action in violation of its obligations under the Charter of the United Nations" (11-0-4)); see also U.N. Security Council, resolution 279 (1970), S/RES/279(1970), May 12, 1970: "Demands the immediate withdrawal of all Israeli armed forces from Lebanese territory." (unanimous); in response to (among other things) S/PV.2280 (June 12, 1981), Israel, at 8, see U.N. Security Council, resolution 487 (1981), S/RES/487(1981), June 19, 1981, OP 1 ("Strongly condemns the military attack by Israel in clear violation of the Charter of the United Nations and the norms of international conduct" (15-0-0)).

209. E.g., in response to (among other things) France, S/4864 (July 21, 1961), at 5, see U.N. Security Council, resolution 164 (1961), S/RES/164(1961), July 22, 1961, OPs 1-2 ("1. Calls for an immediate cease-fire and a return of all armed forces to their original position; 2. Decides to continue the debate" (10-0-0)); in response to (among other things) United Kingdom, S/15119 (May 25, 1982), see U.N. Security Council, resolution 505 (1982), S/RES/505(1982), May 26, 1982, OP 4 ("Requests the Secretary-General to enter into contact immediately with the parties with a view to negotiating mutually acceptable terms for a cease-fire, including, if necessary, arrangements for the dispatch of United Nations observers to monitor compliance with the terms of the cease-fire" (15-0-0); in response to (among other things) United States, S/21492 (Aug. 10, 1990), United Kingdom, S/21501 (Aug. 13, 1990), and United States, S/21537 (Aug. 16, 1990), see U.N. Security Council, resolution 665 (1990), S/RES/665(1990), Aug. 25, 1990, OP 1 ("Calls upon those Member States co-operating with the Government of Kuwait which are deploying maritime forces to the area to use such measures commensurate to the specific circumstances as may be necessary under the authority of the Security Council to halt all inward and outward maritime shipping, in order to inspect and verify their cargoes and destinations and to ensure strict implementation of the provisions related to such shipping laid down in resolution 661 (1990)" (13-0-2) and U.N. Security Council, resolution 678 (1990), S/RES/678(1990), Nov. 29, 1990, OP 2 ("Authorizes Member States co-operating with the Government of Kuwait, unless Iraq on or before 15 January 1991 fully implements, ... the above-mentioned resolutions, to use all necessary means to uphold and implement resolution 660 (1990) and all subsequent relevant resolutions and to restore international peace and security in the area" (12-2-1)); in response to (among other things) Kazakhstan, Kyrgyzstan, Russia, and Tajikistan, S/26290 (Aug. 11, 1993), at 2, see Note by the President of the Council S/26341 (Aug. 23, 1993), at 1 ("The Council expresses its deep concern at the continuing violence and armed conflict in Tajikistan, at the escalating crisis along the Tajik-Afghan border, and at the risk of the conflict threatening the peace and stability of Central Asia and beyond. [ $]$ The Council stresses the urgent need for the cessation of all hostile actions on the Tajik-Afghan border....); arguably in response to (among other things) United States, S/2014/695 (Sept. 23, 2014), United Kingdom, S/2014/851 (Nov. 26, 2014), United Kingdom, S/2015/688 (Sept. 8, 2015), and France, S/2015/745 (Sept. 9, 2015), see U.N. Security Council, resolution 2249 (2015), S/RES/2249(2015), Nov. 20, 2015, PP v, OP 5 ("Determining that, by its violent extremist ideology, its terrorist acts, its continued gross systematic and widespread attacks directed against civilians, 


\section{States' Reactions to "Article 51 Communications"}

Individual States seem to respond - be it in support, opposition, or something else - to self-defense communications reported to the Council relatively infrequently and irregularly. ${ }^{210}$ Perhaps the most common setting in which States respond to "article 51 communications" are meetings of the Council. That said, according to the HLS PILAC catalogue, comparatively few such reports - or even the conduct or claims communicated in those reports - are discussed at any Security Council meeting. ${ }^{211}$ Yet, as noted above, the response or lack of response by States - whether to "article 51 communications" or to Council reactions to those communications - may matter in respect of treaty law and of customary international law.

There is strong evidence to support the view that most States are not systematically made aware of most of these self-defense communications in a timely manner, if at all. States that are not members of the Security Council seeking to stay abreast of "article 51 communications" in real-time apparently need to consult the full text of all Security Council documents and Security Council meeting transcripts. ${ }^{212}$ That is the case regarding Security Council

\footnotetext{
abuses of human rights and violations of international humanitarian law, including those driven on religious or ethnic ground, its eradication of cultural heritage and trafficking of cultural property, but also its control over significant parts and natural resources across Iraq and Syria and its recruitment and training of foreign terrorist fighters whose threat affects all regions and Member States, even those far from conflict zones, the Islamic State in Iraq and the Levant (ISIL, also known as Daesh), constitutes a global and unprecedented threat to international peace and security, ... [5] Calls upon Member States that have the capacity to do so to take all necessary measures, in compliance with international law, in particular with the United Nations Charter, as well as international human rights, refugee and humanitarian law, on the territory under the control of ISIL also known as Da'esh, in Syria and Iraq, to redouble and coordinate their efforts to prevent and suppress terrorist acts committed specifically by ISIL also known as Daesh as well as ANF, and all other individuals, groups, undertakings, and entities associated with Al Qaeda, and other terrorist groups, as designated by the United Nations Security Council, and as may further be agreed by the International Syria Support Group (ISSG) and endorsed by the UN Security Council, pursuant to the Statement of the International Syria Support Group (ISSG) of 14 November, and to eradicate the safe haven they have established over significant parts of Iraq and Syria" (15-0-0)).

210. But see, e.g., below notes 217-222 and the accompanying text; see also Remarks by Patrick Luna, 112 AM. SOC'Y INT'L L. PROC. 50 (2018).

211. See Annex.

212. See The Procedure of the UN Security Council (Loraine Sievers \& Sam Daws eds., 4th ed., 2014), Online Supplement, Mar. 10, 2018, https://www.scprocedure.org/chapter-7-section-12b, permalink: https://perma.cc/6UK5-
} 
documents because, "as ... with all other official documents listed in the [U.N.] Journal, no description [of each document containing an 'article 51 communication'] is supplied, so that those interested in identifying communications submitted pursuant to Article 51 must consult the full text of all regular S/documents." ${ }^{213}$ In terms of scale, it appears that in 2018 at least 1183 documents were given such a document symbol and published as an official Security Council document. Moreover, that tally does not include the verbatim records of Security Council meetings, at which self-defense measures might be communicated (in addition to or separate from a written report). ${ }^{214}$ In 2018 , the Security Council conducted 287 meetings. ${ }^{215}$ In comparison, the HLS PILAC catalogue records that in 2018 four "article 51 communications" were submitted to the Council. ${ }^{216}$ In light of these figures, it would not seem wholly misplaced, at least in respect of 2018, to offer the "needle in a haystack" metaphor.

Informal discussions with several legal advisers to Permanent Missions to the United Nations in New York suggest that, in practice, those legal advisers (at least for States that are not Members of the Security Council) are made aware contemporaneously of "article 51 communications" - if they are made aware of them at all - through a samizdat-like machinery made up of international-law blogs, informal peer networks, and other unofficial sources.

In recent years, certain States and their legal advisers have drawn attention

HFT5 ("The Mexican representative queried whether communications transmitted pursuant to Article 51 are published or referenced in the UN Journal. In fact, ... each has been given a document symbol and published as an official Security Council document.)

213. Id.

214. As noted in the Annex, it is not necessarily clear whether only written communications may count or whether verbal statements may (also) satisfy the reporting requirement laid down in the second sentence of article 51 of the U.N. Charter. So far as the authors of the catalogue are aware, the Security Council has never directly and authoritatively addressed that specific question as such, nor have other U.N. Organs or U.N. Member States writ large. The catalogue presumes that both written and verbal communications may count and therefore includes both types of communications. See Annex.

215. Security Council Meetings in 2018 (undated), http://research.un.org/en/docs/sc/quick/meetings/2018, permalink: https://perma.cc/TV7S-49H5.

216. See Turkey, S/2018/53 (Jan. 22, 2018), at 1-2; Syria, S/2018/141 (Feb. 26, 2018), at 1; Iran, S/2018/891 (Oct. 3, 2018), at 1; Turkey, S/2018/1022 (Nov. 15, 2018). 
to a perceived increase in "article 51 communications" and have expressed concern about the reporting infrastructure. For example, in 2017, in a statement made by El Salvador on behalf of the 33 States of the Community of Latin American and Caribbean States (CELAC), those States "note[d] with concern ... the increase in the number of letters to the Security Council under Article 51 of the Charter submitted by some States in order to have recourse to the use of force in the context of counter-terrorism, most of the times 'ex post facto." ${ }^{217}$ The CELAC States also "reiterate[d] that any use of force which is not in compliance with the UN Charter is not only illegal, it is also unjustifiable and unacceptable," and called for "[f] urther consideration [to] be given in an open and transparent debate on this issue." ${ }^{218}$ In 2018, in a Security Council meeting concerning the Council's working methods, the representative of Brazil called for more attention to be devoted to those working methods as they relate to the use of force. ${ }^{219}$ In connection with that call, he further stated the following:

Communications issued under Article 51 of the Charter of the United Nations - that is, invoking self-defence - and the follow-up of the relevant resolutions authorizing the use of military force are two cases in point. We have witnessed an increase in the number of letters submitted to the Council seeking to justify military action, especially in the context of counterterrorism. The current practice indicates that there is ample room for improvement with regard to the content, timing and circulation of Article 51 letters. A proper follow-up of such communications is also needed, thereby ensuring that the obligations set out in the Charter are fulfilled. ${ }^{220}$

217. El Salvador, Measures to Eliminate International Terrorism, Statement on behalf of the Community of Latin American and Caribbean States (CELAC), Oct. 2, 2017, (unpaginated) 7, http://statements.unmeetings.org/media2/16152279/elsalvador-on-behalf-of-celac-1.pdf, permalink: https://perma.cc/V2FW-ZB4B.

218. Id.

219. See S/PV.8175 (Feb. 6, 2018), Brazil, at 24.

220. Id. See also Remarks by Patrick Luna, above note 210, at 54-55 (legal adviser of Brazil stating the following: "It has been argued, also, that the rest of the membership has been silent and maybe that this silence could be interpreted as acquiescence, and this is also not a fair point for two reasons. One, it is not true that the rest of the membership has remained silent. You will find, for instance, a non-aligned movement statement that has been reiterating the position that Article 51 is not to be rewritten or reinterpreted, and, of course, the NAM [Non-Aligned Movement] compromises more than 120 member states. You would find some Latin American countries, like Brazil and Mexico, stating on the record, in the General Assembly, and 
In 2019, the Legal Adviser of the Permanent Mission of Mexico to the United Nations in New York, writing in his personal capacity, critiqued certain aspects of the article-51-reporting process. He argued that " $\mathrm{t}]$ he way in which this issue [that is, whether the purported silence of many U.N. Member States can or cannot be considered as acquiescence regarding any novel legal interpretations of article 51 of the U.N. Charter on the use of force against terrorists in a third country] is handled by the Security Council is extremely opaque, and not transparent to most Member States." ${ }^{211}$ The core issue, in his view, "is the lack of information, publicity, and transparency."222 (As we note below, Mexico has made a proposal concerning certain aspects of the article-51-reporting process. ${ }^{223}$ )

Zooming out, so far as we are aware, currently there is no publicly available, comprehensive, authoritative, and authentic catalogue of self-defense communications, let alone such a catalogue that also includes relevant associated practice - for example, responses by the Security Council and other States to such communications. It is hoped that the new HLS PILAC catalogue ${ }^{224}$ may prove valuable in this regard. But efforts by researchers are inherently limited in several important respects.

This current state of affairs - marked as it is by the lack of the timely categorization and distribution of "article 51 communications" - has arisen despite the fact that, since the advent of the United Nations, at least four avenues have been pursued to make it possible for Member States to obtain

in the Security Council, that they have problems with, for instance, the unwilling and unable doctrine. And even in academia you will find this kind of divergence, and I would like to point to the plea against the abusive invocation of self-defense as a response to terrorism that was initiated by Professor Olivier Corten and signed by more than 240 international lawyers and academics from thirty-six different countries."); Alex Moorehead, Brazil's Robust Defense of the Legal Prohibition on the Use of Force and Self Defense, JUST SECURITY, Apr. 20, 2018, https://www.justsecurity.org/55126/brazils-robust-defense-legalprohibition-force/, permalink: https://perma.cc/BYK2-AJKW.

221. Pablo Arrocha Olabuenaga, An Insider's View of the Life-Cycle of Self-Defense Reports by U.N. Member States, JUST SECURITY, Apr. 2, 2019, https://www.justsecurity.org/63415/an-insiders-view-of-the-life-cycle-of-self-defense-reports-by-un-member-states/, permalink: https://perma.cc/45N7-PZZV.

222. Id.

223. See below notes $237-39$ and the accompanying text.

224. See Annex. 
information relevant to these communications.

First, in 1952, the General Assembly authorized the Secretary-General to undertake the publication of a repertoire of the practice of the Security Council. ${ }^{225}$ Combined, the Repertoire of the Practice of the Security Council and subsequent Supplements thereto provide "a record of the evolving practice and procedure of the Security Council in the framework of the Charter of the United Nations and the provisional rules of procedure of the Security Council." ${ }^{226}$ However, Supplements are not published in real time, and the most recently finalized supplement is the 18th, which covers 2012-2013. ${ }^{227}$ Moreover, several of the "article 51 communications" identified by HLS PILAC researchers are not included under the part(s) of the published Repertoire and the Supplements thereto covering article 51.228

Second, in 1953, the General Assembly requested the Secretary-General to prepare and circulate among the Member States "a repertory of the practice of United Nations organs appropriately indexed." 229 According to the SecretaryGeneral, the purpose of the Repertory of the Practice of the United Nations Organs "is to document the Organization's application and interpretation of each individual Article of the Charter of the United Nations, to form a legislative

\footnotetext{
225. U.N. General Assembly, resolution 685 (VII) ("Ways and means for making the evidence of customary international law more readily available"), Dec. 5, 1952.

226. U.N. Secretary-General, A/73/190 ("Repertory of Practice of United Nations Organs and Repertoire of the Practice of the Security Council: Report of the Secretary-General"), July 19, 2019, para. 18. In its most recent relevant resolution, the General Assembly called upon the Secretary-General, in undertaking the Repertoire (and its Supplements), to continue to follow the modalities outlined in paragraphs 102 to 106 of his report of September 18, 1952. U.N. General Assembly, resolution 73/206 ("Report of the Special Committee on the Charter of the United Nations and on the Strengthening of the Role of the Organization"), A/RES/73/206, OP 17, Dec. 20, 2018. According to the General Assembly, the quality of the Repertoire and its Supplements is the responsibility of the Secretary-General. Id.

227. See U.N. Security Council, Repertoire of the Practice of the Security Council, https://www.un.org/securitycouncil/content/repertoire/structure; permalink: https://perma.cc/4Q9U-UEXB. Advanced versions of drafts of the 19th Supplement (covering 2014-2015) and the 20th Supplement (covering 2016-2017) of the Repertoire are available online. Id.

228. See Annex.

229. U.N. General Assembly, resolution 796 (VIII) ("Publication of documents concerning the drafting and application of the Charter: Preparatory work with regard to the possible holding of a General Conference of the Members of the United Nations in accordance with Article 109 of the Charter"), A/RES/796/(VIII), Nov. 27, 1953.
} 
history contributing to the knowledge and understanding of the Charter as applied in the practice of the organs of the United Nations." 230 The Repertory and Supplements thereto contain references to practice deemed to pertain to relevant provisions of the Charter, including article 51. However, as with Supplements to the Repertoire, Supplements to the Repertory are not published contemporaneously - and indeed, there is currently a significant backlog of Supplements to the Repertory dating to certain practice covering 1985-1999. ${ }^{231}$ Furthermore, also as with the Repertoire, several of the "article 51 communications" identified by HLS PILAC researchers are not included under the part of the Repertory and the Supplements thereto covering article 51.232

Third, in 1986, the General Assembly-established Special Committee on Enhancing the Effectiveness of the Principle of Non-Use of Force in International Relations considered the self-defense-reporting obligation as part of its assessment of the role of the United Nations. In particular, the Special Committee studied the idea of:

[I]nducing States to comply with the often ignored reporting obligation contained in Article 51 of the Charter by adopting language underscoring

230. See, e.g., A/RES/73/206, above note 226, at OP 2. The quality of the Repertory (and Supplements thereto) is, according to the General Assembly, the responsibility of the Secretary-General. See id. at OP 17.

231. See A/73/190, above note 226, at OPs 3-5. The General Assembly has noted part of the backlog with concern. See, most recently, A/RES/73/206, above note 226, OP 16. As of July 19, 2018, the status of publications of the Repertory and Supplements thereto was reportedly as follows:

30 volumes have been published and 14 have been finalized and submitted for translation and publication. Consequently, from among the 57 volumes of which the publication as a whole (original Repertory and Supplements Nos. 1 to 11 thereto) should consist, work remains to be completed on 13, 6 of which pertain to Supplement No. 11 (2010-2015), on which work has begun (...), and 4 to Supplement No. 10 (2000-2009), which are at different stages of preparation (...). The other three volumes on which work remains to be completed correspond to volume III of Supplements Nos. 7 to 9 [(1985-1999)].

A/73/190, above note 226, at OP 8. Footnotes accompanying the first sentence of the excerpt indicate that the 30 volumes that have been published constitute "Repertory and Supplements Nos. 1 to 6 (1946-1984), for a total of 27 volumes, volumes V and VI of Supplement No. 7 (1985-1988) and volume I of Supplement No. 10 (2000-2009)." and that the 14 volumes that have been finalized and submitted for translation and publication constitute "Volumes I, II and IV of Supplement No. 7 (19851988), volumes I, II, IV, V and VI of Supplements Nos. 8 (1989-1994) and 9 (1995-1999) and volume II of Supplement No. 10 (2000-2009).” Id. at nn.1, 2.

232. See Annex. 
that obligation and by authorizing the Secretary-General, acting on behalf of the Security Council, to enquire of a nation apparently having used force if it wished to assert that its actions were taken in self-defence, thereby deterring uses of force in which no possible claim of self-defence could rationally be made .... ${ }^{233}$

That idea was not ultimately reflected - apparently due to concerns, among others, about delegating to the Secretary-General tasks that were "probably" reserved in the U.N. Charter to the Security Council ${ }^{234}$ — in the related Declaration. ${ }^{235}$

Fourth, in 1975, the General Assembly established the Special Committee on the Charter of the United Nations and on the Strengthening of the Role of the Organization. ${ }^{236}$ In relation to that Committee, in February of 2018 the representative of Mexico noted that, in his view, communications to the Security Council under article 51 of the Charter had increased, in particular with regard to counterterrorism operations, and expressed concern "regarding recent interpretations of the right to self-defence in response to armed attacks perpetuated by non-State actors." 237 A proposal was made that the Special Committee could

233 See A/41/41 ("Report of the Special Committee on Enhancing the Effectiveness of the Principle of Non-Use of Force in International Relations”), Mar. 13, 1986, at 12, para. 46.

234. See id. at 12, para. 47 (stating that "[t] hese [five] ideas elicited a favourable response from some delegations but gave rise to doubts on the part of others.... On point (c) [concerning the idea of authorizing the Secretary-General, acting on behalf of the Security Council, to enquire of a nation apparently having used force if it wished to assert that its actions were taken in self-defence], the remark was made that the Security Council was probably the only organ which could undertake the proposed task. Furthermore, each situation was sui generis, which was the reason why the Security Council enjoyed discretionary powers in discharging its functions in the light of all the circumstances of the case. The Committee should, it was stated, refrain from venturing into the political field and focus on the formulation of provisions of a legal nature.").

235. See U.N. General Assembly, resolution 42/22 ("Declaration on the Enhancement of the Effectiveness of the Principle of Refraining from the Threat or Use of Force in International Relations prepared by the Special Committee"), A/RES/42/22, Nov. 18, 1987.

236. See U.N. General Assembly, resolution 3499 (XXX) ("Special Committee on the Charter of the United Nations and on the Strengthening of the Role of the Organization"), A/RES/3499(XXX), Dec. 15, 1975, para. 1. On December 18, 2015, the General Assembly, with respect to the mandate of the Committee, "[r]equest[ed] the Special Committee ... [t] continue its consideration of all proposals concerning the question of the maintenance of international peace and security in all its aspects in order to strengthen the role of the United Nations and, in this context, to consider other proposals relating to the maintenance of international peace and security already submitted or which may be submitted to the Special Committee...." U.N. General Assembly, resolution 70/117 ("Report of the Special Committee on the Charter of the United Nations and on the Strengthening of the Role of the Organization”), A/RES/70/117, Dec. 18, 2015, para. 3(a).

237. A/73/33 ("Report of the Special Committee on the Charter of the United Nations and on the Strengthening of the Role 
consider "the substantive and procedural aspects of the issue, in order to clarify the interpretation and application of Article 51 and avoid possible abuse of the right to self-defence." ${ }^{238}$ As of mid-2019, that proposal is subject to ongoing debate. ${ }^{239}$

Recalling the earlier-discussed factors as to what may make silence legally relevant (including the deliberate decision not to comment or react), this lack of timely information casts some doubt on the ability to discern States' legal positions from their silence with regard to article-51-related reporting. Indeed, this state of affairs might be a complicating factor in discerning opinio juris in this field more generally.

\section{Case Study: Silence of States and the Security Council and Military Action against Non-State Actors}

One of the jus ad bellum issues that has generated extensive commentary concerns the resort to military action against non-state actors in foreign territory without the consent of the territorial State and without authority of the Security Council. Several strands of the debate and the practice underlying it - including, for example, invocations of purported exercises of the right of self-defense against such non-state actors - can be traced back several decades, if not longer. Here, we take no position on the substantive merits of the various, and often opposing, legal positions elaborated in this debate. Nor do we take a position on whether there is any reasonable room for such debate at all. Instead, we take the existence of the debate as a given, and we focus on the ways in which writers have invoked, and the ways in which other international actors use, silence (or inaction) as purported proof of tacit support for their respective positions.

of the Organization"), Mar. 1, 2018, para. 83.

238. Id.

239. See id. at para. 84; Intervención de México en el debate de la Sexta Comisión sobre el Informe del Comité Especial de la Carta de las Naciones Unidas en el marco de sesiones de la 73a Asamblea General de la ONU, Oct. 12, 2018, https://mision.sre.gob.mx/onu/index.php/eventos/800-intervencion-de-mexico-en-el-debate-de-la-sexta-comision-sobreel-informe-del-comite-especial-de-la-carta-de-las-naciones-unidas-en-el-marco-de-sesiones-de-la-73a-asamblea-generalde-la-onu, permalink: https://perma.cc/U8AR-NX7U; A/AC.182/2019/L.10, paras. 8-9. 
In a 2018 report, the Use of Force Committee of the International Law Association (ILA) stipulated a series of legal questions that pertain to extraterritorial force against non-state actors in foreign territory. ${ }^{240}$ The first question that the report lists is whether, conceptually, a State may invoke the right to self-defense in the case of an attack by an extraterritorial non-state actor, rather than by a State. ${ }^{241}$ Recall that the first sentence of article 51 of the U.N. Charter provides as follows: "Nothing in the present Charter shall impair the inherent right of individual or collective self-defence if an armed attack occurs against a Member of the United Nations, until the Security Council has taken measures necessary to maintain international peace and security." ${ }^{242}$ According to the ILA report, "the heart of the debate" is whether, "if the armed attack is legally one of the non-state actor alone [and not also or separately of the territorial/host State], the victim State may have a right to use force in self-defence against the armed group, but not against the [territorial/host] State." 243

As noted above, certain scholars have invoked the purported silence or inaction of States in respect of several potentially relevant situations, including:

- The U.S. airstrikes in 1998 against al-Qaeda targets in Afghanistan; ${ }^{244}$

\footnotetext{
240. See International Law Association, Use of Force Comm., Final Report on Aggression and Use of Force, 2018, 15, http://www.ila-hq.org/images/ILA/DraftReports/DraftReport_UseOfForce.pdf, permalink: https://perma.cc/F2VG-WDTP.

241. Id. The other questions were formulated as follows: what steps must be taken before any such right (if it is established) can be exercised; whether force against the non-state actor can be distinguished from force against the territorial/host State; whether the territorial/host State might be in violation of international law due to the activities of the non-state actor; and if so, whether this justifies force against the host State itself. Id.

242. U.N. Charter art. 51, first sentence (emphasis added). We do not take a position here on whether or not the content of this treaty provision concerning "armed attack" is reflective of customary international law.

243. International Law Association, Use of Force Comm., above note 240, at 15-16.

244. See José Luis Aragón Cardiel, Amanda Davis, \& Lauranne Macherel, Modern Self-defense in Practice: Two Case Scenarios, 2 HRLR ONLINE 1, 5 n.19 (2018) (citation omitted).
} 
- The U.S. military intervention in late 2001 against al-Qaeda (and the Taliban for harboring al-Qaeda ${ }^{245}$ ) in Afghanistan; ${ }^{246}$

- Military operations in $2002^{247}$ and $2007^{248}$ by Russia against Chechen rebels in Georgia;

- Military operations in 2006 by Ethiopia against the "Islamic Courts" in Somalia; ${ }^{249}$

- Military operations in 2007-08 by Turkey against the PKK in Iraq; ${ }^{250}$

- The incursion in 2008 by Colombia against a Fuerzas Armadas Revolucionarias de Colombia (FARC) camp inside Ecuador's border; ; $^{21}$

- The operation in 2011 by the United States against Osama bin Laden in Pakistan; ${ }^{252}$

- The attack in 2011 by the United States that killed U.S. national Anwar al-Awlaki in Yemen; ${ }^{253}$

- The incursion in 2011 by Kenya into Somalia in response to alleged cross-border attacks by Al-Shabaab; ${ }^{254}$ and

- The international coalition's intervention beginning in 2014 against ISIS in Syria. ${ }^{255}$

\footnotetext{
245. See Michael Byers, The Intervention in Afghanistan-2001-, in THE UsE OF ForCE IN INTERNATIONAL LAW: A CASE-BASED APPROACH 634 (Tom Ruys \& Olivier Corten eds., Alexandra Hofer assistant ed., 2018); Frederic Kirgis, Israel's Intensified Military Campaign Against Terrorism, 6 ASIL InsIgHT, No. 19, Dec. 5, 2001, https://www.asil.org/insights/volume/6/issue/19/israels-intensified-military-campaign-against-terrorism, permalink: https://perma.cc/V3PJ-3JVH.

246. See Cardiel et al., above note 244, at 16-17 (citations omitted); Byers, above note 245, at 634 .

247. See Cardiel et al., above note 244, at 5 n.19 (citation omitted); Michael P. Scharf, How the War Against ISIS Changed International Law, 48 CASE WESTERN RESERVE J. INT'L L. 15, 50 (2016) (citations omitted).

248. See Monica Hakimi, Defensive Force against Non-State Actors: The State of Play, 91 INT’L L. STUD. 1, 14 (2015).

249. See Scharf, above note 247 , at 50 (citations omitted).

250. See Hakimi, above note 248, at 14; Tom Ruys, Quo Vadit Jus ad Bellum?: A Legal Analysis of Turkey's Military Operations against the PKK in Northern Iraq, 9 MELB. J. INT'L L. 334, 344 (2008); Scharf, above note 247, at 50 (citation omitted).

251. See Scharf, above note 247, at 50 (citations omitted).

252. See id. at 51 (citation omitted).

253. See id. (citation omitted).

254. See id. (citation omitted).

255. See Cardiel et al., above note 244 , at 16-17 (citations omitted).
} 


\section{The HLS PILAC catalogue demonstrates that various U.N. Member States have made "article 51 communications" that reflect a position in this debate. ${ }^{256}$ For example, Belgium; ${ }^{257}$ Iran; ${ }^{258}$ Israel; ${ }^{259}$ Germany; ${ }^{260}$ Kazakhstan, Kyrgyzstan,}

256. In addition to the caveats elaborated in the Annex that pertain to the entire catalogue, the following additional caveat should be borne in mind: in respect of certain identified "article 51 communications," it is not necessarily clear whether or not the State submitting the report intended to attribute the allegedly self-defense-generative conduct of the relevant non-state actors (for example, purported "armed attacks" by alleged "terrorists" or "irregular forces") to a State (for example, to the State from whose territory those actors are allegedly launching actions giving rise to a purported exercise of the right of self-defense of the victim State) or to otherwise seek to engage the responsibility of the territorial/host (or another) State (for example, on the grounds that the other State allegedly acquiesced in or otherwise tolerated self-defense-generative conduct of the non-state actors). The catalogue of "article 51 communications" on which we draw distinguishes between three sets of categories with respect to the nature of the authors of the alleged threat giving rise to the claim of self-defense: (1) A State (or States); (2) a State (or States) and non-state actors; or (3) non-state actors. See Annex. The practice described in this part of the paper is drawn only from categories (2) and (3) of the catalogue.

257. See Belgium, S/2016/523 (June 9, 2016) ("ISIL has occupied a certain part of Syrian territory over which the Government of the Syrian Arab Republic does not, at this time, exercise effective control. In the light of this exceptional situation, States that have been subjected to armed attack by ISIL originating in that part of the Syrian territory are therefore justified under Article 51 of the Charter to take necessary measures of self-defence. Exercising the right of collective self-defence, Belgium will support the military measures of those States that have been subjected to attacks by ISIL.") (emphasis added).

258. See Iran, S/25843 (May 26, 1993), at 1 ("During the past few weeks, bands of armed and organized terrorist mercenaries have engaged in trans-border military attacks against and sabotage in Iranian border provinces. These bands, whose headquarters and military bases are located in Iraq where military training, financial and logistical support and intelligence services are provided to them, have admittedly perpetrated terrorist activities inside Iran, resulting in martyrdom of civilians and military personnel and in infliction of damages to Iranian oil installations. [g] ... [ In response to these armed attacks from inside Iraq and in accordance with Article 51 of the Charter of the United Nations, ... the fighter jets of the Islamic Republic Air Force carried out a brief, necessary and proportionate operation against the military bases of the terrorist group where the recent armed attacks against and incursions into Iranian territory had originated."); Iran, S/1994/1273 (Nov. 10, 1994), at 1 ("Over the past weeks, these terrorist groups have intensified their bombing campaigns and armed attacks against civilians and oil installations in the Islamic Republic of Iran resulting in the martyrdom of a number of Iranian nationals and material damages."); Iran, S/1996/602 (July 29, 1996) ("Consequently, in recent weeks transborder armed attacks and sabotage operations by terrorist groups against Iranian border towns, originating from Iraqi territory, have been intensified and escalated.") (emphasis added).

259. See, e.g., Israel, S/9387 (Aug. 12, 1969) ("It is generally known that Lebanon harbours on its territory, and particularly in its southern region bordering with Israel, considerable concentrations of irregular forces which are engaged in waging terror warfare against Israel. [ $\mathbf{G}$ In the face of these attacks Israel was compelled to take, on 11 August 1969, action in self-defence against the terror encampments on the slopes of Mount Hermon. [9] An official communique of the terror organizations command broadcast last night over Radio Damascus confirmed that the Israeli action was directed against bases of the terror organizations. [9] In view of the gravity of the armed attacks perpetrated against Israel from Lebanese territory, I have the honour, on instructions from my Government to request you to convene an urgent meeting of the Security Council.") (emphasis added).

260. See Germany, S/2015/946 (Dec. 10, 2015) ("ISIL has carried out, and continues to carry out, armed attacks 


\section{Russia, Tajikistan, and Uzbekistan; ${ }^{261}$ Portugal; ${ }^{262}$ the United Kingdom; ${ }^{263}$ and the United States ${ }^{264}$ all expressly attributed (at least part of) the authorship of an}

against Iraq, France, and other States. These States have acted, and continue to act, by taking measures of selfdefence.") (emphasis added).

261. See Kazakhstan, Kyrgyzstan, Russia, Tajikistan, and Uzbekistan, S/26290 (Aug. 11, 1993), at 4 (“Particularly alarming are the actions by fighters from the Tajik opposition and the individual Afghan armed groups that support them and the systematic incursions into the territory of Tajikistan, which have resulted in an increasing number of victims among the civilian population, frontier guards and other military personnel. [ $\mathbf{g}$ ] The heads of State proclaim the following: ... If armed attacks from the outside continue, reciprocal and commensurate measures will be taken to stop them, as envisaged by the Treaty on Collective Security concluded between the countries of the Commonwealth of Independent States and by bilateral agreements with Tajikistan, and in accordance with the right of individual or collective self-defence provided for in Article 51 of the Charter of the United Nations.") (emphasis added).

262. See S/PV.1516 (Dec. 4, 1969), Portugal, at 9 ("It is common knowledge that anti-Portuguese organizations operate from Senegal and from the Republic of Guinea against Portuguese Guinea. For several years now those organizations have been carrying out armed attacks against the peaceful rural populations of the Portuguese territory on the other side of the frontier.") (emphasis added).

263. See United Kingdom, S/2015/928 (Dec. 3, 2015) (“On 21 August 2015, armed forces of the United Kingdom of Great Britain and Northern Ireland carried out a precision air strike against an ISIL vehicle in which a target known to be actively engaged in planning and directing imminent armed attacks against the United Kingdom was travelling. ... [ [ ] As reported in our letter of 25 November 2014, ISIL is engaged in an ongoing armed attack against Iraq, and therefore action against ISIL in Syria is lawful in the collective self-defence of Iraq.") (emphasis added).

264. See United States, S/9854 (July 1, 1970), at 1-2 ("Nevertheless, North Viet-Namese and Viet-Cong forces remain in Cambodia in pursuance of their armed attack against the Republic of Viet-Nam. Consequently, the United States will conduct - with the approval of the Cambodian Government - air interdiction missions against North Viet-Namese forces and their efforts to move supplies and personnel through Cambodia towards the Republic of Vietnam and to re-establish base areas for use in the conflict in Viet-Nam. These air interdiction missions are appropriate and limited measures of collective self-defence against the continuing armed attack against the Republic of Viet-Nam being carried on in part from Cambodian territory.") (emphasis added); United States, S/1998/780 (Aug. 20, 1998), at 1 ("In accordance with Article 51 of the Charter of the United Nations, I wish, on behalf of my Government, to report that the United States of America has exercised its right of selfdefence in responding to a series of armed attacks against United States embassies and United States nationals. [g] My Government has obtained convincing information from a variety of reliable sources that the organization of Usama Bin Ladin is responsible for the devastating bombings on 7 August 1998 of the United States embassies in Nairobi and Dar Es Salaam.") (emphasis added); United States, S/2001/946 (Oct. 7, 2001), at 1 ("In accordance with Article 51 of the Charter of the United Nations, I wish, on behalf of my Government, to report that the United States of America, together with other States, has initiated actions in the exercise of its inherent right of individual and collective self-defence following the armed attacks that were carried out against the United States on 11 September 2001. [ ] On 11 September 2001, the United States was the victim of massive and brutal attacks in the states of New York, Pennsylvania and Virginia. These attacks were specifically designed to maximize the loss of life; they resulted in the death of more than 5,000 persons, including nationals of 81 countries, as well as the destruction of four civilian aircraft, the World Trade Center towers and a section of the Pentagon. Since 11 September, my Government has obtained clear and compelling information that the Al-Qaeda organization, which is supported by the Taliban regime in Afghanistan, had a central role in the attacks.") (emphasis added); United States, S/2014/417 (June 18, 2014) ("On behalf of my Government, I wish to report that the United States of 
"armed attack" to non-state actors (note that, in some of those communications, attribution of the authorship of such attacks was made jointly to State and non-state actors $^{265}$ ). Certain other "article 51 communications" - including from Australia, ${ }^{266}$ Canada, ${ }^{267}$ Germany, ${ }^{268}$ the Netherlands, ${ }^{269}$ and New Zealand ${ }^{270}$ - may be

America has taken action in Libya to capture Ahmed Abu Khattalah, a senior leader of the Libyan militant group Ansar al-Sharia-Benghazi in Libya. ... [9] As is well known, the United States Temporary Mission Facility and Annex in Benghazi, Libya, were attacked in September 2012, and the United States Ambassador to Libya and three other Americans were killed. Following a painstaking investigation, the United States Government ascertained that Ahmed Abu Khattalah was a key figure in those armed attacks. The investigation also determined that he continued to plan further armed attacks against United States persons.") (emphasis added).

265. See also above note 256 .

266. See Australia, S/2001/1104 (Nov. 23, 2001), at 1 ("In accordance with Article 51 of the Charter of the United Nations, I am writing on behalf of my Government to report to the Security Council that Australia has taken measures in the exercise of the inherent right of individual and collective self-defence following the armed attacks against the United States of America on 11 September 2001. [ $\mathbf{9}$ ] As you are aware, Australia has strongly condemned those responsible for the September terrorist attacks.") (emphasis added); Australia, S/2015/693 (Sept. 9, 2015) ("Article 51 of the Charter of the United Nations recognizes the inherent right of States to act in individual or collective self-defence where an armed attack occurs against a Member of the United Nations. States must be able to act in self-defence when the Government of the State where the threat is located is unwilling or unable to prevent attacks originating from its territory. The Government of Syria has, by its failure to constrain attacks upon Iraqi territory originating from ISIL bases within Syria, demonstrated that it is unwilling or unable to prevent those attacks.") (emphasis added).

267. See Canada, S/2001/1005 (Oct. 24, 2001) ("In accordance with Article 51 of the Charter of the United Nations, I wish on behalf of my Government to report to the Security Council on measures that Canada has initiated following the armed attacks in the United States on 11 September 2001. Those attacks, which were the subject of Security Council resolutions 1368 (2001) of 12 September 2001 and 1373 (2001) of 28 September 2001, resulted in the deaths of thousands of citizens from many countries, including Canada. [ 9 ] As announced by Canada's Prime Minister, the Right Honourable Jean Chrétien, on 7 October 2001, Canada is deploying naval ships, surveillance and transport airplanes, military personnel and other assets. Our actions are directed against Osama bin Laden's alQa'ida terrorist organization and the Taliban regime that is supporting it.") (emphasis added).

268. See Germany, S/2001/1127 (Nov. 29, 2001) ("In accordance with Article 51 of the Charter of the United Nations, I wish on behalf of my Government to report to the Security Council on measures that the Federal Republic of Germany has initiated following the armed attacks that were carried out against the United States on 11 September 2001. [g] As approved by the German Federal Parliament on 16 November 2001, Germany is providing nuclear, biological and chemical (NBC) defence units, medical units, specialized units, air-transport capacities, naval forces, including navy aviation, and necessary support units. These measures are solely directed against the terrorist network of Bin Laden, Al-Qaida, and those harbouring and supporting it.") (emphasis added).

269. See the Netherlands, S/2001/1171 (Dec. 6, 2001) ("In accordance with Article 51 of the Charter of the United Nations, I wish on behalf of my Government to report to the Security Council on measures that the Kingdom of the Netherlands has taken following the armed attacks against the United States of America on 11 September 2001.") (emphasis added).

270. See New Zealand, S/2001/1193 (Dec. 18, 2001) ("In accordance with Article 51 of the Charter of the United 


\title{
interpreted as implying that non-state actors authored (or at least co-authored) the particular purported "armed attack" at issue. In addition, certain "article 51 communications" - including from Australia, ${ }^{271}$ Denmark,,${ }^{272}$ Iran, ${ }^{273}$ Israel, ${ }^{274}$ the
}

\begin{abstract}
Nations, I am writing on behalf of my Government to report that New Zealand has joined other States in the exercise of its inherent right of individual and collective self-defence following the terrorist attacks in the United States of America on 11 September 2001. [9g] ... New Zealand's military contribution has been employed in support of military operations directed against Osama bin Laden and the Qaeda terrorist organization, and the Taliban which supported and harboured them.") (emphasis added).
\end{abstract}

271. See Australia, S/2015/693 (Sept. 9, 2015) ("Article 51 of the Charter of the United Nations recognizes the inherent right of States to act in individual or collective self-defence where an armed attack occurs against a Member of the United Nations. States must be able to act in self-defence when the Government of the State where the threat is located is unwilling or unable to prevent attacks originating from its territory. The Government of Syria has, by its failure to constrain attacks upon Iraqi territory originating from ISIL bases within Syria, demonstrated that it is unwilling or unable to prevent those attacks. [ $]$ In response to the request for assistance by the Government of Iraq, Australia is therefore undertaking necessary and proportionate military operations against ISIL in Syria in the exercise of the collective self-defence of Iraq.") (emphasis added).

272. See Denmark, S/2016/34 (Jan. 13, 2016) (“... Denmark, as called for by the Council in its resolution 2249 (2015) and in response to the request by the Government of Iraq, is taking necessary and proportionate measures against the so-called Islamic State in Iraq and the Levant (ISIL, also known as Da'esh) in Syria in exercise of the inherent right of collective self-defence as part of international efforts led by the United States of America.") (emphasis added).

273. See Iran, S/1996/602 (July 29, 1996) ("In response to these encroachments by terrorist armed groups and in accordance with its inherent right of self-defence enshrined in Article 51 of the Charter, the Islamic Republic of Iran took immediate and proportional measures, which were necessary for curbing and suppressing such aggressive activities. The details of these operations, which have already been concluded, are as follows: On 28 July 1996, the Iranian defence forces pursued the retreating armed groups that attacked civilian targets in the border towns of Piranshahr, Mahabad and Oroumiyeh, and targeted their training camps in Iraq.") (emphasis added); Iran, S/1999/781 (July 12, 1999), at 2 ("In pursuance of this policy and in the exercise of its right of self-defence under Article 51 of the Charter, the concerned authorities of the Islamic Republic of Iran targeted a well-known active terrorist camp, located in the territory of Iraq, on 10 June 1999. This proportionate action was a necessary defensive measure against the perpetrators of the terrorist crimes that had already been carried out against Iran and its citizens. It also aimed to prevent further recurrence of similar terrorist operations which were being planned and organized at the very same terrorist installations inside Iraq.") (emphasis added).

274. See Israel, S/2010/21 (Jan. 13, 2010) ("Following this escalation in attacks, Israel responded militarily in exercise of its right of self-defence under Article 51 of the Charter of the United Nations. The Israeli response included the precision targeting of a group of terrorists who were preparing to launch additional rockets into Israel, the targeting of a weapons production facility in Tel Hawa, in the Gaza Strip, as well as the destruction of tunnels used to smuggle illegal arms into Gaza. [G] Israel will continue to take the necessary and appropriate measures in self-defence to confront any such terrorist attacks and activities. The Government of Israel is determined to ensure that the situation in southern Israel does not return to the status quo ante of December 2008.") (emphasis added). 


\section{Netherlands, ${ }^{275}$ Norway, ${ }^{276}$ Turkey, ${ }^{277}$ the United Kingdom, ${ }^{278}$ and the United States ${ }^{279}$}

275. See the Netherlands, S/2016/132 (Feb. 10, 2016) ("In accordance with Article 51 of the Charter of the United Nations, I am writing to report to the Security Council that the Kingdom of the Netherlands is taking necessary and proportionate measures against the so-called Islamic State in Iraq and the Levant (ISIL, also known as Daesh) in Syria in the exercise of the inherent right of collective self-defence of Iraq.") (emphasis added).

276. See Norway, S/2016/513 (June 3, 2016) (“... Norway is taking necessary and proportionate measures against the terrorist organization Islamic State in Iraq and the Levant (ISIL, also known as Da'esh) in Syria in the exercise of the right of collective self-defence.") (emphasis added).

277. See Turkey, S/2015/563 (July 24, 2015), at 1 ("Individual and collective self-defence is our inherent right under international law, as reflected in Article 51 of the Charter of the United Nations. [9] On this basis, Turkey has initiated necessary and proportionate military actions against Daesh in Syria, including in coordination with individual members of the Global Coalition, in order to counter the terrorist threat and to safeguard its territory and citizens.") (emphasis added).

278. See United Kingdom, S/2014/851 (Nov. 26, 2014) (reporting that the United Kingdom "is taking measures in support of the collective self-defence of Iraq as part of international efforts led by the United States. [ $\mathbf{g}$ ] These measures are in response to the request by the Government of Iraq for assistance in confronting the attack by the Islamic State in Iraq and the Levant (ISIL) on Iraq, contained in its letter to the President of the Security Council of 20 September 2014 (S/2014/691). The United Kingdom fully supports these international efforts, whose purpose is to end the continuing attack on Iraq, to protect Iraqi citizens and to enable Iraqi forces to regain control of the borders of Iraq by striking ISIL sites and military strongholds in Syria, as necessary and proportionate measures.") (emphasis added); United Kingdom, S/2015/688 (Sept. 8, 2015) (“On 21 August 2015, armed forces of the United Kingdom of Great Britain and Northern Ireland carried out a precision air strike against an ISIL vehicle in which a target known to be actively engaged in planning and directing imminent armed attacks against the United Kingdom was travelling. This air strike was a necessary and proportionate exercise of the individual right of self-defence of the United Kingdom.") (emphasis added); United Kingdom, S/2015/928 (Dec. 3, 2015) ("In accordance with Article 51 of the Charter of the United Nations, and further to our letters of 25 November 2014 (S/2014/851) and 7 September 2015 (S/2015/688), I am therefore writing to report to the Security Council that the United Kingdom of Great Britain and Northern Ireland is taking necessary and proportionate measures against ISIL/Daesh in Syria, as called for by the Council in resolution 2249 (2015), in exercise of the inherent right of individual and collective self-defence.") (emphasis added).

279. See United States, S/1998/780 (Aug. 20, 1998), at 1 (“In response to these terrorist attacks, and to prevent and deter their continuation, United States armed forces today struck at a series of camps and installations used by the Bin Ladin organization to support terrorist actions against the United States and other countries. In particular. United States forces struck a facility being used to produce chemical weapons in the Sudan and terrorist training and basing camps in Afghanistan. [9] These attacks were carried out only after repeated efforts to convince the Government of the Sudan and the Taliban regime in Afghanistan to shut these terrorist activities down and to cease their cooperation with the Bin Ladin organization. That organization has issued a series of blatant warnings that 'strikes will continue from everywhere' against American targets, and we have convincing evidence that further such attacks were in preparation from these same terrorist facilities. The United States, therefore, had no choice but to use armed force to prevent these attacks from continuing. [ ] In doing so, the United States has acted pursuant to the right of self-defence confirmed by Article 51 of the Charter of the United Nations. The targets struck, and the timing and method of attack used, were carefully designed to minimize risks of collateral damage to civilians and to comply with international law, including the rules of necessity and proportionality. [ $\mathbf{g}$ It is the sincere hope of the United States Government that these limited actions will deter and prevent the repetition of unlawful terrorist attacks on the United States and other countries."); United States, S/2014/695 (Sept. 23, 2014) ("States must be able to defend themselves, in accordance with the inherent right of individual and collective self-defence, as reflected in Article 51 of the Charter of the United Nations, when, as is the case here, the government of the State where the threat is located is unwilling or unable to prevent the use of its territory for such attacks. The Syrian regime has shown that it cannot and will not confront these safe havens effectively 
- expressly characterized a self-defense action that was directed at least in part against non-state actors as having conformed to the jus ad bellum principles of necessity and proportionality. And some communications have otherwise addressed (part of) the scope of these principles in this context, including communications from Canada, ${ }^{280}$ Iran, ${ }^{281}$ Israel, ${ }^{282}$ Turkey, ${ }^{283}$ the United Kingdom, ${ }^{284}$ and the United States. ${ }^{285}$

itself. Accordingly, the United States has initiated necessary and proportionate military actions in Syria in order to eliminate the ongoing ISIL threat to Iraq, including by protecting Iraqi citizens from further attacks and by enabling Iraqi forces to regain control of Iraq's borders. In addition, the United States has initiated military actions in Syria against alQaida elements in Syria known as the Khorasan Group to address terrorist threats that they pose to the United States and our partners and allies.") (emphasis added).

280. See Canada, S/2015/221 (Mar. 31, 2015) (“Canada’s military actions against ISIL in Syria are aimed at further degrading ISIL's ability to carry out attacks.") (emphasis added).

281. See Iran, S/1998/934 (Oct. 8, 1998) ("At 6.30 a.m., local time, the Taliban militia launched an attack, using mortar and Dush-K, against the territory of the Islamic Republic of Iran between the Ibrahim Khani and Kondeh Souz border posts in Khorassan Province. The Iranian armed forces took some limited and proportionate measures, in accordance with Article 51 of the Charter, to repel the Taliban attack. At 9.30 a.m., the cross-border attack by the Taliban militia, constituting a flagrant aggression and provocation, was repelled and military operation was halted.") (emphasis added); Iran, S/2001/381 (Apr. 19, 2001), at 1 (" $[I] n$ response to numerous operations by the MKO terrorist organization from its bases inside the territory of Iraq against the Islamic Republic of Iran resulting in human and material losses over the last several months, the armed forces of the Islamic Republic of Iran, in accordance with Article 51 of the Charter of the United Nations, took a limited and proportionate defensive measure against a number of the MKO command and control, training and logistic bases inside Iraq. This operation, which began at 4.15 and concluded at 7.30 in the early hours of this morning, targeted the following MKO bases: ... The Government of the Islamic Republic of Iran emphasizes that this limited and proportionate operation was carried out to stop cross-border attacks against the Islamic Republic of Iran from Iraqi territory by the MKO terrorist organization harboured in Iraq, and should not be construed as infringing the territorial integrity of Iraq.") (emphasis added).

282. See Israel, S/2005/609 (Sept. 28, 2005), at 1 (“... Hamas showered more than 40 Kassam artillery rockets onto the Israeli town of Sderot and elsewhere in the Negev, wounding five persons, two moderately, causing extensive damage and forcing inhabitants of the region to seek bomb shelters and reinforced rooms. [ $\mathbf{g}$ ] In response to the Kassam attacks and as an act of self-defence, Israel deployed forces around the Gaza Strip to prevent further assaults, targeted the terrorist infrastructure of Gaza and pursued a campaign to arrest wanted Palestinian terrorists.") (emphasis added).

283. See Turkey, S/2018/53 (Jan. 22, 2018), at 1 ("In order to counter this terrorist threat, Turkey initiated a military operation on 20 January 2018 against these terrorist elements. The operation is aimed at ensuring our border security, neutralizing terrorists in Afrin and saving the brotherly Syrians. Accordingly, the operation will target only terrorists and their hideouts, shelters, emplacements, weapons, vehicles and equipment.") (emphasis added).

284. See United Kingdom, S/2001/947 (Oct. 7, 2001) (“These forces have now been employed in exercise of the inherent right of individual and collective self-defence, recognized in Article 51, following the terrorist outrage of 11 September, to avert the continuing threat of attacks from the same source.") (emphasis added).

285 See United States, S/2001/946 (Oct. 7, 2001), at 1 ("In response to these attacks, and in accordance with the inherent right of individual and collective self-defence, United States armed forces have initiated actions designed to prevent and deter further attacks on the United States. These actions include measures against Al-Qaeda terrorist training camps and military 
In relation to purported exercises of the right of self-defense directed against non-state actors, Security Council reactions have been inconsistent. In this context, it is not always clear whether the Security Council is or is not reacting to a claim (or multiple claims) of self-defense directed against a nonstate actor in foreign territory without the consent of the territorial/host State - and, if so, what the legal effects of that (non-)reaction may be. Consider two sets of examples.

First, in identical letters dated June 8th, 2004 from the Chargé d'affaires ad interim of the Permanent Mission of Israel to the U.N. addressed to the SecretaryGeneral and the President of the Security Council, Israel alleged several "acts of aggression" by certain non-state "terrorists" operating in Lebanon - acts that Israel alleged "were enabled by the complicity of the Government of Lebanon, and with the support of the Syrian and Iranian regimes that have long sponsored, trained and financed these terrorist groups." 286 Seemingly partly in response to that letter, the Security Council adopted resolution 1553 (2004). In back-to-back operative paragraphs in that resolution, the Security Council "[r]eiterates its strong support for the territorial integrity, sovereignty and political independence of Lebanon within its internationally recognized boundaries" but also "[e]ncourages the Government of Lebanon to continue efforts to ensure the return of its effective authority throughout the south, including the deployment of Lebanese armed forces, stresses the importance of the Government of Lebanon continuing to extend these measures and calls on the Government of Lebanon to do its utmost to ensure a calm environment throughout the south...." 287

installations of the Taliban regime in Afghanistan.) (emphasis added); United States, S/2014/417 (June 18, 2014) (reporting that the United States "has taken action in Libya to capture Ahmed Abu Khattalah, a senior leader of the Libyan militant group Ansar al-Sharia-Benghazi in Libya. .... [ [ ... [T]he United States Temporary Mission Facility and Annex in Benghazi, Libya, were attacked in September 2012, and the United States Ambassador to Libya and three other Americans were killed. Following a painstaking investigation, the United States Government ascertained that Ahmed Abu Khattalah was a key figure in those armed attacks. The investigation also determined that he continued to plan further armed attacks against United States persons. [G] The measures we have taken to capture Abu Khattalah in Libya were therefore necessary to prevent such armed attacks, and were taken in accordance with the United States' inherent right of self-defence.") (emphasis added).

286. See Israel, S/2004/465 (June 8, 2004), at 2.

287. U.N. Security Council, resolution 1553 (2004), S/RES/1553(2004), July 29, 2004, OPs 3-4. 
Second, resolution 2249 (2015) on ISIS - adopted by the Council in 2015 - had been preceded by "article 51 communications" to the Council from the United States, ${ }^{288}$ the United Kingdom, ${ }^{289}$ Turkey, ${ }^{290}$ Canada, ${ }^{291}$ France, ${ }^{292}$ and Australia. ${ }^{293}$ All of those communications contain claims of purportedly exercising the right of self-defense - whether individual, collective, or both individual and collective - against ISIS in Syria. Scholars have drawn attention to certain alleged interpretive ambiguities in resolution 2249, in particular concerning whether or not the Council "authorized" forcible measures against ISIS absent the consent of Syria and/or (otherwise) validated military action against ISIS in Syria in such circumstances. ${ }^{294}$ Commentators have expressed widely differing views on the existence - and, if any, the possible relevance - of the purported silence of other States in respect both of these "article 51 communications" and of the adoption of resolution 2249 itself. $^{295}$ Further complicating the legal situation, after the adoption of the resolution, in "article 51 communications" to the Council reporting military action taken against ISIS in Syria, the United Kingdom, ${ }^{296}$ Germany, ${ }^{297}$ Denmark, ${ }^{298}$ the Netherlands, ${ }^{299}$ Norway, ${ }^{300}$ and Belgium ${ }^{301}$ expressly referenced resolution 2249 , thereby raising the question whether those States

288. See United States, S/2014/695 (Sept. 23, 2014).

289. See United Kingdom, S/2014/851 (Nov. 26, 2014); United Kingdom, S/2015/688 (Sept. 8, 2015).

290. See Turkey, S/2015/127 (Feb. 23, 2015); Turkey, S/2015/563 (July 24, 2015).

291. See Canada, S/2015/221 (Mar. 31, 2015).

292. See France, S/2015/745 (Sept. 9, 2015).

293. See Australia, S/2015/693 (Sept. 9, 2015).

294. See Dapo Akande \& Marko Milanovic, The Constructive Ambiguity of the Security Council's ISIS Resolution, EJIL: TALK!, Nov. 21, 2015, https://www.ejiltalk.org/the-constructive-ambiguity-of-the-security-councils-isis-resolution/, https://perma.cc/V5BE-W8Q7.

295. For example, compare Cardiel et al., above note 244, at 16-17 (stating that "[e]xamples of the use of force to respond to attacks by non-State actors which have met with general acquiescence include ... the international coalition's intervention in Syria against ISIL beginning in 2014.”) (emphasis added; citations omitted) with Remarks by Patrick Luna, above note 210, at 54-55.

296. See United Kingdom, S/2015/928 (Dec. 3, 2015).

297. See Germany, S/2015/946 (Dec. 10, 2015).

298. See Denmark, S/2016/34 (Jan. 13, 2016).

299. See the Netherlands, S/2016/132 (Feb. 10, 2016).

300. See Norway, S/2016/513 (June 3, 2016).

301. See Belgium, S/2016/523 (June 9, 2016). 
meant to claim not only self-defense but perhaps also (at least some measure of) purported Security Council authority in relation to their respective actions.

Despite these limited examples, the Security Council, by and large, does not respond formally - in the sense of the adoption of an act of the Council or the issuance of a presidential statement - to "article 51 communications," irrespective of whether the purported self-defense measures are directed against State actors, non-state actors, or a combination of both. Nor do other States respond with regularity to those communications. This might be because other States are not aware of them. Or, if they are aware of them, those States may not think that it is advisable to respond to a particular "article 51 communication."

Yet as we demonstrated above, under certain conditions it appears that silence or inaction might be capable of contributing to the establishment of an interpretive agreement of a treaty provision and/or to the identification or development of a rule of customary international law. The former might concern, for example, the meaning of "armed attack" in the first sentence of article 51 of the U.N. Charter, including whether or not a non-state actor can author (or at least co-author) such an attack; whereas the latter might pertain to the content of the jus ad bellum principles of necessity and proportionality, including what constitutes the scope of permissible self-defense measures (if any) against non-state actors.

To be certain, in this area neither such silence itself nor the assignment of legal effects to it ought to be lightly presumed. And indeed, recourse to acquiescence where clear jus cogens violations are concerned might not be legally tolerable altogether. Still, as we demonstrate next, several writers expressly ground arguments about the legality of certain uses of force - including self-defense against non-state actors - as well as purported changes to the law by reference to the lack of response by other States and the Security Council.

\section{Invocations of Silence in International Scholarly Discourse}

hough not a universal practice, over the years several scholars have
expressly invoked silence in relation to jus ad bellum. The bulk of these writers have relied on the purported silence of States (and other international 
actors, such as the Security Council) as proof of support for particular legal positions. These invocations by scholars of silence are, by and large, most often made in support of relatively wide claims to resort to force, not least in purported exercise of the right of self-defense. In what follows, we offer some examples of the diverse and wide array of invocations of purported silence in analyses of military actions that are subject to debates as to their (il)legality.

For example, regarding the military raid by Israel in Entebbe, Uganda in 1976, Claus Kreß and Benjamin K. Nußberger argue that the incident called for a response to Israel's self-defense legal claim. ${ }^{302}$ They further contend that because the majority of States remained silent or denounced Israel's action only on a factual basis - it is difficult to escape the conclusion that the majority of States tolerated Israel's basic legal argument. ${ }^{303}$ In the view of Kreß and Nußberger, the raid presented the possibility of a shift in doctrinal interpretation and States were aware of this possibility:

Many other states explicitly acknowledged that the Entebbe incident had precedential potential and hence required international response. For instance, Tanzania stated that ' $(i) t$ is a dangerous precedent which, if allowed to go uncontested, would usher in a new era in international relations'. The fact that states were aware of the possibility of a 'lawcrystallizing' moment is also apparent from the fact that many UN members that did not sit on the UN Security Council exercised their right under Article 31 of the UN Charter to participate in the debate without a vote. In light of the foregoing, the Entebbe incident became one in which a response to a legal claim was called for. If, in these circumstances, the majority of states either remained entirely silent or denounced Israel's action only on a factual basis, it is hard to escape the conclusion that this majority in fact tolerated Israel's basic legal argument. ${ }^{304}$

With respect to the "no-fly zones" over Iraq imposed after the Security Council adopted resolution 687 (1991), Mary Ellen O’Connell argues that “[i]t

302. See Claus Kreß \& Benjamin K. Nußberger, The Entebbe Raid-1976, in The UsE OF ForCE In InTERNATIONAL LAW: A CASE-BASED APPROACH 231 (Tom Ruys \& Olivier Corten eds., Alexandra Hofer assistant ed., 2018).

303. See id.

304. Id. at 232 (emphasis added; citations omitted). 
may be that in the case of the no-fly zones, we have acquiescence to the use of force by the United States and United Kingdom" due to "the fact that for the first year or two after the adoption of Resolution 687, France, too, joined in this policing and other permanent members of the U.N. Security Council did not condemn the use." ${ }^{305}$ O'Connell contends that once such "acquiescence has occurred, it would take a U.N. Security Council resolution to condemn the policing. But the United States and United Kingdom will veto any attempt to condemn their actions and so the policing remains, arguably, lawful." 306

In the view of José Luis Aragón Cardiel, Amanda Davis, and Lauranne Macherel, Tanzania's military intervention in Uganda in 1979 garnered "little international reaction, suggesting acquiescence."307 Those same authors - drawing on the work of Elena Chachko and Ashley Deeks - characterize the following military operations as "[e]xamples of the use of low-level force to respond to attacks by non-State actors which have met with acquiescence": Russia's use of force against Chechen rebels in Georgia in 2002; ${ }^{308}$ Turkey's use of force against Kurdish groups in Iraq from 1999; and U.S. airstrikes against al-Qaeda targets in Afghanistan in 1998. ${ }^{309}$ Cardiel, Davis, and Macherel further describe some of those same military actions - as well as the U.S. intervention in Afghanistan after the attacks of September 11th, 2001 and the international coalition's intervention in Syria against ISIS beginning in $2014-$ as "[e]xamples of the use of force to respond to attacks by non-State actors

305. Mary Ellen O'Connell, American Exceptionalism and the International Law of Self-Defense, 31 DeNV. J. INT'L L. \& POL'Y. 43, 51 (2002).

306. Id.

307. See Cardiel et al., above note 244, at 10 n.34 (citing to Francis Kofi AbIEW, THE Evolution of the Doctrine AND PRACTICE OF HUMANITARIAN INTERVENTION 123 (1999)).

308. See also Hakimi, above note 248, at 14; Scharf, above note 247, at 50.

309. See Cardiel et al., above note 244, at $5 \mathrm{n} .19$ ("Examples of the use of low-level force to respond to attacks by non-State actors which have met with acquiescence include Russia's use of force against Chechen rebels in Georgia in 2002, Turkey's use of force against the Kurds from 1999, and U.S. airstrikes against Al Qaeda targets in Afghanistan in 1998 in retaliation for the bombings of U.S. embassies in Kenya and Tanzania.") (emphasis added; citing to Elena Chachko \& Ashley Deeks, Which States Support the 'Unwilling and Unable' Test?, LAWFARE, Oct. 10, 2016, https://www.lawfareblog.com/whoboard-unwilling-orunable, permalink: https://perma.cc/469Z-TJLL). 
which have met with general acquiescence." ${ }^{310}$

Also with respect to the U.S. intervention in Afghanistan in late 2001, Michael Byers contends that acquiescence played a role in the purported development of customary international law pertaining to U.S. self-defense claims against both al-Qaeda and the Taliban (the latter for allegedly harboring the former). ${ }^{311}$ Frederic Kirgis concurs in that position concerning the Taliban, arguing that "[b]ecause customary international law is often developed through a process of official assertions and acquiescences, the absence of challenge to the US asserted right of self-defense could be taken to indicate acquiescence in an expansion of the right to include defense against governments that harbor or support organized terrorist groups that commit armed attacks in other countries." 312 Theresa Reinhold finds that "[i]t is probably fair to conclude that as a result of international acquiescence in the U.S. intervention in Afghanistan, the existing rules governing the use of force have been called into question...." 313

310. Cardiel et al., above note 244, at 16-17 ("Examples of the use of force to respond to attacks by non-State actors which have met with general acquiescence include Russia's use of force against Chechen rebels in Georgia in 2002, Turkey's use of force against the Kurds from 1999, the United States' intervention in Afghanistan after the 9/11 attacks, and the international coalition's intervention in Syria against ISIL beginning in 2014.") (emphasis added; citations omitted).

311. See, e.g., Byers, above note 245 , at 634 ("In these ways, the United States extended its claim of self-defence to justify action against terrorists who had already committed acts of violence amounting to an armed attack, and against a state that was willingly harbouring them. Although the lower threshold (harbouring rather than controlling) was a step beyond the law as it existed prior to 11 September 2001, it was a much smaller step than if the United States had claimed a right to attack terrorists who simply happened to be within another country's territory. For these reasons, the claim to be acting in selfdefence against both Al Qaeda and the Taliban — and the modification to customary international law entailed by that claimhad a much better chance of securing the expressed or tacit support of other countries. [ $\mathbf{9}$ ] Secure support it did: through the Security Council resolutions discussed above, it secured the statements of more than 100 countries, and acquiescence on the part of all but two others. As a result of this nearly unanimous state practice, the US intervention in Afghanistan in 2001 was legal under the customary international law of self-defence, as it developed in the immediate aftermath of the 11 September 2001 attacks.") (emphasis added); see also Cardiel et al., above note 244, at 16-17 ("Examples of the use of force to respond to attacks by non-State actors which have met with general acquiescence include ... the United States' intervention in Afghanistan after the $9 / 11$ attacks....") (emphasis added; citation omitted).

312. Kirgis, above note 245. See also J. Patrick Kelly, The International Law of Force and the Fight against Terrorism, 21 DEL. LAW. 18, 19 (2003) ("One could persuasively argue that the United Nations acquiescence and the reaction of other nations have expanded the concept of self-defense to include the use of force against States harboring terrorists.").

313. Theresa Reinold, State Weakness, Irregular Warfare, and the Right to Self-defense Post-9/11, 105 AM. J. INT'L L. 244,252 (2011). See also José E. Alvarez, Hegemonic International Law Revisited, 97 AM. J. INT’L L. 873, 879 (2003) (“Given the 
With respect to Turkey's 2008 operations against Kurdish groups in Iraq as well as the 2002 and 2007 Russian operations against Chechen rebels in Georgia, Monica Hakimi argues that "[t]hird States, for the most part, did not endorse the legal claim, but they tacitly condoned the actual operations. They stood by as the unable or unwilling standard was applied." 314 She asserts "that many States might tolerate operations under an unable or unwilling standard without actively supporting these operations or legitimizing them with legal language." 315 More broadly, Hakimi and Jacob Katz Cogan contend that all States participate in the "state code" - which, Hakimi and Cogan argue, is one of the two visions of the legal order through which to understand the jus ad bellum regime, the other being the "institutional code" — "through their actions or reactions in concrete incidents. But the vast majority of states participate in this code only passively or case specifically." 316

Also with respect to the military operations by Turkey against the PKK in Northern Iraq in 2007-08, Tom Ruys appears to contend that refraining from formally condemning Turkey's conduct may be interpreted as reflecting a condoning attitude - an attitude that, in his view, adds to the evidence of State practice of an "evolution towards a more flexible ... interpretation of selfdefence in response to attacks by non-state actors which a state has been

\footnotetext{
legislative efforts in at least one of those resolutions (1373) and the tendency for many of the Council's actions to be read as having broader normative effect, the prospective endorsement of individual and collective self-defense by the Council, together with its later acquiescence in Operation Enduring Freedom, may signal, depending on how the Council's license comes to be interpreted by its licensee, the advent of three new general rules with respect to defensive force in the age of terrorism: [ $\mathbf{g}$ (1) Terrorist violence, at least when of the scale of the events of September 11, 2001, and even when undertaken by a nonstate actor, may constitute an 'armed attack' for purposes of UN Charter Article 51. [ $]$ ] (2) A state's assistance to, harboring of, or post hoc ratification of violent acts undertaken by individuals within its territory, or perhaps even mere negligence in controlling such individuals, may make that state responsible for those acts and justify military action against it. In other words, such state action (or inaction) may constitute a breach of the state's own duty not to violate UN Charter Article 2(4). [G] (3) The right to respond with military force against both terrorist individuals and harboring states does not become impermissible retaliation or illegal anticipatory self-defense, or exceed the rules of proportionality, merely because the threat of continued terrorist attack remains clandestine and unpredictable (as it has been since 9/11).") (emphasis added).

314. Hakimi, above note 248, at 14 .

315. Id.

316. Monica Hakimi \& Jacob Katz Cogan, The Two Codes on the Use of Force, 27 EUR. J. INT'L L. 257, 263 (2016) (emphasis added).
} 


\section{unwilling or unable to prevent." 317}

Michael Scharf - after articulating a general premise that refraining from protesting State conduct may constitute a "favorable" response to a claim ${ }^{318}$ argues that "there has been little protest as other States have begun to cite the U.S. response to al-Qaeda to justify their own acts against terrorist groups operating from neighboring States," giving the following as examples (among others):

- The military operations in 2006 by Ethiopia against the "Islamic Courts" that allegedly had been conducting cross-border attacks from Somalia;

- The operation in 2011 by the United States against Osama bin Laden in Pakistan;

- The attack in 2011 by the United States that killed U.S. national Anwar alAwlaki in Yemen; and

- The incursion in 2011 by Kenya into Somalia in response to alleged crossborder attacks by al-Shabaab. ${ }^{319}$

317. Ruys, above note 250 , at 355 ; see id. at 344 ("In sum, the EU essentially urged Turkey to seek a political solution and to avoid disproportionate military action. European countries did not regard military action as the best answer to PKK violence, but carefully refrained from formally condemning Turkey's behaviour.") (emphasis added); id. ("Other reactions from the international community [that is, other than that of the U.S. and Iraq] were generally analogous to the EU approach.") (emphasis added); and id. at 355: ("Against this background, the Turkish intervention [in Iraq] of 2007-08, combined with the condoning attitude of the international community, adds to the evidence in state practice of an evolution towards a more flexible ... interpretation of self-defence in response to attacks by non-state actors which a state has been unwilling or unable to prevent.") (emphasis added). See also Scharf, above note 247, at 50.

318. Scharf, above note 247, at 24-25 ("Professor Myers McDougle [sic] of Yale Law School famously described the customary international law formation process as one of continuous claim and response. To illustrate this process, consider the question of whether international law permits a State to use force to arrest a terrorist leader in another State without the latter's consent-a question that recently arose when the United States kidnapped an al-Qaeda leader from Libya in October 2013. The claim may be express, such as demanding that its special forces be allowed to enter the territorial State to arrest the terrorist, or implicit, such as sending its special forces into the territorial State without its permission to apprehend the terrorist. The response to the claim may in turn be favorable, such as consenting to the operation or refraining from protesting the extraterritorial apprehension. In such case, the claim and response will begin the process of generating a new rule of customary international law. Some States may imitate the practice and others may passively acquiesce to it.") (emphasis added; citations omitted).

319. Id. at 50-51 (citations omitted). 
Markedly, one of the other examples of such "little protest" invoked by Scharf is the incursion in March of 2008 by Colombia against a FARC camp inside Ecuador's border. ${ }^{320}$ Yet, as Scharf notes, ${ }^{321}$ the Permanent Council of the Organization of American States considered that operation to have constituted "a violation of the sovereignty and territorial integrity of Ecuador and of principles of international law...." 322

To be certain, there are also those scholars who expressly reject the role of silence in such legal argumentation, or at least urge a more restrictive consideration of the ways in which silence can be used in this context. For example, Elisabeth Schweiger and Paulina Starski have cautioned against invoking silence in this field in general. ${ }^{323}$ Along these lines, Christine Gray argues that " $\left.\mathrm{i}\right] \mathrm{t}$ seems that many writers who support a wide right to use force rely only or mainly on US and Israeli claims of a wide right to use force in order to justify their assertions that the law has changed or ought to change. They do not give sufficient weight to the reaction of other States, or they assume that a lack of reaction constitutes agreement and they read silence as acquiescence." 324 This approach, Gray asserts, "weakens the fundamental prohibition of the use of force."325

Carstehn Stahn, commenting on the U.S. intervention in Afghanistan in 2001 , suggests that the "theory" of acquiescence in respect of that situation "is ... generally a weak argument for the validation of measures of self-defence, especially if it is based on the silence of the Council or ambiguous passages of

320. Id. at 50 .

321. Id. at $50 \mathrm{n} .192$ (citations omitted).

322. O.A.S., OEA/Ser.G, CP/RES. 930 (1632/08), Mar. 5, 2008, https://www.oas.org/council/sp/resoluciones/res930.asp, permalink: https://perma.cc/9AP3-J57D ("Que el hecho ocurrido constituye una violación de la soberanía y de la integridad territorial del Ecuador y de principios del derecho internacional”).

323. See Schweiger, Listen, above note 1; Starski, above note 6; Elisabeth Schweiger, The risks of remaining silent: international law formation and the EU silence on drone killings, 1 GLOBAL AFFAIRS 269 (2015). See also André de Hoogh, Restrictivist Reasoning on the Ratione Personae Dimension of Armed Attacks in the Post 9/11 World, 29 LEIDEN J. INT'L L. 19, 39 (2016) (discussing the use of silence in legal argumentation in this field).

324. Christine Gray, The Limits of Force, 376 RECUEIL DES COURS 101, 102-3 (2016).

325. Id. at 103. 
Security Council resolutions." ${ }^{26}$ Byers, although allowing a role for acquiescence with regard to that initial intervention, ${ }^{327}$ also concludes that the purported silence in the face of the continuation of Operation Enduring Freedom - after al-Qaeda had allegedly been pushed out of Afghanistan should not be interpreted as support for the U.S. attempt to extend its selfdefense claim to obtain a long-term presence in Afghanistan, in part because exceptions to the prohibition on force must be "narrowly construed." 328

O'Connell - while finding, as noted above, that the no-fly zones imposed by the United States and the United Kingdom may have been acquiesced in $^{329}$ - sees a "clear" contrast between those no-fly zones, on the one hand, and the December 1998 bombing of Iraq by the United States and the United Kingdom on the purported basis of enforcing a weapons regime against the President of Iraq Saddam Hussein, on the other hand. ${ }^{330}$ In respect of that latter bombing, O'Connell concludes - having earlier drawn attention to the condemnation of that action by China, France, and Russia - that "[t]he Council never acquiesced in the use of

327. See Byers, above note 311 and the accompanying text.

328. See id. at 637-38 ("Another set of questions arises with regard to the US reliance on a claim of self-defence despite the availability of better alternative arguments, such as Resolution 1373 providing Chapter VII authorization, or the 'status of forces agreement' with Afghanistan signalling consent. Does state practice consistent with a legally uncertain self-defence claim matter, if the operation itself is legal for other, more certain reasons? More specifically, did countries refrain from opposing the [U.S.] self-defence claim because they knew that a better justification was available-even if the United States did not make use of it? In such circumstances, acquiescence should not be considered state practice in favour of a claim because, once again, exceptions to the prohibition on force must be narrowly construed. [G] If states respond directly and positively to a self-defence claim, that practice does matter. As we saw above, there was widespread and explicit support in late 2001 for the US claim to a right of self-defence against terrorists who had already committed an act of violence amounting to an armed attack, and a country which was harbouring but not controlling them. [ [ Later, however, the United States sought to extend its self-defence claim to support a long-term presence in Afghanistan, after Al Qaeda had been pushed out of the country, in order to prevent the return to power of a group that had harboured it. This time, there was no such widespread and explicit support for the claim. Instead there was acquiescence, which could just as easily have been based on knowledge of the Afghan Government's consent. Given that the United States was seeking to stretch the right of self-defence further, thus broadening an exception to the prohibition on the use of force (which protects state sovereignty), silence in the face of the continuation of Operation Enduring Freedom should not be interpreted as support for the claim.") (emphasis added; citation omitted).

329. See O'Connell, above note 305 , at 51.

330. Id. 
force to enforce the weapons regime...."331 Also regarding that 1998 Iraqi inspection dispute as well as the Kosovo crisis later that same year, Jules Lobel and Michael Ratner contend that, "[a]s a textual matter, the [U.N.] Charter requires the Security Council to approve affirmatively of nondefensive uses of force. Acquiescence does not suffice." ${ }^{32}$ In the authors' view, "[t]o infer Council authorization either from silence, or from the obscure interstices of Council resolutions, undermines this Charter mandate." 333

Elinor Buys and Andrew Garwood-Gowers state that Operation Decisive Storm - the multinational coalition led by Saudi Arabia on the territory of Yemen beginning in March of 2015 - was "met with widespread approval or acquiescence from the international community." ${ }^{334}$ However, the authors contend that "this does not per se demonstrate an endorsement of the Operation's legality or of the right of unilateral humanitarian intervention." 335 Buys and Garwood-Gowers argue that resolution 2216, which the Security Council adopted in 2015 in relation to the situation, "is of limited significance given that the UN Security Council's failure to condemn cannot be interpreted as its acceptance of the Operation's legal basis." ${ }^{36}$ Yet, the authors assert, "[e]ven if acquiescence could be interpreted as acceptance of a legal basis, in this case it would be difficult to know precisely which of the three legal bases - self-defence, intervention by invitation or humanitarian intervention - such acquiescence related to..." Partly as a result, Buys and Garwood-Gowers

\footnotetext{
331. Id.

332. Jules Lobel \& Michael Ratner, Bypassing the Security Council: Ambiguous Authorizations to Use Force, Cease-Fires and the Iraqi Inspection Regime, 93 AM. J. INT'L L. 124, 130 (1999).

333. Id.

334. Elinor Buys \& Andrew Garwood-Gowers, The (Ir)Relevance of Human Suffering: Humanitarian Intervention and Saudi Arabia's Operation Decisive Storm in Yemen, J. CONFLICT \& SEC. L. 1 (2018) (citation omitted).

335. Id. (citations omitted).

336. Id. at 25 (citations omitted). Nußberger argues that " a policy of silence characterised the ... debate in the Security Council [that ensued after adopting of resolution 2216 in 2015], as states hardly addressed the issue of legality." Benjamin Nußberger, Military strikes in Yemen in 2015: intervention by invitation and self-defence in the course of Yemen's 'model transitional process,' 4 J. USE OF FORCE \& INT'L L. 110, 124 (2017) (emphasis added).
} 
conclude that "there is no clear evidence of support for humanitarian intervention as a legal basis of the Operation." 337

Finally, in relation to the purported legal basis (or bases) for the U.S. airstrike targeting ISIS in Libya in November of 2015, Jake Rylatt concludes - with respect to a distinct notion of silence, namely, silence in the sense of a lack of the expression of a legal position to which to respond in the first place - that "the paucity of publicly available information regarding the strike leaves us searching for a legal justification between the lines, resulting in strained interpretations of official statements and legal uncertainty." 338

\section{CONCLUSION}

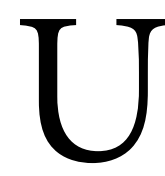

ltimately, there is no quantum of silence that has clear doctrinal force. While numerous States' actions and statements implicate jus ad bellum, most of that conduct and most of those positions do not elicit a response (at least a publicly discernible one) by other international actors. Yet due to the structure of the field, attempts to discern - let alone develop jus ad bellum invite presumptions about, and perceptions of, purported silence.

In light of the diversity of usages and the range of arguments for which silence has been deployed, it seems that silence does not carry a particular default brief. That is, an implied or express invocation of silence in this area is not itself determinative - or even necessarily suggestive - of a particular substantive outcome. That said, in practice, where scholars in this field invoke silence as legally significant, those invocations are more often than not offered in favor of relatively wide claims to resort to force.

As a matter of international law, it is unclear under what precise conditions silence may be accorded any legal significance. With regard to jus ad bellum, we have argued that caution is warranted in attributing legal effects to purported silence, whether of States or of the Security Council. This is particularly the case

337. Buys \& Garwood-Gowers, above note 334, at 25 (citation omitted).

338. Jake Rylatt, The Use of Force against ISIL in Libya and the Sounds of Silence, EJIL:TALK!, Jan. 6, 2016, https://www.ejiltalk.org/theuse-of-force-against-isil-in-libya-and-the-sounds-of-silence/, permalink: https://perma.cc/N2QQ-E2VT. 
because not all States are apparently made aware contemporaneously of "article 51 communications" reported to the Security Council such that the purported silence of non-reactive States in respect of the legal claims that are made or the actions that are described in those reports may be considered deliberate or even conscious.

And yet, notwithstanding the jurisprudential difficulties, as a matter of practice silence by both States and the Security Council is being invoked apparently increasingly - by several scholars in support of legal arguments in this field. Though such invocations are not universal, and though certain other scholars caution against it, the practice is nonetheless evident.

Of course, legal scholarship is not determinative of international law, and its effects on guiding State conduct or the workings of international organizations are by definition limited. Still, international-law scholarship often referenced by courts, regularly relied upon in legal memoranda by government lawyers and those working in international organizations, and featured in reports by think tanks and advocacy groups - may ultimately affect the development and application of both treaties and custom. Indeed, recall that the ICJ Statute expressly treats the writings of certain legal publicists as subsidiary means for the determination of rules of law. ${ }^{339}$

Currently, there are major debates in scholarship and among practitioners as to whether fundamental aspects of the jus ad bellum field are developing. As demonstrated in this paper, silence appears to play a role in how these debates are constructed, which voices are heard, and which perspectives are seen as influencing the trajectories. Legal scholarship has played a key role in framing, reflecting, and amplifying this debate.

The questions of what silence means as a matter of international law and under what conditions it may and should be relied upon merit closer attention and discussion. Silence - whether expressly acknowledged or not, and whether intended or not - seems to be playing a role in the identification, formation, modification, and termination of treaty law and customary international law. This reliance on silence has the capacity to shape and develop international law and 
influence individual States, even where other States do not intend for their lack of a response to play such a role. If that is the case, States that are concerned about existing jus ad bellum, or about how that law may be developing, may therefore wish to consider the contexts in which they speak out and those in which they remain silent.

States, of course, cannot choose whether or not to speak out if they are unaware of particular positions that might merit a response. At the very least, therefore, States should, in our view, be made more easily, directly, and systematically aware of communications to the Security Council regarding the use of force as well as the Council's and other States' responses (or lack of responses) to those communications. 


\title{
ANNEX: \\ HLS PILAC Catalogue of Communications to the SECURity COUNCIL OF MEASURES TAKEN BY UNITED Nations Member STATES in PURPORTED EXERCise OF THE RIgHT OF SELF-DEFENSE: OCTOBER 24, 1945 THROUGH DECEMBER 31, 2018
}

\author{
2019 \\ Editor: Dustin A. Lewis ${ }^{340}$ \\ Contributors: Lindsay Anne Bailey, Emma Broches, Laura Clark, Sonia \\ Chakrabarty, Thejasa Jayachandran, Daniel Levine-Spound, Sarah Libowsky, \\ Samantha Lint, Yang Liu, Carolina Silva-Portero, Shira Shamir, \\ William Ossoff, Tamsin Parzen, and Shanelle Van ${ }^{341}$
}

\section{SUMMARY}

0 o far as we are aware, no existing resource provides a searchable, up-todate, free-of-charge catalogue of communications to the United Nations Security Council of measures taken by U.N. Member States in purported exercise of the right of self-defense since the adoption of the U.N. Charter in 1945. ${ }^{342}$ To help fill this apparent gap, a team of researchers at the Harvard Law

340. Senior Researcher, Harvard Law School Program on International Law and Armed Conflict (HLS PILAC).

341. All of the contributors were, at the time that they contributed to the catalogue, students at Harvard Law School and research assistants at HLS PILAC.

342. Nevertheless, the research team drew on important earlier efforts to identify "article 51 communications," including the following: Repertoire of the Practice of the Security Council and subsequent Supplements thereto, http://www.un.org/en/sc/repertoire/, permalink: https://perma.cc/KZ3D-8U44; Repertory of the Practice of the United Nations Organs and Supplements thereto, http://legal.un.org/repertory/, permalink: https://perma.cc/2KFM-69ML; THE PROCEDURE OF THE UN SECURITY COUNCIL (Loraine Sievers \& Sam Daws eds., 4th ed., 2014) and Supplements thereto, including https://www.scprocedure.org/chapter-7-section-12, 
School Program on International Law and Armed Conflict (HLS PILAC) set out in 2018 to create a catalogue of so-called "article 51 communications" and certain responses by the Security Council to those communications.

\section{BACKGROUND}

\section{Tn the authentic English text, article 51 of the U.N. Charter provides as follows:}

Nothing in the present Charter shall impair the inherent right of individual or collective self-defence if an armed attack occurs against a Member of the United Nations, until the Security Council has taken measures necessary to maintain international peace and security. Measures taken by Members in the exercise of this right of self-defence shall be immediately reported to the Security Council and shall not in any way affect the authority and responsibility of the Security Council under the present Charter to take at any time such action as it deems necessary in order to maintain or restore international peace and security. ${ }^{343}$

\footnotetext{
permalink: https://perma.cc/8HZP-JQXX; https://www.scprocedure.org/chapter-7-section-12b, permalink: https://perma.cc/6UK5HFT5; https://www.scprocedure.org/chapter-7-section-12g, permalink: https://perma.cc/83VL-4UCF; and, especially, https://docs.wixstatic.com/ugd/54a569_dee1a4ae43a74d6b92800bff6a225652.pdf, permalink: https://perma.cc/TH8Y-92CX; Digests of State practice collected in the Journal on the Use of Force and International Law; CHRISTINE GRAY, INTERNATIONAL LAW AND THE USE OF FORCE (4th ed., 2018); Olivier Corten, Ius contra bellum, Positions exprimées à loccasion de précédents particuliers, CENTRE DE DROIT INTERNATIONAL DE L'UNIVERSTTÉ LIBRE DE BRUXELLES (undated), https://iusadbellum.wordpress.com/a-loccasionde-precedents-particuliers/, permalink: https://perma.cc/PZ3S-9W98; James A. Green, The article 51 reporting requirement for selfdefense actions, 55 VIRGINIA J. INT'L L. 563 (2015); OLIVIER CORTEN, THE LAW AGAINST WAR (2012); D.W. Greig, Self-Defence and the Security Council: What Does Article 51 Require?, 40 INT'L \& COMP. L. Q. 366 (1991); Jean Combacau, The Exception of Self-Defense in U.N. Practice, in The CuRrent Legal Regulation of the Use of ForCE 9-38 (Antonio Cassese ed., 1986).

343. Under article 111 of the U.N. Charter, the Chinese, French, Russian, English, and Spanish texts are equally authentic. See U.N. Charter art. 111. The text of article 51 in those languages is as follows: French: "Aucune disposition de la présente Charte ne porte atteinte au droit naturel de légitime défense, individuelle ou collective, dans le cas où un Membre des Nations Unies est lobjet d'une agression armée, jusquà ce que le Conseil de sécurité ait pris les mesures nécessaires pour maintenir la paix et la sécurité internationales. Les mesures prises par des Membres dans lexercice de ce droit de légitime défense sont immédiatement portées à la connaissance du Conseil de sécurité et n’affectent en rien le pouvoir et le devoir qu’a le Conseil, en vertu de la présente Charte, d’agir à tout moment de la manière qu'il juge nécessaire pour maintenir ou rétablir la paix et la sécurité internationales.; Russian: "Настоящий Устав ни в коей мере не затрагивает неотъемлемого права на индивидуальную или коллективную самооборону, если произойдет вооруженное нападение на Члена Организации, до тех пор пока Совет Безопасности не примет мер, необходимых для поддержания международного мира и безопасности. Меры, принятые Членами Организации при осуществлении этого права на самооборону, должны быть немедленно сообщены Совету Безопасности и никоим образом не должны затрагивать полномочий и
} 
The first part of the second sentence of article 51 expressly establishes the obligation of each U.N. Member State to bring to the attention of the Security Council measures taken in (purported) exercise of the right of self-defense. ${ }^{34}$ Submission of such an "article 51 communication" thus satisfies a Member State's obligation under the first part of the second sentence of article 51. The U.N. Charter contains no (further) express provisions regarding the format or content of those communications. It has been argued that the drafting record of what became the reporting obligation laid down in article 51 reveals that the obligation initially arose as part of an attempt to centralize the use of force in the U.N. system and to give the Security Council the opportunity to scrutinize claims of selfdefense. ${ }^{345}$ When submitted in the form of a document, or perhaps in a set of documents, such reports are sometimes informally labeled "article 51 letters," "article 51 reports," or "article 51 communications." 346

ответственности Совета Безопасности, в соответствии с настоящим Уставом, в отношении предпринятия в любое время таких действий, какие он сочтет необходимыми для поддержания или восстановления международного мира и безопасности."; Spanish: "Ninguna disposición de esta Carta menoscabará el derecho inmanente de legítima defensa, individual o colectiva, en caso de ataque armado contra un Miembro de las Naciones Unidas, hasta tanto que el Consejo de Seguridad haya tomado las medidas necesarias para mantener la paz y la seguridad internacionales. Las medidas tomadas por los Miembros en ejercicio del derecho de legítima defensa serán comunicadas inmediatamente al Consejo de Seguridad, y no afectarán en manera alguna la autoridad y responsabilidad del Consejo conforme a la presente Carta para ejercer en cualquier momento la acción que estime necesaria con el fin de mantener o restablecer la paz y la seguridad internacionales."; Chinese: 联合国任何会员国受武力攻击时，在安全理事会采取必要办法，以维持国际和平及安全以前，本宪章不得认为禁 止行使单独或集体自卫之自然权利。会员国因行使此项自卫权而采取之办法，应立向安全理事会报告，此项办法 于任何方面不得影响该会按照本宪章随时采取其所认为必要行动之权责，以维持或恢复国际和平及安全。

344. Pursuant to rule 6 of the Provisional Rules of Procedure of the Security Council, " $t$ t]he Secretary-General shall immediately bring to the attention of all representatives on the Security Council all communications from States, organs of the United Nations, or the Secretary-General concerning any matter for the consideration of the Security Council in accordance with the provisions of the Charter." Provisional Rules of Procedure of the Security Council, S/96/Rev.7, 1983, 2.

345. See Green, above note 342, at 568-69, 603.

346. In English, the denomination "reports" or "communications" might be preferred to "letters" for two reasons. First, "reports" and "communications" both encompass not only letters, strictly defined, but any other type of document irrespective of its designation. Second, "reports" and "communications" both also appear to encompass verbal statements that are made in order to bring to the attention of - in the broad sense of communicating to - the Council measures taken in purported exercise of the right of self-defense. That broader approach seems to align more closely with the equally authentic French text ("portées à la connaissance du Conseil de sécurité") and Spanish text ("serán comunicadas ... al Consejo de Seguridad"). However, as noted below, it is not clear whether verbal statements alone - that is, without an accompanying written submission - would suffice to satisfy the reporting requirement laid down in the second sentence of article 51. In any event, 
In addition to seeking to fulfill an obligation laid down in the U.N. Charter, "article 51 communications" may be legally relevant for other reasons. For example, "article 51 communications" might reveal submitting States' views regarding at least certain aspects of the international legal framework concerning self-defense. For example, an "article 51 communication" may - expressly or implicitly (or both) - convey the submitting State's interpretation regarding legal elements of self-defense, including in relation to such issues as the authorship, form, and scale and effects of what may constitute an "armed attack"; in respect of what contexts self-defense may be undertaken, for what duration, and against whom; and the scope of the jus ad bellum necessity and proportionality principles. An "article 51 communication" may, under certain circumstances, itself constitute State practice or evidence of acceptance as law (opinio juris), or perhaps both, of the submitting State - that is, one or the other, or perhaps both, of the two elements generally recognized as necessary to identify rules of customary international law. In turn, responses to "article 51 communications," which sometimes themselves might take the form of an "article 51 communication," may reveal other States' views concerning legal aspects of self-defense. Meanwhile, at least in accordance with the view of the ICJ, ${ }^{347}$ an absence of an "article 51 communication" may, under certain circumstances, be construed as having legal significance.

\section{Methodology}

\section{A. Target Audience}

The primary intended audience of the catalogue includes legal practitioners and scholars whose work concerns self-defense in particular and the legal regime governing the non-use of force in international relations more generally.

per Green, "reports" might be something of a misnomer itself. See Green, above note 342.

347. See Military and Paramilitary Activities, Judgment, above note 148, at 120-23. 


\section{B. Identifying Communications; Caveats and Limitations}

To identify candidate communications, the research team primarily utilized the 1 U.N. Official Documents System (ODS). ${ }^{348}$ Researchers started by conducting an initial search by entering the following search parameters in ODS:

Symbol field: "S/"

Full text search: "self-defense"; "self-defence"; or "Article 51"

Type of full text search: Find any of these words

Through that process, some "false positives" were identified — for example, S/2016/869 (United States), in which the United States expressly indicates that it does not believe that notification pursuant to article 51 is necessary in the particular circumstances. ${ }^{349}$ Those "false positives" were not ultimately included in the catalogue.

For each returned result, a researcher conducted an initial evaluation as to whether the communication met the parameters for inclusion, which are described below. The candidate communications that passed provisional muster were then reviewed by the general editor of the catalogue. The general editor alone ultimately decided whether or not to include each candidate communication in the catalogue.

As a preliminary matter, it bears emphasis that it is not clear that all of the communications recorded in the catalogue necessarily contain authentic claims of a purported exercise of the right of self-defense as contemplated in the second sentence of article 51 of the U.N. Charter. Nor is the catalogue necessarily comprehensive. So far as the general editor is aware, there is no authoritative, authentic, and comprehensive catalogue either of article 51

348. See U.N. Official Documents System, https://documents.un.org/, permalink: https://perma.cc/9SH8-ULHY.

349. See United States, S/2016/869 (Oct. 17, 2016) (“These actions were taken with the consent of the Government of Yemen. Although the United States therefore does not believe notification pursuant to Article 51 of the Charter of the United Nations is necessary in these circumstances, the United States nevertheless wishes to inform the Council that these actions were taken consistent with international law."). 
communications or of Security Council responses (or lack of responses) thereto. Therefore, several editorial and interpretive decisions were made - including in respect of what communications to include and which to exclude - that may be subject to critique. Moreover, several technical difficulties were encountered in searching for candidate communications.

Searches in the U.N. Official Documents System did not necessarily produce a comprehensive set of "article 51 communications." This might be due in part to limitations concerning the technical searchability of PDFs created by scanning paper documents. Those limitations arise in part because the digital surrogates that is, the PDFs in the U.N. Official Documents System - of the original paper documents are of varying quality. To help address this issue, for letters at least from the 1945-1986 period, researchers also conducted searches within the United Nations Dag Hammarskjold Library, which is an additional U.N. online document catalogue. For those searches, researchers entered the following search parameters in the DAG Repository of U.N. Official Documents:

Content type: Letters/Notes Verbales

Search: "self-defense"; or "self-defence"

In seeking to ensure that every relevant report was evaluated, researchers also reviewed other resources, including existing catalogues and research tools that contain apparent "article 51 communications." 350

Several other difficulties arose in seeking to identify and systematically evaluate candidate communications.

As an editorial matter, in deciding which candidate communications to include, the general editor ultimately elected to read the requirements laid down in article 51 relatively strictly. Therefore, researchers were instructed - in evaluating whether or not to include a communication - to confirm or disconfirm whether a candidate report could be reasonably construed, in the

350. See above note 342 for a list of additional resources consulted. 
terms of the second sentence of article 51, as immediately reporting to the Security Council "[m] easures taken by [a U.N.] Member[] in the exercise of this right of self-defence [that is, the inherent right of individual or collective self-defence if an armed attack occurs against a Member of the United Nations]." On that basis, only those communications that were reasonably construed as meeting six sets of criteria were included: those communications that (i) reported, whether in writing or verbally, (ii) immediately (iii) to the Security Council (iv) measures taken (v) by a U.N. Member State (vi) in (purported) exercise of the right of self-defense.

Regarding element (i), it is not necessarily clear whether only written communications may count or whether verbal statements may (also) satisfy the reporting requirement. So far as the general editor of the catalogue is aware, the Security Council has never directly and authoritatively addressed that specific question as such, nor have other U.N. Organs ${ }^{351}$ or U.N. Member States writ large. The catalogue presumes that both written and verbal communications may count and therefore includes both types of communications.

Further with respect to element (i), it is also not necessarily clear whether, to satisfy the reporting requirement, the communication must, among other things, expressly invoke "self-defense" (or "self-defence"); expressly invoke "article 51"; and/or expressly indicate the existence - and perhaps the author (or authors) - of an "armed attack." So far as the general editor of the catalogue is aware, the Security Council has never directly and authoritatively addressed that question in relation to the reporting requirement, nor have other U.N. Organs or U.N. Member States writ large. The catalogue of reports includes

351. However, in a handful of cases, the ICJ has expressed its perspective regarding certain aspects of the article-51-reporting requirement, including in respect of the requirement's material and temporal scope, its legal nature, and certain consequences that may, in the Court's view, arise (or inferences that may be drawn) from an absence of reporting - or at least excerpted self-defense communications made to the Security Council. Those cases include Military and Paramilitary Activities, Judgment, above note 148, at 105, 120-23; Nuclear Weapons, Advisory Opinion, above note 179, at 245; Oil Platforms (Iran v. U.S.A.), Judgment, 2003 I.C.J. Reports, 161, 185, 193-94 (Nov. 6); Armed Activities on the Territory of the Congo (DRC v. Ug.), Judgment, 2005 I.C.J. Reports,168, 222 (Dec. 19). See also Military and Paramilitary Activities, Judgment, above note 148, Dissenting Opinion of Judge Schwebel, 373-377. See further EECC, Partial Award, Jus Ad Bellum-Ethiopia's Claims 18, para. $11 \mathrm{https}: / /$ pcacases.com/web/sendAttach/763, permalink: https://perma.cc/VN5X-3X6N. 
communications even if they lack those express invocations, provided that the communication may (otherwise), at least on a prima facie basis, be reasonably interpreted to constitute a report of measures taken in a purported exercise of the right of self-defense.

Communications that invoked "article 51" but that did not (otherwise) satisfy the six constituent elements were not included in the catalogue.

Conversely, a lack of an express reference to "article 51" did not by itself constitute a ground to exclude the communication from the catalogue. That interpretive decision was made on the basis that the text of article 51 does not expressly require that, in calling relevant measures to the attention of the Security Council, a U.N. Member must necessarily expressly refer to "article 51."

Regarding element (iii), communications made to other U.N. entities but not (also) to the Security Council were excluded. Where a document was circulated to both the Security Council and the General Assembly, only the Security Council symbol was recorded in the catalogue.

In relation to element (iv), an editorial choice was made to include only those communications that included measures that had already been taken. ${ }^{352}$ That choice was made because the catalogue sought to record only instances of purported defensive force that had occurred in fact. Thus, the catalogue does not include what Professor James Green has characterized as "pre-emptive" reporting. ${ }^{353}$ In addition, communications that entailed threats by a State (or States) to use force in self-defense or signaled that the State(s) would in principle be entitled to use force in self-defense, but that were not (also) accompanied by an actual defensive response, were not included. These

352. The following are some of the examples of communications that were not included in the catalogue because they were not considered to report measures that had already been taken: Argentina, S/14961 (Apr. 9, 1982); Yugoslavia, S/1999/322 (Mar. 24, 1999); Liberia, S/2001/562 (June 6, 2001); Democratic Republic of the Congo, S/2002/286 (Mar. 18, 2002); Democratic Republic of the Congo, S/2004/489 (June 14, 2004); Israel, S/2006/515 (July 12, 2006); Azerbaijan, S/2008/82 (Feb. 8, 2008); Sudan, S/2012/277 (Apr. 30, 2012); Democratic People’s Republic of Korea, S/2013/50 (Jan. 24, 2013).

353. In the words of Professor Green: "reports that were submitted prior to force being used in self-defence (or, in some cases, prior to the expected exercise of defensive force that was ultimately never used)." Green, above note 342, at 599 (emphasis added). See further id. at 599-602. 
editorial choices might be critiqued on the basis that excluding those reports could distort the broader legal picture, by, for example, perhaps downplaying the practice of militarily weaker States that may not be in a position to respond with force to an alleged armed attack. The choice not to include certain other communications - namely, those that expressly or implicitly indicated that measures would be taken if certain conditions were met in the future, ${ }^{354}$ or that (merely) "reaffirmed"355 or "reserved" 356 the right of self-defense, but that did not (also) report that any (new) measures had already been taken ${ }^{357}$ - also reflects an editorial decision.

With respect to element (v), an editorial decision was made to include only communications containing reports of relevant measures taken by the reporting State. Thus, reports of measures taken by other entities were excluded. ${ }^{358}$

With respect to element (vi), only those measures considered by the general editor to fall within the concept of the right of self-defense in the face of an armed attack as "enshrined" - in the words of the ICJ in the Military and Paramilitary Activities in and against Nicaragua case ${ }^{359}$ - in the first sentence of article 51 of the U.N. Charter were included. It bears emphasis, however, there is a lack of universal agreement as to the precise contours of what measures may fit within that concept. It was therefore necessary to take several

\footnotetext{
354. See, e.g., Pakistan, S/25860 (May 28, 1993); Israel, S/2006/1029 (Dec. 26, 2006); Israel, S/2007/285 (May 16, 2007); and Iran, S/2008/377 (June 10, 2008). See also Israel, S/2006/891 (Nov. 15, 2006); Israel, S/2007/733 (Dec. 13, 2007). Israel, S/10244 (June 30, 1971) was not included because it seemed to imply - but did not clearly report - self-defense measures, thus raising a similar interpretative issue. See further, e.g., Cyprus, S/20893 (Oct. 10, 1989); Lebanon, S/1994/954 (Aug. 9, 1994); Iraq, S/2001/805 (Aug. 20, 2001); Pakistan, S/2002/571 (May 22, 2002).

355. See, e.g., Iraq, S/2001/152 (Feb. 21, 2001); Democratic Republic of the Congo, S/2002/286 (Mar. 18, 2002).

356. See, e.g., Russia, S/2002/1012 (Sept. 12, 2002); Israel, S/2006/515 (July 12, 2006).

357. See, e.g., United Kingdom, S/14964 (Apr. 11, 1982); United Kingdom, S/14997 (Apr. 24, 1982); United Kingdom, S/15006 (Apr. 28, 1982); United Kingdom, S/15010 (Apr. 29, 1982); Argentina, S/15018 (Apr. 30, 1982); United Kingdom, S/15058 (May 8, 1982); Rwanda, S/1994/586 (May 17, 1994); Iraq, S/2001/805 (Aug. 20, 2001); Israel, S/2009/131 (Mar. 6, 2009); Israel, S/2009/493 (Oct. 2, 2009); Israel, S/2012/69 (Jan. 27, 2012).

358. See, e.g., Armenia, S/26394 (Sept. 1, 1993), at 2 (Armenia communicating "countermeasures" taken by "the Self-Defence forces of Nagorny Karabakh" in response to alleged attacks by Azerbaijani military units).

359. See Military and Paramilitary Activities, Judgment, above note 351, at 35.
} 
editorial decisions in this connection - for example, whether or not to include "defensive" military action following an alleged breach of an armistice line. (Ultimately, the decision was made by the general editor to include such actions.) Conversely, measures of "defense" of U.N. peacekeeping or peaceenforcement missions were not included, on the basis that they are apparently not (usually) taken in relation to article $51 .{ }^{360}$

Spanning out, these and other editorial and interpretive issues that the research team encountered might be seen as underscoring the relative lack of authoritative, authentic, and comprehensive legal guidance in this area.

Despite these limitations and caveats, it is hoped that the catalogue will provide a useful - if limited - basis to identify and evaluate the context and development of the positions of States and the Security Council over time in relation to self-defense.

\section{Parameters of the Catalogue}

\section{A. Versions and Formats}

$\mathrm{V}$

ersion 1.0 of the catalogue is being released on the HLS PILAC website (https://pilac.law.harvard.edu) in July of 2019. If changes are made to the

\footnotetext{
360. See, e.g., (Draft) I.O. Responsibility Articles art. 42(2), above note 138, at 71 ("In the practice relating to United Nations forces, the term 'self-defence' has often been used in a different sense, with regard to situations other than those contemplated in Article 51 of the Charter of the United Nations. References to 'self-defence' have been made also in relation to the 'defence of the mission. For instance, in relation to UNPROFOR, a memorandum of the Legal Bureau of the Canadian Department of Foreign Affairs and International Trade held that "'[s]elf-defence' could well include the defence of the safe areas and the civilian population in those areas.' While these references to 'self-defence' confirm that self-defence represents a circumstance precluding wrongfulness of conduct by an international organization, the term is given a meaning that encompasses cases other than those in which a State or an international organization responds to an armed attack by a State. In any event, the question of the extent to which United Nations forces are entitled to resort to force depends on the primary rules concerning the scope of the mission and need not be discussed here."). For an array of contemporary perspectives concerning another possibly relevant concept - namely, "soldier self-defense," including whether it may or may not fall within this right - see Elvina Pothelet \& Kevin Jon Heller, Symposium on Soldier Self-Defense and International Law: Highlighting and Framing the Issue, OPINIO JURIS, Apr. 19, 2019, http://opiniojuris.org/2019/04/29/symposium-on-soldier-self-defense-and-internationallaw-highlighting-and-framing-the-issue, permalink: https://perma.cc/7JX5-KFHC (framing the symposium and providing links to its eight contributions to it).
} 
catalogue, subsequent versions will be updated as different versions. The catalogue is being released in July of 2019 in the following formats:

- As an Excel Spreadsheet;

- As a PDF; and

- As a Google Sheet.

The content of the catalogue is the same across formats.

\section{B. Catalogue Fields}

The catalogue includes the following fields:

\section{Chron. Order}

This column records the chronological order of the communication, in descending order (that is, from oldest to newest).

\section{Date of Comm.}

Date of communication - for written reports, this is the date of the document in which the communications was sent to the Security Council; for verbal reports, it is the date of the statement that brought the report to the attention of the Security Council. For written reports, this date is usually found in the subject line of the document transmitting the report. The date is in the following format: Year.Month.Date [YYYY.MM.DD].

\section{Date of UNSC Document}

This column records the date on which the communication was published in a Security Council document. This date is sometimes (slightly) after the date the communication was conveyed by the submitting Member State. The date is in the following format: Year.Month.Date [YYYY.MM.DD].

\section{UNSC Symbol}

This column records the Security Council symbol pertaining to the communication: where both a General Assembly and a Security Council 
symbol are included on the document, only the Security Council symbol is recorded in the catalogue. For example, S/2005/609 (Israel) is recorded, whereas A/60/382-S/2005/609 (Israel) is not recorded. Corrigenda were not recorded in the catalogue; for example, S/9330 (El Salvador) is recorded, but S/9330/CORR.1 (El Salvador) is not (also) recorded.

\section{Member State(s) That Submitted the Comm.}

This column records the U.N. Member State that submitted the communication to the Security Council. For ease of reference and consistency in reporting, certain spellings were standardized or shortened in the database. ${ }^{361}$

\section{Expressly Mentioned UN Members (\& Colonial Holdings \& Protectorates, if any)}

This column records all States, colonial holdings, and/or protectorates explicitly mentioned in the communication, in any respect, including the Member State submitting the communication.

\section{Express or Implied Assertion of Individual, Collective, or Both Self-defense}

This column indicates whether - in the view of the general editor - the measures taken in purported exercise of self-defense were expressly or impliedly undertaken in individual self-defense, collective-self-defense, or both individual and collective self-defense. If neither "individual" nor "collective" is stated verbatim in the communication, the measures contained in the communication were labeled as constituting (as applicable) an implied assertion of "individual" or "collective" selfdefense or both "individual" and "collective" self-defense. Only those communications that contain an express invocation of "individual" selfdefense, "collective" self-defense, or both "individual" and "collective" are recorded as an express assertion of self-defense in this column.

\footnotetext{
361. For example, People's Republic of China to China; Democratic Kampuchea and Democratic Republic of Kampuchea to Kampuchea [Cambodia]; Federal Republic of Yugoslavia to Yugoslavia; Kingdom of the Netherlands to the Netherlands; Islamic Republic of Iran to Iran; Libyan Arab Jamahiriya to Libya; Republic of Vietnam to South Vietnam; Russian Federation to Russia; Syrian Arab Republic to Syria; United Kingdom of Great Britain and Northern Ireland to United Kingdom; United States of America to United States; Viet Nam, Viet-nam, and Viet-Nam to Vietnam.
} 


\section{Nature of the Alleged Threat}

This column indicates whether - in the view of the general editor - the nature of the threat that is addressed in the communication might be characterized as one or more of the following: a conducted attack; a threat of attack; an imminent attack; and/or an indirect attack. As a matter of emphasis, it is noted that these categories are rough sketches and do not correspond to legal categories as such. The categories included in this column are not meant to correspond to such legal notions as "armed attack," "threat of force," or the like.

\section{Expressly Alleged Author(s) of the Threat (If Any Indicated)}

This column records the alleged author, or authors, of the threat where such an author is, or authors are, expressly indicated in the communication by the submitting Member State(s). Where no such author is indicated in the communication, "Not indicated" is recorded.

\section{Nature of the Alleged Author(s) of the Threat (If Any Indicated)}

This column records the nature - whether State(s), non-state actor(s), or both State(s) and non-state actor(s) - of the alleged author, or authors, of the threat where such an author is, or authors are, expressly indicated in the communication by the submitting Member State(s). With respect to the nature of the author(s) of the alleged threat giving rise to the claim of self-defense, the catalogue distinguishes between three sets of categories: (1) A State (or States); (2) non-state actors; or (3) both a State (or States) and non-state actors.

In respect of certain communications, difficulties arose in classifying a particular alleged author as either State or non-state in character. For example, in S/1998/934 (Iran) Iran refers to the alleged author of the threat as the "Taliban militia,"362 whereas in S/2001/946 (United States) the United States refers to the "Taliban regime."363

362. Iran, S/1998/934 (Oct. 8, 1998).

363. United States, S/2001/946 (Oct. 7, 2001), at 1. 
It is also important to bear in mind that, in respect of certain communications, it is not necessarily clear whether or not the State submitting the communication intended to attribute the allegedly self-defense-generative conduct of relevant nonstate actors (for example, a purported "armed attack" by alleged "terrorists" or "irregular forces") to a State (for example, to the State from whose territory those actors are allegedly launching actions giving rise to a purported exercise of the right of self-defense of the victim State) or to otherwise seek to engage the responsibility of another State (for example, on the grounds that the other State allegedly acquiesced in or otherwise tolerated self-defense-generative conduct of the non-state actors).

\section{Summary of Self-defense Alleged Grounds}

This column provides a thumbnail sketch of the grounds - as alleged by the Member State(s) submitting the communication - on which that State (or those States) could take measures in purported exercise of the right of self-defense. As a matter of emphasis, it is noted that the summary is not meant to exhaustively catalogue all of the alleged grounds (where more than one ground is alleged), but rather to merely give a gist of the complaint.

Regarding punctuation: as used in this column, the " $\boldsymbol{~ " ~ s y m b o l ~ i n d i c a t e s ~ a ~}$ paragraph break in the original communication; the " $\mathbf{g}$ " symbol indicates a doubleparagraph break in the original communication; and the ".... symbol indicates a break spanning more than two paragraphs in the original communication.

\section{UNSC Meeting(s) (If Any) at Which the Comm. was Raised}

This column records the meetings of the Security Council, if any, at which the communication was expressly discussed or the conduct underlying the communication was otherwise raised. To help identify meetings, both the U.N. symbol (for example, "S/PV.2247") and the number of the meeting (for example, "2247th") are recorded. Researchers sought to identify such meetings by searching for the Security Council symbol of the communication via online Council meeting records. However, the results in this column should be considered preliminary, due, in part, to the low quality of some online meeting records and to the lack of reliable records extending back to the establishment of the Security Council. 


\section{Responsive Act (If Any) by the UNSC}

This column records the formal responses, if any, of the Security Council in respect of each submitted communication, as identified by researchers. For the purposes of this column, a formal response could include only either (i) an adoption of an act of the Security Council that included a relevant provision (or provisions) or (ii) the issuance of a presidential statement that contained a relevant provision (or provisions). However, the results in this column should be considered preliminary, due, in part, to the low quality of some relevant records.

Where a resolution of the Security Council is recorded, the relevant portion is excerpted verbatim, followed by an indication of the vote pertaining to the resolution.

\section{UN Repertory Inclusion?}

This column records whether a communication was or was not found by a researcher to be referenced in the Repertory of the Practice of United Nations Organs or a Supplement thereto. To make this assessment, a search of the communication's Security Council symbol was made in the online version of the Repertory and Supplements thereto. If the communication was found to be included in the Repertory or a Supplement thereto, the relevant part(s) and/or article(s) - for example, "Chapter VII," "Article 2(4)," and/or "Article 51" - were also recorded. If no such result was identified, "None identified" is recorded. However, the results in this column should be considered preliminary, due, in part, to the low quality of some relevant records and to inconsistent reporting of relevant materials in the Repertory and Supplements thereto.

\section{UNSC Repertoire Inclusion?}

This column records whether a communication was or was not found by a researcher to be referenced in the Repertoire of the Practice of the Security Council or a Supplement thereto. To make this assessment, a search of the communication's Security Council symbol was made in the online version of the Repertoire and Supplements thereto. If the communication was found to be included in the Repertoire or a Supplement thereto, the relevant part(s) and/or article(s) - for example, "Chapter VII," "Article 2(4)," and/or "Article 51" - were also recorded. If no such result was identified, "None identified" is recorded. However, the results in 
this column should be considered preliminary, due, in part, to the low quality of some relevant records and to inconsistent reporting of relevant materials in the Repertory and Supplements thereto.

\section{URL to an English Text}

This column records a source uniform record locator (URL) where the English text, whether in its original submission or through a U.N. translation (the latter for communications submitted in a language other than English), of the report was found.

Note that to access certain URLs, a live session of the ODS website may need to already be open and current in the browser: https://documents.un.org.

\section{URL to Non-English Original Text (If Any)}

Several reports were communicated in languages other than English. This column records, where applicable, a URL for each communication originally made - in whole or in part - in a language other than English. That URL is derived from the link provided via a search for the report in the ODS.

For some communications, part of the report is expressed in one language whereas another part of the report is expressed in another language. ${ }^{364}$ In respect of certain reports, two original languages are listed. ${ }^{365}$ For certain reports, the original-language text is not available via the ODS, even though translated versions are available; ${ }^{366}$ for those reports, "Not available" is recorded in this field.

Note that to access certain URLs, a live session of the ODS website may need to already be open and current in the browser: https://documents.un.org.

\footnotetext{
364. See, e.g., Qatar, Saudi Arabia, the United Arab Emirates, and Kuwait, S/2015/217 (Mar. 27, 2015) (letter and annex in English and enclosure in Arabic).

365. See, e.g., China, S/13294 (May 3, 1979) (listing “CHINESE/ENGLISH” as the original language).

366. See, e.g., Iraq, S/17450 (Sept. 10, 1985) (the Arabic original is not available via ODS whereas the Chinese, English, French, Russian, and Spanish versions are available), https:/documents.un.org/prod/ods.nsf/xpSearchResultsM.xsp, permalink: https://perma.cc/T2VK-MQ2L.
} 


\section{Perma.cc URL}

This column contains a Perma.cc link generated by a researcher of the web address of a version of the English text of the communication. ${ }^{367}$

\section{Credits; Feedback}

\section{A. Acknowledgments}

7 he catalogue authors gratefully acknowledge the following people: Scott Anderson, Ashley Deeks, Mona Khalil, Eliav Lieblich, Marko Milanovic, Tom Ruys, Stephen Townley, and Larissa van den Herik, as well as participants in the 2018-2019 informal "International Law Lunches" hosted in collaboration with the Permanent Missions to the United Nations in New York of Belgium, Liechtenstein, Mexico, Norway, and Switzerland, for discussion and feedback; and Jennifer Allison, Bridget J. Reischer, and Caroline Walters of the Harvard Law School (HLS) Library, as well as other members of the HLS Library staff, for research support.

\section{B. Disclaimers}

TLS PILAC receives generous support from the Swiss Federal Department

1 of Foreign Affairs (FDFA). Any views expressed in this catalogue should not be taken, in any way, to reflect the official opinion of the Swiss FDFA or any entity other than the named HLS PILAC research team. HLS PILAC is grateful for the support that the Swiss FDFA provides for independent research and analysis. The research undertaken by the authors of this catalogue was

\footnotetext{
367. See Perma.cc, About Perma.cc, https://perma.cc/about, permalink: https://perma.cc/BAA5-P2KG ("When a user creates a Perma.cc link, Perma.cc archives the referenced content and generates a link to an archived record of the page. Regardless of what may happen to the original source, the archived record will always be available through the Perma.cc link. ... [ $\mathbf{g}$ ] Perma.cc is developed and maintained by the Harvard Law School Library in conjunction with university law libraries across the country and other organizations in the 'forever' business.").
} 
independent; the views and opinions reflected in this catalogue are those solely of the authors; and the authors alone are responsible for any errors.

C. Copyright

TLS PILAC is releasing the catalogue under a Creative Commons 1 Attribution-NonCommercial-ShareAlike 4.0 International (CC BY-NCSA 4.0) license.

D. Feedback

The research team invites critical feedback on the catalogue. We are particularly interested in finding ways to make the catalogue more useful for practitioners and researchers and in ensuring that the catalogue is as comprehensive and accurate as possible. Please send updates, emendations, suggestions, and other feedback to pilac@law.harvard.edu with "Self-defense Catalogue" in the subject-line of the e-mail. 
VI. HLS PILAC Catalogue of Apparent “Article 51 Communications”

\begin{tabular}{|c|c|c|c|c|c|c|c|c|c|c|c|c|c|c|c|c|c|}
\hline $\begin{array}{l}\text { Chron. } \\
\text { Order }\end{array}$ & $\begin{array}{l}\text { Date of } \\
\text { Comm. }\end{array}$ & $\begin{array}{c}\text { Date of } \\
\text { UNsc } \\
\text { Document }\end{array}$ & UNSC Symbol & \begin{tabular}{|c} 
Member \\
State(s) That \\
Submitted \\
the Comm.
\end{tabular} & \begin{tabular}{||c||} 
Expressly \\
Mentioned UN \\
Members (\& \\
Colonial \\
Holdings \& \\
Protectorates, \\
if any)
\end{tabular} & \begin{tabular}{|c} 
Express or \\
Implied \\
Assertion of \\
Individual, \\
Collective, or \\
Both Self- \\
defense
\end{tabular} & $\begin{array}{c}\text { Nature of } \\
\text { the Alleged } \\
\text { Threat }\end{array}$ & $\begin{array}{l}\text { Expressly Alleged } \\
\text { Author(s) of the } \\
\text { Threat (If Any } \\
\text { Indicated) }\end{array}$ & \begin{tabular}{|l} 
Nature of the \\
Alleged \\
Author(s) of \\
the Threat (If \\
Any \\
Indicated)
\end{tabular} & $\begin{array}{l}\text { Summary of Alleged Self-defense } \\
\text { Grounds }\end{array}$ & $\begin{array}{l}\text { UNSC } \\
\text { Meeting(s) } \\
\text { (If Any) at } \\
\text { Which the } \\
\text { Comm. was } \\
\text { Raised }\end{array}$ & $\begin{array}{l}\text { Responsive Act (If Any) by the } \\
\text { UNSC }\end{array}$ & \begin{tabular}{|c} 
UN \\
Repertory \\
Inclusion?
\end{tabular} & \begin{tabular}{|c|} 
UNSC \\
Repertoire \\
Inclusion?
\end{tabular} & \begin{tabular}{|l} 
URL to an \\
English \\
Text
\end{tabular} & \begin{tabular}{||c||} 
URL to Non- \\
English \\
Original \\
Text (ff Any)
\end{tabular} & $\begin{array}{l}\text { Perma.cc } \\
\text { URL }\end{array}$ \\
\hline 1 & \begin{tabular}{|l|l|}
1950.02 .08 \\
\end{tabular} & 1950.02.08 & S/PV.464 & Pakistan & \begin{tabular}{|} 
Pakistan, India, \\
United \\
Kingdom, \\
United States, \\
France, Japan
\end{tabular} & $\begin{array}{l}\text { Implied } \\
\text { assertion of } \\
\text { "individual" } \\
\text { self-defense }\end{array}$ & $\begin{array}{c}\text { Conducted } \\
\text { attack }\end{array}$ & India & State & $\begin{array}{l}\text { "IIdia not only mounted its offensive, } \\
\text { it subsequently continued to move on } \\
\text { to other areas, occupying certain } \\
\text { portions and rapidly advancing } \\
\text { towards the Pakistan border... [q]... } \\
\text { [n] They [our armies] went, so far as } \\
\text { Kashmir was concerned, in aid of the } \\
\text { freedom of the people, in order to } \\
\text { enable them to hold what territory } \\
\text { was left to them against the Indian } \\
\text { advance. And so far as we were } \\
\text { concerned, that was the main object: } \\
\text { to avoid the imminent danger that } \\
\text { threatened the security of Pakistan } \\
\text { and the economy of Pakistan." }\end{array}$ & $\begin{array}{l}\text { S.PV/464 } \\
\text { (464th) }\end{array}$ & None identified & $\begin{array}{l}\text { Articles 2(7), } \\
23,25,42, \\
55, \& 62(1)\end{array}$ & $\begin{array}{l}\text { Chapter III } \\
\text { (no } \\
\text { particular } \\
\text { article) }\end{array}$ & \begin{tabular}{|l||} 
https: \\
//documen \\
ts-dds-ny. \\
un. \\
org/doc/U \\
NDOC/GEN \\
NDS0/382/ \\
30//df/N5 \\
O38230. \\
pdf? \\
OpenElem \\
ent
\end{tabular} & & $\begin{array}{l}\text { https: } \\
\text { //perma. } \\
\text { cc/5LST- } \\
\text { J8N5 }\end{array}$ \\
\hline 2 & \begin{tabular}{|l|}
1951.05 .07 \\
\end{tabular} & 1951.05.07 & $s / 2126$ & Israel & $\begin{array}{l}\text { Israel, Syria, } \\
\text { United States, } \\
\text { United } \\
\text { Kingdom }\end{array}$ & $\begin{array}{l}\text { Implied } \\
\text { assertion of } \\
\text { "individual" } \\
\text { self-defense }\end{array}$ & $\begin{array}{c}\text { Conducted } \\
\text { attack }\end{array}$ & $\begin{array}{l}\text { Syria and irregular } \\
\text { forces under the } \\
\text { control of Syria }\end{array}$ & $\begin{array}{c}\text { State and } \\
\text { non-state } \\
\text { actors }\end{array}$ & $\begin{array}{l}\text { Breach of the Armistice Agreement by } \\
\text { appearance of forces in the } \\
\text { demilitarized zone; armed entry into } \\
\text { Israeli territory. }\end{array}$ & $\begin{array}{l}\text { S/PV. } 545 \\
\text { (545th) }\end{array}$ & $\begin{array}{l}\text { S/RES/92(1951), third para.: } \\
\text { "CCalls upon the parties or } \\
\text { persons in the areas concerned } \\
\text { to cease fighting, and brings to } \\
\text { the attention of the parties } \\
\text { their obligations under Article } \\
\text { 2, paragraph h, of the Charter } \\
\text { of the United Nations and the } \\
\text { Security Council's resolution of } \\
15 \text { July } 1948 \text { and their } \\
\text { commitments under the } \\
\text { General Armistice Agreement, } \\
\text { and accordingly calls upon } \\
\text { them to comply with these } \\
\text { obligations and } \\
\text { commitments." (10-0-1) }\end{array}$ & No & \begin{tabular}{|l|} 
Articles 39- \\
$40 ;$ Chapter \\
IV (no \\
particular \\
article)
\end{tabular} & 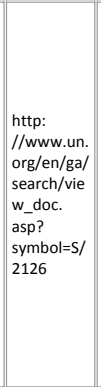 & & $\begin{array}{l}\text { https: } \\
\text { //perma. } \\
\text { cc/AW64- } \\
\text { EWSN }\end{array}$ \\
\hline 3 & \begin{tabular}{|l|}
1951.08 .01 \\
\end{tabular} & 1951.08.01 & $\mathrm{S} / \mathrm{PV} .550$ & Egypt & $\begin{array}{l}\text { Egypt, Israel, } \\
\text { United } \\
\text { Kingdom }\end{array}$ & $\begin{array}{l}\text { Implied } \\
\text { assertion of } \\
\text { "individual" } \\
\text { self-defense }\end{array}$ & $\begin{array}{c}\text { Conducted } \\
\text { attack }\end{array}$ & Israel & State & $\begin{array}{l}\text { Israel's violations of the Egyptian- } \\
\text { Israel General Armistice Agreement, } \\
\text { inter alia, and the ongoing state of } \\
\text { war justify the exercise of the } \\
\text { belligerent rights of visit, search, and } \\
\text { seizure in relation to the Suez Canal. }\end{array}$ & $\begin{array}{l}\text { S/PV. } 550 \\
\text { (550th) }\end{array}$ & $\begin{array}{l}\text { S/RES/95(1951): “Calls upon } \\
\text { Egypt to terminate the } \\
\text { restrictions on the passage of } \\
\text { international commercial } \\
\text { shipping and goods through } \\
\text { the Suez canal wherever } \\
\text { bound and to cease all } \\
\text { interference with such } \\
\text { shipping beyond that essential } \\
\text { to the safety of shipping in the } \\
\text { Canal itself and to the } \\
\text { observance of the } \\
\text { international conventions in } \\
\text { force." (8-0-3) }\end{array}$ & \begin{tabular}{|l} 
Articles 2(7), \\
$16,61,69$, \\
$80, \& 96$
\end{tabular} & $\begin{array}{l}\text { Parts II, IV, } \\
\text { and VII. }\end{array}$ & \begin{tabular}{|l|} 
https: \\
//documen \\
ts-dds-ny. \\
un. \\
org/doc/U \\
NDOC//GEN \\
NDS1/917/ \\
OO//pdf/N5 \\
191700. \\
pdf? \\
OpenElem \\
ent
\end{tabular} & & $\begin{array}{l}\text { https: } \\
\text { //perma. } \\
\text { cc/JGN2- } \\
35 \mathrm{BH}\end{array}$ \\
\hline 4 & \begin{tabular}{|l|}
1951.08 .16 \\
\end{tabular} & 1951.08.16 & $\mathrm{S} / \mathrm{PV} .553$ & Egypt & \begin{tabular}{|l} 
Egypt, Israel, \\
United \\
Kingdom, \\
France, United \\
States, \\
Brazil, The \\
Netherlands, \\
Turkey, Iraq, \\
China
\end{tabular} & $\begin{array}{l}\text { Implied } \\
\text { assertion of } \\
\text { "individual" } \\
\text { self-defense }\end{array}$ & $\begin{array}{c}\text { Conducted } \\
\text { attack }\end{array}$ & Israel & State & $\begin{array}{l}\text { Israel's violations of the Egyptian- } \\
\text { Israel General Armistice Agreement } \\
\text { (inter alia) and the ongoing state of } \\
\text { war justify the exercise of the } \\
\text { belligerent rights of visit, search, and } \\
\text { seizure in relation to the Suez Canal. }\end{array}$ & $\begin{array}{l}\text { S/PV.553 } \\
\text { (553rd) }\end{array}$ & $\begin{array}{l}\text { S/RES/95(1951): “Calls upon } \\
\text { Egypt to terminate the } \\
\text { restrictions on the passage of } \\
\text { international commercial } \\
\text { shipping and goods through } \\
\text { the Suez Canal wherever } \\
\text { bound and to cease all } \\
\text { interference with such } \\
\text { shipping beyond that essential } \\
\text { to to the safety of shipping in the } \\
\text { Canal itself and to the } \\
\text { observance of the } \\
\text { international conventions in } \\
\text { force." (8-0-3) }\end{array}$ & $\begin{array}{l}\text { Articles } 27, \\
55, \& 107\end{array}$ & \begin{tabular}{|l|} 
Articles 48- \\
51; Article \\
24; Chapter \\
XI (no \\
particular \\
article); \\
Chapter VI \\
(no \\
particular \\
article); \\
Chapter VIII \\
(no \\
particular \\
article) \\
\end{tabular} & \begin{tabular}{|l|} 
https: \\
//documen \\
ts-dds-ny. \\
un. \\
org/doc/U \\
NDOC/GEN \\
NDS1/917/ \\
27//dff/N5 \\
191727. \\
pdf? \\
OpenElem \\
ent
\end{tabular} & & $\begin{array}{l}\text { https: } \\
\text { //perma. } \\
\text { cc/DYu4- } \\
\text { 66AA }\end{array}$ \\
\hline
\end{tabular}


VI. HLS PILAC Catalogue of Apparent “Article 51 Communications”

\begin{tabular}{|c|c|c|c|c|c|c|c|c|c|c|c|c|c|c|c|c|c|}
\hline $\begin{array}{c}\text { Chron. } \\
\text { Order }\end{array}$ & $\begin{array}{l}\text { Date of } \\
\text { Comm. }\end{array}$ & $\begin{array}{c}\text { Date of } \\
\text { UNSC } \\
\text { Document }\end{array}$ & UNSC Symbol & \begin{tabular}{|l} 
Member \\
State(s) That \\
Submitted \\
the Comm.
\end{tabular} & \begin{tabular}{|c} 
Expressly \\
Mentioned UN \\
Members (\& \\
Colonial \\
Holdings \& \\
Protectorates, \\
if any)
\end{tabular} & \begin{tabular}{||c|} 
Express or \\
Implied \\
Assertion of \\
Individual, \\
Collective, or \\
Both Self- \\
defense \\
\end{tabular} & \begin{tabular}{|c} 
Nature of \\
the Alleged \\
Threat
\end{tabular} & $\begin{array}{l}\text { Expressly Alleged } \\
\text { Author(s) of the } \\
\text { Threat (If Any } \\
\text { Indicated) }\end{array}$ & $\begin{array}{c}\text { Nature of the } \\
\text { Alleged } \\
\text { Author(s) of } \\
\text { the Threat (If } \\
\text { Any } \\
\text { Indicated) }\end{array}$ & $\begin{array}{l}\text { Summary of Alleged Self-defense } \\
\text { Grounds }\end{array}$ & \begin{tabular}{|c|} 
UNsc \\
Meeting(s) \\
(If Any) at \\
Which the \\
Comm. was \\
Raised
\end{tabular} & \begin{tabular}{|} 
Responsive Act (If Any) by the \\
UNSC
\end{tabular} & \begin{tabular}{|l} 
UN \\
Repertory \\
Inclusion?
\end{tabular} & $\begin{array}{c}\text { UNSC } \\
\text { Repertoire } \\
\text { Inclusion? }\end{array}$ & \begin{tabular}{|l|} 
URL to an \\
English \\
Text
\end{tabular} & \begin{tabular}{||c||} 
URL to Non- \\
English \\
Original \\
Tert (ff Any)
\end{tabular} & $\begin{array}{l}\text { Perma.cc } \\
\text { URL }\end{array}$ \\
\hline 5 & 1954.06 .20 & 1954.06.21 & $\mathrm{s} / 3238$ & Guatemala & \begin{tabular}{|l} 
Guatemala, \\
Honduras, \\
Mexico, United \\
States
\end{tabular} & $\begin{array}{l}\text { Implied } \\
\text { assertion of } \\
\text { "individual" } \\
\text { self-defense }\end{array}$ & $\begin{array}{c}\text { Conducted } \\
\text { attack }\end{array}$ & $\begin{array}{l}\text { Rebels/mercenary } \\
\text { invasion forces, } \\
\text { pilitos of U.S. } \\
\text { nationality, and } \\
\text { aircraft based in } \\
\text { Honduras }\end{array}$ & $\begin{array}{c}\text { States and } \\
\text { non-state } \\
\text { actors }\end{array}$ & $\begin{array}{l}\text { Attacks by rebels on communications } \\
\text { infrastructure, military zones, and } \\
\text { civilian schools; disseminating } \\
\text { subversive propaganda; mercenary } \\
\text { forces occupying townships. }\end{array}$ & \begin{tabular}{|l} 
None \\
identified
\end{tabular} & None identified & Article 52 & \begin{tabular}{|l} 
None \\
identified
\end{tabular} & \begin{tabular}{|l||} 
http: \\
//www.un. \\
org/en/ga/ \\
search/vie \\
w_doc. \\
asp? \\
symbol=s/ \\
3238 \\
\end{tabular} & $\begin{array}{l}\text { http://www. } \\
\text { un. } \\
\text { org/en/ga/se } \\
\text { arch/view_do } \\
\text { c.asp? } \\
\text { symbol=s/323 } \\
\text { 8\&Lang=S }\end{array}$ & $\begin{array}{l}\text { hetps: } \\
\text { ///perma. } \\
\text { cc/72D7- } \\
\text { VLwa }\end{array}$ \\
\hline 6 & 1954.06.22 & 1954.06.23 & $s / 3241$ & Guatemala & $\begin{array}{l}\text { Guatemala, } \\
\text { Honduras, } \\
\text { Nicaragua }\end{array}$ & $\begin{array}{l}\text { Implied } \\
\text { assertion of } \\
\text { "individual" } \\
\text { self-defense }\end{array}$ & $\begin{array}{c}\text { Conducted } \\
\text { attack }\end{array}$ & Not indicated & Not indicated & $\begin{array}{l}\text { Aggressive acts have continued by } \\
\text { land, sea, and air from aiffields and } \\
\text { centers of operations situated outside } \\
\text { Guatemalan territory. }\end{array}$ & $\begin{array}{l}\text { S/PV.676 } \\
\text { (676th) }\end{array}$ & None identified & Article 52 & \begin{tabular}{|l|} 
Article 32; \\
Chapter III \\
(no \\
particular \\
article); \\
Chapter XII \\
(no \\
particular \\
article); \\
AAticle 35; \\
Article 32; \\
Chapter X \\
(no \\
particular \\
article) \\
\end{tabular} & \begin{tabular}{|l||} 
http: \\
|/www.un. \\
org/en/ga/ \\
search/vie \\
w_doc. \\
asp? \\
symbol=s/ \\
3241
\end{tabular} & $\begin{array}{l}\text { http://www. } \\
\text { un. } \\
\text { org/en/ga/se } \\
\text { arch//iew_do } \\
\text { c.asp? } \\
\text { symbol=s/324 } \\
1 \text { 1\&lang=s }\end{array}$ & $\begin{array}{l}\text { https: } \\
\text { ///perma. } \\
\text { cc/47WM- } \\
\text { YF9M } \\
\end{array}$ \\
\hline 7 & 1955.04.11 & 1955.04.11 & S/3389 & Israel & Israel, Egypt & $\begin{array}{l}\text { Implied } \\
\text { assertion of } \\
\text { "individual" } \\
\text { self-defense }\end{array}$ & $\begin{array}{c}\text { Conducted } \\
\text { attack }\end{array}$ & Egypt & State & $\begin{array}{l}\text { Violations of the Armistice Agreement } \\
\text { by way of a landmine blowing up a } \\
\text { patrol vehicle and killing two soldiers } \\
\text { and an attack on a second Israeli } \\
\text { patrol. }\end{array}$ & $\begin{array}{l}\text { S/PV.698 } \\
\text { (698th) }\end{array}$ & None identified & $\begin{array}{l}\text { None } \\
\text { identified }\end{array}$ & \begin{tabular}{|l} 
None \\
identified
\end{tabular} & \begin{tabular}{|l|} 
http: \\
//www.un. \\
org//en/ga/ \\
search/vie \\
w_doc. \\
asp? \\
symbol=s/ \\
3389
\end{tabular} & & \begin{tabular}{|l} 
https: \\
//perma. \\
cc/SGG7- \\
DSZ2
\end{tabular} \\
\hline 8 & 1955.08.29 & 1955.08 .30 & $\mathrm{~s} / 3425$ & Israel & Israel, Egypt & $\begin{array}{l}\text { Implied } \\
\text { assertion of } \\
\text { "individual" } \\
\text { self-defense }\end{array}$ & $\begin{array}{c}\text { Conducted } \\
\text { attack }\end{array}$ & $\begin{array}{l}\text { Egypt and armed } \\
\text { marauders }\end{array}$ & $\begin{array}{c}\text { State and } \\
\text { non-state } \\
\text { actors }\end{array}$ & $\begin{array}{l}\text { Inter alia, Egyptian-backed armed } \\
\text { marauders have caused " } 21 \text { incidents } \\
\text { [that] have occurred on the Gaza strip } \\
\text { border, resulting in } 6 \text { sraelis killed and } \\
10 \text { wounded," in violation of the } \\
\text { Armistice Agreement. }\end{array}$ & \begin{tabular}{|l} 
None \\
identified
\end{tabular} & None identified & $\begin{array}{l}\text { None } \\
\text { identified }\end{array}$ & \begin{tabular}{|l} 
None \\
identified
\end{tabular} & \begin{tabular}{|l|} 
http: \\
//www.un. \\
org/en/ga/ \\
search/vie \\
w_doc. \\
asp? \\
symbol=s/ \\
3425 \\
\end{tabular} & & \begin{tabular}{|l|} 
https: \\
//perma. \\
c/S/S2G- \\
YKV2
\end{tabular} \\
\hline 9 & 1955.09.06 & 1955.09.07 & $\mathrm{s} / 3433$ & Israel & Israel, Egypt & $\begin{array}{l}\text { Implied } \\
\text { assertion of } \\
\text { "individual" } \\
\text { self-defense }\end{array}$ & $\begin{array}{c}\text { Conducted } \\
\text { attack }\end{array}$ & Egypt & State & $\begin{array}{l}\text { "The serious events of the past few } \\
\text { days to which you refer initiated and } \\
\text { sustained by offensive action on the } \\
\text { part of Egypt. Only after a long, } \\
\text { uninterrupted and progressively more } \\
\text { heinous chain of acts of murder and } \\
\text { destruction had rendered the } \\
\text { situation intolerable did Israel, in } \\
\text { sheer self-defence, offer any major } \\
\text { reaction." }\end{array}$ & $\begin{array}{l}\text { S/PV.700 } \\
\text { (700th) (not } \\
\text { clear that the } \\
\text { report was } \\
\text { specifically } \\
\text { discussed, } \\
\text { but noted } \\
\text { that the } \\
\text { parties had } \\
\text { this letter in } \\
\text { front of } \\
\text { them) }\end{array}$ & $\begin{array}{l}\text { S/RES/108(1955), preamble \& } \\
\text { OPs 1-2: “Deploring the recent } \\
\text { outbreak of violence in the } \\
\text { area along the Armistice } \\
\text { Demarcation Line established } \\
\text { between Egypt and Israel on } \\
\text { 24 February 1949, } \\
\text { 1. Notes with approval the } \\
\text { acceptance by both parties of } \\
\text { the appeal of the Chief of Staff } \\
\text { for an unconditional cease-fire; } \\
\text { 2. Calls upon both parties } \\
\text { forthwith to take all steps } \\
\text { necessary to bring about order } \\
\text { and tranquillity in the area, } \\
\text { and in particular to desist from } \\
\text { further acts of violence and to } \\
\text { continue the cease-fire in full } \\
\text { force and effect" (adopted } \\
\text { unanimously) }\end{array}$ & No & $\begin{array}{l}\text { Chapter VIII } \\
\text { (no article) }\end{array}$ & \begin{tabular}{|l||} 
http: \\
//www.un. \\
org/en/ga/ \\
search/vie \\
w_doc. \\
asp? \\
symbol=s/ \\
3433
\end{tabular} & & \begin{tabular}{|l} 
https: \\
//perma. \\
cp/BG55- \\
6DF7
\end{tabular} \\
\hline
\end{tabular}


VI. HLS PILAC Catalogue of Apparent “Article 51 Communications”

\begin{tabular}{|c|c|c|c|c|c|c|c|c|c|c|c|c|c|c|c|c|c|}
\hline $\begin{array}{c}\text { Chron. } \\
\text { Order }\end{array}$ & $\begin{array}{l}\text { Date of } \\
\text { Comm. }\end{array}$ & $\begin{array}{c}\text { Date of } \\
\text { UNsc } \\
\text { Document }\end{array}$ & UNSC Symbol & \begin{tabular}{|c} 
Member \\
State(s) That \\
Submitted \\
the Comm.
\end{tabular} & \begin{tabular}{|c} 
Expressly \\
Mentioned UN \\
Members (\& \\
Colonial \\
Holdings \& \\
Protectorates, \\
if any)
\end{tabular} & \begin{tabular}{|c|} 
Express or \\
Implied \\
Assertion of \\
Individual, \\
Collective, or \\
Both Self- \\
defense
\end{tabular} & \begin{tabular}{|c} 
Nature of \\
the Alleged \\
Threat
\end{tabular} & \begin{tabular}{|l|} 
Expressly Alleged \\
Author(s) of the \\
Threat (ff Any \\
Indicated)
\end{tabular} & \begin{tabular}{|c|} 
Nature of the \\
Alleged \\
Author(s) of \\
the Threat (If \\
Any \\
Indicated) \\
\end{tabular} & $\begin{array}{l}\text { Summary of Alleged Self-defense } \\
\text { Grounds }\end{array}$ & \begin{tabular}{|l} 
UNsc \\
Meeting(s) \\
(If Any) at \\
Which the \\
Comm. was \\
Raised
\end{tabular} & $\begin{array}{l}\text { Responsive Act (If Any) by the } \\
\text { UNSC }\end{array}$ & $\begin{array}{l}\text { UN } \\
\text { Repertory } \\
\text { Inclusion? }\end{array}$ & $\begin{array}{l}\text { UNSC } \\
\text { Repertoire } \\
\text { Inclusion? }\end{array}$ & $\begin{array}{l}\text { URL to an } \\
\text { English } \\
\text { Text }\end{array}$ & \begin{tabular}{|c||} 
URL to Non- \\
English \\
Original \\
Text (ff Any)
\end{tabular} & \begin{tabular}{|l} 
Perma.cc \\
URL
\end{tabular} \\
\hline 10 & 1955.12.29 & 1955.12.30 & $s / 3524$ & Israel & Israel, Syria & $\begin{array}{c}\text { Implied } \\
\text { assertion of } \\
\text { "individual" } \\
\text { self-defense }\end{array}$ & $\begin{array}{c}\text { Conducted } \\
\text { attack }\end{array}$ & Syria & State & $\begin{array}{l}\text { Violations of the Armistice Agreement } \\
\text { by way of a chain of attacks on Lake } \\
\text { Tiberias. }\end{array}$ & $\begin{array}{l}\text { S/PV.710 } \\
\text { (710th); } \\
\text { S/PV.711 } \\
\text { (711th) }\end{array}$ & \begin{tabular}{|l} 
S/RES/111(1956), OP 3: \\
"Condemns the attack of 11 \\
December 19555 [by Irsael \\
regular army forces against \\
Syrian regular army forces on \\
Syrian territoryy as a alagrant \\
violation of the cease-fire \\
provisions of fits resolution of \\
15 July y 1948 , of the terms of \\
the General Armistice \\
Agreement between Israel and \\
Syria, and of Israel's \\
obligations under the Charter" \\
(adopted unanimously)
\end{tabular} & $\begin{array}{l}\text { None } \\
\text { identified }\end{array}$ & $\begin{array}{l}\text { Chapter VIII } \\
\text { (no article) }\end{array}$ & $\begin{array}{l}\text { http: } \\
\text { //www.un. } \\
\text { org/en/ga/ } \\
\text { search/vie } \\
\text { w_doc. } \\
\text { asp? } \\
\text { symbol=s/ } \\
3524\end{array}$ & & $\begin{array}{l}\text { https: } \\
\text { //perma. } \\
\text { cc/6EUM- } \\
\text { WLFU }\end{array}$ \\
\hline 11 & 1956.04.09 & 1956.04.09 & $\mathrm{s} / 3580$ & Israel & Israel, Egypt & $\begin{array}{c}\text { Implied } \\
\text { assertion of } \\
\text { "individual" } \\
\text { self-defense }\end{array}$ & $\begin{array}{c}\text { Conducted } \\
\text { attack }\end{array}$ & \begin{tabular}{|l} 
Egypt and Egyptian \\
gangs operating \\
deep inside Israel's \\
territory \\
dispathed by the \\
Egyptian High \\
Command
\end{tabular} & $\begin{array}{c}\text { State and } \\
\text { non-state } \\
\text { actors }\end{array}$ & \begin{tabular}{|l} 
Egyptian attacks in violation of the \\
General Armistice Agreement \\
between Egypt and Israel.
\end{tabular} & \begin{tabular}{|l} 
None \\
identified
\end{tabular} & None identified & $\begin{array}{l}\text { None } \\
\text { identified }\end{array}$ & \begin{tabular}{|l} 
None \\
identified
\end{tabular} & $\begin{array}{l}\text { http: } \\
\text { //www.un. } \\
\text { org/en//ga/ } \\
\text { search/vie } \\
\text { w_doc. } \\
\text { asp? } \\
\text { spybol=S/ } \\
3580\end{array}$ & & \begin{tabular}{|l} 
https: \\
//perma. \\
cc/Qc99- \\
UMNL
\end{tabular} \\
\hline 12 & 1958.02.13 & 1958.02.13 & $\mathrm{s} / 3951$ & Tunisia & Tunisia, France & $\begin{array}{c}\text { Implied } \\
\text { assertion of } \\
\text { "individual" } \\
\text { self-defense }\end{array}$ & $\begin{array}{c}\text { Conducted } \\
\text { attack }\end{array}$ & France & State & $\begin{array}{l}\text { French act of aggression at Sakiet-Sidi- } \\
\text { Youssef. }\end{array}$ & \begin{tabular}{|l} 
None \\
expressly, \\
but see S/PV. \\
811 (811th); \\
S/PV.819) \\
(819th); and \\
S/PV.820 \\
(820th)
\end{tabular} & None identified & $\begin{array}{l}\text { None } \\
\text { identified }\end{array}$ & \begin{tabular}{|l} 
Articles 48- \\
$51 ;$ Chapter \\
VIII (no \\
particular \\
article; \\
rather, \\
Tunisian \\
Question) \\
\end{tabular} & $\begin{array}{l}\text { http: } \\
\text { //www.un. } \\
\text { org/en/ga/ } \\
\text { search/vie } \\
\text { w_doc. } \\
\text { asp? } \\
\text { symbol=s/ } \\
3951\end{array}$ & $\begin{array}{l}\text { http://www. } \\
\text { un. } \\
\text { org/en/ga/se } \\
\text { arch/view_do } \\
\text { c.aps? } \\
\text { symbol=s/395 } \\
1 \& \text { Lang=F }\end{array}$ & $\begin{array}{l}\text { https: } \\
\text { //perma. } \\
\text { cc/3UB7- } \\
\text { QKGF }\end{array}$ \\
\hline 13 & 1958.03.06 & 1958.03.07 & $\mathrm{s} / 3977$ & $\begin{array}{l}\text { United } \\
\text { Kingdom }\end{array}$ & \begin{tabular}{|c} 
United \\
Kingdom, Aden \\
Protectorate, \\
Yemen
\end{tabular} & $\begin{array}{c}\text { Implied } \\
\text { assertion of } \\
\text { "individual" } \\
\text { self-defense }\end{array}$ & $\begin{array}{c}\text { Conducted } \\
\text { attack }\end{array}$ & Yemen & State & Fire by Yemeni forces. & $\begin{array}{l}\text { None } \\
\text { identified }\end{array}$ & None identified & Article 30 & $\begin{array}{l}\text { None } \\
\text { identified }\end{array}$ & $\begin{array}{l}\text { http: } \\
\text { //www.un. } \\
\text { org/en/ga/ } \\
\text { search/vie } \\
\text { w_doc. } \\
\text { asp? } \\
\text { symbol=S/ } \\
\text { 3977 }\end{array}$ & & $\begin{array}{l}\text { https: } \\
\text { //perma. } \\
\text { cc/82QU- } \\
\text { A9zV }\end{array}$ \\
\hline 14 & 1958.04.17 & 1958.04.17 & $\mathrm{s} / 3989$ & $\begin{array}{l}\text { United } \\
\text { Kingdom }\end{array}$ & \begin{tabular}{|c} 
United \\
Kingdom, Aden \\
Protectorate, \\
Yemen
\end{tabular} & $\begin{array}{c}\text { Implied } \\
\text { assertion of } \\
\text { "individual" } \\
\text { self-defense }\end{array}$ & $\begin{array}{c}\text { Conducted } \\
\text { attack }\end{array}$ & Yemen & State & $\begin{array}{l}\text { "...[T]wo further attacks made by } \\
\text { Yemeni forces against the Aden } \\
\text { Protectorate." }\end{array}$ & $\begin{array}{l}\text { None } \\
\text { identified }\end{array}$ & None identified & $\begin{array}{l}\text { Articles } 30 \text { \& } \\
51\end{array}$ & $\begin{array}{l}\text { None } \\
\text { identified }\end{array}$ & $\begin{array}{l}\text { http: } \\
\text { //wwww.un. } \\
\text { org/en/ga/ } \\
\text { search//vie } \\
\text { w_doc. } \\
\text { asp? } \\
\text { symbol=S/ } \\
\text { 3989 }\end{array}$ & & $\begin{array}{l}\text { https: } \\
\text { //perma. } \\
\text { cc/Yyzz- } \\
\text { 28vP }\end{array}$ \\
\hline 15 & 1958.05.07 & 1958.05.07 & $s / 4004$ & $\begin{array}{l}\text { United } \\
\text { Kingdom }\end{array}$ & \begin{tabular}{|c} 
United \\
Kingdom, Aden \\
Protectorate, \\
Yemen
\end{tabular} & \begin{tabular}{|c|} 
Implied \\
assertion of \\
"individual" \\
self-defense
\end{tabular} & $\begin{array}{c}\text { Conducted } \\
\text { attack }\end{array}$ & Yemen & State & $\begin{array}{l}\text { Fired upon by Yemeni heavy machine- } \\
\text { guns from posts established illegally in } \\
\text { the Aden Protectorate and fired upon } \\
\text { from the Yemen by heavy machine- } \\
\text { guns in and near the fortified Yemeni } \\
\text { barracks near the town of Qataba. }\end{array}$ & \begin{tabular}{|l} 
None \\
identified
\end{tabular} & None identified & Article 30 & \begin{tabular}{|l} 
None \\
identified
\end{tabular} & $\begin{array}{l}\text { http: } \\
\text { //wwww.un. } \\
\text { org/en/ga/ } \\
\text { search//vie } \\
\text { w_doc. } \\
\text { asp? } \\
\text { symbol=S/ } \\
4004\end{array}$ & & \begin{tabular}{|l} 
https: \\
//perma. \\
cc/YS85- \\
PLWY
\end{tabular} \\
\hline
\end{tabular}


VI. HLS PILAC Catalogue of Apparent “Article 51 Communications”

\begin{tabular}{|c|c|c|c|c|c|c|c|c|c|c|c|c|c|c|c|c|c|}
\hline $\begin{array}{c}\text { Chron. } \\
\text { Order }\end{array}$ & $\begin{array}{l}\text { Date of } \\
\text { comm. }\end{array}$ & $\begin{array}{c}\text { Date of } \\
\text { UNsc } \\
\text { Document }\end{array}$ & UNSC Symbol & \begin{tabular}{|c} 
Member \\
State(s) That \\
Submitted \\
the Comm.
\end{tabular} & \begin{tabular}{|c||} 
Expressly \\
Mentioned UN \\
Members (\& \\
Colonial \\
Holdings \& \\
Protectorates, \\
if any) \\
\end{tabular} & \begin{tabular}{||c|} 
Express or \\
Implied \\
Assertion of \\
Individual, \\
Collective, or \\
Both Self- \\
defense \\
\end{tabular} & \begin{tabular}{|c} 
Nature of \\
the Alleged \\
Threat
\end{tabular} & $\begin{array}{l}\text { Expressly Alleged } \\
\text { Author(s) of the } \\
\text { Threat (If Any } \\
\text { Indicated) }\end{array}$ & \begin{tabular}{|c|} 
Nature of the \\
Alleged \\
Author(s) of \\
the Threat (If \\
Any \\
Indicated)
\end{tabular} & $\begin{array}{l}\text { Summary of Alleged Self-defense } \\
\text { Grounds }\end{array}$ & \begin{tabular}{|c||} 
UNsC \\
Meeting(s) \\
(If Any) at \\
Which the \\
Comm. was \\
Raised
\end{tabular} & $\begin{array}{l}\text { Responsive Act (ff Any) by the } \\
\text { UNSC }\end{array}$ & \begin{tabular}{|c} 
UN \\
Repertory \\
Inclusion?
\end{tabular} & $\begin{array}{c}\text { UNSC } \\
\text { Repertoire } \\
\text { Inclusion? }\end{array}$ & \begin{tabular}{|l|} 
URL to an \\
English \\
Text
\end{tabular} & \begin{tabular}{||c||} 
URL to Non- \\
English \\
Original \\
Tert (ff Any)
\end{tabular} & \begin{tabular}{|l} 
Perma.cc \\
URL
\end{tabular} \\
\hline 16 & 1958.05.29 & 1958.05.29 & $s / 4013$ & Tunisia & $\begin{array}{c}\text { Tunisia, } \\
\text { France, United } \\
\text { States, United } \\
\text { Kingdom }\end{array}$ & \begin{tabular}{|c|} 
Implied \\
assertion of \\
"individual" \\
self-defense
\end{tabular} & $\begin{array}{c}\text { Conducted } \\
\text { attack }\end{array}$ & France & State & \begin{tabular}{|l} 
"French troops stationed at Remada \\
made a sortie from their barracks and \\
tried to force a barrier at Bir Kanbout, \\
seven kilometres to the south-west of \\
Remada, opening fire on the Tunisian \\
elements guarding the barrier. Those \\
units having returned the fire, other \\
French units fired at other Tunisian \\
posts in the vicinity.... B-26 bombers \\
and fighters coming from Algeria, \\
presumably from the base at Tebessa, \\
attacked the Remada area, bombing \\
and machine-gunning all groups on \\
the tracks and in the region over a \\
radius of several dozen kilometres."
\end{tabular} & \begin{tabular}{l|} 
S/PV. 819 \\
(819th); \\
S/PV.820 \\
(820th); \\
S/PV.821 \\
(821st); S/PV. \\
826 (826th)
\end{tabular} & None identified & $\begin{array}{l}\text { Articles 2(4), } \\
31,33, \& 40\end{array}$ & $\begin{array}{l}\text { Chapter VIII } \\
\text { (no } \\
\text { particular } \\
\text { article; } \\
\text { rather, The } \\
\text { Tunisian } \\
\text { Question); } \\
\text { Articles 48- } \\
\text { 51; Article } \\
33\end{array}$ & \begin{tabular}{|l||} 
http: \\
//www.un. \\
org/en/ga/ \\
search/vie \\
w_doc. \\
asp? \\
symbol=s/ \\
4013
\end{tabular} & \begin{tabular}{|l|} 
http://www. \\
un. \\
org/en/ga/se \\
arch/view_do \\
casp? \\
symbol=s/401 \\
3\&lang=F
\end{tabular} & $\begin{array}{l}\text { https: } \\
\text { //perma. } \\
\text { cc/6HRQ- } \\
\text { FGNQ }\end{array}$ \\
\hline 17 & 1958.07.09 & 1958.07.09 & $S / 4044$ & $\begin{array}{l}\text { United } \\
\text { Kingdom }\end{array}$ & $\begin{array}{c}\text { United } \\
\text { Kingdom, Aden } \\
\text { Protectorate, } \\
\text { Yemen }\end{array}$ & $\begin{array}{c}\text { Implied } \\
\text { assertion of } \\
\text { "individual" } \\
\text { self-defense }\end{array}$ & $\begin{array}{c}\text { Conducted } \\
\text { attack }\end{array}$ & Yemen & State & $\begin{array}{l}\text { A platoon of Aden Protectorate levies } \\
\text { who were camped around Tamra Fort } \\
\text { in the state of Beihan in the Aden } \\
\text { Protectorate were fired on across the } \\
\text { frontier from Yemen by heavy } \\
\text { machine guns located near the town } \\
\text { of Harib. }\end{array}$ & $\begin{array}{l}\text { None } \\
\text { identified }\end{array}$ & None identified & $\begin{array}{l}\text { None } \\
\text { identified }\end{array}$ & \begin{tabular}{|l} 
None \\
identified
\end{tabular} & \begin{tabular}{|l|} 
http: \\
//www.un. \\
orge//gan \\
search/vie \\
w_doc. \\
asp? \\
symbol=s/ \\
4044 \\
404
\end{tabular} & & $\begin{array}{l}\text { https: } \\
\text { //perma. } \\
\text { cc/4VWH- } \\
\text { AM3M }\end{array}$ \\
\hline 18 & 1958.07.15 & 1958.07.15 & S/PV.827 & Lebanon & \begin{tabular}{|c|} 
Lebanon, \\
United States, \\
United Arab \\
Republic \\
[Egypt], Syria
\end{tabular} & $\begin{array}{l}\text { Express } \\
\text { assertion of } \\
\text { "collective" } \\
\text { self-defense }\end{array}$ & $\begin{array}{l}\text { Indirect } \\
\text { attack }\end{array}$ & $\begin{array}{c}\text { United Arab } \\
\text { Republic [Egypt], } \\
\text { Syria, and armed } \\
\text { men }\end{array}$ & $\begin{array}{l}\text { States and } \\
\text { non-state } \\
\text { actors }\end{array}$ & $\begin{array}{l}\text { Unlawful intervention in the affairs of } \\
\text { Lebanon, including infiltration of } \\
\text { armed men and the supply of arms. }\end{array}$ & $\begin{array}{l}\text { S/PV.827 } \\
\text { (827th) }\end{array}$ & $\begin{array}{l}\text { Draft resolutions by USSR, US, } \\
\text { and Sweden not adopted }\end{array}$ & $\begin{array}{l}\text { Articles } 1(2), \\
2(4), 2(7), \\
12,23,30 \\
51,55, \& 98\end{array}$ & $\begin{array}{l}\text { Articles 48- } \\
\text { 51; Rules 13- } \\
17 ; \text { Rules } \\
21-26 ; \\
\text { Chapter VIII } \\
\text { (no } \\
\text { particular } \\
\text { article) }\end{array}$ & 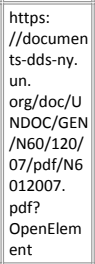 & & \begin{tabular}{|l} 
https: \\
//perma. \\
cc/5KJJ- \\
K39B
\end{tabular} \\
\hline 19 & 1958.07.15 & 1958.07.15 & S/PV.827 & $\begin{array}{l}\text { United } \\
\text { States }\end{array}$ & \begin{tabular}{|l|} 
United States, \\
Lebanon, \\
Jordan, Iraq, \\
United Arab \\
Republic, \\
Greece, Soviet \\
Union, \\
Czechoslovakia \\
, France, \\
Mexico, the \\
Netherlands, \\
Bolivia, India \\
\end{tabular} & $\begin{array}{l}\text { Implied } \\
\text { assertion of } \\
\text { "collective" } \\
\text { self-defense }\end{array}$ & $\begin{array}{l}\text { Indirect } \\
\text { attack }\end{array}$ & $\begin{array}{c}\text { United Arab } \\
\text { Republic [Egypt] }\end{array}$ & State & $\begin{array}{l}\text { "... [T]he President of Lebanon has } \\
\text { asked, with the unanimous } \\
\text { authorization of the Lebanese } \\
\text { Government, for the help of friendly } \\
\text { Governments so as to reserve } \\
\text { Lebanon's integrity and } \\
\text { independence. The United States has } \\
\text { responded positively and affirmatively } \\
\text { to this request in the light of the need } \\
\text { for immediate action...." against } \\
\text { "indirect" aggression in the form of } \\
\text { fomenting civil strife. }\end{array}$ & $\begin{array}{l}\text { S/PV.827 } \\
\text { (827th) }\end{array}$ & $\begin{array}{l}\text { Draft resolutions by USSR, US, } \\
\text { and Sweden not adopted }\end{array}$ & $\begin{array}{l}\text { Articles 1(2), } \\
2(4), 2(7), \\
12,23,30 \\
51,55, \& 98\end{array}$ & $\begin{array}{l}\text { Articles 48- } \\
51 \text {;ules 13- } \\
17 ; \text { Rules } \\
21-26 ; \\
\text { Chapter VIII } \\
\text { (no } \\
\text { particular } \\
\text { article) }\end{array}$ & 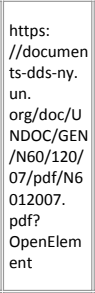 & & $\begin{array}{l}\text { https: } \\
\text { //perma. } \\
\text { cc/5KJJ- } \\
\text { K39B }\end{array}$ \\
\hline 20 & 1958.07.17 & 1958.07.17 & S/PV.831 & $\begin{array}{l}\text { United } \\
\text { Kingdom }\end{array}$ & $\begin{array}{l}\text { United } \\
\text { Kingdom, } \\
\text { Jordan, Iraq, } \\
\text { Lebanon }\end{array}$ & $\begin{array}{l}\text { Implied } \\
\text { assertion of } \\
\text { "collective" } \\
\text { self-defense }\end{array}$ & $\begin{array}{l}\text { Indirect } \\
\text { attack and } \\
\text { threat of } \\
\text { attack }\end{array}$ & Not indicated & Not indicated & $\begin{array}{l}\text { The UK acceded to the request of the } \\
\text { Jordan Government for military aid to } \\
\text { help the King and Government of } \\
\text { Jordan "to preserve its political } \\
\text { independence and territorial } \\
\text { integrity" in the face of the threat of } \\
\text { "indirect aggression - the method of } \\
\text { subversion and the attempt to } \\
\text { overthrow the constituted authority". }\end{array}$ & $\begin{array}{l}\text { S/PV. } 831 \\
\text { (831st) }\end{array}$ & $\begin{array}{l}\text { Draft resolutions by USSR, US, } \\
\text { and Sweden not adopted }\end{array}$ & $\begin{array}{l}\text { Articles } 1(2), \\
2(4), 2(6), 2 \\
(7), 12,13 \\
(1), 24,27, \\
28,30,31, \\
34,35,43 \\
51,73,298\end{array}$ & $\begin{array}{l}\text { Chapter VIII } \\
\text { (no } \\
\text { particular } \\
\text { article); } \\
\text { Rules 10-11; } \\
\text { Articles 48- } \\
51\end{array}$ & \begin{tabular}{|l|l|} 
https: & //documen \\
ts-dds-ny. \\
un. \\
org/doc/U \\
NDOC//GEN \\
/N60/120/ \\
35/pdff/N6 \\
O12035. \\
pdf? \\
OpenElem \\
ent
\end{tabular} & & \begin{tabular}{|l} 
https: \\
//perma. \\
cc/AC54- \\
5TJP
\end{tabular} \\
\hline
\end{tabular}


VI. HLS PILAC Catalogue of Apparent “Article 51 Communications”

\begin{tabular}{|c|c|c|c|c|c|c|c|c|c|c|c|c|c|c|c|c|c|}
\hline $\begin{array}{c}\text { Chron. } \\
\text { Order }\end{array}$ & $\begin{array}{l}\text { Date of } \\
\text { Comm. }\end{array}$ & $\begin{array}{l}\text { Date of } \\
\text { UNsc } \\
\text { Document }\end{array}$ & UNSC Symbol & \begin{tabular}{|c} 
Member \\
State(s) That \\
Submitted \\
the Comm.
\end{tabular} & \begin{tabular}{||c||} 
Expressly \\
Mentioned UN \\
Members (\& \\
Colonial \\
Holdings \& \\
Protectorates, \\
if any)
\end{tabular} & \begin{tabular}{|c} 
Express or \\
Implied \\
Assertion of \\
Individual, \\
Collective, or \\
Both Self- \\
defense
\end{tabular} & \begin{tabular}{|l} 
Nature of \\
the Alleged \\
Threat
\end{tabular} & $\begin{array}{l}\text { Expressly Alleged } \\
\text { Author(s) of the } \\
\text { Threat (If Any } \\
\text { Indicated) }\end{array}$ & \begin{tabular}{|l|} 
Nature of the \\
Alleged \\
Author(s) of \\
the Threat (If \\
Any \\
Indicated)
\end{tabular} & $\begin{array}{l}\text { Summary of Alleged Self-defense } \\
\text { Grounds }\end{array}$ & $\begin{array}{c}\text { UNSC } \\
\text { Meeting(s) } \\
\text { (If Any) at } \\
\text { Which the } \\
\text { Comm. was } \\
\text { Raised }\end{array}$ & $\begin{array}{l}\text { Responsive Act (If Any) by the } \\
\text { UNSC }\end{array}$ & \begin{tabular}{|c} 
UN \\
Repertory \\
Inclusion?
\end{tabular} & \begin{tabular}{|c} 
UNSC \\
Repertoire \\
Inclusion?
\end{tabular} & \begin{tabular}{|l} 
URL to an \\
English \\
Text
\end{tabular} & \begin{tabular}{||c||} 
URL to Non- \\
English \\
Original \\
Text (ff Any)
\end{tabular} & $\begin{array}{l}\text { Perma.cc } \\
\text { URL }\end{array}$ \\
\hline 21 & 1958.09.10 & 1958.09.12 & $s / 4096$ & $\begin{array}{l}\text { United } \\
\text { Kingdom }\end{array}$ & $\begin{array}{l}\text { United } \\
\text { Kingdom, Aden } \\
\text { Protectorate, } \\
\text { Yemen }\end{array}$ & $\begin{array}{l}\text { Implied } \\
\text { assertion of } \\
\text { "individual" } \\
\text { self-defense }\end{array}$ & $\begin{array}{c}\text { Conducted } \\
\text { attack }\end{array}$ & Yemen & State & \begin{tabular}{|l} 
"[A] supply convoy to Mertaa from \\
Kukeiras in the territory of the Aden \\
Protectorate was attacked by fire \\
from Yemeni heary machine guns \\
located on a ridge behind Am Sauma \\
in Yemeni territory and in two small \\
forts in the village itself... Later in the \\
same day the same convoy was fired \\
on by a heavy machine gun located in \\
an open position outside Am Sauma."
\end{tabular} & $\begin{array}{l}\text { None } \\
\text { identified }\end{array}$ & None identified & $\begin{array}{l}\text { Articles } 30 \& \\
51\end{array}$ & $\begin{array}{l}\text { None } \\
\text { identified }\end{array}$ & \begin{tabular}{|l} 
http: \\
//www.un. \\
org//enga/ \\
search/vie \\
w_doc. \\
asp? \\
symbol=s/ \\
4096
\end{tabular} & & $\begin{array}{l}\text { https: } \\
\text { //perma. } \\
\text { cc/5QW3- } \\
\text { Y9PN }\end{array}$ \\
\hline 22 & 1961.07.20 & 1961.07.20 & $s / 4862$ & Tunisia & \begin{tabular}{|c|} 
Tunisia, \\
France, \\
Algeria, United \\
Kingdom, \\
United States
\end{tabular} & $\begin{array}{c}\text { Implied } \\
\text { assertion of } \\
\text { "individual" } \\
\text { self-defense }\end{array}$ & $\begin{array}{c}\text { Conducted } \\
\text { attack }\end{array}$ & France & State & $\begin{array}{l}\text { Inter alia, "the town and Governorate } \\
\text { of Bizerta have been under attacks by } \\
\text { the French navy and air force." }\end{array}$ & $\begin{array}{l}\text { S/PV.961 } \\
\text { (961st); SPV. } \\
\text { 962 (962nd); } \\
\text { S/PV.963 } \\
\text { (963rd); } \\
\text { S/PV.964 } \\
\text { (964th) SPV. } \\
\text { 965 (965th); } \\
\text { S/PV.966 } \\
\text { (966th) }\end{array}$ & $\begin{array}{l}\text { S/RES/164(1961), OPs 1-2: “1. } \\
\text { Calls for an immediate cease- } \\
\text { fire and a return of all armed } \\
\text { forces to their original } \\
\text { position; } \\
\text { 2. Decides to continue the } \\
\text { debate” (10-0-0). } \\
\text { Subsequent draft resolutions } \\
\text { not adopted }\end{array}$ & $\begin{array}{l}\text { Articles 2(4), } \\
12,24,51, \& \\
99\end{array}$ & \begin{tabular}{|l|} 
Article 33; \\
Rules 10-11; \\
Chapter VIII \\
(no \\
particular \\
article)
\end{tabular} & \begin{tabular}{|l} 
http: \\
//www.un. \\
org//enga/ \\
search/vie \\
w_doc. \\
asp? \\
symbol=S/ \\
4862
\end{tabular} & \begin{tabular}{|l||} 
http://www. \\
un. \\
org/en/ga/se \\
arch/view_do \\
c.asp? \\
symbol=s/486 \\
$2 \&$ Lang=F
\end{tabular} & $\begin{array}{l}\text { https: } \\
\text { //perma. } \\
\text { cc/AA69- } \\
\text { LGTD }\end{array}$ \\
\hline 23 & 1961.07.20 & 1961.07.21 & $s / 4864$ & France & France, Tunisia & $\begin{array}{l}\text { Implied } \\
\text { assertion of } \\
\text { "individual" } \\
\text { self-defense }\end{array}$ & $\begin{array}{c}\text { Conducted } \\
\text { attack }\end{array}$ & Tunisia & State & $\begin{array}{l}\text { Inter alia, attacks on French } \\
\text { installations and forces. }\end{array}$ & $\begin{array}{l}\text { None } \\
\text { identified }\end{array}$ & $\begin{array}{l}\text { S/RES/164(1961), OPs 1-2: “1. } \\
\text { Calls for an immediate cease- } \\
\text { fire and a return of all armed } \\
\text { forces to their original } \\
\text { position; } \\
\text { 2. Decides to continue the } \\
\text { debate" (10-0-0). } \\
\text { Subsequent draft resolutions } \\
\text { not adopted }\end{array}$ & $\begin{array}{l}\text { None } \\
\text { identified }\end{array}$ & $\begin{array}{l}\text { Article 33; } \\
\text { Chapter VIII } \\
\text { (no } \\
\text { particular } \\
\text { article) }\end{array}$ & $\begin{array}{l}\text { http: } \\
\text { //www.un. } \\
\text { org//en/ga/ } \\
\text { search/vie } \\
\text { w_doc. } \\
\text { asp? } \\
\text { symbol=S/ } \\
4864\end{array}$ & \begin{tabular}{|l|} 
http://www. \\
un. \\
org/en/ga/se \\
arch/view_do \\
casp? \\
symbol=s/486 \\
$4 \&$ Llang=F
\end{tabular} & $\begin{array}{l}\text { https: } \\
\text { //perma. } \\
\text { cc/2016- } \\
\text { BFU }\end{array}$ \\
\hline 24 & 1961.08.13 & 1961.08.14 & $s / 4924$ & Tunisia & \begin{tabular}{|c||} 
Tunisia, \\
France, Algeria
\end{tabular} & $\begin{array}{l}\text { Implied } \\
\text { assertion of } \\
\text { "individual" } \\
\text { self-defense }\end{array}$ & $\begin{array}{c}\text { Conducted } \\
\text { attack }\end{array}$ & France & State & $\begin{array}{l}\text { Violations of a cease-fire by France by } \\
\text { way of military attacks from Bizerta } \\
\text { westwards and from Algeria } \\
\text { eastwards. }\end{array}$ & $\begin{array}{l}\text { None } \\
\text { identified }\end{array}$ & None identified & Article 51 & $\begin{array}{l}\text { None } \\
\text { identified }\end{array}$ & \begin{tabular}{|l|} 
http: \\
//www.un. \\
org//enga/ \\
search/vie \\
w_doc. \\
asp? \\
symbol=S/ \\
4924 \\
\end{tabular} & $\begin{array}{l}\text { http://www. } \\
\text { un. } \\
\text { org/en/ga/se } \\
\text { arch/view_do } \\
\text { c.asp? } \\
\text { symbol=s/492 } \\
4 \& \text { Llang=F }\end{array}$ & $\begin{array}{l}\text { https: } \\
\text { //perma. } \\
\text { cc/3LMM- } \\
\text { BTEY }\end{array}$ \\
\hline 25 & 1962.01.18 & 1962.01.18 & $\mathrm{s} / 5062$ & $\begin{array}{l}\text { The } \\
\text { Netherlands }\end{array}$ & $\begin{array}{l}\text { The } \\
\text { Netherlands, } \\
\text { Netherlands } \\
\text { New Guinea, } \\
\text { Indonesia }\end{array}$ & $\begin{array}{l}\text { Implied } \\
\text { assertion of } \\
\text { "individual" } \\
\text { self-defense }\end{array}$ & $\begin{array}{c}\text { Conducted } \\
\text { attack }\end{array}$ & Indonesia & State & $\begin{array}{l}\text { Armed attack by Indonesia by way of } \\
\text { motor torpedo boats (MTBs). }\end{array}$ & $\begin{array}{l}\text { None } \\
\text { identified }\end{array}$ & None identified & $\begin{array}{l}\text { None } \\
\text { identified }\end{array}$ & $\begin{array}{l}\text { None } \\
\text { identified }\end{array}$ & \begin{tabular}{|l|} 
http: \\
//www.un. \\
org//enga/ \\
search/vie \\
w_doc. \\
asp? \\
symbol=S/ \\
5062 \\
\end{tabular} & & $\begin{array}{l}\text { https: } \\
\text { //perma. } \\
\text { cc/4XK5- } \\
\text { WB5A }\end{array}$ \\
\hline 26 & 1964.10.07 & 1964.10.07 & $s / 6000$ & Guinea & $\begin{array}{l}\text { Guinea, } \\
\text { Portuguese } \\
\text { Guinea, } \\
\text { Portugal }\end{array}$ & $\begin{array}{l}\text { Implied } \\
\text { assertion of } \\
\text { "individual" } \\
\text { self-defense }\end{array}$ & $\begin{array}{c}\text { Conducted } \\
\text { attack }\end{array}$ & Portugal & State & $\begin{array}{l}\text { "...[D]eliberate provocations and } \\
\text { repeated violations of Guinean air } \\
\text { space by military aircraft of the } \\
\text { Portuguese colonial forces". }\end{array}$ & $\begin{array}{l}\text { S/PV.1206 } \\
\text { (1206th); } \\
\text { S/PV.1210 } \\
\text { (1210th) }\end{array}$ & None identified & $\begin{array}{l}\text { None } \\
\text { identified }\end{array}$ & $\begin{array}{l}\text { None } \\
\text { identified }\end{array}$ & \begin{tabular}{|l|} 
http: \\
//www.un. \\
org/ren//ga/ \\
search/vie \\
w_doc. \\
asp? \\
symbol=s/ \\
6000
\end{tabular} & \begin{tabular}{|l|}
$\mid$ http://www. \\
un. \\
org/en/ga/se \\
arch//iew_do \\
c.asp? \\
symbol=s//600 \\
sylang=F
\end{tabular} & $\begin{array}{l}\text { https: } \\
\text { //perma. } \\
\text { cc/D2MT- } \\
\text { 5XWV }\end{array}$ \\
\hline 27 & 1965.04.07 & 1965.04.07 & $s / 6276$ & $\begin{array}{l}\text { United } \\
\text { Kingdom }\end{array}$ & \begin{tabular}{|c|} 
United \\
Kingdom, \\
Federation of \\
South Arabia
\end{tabular} & $\begin{array}{l}\text { Implied } \\
\text { assertion of } \\
\text { "individual" } \\
\text { self-defense }\end{array}$ & $\begin{array}{c}\text { Conducted } \\
\text { attack }\end{array}$ & Not indicated & Not indicated & $\begin{array}{l}\text { Artillery fire on Federal Regular Army } \\
\text { position. }\end{array}$ & $\begin{array}{l}\text { None } \\
\text { identified }\end{array}$ & None identified & $\begin{array}{l}\text { None } \\
\text { identified }\end{array}$ & $\begin{array}{l}\text { None } \\
\text { identified }\end{array}$ & \begin{tabular}{|l|} 
http: \\
//www.un. \\
org//nenga/ \\
search/vie \\
w_doc. \\
asp? \\
symbol=S/ \\
6276
\end{tabular} & & $\begin{array}{l}\text { https: } \\
\text { //perma. } \\
\text { cc/NEC2- } \\
\text { Q3FC }\end{array}$ \\
\hline
\end{tabular}


VI. HLS PILAC Catalogue of Apparent “Article 51 Communications”

\begin{tabular}{|c|c|c|c|c|c|c|c|c|c|c|c|c|c|c|c|c|c|}
\hline $\begin{array}{c}\text { Chron. } \\
\text { Order }\end{array}$ & $\begin{array}{l}\text { Date of } \\
\text { Comm. }\end{array}$ & $\begin{array}{c}\text { Date of } \\
\text { UNsc } \\
\text { Document }\end{array}$ & || UNSC Symbol & \begin{tabular}{|c} 
Member \\
State(s) That \\
Submitted \\
the Comm.
\end{tabular} & \begin{tabular}{||c||} 
Expressly \\
Mentioned UN \\
Members (\& \\
Colonial \\
Holdings \& \\
Protectorates, \\
if any) \\
\end{tabular} & \begin{tabular}{|c|} 
Express or \\
Implied \\
Assertion of \\
Individual, \\
Collective, or \\
Both Self- \\
defense
\end{tabular} & \begin{tabular}{|c} 
Nature of \\
the Alleged \\
Threat
\end{tabular} & \begin{tabular}{|l} 
Expressly Alleged \\
Author(s) of the \\
Threat (ff Any \\
Indicated)
\end{tabular} & \begin{tabular}{|c|} 
Nature of the \\
Alleged \\
Author(s) of \\
the Threat (If \\
Any \\
Indicated) \\
\end{tabular} & $\begin{array}{l}\text { Summary of Alleged Self-defense } \\
\text { Grounds }\end{array}$ & \begin{tabular}{|c|} 
UNsc \\
Meeting(s) \\
(if Any) at \\
Which the \\
Comm. was \\
Raised
\end{tabular} & $\begin{array}{l}\text { Responsive Act (If Any) by the } \\
\text { UNSC }\end{array}$ & \begin{tabular}{|l} 
UN \\
Repertory \\
Inclusion?
\end{tabular} & $\begin{array}{c}\text { UNSC } \\
\text { Repertoire } \\
\text { Inclusion? }\end{array}$ & $\begin{array}{l}\text { URL to an } \\
\text { English } \\
\text { Text }\end{array}$ & \begin{tabular}{|c} 
URL to Non- \\
English \\
Original \\
Text (If Any)
\end{tabular} & $\begin{array}{l}\text { Perma.cc } \\
\text { URL }\end{array}$ \\
\hline 28 & 1965.09.06 & 1965.09.08 & $s / 6669$ & Pakistan & Pakistan, India & $\begin{array}{l}\text { Express } \\
\text { assertion of } \\
\text { "individual" } \\
\text { self-defense }\end{array}$ & $\begin{array}{c}\text { Conducted } \\
\text { attack }\end{array}$ & India & State & $\begin{array}{l}\text { Inter alia, a series of armed attacks } \\
\text { and occupations across the cease-fire } \\
\text { line. }\end{array}$ & $\begin{array}{l}\text { S/PV.1238 } \\
\text { (1238th) }\end{array}$ & None identified & \begin{tabular}{|l} 
None \\
identified
\end{tabular} & \begin{tabular}{|l|} 
Chapter V \\
(no \\
particular \\
article); \\
Chapter VIII \\
(no \\
particular \\
article) \\
\end{tabular} & $\begin{array}{l}\text { http: } \\
\text { //www.un. } \\
\text { org/en/ga/ } \\
\text { search/vie } \\
\text { w_doc. } \\
\text { asp? } \\
\text { symbol=s/ } \\
6669\end{array}$ & & $\begin{array}{l}\text { hitps: } \\
\text { //perma. } \\
\text { cc } \\
\text { kLXVG }\end{array}$ \\
\hline 29 & 1965.09.17 & 1965.09.17 & $s / 6688$ & India & India, Pakistan & $\begin{array}{l}\text { Implied } \\
\text { assertion of } \\
\text { "individual" } \\
\text { self-defense }\end{array}$ & $\begin{array}{c}\text { Conducted } \\
\text { attack }\end{array}$ & Pakistan & State & $\begin{array}{l}\text { Invasion of Jammu and Kashmir and } \\
\text { attacking across the cease-fire line } \\
\text { and the international frontier. }\end{array}$ & $\begin{array}{l}\text { None } \\
\text { identified }\end{array}$ & None identified & \begin{tabular}{|l} 
None \\
identified
\end{tabular} & $\begin{array}{l}\text { None } \\
\text { identified }\end{array}$ & $\begin{array}{l}\text { http: } \\
\text { //wwww.un. } \\
\text { org/en/ga/ } \\
\text { search/vie } \\
\text { w_doc. } \\
\text { asp? } \\
\text { symbol=S/ } \\
6688\end{array}$ & & $\begin{array}{l}\text { hitps: } \\
\text { //Terma. } \\
\text { cc/35sA- } \\
\text { WFNR }\end{array}$ \\
\hline 30 & 1965.10.16 & 1965.10.16 & s/6796 & Pakistan & Pakistan, India & $\begin{array}{c}\text { Implied } \\
\text { assertion of } \\
\text { "individual" } \\
\text { self-defense }\end{array}$ & $\begin{array}{c}\text { Conducted } \\
\text { attack }\end{array}$ & India & State & Forcible violations of the cease-fire. & \begin{tabular}{|l} 
None \\
identified
\end{tabular} & None identified & \begin{tabular}{|l} 
None \\
identified
\end{tabular} & \begin{tabular}{|l} 
None \\
identified
\end{tabular} & $\begin{array}{l}\text { http: } \\
\text { //wwww.un. } \\
\text { org/en/ga/ } \\
\text { search/vie } \\
\text { w_doc. } \\
\text { asp? } \\
\text { symbol=S/ } \\
6796\end{array}$ & & $\begin{array}{l}\text { hitps: } \\
\text { //perma. } \\
\text { cc//9WHR- } \\
\text { w9W7 }\end{array}$ \\
\hline 31 & 1965.10.29 & 1965.10.31 & $s / 6849$ & Pakistan & Pakistan, India & $\begin{array}{l}\text { Implied } \\
\text { assertion of } \\
\text { "individual" } \\
\text { self-defense }\end{array}$ & $\begin{array}{c}\text { Conducted } \\
\text { attack }\end{array}$ & India & State & $\begin{array}{l}\text { Forcible and non-forcible violations of } \\
\text { the cease-fire. }\end{array}$ & $\begin{array}{l}\text { None } \\
\text { identified }\end{array}$ & None identified & $\begin{array}{l}\text { None } \\
\text { identified }\end{array}$ & $\begin{array}{l}\text { None } \\
\text { identified }\end{array}$ & $\begin{array}{l}\text { http: } \\
\text { //www.un. } \\
\text { org/en/ga/ } \\
\text { search/vie } \\
\text { w_doc. } \\
\text { asp? } \\
\text { symbol=S/ } \\
\text { 6849 }\end{array}$ & & $\begin{array}{l}\text { hitps: } \\
\text { //perma. } \\
\text { cc/sTs9- } \\
\text { 3wD7 }\end{array}$ \\
\hline 32 & 1965.11.01 & 1965.11.01 & $s / 6852$ & Jordan & Jordan, Israel & $\begin{array}{l}\text { Implied } \\
\text { assertion of } \\
\text { "individual" } \\
\text { self-defense }\end{array}$ & $\begin{array}{c}\text { Conducted } \\
\text { attack }\end{array}$ & $\begin{array}{l}\text { Israel and "other } \\
\text { people not wearing" } \\
\text { military uniforms" }\end{array}$ & $\begin{array}{c}\text { State and } \\
\text { non-state } \\
\text { actors }\end{array}$ & $\begin{array}{l}\text { Inter alia, forcible crossing into a "no- } \\
\text { man's land" and plowing operations in } \\
\text { violation of the Armistice Agreement. }\end{array}$ & \begin{tabular}{|l} 
None \\
identified
\end{tabular} & None identified & $\begin{array}{l}\text { None } \\
\text { identified }\end{array}$ & \begin{tabular}{|l} 
None \\
identified
\end{tabular} & $\begin{array}{l}\text { http: } \\
\text { //www.un. } \\
\text { org/ngn/ga/ } \\
\text { search/vie } \\
\text { w_doc. } \\
\text { asp? } \\
\text { spmbol=S/ } \\
6852\end{array}$ & & $\begin{array}{l}\text { hitps: } \\
\text { //perma. } \\
\text { cc//fLU- } \\
\text { RS85 }\end{array}$ \\
\hline 33 & 1965.11.17 & 1965.11.17 & $\mathrm{s} / 6948$ & Pakistan & Pakistan, India & $\begin{array}{l}\text { Implied } \\
\text { assertion of } \\
\text { "individual" } \\
\text { self-defense }\end{array}$ & $\begin{array}{c}\text { Conducted } \\
\text { attack }\end{array}$ & India & State & $\begin{array}{l}\text { Forcible and non-forcible violations of } \\
\text { the cease-fire by Indian troops, } \\
\text { including firing on Pakistan positions. }\end{array}$ & \begin{tabular}{|l} 
None \\
identified
\end{tabular} & None identified & \begin{tabular}{|l} 
None \\
identified
\end{tabular} & \begin{tabular}{|l} 
None \\
identified
\end{tabular} & $\begin{array}{l}\text { http: } \\
\text { //www.un. } \\
\text { org/en//ga/ } \\
\text { search/vie } \\
\text { w_doc. } \\
\text { asp? } \\
\text { spybol=S/ } \\
6948\end{array}$ & & $\begin{array}{l}\text { litps: } \\
\text { ///perma. } \\
\text { cc/p987- } \\
\text { PWZL }\end{array}$ \\
\hline 34 & 1965.11.24 & 1965.11.24 & s/6974 & Pakistan & Pakistan, India & $\begin{array}{l}\text { Implied } \\
\text { assertion of } \\
\text { "individual" } \\
\text { self-defense }\end{array}$ & $\begin{array}{c}\text { Conducted } \\
\text { attack }\end{array}$ & India & State & $\begin{array}{l}\text { Forcible and non-forcible violations of } \\
\text { the cease-fire by Indian troops, } \\
\text { including firing on Pakistan positions } \\
\text { and posts. }\end{array}$ & $\begin{array}{l}\text { None } \\
\text { identified }\end{array}$ & None identified & $\begin{array}{l}\text { None } \\
\text { identified }\end{array}$ & $\begin{array}{l}\text { None } \\
\text { identified }\end{array}$ & $\begin{array}{l}\text { http: } \\
\text { //www.un. } \\
\text { org/en/ga/ } \\
\text { search/vie } \\
\text { w_doc. } \\
\text { asp? } \\
\text { symbol=S/ } \\
6974\end{array}$ & & $\begin{array}{l}\text { lhtps: } \\
\text { l/perma. } \\
\text { cc/89u8- } \\
\text { 3N3J }\end{array}$ \\
\hline 35 & 1965.12.07 & 1965.12.08 & s/7003 & Pakistan & Pakistan, India & $\begin{array}{l}\text { Implied } \\
\text { assertion of } \\
\text { "individual" } \\
\text { self-defense }\end{array}$ & $\begin{array}{c}\text { Conducted } \\
\text { attack }\end{array}$ & India & State & $\begin{array}{l}\text { Forcible and non-forcible violations of } \\
\text { the cease-fire by Indian troops, } \\
\text { including firing on Pakistan posts and } \\
\text { nationals. }\end{array}$ & \begin{tabular}{|l} 
None \\
identified
\end{tabular} & None identified & $\begin{array}{l}\text { None } \\
\text { identified }\end{array}$ & \begin{tabular}{|l} 
None \\
identified
\end{tabular} & $\begin{array}{l}\text { http: } \\
\text { //wwww.un. } \\
\text { org/en/ga/ } \\
\text { search//vie } \\
\text { w_doc. } \\
\text { asp? } \\
\text { symbol=S/ } \\
7003\end{array}$ & & $\begin{array}{l}\text { hitps: } \\
\text { ///perma. } \\
\text { cc//G5G- } \\
\text { 2TE2 }\end{array}$ \\
\hline
\end{tabular}


VI. HLS PILAC Catalogue of Apparent “Article 51 Communications”

\begin{tabular}{|c|c|c|c|c|c|c|c|c|c|c|c|c|c|c|c|c|c|}
\hline $\begin{array}{c}\text { Chron. } \\
\text { Order }\end{array}$ & $\begin{array}{l}\text { Date of } \\
\text { comm. }\end{array}$ & $\begin{array}{l}\text { Date of } \\
\text { UNsc } \\
\text { Document }\end{array}$ & UNSC Symbol & \begin{tabular}{|l} 
Member \\
State(s) That \\
Submitted \\
the Comm.
\end{tabular} & \begin{tabular}{|c} 
Expressly \\
Mentioned UN \\
Members (\& \\
Colonial \\
Holdings \& \\
Protectorates, \\
if any)
\end{tabular} & \begin{tabular}{||c|} 
Express or \\
Implied \\
Assertion of \\
Individual, \\
Collective, or \\
Both Self- \\
defense \\
\end{tabular} & \begin{tabular}{|l}
$\begin{array}{c}\text { Nature of } \\
\text { the Alleged } \\
\text { Threat }\end{array}$ \\
The
\end{tabular} & \begin{tabular}{|l} 
Expressly Alleged \\
Author(s) of the \\
Threat (ff Any \\
Indicated)
\end{tabular} & \begin{tabular}{|l||} 
Nature of the \\
Alleged \\
Author(s) of \\
the Threat (If \\
Any \\
Indicated)
\end{tabular} & $\begin{array}{l}\text { Summary of Alleged Self-defense } \\
\text { Grounds }\end{array}$ & \begin{tabular}{|c} 
UNSC \\
Meeting(s) \\
(If Any) at \\
Which the \\
Comm. was \\
Raised \\
\end{tabular} & $\begin{array}{l}\text { Responsive Act (If Any) by the } \\
\text { UNSC }\end{array}$ & $\begin{array}{l}\text { UN } \\
\text { Repertory } \\
\text { Inclusion? }\end{array}$ & \begin{tabular}{|c|} 
UNSC \\
Repertoire \\
Inclusion?
\end{tabular} & \begin{tabular}{|c||} 
URL to an \\
English \\
Text
\end{tabular} & \begin{tabular}{||c} 
URL to Non- \\
English \\
Original \\
Text (ff Any)
\end{tabular} & $\begin{array}{c}\text { Perma.cc } \\
\text { URL }\end{array}$ \\
\hline 36 & 1965.12.15 & 1965.12.15 & S/7017 & Pakistan & Pakistan, India & $\begin{array}{l}\text { Implied } \\
\text { assertion of } \\
\text { "individual" } \\
\text { self-defense }\end{array}$ & $\begin{array}{c}\text { Conducted } \\
\text { attack }\end{array}$ & India & State & $\begin{array}{l}\text { Forcible and non-forcible violations of } \\
\text { the cease-fire by Indian troops, } \\
\text { including firing on Pakistan posts. }\end{array}$ & $\begin{array}{l}\text { None } \\
\text { identified }\end{array}$ & None identified & \begin{tabular}{|l} 
None \\
identified
\end{tabular} & $\begin{array}{l}\text { None } \\
\text { identified }\end{array}$ & \begin{tabular}{|l||} 
httpp: \\
//www.un. \\
org//nn/gal \\
search/vie \\
w_doc. \\
asp? \\
symbol=s/ \\
smo17 \\
\end{tabular} & & $\begin{array}{l}\text { https: } \\
\text { ///perma. } \\
\text { cc/W8SS- } \\
\text { BMWE }\end{array}$ \\
\hline 37 & 1965.12.16 & 1965.12.18 & S/7027 & India & India, Pakistan & $\begin{array}{l}\text { Implied } \\
\text { assertion of } \\
\text { "individual" } \\
\text { self-defense }\end{array}$ & $\begin{array}{c}\text { Conducted } \\
\text { attack }\end{array}$ & Pakistan & State & $\begin{array}{l}\text { Forcible and non-forcible violations of } \\
\text { the cease-fire by Pakistan troops, } \\
\text { including firing on Indian posts. }\end{array}$ & $\begin{array}{l}\text { None } \\
\text { identified }\end{array}$ & None identified & $\begin{array}{l}\text { None } \\
\text { identified }\end{array}$ & $\begin{array}{l}\text { None } \\
\text { identified }\end{array}$ & \begin{tabular}{|l|l|} 
http: \\
//www.un. \\
org/en/ga/ \\
search/vie \\
w_doc. \\
asp? \\
symbol=s/ \\
7027
\end{tabular} & & $\begin{array}{l}\text { hitps: } \\
\text { ///perma. } \\
\text { ccl/15Y8- } \\
\text { z812 }\end{array}$ \\
\hline 38 & 1965.12.21 & 1965.12.21 & $\mathrm{s} / 7035$ & Pakistan & Pakistan, India & $\begin{array}{l}\text { Implied } \\
\text { assertion of } \\
\text { "individual" } \\
\text { self-defense }\end{array}$ & $\begin{array}{c}\text { Conducted } \\
\text { attack }\end{array}$ & India & State & $\begin{array}{l}\text { Forcible and non-forcible violations of } \\
\text { the cease-fire by Indian troops, } \\
\text { including firing on Pakistan posts. }\end{array}$ & $\begin{array}{l}\text { None } \\
\text { identified }\end{array}$ & None identified & $\begin{array}{l}\text { None } \\
\text { identified }\end{array}$ & $\begin{array}{l}\text { None } \\
\text { identified }\end{array}$ & \begin{tabular}{|l|} 
http: \\
//www.un. \\
org//nn/gal \\
search/vie \\
w_doc. \\
a_ps? \\
symbol=s/ \\
7035 \\
\end{tabular} & & $\begin{array}{l}\text { hitps: } \\
\text { ///perma. } \\
\text { cc/9CCP- } \\
6 \text { GFBB }\end{array}$ \\
\hline 39 & 1966.01 .10 & 1966.01.11 & S/7079 & Pakistan & Pakistan, India & $\begin{array}{l}\text { Implied } \\
\text { assertion of } \\
\text { "individual" } \\
\text { self-defense }\end{array}$ & $\begin{array}{c}\text { Conducted } \\
\text { attack }\end{array}$ & India & State & $\begin{array}{l}\text { Forcible and non-forcible violations of } \\
\text { the cease-fire by Indian troops, } \\
\text { including firing on Pakistan posts. }\end{array}$ & $\begin{array}{l}\text { None } \\
\text { identified }\end{array}$ & None identified & Article 30 & $\begin{array}{l}\text { None } \\
\text { identified }\end{array}$ & \begin{tabular}{|l|} 
httpp: \\
//www.un. \\
org//nn/gal \\
search/vie \\
w_doc. \\
a_p?? \\
symbol=s/ \\
7079 \\
\end{tabular} & & $\begin{array}{l}\text { hitps: } \\
\text { ///perma. } \\
\text { ccl/CAN- } \\
\text { WWK2 }\end{array}$ \\
\hline 40 & 1966.06.29 & 1966.06 .30 & $\mathrm{~s} / 7389$ & India & India, Pakistan & $\begin{array}{l}\text { Implied } \\
\text { assertion of } \\
\text { "individual" } \\
\text { self-defense }\end{array}$ & $\begin{array}{c}\text { Conducted } \\
\text { attack }\end{array}$ & Pakistan & State & $\begin{array}{l}\text { Encroachment committed by Pakistan } \\
\text { armed forces on the Indian side of the } \\
\text { cease-fire line, including firing on } \\
\text { Indian troops. }\end{array}$ & $\begin{array}{l}\text { None } \\
\text { identified }\end{array}$ & None identified & $\begin{array}{l}\text { None } \\
\text { identified }\end{array}$ & $\begin{array}{l}\text { None } \\
\text { identified }\end{array}$ & \begin{tabular}{|l|} 
httpp: \\
//www.un. \\
org/en//ga/ \\
search/vie \\
w_doc. \\
asp? \\
symbol=s/ \\
73m9 \\
\end{tabular} & & $\begin{array}{l}\text { hitps: } \\
\text { ///perma. } \\
\text { ccl/rgsk- } \\
\text { rgcs }\end{array}$ \\
\hline 41 & 1966.07.14 & 1966.07.14 & $\mathrm{s} / 7411$ & Israel & $\begin{array}{l}\text { Israel, Syria, } \\
\text { Lebanon }\end{array}$ & $\begin{array}{l}\text { Implied } \\
\text { assertion of } \\
\text { "individual" } \\
\text { self-defense }\end{array}$ & $\begin{array}{c}\text { Conducted } \\
\text { attack }\end{array}$ & Syria & State & $\begin{array}{l}\text { "... [A] sudden recrudescence of } \\
\text { sabotage and road-mining attacks in } \\
\text { Israel border areas, carried out from } \\
\text { Syria." }\end{array}$ & 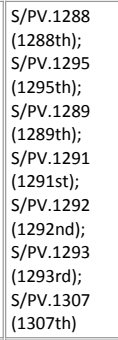 & $\begin{array}{l}\text { Draft resolution (" Condemns } \\
\text { the Israeli wanton attack of } 14 \\
\text { July } 1966, \text { as a flagrant } \\
\text { violation of the cease-fire } \\
\text { provisions of its resolutions of } \\
15 \text { July 1948, of the terms of } \\
\text { the General Arrmistice } \\
\text { Agreement between Israel and } \\
\text { Syria, and of Israel's } \\
\text { obligations under the Charter") } \\
\text { (S/7437) not adopted (6-0-9) }\end{array}$ & $\begin{array}{l}\text { None } \\
\text { identified }\end{array}$ & $\begin{array}{l}\text { Article 1(2); } \\
\text { Chapter VIII } \\
\text { (no } \\
\text { particular } \\
\text { article; } \\
\text { rather, The } \\
\text { Palestine } \\
\text { question) }\end{array}$ & \begin{tabular}{|l||} 
http: \\
//www.un. \\
org//nngal \\
search/vie \\
w_doc. \\
asp? \\
spybol=s/ \\
7411
\end{tabular} & & $\begin{array}{l}\text { hitps: } \\
\text { ///perma. } \\
\text { cc/97kP- } \\
\text { AuzK }\end{array}$ \\
\hline 42 & 1966.08.23 & 1966.08.23 & $s / 7470$ & Syria & Syria, Israel & $\begin{array}{l}\text { Implied } \\
\text { assertion of } \\
\text { "individual" } \\
\text { self-defense }\end{array}$ & $\begin{array}{c}\text { Conducted } \\
\text { attack }\end{array}$ & Israel & State & $\begin{array}{l}\text { Violation of the General Armistice } \\
\text { Agreement by crossing the boundaries } \\
\text { of the defensive area and firing on } \\
\text { Syrian shore position, and } \\
\text { subsequently bombing Syrian } \\
\text { positions. }\end{array}$ & $\begin{array}{l}\text { S/PV.1308 } \\
\text { (1308th) }\end{array}$ & None identified & \begin{tabular}{|l} 
None \\
identified
\end{tabular} & $\begin{array}{l}\text { None } \\
\text { identified }\end{array}$ & \begin{tabular}{|l||} 
httpp: \\
//www.un. \\
org//nn/gal \\
search/vie \\
w_doc. \\
asp? \\
symbol=s/ \\
7470 \\
\end{tabular} & \begin{tabular}{|l|} 
http://www. \\
un. \\
org/en/ga/se \\
arch/view_do \\
c.asp? \\
symbol=S/747 \\
O\&Lang=F \\
\end{tabular} & $\begin{array}{l}\text { hitps: } \\
\text { ///perma. } \\
\text { cc/6FA- } \\
\text { 32XF }\end{array}$ \\
\hline
\end{tabular}


VI. HLS PILAC Catalogue of Apparent “Article 51 Communications”

\begin{tabular}{|c|c|c|c|c|c|c|c|c|c|c|c|c|c|c|c|c|c|}
\hline $\begin{array}{c}\text { Chron. } \\
\text { Order }\end{array}$ & $\begin{array}{l}\text { Date of } \\
\text { comm. }\end{array}$ & \begin{tabular}{|c} 
Date of \\
UNsc \\
Document
\end{tabular} & UNSC Symbol & \begin{tabular}{|c} 
Member \\
State(s) That \\
Submitted \\
the Comm.
\end{tabular} & \begin{tabular}{|c|} 
Expressly \\
Mentioned UN \\
Members (\& \\
Colonial \\
Holdings \& \\
Protectorates, \\
if any) \\
\end{tabular} & \begin{tabular}{||c|} 
Express or \\
Implied \\
Assertion of \\
Individual, \\
Collective, or \\
Both Self- \\
defense \\
\end{tabular} & \begin{tabular}{|c} 
Nature of \\
the Alleged \\
Threat
\end{tabular} & $\begin{array}{l}\text { Expressly Alleged } \\
\text { Author(s) of the } \\
\text { Threat (If Any } \\
\text { Indicated) }\end{array}$ & \begin{tabular}{|c|} 
Nature of the \\
Alleged \\
Author(s) of \\
the Threat (If \\
Any \\
Indicated) \\
\end{tabular} & $\begin{array}{l}\text { Summary of Alleged Self-defense } \\
\text { Grounds }\end{array}$ & \begin{tabular}{|l} 
UNsc \\
Meeting(s) \\
(If Any) at \\
Which the \\
Comm. was \\
Raised
\end{tabular} & $\begin{array}{c}\text { Responsive Act (If Any) by the } \\
\text { UNSC }\end{array}$ & $\begin{array}{c}\text { UN } \\
\text { Repertory } \\
\text { Inclusion? }\end{array}$ & $\begin{array}{c}\text { UNSC } \\
\text { Repertoire } \\
\text { Inclusion? }\end{array}$ & \begin{tabular}{|l|} 
URL to an \\
English \\
Text
\end{tabular} & \begin{tabular}{||c||} 
URL to Non- \\
English \\
OOrinal \\
Text (ff Any)
\end{tabular} & $\begin{array}{l}\text { Perma.cc } \\
\text { URL }\end{array}$ \\
\hline 43 & 1966.11.16 & 1966.11.16 & S/PV.1320 & Israel & \begin{tabular}{|l} 
Israel, Jordan, \\
Syria, Egypt
\end{tabular} & $\begin{array}{l}\text { Implied } \\
\text { assertion of } \\
\text { "individual" } \\
\text { self-defense }\end{array}$ & $\begin{array}{c}\text { Conducted } \\
\text { attack }\end{array}$ & "[R]aiders" & $\begin{array}{l}\text { Non-state } \\
\text { actors }\end{array}$ & $\begin{array}{l}\text { ".... [A]n army vehicle on a regular } \\
\text { patrol was blown up by a mine, killing } \\
\text { three of its occupants and wounding } \\
\text { the other six. This incident again took } \\
\text { place in the border sector adjacent to } \\
\text { the southern Hebron hills, and again it } \\
\text { was evident that the perpetrators had } \\
\text { come from and returned to the same } \\
\text { villages. What is more, we had reason } \\
\text { to believe that this incident was the } \\
\text { first in a fresh series of attacks of an } \\
\text { even more serious nature, planned to } \\
\text { take place in the locality." }\end{array}$ & $\begin{array}{l}\text { S/PV.1320 } \\
\text { (1320th) }\end{array}$ & $\begin{array}{l}\text { S/RES/228(1966), OP 2: } \\
\text { "Censures Israel for this large- } \\
\text { scale military action [that is, } \\
\text { 'the rrave Israel military action } \\
\text { which took place in the } \\
\text { southern Hebron area of } 13 \\
\text { November 1966' in violation } \\
\text { of the United Nations Charter } \\
\text { and of the General Armistice } \\
\text { Agreement between Israel and } \\
\text { Jordan" (14-0-1) }\end{array}$ & \begin{tabular}{|l} 
Articles 2(4), \\
$12,25,31$, \\
$39,40, \& 76$
\end{tabular} & \begin{tabular}{|l} 
Article 2; \\
Chapter VIII \\
(no \\
particular \\
article); \\
Chapter III \\
(no \\
particular \\
article); \\
Rules 21-26; \\
Articles 39- \\
40
\end{tabular} & \begin{tabular}{|l|l|} 
https: \\
//documen \\
ts-dds-ny. \\
un. \\
org/doc/U \\
NDOC/GEN \\
ND69/106/ \\
75/pdf/N6 \\
91065. \\
pdf? \\
OpenElem \\
ent
\end{tabular} & & $\begin{array}{l}\text { https: } \\
\text { //perma. } \\
\text { cc/6W7S- } \\
\text { YDMJ }\end{array}$ \\
\hline 44 & 1967.01.13 & 1967.01.13 & $\mathrm{s} / 7680$ & Syria & Syria, Israel & $\begin{array}{l}\text { Implied } \\
\text { assertion of } \\
\text { "individual" } \\
\text { self-defense }\end{array}$ & $\begin{array}{c}\text { Conducted } \\
\text { attack }\end{array}$ & Israel & State & $\begin{array}{l}\text { Violation of the armistice demarcation } \\
\text { line, including through directing fire } \\
\text { and heavy artillery and shelling on } \\
\text { Syrian positions, and military flights } \\
\text { over Syrian territory. }\end{array}$ & $\begin{array}{l}\text { S/PV.1328 } \\
\text { (1328th) }\end{array}$ & None identified & 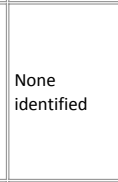 & $\begin{array}{l}\text { None } \\
\text { identified }\end{array}$ & \begin{tabular}{|l|} 
http: \\
//www.un. \\
organ/ga/ \\
search/vie \\
w_doc. \\
asp? \\
symbol=s/ \\
7680 \\
\end{tabular} & & $\begin{array}{l}\text { https: } \\
\text { //perma. } \\
\text { cc/4XCV- } \\
\text { FR7E }\end{array}$ \\
\hline 45 & 1967.04.09 & 1967.04.09 & S/7845 & Syria & Syria, Israel & $\begin{array}{l}\text { Implied } \\
\text { assertion of } \\
\text { "individual" } \\
\text { self-defense }\end{array}$ & $\begin{array}{l}\text { Conducted } \\
\text { attack }\end{array}$ & Israel & State & $\begin{array}{l}\text { Firing against Syrian territory and on } \\
\text { Syrian villages and positions; military } \\
\text { flights into Syrian air space and } \\
\text { bombarding Syrian villages }\end{array}$ & $\begin{array}{l}\text { S/PV.1344 } \\
1344 \text { th); } \\
\text { S/PV.1346 } \\
\text { (1346th) }\end{array}$ & None identified & $\begin{array}{l}\text { None } \\
\text { identified }\end{array}$ & $\begin{array}{l}\text { None } \\
\text { identified }\end{array}$ & \begin{tabular}{|l|} 
http: \\
//www.un. \\
org/en/ga/ \\
search/vie \\
w_doc. \\
asp? \\
symbol=s/ \\
7845
\end{tabular} & & $\begin{array}{l}\text { https: } \\
\text { //perma. } \\
\text { cc/EG5z- } \\
\text { U3SU }\end{array}$ \\
\hline 46 & 1967.04.28 & 1967.04.28 & S/7863 & Syria & Syria, Israel & $\begin{array}{l}\text { Implied } \\
\text { assertion of } \\
\text { "individual" } \\
\text { self-defense }\end{array}$ & $\begin{array}{c}\text { Conducted } \\
\text { attack }\end{array}$ & Israel & State & $\begin{array}{l}\text { Violations of the General Armistice } \\
\text { Agreement, including by sending an } \\
\text { armored tractor in violation of the } \\
\text { General Armistice Agreement, } \\
\text { cultivating a disputed area in the } \\
\text { southern Demilitarized Zone, } \\
\text { exchanging fire, and returning the } \\
\text { tractor again. }\end{array}$ & $\begin{array}{l}\text { S/PV.1344 } \\
\text { (1344th) }\end{array}$ & None identified & $\begin{array}{l}\begin{array}{l}\text { None } \\
\text { identified }\end{array} \\
\text { int }\end{array}$ & $\begin{array}{l}\text { None } \\
\text { identified }\end{array}$ & \begin{tabular}{|l||} 
http: \\
//www.un. \\
org/en/ga/ \\
search/vie \\
wdoc. \\
asp? \\
symbol=s/ \\
7863 \\
\end{tabular} & & \begin{tabular}{|l} 
https: \\
//perma. \\
cc//XFG3- \\
AJ54
\end{tabular} \\
\hline 47 & 1967.06.05 & 1967.06.05 & S/PV.1347 & Israel & Israel, Egypt & $\begin{array}{l}\text { Implied } \\
\text { assertion of } \\
\text { "individual" } \\
\text { self-defense }\end{array}$ & $\begin{array}{c}\text { Conducted } \\
\text { attack }\end{array}$ & Egypt & State & $\begin{array}{l}\text { “...[I]n the early hours of this morning } \\
\text { Egyptian armoured columns moved in } \\
\text { an offensive thrust against Israel's } \\
\text { borders, At the same time Egyptian } \\
\text { planes took off from airfields in Sinai } \\
\text { and struck out towards Israel. } \\
\text { Egyptian artillery in the Gaza Strip } \\
\text { shelled the Israel villages of Kissufim, } \\
\text { Nahal-Oz and Ein Hashelosha. Netania } \\
\text { and Kefar Yavetz have also been } \\
\text { bombed." }\end{array}$ & $\begin{array}{l}\text { S/PV.1347 } \\
\text { (1347th) }\end{array}$ & 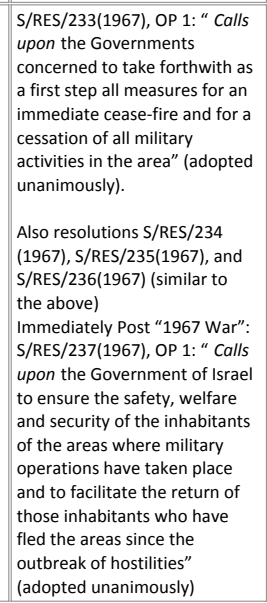 & $\begin{array}{l}\text { Articles } 2(4), \\
2(7), 25,30, \\
76 \text {, and } 98\end{array}$ & $\begin{array}{l}\text { Rules 18-20; } \\
\text { Rules 21-26; } \\
\text { Chapter III } \\
\text { (no } \\
\text { particular } \\
\text { article); } \\
\text { Articles 48- } \\
51 \text { Chapter } \\
\text { VIII (no } \\
\text { particular } \\
\text { article) }\end{array}$ & \begin{tabular}{|l|l|} 
https: \\
//documen \\
st-dds-ny. \\
un. \\
org/doc/U \\
NDOC/GEN \\
ND70/083/ \\
53/pdf/N7 \\
008335. \\
pdf? \\
OpenElem \\
ent
\end{tabular} & & $\begin{array}{l}\text { https: } \\
\text { //perma. } \\
\text { cc/3FDS- } \\
\text { K7WR }\end{array}$ \\
\hline
\end{tabular}


VI. HLS PILAC Catalogue of Apparent "Article 51 Communications"

\begin{tabular}{|c|c|c|c|c|c|c|c|c|c|c|c|c|c|c|c|c|c|}
\hline $\begin{array}{c}\text { Chron. } \\
\text { Order }\end{array}$ & $\begin{array}{l}\text { Date of } \\
\text { Comm. }\end{array}$ & $\begin{array}{l}\text { Date of } \\
\text { UNsc } \\
\text { Document }\end{array}$ & UNSC Symbol & \begin{tabular}{|c} 
Member \\
State(s) That \\
Submitted \\
the Comm.
\end{tabular} & \begin{tabular}{|c|} 
Expressly \\
Mentioned UN \\
Members (\& \\
Colonial \\
Holdings \& \\
Protectorates, \\
if any) \\
\end{tabular} & \begin{tabular}{|c|} 
Express or \\
Implied \\
Assertion of \\
Individual, \\
Collective, or \\
Both Self- \\
defense \\
\end{tabular} & \begin{tabular}{|l} 
Nature of \\
the Alleged \\
Threat
\end{tabular} & $\begin{array}{l}\text { Expressly Alleged } \\
\text { Author(s) of the } \\
\text { Threat (If Any } \\
\text { Indicated) }\end{array}$ & \begin{tabular}{|c|} 
Nature of the \\
Alleged \\
Author(s) of \\
the Threat (If \\
Any \\
Indicated) \\
\end{tabular} & $\begin{array}{l}\text { Summary of Alleged Self-defense } \\
\text { Grounds }\end{array}$ & \begin{tabular}{|l} 
UNsc \\
Meeting(s) \\
(If Any) at \\
Which the \\
Comm. was \\
Raised
\end{tabular} & $\begin{array}{l}\text { Responsive Act (If Any) by the } \\
\text { UNSC }\end{array}$ & $\begin{array}{l}\text { UN } \\
\text { Repertory } \\
\text { Inclusion? }\end{array}$ & \begin{tabular}{|c} 
UNSC \\
Repertoire \\
Inclusion?
\end{tabular} & $\begin{array}{l}\text { URL to an } \\
\text { English } \\
\text { Text }\end{array}$ & \begin{tabular}{|c} 
URL to Non- \\
English \\
Original \\
Text (If Any)
\end{tabular} & $\begin{array}{c}\text { Perma.cc } \\
\text { URL }\end{array}$ \\
\hline 48 & 1967.06.05 & 1967.06.05 & $\mathrm{s} / 7926$ & $\begin{array}{l}\text { United Arab } \\
\text { Republic } \\
\text { [Egypt] }\end{array}$ & $\begin{array}{l}\text { United Arab } \\
\text { Republic } \\
\text { [Egypt], Israel }\end{array}$ & $\begin{array}{l}\text { Implied } \\
\text { assertion of } \\
\text { "individual" } \\
\text { self-defense }\end{array}$ & $\begin{array}{c}\text { Conducted } \\
\text { attack }\end{array}$ & Israel & State & $\begin{array}{l}\text { Attacks against the Gaza strip, Sinai, } \\
\text { airports in Cairo, in the Suez Canal } \\
\text { area, and several other airports within } \\
\text { the United Arab Republic [Egypt]. }\end{array}$ & $\begin{array}{l}\text { S/PV. } 1347 \\
\text { (1347th); } \\
\text { S/PV.1348 } \\
\text { (1348th) }\end{array}$ & $\begin{array}{l}\text { S/RES/233(1967), OP 1: " Calls } \\
\text { upon the Governments } \\
\text { concerned to take forthwith as } \\
\text { a first step all measures for an } \\
\text { immediate cease-fire and for a } \\
\text { cessation of all military } \\
\text { activities in the area" }\end{array}$ & $\begin{array}{l}\text { None } \\
\text { identified }\end{array}$ & \begin{tabular}{|l} 
Chapter VIII \\
(no \\
particular \\
article)
\end{tabular} & $\begin{array}{l}\text { http: } \\
\text { //www.un. } \\
\text { org/en/ga/ } \\
\text { search//ie } \\
\text { w_doc. } \\
\text { asp? } \\
\text { symbol=S/ } \\
7926\end{array}$ & & $\begin{array}{l}\text { litps: } \\
\text { //perma. } \\
\text { cc//778a- } \\
8655\end{array}$ \\
\hline 49 & 1967.07.17 & 1967.07.17 & $s / 8067$ & Jordan & Jordan, Israel & $\begin{array}{l}\text { Implied } \\
\text { assertion of } \\
\text { "individual" } \\
\text { self-defense }\end{array}$ & $\begin{array}{c}\text { Conducted } \\
\text { attack }\end{array}$ & Israel & State & $\begin{array}{l}\text { Violation of Security Council cease-fire } \\
\text { resolutions, including by way of firing } \\
\text { on military patrols and forces. }\end{array}$ & $\begin{array}{l}\text { None } \\
\text { identified }\end{array}$ & None identified & \begin{tabular}{|l} 
None \\
identified
\end{tabular} & $\begin{array}{l}\text { None } \\
\text { identified }\end{array}$ & $\begin{array}{l}\text { http: } \\
\text { //wwww.un. } \\
\text { org/en/ga/ } \\
\text { search//ie } \\
\text { w_doc. } \\
\text { asp? } \\
\text { symbol=S/ } \\
8067\end{array}$ & & $\begin{array}{l}\text { hitps: } \\
\text { ///perma. } \\
\text { ccl/PP56- } \\
\text { JTPH }\end{array}$ \\
\hline 50 & 1967.09.06 & 1967.09.06 & $s / 8140$ & $\begin{array}{l}\text { United Arab } \\
\text { Republic } \\
\text { [Egypt] }\end{array}$ & $\begin{array}{l}\text { United Arab } \\
\text { Republic } \\
\text { [Egypt], Israel, } \\
\text { Greece, India }\end{array}$ & $\begin{array}{l}\text { Implied } \\
\text { assertion of } \\
\text { "individual" } \\
\text { self-defense }\end{array}$ & $\begin{array}{c}\text { Conducted } \\
\text { attack }\end{array}$ & Israel & State & $\begin{array}{l}\text { Attempt to force passage through the } \\
\text { Suez Canal and firing on United Arab } \\
\text { Republic [Egypt] positions. }\end{array}$ & \begin{tabular}{|l} 
None \\
identified
\end{tabular} & None identified & $\begin{array}{l}\begin{array}{l}\text { None } \\
\text { identified }\end{array}\end{array}$ & \begin{tabular}{|l} 
None \\
identified
\end{tabular} & $\begin{array}{l}\text { http: } \\
\text { //www.un. } \\
\text { org/en/ga/ } \\
\text { search/vie } \\
\text { w_doc. } \\
\text { asp? } \\
\text { symbol=s/ } \\
8140\end{array}$ & & $\begin{array}{l}\text { hitps: } \\
\text { ///perma. } \\
\text { cc//ABP3- } \\
\text { G67N }\end{array}$ \\
\hline 51 & 1967.10.10 & 1967.10.10 & $\mathrm{s} / 8188$ & Israel & $\begin{array}{l}\text { Israel, United } \\
\text { Arab Republic } \\
\text { [Egypt] }\end{array}$ & $\begin{array}{l}\text { Implied } \\
\text { assertion of } \\
\text { "individual" } \\
\text { self-defense }\end{array}$ & $\begin{array}{c}\text { Conducted } \\
\text { attack }\end{array}$ & $\begin{array}{c}\text { United Arab } \\
\text { Republic [Egypt] }\end{array}$ & State & $\begin{array}{l}\text { Firing on Israeli forces along the Suez } \\
\text { Canal. }\end{array}$ & $\begin{array}{l}\text { None } \\
\text { identified }\end{array}$ & None identified & $\begin{array}{l}\text { None } \\
\text { identified }\end{array}$ & $\begin{array}{l}\text { Chapter VIII } \\
\text { (no } \\
\text { particular } \\
\text { article) }\end{array}$ & $\begin{array}{l}\text { http: } \\
\text { //wwww.un. } \\
\text { org/en/ga/ } \\
\text { search/vie } \\
\text { w_doc. } \\
\text { asp? } \\
\text { symbol=S/ } \\
8188\end{array}$ & & $\begin{array}{l}\text { hitps: } \\
\text { ///perma. } \\
\text { cc//ZVVV- } \\
\text { TCGL }\end{array}$ \\
\hline 52 & 1967.10.11 & 1967.10.11 & $\mathrm{s} / 8189$ & Thailand & $\begin{array}{l}\text { Thailand, } \\
\text { Cambodia }\end{array}$ & $\begin{array}{l}\text { Implied } \\
\text { assertion of } \\
\text { "individual" } \\
\text { self-defense }\end{array}$ & $\begin{array}{c}\text { Conducted } \\
\text { attack }\end{array}$ & $\begin{array}{l}\text { Cambodia and } \\
\text { "armed elements" }\end{array}$ & $\begin{array}{c}\text { State and } \\
\text { non-state } \\
\text { actors }\end{array}$ & $\begin{array}{l}\text { Provocative and aggressive actions } \\
\text { perpetrated by Cambodian soldiers } \\
\text { and armed elements against Thai } \\
\text { authorities and civilians in the border } \\
\text { areas. }\end{array}$ & $\begin{array}{l}\text { None } \\
\text { identified }\end{array}$ & None identified & $\begin{array}{l}\text { None } \\
\text { identified }\end{array}$ & $\begin{array}{l}\text { None } \\
\text { identified }\end{array}$ & $\begin{array}{l}\text { http: } \\
\text { //www.un. } \\
\text { org/en//ga/ } \\
\text { search/vie } \\
\text { w_doc. } \\
\text { asp? } \\
\text { symbol=S/ } \\
8189\end{array}$ & & $\begin{array}{l}\text { hitps: } \\
\text { ///perma. } \\
\text { cc/f4kF- } \\
\text { P725 }\end{array}$ \\
\hline 53 & 1967.10.22 & 1967.10.22 & $\mathrm{s} / 8205$ & $\begin{array}{l}\text { United Arab } \\
\text { Republic } \\
\text { [Egypt] }\end{array}$ & \begin{tabular}{|l} 
United Arab \\
Republic \\
[Egypt], Israel
\end{tabular} & $\begin{array}{l}\text { Implied } \\
\text { assertion of } \\
\text { "individual" } \\
\text { self-defense }\end{array}$ & $\begin{array}{c}\text { Conducted } \\
\text { attack }\end{array}$ & Israel & State & $\begin{array}{l}\text { Violation of the Security Council's } \\
\text { cease-fire resolution, by way of an } \\
\text { Israeli destroyer in United Arab } \\
\text { Republic [Egypt] territorial waters and } \\
\text { attacks, bombardments, and shelling } \\
\text { of populated cities. }\end{array}$ & $\begin{array}{l}\text { S/PV.1369 } \\
\text { (1369th); } \\
\text { S/PV.1484 } \\
\text { (1484th) }\end{array}$ & None identified & $\begin{array}{l}\text { None } \\
\text { identified }\end{array}$ & $\begin{array}{l}\text { None } \\
\text { identified }\end{array}$ & $\begin{array}{l}\text { http: } \\
\text { //www.un. } \\
\text { org/en//ga/ } \\
\text { search/vie } \\
\text { w_doc. } \\
\text { asp? } \\
\text { spybol=S/ } \\
8205\end{array}$ & & $\begin{array}{l}\text { litps: } \\
\text { //perma. } \\
\text { cc/S5DS- } \\
\text { MGDQ }\end{array}$ \\
\hline 54 & 1968.01.05 & 1968.01.08 & $\mathrm{s} / 8328$ & Israel & Israel, Jordan & $\begin{array}{c}\text { Implied } \\
\text { assertion of } \\
\text { "individual" } \\
\text { self-defense }\end{array}$ & $\begin{array}{c}\text { Conducted } \\
\text { attack }\end{array}$ & Jordan & State & $\begin{array}{l}\text { Breach of the cease-fire, by way of } \\
\text { firing by Jordanian forces from } \\
\text { populated area. }\end{array}$ & \begin{tabular}{|l} 
None \\
identified
\end{tabular} & None identified & $\begin{array}{l}\text { None } \\
\text { identified }\end{array}$ & \begin{tabular}{|l} 
None \\
identified
\end{tabular} & $\begin{array}{l}\text { http: } \\
\text { //wwww.un. } \\
\text { org/en/ga/ } \\
\text { search//ie } \\
\text { w_doc. } \\
\text { asp? } \\
\text { symbol=s/ } \\
8328\end{array}$ & & $\begin{array}{l}\text { litps: } \\
\text { //perma. } \\
\text { cc/RCR2- } \\
69 R E\end{array}$ \\
\hline 55 & 1968.01.05 & 1968.01.09 & $\mathrm{s} / 8332$ & Thailand & $\begin{array}{l}\text { Thailand, } \\
\text { Cambodia }\end{array}$ & $\begin{array}{l}\text { Implied } \\
\text { assertion of } \\
\text { "individual" } \\
\text { self-defense }\end{array}$ & $\begin{array}{c}\text { Conducted } \\
\text { attack }\end{array}$ & Cambodia & State & $\begin{array}{l}\text { Aggressive and piratical acts at the } \\
\text { hands of Cambodian land and naval } \\
\text { forces against Thai authorities and } \\
\text { civilians. }\end{array}$ & \begin{tabular}{|l} 
None \\
identified
\end{tabular} & None identified & $\begin{array}{l}\begin{array}{l}\text { None } \\
\text { identified }\end{array}\end{array}$ & \begin{tabular}{|l} 
None \\
identified
\end{tabular} & $\begin{array}{l}\text { http: } \\
\text { //www.un. } \\
\text { org/en//ga/ } \\
\text { search/vie } \\
\text { w_doc. } \\
\text { asp? } \\
\text { spybol=S/ } \\
8332\end{array}$ & & $\begin{array}{l}\text { litps: } \\
\text { //perma. } \\
\text { cc/PGMT- } \\
\text { KMBX }\end{array}$ \\
\hline
\end{tabular}


VI. HLS PILAC Catalogue of Apparent “Article 51 Communications”

\begin{tabular}{|c|c|c|c|c|c|c|c|c|c|c|c|c|c|c|c|c|c|}
\hline $\begin{array}{c}\text { Chron. } \\
\text { Order }\end{array}$ & $\begin{array}{l}\text { Date of } \\
\text { Comm. }\end{array}$ & $\begin{array}{l}\text { Date of } \\
\text { UNsC } \\
\text { Document }\end{array}$ & UNSC Symbol & \begin{tabular}{|l} 
Member \\
State(s) That \\
Submitted \\
the Comm.
\end{tabular} & \begin{tabular}{|c||} 
Expressly \\
Mentioned UN \\
Members (\& \\
Colonial \\
Holdings \& \\
Protectorates, \\
if any) \\
\end{tabular} & \begin{tabular}{|l} 
Express or \\
Implied \\
Assertion of \\
Individual, \\
Collective, or \\
Both Self- \\
defense \\
\end{tabular} & \begin{tabular}{|l} 
Nature of \\
the Alleged \\
Threat
\end{tabular} & $\begin{array}{l}\text { Expressly Alleged } \\
\text { Author(s) of the } \\
\text { Threat (If Any } \\
\text { Indicated) }\end{array}$ & $\begin{array}{l}\text { Nature of the } \\
\text { Alleged } \\
\text { Author(s) of } \\
\text { the Threat (If } \\
\text { Any } \\
\text { Indicated) }\end{array}$ & $\begin{array}{l}\text { Summary of Alleged Self-defense } \\
\text { Grounds }\end{array}$ & $\begin{array}{l}\text { UNsC } \\
\text { Meeting(s) } \\
\text { (If Any) at } \\
\text { Which the } \\
\text { Comm. was } \\
\text { Raised }\end{array}$ & $\begin{array}{l}\text { Responsive Act (If Any) by the } \\
\text { UNSC }\end{array}$ & $\begin{array}{l}\text { UN } \\
\text { Repertory } \\
\text { Inclusion? }\end{array}$ & \begin{tabular}{|c} 
UNSC \\
Repertoire \\
Inclusion?
\end{tabular} & $\begin{array}{l}\text { URL to an } \\
\text { English } \\
\text { Text }\end{array}$ & \begin{tabular}{|c} 
URL to Non- \\
English \\
Original \\
Tert (If Any)
\end{tabular} & $\begin{array}{l}\text { Perma.cc } \\
\text { URL }\end{array}$ \\
\hline 56 & 1968.01.25 & 1968.01.25 & $\mathrm{s} / 8359$ & Israel & Israel, Jordan & $\begin{array}{c}\text { Implied } \\
\text { assertion of } \\
\text { "individual" } \\
\text { self-defense }\end{array}$ & $\begin{array}{c}\text { Conducted } \\
\text { attack }\end{array}$ & Jordan & State & $\begin{array}{l}\text { Violation of the cease-fire resulting in } \\
\text { loss of life, by way of fire at the } \\
\text { Allenby Bridge. }\end{array}$ & $\begin{array}{l}\text { None } \\
\text { identified }\end{array}$ & None identified & $\begin{array}{l}\text { None } \\
\text { identified }\end{array}$ & $\begin{array}{l}\text { None } \\
\text { identified }\end{array}$ & $\begin{array}{l}\text { http: } \\
\text { //www.un. } \\
\text { org/en//ga/ } \\
\text { search/vie } \\
\text { w_doc. } \\
\text { asp? } \\
\text { spybol=S/ } \\
8359\end{array}$ & & $\begin{array}{l}\text { hitps: } \\
\text { //perma. } \\
\text { ccl//F36- } \\
\text { 8WFJ }\end{array}$ \\
\hline 57 & 1968.01.26 & 1968.01.26 & $\mathrm{s} / 8361$ & Jordan & Jordan, Israel & $\begin{array}{l}\text { Implied } \\
\text { assertion of } \\
\text { "individual" } \\
\text { self-defense }\end{array}$ & $\begin{array}{c}\text { Conducted } \\
\text { attack }\end{array}$ & Israel & State & $\begin{array}{l}\text { Violation of the cease-fire resolution, } \\
\text { by way of firing on Jordanian } \\
\text { positions. }\end{array}$ & $\begin{array}{l}\text { None } \\
\text { identified }\end{array}$ & None identified & \begin{tabular}{|l} 
None \\
identified
\end{tabular} & $\begin{array}{l}\text { None } \\
\text { identified }\end{array}$ & $\begin{array}{l}\text { http: } \\
\text { //www.un. } \\
\text { org/en//ga/ } \\
\text { search/vie } \\
\text { w_doc. } \\
\text { asp? } \\
\text { spybol=S/ } \\
8361\end{array}$ & & $\begin{array}{l}\text { hitps: } \\
\text { //perma. } \\
\text { cc } 7 / 79 \mathrm{YM}- \\
\text { 5F2A }\end{array}$ \\
\hline 58 & 1968.01.30 & 1968.01.30 & $s / 8369$ & $\begin{array}{l}\text { United Arab } \\
\text { Republic } \\
\text { [Egypt] }\end{array}$ & $\begin{array}{l}\text { United Arab } \\
\text { Republic } \\
\text { [Egypt], Israel }\end{array}$ & $\begin{array}{c}\text { Implied } \\
\text { assertion of } \\
\text { "individual" } \\
\text { self-defense }\end{array}$ & $\begin{array}{c}\text { Conducted } \\
\text { attack }\end{array}$ & Israel & State & $\begin{array}{l}\text { Violation of the cease-fire resolutions } \\
\text { adopted by the Security Council, by } \\
\text { way of firing at launches and crew } \\
\text { associated with Suez Canal survey and } \\
\text { shelling of a United Arab Republic } \\
\text { [Egypt] position. }\end{array}$ & $\begin{array}{l}\text { None } \\
\text { identified }\end{array}$ & None identified & \begin{tabular}{|l} 
None \\
identified
\end{tabular} & $\begin{array}{l}\text { None } \\
\text { identified }\end{array}$ & $\begin{array}{l}\text { http: } \\
\text { //www.un. } \\
\text { org/en/ga/ } \\
\text { search/vie } \\
\text { w_doc. } \\
\text { ass? } \\
\text { symbol=s/ } \\
8369\end{array}$ & & $\begin{array}{l}\text { hitps: } \\
\text { //perma. } \\
\text { cc//7RR } \\
\text { BM2R }\end{array}$ \\
\hline 59 & 1968.02.13 & 1968.02.13 & $s / 8400$ & Jordan & Jordan, Israel & $\begin{array}{c}\text { Implied } \\
\text { assertion of } \\
\text { "individual" } \\
\text { self-defense }\end{array}$ & $\begin{array}{c}\text { Conducted } \\
\text { attack }\end{array}$ & Israel & State & $\begin{array}{l}\text { Violation of the cease-fire resolutions, } \\
\text { by way of shelling on a Jordanian } \\
\text { position }\end{array}$ & \begin{tabular}{|l} 
None \\
identified
\end{tabular} & None identified & \begin{tabular}{|l} 
None \\
identified
\end{tabular} & \begin{tabular}{|l} 
None \\
identified
\end{tabular} & $\begin{array}{l}\text { http: } \\
\text { /twww.un. } \\
\text { org/en/ga/ } \\
\text { search/vie } \\
\text { w_doc. } \\
\text { asp? } \\
\text { symbol=s/ } \\
8400\end{array}$ & & $\begin{array}{l}\text { hitps: } \\
\text { //perma. } \\
\text { ccl/FSYY- } \\
\text { FXDY }\end{array}$ \\
\hline 60 & 1968.02.15 & 1968.02.15 & $S / 8405$ & Israel & Israel, Jordan & $\begin{array}{c}\text { Implied } \\
\text { assertion of } \\
\text { "individual" } \\
\text { self-defense }\end{array}$ & $\begin{array}{c}\text { Conducted } \\
\text { attack }\end{array}$ & Jordan & State & $\begin{array}{l}\text { Inter alia, Jordanian armed forces } \\
\text { conducted attacks on Israeli villages } \\
\text { and the civilian population. }\end{array}$ & $\begin{array}{l}\text { None } \\
\text { identified }\end{array}$ & None identified & $\begin{array}{l}\text { None } \\
\text { identified }\end{array}$ & \begin{tabular}{|l} 
None \\
identified
\end{tabular} & $\begin{array}{l}\text { http: } \\
\text { //www.un. } \\
\text { org/en/ga/ } \\
\text { search/vie } \\
\text { w_doc. } \\
\text { asp? } \\
\text { symbol=S/ } \\
8405\end{array}$ & & $\begin{array}{l}\text { https: } \\
\text { //perma. } \\
\text { cc/M6ZG- } \\
\text { GP2B }\end{array}$ \\
\hline 61 & 1968.03.18 & 1968.03.18 & $S / 8470$ & Israel & Israel, Jordan & $\begin{array}{l}\text { Implied } \\
\text { assertion of } \\
\text { "individual" } \\
\text { self-defense }\end{array}$ & $\begin{array}{c}\text { Conducted } \\
\text { attack }\end{array}$ & $\begin{array}{l}\text { Jordan and } \\
\text { "marauders" }\end{array}$ & $\begin{array}{c}\text { State and } \\
\text { non-state } \\
\text { actors }\end{array}$ & $\begin{array}{l}\text { Violations of the cease-fire, including } \\
\text { by way of attacks from Jordanian } \\
\text { positions. }\end{array}$ & $\begin{array}{l}\text { S/PV. } 1407 \\
\text { (1407th) }\end{array}$ & \begin{tabular}{|l} 
S/RES/248(1968), OPs 2-3: “2. \\
Condemns the military action \\
launched by Israel in flagrant \\
violation of the United Nations \\
Charter and the cease-fire \\
resolutions; \\
3. Deplores all violent incidents \\
in violation of the cease-efire \\
and declares that such actions \\
of military reprisal and other \\
grave violations of the cease- \\
fire cannot be tolerated and \\
that the Security Council would \\
have to consider further and \\
more effective steps as \\
envisaged in the Charter to \\
ensure against repeitition of \\
such acts" (adopted \\
unanimously)
\end{tabular} & Article 2(4) & \begin{tabular}{|l|} 
Article 2; \\
Chapter VIII \\
(no \\
particular \\
article)
\end{tabular} & $\begin{array}{l}\text { http: } \\
\text { //www.un. } \\
\text { org/en/ga/ } \\
\text { search/vie } \\
\text { w_doc. } \\
\text { asp? } \\
\text { symbol=s/ } \\
8470\end{array}$ & & $\begin{array}{l}\text { hitps: } \\
\text { //perma. } \\
\text { cc//9007- } \\
\text { PBMD }\end{array}$ \\
\hline 62 & 1968.03.29 & 1968.03.29 & $s / 8510$ & Israel & Israel, Jordan & $\begin{array}{l}\text { Implied } \\
\text { assertion of } \\
\text { "individual" } \\
\text { self-defense }\end{array}$ & $\begin{array}{c}\text { Conducted } \\
\text { attack }\end{array}$ & Jordan & State & $\begin{array}{l}\text { "EE]xtremely grave violation” of the } \\
\text { cease-fire and Security Council } \\
\text { resolution, by way of attack against } \\
\text { Israeli territory. }\end{array}$ & $\begin{array}{l}\text { S/PV.1409 } \\
\text { (1409th) }\end{array}$ & None identified & \begin{tabular}{|l} 
None \\
identified
\end{tabular} & $\begin{array}{l}\text { Chapter VIII } \\
\text { (no } \\
\text { particular } \\
\text { article) }\end{array}$ & $\begin{array}{l}\text { http: } \\
\text { //wwww.un. } \\
\text { org/en/ga/ } \\
\text { search/vie } \\
\text { w_doc. } \\
\text { asp? } \\
\text { symbol=S/ } \\
8510\end{array}$ & & $\begin{array}{l}\text { hitps: } \\
\text { //perma. } \\
\text { cc/LCM3- } \\
\text { 4HYS }\end{array}$ \\
\hline
\end{tabular}


VI. HLS PILAC Catalogue of Apparent “Article 51 Communications”

\begin{tabular}{|c|c|c|c|c|c|c|c|c|c|c|c|c|c|c|c|c|c|}
\hline $\begin{array}{c}\text { Chron. } \\
\text { Order }\end{array}$ & $\begin{array}{l}\text { Date of } \\
\text { comm. }\end{array}$ & $\begin{array}{l}\text { Date of } \\
\text { UNsC } \\
\text { Document }\end{array}$ & | UNSC Symbol & \begin{tabular}{|l} 
Member \\
State(s) That \\
Submitted \\
the Comm.
\end{tabular} & \begin{tabular}{||c||} 
Expressly \\
Mentioned UN \\
Members (\& \\
Colonial \\
Holdings \& \\
Protectorates, \\
if any) \\
\end{tabular} & \begin{tabular}{|l} 
Express or \\
Implied \\
Assertion of \\
Individual, \\
Collective, or \\
Both Self- \\
defense \\
\end{tabular} & \begin{tabular}{|l} 
Nature of \\
the Alleged \\
Threat
\end{tabular} & \begin{tabular}{|l} 
Expressly Alleged \\
Author(s) of the \\
Threat (If Any \\
Indicated)
\end{tabular} & \begin{tabular}{|c|} 
Nature of the \\
Alleged \\
Author(s) of \\
the Threat (If \\
Any \\
Indicated)
\end{tabular} & $\begin{array}{l}\text { Summary of Alleged Self-defense } \\
\text { Grounds }\end{array}$ & $\begin{array}{c}\text { UNSC } \\
\text { Meeting(s) } \\
\text { (If Any) at } \\
\text { Which the } \\
\text { Comm. was } \\
\text { Raised }\end{array}$ & $\begin{array}{l}\text { Responsive Act (If Any) by the } \\
\text { UNSC }\end{array}$ & \begin{tabular}{|l} 
UN \\
Repertory \\
Inclusion?
\end{tabular} & $\begin{array}{l}\text { UNSC } \\
\text { Repertoire } \\
\text { Inclusion? }\end{array}$ & $\begin{array}{l}\text { URL to an } \\
\text { English } \\
\text { Text }\end{array}$ & \begin{tabular}{|c} 
URL to Non- \\
English \\
Original \\
Tert (If Any)
\end{tabular} & $\begin{array}{l}\text { Perma.cc } \\
\text { URL }\end{array}$ \\
\hline 63 & 1968.03.29 & 1968.03.29 & $\mathrm{s} / 8515$ & Israel & Israel, Jordan & $\begin{array}{c}\text { Implied } \\
\text { assertion of } \\
\text { "individual" } \\
\text { self-defense }\end{array}$ & $\begin{array}{c}\text { Conducted } \\
\text { attack }\end{array}$ & Jordan & State & $\begin{array}{l}\text { Violations of the cease-fire, by way of } \\
\text { attack on Israeli villages and the } \\
\text { civilian population, including artillery } \\
\text { fire. }\end{array}$ & $\begin{array}{l}\text { None } \\
\text { identified }\end{array}$ & None identified & $\begin{array}{l}\text { None } \\
\text { identified }\end{array}$ & $\begin{array}{l}\text { None } \\
\text { identified }\end{array}$ & $\begin{array}{l}\text { http: } \\
\text { //wwww.un. } \\
\text { org/en//ga/ } \\
\text { search/vie } \\
\text { w_doc. } \\
\text { asp? } \\
\text { spybol=S/ } \\
8515\end{array}$ & & $\begin{array}{l}\text { hitps: } \\
\text { //perma. } \\
\text { cc/MNNA } \\
\text { BMRU }\end{array}$ \\
\hline 64 & 1968.05.06 & 1968.05.07 & s/8579 & Jordan & Jordan, Israel & $\begin{array}{l}\text { Implied } \\
\text { assertion of } \\
\text { "individual" } \\
\text { self-defense }\end{array}$ & $\begin{array}{c}\text { Conducted } \\
\text { attack }\end{array}$ & Israel & State & $\begin{array}{l}\text { Violations of the cease-fire resolution, } \\
\text { including firing on farms. }\end{array}$ & $\begin{array}{l}\text { S/PV.1437 } \\
\text { (1437th) }\end{array}$ & None identified & $\begin{array}{l}\text { None } \\
\text { identified }\end{array}$ & $\begin{array}{l}\text { None } \\
\text { identified }\end{array}$ & $\begin{array}{l}\text { http: } \\
\text { //www.un. } \\
\text { org/en//ga/ } \\
\text { search/vie } \\
\text { w_doc. } \\
\text { asp? } \\
\text { spybol=S/ } \\
8579\end{array}$ & & $\begin{array}{l}\text { hitps: } \\
\text { //perma. } \\
\text { ccl/RFA- } \\
\text { LEP3 }\end{array}$ \\
\hline 65 & 1968.05.14 & 1968.05.15 & $\mathrm{s} / 8585$ & Israel & Israel, Lebanon & $\begin{array}{c}\text { Implied } \\
\text { assertion of } \\
\text { "individual" } \\
\text { self-defense }\end{array}$ & $\begin{array}{c}\text { Conducted } \\
\text { attack }\end{array}$ & $\begin{array}{l}\text { Lebanon, } \\
\text { Fedayeen, and } \\
\text { "terrorist } \\
\text { organizations" }\end{array}$ & $\begin{array}{c}\text { State and } \\
\text { non-State } \\
\text { actors }\end{array}$ & $\begin{array}{l}\text { Violation of the cease-fire, including } \\
\text { by way of mortar attack from the } \\
\text { direction of a Lebanese village. }\end{array}$ & $\begin{array}{l}\text { S/PV. } 1460 \\
\text { (1460th) }\end{array}$ & None identified & $\begin{array}{l}\text { None } \\
\text { identified }\end{array}$ & $\begin{array}{l}\text { None } \\
\text { identified }\end{array}$ & $\begin{array}{l}\text { http: } \\
\text { //www.un. } \\
\text { org/en/ga/ } \\
\text { search/vie } \\
\text { w_doc. } \\
\text { ass? } \\
\text { symbol=s/ } \\
8585\end{array}$ & & $\begin{array}{l}\text { hitps: } \\
\text { //perma. } \\
\text { cc/6rCFs- } \\
\text { Fsus }\end{array}$ \\
\hline 66 & 1968.06.04 & 1968.06.04 & $\mathrm{s} / 8614$ & Israel & Israel, Jordan & $\begin{array}{l}\text { Implied } \\
\text { assertion of } \\
\text { "individual" } \\
\text { self-defense }\end{array}$ & $\begin{array}{c}\text { Conducted } \\
\text { attack }\end{array}$ & Jordan & State & $\begin{array}{l}\text { Violations of the cease-fire, by way of } \\
\text { artillery barrage mainly in the vicinity } \\
\text { of a police station and on Israeli } \\
\text { villages. }\end{array}$ & $\begin{array}{l}\text { S/PV.1434 } \\
\text { (1434th) }\end{array}$ & \begin{tabular}{|l} 
S/RES/256(1968), OP 1: \\
"Reaffirms its resolution 248 \\
(1968) which, inter alia, \\
declares that grave violations \\
of the cease-fire cannot be \\
tolerated and that the Council \\
would have to consider further \\
and more effective steps as \\
envisaged in the Charter to \\
ensure against repetition of \\
such acts" (adopted \\
unanimously)
\end{tabular} & $\begin{array}{l}\text { None } \\
\text { identified }\end{array}$ & $\begin{array}{l}\text { Chapter VIII } \\
\text { (no } \\
\text { particular } \\
\text { article) }\end{array}$ & $\begin{array}{l}\text { http: } \\
\text { //www.un. } \\
\text { org/en/ga/ } \\
\text { search/vie } \\
\text { w_doc. } \\
\text { asp? } \\
\text { symbol=s/ } \\
8614\end{array}$ & & $\begin{array}{l}\text { hitps: } \\
\text { //perma. } \\
\text { cc/9867- } \\
\text { s4uw }\end{array}$ \\
\hline 67 & 1968.06.15 & 1968.05.15 & $\mathrm{s} / 8637$ & Israel & Israel, Lebanon & $\begin{array}{c}\text { Implied } \\
\text { assertion of } \\
\text { "individual" } \\
\text { self-defense }\end{array}$ & $\begin{array}{c}\text { Conducted } \\
\text { attack }\end{array}$ & Lebanon & State & $\begin{array}{l}\text { "[G]rave breach" of the cease-fire, by } \\
\text { way of mortar fire from Lebanese } \\
\text { territory on an Israeli village. }\end{array}$ & $\begin{array}{l}\text { S/PV.1460 } \\
\text { (1460th) }\end{array}$ & None identified & $\begin{array}{l}\text { None } \\
\text { identified }\end{array}$ & $\begin{array}{l}\text { None } \\
\text { identified }\end{array}$ & $\begin{array}{l}\text { http: } \\
\text { /twww.un. } \\
\text { org/en/ga/ } \\
\text { search/vie } \\
\text { w_doc. } \\
\text { asp? } \\
\text { symbol=S/ } \\
8637\end{array}$ & & $\begin{array}{l}\text { hitps: } \\
\text { //perma. } \\
\text { cc/N262- } \\
\text { 8uam }\end{array}$ \\
\hline 68 & 1968.06.21 & 1968.06.21 & $s / 8649$ & Jordan & Jordan, Israel & $\begin{array}{l}\text { Implied } \\
\text { assertion of } \\
\text { "individual" } \\
\text { self-defense }\end{array}$ & $\begin{array}{c}\text { Conducted } \\
\text { attack }\end{array}$ & Israel & State & $\begin{array}{l}\text { Violation of the cease-fire resolution, } \\
\text { by way of attacks on the East Bank of } \\
\text { the Jordan River, including against } \\
\text { farmers. }\end{array}$ & $\begin{array}{l}\text { S/PV.1437 } \\
(1437 \text { th) }\end{array}$ & None identified & $\begin{array}{l}\text { None } \\
\text { identified }\end{array}$ & $\begin{array}{l}\text { None } \\
\text { identified }\end{array}$ & $\begin{array}{l}\text { http: } \\
\text { //www.un. } \\
\text { org/en/ga/ } \\
\text { search/vie } \\
\text { w_doc. } \\
\text { asp? } \\
\text { symbol=S/ } \\
8649 \\
\end{array}$ & & $\begin{array}{l}\text { hitps: } \\
\text { //perma. } \\
\text { cc/l/18RC- } \\
\text { 72F6 }\end{array}$ \\
\hline 69 & 1968.06 .24 & 1968.06.24 & $\mathrm{s} / 8651$ & Israel & Israel, Jordan & $\begin{array}{l}\text { Implied } \\
\text { assertion of } \\
\text { "individual" } \\
\text { self-defense }\end{array}$ & $\begin{array}{c}\text { Conducted } \\
\text { attack }\end{array}$ & $\begin{array}{l}\text { Jordan and "El } \\
\text { Fatah units" }\end{array}$ & $\begin{array}{c}\text { State and } \\
\text { non-state } \\
\text { actors }\end{array}$ & $\begin{array}{l}\text { Deterioration of the cease-fire by way } \\
\text { of repeated violations of the cease- } \\
\text { fire by Jordanian force, including } \\
\text { through shelling of a settlement from } \\
\text { the East Bank of the Jordan River; } \\
\text { mortar attacks by El Fatah units } \\
\text { supported by Jordanian forces. }\end{array}$ & $\begin{array}{l}\text { S/PV. } 1434 \\
(1434 \text { th); } \\
\text { S/PVV.1437 } \\
\text { (1437th) }\end{array}$ & None identified & $\begin{array}{l}\text { None } \\
\text { identified }\end{array}$ & $\begin{array}{l}\text { None } \\
\text { identified }\end{array}$ & $\begin{array}{l}\text { http: } \\
\text { //www.un. } \\
\text { org/en//ga/ } \\
\text { search/vie } \\
\text { w_doc. } \\
\text { asp? } \\
\text { spybol=S/ } \\
8651\end{array}$ & & $\begin{array}{l}\text { hitps: } \\
\text { //perma. } \\
\text { ccl/DNAC- } \\
\text { 3LCC }\end{array}$ \\
\hline 70 & 1968.07.01 & 1968.07.01 & $\mathrm{s} / 8663$ & Israel & Israel, Jordan & $\begin{array}{l}\text { Implied } \\
\text { assertion of } \\
\text { "individual" } \\
\text { self-defense }\end{array}$ & $\begin{array}{c}\text { Conducted } \\
\text { attack }\end{array}$ & Jordan & State & $\begin{array}{l}\text { Violation of the cease-fire, by way of } \\
\text { artillery attack on Israeli villages. }\end{array}$ & $\begin{array}{l}\text { None } \\
\text { identified }\end{array}$ & None identified & $\begin{array}{l}\text { None } \\
\text { identified }\end{array}$ & $\begin{array}{l}\text { None } \\
\text { identified }\end{array}$ & 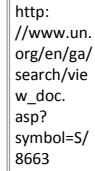 & & $\begin{array}{l}\text { hitps: } \\
\text { //perma. } \\
\text { ccl/8738- } \\
\text { 7H50 }\end{array}$ \\
\hline
\end{tabular}


VI. HLS PILAC Catalogue of Apparent “Article 51 Communications”

\begin{tabular}{|c|c|c|c|c|c|c|c|c|c|c|c|c|c|c|c|c|c|}
\hline $\begin{array}{l}\text { Chron. } \\
\text { Order }\end{array}$ & $\begin{array}{l}\text { Date of } \\
\text { Comm. }\end{array}$ & $\begin{array}{l}\text { Date of } \\
\text { UNsC } \\
\text { Document }\end{array}$ & UNSC Symbol & \begin{tabular}{||c} 
Member \\
State(s) That \\
Submitted \\
the Comm.
\end{tabular} & \begin{tabular}{|c} 
Expressly \\
Mentioned UN \\
Members (\& \\
Colonial \\
Holdings \& \\
Protectorates, \\
if any)
\end{tabular} & \begin{tabular}{||c|} 
Express or \\
Implied \\
Assertion of \\
Individual, \\
Collective, or \\
Both Self- \\
defense \\
\end{tabular} & \begin{tabular}{|l} 
Nature of \\
the Alleged \\
Threat
\end{tabular} & $\begin{array}{l}\text { Expressly Alleged } \\
\text { Author(s) of the } \\
\text { Threat (If Any } \\
\text { Indicated) }\end{array}$ & \begin{tabular}{|c} 
Nature of the \\
Alleged \\
Author(s) of \\
the Threat (If \\
Any \\
Indicated)
\end{tabular} & $\begin{array}{l}\text { Summary of Alleged Self-defense } \\
\text { Grounds }\end{array}$ & $\begin{array}{l}\text { UNsC } \\
\text { Meeting(s) } \\
\text { (If Any) at } \\
\text { Which the } \\
\text { Comm. was } \\
\text { Raised }\end{array}$ & $\begin{array}{l}\text { Responsive Act (If Any) by the } \\
\text { UNSC }\end{array}$ & \begin{tabular}{||c} 
UN \\
Repertory \\
Inclusion?
\end{tabular} & \begin{tabular}{|c} 
UNSC \\
Repertoire \\
Inclusion?
\end{tabular} & \begin{tabular}{|c||} 
URL to an \\
English \\
Text
\end{tabular} & \begin{tabular}{||c||} 
URL to Non- \\
English \\
Original \\
Text (ff Any)
\end{tabular} & $\begin{array}{l}\text { Perma.cc } \\
\text { URL }\end{array}$ \\
\hline 71 & 1968.07.16 & 1968.07.16 & s/8681 & Israel & $\begin{array}{l}\text { Israel, United } \\
\text { Arab Republic } \\
\text { [Egypt] }\end{array}$ & $\begin{array}{c}\text { Implied } \\
\text { assertion of } \\
\text { "individual" } \\
\text { self-defense }\end{array}$ & $\begin{array}{c}\text { Conducted } \\
\text { attack }\end{array}$ & $\begin{array}{l}\text { United Arab } \\
\text { Republic [Egypt] }\end{array}$ & State & $\begin{array}{l}\text { Violation of the cease-fire by Egypt's } \\
\text { "policy of belligerency and its acts of } \\
\text { warfare against Israel" that include } \\
\text { opening fire from artillery positions } \\
\text { established in residential areas. }\end{array}$ & $\begin{array}{l}\text { None } \\
\text { identified }\end{array}$ & None identified & $\begin{array}{l}\text { None } \\
\text { identified }\end{array}$ & \begin{tabular}{|l} 
None \\
identified
\end{tabular} & \begin{tabular}{|l||} 
http: \\
h/www.un. \\
org//nn/ga/ \\
search/vie \\
w_doc. \\
aspp? \\
symbol=s/ \\
8681 \\
\end{tabular} & & \begin{tabular}{|l} 
hitps: \\
//perma. \\
cc $/ 398 D-$ \\
uGTV
\end{tabular} \\
\hline 72 & 1968.08.26 & 1968.08.26 & S/8773 & Jordan & Jordan, Israel & $\begin{array}{l}\text { Implied } \\
\text { assertion of } \\
\text { "individual" } \\
\text { self-defense }\end{array}$ & $\begin{array}{c}\text { Conducted } \\
\text { attack }\end{array}$ & Israel & State & $\begin{array}{l}\text { Lack of compliance with Security } \\
\text { Council resolutions, including by way } \\
\text { of series of attacks against Jordan, } \\
\text { violation of ofdan airspace, and } \\
\text { threats in the form of leaflets or in the } \\
\text { form of direct attacks against civilians. }\end{array}$ & $\begin{array}{l}\text { S/PV.1447 } \\
(1447 \text { th) }\end{array}$ & None identified & $\begin{array}{l}\text { None } \\
\text { identified }\end{array}$ & \begin{tabular}{|l} 
None \\
identified
\end{tabular} & \begin{tabular}{|l||} 
http: \\
//www.un. \\
org/en/ga/ \\
search/vie \\
w_doc. \\
asp? \\
symbol=s/ \\
8773
\end{tabular} & & $\begin{array}{l}\text { https: } \\
\text { //perma. } \\
\text { cc//9E22- } \\
\text { sv8E }\end{array}$ \\
\hline 73 & 1968.09.08 & 1968.09.08 & $\mathrm{s} / 8805$ & Israel & \begin{tabular}{|l} 
Israel, United \\
Arab Republic \\
[Egypt]
\end{tabular} & $\begin{array}{l}\text { Implied } \\
\text { assertion of } \\
\text { "individual" } \\
\text { self-defense }\end{array}$ & $\begin{array}{c}\text { Conducted } \\
\text { attack }\end{array}$ & $\begin{array}{l}\text { United Arab } \\
\text { Republic [Egypt] }\end{array}$ & State & $\begin{array}{l}\text { Violation of the cease-fire, including } \\
\text { by way of firing on Israeli field } \\
\text { engineers and Israeli forces and } \\
\text { through shelling along the Canal } \\
\text { sector. }\end{array}$ & $\begin{array}{l}\text { S/PV.1448 } \\
\text { (1448th); } \\
\text { //PV.11449 } \\
\text { (1449th); } \\
\text { S/PV.1451 } \\
\text { (1451st); } \\
\text { //PV.1452 } \\
\text { (1452nd); } \\
\text { S/PV.1456 } \\
\text { (1456th) }\end{array}$ & $\begin{array}{l}\text { S/RES/258(1968), OPs 1-2: "1. } \\
\text { Insists that the cease-fire } \\
\text { ordered by the Security } \\
\text { Council in its resolutions must } \\
\text { be rigorously respected; } \\
\text { 2. Reaffirms its resolution } 242 \\
\text { (1967) of } 22 \text { November 1967, } \\
\text { and urges all the parties to } \\
\text { extend their fullest co- } \\
\text { operation to the Special } \\
\text { Representative of the } \\
\text { Secretary-General in the } \\
\text { speedd fulfilment of the } \\
\text { mandate entrusted to him } \\
\text { under that resolution." (14-0- } \\
\text { 1) }\end{array}$ & $\begin{array}{l}\text { Articles } 24, \\
25,30,31, \& \\
35\end{array}$ & \begin{tabular}{|l|} 
Rule 9; \\
Chapter VIII \\
(no \\
particular \\
article)
\end{tabular} & \begin{tabular}{|l||} 
http: \\
//www.unn. \\
org/el/gn/ga/ \\
search/vie \\
w_doc. \\
asp? \\
spmbol=s/ \\
8805
\end{tabular} & & $\begin{array}{l}\text { https: } \\
/ / \text { perma. } \\
\text { cc/265j- } \\
\text { FWPS }\end{array}$ \\
\hline 74 & 1968.09.17 & 1968.09.17 & $\mathrm{S} / 8818$ & Israel & Israel, Jordan & $\begin{array}{c}\text { Implied } \\
\text { assertion of } \\
\text { "individual" } \\
\text { self-defense }\end{array}$ & $\begin{array}{c}\text { Conducted } \\
\text { attack }\end{array}$ & Jordan & State & $\begin{array}{l}\text { Repeated and "grave" violations of } \\
\text { the cease-fire as well as of UNSC } \\
\text { resolutions, by way of military attacks } \\
\text { from Jordanian territory, including } \\
\text { firing on Israeli forces. }\end{array}$ & $\begin{array}{l}\text { None } \\
\text { identified }\end{array}$ & None identified & $\begin{array}{l}\text { None } \\
\text { identified }\end{array}$ & \begin{tabular}{|l} 
None \\
identified
\end{tabular} & \begin{tabular}{|l|} 
http: \\
//www.un. \\
org///nngal \\
search/vie \\
w_doc. \\
asp? \\
symbol=s/ \\
sym18 \\
\end{tabular} & & 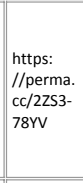 \\
\hline 75 & 1968.10.15 & 1968.10.15 & $\mathrm{S} / 8856$ & Jordan & Jordan, Israel & $\begin{array}{l}\text { Implied } \\
\text { assertion of } \\
\text { "individual" } \\
\text { self-defense }\end{array}$ & $\begin{array}{c}\text { Conducted } \\
\text { attack }\end{array}$ & Israel & State & $\begin{array}{l}\text { Violations of the cease-fire resolution, } \\
\text { by way of attacks directed against } \\
\text { Jordanian villages and farms. }\end{array}$ & \begin{tabular}{|l} 
None \\
identified
\end{tabular} & None identified & $\begin{array}{l}\text { None } \\
\text { identified }\end{array}$ & \begin{tabular}{|l} 
None \\
identified
\end{tabular} & \begin{tabular}{|l||} 
http: \\
//www.un. \\
orge//gn/gal \\
search/vie \\
w_doc. \\
asp? \\
spmbol=s/ \\
s8mb \\
\end{tabular} & & $\begin{array}{l}\text { hitps: } \\
\text { //perma. } \\
\text { cc//4WRC. } \\
\text { aUR3 }\end{array}$ \\
\hline 76 & 1968.10.23 & 1968.10.23 & $s / 8865$ & Israel & Israel, Jordan & \begin{tabular}{|c} 
Implied \\
assertion of \\
"individual" \\
self-defense
\end{tabular} & $\begin{array}{c}\text { Conducted } \\
\text { attack }\end{array}$ & $\begin{array}{l}\text { Jordan and "terror } \\
\text { warfare } \\
\text { organizations" }\end{array}$ & $\begin{array}{l}\text { State and } \\
\text { non-state } \\
\text { actors }\end{array}$ & $\begin{array}{l}\text { Violations of the cease-fire, with, inter } \\
\text { alia, Jordanian forces "firing from } \\
\text { Jordan territory on Israel villages and } \\
\text { citizens and by crossing the cease-fire } \\
\text { line on sabotage missions from their } \\
\text { bases in Jordan"; other acts also } \\
\text { carried out by "terror warfare } \\
\text { organizations which enjoy a semi- } \\
\text { official status in Jordan and which } \\
\text { publicly claim responsibility for a long } \\
\text { list of attacks on Israel from Jordan } \\
\text { territory." }\end{array}$ & \begin{tabular}{|l} 
None \\
identified
\end{tabular} & None identified & $\begin{array}{l}\text { None } \\
\text { identified }\end{array}$ & \begin{tabular}{|l} 
None \\
identified
\end{tabular} & \begin{tabular}{|l||} 
http: \\
//www.un. \\
org///nngal \\
search/vie \\
w_doc. \\
asp? \\
symbol=s/ \\
s865
\end{tabular} & & 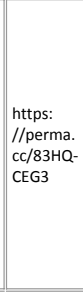 \\
\hline
\end{tabular}


VI. HLS PILAC Catalogue of Apparent “Article 51 Communications”

\begin{tabular}{|c|c|c|c|c|c|c|c|c|c|c|c|c|c|c|c|c|c|}
\hline $\begin{array}{c}\text { Chron. } \\
\text { Order }\end{array}$ & $\begin{array}{l}\text { Date of } \\
\text { Comm. }\end{array}$ & $\begin{array}{l}\text { Date of } \\
\text { UNsc } \\
\text { Document }\end{array}$ & UNSC Symbol & $\begin{array}{l}\text { Member } \\
\text { State(s) That } \\
\text { Submitted } \\
\text { the Comm. }\end{array}$ & \begin{tabular}{|c|} 
Expressly \\
Mentioned UN \\
Members (\& \\
Colonial \\
Holdings \& \\
Protectorates, \\
if any) \\
\end{tabular} & \begin{tabular}{||c|} 
Express or \\
Implied \\
Assertion of \\
Individual, \\
Collective, or \\
Both Self- \\
defense \\
\end{tabular} & \begin{tabular}{|c}
$\begin{array}{c}\text { Nature of } \\
\text { the Alleged } \\
\text { Threat }\end{array}$ \\
To
\end{tabular} & $\begin{array}{l}\text { Expressly Alleged } \\
\text { Author(s) of the } \\
\text { Threat (If Any } \\
\text { Indicated) }\end{array}$ & \begin{tabular}{|c|} 
Nature of the \\
Alleged \\
Author(s) of \\
the Threat (If \\
Any \\
Indicated)
\end{tabular} & $\begin{array}{l}\text { Summary of Alleged Self-defense } \\
\text { Grounds }\end{array}$ & \begin{tabular}{|c|} 
UNSC \\
Meeting(s) \\
(If Any) at \\
Which the \\
Comm. was \\
Raised \\
\end{tabular} & $\begin{array}{l}\text { Responsive Act (If Any) by the } \\
\text { UNSC }\end{array}$ & $\begin{array}{l}\text { UN } \\
\text { Repertory } \\
\text { Inclusion? }\end{array}$ & \begin{tabular}{|c|} 
UNSC \\
Repertoire \\
Inclusion?
\end{tabular} & \begin{tabular}{|l|} 
URL to an \\
English \\
Text
\end{tabular} & \begin{tabular}{||c} 
URL to Non- \\
English \\
Original \\
Text (ff Any)
\end{tabular} & $\begin{array}{l}\text { Perma.cc } \\
\text { URL }\end{array}$ \\
\hline 77 & 1968.12.02 & 1968.12.02 & $\mathrm{s} / 8912$ & Israel & Israel, Jordan & $\begin{array}{l}\text { Implied } \\
\text { assertion of } \\
\text { "individual" } \\
\text { self-defense }\end{array}$ & $\begin{array}{c}\text { Conducted } \\
\text { attack }\end{array}$ & \begin{tabular}{|l} 
Jordan, "terror \\
warfare \\
organizations", "Al- \\
Assif'a, the military \\
arm of El-Fatah", \\
and "a group which \\
calls stself "The \\
Popular Front for \\
the Liberation of \\
Palestine"” \\
\end{tabular} & $\begin{array}{l}\text { State and } \\
\text { non-state } \\
\text { actors }\end{array}$ & $\begin{array}{l}\text { Continuing violations of the cease-fire } \\
\text { by way of a "pact" between the } \\
\text { Jordanian government and terrorist } \\
\text { organizations operating within Jordan } \\
\text { against Israel, which has resulted in } \\
\text { attacks across the cease-fire line } \\
\text { against Irraeli forces and civilians, } \\
\text { "indiscriminate terror raids" against } \\
\text { civilians, and shelling of Israeli villages } \\
\text { and towns. }\end{array}$ & $\begin{array}{l}\text { None } \\
\text { identified }\end{array}$ & None identified & $\begin{array}{l}\text { None } \\
\text { identified }\end{array}$ & $\begin{array}{l}\text { None } \\
\text { identified }\end{array}$ & \begin{tabular}{l||} 
http: \\
|/www.un. \\
org/en/ga/ \\
search/vie \\
w_doc. \\
asp? \\
symbol=s/ \\
8912
\end{tabular} & & $\begin{array}{l}\text { hitps: } \\
\text { ///perma. } \\
\text { ccl/5S3- } \\
\text { 552H }\end{array}$ \\
\hline 78 & 1968.12.03 & 1968.12.03 & $\mathrm{S} / 8917$ & Israel & $\begin{array}{l}\text { Israel, Jordan, } \\
\text { Iraq }\end{array}$ & $\begin{array}{l}\text { Implied } \\
\text { assertion of } \\
\text { "individual" } \\
\text { self-defense }\end{array}$ & $\begin{array}{c}\text { Conducted } \\
\text { attack }\end{array}$ & Jordan, Iraq & States & $\begin{array}{l}\text { Violation of cease-fire by, inter alia, } \\
\text { Iraai forces in Jordan "launching an } \\
\text { assault on Israeli villages from } 122 \\
\mathrm{~mm} \text { guns". }\end{array}$ & $\begin{array}{l}\text { None } \\
\text { identified }\end{array}$ & None identified & $\begin{array}{l}\text { None } \\
\text { identified }\end{array}$ & $\begin{array}{l}\text { None } \\
\text { identified }\end{array}$ & \begin{tabular}{|l||} 
http: \\
//www.un. \\
org//en/ga/ \\
search/vie \\
w_doc. \\
asp? \\
symbol=s/ \\
8917 \\
\end{tabular} & & $\begin{array}{l}\text { hitps: } \\
\text { ///perma. } \\
\text { ccl/ar38- } \\
\text { sVlE }\end{array}$ \\
\hline 79 & 1968.12.04 & 1968.12.04 & $\mathrm{s} / 8919$ & Israel & $\begin{array}{l}\text { Israel, Jordan, } \\
\text { Iraq }\end{array}$ & $\begin{array}{l}\text { Implied } \\
\text { assertion of } \\
\text { "individual" } \\
\text { self-defense }\end{array}$ & $\begin{array}{c}\text { Conducted } \\
\text { attack }\end{array}$ & \begin{tabular}{|l} 
Iraai forces in \\
Jordan, "terror \\
commandos", and \\
"terror \\
organizations"
\end{tabular} & $\begin{array}{l}\text { State and } \\
\text { non-state } \\
\text { actors }\end{array}$ & $\begin{array}{l}\text { Fire from Jordanian territory on Israeli } \\
\text { workers and forces, and supporting } \\
\text { and participating (including, e.g., by } \\
\text { way or "funds, military equipment, } \\
\text { explosives, transportation and ... assist } \\
\text { lingt lhem with training and } \\
\text { intelligence information") in the } \\
\text { "terror warfare pursued against Israel } \\
\text { from Jordanian territory". }\end{array}$ & $\begin{array}{l}\text { None } \\
\text { identified }\end{array}$ & None identified & $\begin{array}{l}\text { None } \\
\text { identified }\end{array}$ & $\begin{array}{l}\text { None } \\
\text { identified }\end{array}$ & \begin{tabular}{l||} 
http: \\
//www.un. \\
org/en/ga/ \\
search/vie \\
w_doc. \\
asp? \\
symbol=s/ \\
8919
\end{tabular} & & $\begin{array}{l}\text { hitps: } \\
\text { ///perma. } \\
\text { cc/2BSV- } \\
\text { BPQ3 }\end{array}$ \\
\hline 80 & 1969.02.28 & 1969.02.28 & $s / 9033$ & Israel & $\begin{array}{l}\text { Israel, Syria, } \\
\text { Lebanon, } \\
\text { Algeria, Egypt, } \\
\text { China }\end{array}$ & $\begin{array}{l}\text { Implied } \\
\text { assertion of } \\
\text { "individual" } \\
\text { self-defense }\end{array}$ & $\begin{array}{c}\text { Conducted } \\
\text { attack }\end{array}$ & Syria and el-Fatah & $\begin{array}{c}\text { State and } \\
\text { non-state } \\
\text { actors }\end{array}$ & $\begin{array}{l}\text { "[M]arked upsurge in Arab terror } \\
\text { warfare against Israel” connected with } \\
\text { the violation by Syria of international } \\
\text { obligations and of the cease-fire } \\
\text { established by the Security Council. }\end{array}$ & $\begin{array}{l}\text { None } \\
\text { identified }\end{array}$ & None identified & $\begin{array}{l}\text { None } \\
\text { identified }\end{array}$ & $\begin{array}{l}\text { None } \\
\text { identified }\end{array}$ & \begin{tabular}{|l||} 
http: \\
//www.un. \\
orga/en/ga/ \\
search/vie \\
w_doc. \\
asp? \\
symbol=s/ \\
9033 \\
\end{tabular} & & $\begin{array}{l}\text { hitps: } \\
\text { ///perma. } \\
\text { ccl/4DP- } \\
6 \mathrm{RCN}\end{array}$ \\
\hline 81 & 1969.03.04 & 1969.03.04 & $s / 9039$ & Jordan & Jordan, Israel & $\begin{array}{l}\text { Implied } \\
\text { assertion of } \\
\text { "individual" } \\
\text { self-defense }\end{array}$ & $\begin{array}{c}\text { Conducted } \\
\text { attack }\end{array}$ & Israel & State & $\begin{array}{l}\text { Violation of the cease-fire resolution } \\
\text { and the Armistice Agreement by way } \\
\text { of, inter alia, attacks against Jordanian } \\
\text { villages and towns. }\end{array}$ & $\begin{array}{l}\text { S/PV.1466 } \\
\text { (1466th) }\end{array}$ & None identified & $\begin{array}{l}\text { Chapter VII } \\
\text { (no } \\
\text { particular } \\
\text { article) }\end{array}$ & \begin{tabular}{|l|} 
Editorial \\
note; \\
Chapter VIII \\
Maintenanc \\
e of \\
international \\
peace and \\
security \\
(letters) \\
\end{tabular} & \begin{tabular}{l||} 
http: \\
//www.un. \\
org/en/ga/ \\
search/vie \\
w_doc. \\
asp? \\
symbol=s/ \\
9039
\end{tabular} & & $\begin{array}{l}\text { hitps: } \\
\text { ///perma. } \\
\text { cc/Mgur- } \\
\text { GRYN }\end{array}$ \\
\hline 82 & 1969.03.09 & 1969.03.10 & $s / 9062$ & Israel & $\begin{array}{l}\text { Israel, United } \\
\text { Arab Republic } \\
\text { [Egypt] }\end{array}$ & $\begin{array}{l}\text { Implied } \\
\text { assertion of } \\
\text { "individual" } \\
\text { self-defense }\end{array}$ & $\begin{array}{c}\text { Conducted } \\
\text { attack }\end{array}$ & $\begin{array}{l}\text { United Arab } \\
\text { Republic [Egypt] }\end{array}$ & State & $\begin{array}{l}\text { "GG]rave" violation of the cease-fire by } \\
\text { way of, inter alia, "large-scale } \\
\text { aggressive armed attack by the United } \\
\text { Arab Republic [Egypt] forces against } \\
\text { lsraeli forces". }\end{array}$ & $\begin{array}{l}\text { None } \\
\text { identified }\end{array}$ & None identified & $\begin{array}{l}\text { None } \\
\text { identified }\end{array}$ & $\begin{array}{l}\text { None } \\
\text { identified }\end{array}$ & \begin{tabular}{|l||} 
http: \\
//www.un. \\
org//en/ga/ \\
search/vie \\
w_doc. \\
asp? \\
symbol=s/ \\
9062
\end{tabular} & & $\begin{array}{l}\text { hitps: } \\
\text { ///perma. } \\
\text { cc/NRKK4- } \\
\text { Aax3 }\end{array}$ \\
\hline 83 & 1969.03.10 & 1969.03.10 & $s / 9065$ & Israel & Israel, Jordan & $\begin{array}{l}\text { Implied } \\
\text { assertion of } \\
\text { "individual" } \\
\text { self-defense }\end{array}$ & $\begin{array}{c}\text { Conducted } \\
\text { attack }\end{array}$ & \begin{tabular}{|l} 
Jordan, "irregular \\
forces", and \\
"armed bands, \\
terrorists and \\
saboteurs"
\end{tabular} & $\begin{array}{c}\text { State and } \\
\text { non-state } \\
\text { actors }\end{array}$ & $\begin{array}{l}\text { "DD]liberate armed breaches" of the } \\
\text { cease-fire, including by way of } \\
\text { "numerous attacks ... launched from } \\
\text { Jordan, by regular and irregular forces, } \\
\text { in the form of bombardment and } \\
\text { firing at the territory of Israel and its } \\
\text { population, armed incursions and } \\
\text { laying of mines and explosive } \\
\text { charges." }\end{array}$ & $\begin{array}{l}\text { None } \\
\text { identified }\end{array}$ & None identified & $\begin{array}{l}\text { None } \\
\text { identified }\end{array}$ & $\begin{array}{l}\text { None } \\
\text { identified }\end{array}$ & \begin{tabular}{l||} 
http: \\
//www.un. \\
org/en/ga/ \\
search/vie \\
w_doc. \\
asp? \\
symbol=s/ \\
9065
\end{tabular} & & $\begin{array}{l}\text { hitps: } \\
\text { ///perma. } \\
\text { cc/ZV3R- } \\
\text { RULD }\end{array}$ \\
\hline
\end{tabular}


VI. HLS PILAC Catalogue of Apparent "Article 51 Communications"

\begin{tabular}{|c|c|c|c|c|c|c|c|c|c|c|c|c|c|c|c|c|c|}
\hline $\begin{array}{c}\text { Chron. } \\
\text { Order }\end{array}$ & $\begin{array}{l}\text { Date of } \\
\text { Comm. }\end{array}$ & $\begin{array}{c}\text { Date of } \\
\text { UNsc } \\
\text { Document }\end{array}$ & UNSC Symbol & \begin{tabular}{|c} 
Member \\
State(s) That \\
Submitted \\
the Comm.
\end{tabular} & \begin{tabular}{||c||} 
Expressly \\
Mentioned UN \\
Members (\& \\
Colonial \\
Holdings \& \\
Protectorates, \\
if any) \\
\end{tabular} & \begin{tabular}{|c|} 
Express or \\
Implied \\
Assertion of \\
Individual, \\
Collective, or \\
Both Self- \\
defense \\
\end{tabular} & $\begin{array}{c}\text { Nature of } \\
\text { the Alleged } \\
\text { Threat }\end{array}$ & \begin{tabular}{|l} 
Expressly Alleged \\
Author(s) of the \\
Threat (If Any \\
Indicated)
\end{tabular} & \begin{tabular}{|l|} 
Nature of the \\
Alleged \\
Author(s) of \\
the Threat (If \\
Any \\
Indicated)
\end{tabular} & $\begin{array}{l}\text { Summary of Alleged Self-defense } \\
\text { Grounds }\end{array}$ & \begin{tabular}{|l} 
UNsc \\
Meeting(s) \\
(If Any) at \\
Which the \\
Comm. was \\
Raised
\end{tabular} & $\begin{array}{l}\text { Responsive Act (If Any) by the } \\
\text { UNSC }\end{array}$ & $\begin{array}{l}\text { UN } \\
\text { Repertory } \\
\text { Inclusion? }\end{array}$ & \begin{tabular}{|c|} 
UNSC \\
Repertoire \\
Inclusion?
\end{tabular} & \begin{tabular}{|c||} 
URL to an \\
English \\
Text
\end{tabular} & \begin{tabular}{||c||} 
URL to Non- \\
English \\
Original \\
Text (ff Any)
\end{tabular} & $\begin{array}{l}\text { Perma.cc } \\
\text { URL }\end{array}$ \\
\hline 84 & 1969.03.11 & 1969.03.11 & $s / 9071$ & Israel & \begin{tabular}{|c} 
Israel, United \\
Arab Republic \\
[Egypt]
\end{tabular} & \begin{tabular}{|c} 
Implied \\
assertion of \\
"individual" \\
self-defense
\end{tabular} & $\begin{array}{c}\text { Conducted } \\
\text { attack }\end{array}$ & $\begin{array}{l}\text { United Arab } \\
\text { Republic [Egypt] }\end{array}$ & State & $\begin{array}{l}\text { "G]rave breaches" of the cease-fire, } \\
\text { including firing on Israeli forces. }\end{array}$ & $\begin{array}{l}\text { None } \\
\text { identified }\end{array}$ & None identified & $\begin{array}{l}\text { None } \\
\text { identified }\end{array}$ & $\begin{array}{l}\text { None } \\
\text { identified }\end{array}$ & \begin{tabular}{|l||} 
http: \\
h/www.un. \\
org//nn/ga/ \\
search/vie \\
w_doc. \\
asp? \\
symbol=s/ \\
9071
\end{tabular} & & $\begin{array}{l}\text { https: } \\
\text { //perma. } \\
\text { cc/44MR- } \\
\text { SHEW }\end{array}$ \\
\hline 85 & 1969.03.17 & 1969.03.17 & s/9089 & Israel & Israel, Jordan & \begin{tabular}{|c|} 
Implied \\
assertion of \\
"individual" \\
self-defense
\end{tabular} & $\begin{array}{c}\text { Conducted } \\
\text { attack }\end{array}$ & \begin{tabular}{|l} 
Jordan and "terror \\
organizations"
\end{tabular} & $\begin{array}{c}\text { State and } \\
\text { non-state } \\
\text { actors }\end{array}$ & $\begin{array}{l}\text { Violation of the cease-fire, including } \\
\text { by way of "armed attacks against } \\
\text { Israel by regular and irregular forces } \\
\text { from Jordan ... These murrderous } \\
\text { attacks, and in particular the acts of } \\
\text { violence carried out indiscriminately } \\
\text { by terroror organizaztions against the } \\
\text { civilian population have continued } \\
\text { unabated." }\end{array}$ & $\begin{array}{l}\text { None } \\
\text { identified }\end{array}$ & $\begin{array}{l}\text { S/RES/265(1969), OP 3: } \\
\text { "Condemns the recent } \\
\text { premeditated air attacks } \\
\text { launched by Israel on } \\
\text { Jordanian villages and } \\
\text { populated areas in flagrant } \\
\text { violation of the United Nations } \\
\text { Charter and the cease-fire } \\
\text { resolutions, and warns once } \\
\text { again that if such attacks were } \\
\text { to be repeated the Security } \\
\text { Council would have to meet to } \\
\text { consider further and more } \\
\text { effective steps as envisaged in } \\
\text { the Charter to ensure against } \\
\text { repetition of such attacks." } \\
\text { (11-0-4) }\end{array}$ & $\begin{array}{l}\text { None } \\
\text { identified }\end{array}$ & \begin{tabular}{|l} 
Chapter VIII \\
(no \\
particular \\
article)
\end{tabular} & \begin{tabular}{l|l||} 
http: \\
h/www.un. \\
org//nn/gal \\
search/vie \\
w_doc. \\
asp? \\
symbol=s/ \\
9089
\end{tabular} & & $\begin{array}{l}\text { https: } \\
\text { //perma. } \\
\text { cc/M2Y5- } \\
\text { A8VD }\end{array}$ \\
\hline 86 & 1969.03.24 & 1969.03.24 & s/9106 & Israel & \begin{tabular}{|l} 
Israel, United \\
Arab Republic \\
[Egypt]
\end{tabular} & \begin{tabular}{|c|} 
Implied \\
assertion of \\
"individual" \\
self-defense
\end{tabular} & $\begin{array}{c}\text { Conducted } \\
\text { attack }\end{array}$ & $\begin{array}{l}\text { United Arab } \\
\text { Republic [Egypt] }\end{array}$ & State & $\begin{array}{l}\text { Inter alia, "artillery fire was opened by } \\
\text { the UAR forces across the Canal on } \\
\text { Israeli forces at several points in the } \\
\text { section between the Bitter Lake and } \\
\text { Port Taufiq." }\end{array}$ & $\begin{array}{l}\text { None } \\
\text { identified }\end{array}$ & None identified & \begin{tabular}{|l} 
None \\
identified
\end{tabular} & $\begin{array}{l}\text { None } \\
\text { identified }\end{array}$ & \begin{tabular}{|l|l|} 
http: \\
//www.un. \\
org/en/ga/ \\
search/vie \\
w_doc. \\
asp? \\
symbol=s/ \\
9106
\end{tabular} & & $\begin{array}{l}\text { https: } \\
\text { //perma. } \\
\text { cc/9P4E- } \\
\text { 5LUD }\end{array}$ \\
\hline 87 & 1969.03.25 & 1969.03.26 & $s / 9111$ & Syria & $\begin{array}{c}\text { Syria, Israel, } \\
\text { Egypt, Jordan, } \\
\text { Iraq }\end{array}$ & \begin{tabular}{|c|}
\multicolumn{1}{|c|}{ Implied } \\
assertion of \\
"individual" a \\
nd implied \\
assertio of \\
"collective" \\
self-defense
\end{tabular} & $\begin{array}{c}\text { Conducted } \\
\text { attack, } \\
\text { threat of } \\
\text { attack, and } \\
\text { imminent } \\
\text { attack }\end{array}$ & Israel & State & \begin{tabular}{|l} 
Inter alia, "Israeli imminent danger \\
threatening the very existencec" of \\
Arab states and their peoples as well \\
as "a continued, ruthless occupation \\
and the threat of further Israeli \\
expansion," by way of "premeditated \\
aggressive attacks against Arab \\
contries, irrespective of whether the \\
objectives are civilian or military."
\end{tabular} & $\begin{array}{l}\text { None } \\
\text { identified }\end{array}$ & None identified & \begin{tabular}{|l} 
None \\
identified
\end{tabular} & \begin{tabular}{|l} 
None \\
identified
\end{tabular} & \begin{tabular}{|l||} 
http: \\
I/www.un. \\
org//nn/ga/ \\
search/vie \\
w_doc. \\
asp? \\
symbol=s/ \\
9111
\end{tabular} & & $\begin{array}{l}\text { https: } \\
\text { //perma. } \\
\text { cc/AMR3- } \\
\text { RFUC }\end{array}$ \\
\hline 88 & 1969.03.27 & 1969.03.27 & S/PV.1466 & Israel & $\begin{array}{l}\text { Israel, Jordan, } \\
\text { Egypt, Syria, } \\
\text { Iraq }\end{array}$ & \begin{tabular}{|c|} 
Implied \\
assertion of \\
"individual" \\
self-defense
\end{tabular} & $\begin{array}{c}\text { Conducted } \\
\text { attack }\end{array}$ & El-Fatah & $\begin{array}{c}\text { Non-state } \\
\text { actors }\end{array}$ & $\begin{array}{l}\text { "The most serious incidents which } \\
\text { occurred in the period under survey } \\
\text { were the terror activities carried out } \\
\text { by raiders inside populated centres." }\end{array}$ & $\begin{array}{l}\text { S/PV.1466 } \\
\text { (1466th) }\end{array}$ & \begin{tabular}{|l} 
S/RES/265(1969), OP 3: \\
"Condemns the recent \\
premeditated air attacks \\
launched by Israel on \\
Jordanian villages and \\
populated areas in flagrant \\
violation of the United Nations \\
Charter and the eease-fire \\
resolutions, and warns once \\
again that if such attacks were \\
to be repeated the Security \\
Council would have to meet to \\
consider further and more \\
effective steps as envisaged in \\
the Charter to ensure against \\
repetition of such attacks." \\
(11-0-4)
\end{tabular} & $\begin{array}{l}\text { Chapter V; } \\
\text { Chapter VI; } \\
\text { Articles 2(4), } \\
\text { 12, and 33 }\end{array}$ & $\begin{array}{l}\text { Part III } \\
\text { Adoption of } \\
\text { the rule of } \\
\text { the agenda } \\
\text { (rule 9); } \\
\text { Article 35(1); } \\
\text { Chapter XII; } \\
\text { Chapter VI:; } \\
\text { Chapter VIII }\end{array}$ & 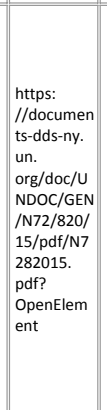 & & $\begin{array}{l}\text { https: } \\
\text { //perma. } \\
\text { cc/T2QK- } \\
\text { JYN6 }\end{array}$ \\
\hline
\end{tabular}


VI. HLS PILAC Catalogue of Apparent “Article 51 Communications”

\begin{tabular}{|c|c|c|c|c|c|c|c|c|c|c|c|c|c|c|c|c|c|}
\hline $\begin{array}{l}\text { Chron. } \\
\text { Order }\end{array}$ & $\begin{array}{l}\text { Date of } \\
\text { comm. }\end{array}$ & $\begin{array}{c}\text { Date of } \\
\text { UNSC } \\
\text { Document }\end{array}$ & UNSC Symbol & \begin{tabular}{||c} 
Member \\
State(s) That \\
Submitted \\
the Commm.
\end{tabular} & \begin{tabular}{||c|} 
Expressly \\
Mentioned UN \\
Members (\& \\
Colonial \\
Holdings \& \\
Protectorates, \\
if any) \\
\end{tabular} & \begin{tabular}{||c|} 
Express or \\
Implied \\
Assertion of \\
Individual, \\
Collective, or \\
Both Self- \\
defense \\
\end{tabular} & \begin{tabular}{|l} 
Nature of \\
the Alleged \\
Threat
\end{tabular} & $\begin{array}{l}\text { Expressly Alleged } \\
\text { Author(s) of the } \\
\text { Threat (If Any } \\
\text { Indicated) }\end{array}$ & \begin{tabular}{|l|} 
Nature of the \\
Alleged \\
Author(s) of \\
the Threat (If \\
Any \\
Indicated)
\end{tabular} & $\begin{array}{l}\text { Summary of Alleged Self-defense } \\
\text { Grounds }\end{array}$ & $\begin{array}{l}\text { UNsC } \\
\text { Meeting(s) } \\
\text { (If Any) at } \\
\text { Which the } \\
\text { Comm. was } \\
\text { Raised }\end{array}$ & $\begin{array}{l}\text { Responsive Act (If Any) by the } \\
\text { UNSC }\end{array}$ & \begin{tabular}{|l} 
UN \\
Repertory \\
Inclusion?
\end{tabular} & \begin{tabular}{|} 
UNSC \\
Repertioire \\
Inclusion?
\end{tabular} & \begin{tabular}{|l|} 
URL to an \\
English \\
Text
\end{tabular} & \begin{tabular}{|c||} 
URL to Non- \\
English \\
Original \\
Text (ff Any)
\end{tabular} & $\begin{array}{l}\text { Perma.cc } \\
\text { URL }\end{array}$ \\
\hline 89 & 1969.04.01 & 1969.04.01 & $\mathrm{s} / 9125$ & Iraq & $\begin{array}{l}\text { Iraq, Syria, } \\
\text { Israel }\end{array}$ & $\begin{array}{l}\text { Implied } \\
\text { assertion } \\
\text { individual and } \\
\text { collective self- } \\
\quad \text { defense }\end{array}$ & $\begin{array}{l}\text { Conducted } \\
\text { attack, } \\
\text { threat of } \\
\text { attack, and } \\
\text { indirect } \\
\text { attack }\end{array}$ & Israel & State & $\begin{array}{l}\text { Stationing of Iraqi forces in Syria } \\
\text { justified because of, inter alia, } \\
\text { occupation by Israel of "Cclonsiderable } \\
\text { parts of the territories of [] Arab } \\
\text { Statete" and "Irsaeli plans of } \\
\text { expansion" and Israeli breaches of } \\
\text { cease-fire. }\end{array}$ & $\begin{array}{l}\text { None } \\
\text { identified }\end{array}$ & None identified & $\begin{array}{l}\text { None } \\
\text { identified }\end{array}$ & $\begin{array}{l}\text { None } \\
\text { identified }\end{array}$ & \begin{tabular}{|l||} 
http: \\
|/www.un. \\
org/en/ga/ \\
search/vie \\
w_doc. \\
asp? \\
symbol=s/ \\
9125 \\
\end{tabular} & & $\begin{array}{l}\text { hitps: } \\
\text { //perma. } \\
\text { c/c29299. } \\
\text { ssa.5 }\end{array}$ \\
\hline 90 & 1969.04.08 & 1969.04.08 & S/9137 & Israel & Israel, Jordan & \begin{tabular}{|l} 
Implied \\
assertion of \\
"individual" \\
self-defense
\end{tabular} & $\begin{array}{c}\text { Conducted } \\
\text { attack }\end{array}$ & Not indicated & Not indicated & \begin{tabular}{|l} 
A "wanton and unprovoked night \\
attack against a peaceful city and its \\
civilian residents" from Jordanian \\
territory, among other ceasfire \\
violations and "aggressive acts".
\end{tabular} & $\begin{array}{l}\text { None } \\
\text { identified }\end{array}$ & None identified & $\begin{array}{l}\text { None } \\
\text { identified }\end{array}$ & $\begin{array}{l}\text { None } \\
\text { identified }\end{array}$ & \begin{tabular}{|l|} 
http: \\
//www.un. \\
org/en/ga/ \\
search/vie \\
w_doc. \\
asp? \\
symbol=s/ \\
9137 \\
\end{tabular} & & $\begin{array}{l}\text { hitps: } \\
\text { //perma. } \\
\text { cl/EGHS- } \\
\text { JEEE }\end{array}$ \\
\hline 91 & 1969.04.14 & 1969.04.14 & s/9157 & \begin{tabular}{|l} 
United Arab \\
Republic \\
[Egypt]
\end{tabular} & \begin{tabular}{||l} 
United Arab \\
Republic \\
[Egypt], Israel
\end{tabular} & $\begin{array}{l}\text { Implied } \\
\text { assertion of } \\
\text { "individual" } \\
\text { self-defense }\end{array}$ & $\begin{array}{c}\text { Conducted } \\
\text { attack }\end{array}$ & Israel & State & \begin{tabular}{|l} 
Repeated violations of cease-fire and \\
lengthy military engagement \\
(including Israeli jets attempting to \\
penetrate United Arab Republic \\
[Egptt airspace and artillery and tank \\
firel, which evidence Israel's \\
"calculated attempts to sow havoc \\
and disseminate destruction in the \\
area."
\end{tabular} & $\begin{array}{l}\text { None } \\
\text { identified }\end{array}$ & None identified & $\begin{array}{l}\text { None } \\
\text { identified }\end{array}$ & $\begin{array}{l}\text { None } \\
\text { identified }\end{array}$ & \begin{tabular}{|l||} 
http: \\
|/www.un. \\
org/en/ga/ \\
search/vie \\
w_doc. \\
asp? \\
symbol=s/ \\
9157
\end{tabular} & & $\begin{array}{l}\text { hittps: } \\
\text { //perma. } \\
\text { c/c22C2. } \\
\text { AlH4 }\end{array}$ \\
\hline 92 & 1969.05.01 & 1969.05.01 & $\mathrm{s} / 9189$ & \begin{tabular}{|l} 
United Arab \\
Republic \\
[Egypt]
\end{tabular} & \begin{tabular}{||l} 
United Arab \\
Republic \\
[Egypt], Israel
\end{tabular} & $\begin{array}{l}\text { Implied } \\
\text { assertion of } \\
\text { "individual" } \\
\text { self-defense }\end{array}$ & $\begin{array}{c}\text { Conducted } \\
\text { attack }\end{array}$ & Israel & State & $\begin{array}{l}\text { "CC]ontinuous Israeli violations of the } \\
\text { cease-fire" by way of, inter alia, "the } \\
\text { Israeli occupying forces open[ing] } \\
\text { intermittent fire from small arms and } \\
\text { tanks on different points along the } \\
\text { Suez Canal." }\end{array}$ & $\begin{array}{l}\text { None } \\
\text { identified }\end{array}$ & None identified & $\begin{array}{l}\text { None } \\
\text { identified }\end{array}$ & $\begin{array}{l}\text { None } \\
\text { identified }\end{array}$ & \begin{tabular}{|l|} 
http: \\
//www.un. \\
orge//ga/ \\
search/vie \\
w_doc. \\
asp? \\
symbol=s/ \\
9189
\end{tabular} & & $\begin{array}{l}\text { hittps: } \\
\text { //perma. } \\
\text { c/cPPQM- } \\
\text { HB83 }\end{array}$ \\
\hline 93 & 1969.05.07 & 1969.05.07 & $s / 9194$ & Israel & \begin{tabular}{||l} 
United Arab \\
Republic \\
[Egypt], Israel
\end{tabular} & $\begin{array}{l}\text { Implied } \\
\text { assertion of } \\
\text { "individual" } \\
\text { self-defense }\end{array}$ & $\begin{array}{c}\text { Conducted } \\
\text { attack }\end{array}$ & $\begin{array}{c}\text { United Arab } \\
\text { Republic [Egypt] }\end{array}$ & State & \begin{tabular}{|l} 
"The United Arab Republic [Egypt] \\
campaign against the cease-fire is an \\
aspect of its proclaimed doctrine of \\
offensive military actions against \\
Israel.". "Confronted with Egyptian \\
aggression [by way of, inter alia, \\
cease-fire violations], Israel is forced \\
to take measures of self-defence."
\end{tabular} & $\begin{array}{l}\text { S/PV. } 1484 \\
\text { (1484th) }\end{array}$ & None identified & $\begin{array}{l}\text { None } \\
\text { identified }\end{array}$ & $\begin{array}{l}\text { None } \\
\text { identified }\end{array}$ & \begin{tabular}{|l||} 
http: \\
//www.un. \\
org/en/ga/ \\
search/vie \\
wdoc. \\
asp? \\
symbol=s/ \\
9194
\end{tabular} & & $\begin{array}{l}\text { hitps: } \\
\text { //Perma. } \\
\text { cl/RPPP- } \\
\text { 2XLF }\end{array}$ \\
\hline 94 & 1969.05.16 & 1969.05.16 & $\mathrm{s} / 9211$ & Jordan & Jordan, Israel & $\begin{array}{l}\text { Implied } \\
\text { assertion of } \\
\text { "individual" } \\
\text { self-defense }\end{array}$ & $\begin{array}{c}\text { Conducted } \\
\text { attack }\end{array}$ & Israel & State & \begin{tabular}{|l} 
"IS]eries of Israeli attacks against \\
Jordan in direct violation of the \\
ceasefire resolution and the Armistice \\
Agreement... [See] the attached list \\
of more than eighty incidents.... \\
Israeli forces opened fire on Jordanian \\
positions near Mindassa using \\
machine-guns and mortar artillery."
\end{tabular} & $\begin{array}{l}\text { None } \\
\text { identified }\end{array}$ & None identified & $\begin{array}{l}\text { None } \\
\text { identified }\end{array}$ & $\begin{array}{l}\text { None } \\
\text { identified }\end{array}$ & \begin{tabular}{|l||} 
http: \\
//www.un. \\
org/en/ga/ \\
search/vie \\
wdoc. \\
asp? \\
symbol=s/ \\
g211 \\
\end{tabular} & & $\begin{array}{l}\text { hitps: } \\
\text { //perma. } \\
\text { c/crc744 } \\
\text { TBQw }\end{array}$ \\
\hline 95 & 1969.05.16 & 1969.05.16 & $\mathrm{s} / 9212$ & Jordan & Jordan, Israel & $\begin{array}{l}\text { Implied } \\
\text { assertion of } \\
\text { "individual" } \\
\text { self-defense }\end{array}$ & $\begin{array}{c}\text { Conducted } \\
\text { attack }\end{array}$ & Israel & State & $\begin{array}{l}\text { "Israeli systematic steps endangering } \\
\text { life and property in the occupied } \\
\text { Jordan valley," including by way of, } \\
\text { inter alia, destroying a farm and } \\
\text { school, building entrenchments, and } \\
\text { shelling Jordanian positions. }\end{array}$ & \begin{tabular}{|l} 
None \\
identified
\end{tabular} & None identified & $\begin{array}{l}\text { None } \\
\text { identified }\end{array}$ & $\begin{array}{l}\text { None } \\
\text { identified }\end{array}$ & \begin{tabular}{|l||} 
http: \\
//www.un. \\
org/en/ga/ \\
search/vie \\
w_doc. \\
asp? \\
symbol=s/ \\
9212
\end{tabular} & & $\begin{array}{l}\text { hittps: } \\
\text { //perma. } \\
\text { cl/6ruUM- } \\
\text { 26UE }\end{array}$ \\
\hline 96 & 1969.05.24 & 1969.05.25 & $\mathrm{s} / 9221$ & Israel & Israel, Jordan & $\begin{array}{l}\text { Implied } \\
\text { assertion of } \\
\text { "individual" } \\
\text { self-defense }\end{array}$ & \begin{tabular}{|c} 
Conducted \\
attack
\end{tabular} & $\begin{array}{l}\text { Jordan and "terror } \\
\text { organizations" }\end{array}$ & $\begin{array}{c}\text { State and } \\
\text { non-state } \\
\text { actors }\end{array}$ & $\begin{array}{l}\text { "[A]rmed attacks against civilians, } \\
\text { carried out from Jordan in violation of } \\
\text { the cease-fire, are continuing." "R] } \\
\text { egular and irregular forces operating } \\
\text { from Jordanian territory have, in } \\
\text { recent months, intensified their } \\
\text { attacks against ssrael. These acts of } \\
\text { aggression by shelling, armed raids } \\
\text { and sabotage, have been directed } \\
\text { primarily against civilians." }\end{array}$ & $\begin{array}{l}\text { None } \\
\text { identified }\end{array}$ & None identified & $\begin{array}{l}\text { None } \\
\text { identified }\end{array}$ & $\begin{array}{l}\text { None } \\
\text { identified }\end{array}$ & \begin{tabular}{|l||} 
http: \\
//www.un. \\
org/en/ga/ \\
search/vie \\
w_doc. \\
asp? \\
symbol=s/ \\
9221
\end{tabular} & & $\begin{array}{l}\text { hitps: } \\
\text { //Perma. } \\
\text { c/5KGG5- } \\
\text { HAJE }\end{array}$ \\
\hline
\end{tabular}


VI. HLS PILAC Catalogue of Apparent “Article 51 Communications”

\begin{tabular}{|c|c|c|c|c|c|c|c|c|c|c|c|c|c|c|c|c|c|}
\hline $\begin{array}{l}\text { Chron. } \\
\text { Order }\end{array}$ & $\begin{array}{l}\text { Date of } \\
\text { Comm. }\end{array}$ & $\begin{array}{l}\text { Date of } \\
\text { UNSC } \\
\text { Document }\end{array}$ & UNSC Symbol & \begin{tabular}{||c} 
Member \\
State(s) That \\
Submitted \\
the Comm.
\end{tabular} & \begin{tabular}{|c|} 
Expressly \\
Mentioned UN \\
Members (\& \\
Colonial \\
Holdings \& \\
Protectorates, \\
if any) \\
\end{tabular} & \begin{tabular}{|l|} 
Express or \\
Implied \\
Assertion of \\
Individual, \\
Collective, or \\
Both Self- \\
defense \\
\end{tabular} & $\begin{array}{c}\text { Nature of } \\
\text { the Alleged } \\
\text { Threat }\end{array}$ & $\begin{array}{l}\text { Expressly Alleged } \\
\text { Author(s) of the } \\
\text { Threat (If Any } \\
\text { Indicated) }\end{array}$ & \begin{tabular}{|c} 
Nature of the \\
Alleged \\
Author(s) of \\
the Threat (If \\
Any \\
Indicated)
\end{tabular} & $\begin{array}{l}\text { Summary of Alleged Self-defense } \\
\text { Grounds }\end{array}$ & $\begin{array}{l}\text { UNsC } \\
\text { Meeting(s) } \\
\text { (If Any) at } \\
\text { Which the } \\
\text { Comm. was } \\
\text { Raised }\end{array}$ & $\begin{array}{l}\text { Responsive Act (If Any) by the } \\
\text { UNSC }\end{array}$ & $\begin{array}{l}\text { UN } \\
\text { Repertory } \\
\text { Inclusion? }\end{array}$ & $\begin{array}{l}\text { UNsC } \\
\text { Repertoire } \\
\text { Inclusion? }\end{array}$ & \begin{tabular}{|l|} 
URL to an \\
English \\
Text
\end{tabular} & \begin{tabular}{||c||} 
URL to Non- \\
English \\
Original \\
Text (ff Any)
\end{tabular} & $\begin{array}{l}\text { Perma.cc } \\
\text { URL }\end{array}$ \\
\hline 97 & 1969.07.03 & 1969.07.03 & s/9314 & El Salvador & $\begin{array}{l}\text { El Salvador, } \\
\text { Honduras }\end{array}$ & $\begin{array}{l}\text { Implied } \\
\text { assertion of } \\
\text { "individual" } \\
\text { self-defense }\end{array}$ & $\begin{array}{c}\text { Conducted } \\
\text { attack }\end{array}$ & Honduras & State & $\begin{array}{l}\text { "FFlagrant aggression" of the } \\
\text { Honduran government }- \text { in order to } \\
\text { "complicate the conflict which it has } \\
\text { provoked with El Salvadador in order to } \\
\text { obstruct the investigation by the Inter- } \\
\text { American Commission on Human } \\
\text { Rights concerning the genocide which } \\
\text { is being committed against } \\
\text { Salvadorians residing in Honduran } \\
\text { territory" - by way of, inter alia, } \\
\text { armed air and ground attacks. }\end{array}$ & $\begin{array}{l}\text { None } \\
\text { identified }\end{array}$ & None identified & Article 54 & Article 54 & \begin{tabular}{|l||} 
http: \\
|/www.un. \\
org/en/ga/ \\
search/vie \\
w_doc. \\
asp? \\
symbol=s/ \\
9314
\end{tabular} & $\begin{array}{l}\text { http://www. } \\
\text { un. } \\
\text { org/en/ga/se } \\
\text { arch/view_do } \\
\text { casp? } \\
\text { symbol=s/931 } \\
\text { 4\&Lang=s }\end{array}$ & \begin{tabular}{|l} 
https: \\
///perma. \\
c//YYU7. \\
DG5Z
\end{tabular} \\
\hline 98 & 1969.07.10 & 1969.07.10 & s/9320 & Syria & \begin{tabular}{|l} 
Syria, Israel, \\
United States
\end{tabular} & $\begin{array}{l}\text { Implied } \\
\text { assertion of } \\
\text { "individual" } \\
\text { self-defense }\end{array}$ & $\begin{array}{l}\text { Conducted } \\
\text { attack }\end{array}$ & Israel & State & $\begin{array}{l}\text { Israeli premeditated air attack against } \\
\text { Syria as "part of a yet new aggressive } \\
\text { military strategy". }\end{array}$ & $\begin{array}{l}\text { None } \\
\text { identified }\end{array}$ & None identified & $\begin{array}{l}\text { None } \\
\text { identified }\end{array}$ & $\begin{array}{l}\text { None } \\
\text { identified }\end{array}$ & \begin{tabular}{|l|} 
http: \\
//www.un. \\
org/en/ga/ \\
search/vie \\
w_doc. \\
asp? \\
symbol=s/ \\
9320
\end{tabular} & & \begin{tabular}{|l} 
https: \\
//perma. \\
cc/E2GT- \\
MX2E
\end{tabular} \\
\hline 99 & 1969.07.15 & 1969.07.15 & s/9329 & Honduras & \begin{tabular}{|l} 
Honduras, El \\
Salvador, \\
Nicaragua, \\
Costa Rica, \\
Guatemala
\end{tabular} & $\begin{array}{l}\text { Implied } \\
\text { assertion of } \\
\text { "individual" } \\
\text { self-defense }\end{array}$ & $\begin{array}{c}\text { Conducted } \\
\text { attack }\end{array}$ & El Salvador & State & $\begin{array}{l}\text { "EE]vents which have disturbed the } \\
\text { peace and security in the Central } \\
\text { American region," including, inter alia, } \\
\text { air raids and ground attacks in } \\
\text { Honduras. }\end{array}$ & $\begin{array}{l}\text { None } \\
\text { identified }\end{array}$ & None identified & Article 54 & Article 54 & \begin{tabular}{|l|} 
http: \\
//www.un. \\
org//nn/ga/ \\
search/vie \\
w_doc. \\
asp? \\
symbol=s/ \\
9329
\end{tabular} & $\begin{array}{l}\text { http://www. } \\
\text { un. } \\
\text { org/en/ga/se } \\
\text { arch/view_do } \\
\text { c.asp? } \\
\text { symbol=s/932 } \\
\text { 9\&Llang=s }\end{array}$ & $\begin{array}{l}\text { https: } \\
\text { //perma. } \\
\text { cc/FMMQ- } \\
\text { GDNW }\end{array}$ \\
\hline 100 & 1969.07.15 & 1969.07.15 & s/9330 & El Salvador & $\begin{array}{l}\text { El Salvador, } \\
\text { Honduras }\end{array}$ & $\begin{array}{l}\text { Implied } \\
\text { assertion of } \\
\text { "individual" } \\
\text { self-defense }\end{array}$ & $\begin{array}{l}\text { Conducted } \\
\text { attack and } \\
\text { indirect } \\
\text { attack }\end{array}$ & Honduras & State & \begin{tabular}{|l} 
Inter alia, "Honduran troops \\
encouraged and led by agents of the \\
public authorities have, since 15 June \\
this year, been ruthlessly persecuting \\
Salvadadoian residents merely on the \\
ground of their beis nationals of El \\
Salvador.... [T]he Government of \\
Honduras resorted to indirect \\
aggression which took the form, first, \\
of public and undisguised appeals for \\
internal subversion in El Salvador and, \\
more recently, of frontier incidents \\
lasting for several days.".
\end{tabular} & $\begin{array}{l}\text { None } \\
\text { identified }\end{array}$ & None identified & Article 54 & Article 54 & \begin{tabular}{|l||} 
http: \\
//www.un. \\
org/en/ga/ \\
search/vie \\
wdoc. \\
asp? \\
symbol=s/ \\
9330
\end{tabular} & $\begin{array}{l}\text { http://www. } \\
\text { un. } \\
\text { org/en/ga/se } \\
\text { arch/view_do } \\
\text { casp? } \\
\text { symbol=s/9933 } \\
\text { o\&lang=s }\end{array}$ & \begin{tabular}{|l} 
https: \\
//perma. \\
cc/4GGX- \\
EVEZ
\end{tabular} \\
\hline 101 & 1969.07.22 & 1969.07.23 & $s / 9349$ & Israel & $\begin{array}{l}\text { Israel, United } \\
\text { Arab Republic } \\
\text { [Egypt] }\end{array}$ & $\begin{array}{l}\text { Implied } \\
\text { assertion of } \\
\text { "individual" } \\
\text { self-defense }\end{array}$ & $\begin{array}{l}\text { Conducted } \\
\text { attack }\end{array}$ & $\begin{array}{l}\text { United Arab } \\
\text { Republic [Egypt] }\end{array}$ & State & $\begin{array}{l}\text { "[D]eliberate policy of the United Arab } \\
\text { Republic [Egypt] of violating the } \\
\text { cease-fire by premeditated acts of } \\
\text { military aggression...." “[C]ontinous } \\
\text { attempts made by the United Arab } \\
\text { Republic [Egypt] armed forces to } \\
\text { implement this policy of incessant acts } \\
\text { of aggression...." }\end{array}$ & \begin{tabular}{|l} 
None \\
identified
\end{tabular} & None identified & $\begin{array}{l}\text { None } \\
\text { identified }\end{array}$ & $\begin{array}{l}\text { None } \\
\text { identified }\end{array}$ & \begin{tabular}{|l||} 
http: \\
//www.un. \\
org/en/ga/ \\
search/vie \\
w_doc. \\
asp? \\
symbol=s/ \\
9349 \\
\end{tabular} & & \begin{tabular}{|l} 
https: \\
//perma. \\
cc/339k- \\
v88M
\end{tabular} \\
\hline
\end{tabular}


VI. HLS PILAC Catalogue of Apparent “Article 51 Communications”

\begin{tabular}{|c|c|c|c|c|c|c|c|c|c|c|c|c|c|c|c|c|c|}
\hline $\begin{array}{l}\text { Chron. } \\
\text { Order }\end{array}$ & $\begin{array}{l}\text { Date of } \\
\text { Comm. }\end{array}$ & $\begin{array}{l}\text { Date of } \\
\text { UNsC } \\
\text { Document }\end{array}$ & | UNSC Symbol & \begin{tabular}{|c} 
Member \\
State(s) That \\
Submitted \\
the Comm.
\end{tabular} & \begin{tabular}{|c|} 
Expressly \\
Mentioned UN \\
Members (\& \\
Colonial \\
Holdings \& \\
Protectorates, \\
if any) \\
\end{tabular} & \begin{tabular}{|c|} 
Express or \\
Implied \\
Assertion of \\
Individual, \\
Collective, or \\
Both Self- \\
defense \\
\end{tabular} & \begin{tabular}{|c} 
Nature of \\
the Alleged \\
Threat
\end{tabular} & \begin{tabular}{|l|} 
Expressly Alleged \\
Author(s) of the \\
Threat (ff Any \\
Indicated)
\end{tabular} & \begin{tabular}{|c|} 
Nature of the \\
Alleged \\
Author(s) of \\
the Threat (If \\
Any \\
Indicated) \\
\end{tabular} & $\begin{array}{l}\text { Summary of Alleged Self-defense } \\
\text { Grounds }\end{array}$ & $\begin{array}{l}\text { UNSC } \\
\text { Meeting(s) } \\
\text { (If Any) at } \\
\text { Which the } \\
\text { Comm. was } \\
\text { Raised }\end{array}$ & $\begin{array}{l}\text { Responsive Act (If Any) by the } \\
\text { UNSC }\end{array}$ & \begin{tabular}{|c|} 
UN \\
Repertory \\
Inclusion?
\end{tabular} & $\begin{array}{l}\text { UNSC } \\
\text { Repertoire } \\
\text { Inclusion? }\end{array}$ & \begin{tabular}{|l} 
URL to an \\
English \\
Text
\end{tabular} & \begin{tabular}{||c||} 
URL to Non- \\
English \\
Original \\
Text (ff Any)
\end{tabular} & \begin{tabular}{|l} 
Perma.cc \\
URL
\end{tabular} \\
\hline 102 & 1969.07.24 & 1969.07.24 & $s / 9358$ & El Salvador & $\begin{array}{l}\text { El Salvador, } \\
\text { Honduras }\end{array}$ & $\begin{array}{c}\text { Implied } \\
\text { assertion of } \\
\text { "individual" } \\
\text { self-defense }\end{array}$ & \begin{tabular}{|l} 
Conducted \\
attack and \\
indirect \\
attack
\end{tabular} & Honduras & State & 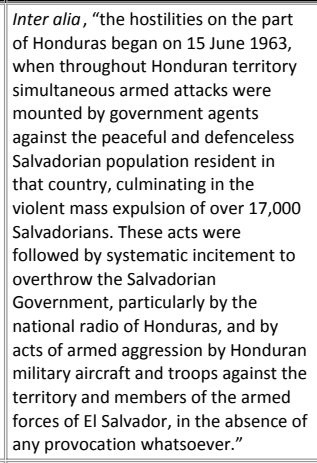 & $\begin{array}{l}\text { None } \\
\text { identified }\end{array}$ & None identified & Article 54 & Article 54 & \begin{tabular}{|l||} 
http: \\
//www.un. \\
orgelennga/ \\
search/vie \\
w_doc. \\
asp? \\
symbol=s/ \\
s358
\end{tabular} & & \begin{tabular}{|l} 
https: \\
//perma. \\
cc/952S- \\
3B9V
\end{tabular} \\
\hline 103 & 1969.08.06 & 1969.08.06 & s/9379 & Israel & $\begin{array}{l}\text { Israel, Syria, } \\
\text { Jordan }\end{array}$ & $\begin{array}{c}\text { Implied } \\
\text { assertion of } \\
\text { "individual" } \\
\text { self-defense }\end{array}$ & $\begin{array}{c}\text { Conducted } \\
\text { attack }\end{array}$ & Syria & State & \begin{tabular}{|l} 
“... Syria has increased in recent weeks \\
its acts of aggression along the cease- \\
fire lines. It has pledged itself to wage \\
a 'war of fatritition', concentrating arge \\
forces along the cease-fire line and \\
introducing Syrian forces into \\
Jordanian territory to be used as an \\
additional base for warfare against \\
Israel."
\end{tabular} & $\begin{array}{l}\text { None } \\
\text { identified }\end{array}$ & None identified & $\begin{array}{l}\text { None } \\
\text { identified }\end{array}$ & $\begin{array}{l}\text { None } \\
\text { identified }\end{array}$ & \begin{tabular}{|l||} 
http: \\
//www.un. \\
orge/len/ga/ \\
search/vie \\
w_doc. \\
asp? \\
symbol=s/ \\
9379
\end{tabular} & & \begin{tabular}{|l} 
https: \\
//perma. \\
cc/2RR7- \\
VMVL
\end{tabular} \\
\hline 104 & 1969.08.12 & 1969.08.12 & $S / 9387$ & Israel & Israel, Lebanon & \begin{tabular}{|c} 
Implied \\
assertion of \\
"individual" \\
self-defense
\end{tabular} & $\begin{array}{c}\text { Conducted } \\
\text { attack }\end{array}$ & $\begin{array}{l}\text { Lebanon and } \\
\text { "terror } \\
\text { organizations" }\end{array}$ & $\begin{array}{c}\text { State and } \\
\text { non-state } \\
\text { actors }\end{array}$ & \begin{tabular}{|l} 
"The cease-fire to which Lebanon is \\
committed forbids all military \\
activities. In explicit violation of this \\
obligation, repeated attacks have \\
been launched against Israel from \\
Lebanese territory.... It is generally \\
known that Lebanon harbours on its \\
territory, and particularly in its \\
southern region bordering with Israel, \\
considerable concentrations of \\
irregular forces which are engaged in \\
waging terror warfare against Israel."
\end{tabular} & $\begin{array}{l}\text { S/PV.1498 } \\
\text { (1498th); } \\
\text { S/PV.1502 } \\
\text { (1502nd); } \\
\text { S/PV. 1504 } \\
\text { (1504th) }\end{array}$ & $\begin{array}{l}\text { S/RES/270(1969), OP 1: } \\
\text { "Condemns the premeditated } \\
\text { air attack by Israel on villages } \\
\text { in southern Lebanon in } \\
\text { violation of its obligations } \\
\text { under the Charter and Security } \\
\text { Council resolutions" (adopted } \\
\text { without vote). }\end{array}$ & $\begin{array}{l}\text { Articles 2(4), } \\
31, \& 35(1)\end{array}$ & $\begin{array}{l}\text { Chapter II } \\
\text { (agenda); } \\
\text { Chapter VIII; } \\
\text { Editorial } \\
\text { note }\end{array}$ & \begin{tabular}{|l||} 
http: \\
//www.un. \\
org/en/ga/ \\
search/vie \\
w_doc. \\
asp? \\
symbol=s/ \\
s387
\end{tabular} & & $\begin{array}{l}\text { https: } \\
\text { //perma. } \\
\text { cc/EAN8- } \\
\text { EHUK }\end{array}$ \\
\hline 105 & 1969.12.04 & 1969.12.04 & S/PV.1516 & Portugal & $\begin{array}{l}\text { Portugal, } \\
\text { Portuguese } \\
\text { Guinea, } \\
\text { Senegal }\end{array}$ & $\begin{array}{c}\text { Implied } \\
\text { assertion of } \\
\text { "individual" } \\
\text { self-defense }\end{array}$ & $\begin{array}{c}\text { Conducted } \\
\text { attack }\end{array}$ & $\begin{array}{l}\text { Senegal and } \\
\text { "armed bands"/ } \\
\text { "raiders" }\end{array}$ & $\begin{array}{c}\text { State and } \\
\text { non-state } \\
\text { actors }\end{array}$ & $\begin{array}{l}\text { Attacks carried out by armed bands } \\
\text { based in Senegal and by Senegal } \\
\text { against Portuguese Guinea. }\end{array}$ & $\begin{array}{l}\text { S/PV.1516 } \\
\text { (1516th); } \\
\text { S/PV.1520 } \\
\text { (1520th) }\end{array}$ & None identified & $\begin{array}{l}\text { Articles 2(4), } \\
12,31, \& 35\end{array}$ & \begin{tabular}{|l} 
Article 2; \\
Article 33; \\
Chapter I \\
(provisional \\
rules); \\
Chapter III; \\
Chapter VIII
\end{tabular} & 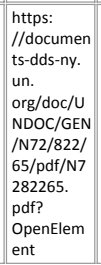 & & $\begin{array}{l}\text { https: } \\
\text { //perma. } \\
\text { cc//R66- } \\
\text { 5XM2 }\end{array}$ \\
\hline 106 & 1969.12.16 & 1969.12.16 & $\mathrm{s} / 9560$ & Israel & Israel, Jordan & $\begin{array}{c}\text { Implied } \\
\text { assertion of } \\
\text { "individual" } \\
\text { self-defense }\end{array}$ & $\begin{array}{c}\text { Conducted } \\
\text { attack }\end{array}$ & $\begin{array}{c}\text { Jordan and "terror } \\
\text { squads" }\end{array}$ & $\begin{array}{c}\text { State and } \\
\text { non-state } \\
\text { actors }\end{array}$ & \begin{tabular}{|l} 
Violation of the cease-fire by Jordan, \\
in relation, inter alia, to "a series of \\
attacks carried out against Israeli \\
villages in the Beit Shean valley by \\
terror squads operating from \\
Jordanian territory, ...."
\end{tabular} & \begin{tabular}{|l} 
None \\
identified
\end{tabular} & None identified & $\begin{array}{l}\text { None } \\
\text { identified }\end{array}$ & $\begin{array}{l}\text { None } \\
\text { identified }\end{array}$ & 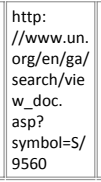 & & \begin{tabular}{|l} 
https: \\
//perma. \\
cc/DNZZ- \\
N8JK
\end{tabular} \\
\hline
\end{tabular}


VI. HLS PILAC Catalogue of Apparent “Article 51 Communications”

\begin{tabular}{|c|c|c|c|c|c|c|c|c|c|c|c|c|c|c|c|c|c|}
\hline $\begin{array}{l}\text { Chron. } \\
\text { Order }\end{array}$ & $\begin{array}{l}\text { Date of } \\
\text { Comm. }\end{array}$ & \begin{tabular}{|c} 
Date of \\
UNsc \\
Document
\end{tabular} & UNSC Symbol & \begin{tabular}{|c} 
Member \\
State(s) That \\
Submitted \\
the Comm.
\end{tabular} & \begin{tabular}{||c||} 
Expressly \\
Mentioned UN \\
Members (\& \\
Colonial \\
Holdings \& \\
Protectorates, \\
if any) \\
\end{tabular} & \begin{tabular}{|l} 
Express or \\
Implied \\
Assertion of \\
Individual, \\
Collective, or \\
Both Self- \\
defense
\end{tabular} & \begin{tabular}{|c} 
Nature of \\
the Alleged \\
Threat
\end{tabular} & $\begin{array}{l}\text { Expressly Alleged } \\
\text { Author(s) of the } \\
\text { Threat (If Any } \\
\text { Indicated) }\end{array}$ & \begin{tabular}{|c|} 
Nature of the \\
Alleged \\
Author(s) of \\
the Threat (If \\
Any \\
Indicated) \\
\end{tabular} & $\begin{array}{l}\text { Summary of Alleged Self-defense } \\
\text { Grounds }\end{array}$ & \begin{tabular}{|c|} 
UNsc \\
Meeting(s) \\
(if Any) at \\
Which the \\
Comm. was \\
Raised
\end{tabular} & $\begin{array}{l}\text { Responsive Act (If Any) by the } \\
\text { UNSC }\end{array}$ & \begin{tabular}{|l} 
UN \\
Repertory \\
Inclusion?
\end{tabular} & \begin{tabular}{|c|} 
UNSC \\
Repertoire \\
Inclusion?
\end{tabular} & \begin{tabular}{|l} 
URL to an \\
English \\
Text
\end{tabular} & \begin{tabular}{|c} 
URL to Non- \\
English \\
Original \\
Text (If Any)
\end{tabular} & $\begin{array}{l}\text { Perma.cc } \\
\text { URL }\end{array}$ \\
\hline 107 & 1970.01.15 & 1970.01.15 & s/9604 & Israel & $\begin{array}{c}\text { Israel, } \\
\text { Lebanon, Syria }\end{array}$ & $\begin{array}{l}\text { Implied } \\
\text { assertion of } \\
\text { "individual" } \\
\text { self-defense }\end{array}$ & $\begin{array}{c}\text { Conducted } \\
\text { attack }\end{array}$ & $\begin{array}{l}\text { Lebanon and } \\
\text { "terror } \\
\text { organizations" }\end{array}$ & $\begin{array}{c}\text { State and } \\
\text { non-state } \\
\text { actors }\end{array}$ & \begin{tabular}{|l} 
Inter alia, violation of the cease-fire by \\
Lebanon by way of continued and \\
growing aggression from Lebanese \\
territory against Israel, including \\
because "...ebanese territory is, and \\
has been for several months now, \\
serving as a base for the training of \\
terror organizations engaged in \\
warfare against Israel and for the \\
actual perpetration of incessant and \\
increasingly provocative acts of \\
aggression against Israel and its \\
citizens."
\end{tabular} & $\begin{array}{l}\text { None } \\
\text { identified }\end{array}$ & None identified & $\begin{array}{l}\text { None } \\
\text { identified }\end{array}$ & $\begin{array}{l}\text { Article 2(4); } \\
\text { Chapter VIII }\end{array}$ & $\begin{array}{l}\text { http: } \\
\text { //www.un. } \\
\text { org/en/ga/ } \\
\text { search/vie } \\
\text { w_doc. } \\
\text { asp? } \\
\text { symbol=s/ } \\
\text { 9604 }\end{array}$ & & $\begin{array}{l}\text { hitps: } \\
\text { //perma. } \\
\text { cc//BBB3- } \\
\text { aPHA }\end{array}$ \\
\hline 108 & 1970.01.22 & 1970.01.22 & $s / 9613$ & Israel & Israel, Jordan & $\begin{array}{l}\text { Implied } \\
\text { assertion of } \\
\text { "individual" } \\
\text { self-defense }\end{array}$ & $\begin{array}{c}\text { Conducted } \\
\text { attack }\end{array}$ & $\begin{array}{l}\text { Jordan and } \\
\text { "irregular forces" }\end{array}$ & $\begin{array}{c}\text { State and } \\
\text { non-state } \\
\text { actors }\end{array}$ & \begin{tabular}{|l} 
Inter alia, violation of the cease-fire by \\
Jordan, including that "[a]ltogether \\
twenty-three armed attacks have \\
occurred in this area in the course of \\
the last four weeks. [N] These \\
continuous attacks and the failure by \\
the Jordanian Government to take \\
steps to ensure the maintenance of \\
the cease-fire by regular and irregular \\
forces in its territory, have compelled \\
Israel to resort to self-defense \\
measures."
\end{tabular} & $\begin{array}{l}\text { None } \\
\text { identified }\end{array}$ & None identified & $\begin{array}{l}\text { None } \\
\text { identified }\end{array}$ & \begin{tabular}{|l} 
None \\
identified
\end{tabular} & $\begin{array}{l}\text { http: } \\
\text { //www.un. } \\
\text { org/en/ga/ } \\
\text { search/vie } \\
\text { w_doc. } \\
\text { asp? } \\
\text { symbol=s/ } \\
\text { 9613 }\end{array}$ & & $\begin{array}{l}\text { hitps: } \\
\text { //perma. } \\
\text { cc//5SV- } \\
\text { PGTC }\end{array}$ \\
\hline 109 & 1970.02.21 & 1970.02.23 & s/9658 & Israel & \begin{tabular}{|c} 
Israel, United \\
Arab Republic \\
[Egypt]
\end{tabular} & $\begin{array}{l}\text { Implied } \\
\text { assertion of } \\
\text { "individual" } \\
\text { self-defense }\end{array}$ & $\begin{array}{c}\text { Conducted } \\
\text { attack }\end{array}$ & $\begin{array}{c}\text { United Arab } \\
\text { Republic [Egypt] }\end{array}$ & State & $\begin{array}{l}\text { Inter alia, violation of the cease-fire by } \\
\text { way of "... unabated warfare which } \\
\text { Egypt is waging against [lsrael]”. }\end{array}$ & $\begin{array}{l}\text { None } \\
\text { identified }\end{array}$ & None identified & $\begin{array}{l}\text { None } \\
\text { identified }\end{array}$ & $\begin{array}{l}\text { None } \\
\text { identified }\end{array}$ & $\begin{array}{l}\text { http: } \\
\text { //www.un. } \\
\text { org/ngn/ga/ } \\
\text { search/vie } \\
\text { w_doc. } \\
\text { asp? } \\
\text { symbol=S/ } \\
9658 \\
\end{array}$ & & $\begin{array}{l}\text { hitps: } \\
\text { //perma. } \\
\text { cc/JvV8- } \\
\text { 5XFJ }\end{array}$ \\
\hline 110 & 1970.02.27 & 1970.02.27 & $s / 9671$ & Israel & \begin{tabular}{|c} 
Israel, Syria, \\
Iraq, Jordan, \\
Sudan, United \\
Arab Republic \\
[Egypt]
\end{tabular} & $\begin{array}{l}\text { Implied } \\
\text { assertion of } \\
\text { "individual" } \\
\text { self-defense }\end{array}$ & $\begin{array}{c}\text { Conducted } \\
\text { attack and } \\
\text { threat of } \\
\text { attack }\end{array}$ & $\begin{array}{c}\text { United Arab } \\
\text { Republic [Egypt] }\end{array}$ & State & $\begin{array}{l}\text { Violation of the cease-fire by Egypt: } \\
\text { Egyptian President Nasser made } \\
\text { statements declaring that cease-fire } \\
\text { lines would no ologer be honored, as } \\
\text { well as concerning "heavy artillery } \\
\text { barrages," "raids and abductions } \\
\text { beyond the cease-fire lines," and } \\
\text { "attempts to initiate offensive military } \\
\text { operations". }\end{array}$ & $\begin{array}{l}\text { None } \\
\text { identified }\end{array}$ & None identified & $\begin{array}{l}\text { None } \\
\text { identified }\end{array}$ & $\begin{array}{l}\text { None } \\
\text { identified }\end{array}$ & $\begin{array}{l}\text { http: } \\
\text { //www.un. } \\
\text { org/en/ga/ } \\
\text { search/vie } \\
\text { w_doc. } \\
\text { asp? } \\
\text { symbol=s/ } \\
\text { 9671 }\end{array}$ & & $\begin{array}{l}\text { hitps: } \\
\text { //perma. } \\
\text { cclp8sL- } \\
\text { XYTH }\end{array}$ \\
\hline 111 & 1970.03.09 & 1970.03.10 & $s / 9692$ & $\begin{array}{l}\text { United } \\
\text { States }\end{array}$ & $\begin{array}{l}\text { United States, } \\
\text { Cambodia, } \\
\text { Vietnam }\end{array}$ & $\begin{array}{l}\text { Implied } \\
\text { assertion of } \\
\text { "individual" } \\
\text { self-defense }\end{array}$ & $\begin{array}{c}\text { Conducted } \\
\text { attack }\end{array}$ & $\begin{array}{c}\text { Cambodia and } \\
\text { Vietcong/North } \\
\text { Vietnamese forces }\end{array}$ & $\begin{array}{c}\text { State and } \\
\text { non-state } \\
\text { actors }\end{array}$ & $\begin{array}{l}\text { "The United States Government again } \\
\text { expresses its profound concern over } \\
\text { these violations of Cambodian } \\
\text { neutrality, and calls upon the Royal } \\
\text { Cambodian Government to take the } \\
\text { necessary measures to prevent such } \\
\text { use of fits territory by Viet Cong/North } \\
\text { Viet-Namese forces." Inter alia: "[i]n } \\
\text { the case of Dak Dam, the United } \\
\text { States Government concludes that } \\
\text { Cambodian forces occupying the post } \\
\text { could not have been unaware of the } \\
\text { presence of Viet Cong/North Viet- } \\
\text { Namese artillery positions in close } \\
\text { proximity to the post and village, and } \\
\text { of the fact that this artill very was firing } \\
\text { at Viet-Namese territory." }\end{array}$ & $\begin{array}{l}\text { None } \\
\text { identified }\end{array}$ & None identified & $\begin{array}{l}\text { None } \\
\text { identified }\end{array}$ & $\begin{array}{l}\text { None } \\
\text { identified }\end{array}$ & $\begin{array}{l}\text { http: } \\
\text { //www.un. } \\
\text { org/nen//ag/ } \\
\text { search/vie } \\
\text { w_doc. } \\
\text { asp? } \\
\text { spybol=S/ } \\
9692\end{array}$ & & $\begin{array}{l}\text { hitps: } \\
\text { //perma. } \\
\text { cc//1/G3- } \\
\text { LSG5 }\end{array}$ \\
\hline
\end{tabular}


VI. HLS PILAC Catalogue of Apparent “Article 51 Communications”

\begin{tabular}{|c|c|c|c|c|c|c|c|c|c|c|c|c|c|c|c|c|c|}
\hline $\begin{array}{l}\text { Chron. } \\
\text { Order }\end{array}$ & $\begin{array}{l}\text { Date of } \\
\text { Comm. }\end{array}$ & \begin{tabular}{|c} 
Date of \\
UNsc \\
Document
\end{tabular} & | UNSC Symbol & \begin{tabular}{|c} 
Member \\
State(s) That \\
Submitted \\
the Comm.
\end{tabular} & \begin{tabular}{||c||} 
Expressly \\
Mentioned UN \\
Members (\& \\
Colonial \\
Holdings \& \\
Protectorates, \\
if any) \\
\end{tabular} & \begin{tabular}{|l} 
Express or \\
Implied \\
Assertion of \\
Individual, \\
Collective, or \\
Both Self- \\
defense
\end{tabular} & \begin{tabular}{|c} 
Nature of \\
the Alleged \\
Threat
\end{tabular} & \begin{tabular}{|l} 
Expressly Alleged \\
Author(s) of the \\
Threat (ff Any \\
Indicated)
\end{tabular} & \begin{tabular}{|c|} 
Nature of the \\
Alleged \\
Author(s) of \\
the Threat (If \\
Any \\
Indicated) \\
\end{tabular} & $\begin{array}{l}\text { Summary of Alleged Self-defense } \\
\text { Grounds }\end{array}$ & \begin{tabular}{|l} 
UNsc \\
Meeting(s) \\
(If Any) at \\
Which the \\
Comm. was \\
Raised
\end{tabular} & $\begin{array}{l}\text { Responsive Act (If Any) by the } \\
\text { UNSC }\end{array}$ & \begin{tabular}{|l} 
UN \\
Repertory \\
Inclusion?
\end{tabular} & \begin{tabular}{|l} 
UNSC \\
Repertoire \\
Inclusion?
\end{tabular} & \begin{tabular}{|l} 
URL to an \\
English \\
Text
\end{tabular} & \begin{tabular}{|c||} 
URL to Non- \\
English \\
Original \\
Text (ff Any)
\end{tabular} & $\begin{array}{l}\text { Perma.cc } \\
\text { URL }\end{array}$ \\
\hline 112 & 1970.03.16 & 1970.03.16 & $s / 9706$ & Israel & Israel, Syria & $\begin{array}{l}\text { Implied } \\
\text { assertion of } \\
\text { "individual" } \\
\text { self-defense }\end{array}$ & $\begin{array}{c}\text { Conducted } \\
\text { attack }\end{array}$ & $\begin{array}{l}\text { Syria and "irregular } \\
\text { forces" }\end{array}$ & $\begin{array}{c}\text { State and } \\
\text { non-state } \\
\text { actors }\end{array}$ & $\begin{array}{l}\text { Violation of the cease-fire by Syria: } \\
\text { "Armed attacks perpetrated from } \\
\text { Syrian territory by regular and } \\
\text { irregular forces, in violation of the } \\
\text { cease-fire, have again been intensified } \\
\text { in recent days causing loss of life and } \\
\text { damage." }\end{array}$ & $\begin{array}{l}\text { None } \\
\text { identified }\end{array}$ & None identified & $\begin{array}{l}\text { None } \\
\text { identified }\end{array}$ & \begin{tabular}{|l} 
None \\
identified
\end{tabular} & $\begin{array}{l}\text { http: } \\
\text { //wwww.un. } \\
\text { org/en//ga/ } \\
\text { search/vie } \\
\text { w_doc. } \\
\text { asp? } \\
\text { spybol=S/ } \\
9706\end{array}$ & & $\begin{array}{l}\text { hitps: } \\
\text { //perma. } \\
\text { cc/4LA3- } \\
\text { a22Ls }\end{array}$ \\
\hline 113 & 1970.03 .25 & 1970.03.25 & $S / 9722$ & Israel & Israel, Lebanon & $\begin{array}{l}\text { Implied } \\
\text { assertion of } \\
\text { "individual" } \\
\text { self-defense }\end{array}$ & $\begin{array}{c}\text { Conducted } \\
\text { attack }\end{array}$ & $\begin{array}{l}\text { Lebanon and } \\
\text { "irregular forces" }\end{array}$ & $\begin{array}{c}\text { State and } \\
\text { non-state } \\
\text { actors }\end{array}$ & $\begin{array}{l}\text { Violation of the cease-fire by Lebanon: } \\
\text { "It is a matter of general knowledge } \\
\text { that a campaign of incessant } \\
\text { aggression has been going on from } \\
\text { Lebanese territory against Israel. This } \\
\text { campaign directed against peaceful } \\
\text { Israeli ivillages and towns and their } \\
\text { civilian population and has now been } \\
\text { extended to the entire length of the } \\
\text { Israel-Lebanese border. The armed } \\
\text { attacks and sabotage raids are taking } \\
\text { place daily. Just as the Lebanese } \\
\text { Government cannot acquit itself of } \\
\text { responsibility for allowing these } \\
\text { attacks to continue, so it cannot } \\
\text { expect Israel to leave its territory and } \\
\text { its citizens undefended." }\end{array}$ & $\begin{array}{l}\text { None } \\
\text { identified }\end{array}$ & None identified & $\begin{array}{l}\text { None } \\
\text { identified }\end{array}$ & $\begin{array}{l}\text { None } \\
\text { identified }\end{array}$ & $\begin{array}{l}\text { http: } \\
\text { //www.un. } \\
\text { org/en/ga/ } \\
\text { search/vie } \\
\text { w_doc. } \\
\text { asp? } \\
\text { symbol=s/ } \\
\text { 9722 }\end{array}$ & & $\begin{array}{l}\text { https: } \\
\text { //perma. } \\
\text { cc//AD8- } \\
\text { XRLL }\end{array}$ \\
\hline 114 & 1970.04.06 & 1970.04.06 & $S / 9739$ & Israel & \begin{tabular}{||l|} 
Israel, Syria, \\
Iraq, Jordan, \\
Sudan, United \\
Arab Republic \\
[Egypt]
\end{tabular} & $\begin{array}{c}\text { Implied } \\
\text { assertion of } \\
\text { "individual" } \\
\text { self-defense }\end{array}$ & $\begin{array}{c}\text { Conducted } \\
\text { attack }\end{array}$ & $\begin{array}{l}\text { Syria and "irregular } \\
\text { forces" }\end{array}$ & $\begin{array}{c}\text { State and } \\
\text { non-state } \\
\text { actors }\end{array}$ & $\begin{array}{l}\text { Violation of the cease-fire by Syria, } \\
\text { inter alia: "The Government of Syria } \\
\text { rejects the Security Council call for a } \\
\text { just and lasting peace with Israel, } \\
\text { repudiates the ecase-fire, openly } \\
\text { proclaims its intention to pursue } \\
\text { aggression against Israel, launches } \\
\text { armed attacks across the cease-fire } \\
\text { lines, and when Israel acts in self- } \\
\text { defence, complains that Israeli } \\
\text { defensive measures prove effective." }\end{array}$ & \begin{tabular}{|l} 
None \\
identified
\end{tabular} & None identified & $\begin{array}{l}\text { None } \\
\text { identified }\end{array}$ & \begin{tabular}{|l} 
None \\
identified
\end{tabular} & $\begin{array}{l}\text { http: } \\
\text { //www.un. } \\
\text { org/en/ga/ } \\
\text { search/vie } \\
\text { w_doc. } \\
\text { asp? } \\
\text { symbol=S/ } \\
\text { 9739 }\end{array}$ & & $\begin{array}{l}\text { hitps: } \\
\text { ///perma. } \\
\text { cc//XH34- } \\
\text { DALH }\end{array}$ \\
\hline 115 & 1970.04.09 & 1970.04.09 & $s / 9745$ & Israel & \begin{tabular}{|c} 
Israel, United \\
Arab Republic \\
[Egypt]
\end{tabular} & $\begin{array}{l}\text { Implied } \\
\text { assertion of } \\
\text { "individual" } \\
\text { self-defense }\end{array}$ & $\begin{array}{c}\text { Conducted } \\
\text { attack }\end{array}$ & Egypt & State & $\begin{array}{l}\text { Violation of the cease-fire by Egypt; } \\
\text { report concerning disputed "air action } \\
\ldots \text {... undertaken [by Israel] against } \\
\text { Egyptian military installations situated } \\
\text { at Salahiye." }\end{array}$ & $\begin{array}{l}\text { None } \\
\text { identified }\end{array}$ & None identified & $\begin{array}{l}\text { None } \\
\text { identified }\end{array}$ & $\begin{array}{l}\text { None } \\
\text { identified }\end{array}$ & $\begin{array}{l}\text { http: } \\
\text { //wwww.un. } \\
\text { org/en/ga/ } \\
\text { search//ie } \\
\text { w_doc. } \\
\text { asp? } \\
\text { symbol=S/ } \\
\text { 9745 }\end{array}$ & & $\begin{array}{l}\text { hitps: } \\
\text { //perma. } \\
\text { cc//62- } \\
\text { TFF4 }\end{array}$ \\
\hline 116 & 1970.04.26 & 1970.04.27 & $s / 9767$ & Israel & Israel, Jordan & \begin{tabular}{|c|} 
Implied \\
assertion of \\
"individual" \\
self-defense
\end{tabular} & $\begin{array}{c}\text { Conducted } \\
\text { attack }\end{array}$ & \begin{tabular}{|l} 
Jordan and \\
irregular forces \\
(including "the \\
terrororoganization \\
El Assifa")
\end{tabular} & $\begin{array}{c}\text { State and } \\
\text { non-state } \\
\text { actors }\end{array}$ & $\begin{array}{l}\text { Violation of the cease-fire by Jordan: } \\
\text { "Ia]cts of aggression perpetrated from } \\
\text { Jordanian territory by regular and } \\
\text { irregular forces are contining } \\
\text { unabated. The operations of the } \\
\text { irregular forces engaged in terror } \\
\text { warfare against Israeli civilian } \\
\text { population are co-ordinated with the } \\
\text { Jordanian authorities. The armed } \\
\text { attacks are directed against Israeli } \\
\text { villages and towns and other civilian } \\
\text { targets.". }\end{array}$ & $\begin{array}{l}\text { None } \\
\text { identified }\end{array}$ & None identified & \begin{tabular}{|l} 
None \\
identified
\end{tabular} & \begin{tabular}{|l} 
None \\
identified
\end{tabular} & $\begin{array}{l}\text { http: } \\
\text { //www.un. } \\
\text { org/en/ga/ } \\
\text { search/vie } \\
\text { w_doc. } \\
\text { asp? } \\
\text { symbol=s/ } \\
\text { 9767 }\end{array}$ & & $\begin{array}{l}\text { hitps: } \\
\text { ///perma. } \\
\text { cc/T772- } \\
\text { NeR8 }\end{array}$ \\
\hline
\end{tabular}


VI. HLS PILAC Catalogue of Apparent “Article 51 Communications”

\begin{tabular}{|c|c|c|c|c|c|c|c|c|c|c|c|c|c|c|c|c|c|}
\hline $\begin{array}{c}\text { Chron. } \\
\text { Order }\end{array}$ & $\begin{array}{l}\text { Date of } \\
\text { Comm. }\end{array}$ & $\begin{array}{c}\text { Date of } \\
\text { UNsC } \\
\text { Document }\end{array}$ & UNSC Symbol & $\begin{array}{c}\text { Member } \\
\text { State(s) That } \\
\text { Submitted } \\
\text { the Commm. }\end{array}$ & \begin{tabular}{|c||} 
Expressly \\
Mentioned UN \\
Members (\& \\
Colonial \\
Holdings \& \\
Protectorates, \\
if any) \\
\end{tabular} & \begin{tabular}{||l|} 
Express or \\
Implied \\
Assertion of \\
Individual, \\
Collective, or \\
Both Self- \\
defense \\
\end{tabular} & \begin{tabular}{|c}
$\begin{array}{c}\text { Nature of } \\
\text { the Alleged } \\
\text { Threat }\end{array}$
\end{tabular} & \begin{tabular}{|l} 
Expressly Alleged \\
Author(s) of the \\
Threat (If Any \\
Indicated)
\end{tabular} & \begin{tabular}{|c|} 
Nature of the \\
Alleged \\
Author(s) of \\
the Threat (if \\
Any \\
Indicated)
\end{tabular} & $\begin{array}{l}\text { Summary of Alleged Self-defense } \\
\text { Grounds }\end{array}$ & $\begin{array}{l}\text { UNsC } \\
\text { Meeting(s) } \\
\text { (If Any) at } \\
\text { Which the } \\
\text { Comm. was } \\
\text { Raised }\end{array}$ & $\begin{array}{c}\text { Responsive Act (If Any) by the } \\
\text { UNSC }\end{array}$ & \begin{tabular}{|c} 
UN \\
Repertory \\
Inclusion?
\end{tabular} & \begin{tabular}{||c|} 
UNSC \\
Repertoire \\
Inclusion?
\end{tabular} & \begin{tabular}{|l||} 
URL to an \\
English \\
Text
\end{tabular} & \begin{tabular}{||c||} 
URL to Non- \\
English \\
Original \\
Text (ff Any)
\end{tabular} & \begin{tabular}{|l} 
Perma.cc \\
URL
\end{tabular} \\
\hline 117 & 1970.05 .04 & 1970.05 .04 & S/PV.1540 & Israel & |srael, Lebanon & $\begin{array}{l}\text { Implied } \\
\text { assertion of } \\
\text { "individual" } \\
\text { self-defense }\end{array}$ & $\begin{array}{c}\text { Conducted } \\
\text { attack }\end{array}$ & $\begin{array}{l}\text { "[A] squad of } \\
\text { irregular forces" }\end{array}$ & $\begin{array}{l}\text { Non-state } \\
\text { actors }\end{array}$ & $\begin{array}{l}\text { "....F fFurther attacks in the long series } \\
\text { of acts of aggression perpetrated in } \\
\text { recent months from Lebanon against } \\
\text { Israeli border towns and villages } \\
\text { occurred again in upper Galiliee last } \\
\text { night and in the early hours of this } \\
\text { morning." }\end{array}$ & $\begin{array}{l}\text { S/PV.1540 } \\
\text { (1540th) }\end{array}$ & None identified & $\begin{array}{l}\text { Articles 2(4), } \\
12,40, \& 73\end{array}$ & \begin{tabular}{|l|} 
Articles 2 \& \\
39-40; \\
Chapter I; \\
Chapter V; \\
Chapter VIII
\end{tabular} & \begin{tabular}{|l|} 
https: \\
//documen \\
ts-dds-ny. \\
un. \\
org/doc/U \\
NDDC//G2N \\
NN7/820/ \\
65/pdf/N7 \\
382065. \\
pdf? \\
OpenElem \\
ent \\
\end{tabular} & & \begin{tabular}{|l} 
https: \\
//perma. \\
c/MKT3- \\
DWFD
\end{tabular} \\
\hline 118 & 1970.05 .05 & 1970.05 .05 & $s / 9781$ & $\begin{array}{l}\text { United } \\
\text { States }\end{array}$ & \begin{tabular}{|l|} 
United States, \\
Cambodia, \\
South \\
Vietnam, \\
North Vietnam
\end{tabular} & \begin{tabular}{|c} 
Express \\
assertion of \\
"collective" \\
self-defense
\end{tabular} & $\begin{array}{c}\text { Conducted } \\
\text { attack }\end{array}$ & $\begin{array}{l}\text { North Vietnam and } \\
\text { Vietcong }\end{array}$ & $\begin{array}{c}\text { State and } \\
\text { non-state } \\
\text { actors }\end{array}$ & \begin{tabular}{|l} 
Maintenance of military bases by \\
North Vietnamese and Vietcong forces \\
in the territory vore which Cambodia \\
lacks control; forces using this \\
territory to prepare for attacks on \\
South Vietnam. “The measures of \\
collective self-defence being taken by \\
United States and South Viet-Namese \\
forces are restricted in extent, \\
purpose and time. They are confined \\
to the border areas over which the \\
Cambodian Government has ceased to \\
exericie any effective control and \\
which has been completely occupied \\
by North Viet-Namese and Viet Cong \\
forces.”
\end{tabular} & $\begin{array}{l}\text { None } \\
\text { identified }\end{array}$ & None identified & $\begin{array}{l}\text { None } \\
\text { identified }\end{array}$ & $\begin{array}{l}\text { None } \\
\text { identified }\end{array}$ & \begin{tabular}{l||} 
http: \\
//www.un. \\
org/en/ga/ \\
search/vie \\
w_doc. \\
asp? \\
symbol=s/ \\
9781
\end{tabular} & & \begin{tabular}{|l} 
https: \\
//perma. \\
cc/4GGT- \\
$8 \times 67$
\end{tabular} \\
\hline 119 & 1970.05 .12 & 1970.05.12 & S/PV.1537 & Israel & $\begin{array}{c}\text { Israel, } \\
\text { Lebanon, Syria, } \\
\text { Jordan }\end{array}$ & \begin{tabular}{|c} 
Implied \\
assertion of \\
"individual" \\
self-defense
\end{tabular} & $\begin{array}{c}\text { Conducted } \\
\text { attack }\end{array}$ & $\begin{array}{l}\text { "[T]error } \\
\text { organizations in } \\
\text { south-east } \\
\text { Lebanon" }\end{array}$ & $\begin{array}{l}\text { Non-state } \\
\text { actors }\end{array}$ & $\begin{array}{l}\text { ".... Lebanese territory has become a } \\
\text { base from which continuous attacks } \\
\text { were being carried out against Iraaeli } \\
\text { towns and villages and their civilian } \\
\text { population." }\end{array}$ & $\begin{array}{l}\text { S/PV.1537 } \\
(1537 \text { th) }\end{array}$ & \begin{tabular}{|l|} 
S/RES/279(1970): “Demands \\
the immediate withdrawal of \\
all Israeli armed forces from \\
Lebanese territory." \\
(unanimous). \\
S/RES/280(1970), inter allia, OP \\
2: "Condemns Israel for its \\
premeditated military action in \\
violation of its obligations \\
under the Charter of the \\
United Nations" (11-0-4).
\end{tabular} & $\begin{array}{l}\text { Articles 2(4), } \\
12,27,35, \\
73, \& 83 ; \\
\text { Chapter VIII }\end{array}$ & \begin{tabular}{|l|} 
Articles 39- \\
40; Chapter \\
I; Chapter IV; \\
Chapter VIII; \\
Chapter XII
\end{tabular} & \begin{tabular}{|l|} 
https: \\
//documen \\
tst-dds-ny. \\
un. \\
org/doc/U/U \\
NDOCC/GEN \\
NN73/820/ \\
55/pdf/N7 \\
382055. \\
pdf? \\
OpenElem \\
ent
\end{tabular} & & $\begin{array}{l}\text { https: } \\
\text { //perma. } \\
\text { c/ c/978- } \\
\text { QPVL }\end{array}$ \\
\hline 120 & 1970.07.01 & 1970.07.01 & $\mathrm{s} / 9854$ & $\begin{array}{l}\text { United } \\
\text { States }\end{array}$ & \begin{tabular}{|l|} 
United States, \\
Cambodia, \\
South \\
Vietnam, \\
North Vietnam
\end{tabular} & $\begin{array}{l}\text { Express } \\
\text { assertion of } \\
\text { "collective" } \\
\text { self-defense }\end{array}$ & $\begin{array}{c}\text { Conducted } \\
\text { attack and } \\
\text { threat of } \\
\text { attack }\end{array}$ & $\begin{array}{l}\text { North Vietnam and } \\
\text { Vietcong }\end{array}$ & $\begin{array}{c}\text { State and } \\
\text { non-state } \\
\text { actors }\end{array}$ & $\begin{array}{l}\text { Continued aggressive action by the } \\
\text { North Vietnamese and Vietcong from } \\
\text { Cambodian territory: “...North Viet- } \\
\text { Namese and Viet-Cong forces remain } \\
\text { in Cambodia in pursuance of their } \\
\text { armed attack against the Republic of } \\
\text { Viet-Nam.” } \\
\end{array}$ & $\begin{array}{l}\text { None } \\
\text { identified }\end{array}$ & None identified & $\begin{array}{l}\text { None } \\
\text { identified }\end{array}$ & $\begin{array}{l}\text { None } \\
\text { identified }\end{array}$ & \begin{tabular}{|l||} 
http: \\
|/www.un. \\
org/en/ga/ \\
search/vie \\
w_doc. \\
asp? \\
symbol=s/ \\
9854 \\
\end{tabular} & & \begin{tabular}{|l} 
https: \\
//perma. \\
cc/ZZKU- \\
FW4N
\end{tabular} \\
\hline 121 & 1970.07 .20 & 1970.07.20 & S/9879 & Israel & $\mid$ | Israel, Jordan & \begin{tabular}{|c} 
Implied \\
assertion of \\
"individual" \\
self-defense
\end{tabular} & $\begin{array}{l}\text { Conducted } \\
\text { attack }\end{array}$ & $\begin{array}{l}\text { Jordan and } \\
\text { "irregular forces" }\end{array}$ & $\begin{array}{c}\text { State and } \\
\text { non-state } \\
\text { actors }\end{array}$ & $\begin{array}{l}\text { Violation of the cease-fire by Jordan } \\
\text { and increased cooperation by Jordan } \\
\text { with "irregular forces waging terror } \\
\text { warfare against Israel": "Ithese acts } \\
\text { of aggression have compelled Israel to } \\
\text { act in self-defence eagainst the sources } \\
\text { of fire and the bases of the attacking } \\
\text { forces." }\end{array}$ & $\begin{array}{l}\text { None } \\
\text { identified }\end{array}$ & None identified & $\begin{array}{l}\text { None } \\
\text { identified }\end{array}$ & $\begin{array}{l}\text { None } \\
\text { identified }\end{array}$ & \begin{tabular}{l||} 
http: \\
//www.un. \\
org/en/ga/ \\
search/vie \\
w_doc. \\
asp? \\
symbol=s/ \\
9879 \\
\end{tabular} & & $\begin{array}{l}\text { https: } \\
\text { //perma. } \\
\text { cc/7QYYA- } \\
\text { 6F8L }\end{array}$ \\
\hline
\end{tabular}


VI. HLS PILAC Catalogue of Apparent “Article 51 Communications”

\begin{tabular}{|c|c|c|c|c|c|c|c|c|c|c|c|c|c|c|c|c|c|}
\hline $\begin{array}{l}\text { Chron. } \\
\text { Order }\end{array}$ & $\begin{array}{l}\text { Date of } \\
\text { Comm. }\end{array}$ & $\begin{array}{c}\text { Date of } \\
\text { UNsc } \\
\text { Document }\end{array}$ & UNSC Symbol & \begin{tabular}{||c} 
Member \\
State(s) That \\
Submitted \\
the Comm.
\end{tabular} & \begin{tabular}{||c|} 
Expressly \\
Mentioned UN \\
Members (\& \\
Colonial \\
Holdings \& \\
Protectorates, \\
if any)
\end{tabular} & \begin{tabular}{||c|} 
Express or \\
Implied \\
Assertion of \\
Individual, \\
Collective, or \\
Both Self- \\
defense \\
\end{tabular} & $\begin{array}{c}\text { Nature of } \\
\text { the Alleged } \\
\text { Threat }\end{array}$ & \begin{tabular}{|l|} 
Expressly Alleged \\
Author(s) of the \\
Threat (If Any \\
Indicated)
\end{tabular} & $\begin{array}{l}\text { Nature of the } \\
\text { Alleged } \\
\text { Author(s) of } \\
\text { the Threat (If } \\
\text { Any } \\
\text { Indicated) }\end{array}$ & $\begin{array}{l}\text { Summary of Alleged Self-defense } \\
\text { Grounds }\end{array}$ & $\begin{array}{l}\text { UNsC } \\
\text { Meeting(s) } \\
\text { (If Any) at } \\
\text { Which the } \\
\text { Comm. was } \\
\text { Raised }\end{array}$ & $\begin{array}{l}\text { Responsive Act (If Any) by the } \\
\text { UNSC }\end{array}$ & \begin{tabular}{||c|} 
UN \\
Repertory \\
Inclusion?
\end{tabular} & \begin{tabular}{|c|} 
UNSC \\
Repertoire \\
Inclusion?
\end{tabular} & \begin{tabular}{|c||} 
URL to an \\
English \\
Text
\end{tabular} & \begin{tabular}{||c||} 
URL to Non- \\
English \\
Original \\
Text (ff Any)
\end{tabular} & $\begin{array}{c}\text { Perma.cc } \\
\text { URL }\end{array}$ \\
\hline 122 & 1970.09.05 & 1970.09.05 & S/PV.1551 & Israel & \begin{tabular}{|c} 
Israel, \\
Lebanon, Syria
\end{tabular} & $\begin{array}{c}\text { Implied } \\
\text { assertion of } \\
\text { "individual" } \\
\text { self-defense }\end{array}$ & $\begin{array}{c}\text { Conducted } \\
\text { attack }\end{array}$ & $\begin{array}{l}\text { Lebanon and } \\
\text { terrorists }\end{array}$ & $\begin{array}{c}\text { State and } \\
\text { non-state } \\
\text { actors }\end{array}$ & $\begin{array}{l}\text { “... [C]ontinuous acts of aggression } \\
\text { committed from Lebanese territory } \\
\text { and of the admitted helplessness of } \\
\text { the Lebanese authorities to control } \\
\text { their own territory”. }\end{array}$ & $\begin{array}{l}\text { S/PV.1551 } \\
\text { (1551st) }\end{array}$ & $\begin{array}{l}\text { S/RES/285(1970): " Demands } \\
\text { the complete and immediate } \\
\text { withdrawal of all Israeli armed } \\
\text { forces from Lebanese } \\
\text { territory." (14-0-1) }\end{array}$ & $\begin{array}{l}\text { None } \\
\text { identified }\end{array}$ & $\begin{array}{l}\text { None } \\
\text { identified }\end{array}$ & 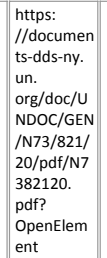 & & $\begin{array}{l}\text { hitps: } \\
\text { //perma. } \\
\text { ccl/288- } \\
\text { r594 }\end{array}$ \\
\hline 123 & 1971.02.08 & 1971.02.08 & $S / 10104$ & $\begin{array}{l}\text { South } \\
\text { Vietnam }\end{array}$ & \begin{tabular}{|} 
South \\
Vietnam, \\
North \\
Vietnam, \\
Khmer \\
Republic \\
[Cambodia], \\
Laos
\end{tabular} & $\begin{array}{c}\text { Implied } \\
\text { assertion of } \\
\text { "individual" } \\
\text { self-defense }\end{array}$ & $\begin{array}{c}\text { Conducted } \\
\text { attack }\end{array}$ & North Vietnam & State & $\begin{array}{l}\text { Disrupting Communist North } \\
\text { Vietnamese forces occupying Laotian } \\
\text { border territory: “... the attacks of our } \\
\text { armed forces against the Communist } \\
\text { North Viet-Namese troops along the } \\
\text { borders on the Laotian territory do } \\
\text { not constitute an act of belligerence of } \\
\text { the Republic of Viet-Nam, but are } \\
\text { solely a necessary act of legitimate } \\
\text { self-defence of the Republic of Viet- } \\
\text { Nam against the Communist North } \\
\text { Viet-Namese aggressors.” }\end{array}$ & $\begin{array}{l}\text { None } \\
\text { identified }\end{array}$ & None identified & $\begin{array}{l}\text { None } \\
\text { identified }\end{array}$ & $\begin{array}{l}\text { None } \\
\text { identified }\end{array}$ & \begin{tabular}{|l||} 
http: \\
//www.un. \\
org///nngal \\
search/vie \\
w_doc. \\
asp? \\
symbol=s/ \\
10104
\end{tabular} & & $\begin{array}{l}\text { hitps: } \\
\text { ///perma. } \\
\text { cc//KB2D- } \\
\text { gu4U }\end{array}$ \\
\hline 124 & 1971.09.29 & 1971.09.29 & $s / 10343$ & Portugal & \begin{tabular}{|l} 
Portugal, \\
Portuguese \\
Guinea, \\
Senegal, Soviet \\
Union
\end{tabular} & $\begin{array}{c}\text { Implied } \\
\text { assertion of } \\
\text { "individual" } \\
\text { self-defense }\end{array}$ & $\begin{array}{c}\text { Conducted } \\
\text { attack }\end{array}$ & $\begin{array}{l}\text { Partido Africano da da } \\
\text { Independência da } \\
\text { Guiné e Cabo } \\
\text { Verde (PAIGC) }\end{array}$ & $\begin{array}{c}\text { Non-state } \\
\text { actors }\end{array}$ & $\begin{array}{l}\text { In rejecting accusations concerning } \\
\text { the explosion of mines allegedly } \\
\text { placed by the Portuguese army in } \\
\text { Senegalese territury, Portugal states } \\
\text { that the authorities of Portuguese } \\
\text { Guinea are "doing nothing but } \\
\text { exercisising their right of legitimate self- } \\
\text { defence" amid the perpetration of } \\
\text { "warlike acts of violence against } \\
\text { Portuguesese populations" and "acts of } \\
\text { violence and destruction in } \\
\text { Portuguese Guinea" by the Partido } \\
\text { Africano da Independência da Guiné e } \\
\text { Cabo Verde (PAIGC). }\end{array}$ & $\begin{array}{l}\text { S/PV.1599 } \\
\text { (1599th); } \\
\text { S/PV.1600 } \\
\text { (1600th); } \\
\text { //PV.1601 } \\
\text { (1601st) }\end{array}$ & None identified & Article 51 & Chapter VIII & \begin{tabular}{|l||} 
http: \\
I/www.un. \\
org//nn/ga/ \\
search/vie \\
w_doc. \\
asp? \\
symbol=s/ \\
10343
\end{tabular} & & $\begin{array}{l}\text { hitps: } \\
\text { //Tperma. } \\
\text { cc//EE2- } \\
\text { EVBBH }\end{array}$ \\
\hline 125 & 1971.12.12 & 1971.12.12 & $S / 10445$ & India & India, Pakistan & $\begin{array}{c}\text { Implied } \\
\text { assertion of } \\
\text { "individual" } \\
\text { self-defense }\end{array}$ & $\begin{array}{c}\text { Conducted } \\
\text { attack }\end{array}$ & Pakistan & State & $\begin{array}{l}\text { Following assault on Pakistanis in the } \\
\text { Eastern Province of Pakistan, which } \\
\text { led to refugees fleeing to India, } \\
\text { Pakistan attacked Indian airfields: } \\
\text { "India is a victim of yet another } \\
\text { unprovoked Pakistani aggression and } \\
\text { is engaged in defending its national } \\
\text { sovereignty and territorial integrity in } \\
\text { the exercise of its legitimate right of } \\
\text { self-defence." }\end{array}$ & $\begin{array}{l}\text { S/PV.1611 } \\
\text { (1611th); } \\
\text { S/PV.1613 } \\
\text { (1613th); } \\
\text { S/PV.11621 } \\
\text { (1621st) }\end{array}$ & None identified & $\begin{array}{l}\text { None } \\
\text { identified }\end{array}$ & Chapter VIII & 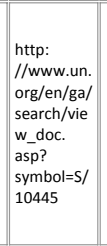 & & 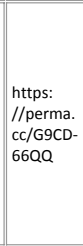 \\
\hline 126 & 1972.02.25 & 1972.02.25 & $\mathrm{s} / 10550$ & Israel & | Israel, Lebanon & $\begin{array}{l}\text { Implied } \\
\text { assertion of } \\
\text { "individual" } \\
\text { self-defense }\end{array}$ & $\begin{array}{c}\text { Conducted } \\
\text { attack }\end{array}$ & \begin{tabular}{|c} 
Lebanon and \\
"irregular forces"/ \\
"terrorists"
\end{tabular} & $\begin{array}{c}\text { State and } \\
\text { non-state } \\
\text { actors }\end{array}$ & \begin{tabular}{|l} 
Israel responding to attacks \\
committed against it thy \\
terrorists/sirregular forces from \\
Lebanese territory: “i]n the face of \\
these [armed] attacks Israel was \\
compelled to take action in self- \\
defence on 25 February 1972 against \\
encampments of terrorists, from \\
which they set out on their forays \\
against targets on Israeli soil."
\end{tabular} & $\begin{array}{l}\text { S/PV.1643 } \\
\text { (1643rd); } \\
\text { S/PV.1644 } \\
\text { (1644th) }\end{array}$ & None identified & \begin{tabular}{|l|} 
Articles 2(4), \\
$23, \& 35$
\end{tabular} & Chapter VIII & \begin{tabular}{|l||} 
http: \\
//www.un. \\
orge//gn/gal \\
search/vie \\
w_doc. \\
asp? \\
symbol=s/ \\
10550
\end{tabular} & & $\begin{array}{l}\text { hitps: } \\
\text { //Terma. } \\
\text { cc/RMHG- } \\
\text { kJfV }\end{array}$ \\
\hline
\end{tabular}


VI. HLS PILAC Catalogue of Apparent “Article 51 Communications”

\begin{tabular}{|c|c|c|c|c|c|c|c|c|c|c|c|c|c|c|c|c|c|}
\hline $\begin{array}{l}\text { Chron. } \\
\text { Order }\end{array}$ & $\begin{array}{l}\text { Date of } \\
\text { Comm. }\end{array}$ & $\begin{array}{c}\text { Date of } \\
\text { UNsC } \\
\text { Document }\end{array}$ & UNSC Symbol & \begin{tabular}{|c} 
Member \\
State(s) That \\
Submitted \\
the Comm.
\end{tabular} & \begin{tabular}{|c|} 
Expressly \\
Mentioned UN \\
Members (\& \\
Colonial \\
Holdings \& \\
Protectorates, \\
if any) \\
\end{tabular} & \begin{tabular}{|l} 
Express or \\
Implied \\
Assertion of \\
Individual, \\
Collective, or \\
Both Self- \\
defense
\end{tabular} & \begin{tabular}{|c} 
Nature of \\
the Alleged \\
Threat
\end{tabular} & $\begin{array}{l}\text { Expressly Alleged } \\
\text { Author(s) of the } \\
\text { Threat (If Any } \\
\text { Indicated) }\end{array}$ & \begin{tabular}{|c|} 
Nature of the \\
Alleged \\
Author(s) of \\
the Threat (If \\
Any \\
Indicated) \\
\end{tabular} & $\begin{array}{l}\text { Summary of Alleged Self-defense } \\
\text { Grounds }\end{array}$ & \begin{tabular}{|c|} 
UNSC \\
Meeting(s) \\
(If Any) at \\
Which the \\
Comm. was \\
Raised \\
\end{tabular} & $\begin{array}{l}\text { Responsive Act (If Any) by the } \\
\text { UNSC }\end{array}$ & \begin{tabular}{||c} 
UN \\
Repertory \\
Inclusion?
\end{tabular} & \begin{tabular}{|} 
UNSC \\
Repertoire \\
Inclusion?
\end{tabular} & \begin{tabular}{|c||} 
URL to an \\
English \\
Text
\end{tabular} & \begin{tabular}{||c||} 
URL to Non- \\
English \\
Original \\
Text (ff Any)
\end{tabular} & $\begin{array}{l}\text { Perma.cc } \\
\text { URL }\end{array}$ \\
\hline 127 & 1972.05.08 & 1972.05.09 & $s / 10631$ & $\begin{array}{l}\text { United } \\
\text { States }\end{array}$ & $\begin{array}{l}\text { United States, } \\
\text { South } \\
\text { Vietnam, } \\
\text { North } \\
\text { Vietnam, } \\
\text { Soviet Union }\end{array}$ & $\begin{array}{l}\text { Express } \\
\text { assertion of } \\
\text { "collective" } \\
\text { self-defense }\end{array}$ & $\begin{array}{c}\text { Conducted } \\
\text { attack }\end{array}$ & North Vietnam & State & \begin{tabular}{|l} 
Invasion across de-militarized zone by \\
North Vietnamese forces: "[the \\
President of the United States of \\
America today announced that he had \\
directed United States forces in South- \\
East Asia to take eadditional measures, \\
in conjunction with the forces of the \\
Republic of Viet-Nam, in response to \\
the new armed attacks launched by \\
North Viet-Nam. The President \\
directed that the entrances to the \\
ports of North Viet-Nam be mined and \\
that the delivery of seaborne supplies \\
to North Viet-Nam be prevented."
\end{tabular} & $\begin{array}{l}\text { None } \\
\text { identified }\end{array}$ & None identified & $\begin{array}{l}\text { None } \\
\text { identified }\end{array}$ & $\begin{array}{l}\text { None } \\
\text { identified }\end{array}$ & 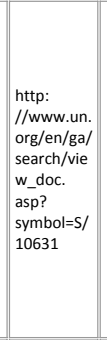 & & \begin{tabular}{|l} 
https: \\
//perma. \\
c/9WWR- \\
UK54
\end{tabular} \\
\hline 128 & 1972.09.27 & 1972.09.27 & $s / 10801$ & Israel & $\begin{array}{l}\text { Israel, } \\
\text { Lebanon, } \\
\text { Egypt, Syria }\end{array}$ & $\begin{array}{c}\text { Implied } \\
\text { assertion of } \\
\text { "individual" } \\
\text { self-defense }\end{array}$ & $\begin{array}{c}\text { Conducted } \\
\text { attack }\end{array}$ & $\begin{array}{c}\text { Lebanon and } \\
\text { "murder squads"/ } \\
\text { "error } \\
\text { organizations" }\end{array}$ & $\begin{array}{c}\text { State and } \\
\text { non-state } \\
\text { actors }\end{array}$ & \begin{tabular}{|l} 
Reiterating an earlier report that \\
Israel's action on 16 September 1972 \\
was part of Israel's continuing defense \\
against terror organizations, which \\
Lebanese authorities "continue to \\
support and shelter ... thus compelling \\
Israel to strike back at them in the \\
exercise of legitimate self-defence."
\end{tabular} & $\begin{array}{l}\text { None } \\
\text { identified }\end{array}$ & None identified & $\begin{array}{l}\text { None } \\
\text { identified }\end{array}$ & $\begin{array}{l}\text { None } \\
\text { identified }\end{array}$ & \begin{tabular}{|l||} 
http: \\
//www.un. \\
org/en/ga/ \\
search/vie \\
W_doc. \\
asp? \\
symbol=s/ \\
10801
\end{tabular} & & \begin{tabular}{|l} 
https: \\
//perma. \\
cc/7G9a- \\
v8FS
\end{tabular} \\
\hline 129 & 1973.09.16 & 1973.09.16 & $5 / 11030$ & Israel & $\begin{array}{l}\text { Israel, Egypt, } \\
\text { Syria }\end{array}$ & \begin{tabular}{|c|} 
Implied \\
assertion of \\
"individual" \\
self-defense
\end{tabular} & $\begin{array}{c}\text { Conducted } \\
\text { attack }\end{array}$ & $\begin{array}{l}\text { Egypt, Syria, and } \\
\text { "other Arab" } \\
\text { States" }\end{array}$ & States & $\begin{array}{l}\text { Attack on Israel by Egypt, Syria, and } \\
\text { "other Arab States": “As confirmed by } \\
\text { the independent testimony of United } \\
\text { Nations military observers, Egypt and } \\
\text { Syria, on } 6 \text { October, launched a } \\
\text { massive military attack against Israel, } \\
\text { in which they are aided by other Arab } \\
\text { States. In the exercise of the inherent } \\
\text { right of selff-defence, Israel is } \\
\text { conducting the military operations } \\
\text { necessitated by the situation created } \\
\text { by the Egyptian onslaught. In the } \\
\text { course of these operations, the Israeli } \\
\text { Air Force has taken action against } \\
\text { military targets in Egypt...." }\end{array}$ & $\begin{array}{l}\text { None } \\
\text { identified }\end{array}$ & None identified & $\begin{array}{l}\text { None } \\
\text { identified }\end{array}$ & $\begin{array}{l}\text { None } \\
\text { identified }\end{array}$ & \begin{tabular}{l|l||} 
http: \\
//www.un. \\
orge/en/ga/ \\
search/vie \\
w_doc. \\
asp? \\
spmbol=s/ \\
11030
\end{tabular} & & $\begin{array}{l}\text { https: } \\
\text { //perma. } \\
\text { cc/grvX- } \\
\text { w9VD }\end{array}$ \\
\hline 130 & 1973.10.07 & 1973.10.07 & $S / 11011$ & Israel & $\begin{array}{l}\text { Israel, Egypt, } \\
\text { Syria }\end{array}$ & \begin{tabular}{|l} 
Implied \\
assertion of \\
"individual" \\
self-defense
\end{tabular} & $\begin{array}{c}\text { Conducted } \\
\text { attack }\end{array}$ & Egypt and Syria & States & $\begin{array}{l}\text { Egypt and Syria launched an attack } \\
\text { against Israel: “...Egypt and Syria } \\
\text { launched a sudden unprovoked attack } \\
\text { against Israel across the cease-fire } \\
\text { lines. The fact of this aggression has } \\
\text { been fully confirmed by United } \\
\text { Nations military observers in the two } \\
\text { sectors concerned... Israel is now } \\
\text { engaged in defending itself against } \\
\text { this treacherous assault. It will spare } \\
\text { no effort, in exercise of its right to } \\
\text { self-defence, until the aggressors have } \\
\text { been thrown back and the cease-fire } \\
\text { structure agreed by the parties in } \\
1967 \text { and the 1970 s restored.” }\end{array}$ & $\begin{array}{l}\text { None } \\
\text { identified }\end{array}$ & None identified & $\begin{array}{l}\text { None } \\
\text { identified }\end{array}$ & $\begin{array}{l}\text { None } \\
\text { identified }\end{array}$ & \begin{tabular}{|l||} 
http: \\
//www.un. \\
org///nngal \\
search/vie \\
w_doc. \\
asp? \\
symbol=s/ \\
syo11
\end{tabular} & & \begin{tabular}{|l} 
https: \\
///perma. \\
cc/LLT5- \\
GFZ6
\end{tabular} \\
\hline
\end{tabular}


VI. HLS PILAC Catalogue of Apparent “Article 51 Communications”

\begin{tabular}{|c|c|c|c|c|c|c|c|c|c|c|c|c|c|c|c|c|c|}
\hline $\begin{array}{l}\text { Chron. } \\
\text { Order }\end{array}$ & $\begin{array}{l}\text { Date of } \\
\text { comm. }\end{array}$ & $\begin{array}{c}\text { Date of } \\
\text { UNSC } \\
\text { Document }\end{array}$ & UNSC Symbol & \begin{tabular}{||c} 
Member \\
State(s) That \\
Submitted \\
the Comm.
\end{tabular} & \begin{tabular}{||c||} 
Expressly \\
Mentioned UN \\
Members (\& \\
Colonial \\
Holdings \& \\
Protectorates, \\
if any) \\
\end{tabular} & \begin{tabular}{|c|} 
Express or \\
Implied \\
Assertion of \\
Individual, \\
Collective, or \\
Both Self- \\
defense \\
\end{tabular} & \begin{tabular}{|l} 
Nature of \\
the Alleged \\
Threat
\end{tabular} & $\begin{array}{l}\text { Expressly Alleged } \\
\text { Author(s) of the } \\
\text { Threat (ff Any } \\
\text { Indicated) }\end{array}$ & \begin{tabular}{|c} 
Nature of the \\
Alleged \\
Author(s) of \\
the Threat (If \\
Any \\
Indicated)
\end{tabular} & $\begin{array}{l}\text { Summary of Alleged Self-defense } \\
\text { Grounds }\end{array}$ & $\begin{array}{c}\text { UNSC } \\
\text { Meeting(s) } \\
\text { (If Any) at } \\
\text { Which the } \\
\text { Comm. was } \\
\text { Raised }\end{array}$ & $\begin{array}{l}\text { Responsive Act (If Any) by the } \\
\text { UNSC }\end{array}$ & \begin{tabular}{|l} 
UN \\
Repertory \\
Inclusion?
\end{tabular} & \begin{tabular}{|c|} 
UNSC \\
Repertore \\
Inclusion?
\end{tabular} & \begin{tabular}{|c||} 
URL to an \\
English \\
Text
\end{tabular} & \begin{tabular}{||c||} 
URL to Non- \\
English \\
Original \\
Text (If Any)
\end{tabular} & $\begin{array}{l}\text { Perma.cc } \\
\text { URL }\end{array}$ \\
\hline 131 & 1974.01.21 & 1974.01.21 & $s / 11201$ & China & $\begin{array}{l}\text { China, South } \\
\text { Vietnam }\end{array}$ & $\begin{array}{c}\text { Implied } \\
\text { assertion of } \\
\text { "individual" } \\
\text { self-defense }\end{array}$ & \begin{tabular}{|c} 
Conducted \\
attack
\end{tabular} & South Vietnam & State & 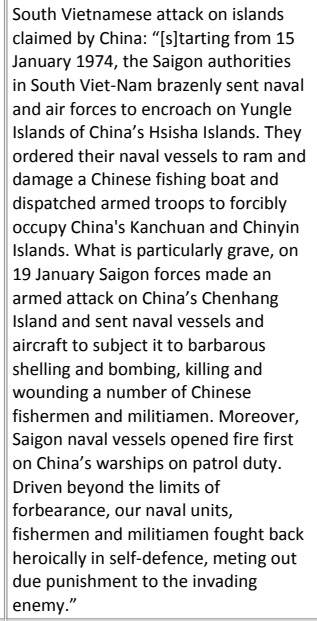 & $\begin{array}{l}\text { None } \\
\text { identified }\end{array}$ & None identified & $\begin{array}{l}\text { None } \\
\text { identified }\end{array}$ & \begin{tabular}{|l} 
None \\
identified
\end{tabular} & 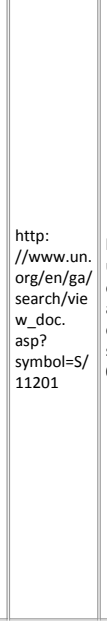 & \begin{tabular}{|l} 
http://www. \\
un. \\
org/en/ga/se \\
arch//iew_do \\
c.asp? \\
symbol=s/112 \\
018Llang=C
\end{tabular} & \begin{tabular}{|l} 
hitps: \\
//perma. \\
ccl/C2TD- \\
72CA
\end{tabular} \\
\hline 132 & 1974.03.06 & 1974.03.06 & $s / 11230$ & Iran & Iran, Iraq & $\begin{array}{c}\text { Implied } \\
\text { assertion of } \\
\text { "individual" } \\
\text { self-defense }\end{array}$ & \begin{tabular}{|c} 
Conducted \\
attack
\end{tabular} & Iraq & State & $\begin{array}{l}\text { Iraqi forces firing on Iranian border } \\
\text { patrols: “... Iraqi forces resumed the } \\
\text { shelling of Iranian border posts in the } \\
\text { area of Khan Leili. Iranian border } \\
\text { patrols, acting in self-defence, } \\
\text { returned the fire. So far, one Iranian } \\
\text { soldier has been killed and three have } \\
\text { been injured." }\end{array}$ & \begin{tabular}{|l} 
None \\
identified
\end{tabular} & None identified & $\begin{array}{l}\text { None } \\
\text { identified }\end{array}$ & \begin{tabular}{|l|l} 
None \\
identified
\end{tabular} & \begin{tabular}{|l||} 
http: \\
//www.un. \\
orge//gn/ga/ \\
search/vie \\
w_doc. \\
asp? \\
spmbol=s/ \\
y1230 \\
\end{tabular} & & $\begin{array}{l}\text { hitps: } \\
\text { //perma. } \\
\text { cc/6BUL- } \\
\text { 4STF }\end{array}$ \\
\hline 133 & 1974.03.12 & 1974.03.12 & $\mathrm{s} / 11233$ & Iraq & Iraq, Iran & $\begin{array}{c}\text { Implied } \\
\text { assertion of } \\
\text { "individual" } \\
\text { self-defense }\end{array}$ & $\begin{array}{c}\text { Conducted } \\
\text { attack }\end{array}$ & Iran & State & 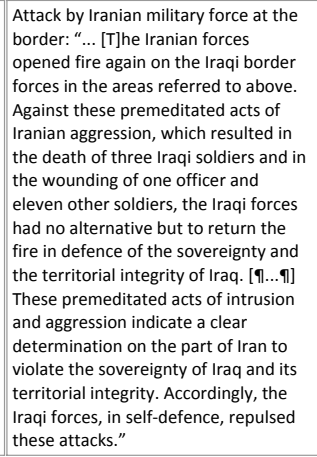 & $\begin{array}{l}\text { None } \\
\text { identified }\end{array}$ & None identified & $\begin{array}{l}\text { None } \\
\text { identified }\end{array}$ & $\begin{array}{l}\text { None } \\
\text { identified }\end{array}$ & \begin{tabular}{|l||} 
http: \\
//wwww.un. \\
org/en/ga/ \\
search/vie \\
w_doc. \\
asp? \\
symbol=s/ \\
11233
\end{tabular} & & $\begin{array}{l}\text { hitps: } \\
\text { //perma. } \\
\text { cc//4GLL- } \\
\text { 7ESB }\end{array}$ \\
\hline 134 & 1974.04.10 & 1974.04.10 & $s / 11257$ & Israel & Israel, Syria & $\begin{array}{c}\text { Implied } \\
\text { assertion of } \\
\text { "individual" } \\
\text { self-defense }\end{array}$ & \begin{tabular}{|c} 
Conducted \\
attack
\end{tabular} & Syria & State & $\begin{array}{l}\text { Armed attacks by Syria along the } \\
\text { cease-fire line: "ijn the face of Syria's } \\
\text { grave and ceaseless aggression and its } \\
\text { aforesaid incursion, the Israeli forces } \\
\text { have, as in the past, responded in self- } \\
\text { defence and have acted to preserve } \\
\text { the integrity of the cease-fire line." }\end{array}$ & \begin{tabular}{|l} 
None \\
identified
\end{tabular} & None identified & $\begin{array}{l}\text { None } \\
\text { identified }\end{array}$ & \begin{tabular}{|l} 
None \\
identified
\end{tabular} & \begin{tabular}{|l||} 
http: \\
//www.un. \\
orge//gal \\
search/vie \\
w_doc. \\
asp? \\
symbol=s/ \\
11257 \\
1257
\end{tabular} & & $\begin{array}{l}\text { https: } \\
\text { //perma. } \\
\text { cc } \\
\text { EusGa- } \\
\text { Eusa }\end{array}$ \\
\hline
\end{tabular}


VI. HLS PILAC Catalogue of Apparent “Article 51 Communications”

\begin{tabular}{|c|c|c|c|c|c|c|c|c|c|c|c|c|c|c|c|c|c|}
\hline $\begin{array}{l}\text { Chron. } \\
\text { Order }\end{array}$ & $\begin{array}{l}\text { Date of } \\
\text { Comm. }\end{array}$ & $\begin{array}{c}\text { Date of } \\
\text { UNsc } \\
\text { Document }\end{array}$ & UNSC Symbol & \begin{tabular}{|c} 
Member \\
State(s) That \\
Submitted \\
the Comm.
\end{tabular} & \begin{tabular}{|c} 
Expressly \\
Mentioned UN \\
Members (\& \\
Colonial \\
Holdings \& \\
Protectorates, \\
if any)
\end{tabular} & \begin{tabular}{|c} 
Express or \\
Implied \\
Assertion of \\
Individual, \\
Collective, or \\
Both Self- \\
defense \\
\end{tabular} & $\begin{array}{c}\text { Nature of } \\
\text { the Alleged } \\
\text { Threat }\end{array}$ & \begin{tabular}{|l|} 
Expressly Alleged \\
Author(s) of the \\
Threat (If Any \\
Indicated)
\end{tabular} & \begin{tabular}{|l|} 
Nature of the \\
Alleged \\
Author(s) of \\
the Threat (If \\
Any \\
Indicated)
\end{tabular} & $\begin{array}{l}\text { Summary of Alleged Self-defense } \\
\text { Grounds }\end{array}$ & \begin{tabular}{|c|} 
UNsc \\
Meeting(s) \\
(if Any) at \\
Which the \\
Comm. was \\
Raised
\end{tabular} & $\begin{array}{l}\text { Responsive Act (If Any) by the } \\
\text { UNSC }\end{array}$ & \begin{tabular}{||c} 
UN \\
Repertory \\
Inclusion?
\end{tabular} & \begin{tabular}{|c|} 
UNSC \\
Repertoire \\
Inclusion?
\end{tabular} & \begin{tabular}{|l} 
URL to an \\
English \\
Text
\end{tabular} & \begin{tabular}{|c} 
URL to Non- \\
English \\
Original \\
Text (If Any)
\end{tabular} & $\begin{array}{c}\text { Perma.cc } \\
\text { URL }\end{array}$ \\
\hline 135 & 1974.04.16 & 1974.04.16 & $S / 11267$ & Israel & $\begin{array}{l}\text { Israel, Syria, } \\
\text { Soviet Union }\end{array}$ & $\begin{array}{c}\text { Implied } \\
\text { assertion of } \\
\text { "individual" } \\
\text { self-defense }\end{array}$ & $\begin{array}{c}\text { Conducted } \\
\text { attack }\end{array}$ & Syria & State & $\begin{array}{l}\text { Syrian attacks across cease-fire line, } \\
\text { amid statements that Syrian } \\
\text { government considers the war to be } \\
\text { ongoing. “... Syrian forces carried out } \\
\text { armed incursions and assaults across } \\
\text { the cease-fire line in the Hermon area } \\
\text { causing the Israel Defence Forces to } \\
\text { respond in self-defence and with a } \\
\text { view to preserving the integrity of the } \\
\text { cease-fire line and repelling the Syrian } \\
\text { attacks.” }\end{array}$ & $\begin{array}{l}\text { None } \\
\text { identified }\end{array}$ & None identified & $\begin{array}{l}\text { None } \\
\text { identified }\end{array}$ & $\begin{array}{l}\text { None } \\
\text { identified }\end{array}$ & $\begin{array}{l}\text { http: } \\
\text { //www.un. } \\
\text { org/en/ga/ } \\
\text { search/vie } \\
\text { w_doc. } \\
\text { asp? } \\
\text { symbol=S/ } \\
11267\end{array}$ & & $\begin{array}{l}\text { hittps: } \\
\text { ///perma. } \\
\text { cc/JuYg- } \\
\text { www4 }\end{array}$ \\
\hline 136 & 1974.04.22 & 1974.04.22 & $S / 11270$ & Israel & Israel, Syria & $\begin{array}{l}\text { Implied } \\
\text { assertion of } \\
\text { "individual" } \\
\text { self-defense }\end{array}$ & $\begin{array}{c}\text { Conducted } \\
\text { attack }\end{array}$ & Syria & State & $\begin{array}{l}\text { Syrian attacks continue along the } \\
\text { cease-fire line: "[d]uring this period, } \\
\text { the Syrian forces have perpetrated } 38 \\
\text { artillery attacks, including attacks in } \\
\text { the Hermon area, and opened anti- } \\
\text { tank missile fire in one case. These } \\
\text { Syrian attacks have resulted in } \\
\text { casualties. As in the past, the Israel } \\
\text { Defence Forces were constrained to } \\
\text { take action in self-defence and to } \\
\text { ensure the integrity of the cease-fire } \\
\text { line." }\end{array}$ & $\begin{array}{l}\text { None } \\
\text { identified }\end{array}$ & None identified & $\begin{array}{l}\text { None } \\
\text { identified }\end{array}$ & $\begin{array}{l}\text { None } \\
\text { identified }\end{array}$ & $\begin{array}{l}\text { http: } \\
\text { //www.un. } \\
\text { org/en/ga/ } \\
\text { search/vie } \\
\text { w_doc. } \\
\text { asp? } \\
\text { symbol=S/ } \\
11270\end{array}$ & & \begin{tabular}{|l} 
hitps: \\
///perma. \\
cc//NZW6- \\
a37E
\end{tabular} \\
\hline 137 & 1974.05.18 & 1974.05.18 & $S / 11290$ & Israel & Israel, Lebanon & $\begin{array}{l}\text { Implied } \\
\text { assertion of } \\
\text { "individual" } \\
\text { self-defense }\end{array}$ & $\begin{array}{c}\text { Conducted } \\
\text { attack }\end{array}$ & $\begin{array}{l}\text { Lebanon and terror } \\
\text { organizations in } \\
\text { Lebanon ("murder } \\
\text { organizations"/ } \\
\text { "murder squad") }\end{array}$ & $\begin{array}{c}\text { State and } \\
\text { non-state } \\
\text { actors }\end{array}$ & 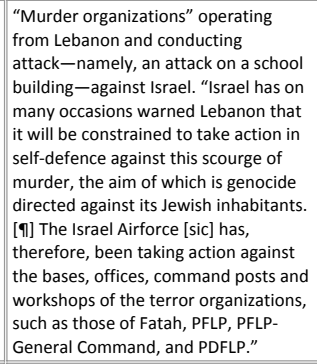 & $\begin{array}{l}\text { S/PV.2113 } \\
\text { (2113th) }\end{array}$ & None identified & $\begin{array}{l}\text { None } \\
\text { identified }\end{array}$ & $\begin{array}{l}\text { None } \\
\text { identified }\end{array}$ & $\begin{array}{l}\text { http: } \\
\text { //www.un. } \\
\text { org/en/ga/ } \\
\text { search/vie } \\
\text { w_doc. } \\
\text { asp? } \\
\text { symbol=s/ } \\
11290\end{array}$ & & $\begin{array}{l}\text { hitps: } \\
\text { //perma. } \\
\text { cc/867X- } \\
\text { NaG3 }\end{array}$ \\
\hline 138 & 1974.12.19 & 1974.12.19 & $s / 11585$ & Israel & Israel, Lebanon & $\begin{array}{c}\text { Implied } \\
\text { assertion of } \\
\text { "individual" } \\
\text { self-defense }\end{array}$ & $\begin{array}{c}\text { Conducted } \\
\text { attack }\end{array}$ & \begin{tabular}{|l} 
Lebanon and terror \\
organizations in \\
Lebanon ("PLO \\
terror \\
organizations")
\end{tabular} & $\begin{array}{c}\text { State and } \\
\text { non-state } \\
\text { actors }\end{array}$ & 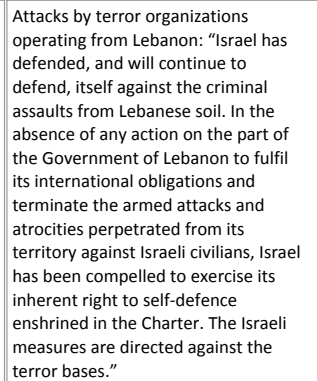 & $\begin{array}{l}\text { None } \\
\text { identified }\end{array}$ & None identified & $\begin{array}{l}\text { None } \\
\text { identified }\end{array}$ & $\begin{array}{l}\text { None } \\
\text { identified }\end{array}$ & $\begin{array}{l}\text { http: } \\
\text { //www.un. } \\
\text { org/en/ga/ } \\
\text { search/vie } \\
\text { w_doc. } \\
\text { asp? } \\
\text { symbol=S/ } \\
11585\end{array}$ & & $\begin{array}{l}\text { hitps: } \\
\text { //perma. } \\
\text { cc/L4us- } \\
\text { 30/8 }\end{array}$ \\
\hline
\end{tabular}


VI. HLS PILAC Catalogue of Apparent “Article 51 Communications”

\begin{tabular}{|c|c|c|c|c|c|c|c|c|c|c|c|c|c|c|c|c|c|}
\hline $\begin{array}{l}\text { Chron. } \\
\text { Order }\end{array}$ & $\begin{array}{l}\text { Date of } \\
\text { comm. }\end{array}$ & $\begin{array}{c}\text { Date of } \\
\text { UNsC } \\
\text { Document }\end{array}$ & UNSC Symbol & \begin{tabular}{||c} 
Member \\
State(s) That \\
Submitted \\
the Comm.
\end{tabular} & \begin{tabular}{|c|} 
Expressly \\
Mentioned UN \\
Members (\& \\
Colonial \\
Holdings \& \\
Protectorates, \\
if any)
\end{tabular} & \begin{tabular}{|c|} 
Express or \\
Implied \\
Assertion of \\
Individual, \\
Collective, or \\
Both Self- \\
defense
\end{tabular} & \begin{tabular}{|l}
$\begin{array}{c}\text { Nature of } \\
\text { the Alleged } \\
\text { Threat }\end{array}$
\end{tabular} & $\begin{array}{l}\text { Expressly Alleged } \\
\text { Author(s) of the } \\
\text { Threat (If Any } \\
\text { Indicated) }\end{array}$ & $\begin{array}{l}\text { Nature of the } \\
\text { Alleged } \\
\text { Author(s) of } \\
\text { the Threat (If } \\
\text { Any } \\
\text { Indicated) }\end{array}$ & $\begin{array}{l}\text { Summary of Alleged Self-defense } \\
\text { Grounds }\end{array}$ & $\begin{array}{c}\text { UNSC } \\
\text { Meeting(s) } \\
\text { (If Any) at } \\
\text { Which the } \\
\text { Comm. was } \\
\text { Raised }\end{array}$ & $\begin{array}{l}\text { Responsive Act (ff Any) by the } \\
\text { UNSC }\end{array}$ & \begin{tabular}{||c} 
UN \\
Repertory \\
Inclusion?
\end{tabular} & $\begin{array}{c}\text { UNSC } \\
\text { Repertoire } \\
\text { Inclusion? }\end{array}$ & \begin{tabular}{|c||} 
URL to an \\
English \\
Text
\end{tabular} & \begin{tabular}{||c||} 
URL to Non- \\
English \\
Original \\
Text (ff Any)
\end{tabular} & $\begin{array}{l}\text { Perma.cc } \\
\text { URL }\end{array}$ \\
\hline 139 & 1975.05.14 & 1975.05.15 & $s / 11689$ & $\begin{array}{l}\text { United } \\
\text { States }\end{array}$ & $\begin{array}{c}\text { United States, } \\
\text { Cambodia, } \\
\text { South Vietnam }\end{array}$ & $\begin{array}{l}\text { Implied } \\
\text { assertion of } \\
\text { "individual" } \\
\text { self-defense }\end{array}$ & $\begin{array}{c}\text { Conducted } \\
\text { attack }\end{array}$ & Cambodia & State & $\begin{array}{l}\text { Unarmed commercial vessel owned by } \\
\text { an American company fired on and } \\
\text { forcibly boarded by Cambodian } \\
\text { authorities: "tthe United States } \\
\text { Government immediately took steps } \\
\text { through diplomatic channels to } \\
\text { recover the vessel and arrange the } \\
\text { return of the crew. It earnestly sought } \\
\text { the urgent co-operation of all } \\
\text { concerned to this end, but no } \\
\text { response has been forthcoming." }\end{array}$ & $\begin{array}{l}\text { None } \\
\text { identified }\end{array}$ & None identified & $\begin{array}{l}\text { None } \\
\text { identified }\end{array}$ & $\begin{array}{l}\text { None } \\
\text { identified }\end{array}$ & \begin{tabular}{|l||} 
http: \\
//www.un. \\
orge//gn/gal \\
search//vie \\
w_doc. \\
asp? \\
spmbol=s/ \\
symbs \\
11689
\end{tabular} & & $\begin{array}{l}\text { https: } \\
\text { //perma. } \\
\text { cc//PHC- } \\
\text { 7WSE }\end{array}$ \\
\hline 140 & 1975.05.14 & 1975.05.15 & $\mathrm{s} / 11690$ & Israel & Israel, Lebanon & $\begin{array}{c}\text { Implied } \\
\text { assertion of } \\
\text { "individual" } \\
\text { self-defense }\end{array}$ & $\begin{array}{c}\text { Conducted } \\
\text { attack }\end{array}$ & $\begin{array}{l}\text { Lebanon and } \\
\text { Palestinian } \\
\text { "murder } \\
\text { organizations" }\end{array}$ & $\begin{array}{c}\text { State and } \\
\text { non-state } \\
\text { actors }\end{array}$ & 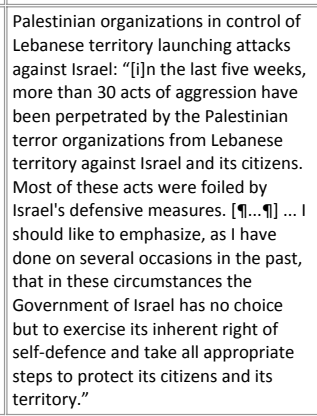 & $\begin{array}{l}\text { None } \\
\text { identified }\end{array}$ & None identified & $\begin{array}{l}\text { None } \\
\text { identified }\end{array}$ & \begin{tabular}{|l} 
None \\
identified
\end{tabular} & \begin{tabular}{|l||} 
http: \\
//www.un. \\
org///nn/gal \\
search/vie \\
w_doc. \\
asp? \\
symbol=s/ \\
symbol \\
11690
\end{tabular} & & $\begin{array}{l}\text { hitps: } \\
\text { //Perma. } \\
\text { cc/NENA- } \\
\text { HH2D }\end{array}$ \\
\hline 141 & 1975.08.26 & 1975.08.26 & $\mathrm{s} / 11817$ & Israel & Israel, Lebanon & $\begin{array}{c}\text { Implied } \\
\text { assertion of } \\
\text { "individual" } \\
\text { self-defense }\end{array}$ & $\begin{array}{c}\text { Conducted } \\
\text { attack }\end{array}$ & $\begin{array}{l}\text { Lebanon and PLO } \\
\text { "terror } \\
\text { organization" }\end{array}$ & $\begin{array}{c}\text { State and } \\
\text { non-state } \\
\text { actors }\end{array}$ & 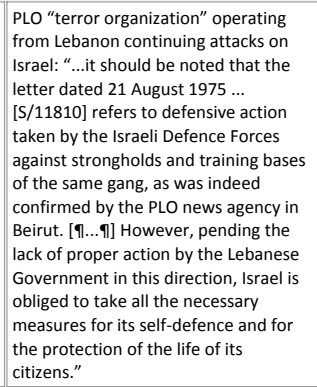 & $\begin{array}{l}\text { None } \\
\text { identified }\end{array}$ & None identified & $\begin{array}{l}\text { None } \\
\text { identified }\end{array}$ & $\begin{array}{l}\text { None } \\
\text { identified }\end{array}$ & \begin{tabular}{|l||} 
http: \\
//www.un. \\
org///nnga/ \\
search/vie \\
w_doc. \\
asp? \\
symbol=s/ \\
s1817
\end{tabular} & & $\begin{array}{l}\text { hitps: } \\
\text { //perma. } \\
\text { ccl/775- } \\
\text { r26F }\end{array}$ \\
\hline 142 & 1976.07.09 & 1976.07.09 & S/PV.1939 & Israel & \begin{tabular}{|l} 
Israel, Uganda, \\
Libya, Austria, \\
France, \\
Lebanon, \\
Sudan, Tunisia, \\
West \\
Germany, \\
France, \\
Switzerland, \\
Kenya, \\
Somalia, \\
Ethiopia, \\
Djibouti, \\
United States, \\
Tanzania,
\end{tabular} & $\begin{array}{l}\text { Implied } \\
\text { assertion of } \\
\text { "individual" } \\
\text { self-defense }\end{array}$ & \begin{tabular}{|l} 
Conducted \\
attack, \\
threat of \\
attack
\end{tabular} & $\begin{array}{l}\text { Ugandan } \\
\text { Government and } \\
\text { the PLO }\end{array}$ & $\begin{array}{c}\text { State and } \\
\text { non-state } \\
\text { actors }\end{array}$ & $\begin{array}{l}\text { Hijacking of Air France flight } 139 \text { and } \\
\text { hostage-taking }\end{array}$ & $\begin{array}{l}\text { S/PV.1939 } \\
\text { (1939th), } \\
\text { S/PV.1340 } \\
\text { (1340th), S. } \\
\text { PV/1341 } \\
\text { (1341st), S. } \\
\text { PV/1342 } \\
\text { (1342nd), S. } \\
\text { PV/1343 } \\
\text { (1343rd) (see } \\
\text { also } \\
\text { document } \\
\text { S/12123) }\end{array}$ & None identified & $\begin{array}{l}\text { None } \\
\text { identified }\end{array}$ & $\begin{array}{l}\text { Articles 48- } \\
51\end{array}$ & \begin{tabular}{|l||} 
https: \\
//documen \\
ts-dds-ny. \\
un. \\
org/doc/U \\
NDOC/GEN \\
NDL/760/ \\
Th/pdf/NL \\
796007. \\
pdf? \\
OpenElem \\
ent
\end{tabular} & & $\begin{array}{l}\text { https: } \\
\text { //perma. } \\
\text { cc//WKV2- } \\
\text { DHV8 }\end{array}$ \\
\hline
\end{tabular}


VI. HLS PILAC Catalogue of Apparent “Article 51 Communications”

\begin{tabular}{|c|c|c|c|c|c|c|c|c|c|c|c|c|c|c|c|c|c|}
\hline $\begin{array}{l}\text { Chron. } \\
\text { Order }\end{array}$ & $\begin{array}{l}\text { Date of } \\
\text { Comm. }\end{array}$ & $\begin{array}{c}\text { Date of } \\
\text { UNSC } \\
\text { Document }\end{array}$ & | UNSC Symbol & \begin{tabular}{|c} 
Member \\
State(s) That \\
Submitted \\
the Comm.
\end{tabular} & \begin{tabular}{|c|} 
Expressly \\
Mentioned UN \\
Members (\& \\
Colonial \\
Holdings \& \\
Protectorates, \\
if any) \\
\end{tabular} & \begin{tabular}{||c|} 
Express or \\
Implied \\
Assertion of \\
Individual, \\
Collective, or \\
Both Self- \\
defense \\
\end{tabular} & \begin{tabular}{|l} 
Nature of \\
the Alleged \\
Threat
\end{tabular} & $\begin{array}{l}\text { Expressly Alleged } \\
\text { Author(s) of the } \\
\text { Threat (If fany } \\
\text { Indicated) }\end{array}$ & \begin{tabular}{|c} 
Nature of the \\
Alleged \\
Author(s) of \\
the Threat (ff \\
Any \\
Indicated)
\end{tabular} & $\begin{array}{l}\text { Summary of Alleged Self-defense } \\
\text { Grounds }\end{array}$ & \begin{tabular}{|c} 
UNSC \\
Meeting(s) \\
(If Any) at \\
Which the \\
Comm. was \\
Raised
\end{tabular} & $\begin{array}{l}\text { Responsive Act (If Any) by the } \\
\text { UNSC }\end{array}$ & $\begin{array}{l}\text { UN } \\
\text { Repertory } \\
\text { Inclusion? }\end{array}$ & \begin{tabular}{|l} 
UNSC \\
Repertoire \\
Inclusion?
\end{tabular} & \begin{tabular}{|c||} 
URL to an \\
English \\
Text
\end{tabular} & \begin{tabular}{||c||} 
URL to Non- \\
English \\
Original \\
Text (ff Any)
\end{tabular} & $\begin{array}{l}\text { Perma.cc } \\
\text { URL }\end{array}$ \\
\hline 143 & 1977.12.22 & 1977.12.22 & $\mathrm{s} / 12504$ & Mauritania & $\begin{array}{l}\text { Mauritania, } \\
\text { Algeria, } \\
\text { Morocco, } \\
\text { Tunisia, Libya }\end{array}$ & $\begin{array}{l}\text { Implied } \\
\text { assertion of } \\
\text { "individual" } \\
\text { self-defense }\end{array}$ & $\begin{array}{l}\text { Conducted } \\
\text { attack }\end{array}$ & $\begin{array}{l}\text { Algeria and } \\
\text { mercenaries }\end{array}$ & $\begin{array}{c}\text { State and } \\
\text { non-state } \\
\text { actors }\end{array}$ & 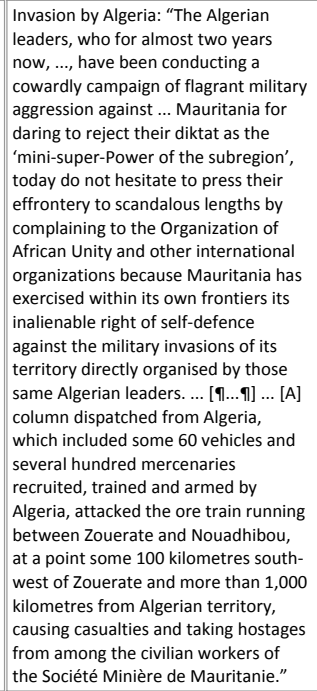 & $\begin{array}{l}\text { None } \\
\text { identified }\end{array}$ & None identified & $\begin{array}{l}\text { None } \\
\text { identified }\end{array}$ & $\begin{array}{l}\text { None } \\
\text { identified }\end{array}$ & 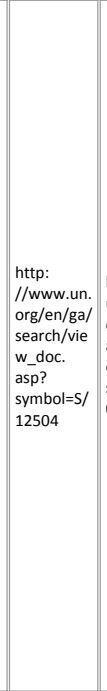 & \begin{tabular}{|l||} 
http://www. \\
un. \\
org/en/ga/se \\
arch//view_do \\
c.asp? \\
symbol=s/125 \\
04\&Llang=F
\end{tabular} & $\begin{array}{l}\text { hitps: } \\
\text { //perma. } \\
\text { cc//E65S- } \\
\text { VEAR }\end{array}$ \\
\hline 144 & 1979.01.08 & 1979.01.08 & $s / 13011$ & Vietnam & $\begin{array}{c}\text { Vietnam, } \\
\text { Kampuchea } \\
\text { [Cambodia], } \\
\text { China }\end{array}$ & $\begin{array}{c}\text { Implied } \\
\text { assertion of } \\
\text { "individual" } \\
\text { self-defense }\end{array}$ & $\begin{array}{c}\text { Conducted } \\
\text { attack }\end{array}$ & $\begin{array}{c}\text { Democratic } \\
\text { Republic of } \\
\text { Kampuchea } \\
\text { [Cambodia] and } \\
\text { China }\end{array}$ & States & \begin{tabular}{|l} 
Pol Pot-leng Sary clique committing \\
attacks against Vietnam: “ijnstigated \\
and supported by the Peking \\
authorities, the Pol Pot-leng Sary \\
clique have waged a large-scale war of \\
aggression along Viet Nam's south- \\
western border, , committing \\
extremely barbarous crimes against \\
the Vietnamese people....”
\end{tabular} & \begin{tabular}{|l} 
None \\
identified
\end{tabular} & None identified & $\begin{array}{l}\text { None } \\
\text { identified }\end{array}$ & Article 2(7) & \begin{tabular}{|l||} 
http: \\
//www.un. \\
org///nngal \\
search/vie \\
w_doc. \\
asp? \\
symbol=s/ \\
syo11
\end{tabular} & & 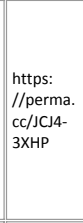 \\
\hline 145 & 1979.02.17 & 1978.02.17 & $s / 13094$ & China & $\begin{array}{c}\text { China, } \\
\text { Vietnam, } \\
\text { Soviet Union }\end{array}$ & $\begin{array}{c}\text { Implied } \\
\text { assertion of } \\
\text { "individual" } \\
\text { self-defense }\end{array}$ & $\begin{array}{c}\text { Conducted } \\
\text { attack }\end{array}$ & Vietnam & State & $\begin{array}{l}\text { "Ignoring China's repeated warnings, } \\
\text { the Vietnamese authorities have of } \\
\text { late continually sent armed forces to } \\
\text { encroach on Chinese territory and } \\
\text { attack Chinese frontier guards and } \\
\text { inhabitants, causing a rapid } \\
\text { deterioration of the situation and } \\
\text { seriously threatening the peace and } \\
\text { security of China's frontiers." }\end{array}$ & $\begin{array}{l}\text { None } \\
\text { identified }\end{array}$ & None identified & $\begin{array}{l}\text { None } \\
\text { identified }\end{array}$ & \begin{tabular}{|l} 
None \\
identified
\end{tabular} & 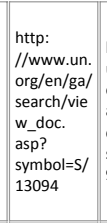 & \begin{tabular}{|l|} 
http://www. \\
un. \\
org/en/ga/se \\
arch/view_do \\
casp? \\
symbol=s/130 \\
94\&Llang=c
\end{tabular} & $\begin{array}{l}\text { hitps: } \\
\text { //perma. } \\
\text { cc//CYYS- } \\
87725\end{array}$ \\
\hline 146 & 1979.04.04 & 1979.04.04 & $\mathrm{s} / 13222$ & Vietnam & Vietnam, China & $\begin{array}{l}\text { Implied } \\
\text { assertion of } \\
\text { "individual" } \\
\text { self-defense }\end{array}$ & $\begin{array}{c}\text { Conducted } \\
\text { attack and } \\
\text { threat of } \\
\text { attack }\end{array}$ & China & State & \begin{tabular}{|l} 
Continuued occupation of Vietnamese \\
territory by Chinese troops, despite \\
statements otherwise: "ssince 17 \\
February 1979, the Chinese rulers \\
have mobilized over half a million \\
troops to wage a war of aggression \\
against Viet Nam, an independent and \\
sovereign country." \\
\end{tabular} & \begin{tabular}{|l} 
None \\
identified
\end{tabular} & None identified & $\begin{array}{l}\text { None } \\
\text { identified }\end{array}$ & $\begin{array}{l}\text { None } \\
\text { identified }\end{array}$ & \begin{tabular}{|l||} 
http: \\
//www.un. \\
org/en/ga/ \\
search/vie \\
w_doc. \\
asp? \\
symbol=s/ \\
13222 \\
\end{tabular} & & $\begin{array}{l}\text { hitps: } \\
\text { //perma. } \\
\text { ccl/6VLL- } \\
\text { H7RL }\end{array}$ \\
\hline
\end{tabular}


VI. HLS PILAC Catalogue of Apparent “Article 51 Communications”

\begin{tabular}{|c|c|c|c|c|c|c|c|c|c|c|c|c|c|c|c|c|c|}
\hline $\begin{array}{c}\text { Chron. } \\
\text { Order }\end{array}$ & $\begin{array}{l}\text { Date of } \\
\text { Comm. }\end{array}$ & $\begin{array}{l}\text { Date of } \\
\text { UNSC } \\
\text { Document }\end{array}$ & UNSC Symbol & \begin{tabular}{||c} 
Member \\
State(s) That \\
Submitted \\
the Comm.
\end{tabular} & \begin{tabular}{|c||} 
Expressly \\
Mentioned UN \\
Members (\& \\
Colonial \\
Holdings \& \\
Protectorates, \\
if any) \\
\end{tabular} & \begin{tabular}{|l|} 
Express or \\
Implied \\
Assertion of \\
Individual, \\
Collective, or \\
Both Self- \\
defense \\
\end{tabular} & \begin{tabular}{|c} 
Nature of \\
the Alleged \\
Threat
\end{tabular} & \begin{tabular}{|l} 
Expressly Alleged \\
Author(s) of the \\
Threat (ff Ann \\
Indicated)
\end{tabular} & \begin{tabular}{|c|} 
Nature of the \\
Alleged \\
Author(s) of \\
the Threat (If \\
Any \\
Indicated) \\
\end{tabular} & $\begin{array}{l}\text { Summary of Alleged Self-defense } \\
\text { Grounds }\end{array}$ & \begin{tabular}{|c|} 
UNSC \\
Meeting(s) \\
(If Any) at \\
Which the \\
Comm. was \\
Raised \\
\end{tabular} & $\begin{array}{l}\text { Responsive Act (If Any) by the } \\
\text { UNSC }\end{array}$ & $\begin{array}{l}\text { UN } \\
\text { Repertory } \\
\text { Inclusion? }\end{array}$ & \begin{tabular}{|} 
UNSC \\
Repertoire \\
Inclusion?
\end{tabular} & \begin{tabular}{|l|} 
URL to an \\
English \\
Text
\end{tabular} & \begin{tabular}{||c||} 
URL to Non- \\
English \\
Original \\
Text (ff Any)
\end{tabular} & $\begin{array}{c}\text { Perma.cc } \\
\text { URL }\end{array}$ \\
\hline 147 & 1979.04.26 & 1979.04.26 & $s / 13275$ & Vietnam & Vietnam, China & $\begin{array}{c}\text { Implied } \\
\text { assertion of } \\
\text { "individual" } \\
\text { self-defense }\end{array}$ & $\begin{array}{c}\text { Conducted } \\
\text { attack }\end{array}$ & China & State & \begin{tabular}{|l} 
Continued attacks by Chinese troops \\
on Vietnamese civilians: “[a]t present, \\
while the negotiations between the \\
two Governments are under way, \\
Chinese troops are still occupying over \\
10 points on Vietnamese territory.... \\
At the same time, the Chinese side has \\
intensified naval intrusions into the \\
territorial waters of Viet Nam. So \\
Chinese forces have violated Viet \\
Nam's territory, territorial waters and \\
air space."
\end{tabular} & $\begin{array}{l}\text { None } \\
\text { identified }\end{array}$ & None identified & $\begin{array}{l}\text { None } \\
\text { identified }\end{array}$ & $\begin{array}{l}\text { None } \\
\text { identified }\end{array}$ & \begin{tabular}{|l||} 
http: \\
l/www.un. \\
org/en/ga/ \\
search/vie \\
w_doc. \\
asp? \\
symbol=s/ \\
13275
\end{tabular} & & \begin{tabular}{|l} 
https: \\
//perma. \\
cc/F44Q- \\
L34Z
\end{tabular} \\
\hline 148 & 1979.05.03 & 1979.05 .03 & $\mathrm{~s} / 13294$ & China & $\begin{array}{c}\text { China, } \\
\text { Vietnam, } \\
\text { Kampuchea } \\
\text { [Cambodia], } \\
\text { Laos }\end{array}$ & $\begin{array}{c}\text { Implied } \\
\text { assertion of } \\
\text { "individual" } \\
\text { self-defense }\end{array}$ & $\begin{array}{c}\text { Conducted } \\
\text { attack }\end{array}$ & Vietnam & State & $\begin{array}{l}\text { Expulsion of Chinese and Vietnamese } \\
\text { citizens into Chinese territory, as well } \\
\text { as clashes at the border: "[t]urning a } \\
\text { deaf ear to China's well-meaning } \\
\text { admonitions and warnings, it became } \\
\text { more unscrupulous and continued to } \\
\text { escalate its armed provocations and } \\
\text { incursions. It was only when things } \\
\text { became absolutely intolerable that } \\
\text { Chinese frontier troops exercised their } \\
\text { right to self-defence and made the } \\
\text { necessary counter-attack against the } \\
\text { Vietnamese aggressors." }\end{array}$ & \begin{tabular}{|l} 
None \\
identified
\end{tabular} & None identified & $\begin{array}{l}\text { None } \\
\text { identified }\end{array}$ & \begin{tabular}{|l} 
None \\
identified
\end{tabular} & \begin{tabular}{|l||} 
http: \\
|/www.un. \\
org/en/ga/ \\
search/vie \\
w_doc. \\
asp? \\
symbol=s/ \\
13294
\end{tabular} & \begin{tabular}{|l|} 
http://www. \\
un. \\
org/en/ga/se \\
arch/view_do \\
casp? \\
symbol=s/132 \\
94\&Llang=C
\end{tabular} & $\begin{array}{l}\text { https: } \\
\text { //perma. } \\
\text { c/5FZZH- } \\
\text { SNKP } \\
\end{array}$ \\
\hline 149 & 1979.06.13 & 1979.06.14 & S/13394 & Morocco & $\begin{array}{l}\text { Morocco, } \\
\text { Algeria }\end{array}$ & $\begin{array}{l}\text { Implied } \\
\text { assertion of } \\
\text { "individual" } \\
\text { self-defense }\end{array}$ & $\begin{array}{c}\text { Conducted } \\
\text { attack }\end{array}$ & Algeria & State & $\begin{array}{l}\text { "... Morocco was the victim of two } \\
\text { flagrant attacks, carried out and } \\
\text { directed by forces whose point of } \\
\text { departure was situated in } \\
\text { neighbouring Algerian territory, to } \\
\text { which they returned after committing } \\
\text { their heinous crimes." }\end{array}$ & $\begin{array}{l}\text { S/PV.2151 } \\
\text { (2151st); } \\
\text { S/PV.2152 } \\
\text { (2152nd); } \\
\text { S/PV. 2153 } \\
\text { (2153rd); } \\
\text { S/PV. 2154 } \\
\text { (2154th) }\end{array}$ & None identified & $\begin{array}{l}\text { Articles 24, } \\
35, \& 51\end{array}$ & \begin{tabular}{|l} 
Editorial \\
note; \\
Chapter VIII
\end{tabular} & \begin{tabular}{|l||} 
http: \\
//www.un. \\
org/en/ga/ \\
search/vie \\
w_doc. \\
asp? \\
symbol=s/ \\
13394 \\
1394 \\
\end{tabular} & \begin{tabular}{|l|} 
http://www. \\
un. \\
org/en/ga/se \\
arch/view_do \\
casp? \\
symbol=s/133 \\
94\&Llang=F
\end{tabular} & \begin{tabular}{|l} 
https: \\
//perma. \\
cc/C/CLLG- \\
6GR5
\end{tabular} \\
\hline 150 & 1979.09.07 & 1979.09.07 & s/13531 & Vietnam & $\begin{array}{l}\text { Vietnam, Laos, } \\
\text { China, } \\
\text { Kampuchea } \\
\text { [Cambodia] }\end{array}$ & $\begin{array}{c}\text { Implied } \\
\text { assertion of } \\
\text { "individual" } \\
\text { self-defense }\end{array}$ & $\begin{array}{c}\text { Conducted } \\
\text { attack }\end{array}$ & $\begin{array}{c}\text { Kampuchea } \\
\text { [Cambodia] and } \\
\text { China }\end{array}$ & State & 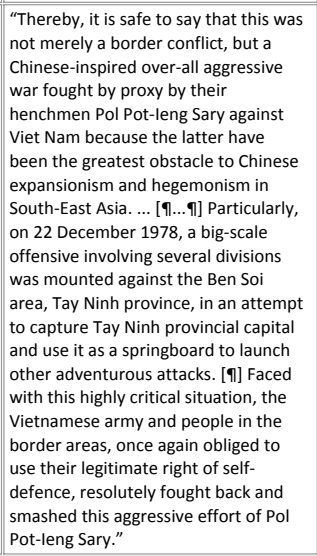 & $\begin{array}{l}\text { None } \\
\text { identified }\end{array}$ & None identified & $\begin{array}{l}\text { None } \\
\text { identified }\end{array}$ & $\begin{array}{l}\text { None } \\
\text { identified }\end{array}$ & \begin{tabular}{|l||} 
http: \\
//www.un. \\
org/en/ga/ \\
search/vie \\
w_doc. \\
asp? \\
symbol=s/ \\
13531
\end{tabular} & & \begin{tabular}{|l} 
https: \\
//perma. \\
cc/aEGM- \\
4Z4K
\end{tabular} \\
\hline
\end{tabular}


VI. HLS PILAC Catalogue of Apparent “Article 51 Communications”

\begin{tabular}{|c|c|c|c|c|c|c|c|c|c|c|c|c|c|c|c|c|c|}
\hline $\begin{array}{c}\text { Chron. } \\
\text { Order }\end{array}$ & $\begin{array}{l}\text { Date of } \\
\text { Comm. }\end{array}$ & $\begin{array}{c}\text { Date of } \\
\text { UNsC } \\
\text { Document }\end{array}$ & UNSC Symbol & \begin{tabular}{||c} 
Member \\
State(s) That \\
Submitted \\
the Comm.
\end{tabular} & \begin{tabular}{|c||} 
Expressly \\
Mentioned UN \\
Members (\& \\
Colonial \\
Holdings \& \\
Protectorates, \\
if any) \\
\end{tabular} & \begin{tabular}{||c|} 
Express or \\
Implied \\
Assertion of \\
Individual, \\
Collective, or \\
Both Self- \\
defense \\
\end{tabular} & \begin{tabular}{|c} 
Nature of \\
the Alleged \\
Threat
\end{tabular} & $\begin{array}{l}\text { Expressly Alleged } \\
\text { Author(s) of the } \\
\text { Threat (If Any } \\
\text { Indicated) }\end{array}$ & \begin{tabular}{|c|} 
Nature of the \\
Alleged \\
Author(s) of \\
the Threat (If \\
Any \\
Indicated) \\
\end{tabular} & $\begin{array}{l}\text { Summary of Alleged Self-defense } \\
\text { Grounds }\end{array}$ & \begin{tabular}{|c|} 
UNSC \\
Meeting(s) \\
(If Any) at \\
Which the \\
Comm. was \\
Raised \\
\end{tabular} & $\begin{array}{l}\text { Responsive Act (If Any) by the } \\
\text { UNSC }\end{array}$ & $\begin{array}{l}\text { UN } \\
\text { Repertory } \\
\text { Inclusion? }\end{array}$ & \begin{tabular}{|c} 
UNsC \\
Repertoire \\
Inclusion?
\end{tabular} & \begin{tabular}{|l||} 
URL to an \\
English \\
Text
\end{tabular} & \begin{tabular}{|c||} 
URL to Non- \\
English \\
OOriginal \\
Tert (ff Any)
\end{tabular} & $\begin{array}{l}\text { Perma.cc } \\
\text { URL }\end{array}$ \\
\hline 151 & 1979.11.23 & 1979.11.26 & $\mathrm{s} / 13647$ & Thailand & $\begin{array}{l}\text { Thailand, } \\
\text { Kampuchea } \\
\text { [Cambodia] }\end{array}$ & \begin{tabular}{|l} 
Implied \\
assertion of \\
"individual" \\
self-defense
\end{tabular} & $\begin{array}{c}\text { Conducted } \\
\text { attack }\end{array}$ & $\begin{array}{l}\text { "Foreign fighters" } \\
\text { inside Kampuchea } \\
\text { [Cambodia] }\end{array}$ & Not indicated & \begin{tabular}{|l} 
Spillover of clashes in Kampuchea \\
[Cambodia] into Thailand's territory: \\
“... while searching for the marine \\
who was misssing as a result of the \\
clash ..., a s 10 -man Thai Patrol Unit \\
came under heavy mortar and M-79 \\
rocket attack, fired from foreign \\
forces inside Kampuchea [Cambodia]. \\
The Thai Patrol Unit, in an act of self- \\
defence, was forced to return fire \\
until the firing ceased at 3 p.m.””
\end{tabular} & $\begin{array}{l}\text { None } \\
\text { identified }\end{array}$ & None identified & $\begin{array}{l}\text { None } \\
\text { identified }\end{array}$ & $\begin{array}{l}\text { None } \\
\text { identified }\end{array}$ & \begin{tabular}{|l||} 
http: \\
|/www.un. \\
org/en/ga/ \\
search/vie \\
w_doc. \\
asp? \\
symbol=s/ \\
13647
\end{tabular} & & \begin{tabular}{|l} 
https: \\
//perma. \\
cc/s6KN- \\
scSU
\end{tabular} \\
\hline 152 & 1979.12.21 & 1979.12.21 & $s / 13701$ & China & China, Vietnam & \begin{tabular}{|c|} 
Implied \\
assertion of \\
"individual" \\
self-defense
\end{tabular} & $\begin{array}{c}\text { Conducted } \\
\text { attack }\end{array}$ & $\begin{array}{l}\text { Viet Nam Socialist } \\
\text { Republic }\end{array}$ & State & \begin{tabular}{|l} 
Armed attack by Vietnamese troops \\
against Chinese border town: “... over \\
one hundred armed Vietnamese \\
personnel invaded the district of \\
Taoguochung, Malipo County, Yunnan \\
Province. They wildly opened fire on a \\
Chinese village and a farm and killed \\
or wounded a number of Chinese \\
border inhabitants and staff and \\
workers of the farm and destroyed \\
some houses, thus inflicting \\
substantial losses of lives and property \\
on the local population. The Chinese \\
border guards and militia there were \\
forced to hit back in self-defence and \\
drove the Vietnamese aggressor \\
troops out of the Chinese border.”
\end{tabular} & $\begin{array}{l}\text { None } \\
\text { identified }\end{array}$ & None identified & $\begin{array}{l}\text { None } \\
\text { identified }\end{array}$ & $\begin{array}{l}\text { None } \\
\text { identified }\end{array}$ & \begin{tabular}{|l||} 
http: \\
|/www.un. \\
org/en/ga/ \\
search/vie \\
w_doc. \\
asp? \\
symbol=s/ \\
13701
\end{tabular} & \begin{tabular}{|l|l} 
http://www. \\
un. \\
org/en/ga/se \\
arch/view_do \\
c.asp? \\
symbol=s/137 \\
01\&lang=c
\end{tabular} & $\begin{array}{l}\text { https: } \\
\text { //perma. } \\
\text { c/ /TP8Z- } \\
\text { PX54 }\end{array}$ \\
\hline 153 & 1980.04 .25 & 1980.04 .25 & $\mathrm{~s} / 13908$ & $\begin{array}{l}\text { United } \\
\text { States }\end{array}$ & $\begin{array}{c}\text { United States, } \\
\text { Iran }\end{array}$ & \begin{tabular}{|c} 
Implied \\
assertion of \\
"individual" \\
self-defense
\end{tabular} & $\begin{array}{c}\text { Conducted } \\
\text { attack }\end{array}$ & Iran & State & Iranian armed attack on U.S. embassy. & \begin{tabular}{|l} 
None \\
identified
\end{tabular} & None identified & $\begin{array}{l}\text { Articles } 51 \\
\text { and } 94\end{array}$ & Article 51 & \begin{tabular}{|l|} 
http: \\
//www.un. \\
organengal \\
search/vie \\
w_doc. \\
asp? \\
symbol=s/ \\
13908 \\
1390
\end{tabular} & & $\begin{array}{l}\text { https: } \\
\text { //perma. } \\
\text { c/L3JM- } \\
\text { RM6J }\end{array}$ \\
\hline 154 & 1980.07.23 & 1980.07.25 & $S / 14072$ & Thailand & $\begin{array}{l}\text { Thailand, } \\
\text { Vietnam, } \\
\text { Kampuchea } \\
\text { [Cambodia] }\end{array}$ & $\begin{array}{c}\text { Implied } \\
\text { assertion of } \\
\text { "individual" } \\
\text { self-defense }\end{array}$ & $\begin{array}{c}\text { Conducted } \\
\text { attack }\end{array}$ & Viet Nam & State & \begin{tabular}{|l} 
Vietnamese troops entering Thailand: \\
"It]he allegation that Thai troops \\
intruded into Kampuchea [Cambodia] \\
is therefore a distortion aimed at \\
creating tension. Thailand was only \\
acting in self-defence when it took \\
action to repulse Vietnamese forces \\
which intruded into Thailand."
\end{tabular} & \begin{tabular}{|l} 
None \\
identified
\end{tabular} & None identified & $\begin{array}{l}\text { None } \\
\text { identified }\end{array}$ & $\begin{array}{l}\text { None } \\
\text { identified }\end{array}$ & \begin{tabular}{|l||} 
http: \\
//www.un. \\
org/en/ga/ \\
search/vie \\
w_doc. \\
asp? \\
symbol=s/ \\
14072
\end{tabular} & & \begin{tabular}{|l} 
https: \\
//perma. \\
cc/3X3L- \\
2RQN
\end{tabular} \\
\hline 155 & 1980.09.24 & 1980.09.24 & $S / 14192$ & Iraq & Iraq, Iran & \begin{tabular}{|c} 
Implied \\
assertion of \\
"individual" \\
self-defense
\end{tabular} & $\begin{array}{c}\text { Conducted } \\
\text { attack }\end{array}$ & Iran & State & \begin{tabular}{|l|} 
Iran's violation of Algiers Agreement, \\
leading to Iraq's termination of the \\
Agreement: “thhe Government of the \\
Republic of Iraq has clearly stated its \\
position, that it is not interested in \\
escalating the conflict with Iran. But \\
unfortunately Iran escalated the \\
conflict by its indiscriminate actions \\
against the interests of riaq, the \\
region, and the international \\
community. Consequently, my \\
Government was left only with a \\
narrow choice, namely, to act in self- \\
defence."
\end{tabular} & $\begin{array}{l}\text { S/PV.2247 } \\
\text { (2247th) }\end{array}$ & $\begin{array}{l}\text { S/RES/479(1980), OP 1: “Calls } \\
\text { upon Iran and Iraq to refrain } \\
\text { immediately from any further } \\
\text { use of force and to settle their } \\
\text { dispute by peaceful means and } \\
\text { in conformity with principles of } \\
\text { justice and international } \\
\text { law" (15-0) }\end{array}$ & $\begin{array}{l}\text { None } \\
\text { identified }\end{array}$ & $\begin{array}{l}\text { Consideratio } \\
\text { n of } \\
\text { Questions } \\
\text { under the } \\
\text { Council's } \\
\text { Responsibilit } \\
\text { y for the } \\
\text { Maintenanc } \\
\text { e of } \\
\text { International } \\
\text { Peace and } \\
\text { Security }\end{array}$ & \begin{tabular}{|l||} 
http: \\
//www.un. \\
org/en/ga/ \\
search/vie \\
w_doc. \\
asp? \\
symbol=s/ \\
14192
\end{tabular} & & \begin{tabular}{|l} 
https: \\
//perma. \\
cc/TB7A- \\
HH8U
\end{tabular} \\
\hline
\end{tabular}


VI. HLS PILAC Catalogue of Apparent “Article 51 Communications”

\begin{tabular}{|c|c|c|c|c|c|c|c|c|c|c|c|c|c|c|c|c|c|}
\hline $\begin{array}{l}\text { Chron. } \\
\text { Order }\end{array}$ & $\begin{array}{l}\text { Date of } \\
\text { comm. }\end{array}$ & \begin{tabular}{|c} 
Date of \\
UNsc \\
Document
\end{tabular} & UNSC Symbol & \begin{tabular}{||c} 
Member \\
State(s) That \\
Submitted \\
the Comm.
\end{tabular} & \begin{tabular}{|c|} 
Expressly \\
Mentioned UN \\
Members (\& \\
Colonial \\
Holdings \& \\
Protectorates, \\
if any) \\
\end{tabular} & \begin{tabular}{||c|} 
Express or \\
Implied \\
Assertion of \\
Individual, \\
Collective, or \\
Both Self- \\
defense \\
\end{tabular} & \begin{tabular}{|c} 
Nature of \\
the Alleged \\
Threat
\end{tabular} & $\begin{array}{l}\text { Expressly Alleged } \\
\text { Author(s) of the } \\
\text { Threat (If Any } \\
\text { Indicated) }\end{array}$ & \begin{tabular}{|c|} 
Nature of the \\
Alleged \\
Author(s) of \\
the Threat (If \\
Any \\
Indicated) \\
\end{tabular} & $\begin{array}{l}\text { Summary of Alleged Self-defense } \\
\text { Grounds }\end{array}$ & \begin{tabular}{||c|} 
UNSC \\
Meeting(s) \\
(If Any) at \\
Which the \\
Comm. was \\
Raised \\
\end{tabular} & $\begin{array}{l}\text { Responsive Act (If Any) by the } \\
\text { UNSC }\end{array}$ & $\begin{array}{c}\text { UN } \\
\text { Repertory } \\
\text { Inclusion? }\end{array}$ & \begin{tabular}{|c|} 
UNSC \\
Repertoire \\
Inclusion?
\end{tabular} & \begin{tabular}{|l||} 
URL to an \\
English \\
Text
\end{tabular} & \begin{tabular}{||c||} 
URL to Non- \\
English \\
Original \\
Tert (ff Any)
\end{tabular} & $\begin{array}{l}\text { Perma.cc } \\
\text { URL }\end{array}$ \\
\hline 156 & 1980.10 .01 & 1980.10.01 & $s / 14206$ & Iran & Iran, Iraq & $\begin{array}{c}\text { Implied } \\
\text { assertion of } \\
\text { "individual" } \\
\text { self-defense }\end{array}$ & $\begin{array}{c}\text { Conducted } \\
\text { attack }\end{array}$ & Iraq & State & \begin{tabular}{|l} 
Iraqi agents assisting counter- \\
revolutionary groups and expelling \\
Iraqis of Iranian or Shitite origin from \\
Iraqi territory: "bly waging a war of \\
aggression inside our territory and \\
striking against our vital interests, the \\
Iraqi Government left us no choice but \\
that of self-defence in order to secure \\
our sovereignty and protect our \\
interest."
\end{tabular} & $\begin{array}{l}\text { S/PV.2250 } \\
\text { (2250th) }\end{array}$ & None identified & $\begin{array}{l}\text { None } \\
\text { identified }\end{array}$ & \begin{tabular}{|l|} 
Consideratio \\
n of \\
Questions \\
under the \\
Council's \\
Responsibilit \\
y for the \\
Maintenanc \\
e of \\
International \\
Peace and \\
Security \\
\end{tabular} & \begin{tabular}{|l||} 
http: \\
//www.un. \\
org/en/ga/ \\
search/vie \\
w_doc. \\
asp? \\
symbol=s/ \\
14206
\end{tabular} & & $\begin{array}{l}\text { hitps: } \\
\text { ///perma. } \\
\text { cc//FYY5- } \\
\text { 72UL }\end{array}$ \\
\hline 157 & 1980.10 .27 & 1980.10.27 & $\mathrm{S} / 14236$ & Iraq & Iraq, Iran & \begin{tabular}{|c} 
Implied \\
assertion of \\
"individual" \\
self-defense
\end{tabular} & $\begin{array}{c}\text { Conducted } \\
\text { attack }\end{array}$ & Iran & State & $\begin{array}{l}\text { Iranian shelling of Iraqi towns and } \\
\text { closing of fraq river necessary for } \\
\text { navigation: "[itt became necessary to } \\
\text { push the Iranian forces sway from } \\
\text { Iraqi towns situated within the range } \\
\text { of Iranian heavy and long-range } \\
\text { artillery capable of shelling them and } \\
\text { which actually shelled them, as we } \\
\text { have mentioned, beginning on } \\
\text { September 1980." }\end{array}$ & $\begin{array}{l}\text { S/PV.2254 } \\
\text { (2254th) }\end{array}$ & None identified & $\begin{array}{l}\text { None } \\
\text { identified }\end{array}$ & $\begin{array}{l}\text { None } \\
\text { identified }\end{array}$ & \begin{tabular}{|l||} 
http: \\
|/www.un. \\
org/en/ga/ \\
search/vie \\
w_doc. \\
asp? \\
symbol=s/ \\
14236
\end{tabular} & & $\begin{array}{l}\text { hitps: } \\
\text { ///perma. } \\
\text { cc/NTVJ- } \\
\text { XRRT }\end{array}$ \\
\hline 158 & 1981.06.12 & 1981.06.12 & $\mathrm{S} / \mathrm{PV} .2280$ & Israel & Iraq & $\begin{array}{l}\text { Implied } \\
\text { assertion of } \\
\text { "individual" } \\
\text { self-defense }\end{array}$ & $\begin{array}{l}\text { Threat of } \\
\text { attack }\end{array}$ & Iraq & State & 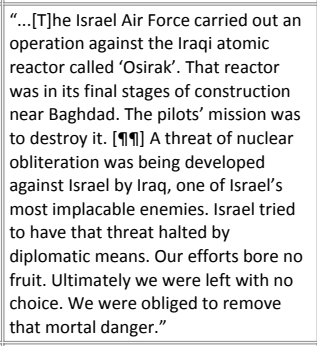 & $\begin{array}{l}\text { S/PV.2280 } \\
\text { (2280th); } \\
\text { S/PV.2281 } \\
\text { (2221st); } \\
\text { S/PV.2282 } \\
\text { (228ndd; } \\
\text { S/PV.2283 } \\
\text { (2283rd); } \\
\text { S/PV.2284 } \\
\text { (2284th); } \\
\text { S/PV.2286 } \\
\text { (2286h); } \\
\text { S/PV.2288 } \\
\text { (2288th) }\end{array}$ & $\begin{array}{l}\text { S/RES/487(1981), OP 1: } \\
\text { "Strongly condemns the } \\
\text { military attack by Israel in clear } \\
\text { violation of the Charter of the } \\
\text { United Nations and the norms } \\
\text { of international conduct" (15- } \\
0-0) \text {. }\end{array}$ & $\begin{array}{l}\text { Articles } 2(4), \\
31,39,41, \& \\
51\end{array}$ & \begin{tabular}{|l|} 
Articles 2(4), \\
$31,32,35$, \\
$39,42, \& 51 ;$ \\
Provisional \\
Rule of \\
Procedure \\
11
\end{tabular} & \begin{tabular}{|l|l|} 
https: & //documen \\
ts-dds-ny. \\
un. \\
org/doc/U \\
NDOC/GEN \\
ND70/036/ \\
78/pdf/N7 \\
003678. \\
pdf? \\
OpenElem \\
ent
\end{tabular} & & $\begin{array}{l}\text { hitps: } \\
\text { //perma. } \\
\text { cc//2VXX- } \\
\text { JzP2 }\end{array}$ \\
\hline 159 & 1981.08.19 & 1981.08.19 & $s / 14632$ & $\begin{array}{l}\text { United } \\
\text { States }\end{array}$ & $\begin{array}{c}\text { United States, } \\
\text { Libya }\end{array}$ & $\begin{array}{c}\text { Implied } \\
\text { assertion of } \\
\text { "individual" } \\
\text { self-defense }\end{array}$ & $\begin{array}{c}\text { Conducted } \\
\text { attack }\end{array}$ & Libya & State & $\begin{array}{l}\text { "...United States aircraft participating } \\
\text { in a routine peaceful naval exercise in } \\
\text { international waters in the } \\
\text { Mediterranean sea were subject to an } \\
\text { unprovoked attack by Libyan aircraft." }\end{array}$ & $\begin{array}{l}\text { None } \\
\text { identified }\end{array}$ & None identified & $\begin{array}{l}\text { None } \\
\text { identified }\end{array}$ & $\begin{array}{l}\text { None } \\
\text { identified }\end{array}$ & \begin{tabular}{|l|} 
http: \\
//www.un. \\
organengal \\
search/vie \\
w_doc. \\
asp? \\
symbol=s/ \\
14632 \\
\end{tabular} & & $\begin{array}{l}\text { https: } \\
\text { //perma. } \\
\text { cc /744G- } \\
\text { DHCM }\end{array}$ \\
\hline 160 & 1982.01.22 & 1982.01.26 & $S / 14846$ & Thailand & $\begin{array}{l}\text { Thailand, } \\
\text { Kampuchea } \\
\text { [Cambodia], } \\
\text { Vietnam }\end{array}$ & $\begin{array}{c}\text { Implied } \\
\text { assertion of } \\
\text { "individual" } \\
\text { self-defense }\end{array}$ & $\begin{array}{c}\text { Conducted } \\
\text { attack }\end{array}$ & $\begin{array}{l}\text { Vietnam and } \\
\text { Vietnamese- } \\
\text { controlled armed } \\
\text { boats }\end{array}$ & $\begin{array}{c}\text { State and } \\
\text { non-state } \\
\text { actors }\end{array}$ & $\begin{array}{l}\text { Thai fishing trawlers attacked by } \\
\text { Vietnamese-controlled boats, crewed } \\
\text { by individuals forced by Vietnamese } \\
\text { occupation forces: "sleveral Thai } \\
\text { fishing trawlers have been attacked } \\
\text { and seized in Thai territorial waters by } \\
\text { the Vietnamese-controlled armed } \\
\text { boats." }\end{array}$ & $\begin{array}{l}\text { None } \\
\text { identified }\end{array}$ & None identified & $\begin{array}{l}\text { None } \\
\text { identified }\end{array}$ & $\begin{array}{l}\text { None } \\
\text { identified }\end{array}$ & \begin{tabular}{|l||} 
http: \\
//www.un. \\
org/en/ga/ \\
search/vie \\
wdoc. \\
asp? \\
symbol=s/ \\
14846
\end{tabular} & & $\begin{array}{l}\text { hitps: } \\
\text { ///perma. } \\
\text { cc//F3J- } \\
\text { MVT9 }\end{array}$ \\
\hline 161 & 1982.04.09 & 1982.04.10 & $\mathrm{s} / 14963$ & $\begin{array}{l}\text { United } \\
\text { Kingdom }\end{array}$ & $\begin{array}{l}\text { United } \\
\text { Kingdom, } \\
\text { Argentina }\end{array}$ & $\begin{array}{l}\text { Implied } \\
\text { assertion of } \\
\text { "individual" } \\
\text { self-defense }\end{array}$ & $\begin{array}{c}\text { Conducted } \\
\text { attack and } \\
\text { threat of } \\
\text { attack }\end{array}$ & Argentina & State & $\begin{array}{l}\text { Argentina building up forces in } \\
\text { Falkland slalands: "Argentina has been } \\
\text { steadily reinforcing its armed forces in } \\
\text { the Falkland Islands, following the } \\
\text { invasion on } 2 \text { April } 1982 \text {. [f]] ... 'From } \\
\text { the time indicated, any Argentine } \\
\text { warships and Argentine naval } \\
\text { auxiliaries found within this zone will } \\
\text { be treated as hostile and are liable to } \\
\text { be attacked by British forces."." }\end{array}$ & $\begin{array}{l}\text { None } \\
\text { identified }\end{array}$ & $\begin{array}{l}\text { None identified (But see, from } \\
\text { the day before the } \\
\text { communication was } \\
\text { submitted, S/RES } 5 \text { /502(1982), } \\
\text { preamble and OP 2: } \\
\text { "Determining that there exists } \\
\text { a breach of the peace in the } \\
\text { region of the Falkland Islands } \\
\text { (Illas Malvinas),... } \\
\text { 2. Demands an immediate } \\
\text { withdrawal of all Argentine } \\
\text { forces from the Falkland } \\
\text { Islands (Islas Malvinas)...") }\end{array}$ & Article 51 & Article 51 & \begin{tabular}{|l||} 
http: \\
|/www.un. \\
org/en/ga/ \\
search/vie \\
w_doc. \\
asp? \\
symbol=s/ \\
14963
\end{tabular} & & $\begin{array}{l}\text { https: } \\
/ / / p e r m a . \\
\text { cc/20DE- } \\
\text { akxc }\end{array}$ \\
\hline
\end{tabular}


VI. HLS PILAC Catalogue of Apparent “Article 51 Communications”

\begin{tabular}{|c|c|c|c|c|c|c|c|c|c|c|c|c|c|c|c|c|c|}
\hline $\begin{array}{l}\text { Chron. } \\
\text { Order }\end{array}$ & $\begin{array}{l}\text { Date of } \\
\text { Comm. }\end{array}$ & $\begin{array}{c}\text { Date of } \\
\text { UNsc } \\
\text { Document }\end{array}$ & | UNSC Symbol & \begin{tabular}{|c} 
Member \\
State(s) That \\
Submitted \\
the Comm.
\end{tabular} & \begin{tabular}{|c|} 
Expressly \\
Mentioned UN \\
Members (\& \\
Colonial \\
Holdings \& \\
Protectorates, \\
if any) \\
\end{tabular} & \begin{tabular}{|c|} 
Express or \\
Implied \\
Assertion of \\
Individual, \\
Collective, or \\
Both Self- \\
defense \\
\end{tabular} & \begin{tabular}{|c} 
Nature of \\
the Alleged \\
Threat
\end{tabular} & \begin{tabular}{|l} 
Expressly Alleged \\
Author(s) of the \\
Threat (ff Any \\
Indicated)
\end{tabular} & \begin{tabular}{|c|} 
Nature of the \\
Alleged \\
Author(s) of \\
the Threat (If \\
Any \\
Indicated) \\
\end{tabular} & $\begin{array}{l}\text { Summary of Alleged Self-defense } \\
\text { Grounds }\end{array}$ & \begin{tabular}{|l} 
UNsc \\
Meeting(s) \\
(If Any) at \\
Which the \\
Comm. was \\
Raised
\end{tabular} & $\begin{array}{l}\text { Responsive Act (If Any) by the } \\
\text { UNSC }\end{array}$ & \begin{tabular}{|l} 
UN \\
Repertory \\
Inclusion?
\end{tabular} & $\begin{array}{c}\text { UNSC } \\
\text { Repertoire } \\
\text { Inclusion? }\end{array}$ & $\begin{array}{l}\text { URL to an } \\
\text { English } \\
\text { Text }\end{array}$ & \begin{tabular}{||c||} 
URL to Non- \\
English \\
OOrinal \\
Text (ff Any)
\end{tabular} & $\begin{array}{l}\text { Perma.cc } \\
\text { URL }\end{array}$ \\
\hline 162 & 1982.04.16 & 1982.04.16 & $S / 14984$ & Argentina & $\begin{array}{l}\text { Argentina, } \\
\text { United } \\
\text { Kingdom, } \\
\text { United States }\end{array}$ & $\begin{array}{l}\text { Implied } \\
\text { assertion of } \\
\text { "individual" } \\
\text { self-defense }\end{array}$ & $\begin{array}{c}\text { Conducted } \\
\text { attack }\end{array}$ & United Kingdom & State & $\begin{array}{l}\text { United Kingdom's naval blockade of } \\
\text { Falkland Islands: "[i]n the face of the } \\
\text { announcement of the dispatching of } \\
\text { the fleet, which clearly demonstrated } \\
\text { a lack of readiness on the part of the } \\
\text { United Kingdom to comply with } \\
\text { paragraph } 1 \text { of resolution } 502 \text { (1982), } \\
\text {...." }\end{array}$ & $\begin{array}{l}\text { S/PV. } 2360 \\
\text { (2360th) }\end{array}$ & None identified & Article 51 & Article 51 & $\begin{array}{l}\text { http: } \\
\text { //www.un. } \\
\text { org/en/ga/ } \\
\text { search/vie } \\
\text { w_doc. } \\
\text { asp? } \\
\text { symbol=S/ } \\
14984\end{array}$ & $\begin{array}{l}\text { http://www. } \\
\text { un. } \\
\text { org/en/ga/se } \\
\text { arch/view_do } \\
\text { casp? } \\
\text { symbol=s/149 } \\
\text { 84\&lang=s }\end{array}$ & $\begin{array}{l}\text { hitps: } \\
\text { //perma. } \\
\text { ccl/g2x7- } \\
\text { YTW5 }\end{array}$ \\
\hline 163 & 1982.04.26 & 1982.04.26 & $s / 15002$ & $\begin{array}{l}\text { United } \\
\text { Kingdom }\end{array}$ & $\begin{array}{l}\text { Argentina, } \\
\text { United } \\
\text { Kingdom }\end{array}$ & $\begin{array}{l}\text { Implied } \\
\text { assertion of } \\
\text { "individual" } \\
\text { self-defense }\end{array}$ & $\begin{array}{c}\text { Conducted } \\
\text { attack }\end{array}$ & Argentina & State & $\begin{array}{l}\text { Argentina's invasion of South Georgia: } \\
\text { "[oln } 3 \text { April 1982, ..., Argentina } \\
\text { carried out an armed invasion of the } \\
\text { island of South Georgia. The small } \\
\text { British garrison resisted but was } \\
\text { eventually captured." }\end{array}$ & $\begin{array}{l}\text { None } \\
\text { identified }\end{array}$ & None identified & $\begin{array}{l}\text { None } \\
\text { identified }\end{array}$ & $\begin{array}{l}\text { None } \\
\text { identified }\end{array}$ & $\begin{array}{l}\text { http: } \\
\text { //www.un. } \\
\text { org/en/ga/ } \\
\text { search/vie } \\
\text { w_doc. } \\
\text { asp? } \\
\text { symbol=S/ } \\
15002\end{array}$ & & $\begin{array}{l}\text { hitps: } \\
\text { ///perma. } \\
\text { cc/28EN- } \\
4 Y \times L L\end{array}$ \\
\hline 164 & 1982.04 .30 & 1982.04 .30 & $\mathrm{~s} / 15016$ & $\begin{array}{l}\text { United } \\
\text { Kingdom }\end{array}$ & $\begin{array}{l}\text { United } \\
\text { Kingdom, } \\
\text { Argentina }\end{array}$ & $\begin{array}{c}\text { Implied } \\
\text { assertion of } \\
\text { "individual" } \\
\text { self-defense }\end{array}$ & $\begin{array}{c}\text { Conducted } \\
\text { attack }\end{array}$ & Argentina & State & $\begin{array}{l}\text { Argentina's attacks on Falkland Islands } \\
\text { and South Georgia and occupation of } \\
\text { the Falkland Islands. }\end{array}$ & $\begin{array}{l}\text { S/PV.2362 } \\
\text { (2362nd) }\end{array}$ & None identified & Article 51 & Article 51 & $\begin{array}{l}\text { http: } \\
\text { //wwww.un. } \\
\text { org/en/ga/ } \\
\text { search/vie } \\
\text { w_doc. } \\
\text { asp? } \\
\text { symbol=S/ } \\
15016\end{array}$ & & $\begin{array}{l}\text { hitps: } \\
\text { //Terma. } \\
\text { cct/M43- } \\
\text { BVHR }\end{array}$ \\
\hline 165 & 1982.04 .30 & 1982.04.30 & $S / 15017$ & $\begin{array}{l}\text { United } \\
\text { Kingdom }\end{array}$ & $\begin{array}{l}\text { United } \\
\text { Kingdom, } \\
\text { Argentina, } \\
\text { Peru }\end{array}$ & $\begin{array}{l}\text { Implied } \\
\text { assertion of } \\
\text { "individual" } \\
\text { self-defense }\end{array}$ & $\begin{array}{c}\text { Conducted } \\
\text { attack }\end{array}$ & Argentina & State & $\begin{array}{l}\text { Argentina's violation of resolution } \\
502 \text {, regarding the Falkland Islands. }\end{array}$ & $\begin{array}{l}\text { None } \\
\text { identified }\end{array}$ & None identified & $\begin{array}{l}\text { None } \\
\text { identified }\end{array}$ & $\begin{array}{l}\text { None } \\
\text { identified }\end{array}$ & $\begin{array}{l}\text { http: } \\
\text { //wwww.un. } \\
\text { org/en/ga/ } \\
\text { search/vie } \\
\text { w_doc. } \\
\text { asp? } \\
\text { symbol=S/ } \\
15017\end{array}$ & & $\begin{array}{l}\text { hitps: } \\
\text { ///perma. } \\
\text { cc/fonNN- } \\
\text { ult66 }\end{array}$ \\
\hline 166 & 1982.04 .30 & 1982.04.30 & $S / 15021$ & Argentina & $\begin{array}{l}\text { Argentina, } \\
\text { United } \\
\text { Kingdom }\end{array}$ & $\begin{array}{l}\text { Implied } \\
\text { assertion of } \\
\text { "individual" } \\
\text { self-defense }\end{array}$ & $\begin{array}{c}\text { Conducted } \\
\text { attack }\end{array}$ & United Kingdom & State & \begin{tabular}{|l} 
"TThe continuation of the British \\
Government's punitive actions...."
\end{tabular} & $\begin{array}{l}\text { S/PV.2360 } \\
\text { (2360th) }\end{array}$ & None identified & $\begin{array}{l}\text { None } \\
\text { identified }\end{array}$ & Article 51 & $\begin{array}{l}\text { http: } \\
\text { //www.un. } \\
\text { org/en//ga/ } \\
\text { search/vie } \\
\text { w_doc. } \\
\text { asp? } \\
\text { spybol=S/ } \\
15021\end{array}$ & $\begin{array}{l}\text { hitp://www. } \\
\text { un. } \\
\text { org/en/ga/se } \\
\text { arch/view_do } \\
\text { c.asp? } \\
\text { symbl=s/150 } \\
\text { 218lang=s } \\
\end{array}$ & $\begin{array}{l}\text { hitps: } \\
\text { //perma. } \\
\text { cc T/T2Y5- } \\
\text { EQKzz }\end{array}$ \\
\hline 167 & 1982.05.01 & 1982.05.01 & $s / 15025$ & $\begin{array}{l}\text { United } \\
\text { Kingdom }\end{array}$ & $\begin{array}{l}\text { United } \\
\text { Kingdom, } \\
\text { Argentina }\end{array}$ & $\begin{array}{l}\text { Implied } \\
\text { assertion of } \\
\text { "individual" } \\
\text { self-defense }\end{array}$ & $\begin{array}{c}\text { Conducted } \\
\text { attack }\end{array}$ & Argentina & State & $\begin{array}{l}\text { "[T]he refusal of Argentina to comply } \\
\text { with paragraph } 2 \text { of resolution } 502 \\
\text { following its invasion of British } \\
\text { territory." }\end{array}$ & \begin{tabular}{|l} 
None \\
identified
\end{tabular} & None identified & $\begin{array}{l}\text { None } \\
\text { identified }\end{array}$ & \begin{tabular}{|l} 
None \\
identified
\end{tabular} & $\begin{array}{l}\text { http: } \\
\text { //www.un. } \\
\text { org/en//ga/ } \\
\text { search/vie } \\
\text { w_doc. } \\
\text { asp? } \\
\text { spybol=S/ } \\
15025\end{array}$ & & $\begin{array}{l}\text { litps: } \\
\text { ///perma. } \\
\text { cc/KKR } \\
\text { ZFMR }\end{array}$ \\
\hline 168 & 1982.05.01 & 1982.05.01 & $s / 15026$ & Argentina & $\begin{array}{l}\text { Argentina, } \\
\text { United } \\
\text { Kingdom }\end{array}$ & $\begin{array}{l}\text { Implied } \\
\text { assertion of } \\
\text { "individual" } \\
\text { self-defense }\end{array}$ & $\begin{array}{c}\text { Conducted } \\
\text { attack }\end{array}$ & United Kingdom & State & $\begin{array}{l}\text { "[T]he successive attacks by the British } \\
\text { Air Force against Puerto Argentina in } \\
\text { the Malvinas Islands ...." }\end{array}$ & $\begin{array}{l}\text { None } \\
\text { identified }\end{array}$ & None identified & Article 24 & Article 24 & $\begin{array}{l}\text { http: } \\
\text { //www.un. } \\
\text { org/en/ga/ } \\
\text { search/vie } \\
\text { w_doc. } \\
\text { asp? } \\
\text { symbol=s/ } \\
15026\end{array}$ & \begin{tabular}{|l||} 
http://www. \\
un. \\
org/en/ga/se \\
arch/view_do \\
c.asp? \\
symbol=S/150 \\
26\&Lang=S \\
\end{tabular} & $\begin{array}{l}\text { hitps: } \\
\text { //perma. } \\
\text { cc/1557- } \\
\text { Ts522 }\end{array}$ \\
\hline 169 & 1982.05.02 & 1982.05.02 & $S / 15027$ & $\begin{array}{l}\text { United } \\
\text { Kingdom }\end{array}$ & $\begin{array}{l}\text { United } \\
\text { Kingdom, } \\
\text { Argentina }\end{array}$ & $\begin{array}{l}\text { Implied } \\
\text { assertion of } \\
\text { "individual" } \\
\text { self-defense }\end{array}$ & $\begin{array}{c}\text { Conducted } \\
\text { attack }\end{array}$ & Argentina & State & $\begin{array}{l}\text { "During the evening the Argentinians } \\
\text { mounted a bombing raid on our Task } \\
\text { Force." }\end{array}$ & \begin{tabular}{|l} 
None \\
identified
\end{tabular} & None identified & Article 51 & Article 51 & $\begin{array}{l}\text { http: } \\
\text { //wwww.un. } \\
\text { org/en/ga/ } \\
\text { search//vie } \\
\text { w_doc. } \\
\text { asp? } \\
\text { symbol=S/ } \\
15027\end{array}$ & & $\begin{array}{l}\text { hitps: } \\
\text { ///perma. } \\
\text { cc/NARQ- } \\
\text { 94AA }\end{array}$ \\
\hline
\end{tabular}


VI. HLS PILAC Catalogue of Apparent “Article 51 Communications”

\begin{tabular}{|c|c|c|c|c|c|c|c|c|c|c|c|c|c|c|c|c|c|}
\hline $\begin{array}{l}\text { Chron. } \\
\text { Order }\end{array}$ & $\begin{array}{l}\text { Date of } \\
\text { Comm. }\end{array}$ & $\begin{array}{l}\text { Date of } \\
\text { UNsC } \\
\text { Document }\end{array}$ & | UNSC Symbol & \begin{tabular}{||c} 
Member \\
State(s) That \\
Submitted \\
the Comm.
\end{tabular} & \begin{tabular}{||c||} 
Expressly \\
Mentioned UN \\
Members (\& \\
Colonial \\
Holdings \& \\
Protectorates, \\
if any) \\
\end{tabular} & \begin{tabular}{|c|} 
Express or \\
Implied \\
Assertion of \\
Individual, \\
Collective, or \\
Both Self- \\
defense \\
\end{tabular} & \begin{tabular}{|l}
$\begin{array}{c}\text { Nature of } \\
\text { the Alleged } \\
\text { Threat }\end{array}$
\end{tabular} & $\begin{array}{l}\text { Expressly Alleged } \\
\text { Author(s) of the } \\
\text { Threat (If Any } \\
\text { Indicated) }\end{array}$ & \begin{tabular}{|c} 
Nature of the \\
Alleged \\
Author(s) of \\
the Threat (If \\
Any \\
Indicated)
\end{tabular} & $\begin{array}{l}\text { Summary of Alleged Self-defense } \\
\text { Grounds }\end{array}$ & $\begin{array}{c}\text { UNSC } \\
\text { Meeting(s) } \\
\text { (If Any) at } \\
\text { Which the } \\
\text { Comm. was } \\
\text { Raised }\end{array}$ & $\begin{array}{l}\text { Responsive Act (If Any) by the } \\
\text { UNSC }\end{array}$ & $\begin{array}{l}\text { UN } \\
\text { Repertory } \\
\text { Inclusion? }\end{array}$ & \begin{tabular}{|c} 
UNSC \\
Repertoire \\
Inclusion?
\end{tabular} & $\begin{array}{l}\text { URL to an } \\
\text { English } \\
\text { Text }\end{array}$ & \begin{tabular}{||c||} 
URL to Non- \\
English \\
Original \\
Text (ff Any)
\end{tabular} & $\begin{array}{l}\text { Perma.cc } \\
\text { URL }\end{array}$ \\
\hline 170 & 1982.05.03 & 1982.05.04 & S/15031 & $\begin{array}{l}\text { United } \\
\text { Kingdom }\end{array}$ & $\begin{array}{l}\text { United } \\
\text { Kingdom, } \\
\text { Argentina }\end{array}$ & $\begin{array}{c}\text { Implied } \\
\text { assertion of } \\
\text { "individual" } \\
\text { self-defense }\end{array}$ & $\begin{array}{c}\text { Conducted } \\
\text { attack and } \\
\text { threat of } \\
\text { attack }\end{array}$ & Argentina & State & 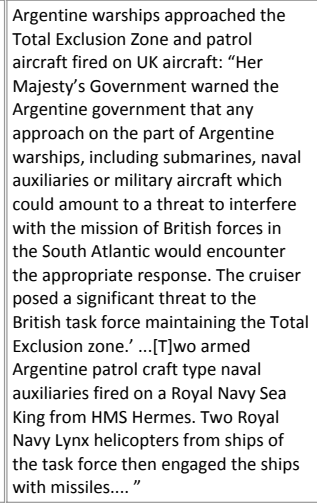 & $\begin{array}{l}\text { None } \\
\text { identified }\end{array}$ & None identified & Article 51 & Article 51 & $\begin{array}{l}\text { http: } \\
\text { //www.un. } \\
\text { org/en/ga/ } \\
\text { search/vie } \\
\text { w_doc. } \\
\text { asp? } \\
\text { symbol=s/ } \\
15031\end{array}$ & & $\begin{array}{l}\text { hitps: } \\
\text { //perma. } \\
\text { cc//MzZ7- } \\
\text { A4XH }\end{array}$ \\
\hline 171 & 1982.05.04 & 1982.05.04 & $s / 15040$ & $\begin{array}{l}\text { United } \\
\text { Kingdom }\end{array}$ & $\begin{array}{l}\text { United } \\
\text { Kingdom, } \\
\text { Argentina }\end{array}$ & $\begin{array}{c}\text { Implied } \\
\text { assertion of } \\
\text { "individual" } \\
\text { self-defense }\end{array}$ & $\begin{array}{c}\text { Conducted } \\
\text { attack }\end{array}$ & Argentina & State & 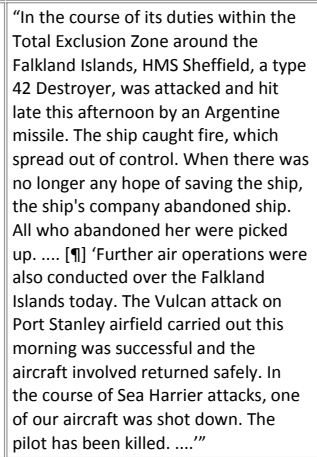 & \begin{tabular}{|l} 
oone \\
identified
\end{tabular} & None identified & Article 51 & Article 51 & $\begin{array}{l}\text { http: } \\
\text { /twww.un. } \\
\text { org/en/ga/ } \\
\text { search/vie } \\
\text { w_doc. } \\
\text { asp? } \\
\text { symbol=s/ } \\
15040\end{array}$ & & 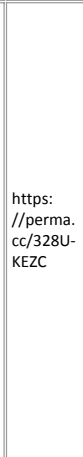 \\
\hline 172 & 1982.05.04 & 1982.05.04 & $S / 15041$ & $\begin{array}{c}\text { United } \\
\text { Kingdom }\end{array}$ & $\begin{array}{l}\text { United } \\
\text { Kingdom, } \\
\text { Argentina }\end{array}$ & $\begin{array}{c}\text { Implied } \\
\text { assertion of } \\
\text { "individual" } \\
\text { self-defense }\end{array}$ & $\begin{array}{l}\text { Conducted } \\
\text { attack }\end{array}$ & Argentina & State & $\begin{array}{l}\text { Argentina's use of force to invade } \\
\text { South Georgia and continued } \\
\text { occupation of the Falkland Islands. }\end{array}$ & \begin{tabular}{|l} 
None \\
identified
\end{tabular} & None identified & Article 51 & $\begin{array}{l}\text { Articles 24, } \\
51\end{array}$ & $\begin{array}{l}\text { http: } \\
\text { //www.un. } \\
\text { org/en//ga/ } \\
\text { search/vie } \\
\text { w_doc. } \\
\text { asp? } \\
\text { spybol=S/ } \\
15041\end{array}$ & & $\begin{array}{l}\text { hitps: } \\
\text { //perma. } \\
\text { cc//5069- } \\
\text { a986 }\end{array}$ \\
\hline 173 & 1982.05.05 & 1982.05.05 & $s / 15046$ & Argentina & $\begin{array}{l}\text { Argentina, } \\
\text { United } \\
\text { Kingdom }\end{array}$ & $\begin{array}{c}\text { Implied } \\
\text { assertion of } \\
\text { "individual" } \\
\text { self-defense }\end{array}$ & $\begin{array}{l}\text { Conducted } \\
\text { attack }\end{array}$ & United Kingdom & State & $\begin{array}{l}\text { UK raid on Puerto Argentino: “... an air } \\
\text { raid by three Sea Harrier aircraft was } \\
\text { carried out on Base Cóndor at Puerto } \\
\text { Darwin in the Malvinas Islands. [ๆ] } \\
\text { Two of the intruding aircraft were } \\
\text { shot down by anti aircraft artillery } \\
\text { fire.” }\end{array}$ & \begin{tabular}{|l} 
None \\
identified
\end{tabular} & None identified & \begin{tabular}{|l} 
None \\
identified
\end{tabular} & \begin{tabular}{|l} 
None \\
identified
\end{tabular} & $\begin{array}{l}\text { http: } \\
\text { //www.un. } \\
\text { org/en//ga/ } \\
\text { search/vie } \\
\text { w_doc. } \\
\text { asp? } \\
\text { spybol=S/ } \\
15046\end{array}$ & \begin{tabular}{|l} 
http://www. \\
un. \\
org/en/ga/se \\
arch/view_do \\
c.asp? \\
symbol=s/150 \\
46\&lang=s
\end{tabular} & $\begin{array}{l}\text { hitps: } \\
\text { //perma. } \\
\text { cc/5KNR- } \\
\text { 2JUC }\end{array}$ \\
\hline 174 & 1982.05.06 & 1982.05.07 & $\mathrm{s} / 15053$ & Argentina & $\begin{array}{l}\text { Argentina, } \\
\text { United } \\
\text { Kingdom }\end{array}$ & $\begin{array}{c}\text { Implied } \\
\text { assertion of } \\
\text { "individual" } \\
\text { self-defense }\end{array}$ & $\begin{array}{c}\text { Conducted } \\
\text { attack }\end{array}$ & United Kingdom & State & \begin{tabular}{|l} 
Attacks by United Kingdom task force: \\
"“.. in the course of the actions carried \\
out by the Argentine Air Force in \\
exercise of the right of self-defence \\
against the attacks of the United \\
Kingdom task force the Britith \\
destroyer H.M.S. Sheffield was \\
seriously damaged and had to be \\
abandoned by its crew.”.
\end{tabular} & $\begin{array}{l}\text { None } \\
\text { identified }\end{array}$ & None identified & $\begin{array}{l}\text { None } \\
\text { identified }\end{array}$ & \begin{tabular}{|l} 
None \\
identified
\end{tabular} & $\begin{array}{l}\text { http: } \\
\text { //www.un. } \\
\text { org/en/ga/ } \\
\text { search/vie } \\
\text { w_doc. } \\
\text { asp? } \\
\text { symbol=s/ } \\
15053\end{array}$ & \begin{tabular}{|l||} 
http://www. \\
un. \\
org/en/ga/se \\
arch/view_do \\
c.asp? \\
symbol=s/150 \\
53\&Lang=s
\end{tabular} & $\begin{array}{l}\text { hitps: } \\
\text { //perma. } \\
\text { cc//966W- } \\
\text { xMGD }\end{array}$ \\
\hline
\end{tabular}


VI. HLS PILAC Catalogue of Apparent “Article 51 Communications”

\begin{tabular}{|c|c|c|c|c|c|c|c|c|c|c|c|c|c|c|c|c|c|}
\hline $\begin{array}{l}\text { Chron. } \\
\text { Order }\end{array}$ & $\begin{array}{l}\text { Date of } \\
\text { Comm. }\end{array}$ & \begin{tabular}{|c} 
Date of \\
UNsc \\
Document
\end{tabular} & UNSC Symbol & \begin{tabular}{|c} 
Member \\
State(s) That \\
Submitted \\
the Comm.
\end{tabular} & \begin{tabular}{|c|} 
Expressly \\
Mentioned UN \\
Members (\& \\
Colonial \\
Holdings \& \\
Protectorates, \\
if any) \\
\end{tabular} & \begin{tabular}{|c|} 
Express or \\
Implied \\
Assertion of \\
Individual, \\
Collective, or \\
Both Self- \\
defense \\
\end{tabular} & \begin{tabular}{|c}
$\begin{array}{c}\text { Nature of } \\
\text { the Alleged } \\
\text { Threat }\end{array}$ \\
\end{tabular} & $\begin{array}{l}\text { Expressly Alleged } \\
\text { Author(s) of the } \\
\text { Threat (If Any } \\
\text { Indicated) }\end{array}$ & $\begin{array}{l}\text { Nature of the } \\
\text { Alleged } \\
\text { Author(s) of } \\
\text { the Threat (If } \\
\text { Any } \\
\text { Indicated) }\end{array}$ & $\begin{array}{l}\text { Summary of Alleged Self-defense } \\
\text { Grounds }\end{array}$ & \begin{tabular}{|c} 
UNSC \\
Meeting(s) \\
(If Any) at \\
Which the \\
Comm. was \\
Raised
\end{tabular} & $\begin{array}{l}\text { Responsive Act (If Any) by the } \\
\text { UNSC }\end{array}$ & \begin{tabular}{|l} 
UN \\
Repertory \\
Inclusion?
\end{tabular} & \begin{tabular}{|l} 
UNSC \\
Repertoire \\
Inclusion?
\end{tabular} & \begin{tabular}{|c|} 
URL to an \\
English \\
Text
\end{tabular} & \begin{tabular}{|l} 
URL to Non- \\
English \\
Original \\
Text (ff Any)
\end{tabular} & $\begin{array}{l}\text { Perma.cc } \\
\text { URL }\end{array}$ \\
\hline 175 & \begin{tabular}{|l|}
1982.05 .10 \\
\end{tabular} & 1982.05.10 & $S / 15063$ & $\begin{array}{l}\text { United } \\
\text { Kingdom }\end{array}$ & $\begin{array}{l}\text { United } \\
\text { Kingdom, } \\
\text { Argentina }\end{array}$ & \begin{tabular}{|c|} 
Implied \\
assertion of \\
"individual" \\
self-defense
\end{tabular} & $\begin{array}{c}\text { Conducted } \\
\text { attack }\end{array}$ & Argentina & State & 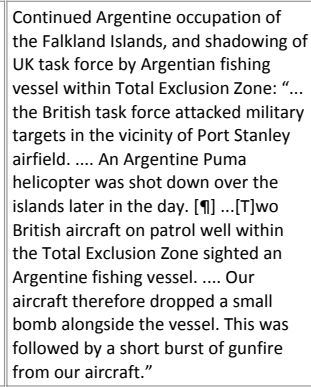 & $\begin{array}{l}\text { None } \\
\text { identified }\end{array}$ & None identified & $\begin{array}{l}\text { None } \\
\text { identified }\end{array}$ & $\begin{array}{l}\text { None } \\
\text { identified }\end{array}$ & $\begin{array}{l}\text { http: } \\
\text { //www.un. } \\
\text { org/en/ga/ } \\
\text { search/vie } \\
\text { w_doc. } \\
\text { asp? } \\
\text { symbol=s/ } \\
15063\end{array}$ & & $\begin{array}{l}\text { https: } \\
\text { //perma. } \\
\text { cc/Ys3z- } \\
\text { CBPT }\end{array}$ \\
\hline 176 & \begin{tabular}{|l|}
1982.05 .13 \\
\end{tabular} & 1982.05.14 & $S / 15081$ & $\begin{array}{l}\text { United } \\
\text { Kingdom }\end{array}$ & $\begin{array}{l}\text { United } \\
\text { Kingdom, } \\
\text { Argentina }\end{array}$ & \begin{tabular}{|c|} 
Implied \\
assertion of \\
"individual" \\
self-defense
\end{tabular} & $\begin{array}{c}\text { Conducted } \\
\text { attack }\end{array}$ & Argentina & State & \begin{tabular}{|l} 
Attack on UK ships by Argentinian \\
aircraft: “The Ministry of Defence in \\
London has announced that ... two \\
Royal Navy ships in the course ef \\
enforcing the Total Exclusion Zone \\
were attacked by Argentine Skyhawk \\
aircraft. The aircraft approached in \\
three waves. In the first wave there \\
were four aircraft, two of which were \\
shot down. A third aircraft flew into \\
the sea whilst taking evasive action."
\end{tabular} & $\begin{array}{l}\text { None } \\
\text { identified }\end{array}$ & None identified & Article 51 & Article 51 & $\begin{array}{l}\text { http: } \\
\text { //www.un. } \\
\text { org/en/ga/ } \\
\text { search/vie } \\
\text { w_doc. } \\
\text { ass? } \\
\text { symbol=s/ } \\
15081\end{array}$ & & $\begin{array}{l}\text { https: } \\
\text { //perma. } \\
\text { cc/7/36- } \\
\text { NSAC }\end{array}$ \\
\hline 177 & \begin{tabular}{|l|}
1982.05 .15 \\
\end{tabular} & 1982.05.15 & S/15084 & $\begin{array}{l}\text { United } \\
\text { Kingdom }\end{array}$ & $\begin{array}{l}\text { United } \\
\text { Kingdom, } \\
\text { Argentina }\end{array}$ & \begin{tabular}{|c|} 
Implied \\
assertion of \\
"individual" \\
self-defense
\end{tabular} & $\begin{array}{c}\text { Conducted } \\
\text { attack }\end{array}$ & Argentina & State & \begin{tabular}{|l} 
"Last night a raid was carried out by \\
British forces on military installations \\
and aircraft on an airstrip on Pebble \\
Island in the north of West Falkland.... \\
I must emphasise that this was a raid \\
and not an invasion of the Falkland \\
Islands. It was a limited military action \\
designed and executed as part of the \\
task force's continuing role in \\
enforcing the Total Exclusion Zone....."
\end{tabular} & $\begin{array}{l}\text { None } \\
\text { identified }\end{array}$ & None identified & $\begin{array}{l}\text { None } \\
\text { identified }\end{array}$ & $\begin{array}{l}\text { None } \\
\text { identified }\end{array}$ & $\begin{array}{l}\text { http: } \\
\text { //www.un. } \\
\text { org/en/ga/ } \\
\text { search/vie } \\
\text { w_doc. } \\
\text { asp? } \\
\text { symbol=s/ } \\
15084\end{array}$ & & \begin{tabular}{|l} 
https: \\
//perma. \\
cc/aBF8- \\
F2Z9
\end{tabular} \\
\hline 178 & \begin{tabular}{|l|}
1982.05 .22 \\
\end{tabular} & 1982.05.22 & $s / 15102$ & Argentina & $\begin{array}{l}\text { Argentina, } \\
\text { United } \\
\text { Kingdom }\end{array}$ & \begin{tabular}{|c|} 
Implied \\
assertion of \\
"individual" \\
self-defense
\end{tabular} & $\begin{array}{c}\text { Conducted } \\
\text { attack }\end{array}$ & United Kingdom & State & $\begin{array}{l}\text { Argentine military forces carried out } \\
\text { attacks on British military aircrafts and } \\
\text { helicopters. }\end{array}$ & $\begin{array}{l}\text { S/PV.2362 } \\
\text { (2362nd) }\end{array}$ & None identified & $\begin{array}{l}\text { None } \\
\text { identified }\end{array}$ & Article 51 & $\begin{array}{l}\text { http: } \\
\text { //www.un. } \\
\text { org/en//ga/ } \\
\text { search/vie } \\
\text { w_doc. } \\
\text { asp? } \\
\text { spybol=S/ } \\
15102\end{array}$ & $\begin{array}{l}\text { http://www. } \\
\text { un. } \\
\text { org/en/ga/se } \\
\text { arch/view_do } \\
\text { c.asp? } \\
\text { symbol=s/151 } \\
\text { o2\&lang=s }\end{array}$ & $\begin{array}{l}\text { https: } \\
\text { //perma. } \\
\text { cc/ZRBP7- } \\
\text { ZTVM }\end{array}$ \\
\hline 179 & \begin{tabular}{|l|}
1982.05 .23 \\
\end{tabular} & 1982.05.23 & S/15104 & $\begin{array}{l}\text { United } \\
\text { Kingdom }\end{array}$ & $\begin{array}{l}\text { United } \\
\text { Kingdom, } \\
\text { Argentina }\end{array}$ & \begin{tabular}{|c|} 
Implied \\
assertion of \\
"individual" \\
self-defense
\end{tabular} & $\begin{array}{c}\text { Conducted } \\
\text { attack }\end{array}$ & Argentina & State & $\begin{array}{l}\text { UK military conducted, inter alia, } \\
\text { ground, air, and naval attacks on } \\
\text { Argentine military, "in the face of } \\
\text { Argentina's invasion of the Falkland } \\
\text { Islands and illegal use of force to } \\
\text { occupy them and to subjugate their } \\
\text { people." }\end{array}$ & $\begin{array}{l}\text { S/PV.2364 } \\
\text { (2364th) }\end{array}$ & None identified & $\begin{array}{l}\text { None } \\
\text { identified }\end{array}$ & Article 51 & $\begin{array}{l}\text { http: } \\
\text { //www.un. } \\
\text { org/en/ga/ } \\
\text { search/vie } \\
\text { w_doc. } \\
\text { asp? } \\
\text { symbol=s/ } \\
15104\end{array}$ & & \begin{tabular}{|l} 
https: \\
//perma. \\
cc/5JK5- \\
TRQ3
\end{tabular} \\
\hline 180 & \begin{tabular}{|l|l|}
1982.05 .25 \\
\end{tabular} & 1982.05.25 & $s / 15119$ & $\begin{array}{l}\text { United } \\
\text { Kingdom }\end{array}$ & $\begin{array}{l}\text { United } \\
\text { Kingdom, } \\
\text { Argentina, } \\
\text { Nicaragua, } \\
\text { Panama, } \\
\text { Venemaela, } \\
\text { Uruguay, } \\
\text { Paraguay, } \\
\text { Bolivia }\end{array}$ & \begin{tabular}{|c|} 
Implied \\
assertion of \\
"individual" \\
self-defense
\end{tabular} & $\begin{array}{c}\text { Conducted } \\
\text { attack }\end{array}$ & Argentina & State & $\begin{array}{l}\text { "“...Argentina's armed invasion of the } \\
\text { Falkland Islands." }\end{array}$ & $\begin{array}{l}\text { S/PV.2368 } \\
\text { (2368th) }\end{array}$ & \begin{tabular}{|l} 
S/RES/505(1982), OP 4: \\
"Requests the Secretary- \\
General to enter into contact \\
immediately with the parties \\
with a view to negotiating \\
mutually acceptable terms for \\
a cease-fire, including, if \\
necessary, arrangements for \\
the dispatch of United Nations \\
observers to monitor \\
compliance with the terms of \\
the cease-fire" (15-0)
\end{tabular} & \begin{tabular}{|l} 
None \\
identified
\end{tabular} & Article 51 & $\begin{array}{l}\text { http: } \\
\text { //www.un. } \\
\text { org/en/ga/ } \\
\text { search/vie } \\
\text { w_doc. } \\
\text { asp? } \\
\text { symbol=s/ } \\
15119\end{array}$ & & \begin{tabular}{|l} 
https: \\
//perma. \\
cc/MC8W- \\
4KE8
\end{tabular} \\
\hline
\end{tabular}


VI. HLS PILAC Catalogue of Apparent “Article 51 Communications”

\begin{tabular}{|c|c|c|c|c|c|c|c|c|c|c|c|c|c|c|c|c|c|}
\hline $\begin{array}{l}\text { Chron. } \\
\text { Order }\end{array}$ & $\begin{array}{l}\text { Date of } \\
\text { Comm. }\end{array}$ & $\begin{array}{c}\text { Date of } \\
\text { UNsc } \\
\text { Document }\end{array}$ & | UNSC Symbol & \begin{tabular}{|c} 
Member \\
State(s) That \\
Submitted \\
the Comm.
\end{tabular} & \begin{tabular}{|c} 
Expressly \\
Mentioned UN \\
Members (\& \\
Colonial \\
Holdings \& \\
Protectorates, \\
if any)
\end{tabular} & \begin{tabular}{|c|} 
Express or \\
Implied \\
Assertion of \\
Individual, \\
Collective, or \\
Both Self- \\
defense
\end{tabular} & \begin{tabular}{|c} 
Nature of \\
the Alleged \\
Threat
\end{tabular} & \begin{tabular}{|l} 
Expressly Alleged \\
Author(s) of the \\
Threat (ff Any \\
Indicated)
\end{tabular} & $\begin{array}{l}\text { Nature of the } \\
\text { Alleged } \\
\text { Author(s) of } \\
\text { the Threat (If } \\
\text { Any } \\
\text { Indicated) }\end{array}$ & $\begin{array}{l}\text { Summary of Alleged Self-defense } \\
\text { Grounds }\end{array}$ & \begin{tabular}{|l} 
UNsc \\
Meeting(s) \\
(If Any) at \\
Which the \\
Comm. was \\
Raised
\end{tabular} & $\begin{array}{l}\text { Responsive Act (If Any) by the } \\
\text { UNSC }\end{array}$ & \begin{tabular}{|l} 
UN \\
Repertory \\
Inclusion?
\end{tabular} & $\begin{array}{c}\text { UNSC } \\
\text { Repertoire } \\
\text { Inclusion? }\end{array}$ & $\begin{array}{l}\text { URL to an } \\
\text { English } \\
\text { Text }\end{array}$ & \begin{tabular}{|c||} 
URL to Non- \\
English \\
Original \\
Text (ff Any)
\end{tabular} & $\begin{array}{l}\text { Perma.cc } \\
\text { URL }\end{array}$ \\
\hline 181 & 1982.05.26 & 1982.05.26 & $\mathrm{S} / 15128$ & Argentina & $\begin{array}{l}\text { Argentina, } \\
\text { United } \\
\text { Kingdom }\end{array}$ & $\begin{array}{l}\text { Implied } \\
\text { assertion of } \\
\text { "individual" } \\
\text { self-defense }\end{array}$ & $\begin{array}{c}\text { Conducted } \\
\text { attack }\end{array}$ & United Kingdom & State & $\begin{array}{l}\text { Argentine Air Force aircraft used } \\
\text { bombs to sink a UK missile destroyer } \\
\text { and Argentine Navy used missiles to } \\
\text { sink a UK aircraft transport vessel. }\end{array}$ & $\begin{array}{l}\text { None } \\
\text { identified }\end{array}$ & None identified & $\begin{array}{l}\text { None } \\
\text { identified }\end{array}$ & Article 51 & $\begin{array}{l}\text { http: } \\
\text { //www.un. } \\
\text { org/en//ga/ } \\
\text { search/vie } \\
\text { w_doc. } \\
\text { asp? } \\
\text { spybol=S/ } \\
15128\end{array}$ & $\begin{array}{l}\text { http://www. } \\
\text { un. } \\
\text { org/en/ga/se } \\
\text { arch/view_do } \\
\text { c.asp? } \\
\text { symbol=s/151 } \\
\text { 28\&Lang=s }\end{array}$ & $\begin{array}{l}\text { hitps: } \\
\text { //Perma. } \\
\text { cc//744L- } \\
\text { u4XLL }\end{array}$ \\
\hline 182 & 1982.05.27 & 1982.05.27 & $s / 15131$ & Argentina & $\begin{array}{l}\text { Argentina, } \\
\text { United } \\
\text { Kingdom }\end{array}$ & $\begin{array}{l}\text { Implied } \\
\text { assertion of } \\
\text { "individual" } \\
\text { self-defense }\end{array}$ & $\begin{array}{c}\text { Conducted } \\
\text { attack }\end{array}$ & United Kingdom & State & $\begin{array}{l}\text { Argentine Armed Forces sunk and } \\
\text { damaged UK vessels, shot down UK } \\
\text { aircrafts, and damaged/destroyed UK } \\
\text { helicopters. }\end{array}$ & $\begin{array}{l}\text { None } \\
\text { identified }\end{array}$ & None identified & $\begin{array}{l}\text { None } \\
\text { identified }\end{array}$ & Article 51 & $\begin{array}{l}\text { http: } \\
\text { //wwww.un. } \\
\text { org/en/ga/ } \\
\text { search//ie } \\
\text { w_doc. } \\
\text { asp? } \\
\text { symbol=S/ } \\
15131\end{array}$ & $\begin{array}{l}\text { http://www. } \\
\text { un. } \\
\text { org/en/ga/se } \\
\text { arch/view_do } \\
\text { c.asp? } \\
\text { symbol=s/151 } \\
\text { 318Lang=s }\end{array}$ & $\begin{array}{l}\text { hitps: } \\
\text { //perma. } \\
\text { cc/Jl/C2- } \\
\text { aGRR }\end{array}$ \\
\hline 183 & 1982.05.27 & 1982.05.28 & $s / 15134$ & $\begin{array}{l}\text { United } \\
\text { Kingdom }\end{array}$ & $\begin{array}{l}\text { United } \\
\text { Kingdom, } \\
\text { Argentina }\end{array}$ & $\begin{array}{l}\text { Implied } \\
\text { assertion of } \\
\text { "individual" } \\
\text { self-defense }\end{array}$ & $\begin{array}{c}\text { Conducted } \\
\text { attack }\end{array}$ & Argentina & State & $\begin{array}{l}\text { Argentine Air Force attacked British } \\
\text { ships, and UK responded with force } \\
\text { "in the face of Argentina's invasion of } \\
\text { the Falkland Islands and the illegal use } \\
\text { of force to occupy them and to } \\
\text { subjugate their people." }\end{array}$ & $\begin{array}{l}\text { None } \\
\text { identified }\end{array}$ & None identified & $\begin{array}{l}\text { None } \\
\text { identified }\end{array}$ & Article 51 & $\begin{array}{l}\text { http: } \\
\text { //www.un. } \\
\text { org/en/ga/ } \\
\text { search/vie } \\
\text { w_doc. } \\
\text { ass? } \\
\text { symbol=s/ } \\
15134\end{array}$ & & $\begin{array}{l}\text { hitps: } \\
\text { //Terma. } \\
\text { cc//8QRY } \\
\text { sJoF }\end{array}$ \\
\hline 184 & 1982.05.28 & 1982.05.28 & $S / 15136$ & Argentina & $\begin{array}{l}\text { Argentina, } \\
\text { Brazil, United } \\
\text { Kingdom }\end{array}$ & $\begin{array}{l}\text { Implied } \\
\text { assertion of } \\
\text { "individual" } \\
\text { self-defense }\end{array}$ & $\begin{array}{c}\text { Conducted } \\
\text { attack }\end{array}$ & United Kingdom & State & $\begin{array}{l}\text { Argentine Air Force attacks in } \\
\text { response to British attacks on } \\
\text { Argentine Air Force and Army. }\end{array}$ & \begin{tabular}{|l} 
None \\
identified
\end{tabular} & None identified & $\begin{array}{l}\text { None } \\
\text { identified }\end{array}$ & Article 51 & $\begin{array}{l}\text { http: } \\
\text { //www.un. } \\
\text { org/en/ga/ } \\
\text { search/vie } \\
\text { w_doc. } \\
\text { asp? } \\
\text { symbol=s/ } \\
15136\end{array}$ & $\mid \begin{array}{l}\text { http://www. } \\
\text { un. } \\
\text { org/en/ga/se } \\
\text { archh/view_do } \\
\text { c.asp? } \\
\text { symbol=s/151 } \\
\text { 36\&lang=s }\end{array}$ & $\begin{array}{l}\text { hitps: } \\
\text { //perma. } \\
\text { cc/A8VM- } \\
\text { cs27 }\end{array}$ \\
\hline 185 & 1982.05.31 & 1982.05.31 & $S / 15147$ & Argentina & $\begin{array}{l}\text { Argentina, } \\
\text { United } \\
\text { Kingdom }\end{array}$ & $\begin{array}{l}\text { Implied } \\
\text { assertion of } \\
\text { "individual" } \\
\text { self-defense }\end{array}$ & $\begin{array}{c}\text { Conducted } \\
\text { attack }\end{array}$ & United Kingdom & State & $\begin{array}{l}\text { British Navy attacked Argentine Air } \\
\text { Force aircrafts, and Argentine Air } \\
\text { Force responded with attacks. }\end{array}$ & $\begin{array}{l}\text { None } \\
\text { identified }\end{array}$ & None identified & $\begin{array}{l}\text { None } \\
\text { identified }\end{array}$ & Article 51 & $\begin{array}{l}\text { http: } \\
\text { //www.un. } \\
\text { org/en//ga/ } \\
\text { search/vie } \\
\text { w_doc. } \\
\text { asp? } \\
\text { symbol=S/ } \\
15147\end{array}$ & $\mid \begin{array}{l}\text { http://www. } \\
\text { un. } \\
\text { org/en/ga/se } \\
\text { arch/view_do } \\
\text { c.asp? } \\
\text { symbol=s/151 } \\
478 \text { lang=s }\end{array}$ & $\begin{array}{l}\text { hitps: } \\
\text { ///perma. } \\
\text { cc/222VV- } \\
\text { F5sm9 }\end{array}$ \\
\hline 186 & 1982.06.01 & 1982.06.01 & $S / 15148$ & $\begin{array}{l}\text { United } \\
\text { Kingdom }\end{array}$ & $\begin{array}{l}\text { United } \\
\text { Kingdom, } \\
\text { Argentina }\end{array}$ & $\begin{array}{l}\text { Implied } \\
\text { assertion of } \\
\text { "individual" } \\
\text { self-defense }\end{array}$ & $\begin{array}{c}\text { Conducted } \\
\text { attack }\end{array}$ & Argentina & State & \begin{tabular}{|l} 
"It was Argentina which first used \\
force by launching an armed attack on \\
the Falkland Islands. That attack was a \\
wholly unjustifiable act of aggression \\
and a breach of the principles of the \\
Charter. It took place at a time when \\
negotiations were still in progress and \\
resulted in the overwhelming of a tiny \\
British garrison by a vastly larger \\
Argentine force.".
\end{tabular} & $\begin{array}{l}\text { None } \\
\text { identified }\end{array}$ & None identified & $\begin{array}{l}\text { None } \\
\text { identified }\end{array}$ & Article 51 & $\begin{array}{l}\text { http: } \\
\text { //www.un. } \\
\text { org/en/ga/ } \\
\text { search/vie } \\
\text { w_doc. } \\
\text { asp? } \\
\text { symbol=S/ } \\
15148\end{array}$ & & $\begin{array}{l}\text { hitps: } \\
\text { ///perma. } \\
\text { cc//2rV- } \\
\text { s9C6 }\end{array}$ \\
\hline 187 & 1982.06.04 & 1982.06.04 & $S / 15160$ & Argentina & $\begin{array}{l}\text { Argentina, } \\
\text { United } \\
\text { Kingdom }\end{array}$ & $\begin{array}{l}\text { Implied } \\
\text { assertion of } \\
\text { "individual" } \\
\text { self-defense }\end{array}$ & $\begin{array}{c}\text { Conducted } \\
\text { attack }\end{array}$ & United Kingdom & State & $\begin{array}{l}\text { Argentine Armed Forces exchanged } \\
\text { artillery fire with British Forces, } \\
\text { subjected them to "intense shelling". }\end{array}$ & $\begin{array}{l}\text { S/PV. } 2373 \\
\text { (2373rd) }\end{array}$ & None identified & $\begin{array}{l}\text { None } \\
\text { identified }\end{array}$ & Article 51 & $\begin{array}{l}\text { http: } \\
\text { //www.un. } \\
\text { org/ngn/ga/ } \\
\text { search/vie } \\
\text { w_doc. } \\
\text { asp? } \\
\text { spybol=S/ } \\
15160\end{array}$ & $\left\{\begin{array}{l}\text { http: //www. } \\
\text { un. } \\
\text { org/en/ga/se } \\
\text { arch//view_do } \\
\text { c.asp? } \\
\text { symbol=s/151 } \\
60 \& \text { Lang=s }\end{array}\right.$ & $\begin{array}{l}\text { hitps: } \\
\text { //perma. } \\
\text { cc//NAUB- } \\
\text { 4xVW }\end{array}$ \\
\hline 188 & 1982.06.05 & 1982.06.07 & $s / 15169$ & Argentina & $\begin{array}{l}\text { Argentina, } \\
\text { United } \\
\text { Kingdom }\end{array}$ & $\begin{array}{l}\text { Implied } \\
\text { assertion of } \\
\text { "individual" } \\
\text { self-defense }\end{array}$ & $\begin{array}{c}\text { Conducted } \\
\text { attack }\end{array}$ & United Kingdom & State & $\begin{array}{l}\text { Argentine Armed Forces conducted } \\
\text { isolated patrol actions and artillery } \\
\text { fire, "repulsed an enemy air } \\
\text { incursion," and carried out bombing } \\
\text { raids (noting that there was no enemy } \\
\text { opposition or air activity). }\end{array}$ & \begin{tabular}{|l} 
None \\
identified
\end{tabular} & None identified & $\begin{array}{l}\text { None } \\
\text { identified }\end{array}$ & Article 51 & $\begin{array}{l}\text { http: } \\
\text { //wwww.un. } \\
\text { org/en/ga/ } \\
\text { search//vie } \\
\text { w_doc. } \\
\text { asp? } \\
\text { symbol=S/ } \\
15169\end{array}$ & $\begin{array}{l}\text { http: //www. } \\
\text { un. } \\
\text { org/en/ga/se } \\
\text { arch//iew_do } \\
\text { c.asp? } \\
\text { symbol=s/151 } \\
698 \text { Llang=s }=5\end{array}$ & $\begin{array}{l}\text { hitps: } \\
\text { //perma. } \\
\text { ccl/A8ZC- } \\
\text { PR8E }\end{array}$ \\
\hline
\end{tabular}


VI. HLS PILAC Catalogue of Apparent “Article 51 Communications”

\begin{tabular}{|c|c|c|c|c|c|c|c|c|c|c|c|c|c|c|c|c|c|}
\hline $\begin{array}{l}\text { Chron. } \\
\text { Order }\end{array}$ & $\begin{array}{l}\text { Date of } \\
\text { Comm. }\end{array}$ & $\begin{array}{l}\text { Date of } \\
\text { UNSC } \\
\text { Document }\end{array}$ & UNSC Symbol & \begin{tabular}{||c} 
Member \\
State(s) That \\
Submitted \\
the Comm.
\end{tabular} & \begin{tabular}{|c|} 
Expressly \\
Mentioned UN \\
Members (\& \\
Colonial \\
Holdings \& \\
Protectorates, \\
if any) \\
\end{tabular} & \begin{tabular}{||c|} 
Express or \\
Implied \\
Assertion of \\
Individual, \\
Collective, or \\
Both Self- \\
defense \\
\end{tabular} & \begin{tabular}{|l} 
Nature of \\
the Alleged \\
Threat
\end{tabular} & $\begin{array}{l}\text { Expressly Alleged } \\
\text { Author(s) of the } \\
\text { Threat (If Any } \\
\text { Indicated) }\end{array}$ & \begin{tabular}{|c} 
Nature of the \\
Alleged \\
Author(s) of \\
the Threat (If \\
Any \\
Indicated)
\end{tabular} & $\begin{array}{l}\text { Summary of Alleged Self-defense } \\
\text { Grounds }\end{array}$ & $\begin{array}{l}\text { UNsC } \\
\text { Meeting(s) } \\
\text { (If Any) at } \\
\text { Which the } \\
\text { Comm. was } \\
\text { Raised }\end{array}$ & $\begin{array}{l}\text { Responsive Act (If Any) by the } \\
\text { UNSC }\end{array}$ & $\begin{array}{l}\text { UN } \\
\text { Repertory } \\
\text { Inclusion? }\end{array}$ & \begin{tabular}{|c} 
UNsC \\
Repertoire \\
Inclusion?
\end{tabular} & \begin{tabular}{|c|} 
URL to an \\
English \\
Text
\end{tabular} & \begin{tabular}{|c||} 
URL to Non- \\
English \\
Original \\
Text (ff Any)
\end{tabular} & $\begin{array}{l}\text { Perma.cc } \\
\text { URL }\end{array}$ \\
\hline 189 & 1982.06.07 & 1982.06.07 & S/15177 & Argentina & $\begin{array}{l}\text { Argentina, } \\
\text { United } \\
\text { Kingdom }\end{array}$ & $\begin{array}{c}\text { Implied } \\
\text { assertion of } \\
\text { "individual" } \\
\text { self-defense }\end{array}$ & $\begin{array}{c}\text { Conducted } \\
\text { attack }\end{array}$ & United Kingdom & State & $\begin{array}{l}\text { Argentine reconnaissance operations, } \\
\text { bombing raids, and exchange of } \\
\text { artillery fire with the UK. }\end{array}$ & $\begin{array}{l}\text { None } \\
\text { identified }\end{array}$ & None identified & $\begin{array}{l}\text { None } \\
\text { identified }\end{array}$ & No & \begin{tabular}{|l||} 
http: \\
//www.un. \\
org//nen//gai \\
search/vie \\
w_doc. \\
asp? \\
symbol=s/ \\
15177 \\
\end{tabular} & $\begin{array}{l}\text { http://www. } \\
\text { un. } \\
\text { org/en/ga/se } \\
\text { arch/view_do } \\
\text { c.asp? } \\
\text { symbol=s/151 } \\
778 \text { Lang=s }\end{array}$ & $\begin{array}{l}\text { https: } \\
\text { ///perma. } \\
\text { cc/BGTC- } \\
\text { 4V9M }\end{array}$ \\
\hline 190 & 1982.06 .08 & 1982.06 .08 & $\mathrm{~s} / 15181$ & Argentina & $\begin{array}{l}\text { Argentina, } \\
\text { United } \\
\text { Kingdom }\end{array}$ & $\begin{array}{l}\text { Implied } \\
\text { assertion of } \\
\text { "individual" } \\
\text { self-defense }\end{array}$ & $\begin{array}{c}\text { Conducted } \\
\text { attack }\end{array}$ & United Kingdom & State & $\begin{array}{l}\text { Argentine artillery fire, confrontation } \\
\text { with enemy forces which resulted in } \\
\text { the enemy forces withdrawing, enemy } \\
\text { aircrafts made incursions over } \\
\text { Argentine positions and were } \\
\text { "repulsed, "and sporadic exchanges of } \\
\text { artillery fire between forces. }\end{array}$ & $\begin{array}{l}\text { None } \\
\text { identified }\end{array}$ & None identified & $\begin{array}{l}\text { None } \\
\text { identified }\end{array}$ & Article 51 & \begin{tabular}{|l|} 
http: \\
h/www.un. \\
org/en/ga/ \\
search/vie \\
w_doc. \\
asp? \\
spmbol=s/ \\
15181
\end{tabular} & $\begin{array}{l}\text { http://www. } \\
\text { un. } \\
\text { org/en/ga/se } \\
\text { arch/view_do } \\
\text { c.asp? } \\
\text { symbol=s/151 } \\
\text { 818Lang=s }\end{array}$ & $\begin{array}{l}\text { https: } \\
\text { //perma. } \\
\text { cc/PWD8- } \\
\text { 4PX9 }\end{array}$ \\
\hline 191 & 1982.06.09 & 1982.06.09 & $\mathrm{S} / 15189$ & Argentina & $\begin{array}{l}\text { Argentina, } \\
\text { United } \\
\text { Kingdom }\end{array}$ & $\begin{array}{l}\text { Implied } \\
\text { assertion of } \\
\text { "individual" } \\
\text { self-defense }\end{array}$ & $\begin{array}{c}\text { Conducted } \\
\text { attack }\end{array}$ & United Kingdom & State & $\begin{array}{l}\text { "[A]ircraft of the Argentine Air Force } \\
\text { attacked United Kingdom forces which } \\
\text { were attempting to disembark at } \\
\text { Pleasant Bay" and UK forces suffered } \\
\text { damage as a result. }\end{array}$ & $\begin{array}{l}\text { None } \\
\text { identified }\end{array}$ & None identified & $\begin{array}{l}\text { None } \\
\text { identified }\end{array}$ & Article 51 & \begin{tabular}{|l||} 
http: \\
//www.un. \\
org//engal \\
search/vie \\
w_doc. \\
asp? \\
symbol=s/ \\
15189 \\
\end{tabular} & $\begin{array}{l}\text { http://www. } \\
\text { un. } \\
\text { org/en/ga/se } \\
\text { archh/view_do } \\
\text { c.asp? } \\
\text { symbol=s/151 } \\
\text { 89\&lang=s }\end{array}$ & \begin{tabular}{|l} 
https: \\
//perma. \\
cc/WZK8- \\
LFUB
\end{tabular} \\
\hline 192 & 1982.06.10 & 1982.06.10 & S/15192 & Argentina & $\begin{array}{l}\text { Argentina, } \\
\text { United } \\
\text { Kingdom }\end{array}$ & \begin{tabular}{|c} 
Implied \\
assertion of \\
"individual" \\
self-defense
\end{tabular} & $\begin{array}{c}\text { Conducted } \\
\text { attack }\end{array}$ & United Kingdom & State & $\begin{array}{l}\text { UK forces attempted to infiltrate } \\
\text { Aagentine defenses, were repulsed } \\
\text { after combat with Argentine Army, } \\
\text { and then an artillery duel occurred } \\
\text { between forces, followed by further } \\
\text { exchanges of artillery fire between UK } \\
\text { forces and Argentine Army and Air } \\
\text { Force. }\end{array}$ & $\begin{array}{l}\text { None } \\
\text { identified }\end{array}$ & None identified & $\begin{array}{l}\text { None } \\
\text { identified }\end{array}$ & Article 51 & \begin{tabular}{|l||} 
http: \\
//www.un. \\
org/en/ga/ \\
search/vie \\
w_doc. \\
asp? \\
spmbol=s/ \\
15192 \\
\end{tabular} & $\begin{array}{l}\text { http://www. } \\
\text { un. } \\
\text { org/en/ga/se } \\
\text { arch/view_do } \\
\text { c.aps? } \\
\text { symbol=s/151 } \\
\text { 92\&lang=s }\end{array}$ & \begin{tabular}{|l} 
https: \\
//perma. \\
cc/77G62- \\
2FSB
\end{tabular} \\
\hline 193 & 1982.06.11 & 1982.06.13 & $\mathrm{s} / 15201$ & Argentina & $\begin{array}{l}\text { Argentina, } \\
\text { United } \\
\text { Kingdom }\end{array}$ & $\begin{array}{l}\text { Implied } \\
\text { assertion of } \\
\text { "individual" } \\
\text { self-defense }\end{array}$ & $\begin{array}{l}\text { Conducted } \\
\text { attack }\end{array}$ & United Kingdom & State & $\begin{array}{l}\text { Argentine Air Force carried out } \\
\text { attacks, and Argentine Army carried } \\
\text { out artillery fire. }\end{array}$ & \begin{tabular}{|l} 
None \\
identified
\end{tabular} & None identified & $\begin{array}{l}\text { None } \\
\text { identified }\end{array}$ & Article 51 & \begin{tabular}{|l|} 
http: \\
//www.un. \\
org//en/ga/ \\
search/vie \\
w_doc. \\
a_p? \\
symbol=s/ \\
15201 \\
\end{tabular} & \begin{tabular}{|l|} 
http://www. \\
un. \\
org/en/ga/se \\
arch/view_do \\
c.asp? \\
symbol=s/152 \\
o1\&lang=s
\end{tabular} & \begin{tabular}{|l} 
https: \\
//perma. \\
cc/8TTE- \\
A3TK
\end{tabular} \\
\hline 194 & 1982.06.12 & 1982.06.13 & $\mathrm{s} / 15202$ & Argentina & $\begin{array}{l}\text { Argentina, } \\
\text { United } \\
\text { Kingdom, } \\
\text { Uruguay }\end{array}$ & $\begin{array}{l}\text { Implied } \\
\text { assertion of } \\
\text { "individual" } \\
\text { self-defense }\end{array}$ & $\begin{array}{c}\text { Conducted } \\
\text { attack }\end{array}$ & United Kingdom & State & \begin{tabular}{|l} 
Argentine air attacks and \\
bombardment of enemy forces; states \\
that UK Government and British Press \\
"not only distort and conceal \\
information but are primarily intent \\
on denying casualties and material \\
losses, and at times issue reports that \\
are ridiculous and incredible in the \\
light of the facts."
\end{tabular} & \begin{tabular}{|l} 
None \\
identified
\end{tabular} & None identified & $\begin{array}{l}\text { None } \\
\text { identified }\end{array}$ & Article 51 & \begin{tabular}{|l||} 
http: \\
//www.un. \\
org//en/ga/ \\
search/vie \\
w_doc. \\
asp? \\
symbol=s/ \\
15202
\end{tabular} & $\begin{array}{l}\text { http: //www. } \\
\text { un. } \\
\text { org/en/ga/se } \\
\text { arch/view_do } \\
\text { c.aps? } \\
\text { symbol=s/152 } \\
\text { o2\&lang=S }\end{array}$ & $\begin{array}{l}\text { https: } \\
\text { //perma. } \\
\text { cc/67ET- } \\
\text { MSQ3 }\end{array}$ \\
\hline 195 & 1982.06.12 & 1982.06.13 & S/15204 & Argentina & $\begin{array}{l}\text { Argentina, } \\
\text { United } \\
\text { Kingdom }\end{array}$ & $\begin{array}{l}\text { Implied } \\
\text { assertion of } \\
\text { "individual" } \\
\text { self-defense }\end{array}$ & $\begin{array}{l}\text { Conducted } \\
\text { attack }\end{array}$ & United Kingdom & State & $\begin{array}{l}\text { British aircraft attacked Argentine } \\
\text { hospital ship and "bombard[ed] in an } \\
\text { indiscriminate manner the city of } \\
\text { Puerto Argentino" which was } \\
\text { characterized as an attack directed at } \\
\text { civilians. The two acts "cause[] grave } \\
\text { concern at the lack of respect for } \\
\text { human rights demonstrated by Great } \\
\text { Britain, an attitude which clearly } \\
\text { constitutes an affront to the Western } \\
\text { world." }\end{array}$ & \begin{tabular}{|l} 
None \\
identified
\end{tabular} & None identified & $\begin{array}{l}\text { None } \\
\text { identified }\end{array}$ & Article 51 & \begin{tabular}{|l||} 
http: \\
//www.un. \\
org//enga/ \\
search/vie \\
w_doc. \\
a_p? \\
symbol=s/ \\
15204
\end{tabular} & $\begin{array}{l}\text { http://www. } \\
\text { un. } \\
\text { org/en/ga/se } \\
\text { arch/view_do } \\
\text { c.asp? } \\
\text { symbol=s/152 } \\
\text { o4\&lang=S }\end{array}$ & $\begin{array}{l}\text { https: } \\
\text { //perma. } \\
\text { cc//Z87- } \\
\text { WSRA }\end{array}$ \\
\hline
\end{tabular}


VI. HLS PILAC Catalogue of Apparent “Article 51 Communications”

\begin{tabular}{|c|c|c|c|c|c|c|c|c|c|c|c|c|c|c|c|c|c|}
\hline $\begin{array}{c}\text { Chron. } \\
\text { Order }\end{array}$ & $\begin{array}{l}\text { Date of } \\
\text { Comm. }\end{array}$ & $\begin{array}{c}\text { Date of } \\
\text { UNsc } \\
\text { Document }\end{array}$ & UNSC Symbol & \begin{tabular}{|c} 
Member \\
State(s) That \\
Submitted \\
the Comm.
\end{tabular} & \begin{tabular}{|c|} 
Expressly \\
Mentioned UN \\
Members (\& \\
Colonial \\
Holdings \& \\
Protectorates, \\
if any) \\
\end{tabular} & \begin{tabular}{|l} 
Express or \\
Implied \\
Assertion of \\
Individual, \\
Collective, or \\
Both Self- \\
defense
\end{tabular} & \begin{tabular}{|l} 
Nature of \\
the Alleged \\
Threat
\end{tabular} & $\begin{array}{l}\text { Expressly Alleged } \\
\text { Author(s) of the } \\
\text { Threat (If Any } \\
\text { Indicated) }\end{array}$ & \begin{tabular}{|l|} 
Nature of the \\
Alleged \\
Author(s) of \\
the Threat (If \\
Any \\
Indicated)
\end{tabular} & $\begin{array}{l}\text { Summary of Alleged Self-defense } \\
\text { Grounds }\end{array}$ & \begin{tabular}{|l} 
UNsc \\
Meeting(s) \\
(If Any) at \\
Which the \\
Comm. was \\
Raised
\end{tabular} & $\begin{array}{l}\text { Responsive Act (If Any) by the } \\
\text { UNSC }\end{array}$ & $\begin{array}{l}\text { UN } \\
\text { Repertory } \\
\text { Inclusion? }\end{array}$ & \begin{tabular}{|c|} 
UNSC \\
Repertoire \\
Inclusion?
\end{tabular} & \begin{tabular}{|c||} 
URL to an \\
English \\
Text
\end{tabular} & \begin{tabular}{||c||} 
URL to Non- \\
English \\
Original \\
Text (ff Any)
\end{tabular} & Perma.cc \\
\hline 196 & 1982.06.12 & 1982.06.13 & $s / 15205$ & Argentina & $\begin{array}{c}\text { Argentina, } \\
\text { United } \\
\text { Kingdom }\end{array}$ & $\begin{array}{l}\text { Implied } \\
\text { assertion of } \\
\text { "individual" } \\
\text { self-defense }\end{array}$ & $\begin{array}{c}\text { Conducted } \\
\text { attack }\end{array}$ & United Kingdom & State & $\begin{array}{l}\text { UK forces began a land attack against } \\
\text { Argentine positions, resulting in } \\
\text { "heavy fighting" in the Puerto } \\
\text { Argentino area. }\end{array}$ & $\begin{array}{l}\text { None } \\
\text { identified }\end{array}$ & None identified & $\begin{array}{l}\text { None } \\
\text { identified }\end{array}$ & Article 51 & \begin{tabular}{|l||} 
http: \\
t/www.un. \\
org//nn/ga/ \\
search/vie \\
w_doc. \\
asp?? \\
symbol=s/ \\
15205
\end{tabular} & \begin{tabular}{|l||} 
http://www. \\
un. \\
org/en/ga/se \\
arch/view_do \\
c.asp? \\
symbol=S/152 \\
O5\&Lang=S \\
\end{tabular} & $\begin{array}{l}\text { https: } \\
\text { //perma. } \\
\text { cc/P39M- } \\
\text { YU68 } \\
\end{array}$ \\
\hline 197 & 1982.06.12 & 1982.06.13 & $S / 15207$ & Argentina & $\begin{array}{c}\text { Argentina, } \\
\text { United } \\
\text { Kingdom }\end{array}$ & $\begin{array}{l}\text { Implied } \\
\text { assertion of } \\
\text { "individual" } \\
\text { self-defense }\end{array}$ & $\begin{array}{c}\text { Conducted } \\
\text { attack }\end{array}$ & United Kingdom & State & 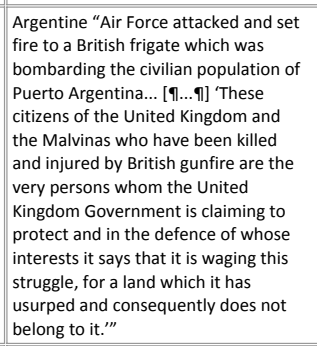 & $\begin{array}{l}\text { None } \\
\text { identified }\end{array}$ & None identified & \begin{tabular}{|l} 
None \\
identified
\end{tabular} & Article 51 & \begin{tabular}{|l||} 
http: \\
//www.un. \\
org//nn/ga/ \\
search/vie \\
w_doc. \\
asp? \\
symbol=s/ \\
15207
\end{tabular} & $\begin{array}{l}\text { http://www. } \\
\text { un. } \\
\text { org/en/ga/se } \\
\text { arch/view_do } \\
\text { c.aps? } \\
\text { symbol=s/152 } \\
\text { 07\&lang=s }\end{array}$ & $\begin{array}{l}\text { hetps: } \\
\text { //perma. } \\
\text { cc/577B- } \\
\text { VS7s }\end{array}$ \\
\hline 198 & 1982.06.13 & 1982.06.14 & $\mathrm{S} / 15212$ & Argentina & $\begin{array}{l}\text { Argentina, } \\
\text { United } \\
\text { Kingdom }\end{array}$ & $\begin{array}{l}\text { Implied } \\
\text { assertion of } \\
\text { "individual" } \\
\text { self-defense }\end{array}$ & $\begin{array}{c}\text { Conducted } \\
\text { attack }\end{array}$ & United Kingdom & State & $\begin{array}{l}\text { UK troops advanced } 3.5 \mathrm{~km} \text { behind } \\
\text { Argentine defense lines, but "[t]he } \\
\text { situation is at present unchanged as } \\
\text { fighting is continuing with heary } \\
\text { artillery and mortar fire from both } \\
\text { sides." }\end{array}$ & $\begin{array}{l}\text { None } \\
\text { identified }\end{array}$ & None identified & \begin{tabular}{|l} 
None \\
identified
\end{tabular} & Article 51 & \begin{tabular}{|l|l|} 
http: & \\
//www.un. \\
org/en/ga/ \\
search/vie \\
w_doc. \\
asp? \\
symbol=s/ \\
15212
\end{tabular} & $\begin{array}{l}\text { hitp://www. } \\
\text { un. } \\
\text { org/en/ga/se } \\
\text { arch//iew_do } \\
\text { c.asp? } \\
\text { symbol=s/152 } \\
\text { 12\&Llang=s }\end{array}$ & $\begin{array}{l}\text { https: } \\
\text { //perma. } \\
\text { cc/9c34- } \\
\text { R4BB }\end{array}$ \\
\hline 199 & 1982.06.14 & 1982.06.14 & $\mathrm{s} / 15214$ & Argentina & $\begin{array}{c}\text { Argentina, } \\
\text { United } \\
\text { Kingdom }\end{array}$ & $\begin{array}{l}\text { Implied } \\
\text { assertion of } \\
\text { "individual" } \\
\text { self-defense }\end{array}$ & $\begin{array}{c}\text { Conducted } \\
\text { attack }\end{array}$ & United Kingdom & State & $\begin{array}{l}\text { Exchanges of artillery fire between } \\
\text { Argentine and British forces over } 2 \\
\text { days. }\end{array}$ & $\begin{array}{l}\text { None } \\
\text { identified }\end{array}$ & None identified & $\begin{array}{l}\text { None } \\
\text { identified }\end{array}$ & Article 51 & \begin{tabular}{|l||} 
http: \\
//www.un. \\
org/en/ga/ \\
search/vie \\
w_doc. \\
asp? \\
symbol=s/ \\
15214
\end{tabular} & $\begin{array}{l}\text { http://www. } \\
\text { un: } \\
\text { org/en/ga/se } \\
\text { arch/view_do } \\
\text { c.asp? } \\
\text { symbol=s/152 } \\
14 \& \text { Lang=s }\end{array}$ & 2 \\
\hline 200 & 1982.06.14 & 1982.06.15 & S/15217 & Argentina & $\begin{array}{l}\text { Argentina, } \\
\text { United } \\
\text { Kingdom }\end{array}$ & $\begin{array}{l}\text { Implied } \\
\text { assertion of } \\
\text { "individual" } \\
\text { self-defense }\end{array}$ & $\begin{array}{c}\text { Conducted } \\
\text { attack }\end{array}$ & United Kingdom & State & \begin{tabular}{|l} 
Argentine forces fought in the face of \\
a UK "advance to reach key positions \\
of the Argentine defense located on \\
Tumbledown Mountain and Wireless \\
Ridge" $4 k m$ to the west of Puerto \\
Argentino. British troops "occupied" \\
both areas and "continued their \\
advance" with Argentine forces \\
continuing to fight.
\end{tabular} & \begin{tabular}{|l} 
None \\
identified
\end{tabular} & None identified & \begin{tabular}{|l} 
None \\
identified
\end{tabular} & Article 51 & \begin{tabular}{l||} 
http: \\
t/www.un. \\
org//nn/ga/ \\
search/vie \\
w_doc. \\
aspp? \\
symbol=s/ \\
15217
\end{tabular} & $\begin{array}{l}\text { http://www. } \\
\text { un. } \\
\text { org/en/ga/se } \\
\text { arch/view_do } \\
\text { c.aps? } \\
\text { symbol=s/152 } \\
17 \& \text { Lang=s }\end{array}$ & $\begin{array}{l}\text { https: } \\
\text { //perma. } \\
\text { cc//C63A- } \\
5 \text { ER8 }\end{array}$ \\
\hline 201 & 1982.06.21 & 1982.06.21 & $S / 15246$ & $\begin{array}{l}\text { United } \\
\text { Kingdom }\end{array}$ & $\begin{array}{l}\text { United } \\
\text { Kingdom, } \\
\text { Argentina }\end{array}$ & $\begin{array}{l}\text { Implied } \\
\text { assertion of } \\
\text { "individual" } \\
\text { self-defense }\end{array}$ & $\begin{array}{c}\text { Conducted } \\
\text { attack }\end{array}$ & Argentina & State & $\begin{array}{l}\text { The United Kingdom reports the } \\
\text { "recovery of possession of the South } \\
\text { Sandwich Islands." An Argentine } \\
\text { station composed of } 10 \text { naval and } 1 \text { air } \\
\text { force personnel "formally } \\
\text { surrendered" and "at no time were } \\
\text { any shots fired by British forces." }\end{array}$ & $\begin{array}{l}\text { None } \\
\text { identified }\end{array}$ & None identified & \begin{tabular}{|l} 
None \\
identified
\end{tabular} & Article 51 & \begin{tabular}{|l|} 
http: \\
h/www.un. \\
org//nn/ga/ \\
search/vie \\
w_doc. \\
asp? \\
symbol=s/ \\
15246 \\
\end{tabular} & & $\begin{array}{l}\text { https: } \\
\text { //perma. } \\
\text { cc/B2DS- } \\
\text { X8B9 }\end{array}$ \\
\hline 202 & 1982.06.23 & 1982.06.23 & $s / 15249$ & $\begin{array}{l}\text { United } \\
\text { Kingdom }\end{array}$ & $\begin{array}{l}\text { United } \\
\text { Kingdom, } \\
\text { Argentina }\end{array}$ & $\begin{array}{l}\text { Implied } \\
\text { assertion of } \\
\text { "individual" } \\
\text { self-defense }\end{array}$ & $\begin{array}{c}\text { Conducted } \\
\text { attack }\end{array}$ & Argentina & State & $\begin{array}{l}\text { The United Kingdom rejects Argentina' } \\
\text { s letter of June } 18,1982 \text { 's description } \\
\text { of British action in Falkland Islands as } \\
\text { "armed aggression" " yy arguing that it } \\
\text { was actually Argentina who } \\
\text { committed armed aggression. }\end{array}$ & $\begin{array}{l}\text { None } \\
\text { identified }\end{array}$ & None identified & $\begin{array}{l}\text { None } \\
\text { identified }\end{array}$ & Article 51 & \begin{tabular}{|l||} 
http: \\
//www.un. \\
org/en/ga/ \\
search/vie \\
w_doc. \\
asp? \\
symbol=s/ \\
15249
\end{tabular} & & $\begin{array}{l}\text { https: } \\
\text { //perma. } \\
\text { cc/MR2N- } \\
\text { YSM2 }\end{array}$ \\
\hline
\end{tabular}


VI. HLS PILAC Catalogue of Apparent “Article 51 Communications”

\begin{tabular}{|c|c|c|c|c|c|c|c|c|c|c|c|c|c|c|c|c|c|}
\hline $\begin{array}{l}\text { Chron. } \\
\text { Order }\end{array}$ & $\begin{array}{l}\text { Date of } \\
\text { Comm. }\end{array}$ & \begin{tabular}{|c} 
Date of \\
UNSC \\
Document
\end{tabular} & | UNSC Symbol & \begin{tabular}{||c} 
Member \\
State(s) That \\
Submitted \\
the Comm.
\end{tabular} & \begin{tabular}{|c|} 
Expressly \\
Mentioned UN \\
Members (\& \\
Colonial \\
Holdings \& \\
Protectorates, \\
if any) \\
\end{tabular} & \begin{tabular}{|c|} 
Express or \\
Implied \\
Assertion of \\
Individual, \\
Collective, or \\
Both Self- \\
defense
\end{tabular} & \begin{tabular}{|c} 
Nature of \\
the Alleged \\
Threat
\end{tabular} & $\begin{array}{l}\text { Expressly Alleged } \\
\text { Author(s) of the } \\
\text { Threat (If Any } \\
\text { Indicated) }\end{array}$ & $\begin{array}{l}\text { Nature of the } \\
\text { Alleged } \\
\text { Author(s) of } \\
\text { the Threat (If } \\
\text { Any } \\
\text { Indicated) }\end{array}$ & $\begin{array}{l}\text { Summary of Alleged Self-defense } \\
\text { Grounds }\end{array}$ & \begin{tabular}{|c|} 
UNsC \\
Meeting(s) \\
(if Any) at \\
Which the \\
Comm. was \\
Raised
\end{tabular} & $\begin{array}{l}\text { Responsive Act (If Any) by the } \\
\text { UNSC }\end{array}$ & \begin{tabular}{||c} 
UN \\
Repertory \\
Inclusion?
\end{tabular} & \begin{tabular}{|c} 
UNSC \\
Repertoire \\
Inclusion?
\end{tabular} & \begin{tabular}{|c|} 
URL to a a \\
English \\
Text
\end{tabular} & \begin{tabular}{|c||} 
URL to Non- \\
English \\
Original \\
Text (ff Any)
\end{tabular} & $\begin{array}{l}\text { Perma.cc } \\
\text { URL }\end{array}$ \\
\hline 203 & 1982.11.03 & 1982.11.04 & $S / 15478$ & Iran & Iran, Iraq & $\begin{array}{c}\text { Implied } \\
\text { assertion of } \\
\text { "individual" } \\
\text { self-defense }\end{array}$ & $\begin{array}{c}\text { Conducted } \\
\text { attack }\end{array}$ & Iraq & State & \begin{tabular}{|l} 
On 1 Nov. 1982, Iranian forces \\
"launched a successful operation \\
against Iraq's forces of occupation \\
inside Iran in exercising their \\
inalienable right of self-defense." Iran \\
states that the operation was \\
"launched solely to regain territories \\
which had been under illegal Iraqi \\
occupation since the early days of \\
Irraq's aggression." Earlier that year, \\
the Iragi regime announced that "it \\
was unilaterally withdrawing all its \\
troops to internationally recognized \\
boundaries" but it tstill had many \\
territories under "illegal occupation."
\end{tabular} & $\begin{array}{l}\text { None } \\
\text { identified }\end{array}$ & None identified & $\begin{array}{l}\text { None } \\
\text { identified }\end{array}$ & Article 37 & $\begin{array}{l}\text { http: } \\
\text { /twww.un. } \\
\text { org/en/ga/ } \\
\text { search/vie } \\
\text { w_doc. } \\
\text { asp? } \\
\text { symbol=s/ } \\
15478\end{array}$ & & $\begin{array}{l}\text { https: } \\
\text { //perma. } \\
\text { cc PlPWGG } \\
\text { BTYT }\end{array}$ \\
\hline 204 & 1982.12.21 & 1982.12.21 & $s / 15536$ & Honduras & $\begin{array}{l}\text { Honduras, } \\
\text { Nicaragua }\end{array}$ & $\begin{array}{c}\text { Implied } \\
\text { assertion of } \\
\text { "individual" } \\
\text { self-defense }\end{array}$ & \begin{tabular}{|l} 
Conducted \\
attack and \\
threat of \\
attack
\end{tabular} & Nicaragua & State & 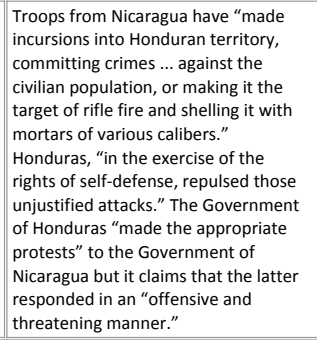 & $\begin{array}{l}\text { None } \\
\text { identified }\end{array}$ & None identified & $\begin{array}{l}\text { None } \\
\text { identified }\end{array}$ & $\begin{array}{l}\text { None } \\
\text { identified }\end{array}$ & $\begin{array}{l}\text { http: } \\
\text { //www.un. } \\
\text { org/en/ga/ } \\
\text { search/vie } \\
\text { w_doc. } \\
\text { asp? } \\
\text { symbol=s/ } \\
15536\end{array}$ & $\left\{\begin{array}{l}\text { http://www. } \\
\text { un. } \\
\text { org/en/ga/se } \\
\text { arch//iew_do } \\
\text { c.asp? } \\
\text { symbol=s/155 } \\
\text { 36\&Llang=s }\end{array}\right.$ & $\begin{array}{l}\text { hitps: } \\
\text { //perma. } \\
\text { cc/RAA4- } \\
\text { FP39 }\end{array}$ \\
\hline 205 & 1983.01.07 & 1983.01.12 & $\mathrm{s} / 15559$ & Thailand & $\begin{array}{l}\text { Thailand, } \\
\text { Kampuchea } \\
\text { [Cambodia], } \\
\text { Vietnam }\end{array}$ & $\begin{array}{l}\text { Implied } \\
\text { assertion of } \\
\text { "individual" } \\
\text { self-defense }\end{array}$ & $\begin{array}{c}\text { Conducted } \\
\text { attack }\end{array}$ & Vietnam & State & 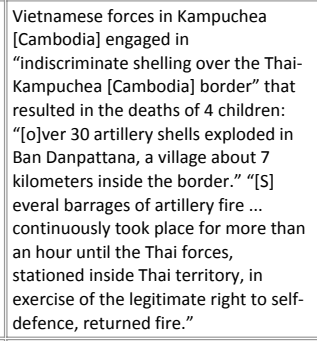 & $\begin{array}{l}\text { None } \\
\text { identified }\end{array}$ & None identified & $\begin{array}{l}\text { None } \\
\text { identified }\end{array}$ & $\begin{array}{l}\text { None } \\
\text { identified }\end{array}$ & $\begin{array}{l}\text { http: } \\
\text { //www.un. } \\
\text { org/en/ga/ } \\
\text { search/vie } \\
\text { w_doc. } \\
\text { asp? } \\
\text { symbol=s/ } \\
15559\end{array}$ & & $\begin{array}{l}\text { hitps: } \\
\text { //perma. } \\
\text { cc//VBS5- } \\
\text { MYra }\end{array}$ \\
\hline 206 & 1983.06.10 & 1983.06.14 & $\mathrm{s} / 15826$ & Iraq & $\begin{array}{l}\text { Iraq, Iran, } \\
\text { Pakistan }\end{array}$ & $\begin{array}{c}\text { Implied } \\
\text { assertion of } \\
\text { "individual" } \\
\text { self-defense }\end{array}$ & $\begin{array}{c}\text { Conducted } \\
\text { attack }\end{array}$ & Iran & State & \begin{tabular}{|l} 
Iran began bombing Iraqi \\
towns//villages in July of 1980 and \\
intensified its bombardement of some \\
towns in September, in response to \\
which Iraq exercised tit right of self- \\
defense. Following the Security \\
Council's intervention and adoption of \\
Resolution 479, Iraq declared its \\
acceptance but Iran "rejected the \\
resolution categorically." Iraq states \\
that Iran is therefore solely \\
responsible for "the continuation of \\
the fighting and ... for all the \\
consequences ensuing therefrom."
\end{tabular} & $\begin{array}{l}\text { None } \\
\text { identified }\end{array}$ & None identified & $\begin{array}{l}\text { Articles } 51 \\
\text { and } 98\end{array}$ & $\begin{array}{l}\text { Articles } 25 \\
\text { and } 51\end{array}$ & $\begin{array}{l}\text { http: } \\
\text { //www.un. } \\
\text { org/en/ga/ } \\
\text { search/vie } \\
\text { w_doc. } \\
\text { asp? } \\
\text { symbol=s/ } \\
15826\end{array}$ & $\left\{\begin{array}{l}\text { http://www. } \\
\text { un. } \\
\text { org/en/ga/se } \\
\text { arch//iew_do } \\
\text { c.asp? } \\
\text { symbol=s/158 } \\
26 \& L \text { Lang=A }\end{array}\right.$ & $\begin{array}{l}\text { hitps: } \\
\text { //perma. } \\
\text { cc//Ess5- } \\
\text { Gl5s }\end{array}$ \\
\hline
\end{tabular}


VI. HLS PILAC Catalogue of Apparent “Article 51 Communications”

\begin{tabular}{|c|c|c|c|c|c|c|c|c|c|c|c|c|c|c|c|c|c|}
\hline $\begin{array}{l}\text { Chron. } \\
\text { Order }\end{array}$ & $\begin{array}{l}\text { Date of } \\
\text { Comm. }\end{array}$ & $\begin{array}{c}\text { Date of } \\
\text { UNsC } \\
\text { Document }\end{array}$ & UNSC Symbol & \begin{tabular}{||c} 
Member \\
State(s) That \\
Submitted \\
the Comm.
\end{tabular} & \begin{tabular}{||c||} 
Expressly \\
Mentioned UN \\
Members (\& \\
Colonial \\
Holdings \& \\
Protectorates, \\
if any) \\
\end{tabular} & \begin{tabular}{|c} 
Express or \\
Implied \\
Assertion of \\
Individual, \\
Collective, or \\
Both Self- \\
defense \\
\end{tabular} & \begin{tabular}{|l}
$\begin{array}{c}\text { Nature of } \\
\text { the Alleged } \\
\text { Threat }\end{array}$
\end{tabular} & \begin{tabular}{|l} 
Expressly Alleged \\
Author(s) of the \\
Threat (If Any \\
Indicated)
\end{tabular} & \begin{tabular}{|c|} 
Nature of the \\
Alleged \\
Author(s) of \\
the Threat (If \\
Any \\
Indicated) \\
\end{tabular} & $\begin{array}{l}\text { Summary of Alleged Self-defense } \\
\text { Grounds }\end{array}$ & $\begin{array}{c}\text { UNSC } \\
\text { Meeting(s) } \\
\text { (If Any) at } \\
\text { Which the } \\
\text { Comm. was } \\
\text { Raised }\end{array}$ & $\begin{array}{l}\text { Responsive Act (If Any) by the } \\
\text { UNSC }\end{array}$ & $\begin{array}{l}\text { UN } \\
\text { Repertory } \\
\text { Inclusion? }\end{array}$ & $\begin{array}{c}\text { UNSC } \\
\text { Repertoire } \\
\text { Inclusion? }\end{array}$ & $\begin{array}{l}\text { URL to an } \\
\text { English } \\
\text { Text }\end{array}$ & \begin{tabular}{|c||} 
URL to Non- \\
English \\
Original \\
Text (If Any)
\end{tabular} & $\begin{array}{l}\text { Perma.cc } \\
\text { URL }\end{array}$ \\
\hline 207 & 1983.07.21 & 1983.07.21 & $s / 15879$ & Nicaragua & $\begin{array}{l}\text { Nicaragua, } \\
\text { Honduras, } \\
\text { United States }\end{array}$ & $\begin{array}{l}\text { Implied } \\
\text { assertion of } \\
\text { "individual" } \\
\text { self-defense }\end{array}$ & $\begin{array}{c}\text { Conducted } \\
\text { attack }\end{array}$ & Honduras & State & $\begin{array}{l}\text { Two Honduran coastguard vessels } \\
\text { attacked (in an unspecified manner) a } \\
\text { Nicaraguan patrol vessel in } \\
\text { Nicaraguan territorial waters. The } \\
\text { Nicaraguan vessel exercised the right } \\
\text { of self-defense and the confrontation } \\
\text { lasted for 90 minutes. Nicaragua } \\
\text { further states that multiple Honduran } \\
\text { aircraft "violated] Nicaraguan } \\
\text { airspace" the previous day and that } \\
\text { two U.S. Naval frigates were spotted } \\
\text { in Nicaraguan waters. }\end{array}$ & $\begin{array}{l}\text { None } \\
\text { identified }\end{array}$ & None identified & $\begin{array}{l}\text { None } \\
\text { identified }\end{array}$ & $\begin{array}{l}\text { None } \\
\text { identified }\end{array}$ & $\begin{array}{l}\text { http: } \\
\text { //www.un. } \\
\text { org/en/ga/ } \\
\text { search/vie } \\
\text { w_doc. } \\
\text { asp? } \\
\text { symbol=s/ } \\
15879\end{array}$ & $\begin{array}{l}\text { http://www. } \\
\text { un. } \\
\text { org/en/ga/se } \\
\text { arch//view_do } \\
\text { c.asp? } \\
\text { symbol=s/158 } \\
\text { 79\&Lang=s }\end{array}$ & \begin{tabular}{|l} 
https: \\
//perma. \\
cc/BSSM- \\
HR4Z
\end{tabular} \\
\hline 208 & 1983.08.01 & 1983.08.01 & S/15897 & Chad & Chad, Libya & $\begin{array}{c}\text { Implied } \\
\text { assertion of } \\
\text { "individual" } \\
\text { self-defense }\end{array}$ & $\begin{array}{c}\text { Conducted } \\
\text { attack }\end{array}$ & Libya & State & \begin{tabular}{|l} 
Chad points to various instances of \\
"aggression" "irected at it by Libya \\
and says that it (Chad) is "forced by \\
reasons of self-defense to repulse that \\
aggression." Chad also states that it \\
seeks a "peaceful settlement of the \\
dissute between it and Libya" while \\
rejecting Libya's contention that it \\
seeks to "settl[le] its frontier dispute \\
by force."
\end{tabular} & $\begin{array}{l}\text { S/PV.2462 } \\
\text { (2462nd) }\end{array}$ & None identified & Article 51 & $\begin{array}{l}\text { Article 2(7); } \\
\text { Consideratio } \\
\text { n of } \\
\text { Questions } \\
\text { under the } \\
\text { Council's } \\
\text { Responsibilit } \\
\text { y for the } \\
\text { Maintenanc } \\
\text { e of } \\
\text { International } \\
\text { Peace and } \\
\text { Security }\end{array}$ & $\begin{array}{l}\text { http: } \\
\text { //www.un. } \\
\text { org/en/ga/ } \\
\text { search/vie } \\
\text { w_doc. } \\
\text { asp? } \\
\text { symbol=S/ } \\
15897\end{array}$ & \begin{tabular}{|l} 
http://www. \\
un. \\
org/en/ga/se \\
arch//iew_do \\
c.asp? \\
symbol=s/158 \\
97\&Llang/F
\end{tabular} & $\begin{array}{l}\text { https: } \\
\text { //perma. } \\
\text { c/RXKE- } \\
\text { 95DC }\end{array}$ \\
\hline 209 & 1983.09.09 & 1983.09.09 & $S / 15973$ & Nicaragua & $\begin{array}{l}\text { Nicaragua, } \\
\text { Honduras }\end{array}$ & $\begin{array}{c}\text { Implied } \\
\text { assertion of } \\
\text { "individual" } \\
\text { self-defense }\end{array}$ & $\begin{array}{c}\text { Conducted } \\
\text { attack and } \\
\text { threat of } \\
\text { attack }\end{array}$ & Honduras & State & \begin{tabular}{|l} 
A Sandinista artillery boat on routine \\
patrol came upon an Honduran fishing \\
boat "fishing illegally" "in Nicaraguan \\
waters. The artillery boat gave chase, \\
later being joined by another \\
Nicaraguan boat. Three Honduran \\
coastguard vessels "entered \\
Nicaraguan waters illegally, and \\
absolutely without cause... attacked" \\
the two vessels. The naval boats \\
responded with an attackin in exercise \\
of their right of self-defense and their \\
duty to "safeguard the integrity of the \\
national territory."
\end{tabular} & $\begin{array}{l}\text { None } \\
\text { identified }\end{array}$ & None identified & $\begin{array}{l}\text { None } \\
\text { identified }\end{array}$ & $\begin{array}{l}\text { None } \\
\text { identified }\end{array}$ & $\begin{array}{l}\text { http: } \\
\text { //www.un. } \\
\text { org/en/ga/ } \\
\text { search/vie } \\
\text { w_doc. } \\
\text { asp? } \\
\text { symbol=s/ } \\
15973\end{array}$ & \begin{tabular}{|l} 
http://www. \\
un. \\
org/en/ga/se \\
arch/view_do \\
casp? \\
symbol=s/159 \\
$73 \&$ Lang=s
\end{tabular} & 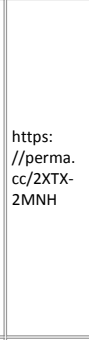 \\
\hline 210 & 1983.10.20 & 1983.10.21 & $\mathrm{s} / 16060$ & Honduras & $\begin{array}{l}\text { Honduras, } \\
\text { Nicaragua }\end{array}$ & $\begin{array}{c}\text { Implied } \\
\text { assertion of } \\
\text { "individual" } \\
\text { self-defense }\end{array}$ & $\begin{array}{c}\text { Conducted } \\
\text { attack }\end{array}$ & Nicaragua & State & 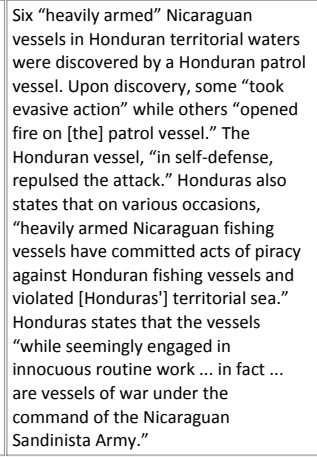 & $\begin{array}{l}\text { None } \\
\text { identified }\end{array}$ & None identified & $\begin{array}{l}\text { None } \\
\text { identified }\end{array}$ & $\begin{array}{l}\text { None } \\
\text { identified }\end{array}$ & $\begin{array}{l}\text { http: } \\
\text { /twww.un. } \\
\text { org/en/ga/ } \\
\text { search/vie } \\
\text { w_doc. } \\
\text { asp? } \\
\text { symbol=S/ } \\
16060\end{array}$ & $\begin{array}{l}\text { http://www. } \\
\text { un. } \\
\text { org//en/ga/se } \\
\text { arch/view_do } \\
\text { c.asp? } \\
\text { symbol=s/160 } \\
\text { 60\&Lang=s }\end{array}$ & $\begin{array}{l}\text { https: } \\
\text { //perma. } \\
\text { cc/W4SM- } \\
\text { HHKZ }\end{array}$ \\
\hline
\end{tabular}


VI. HLS PILAC Catalogue of Apparent “Article 51 Communications”

\begin{tabular}{|c|c|c|c|c|c|c|c|c|c|c|c|c|c|c|c|c|c|}
\hline $\begin{array}{l}\text { Chron. } \\
\text { Order }\end{array}$ & $\begin{array}{l}\text { Date of } \\
\text { comm. }\end{array}$ & \begin{tabular}{|c} 
Date of \\
UNsc \\
Document
\end{tabular} & UNSC Symbol & \begin{tabular}{||c} 
Member \\
State(s) That \\
Submitted \\
the Comm.
\end{tabular} & \begin{tabular}{|c} 
Expressly \\
Mentioned UN \\
Members (\& \\
Colonial \\
Holdings \& \\
Protectorates, \\
if any)
\end{tabular} & \begin{tabular}{||c|} 
Express or \\
Implied \\
Assertion of \\
Individual, \\
Collective, or \\
Both Self- \\
defense \\
\end{tabular} & \begin{tabular}{|c} 
Nature of \\
the Alleged \\
Threat
\end{tabular} & $\begin{array}{l}\text { Expressly Alleged } \\
\text { Author(s) of the } \\
\text { Threat (If Any } \\
\text { Indicated) }\end{array}$ & \begin{tabular}{|c|} 
Nature of the \\
Alleged \\
Author(s) of \\
the Threat (If \\
Any \\
Indicated) \\
\end{tabular} & $\begin{array}{l}\text { Summary of Alleged Self-defense } \\
\text { Grounds }\end{array}$ & \begin{tabular}{|c|} 
UNsc \\
Meeting(s) \\
(If fany) at \\
Which the \\
Comm. was \\
Raised
\end{tabular} & $\begin{array}{l}\text { Responsive Act (If Any) by the } \\
\text { UNSC }\end{array}$ & \begin{tabular}{|l} 
UN \\
Repertory \\
Inclusion?
\end{tabular} & \begin{tabular}{|c} 
UNSC \\
Repertoire \\
Inclusion?
\end{tabular} & \begin{tabular}{||c|} 
URL to an \\
English \\
Text
\end{tabular} & \begin{tabular}{|c||} 
URL to Non- \\
English \\
OOriginal \\
Tert (ff Any)
\end{tabular} & $\begin{array}{l}\text { Perma.cc } \\
\text { URL }\end{array}$ \\
\hline 211 & 1983.12.04 & 1983.12.04 & $S / 16197$ & $\begin{array}{l}\text { United } \\
\text { States }\end{array}$ & $\begin{array}{l}\text { United States, } \\
\text { Lebanon, Syria }\end{array}$ & $\begin{array}{c}\text { Implied } \\
\text { assertion of } \\
\text { "individual" } \\
\text { self-defense }\end{array}$ & $\begin{array}{c}\text { Conducted } \\
\text { attack }\end{array}$ & Syria & State & \begin{tabular}{|l} 
Two US aircraft conducting a "routine \\
reconnaissance flight over Lebanese \\
territory were fired upon by anti- \\
aircraft emplacements ... and surface- \\
to-air missiles ... from a number of \\
Syrian positions within Lebanon." The \\
next day, U.S. Navy aircraft "carried \\
out air strikes against the Syrian army \\
anti-aircraft concentrations" it said \\
were responsible for the attack. The \\
complaint states that the presence of \\
U.S. forces in Lebanon "is authorized \\
by the Government of Lebanon under \\
an international agreement" and the \\
same agreement authorizes them to \\
"take measures in self-defense."
\end{tabular} & $\begin{array}{l}\text { None } \\
\text { identified }\end{array}$ & None identified & $\begin{array}{l}\text { None } \\
\text { identified }\end{array}$ & $\begin{array}{l}\text { None } \\
\text { identified }\end{array}$ & \begin{tabular}{|l||} 
http: \\
//www.un. \\
org/en/ga/ \\
search/vie \\
w_doc. \\
asp? \\
symbol=s/ \\
16197
\end{tabular} & & $\begin{array}{l}\text { hitps: } \\
\text { //perma. } \\
\text { cc//GRE- } \\
\text { THPQ }\end{array}$ \\
\hline 212 & 1983.12.06 & 1983.12.06 & $s / 16200$ & Nicaragua & $\begin{array}{r}\text { Nicaragua, } \\
\text { Honduras }\end{array}$ & $\begin{array}{l}\text { Implied } \\
\text { assertion of } \\
\text { "individual" } \\
\text { self-defense }\end{array}$ & $\begin{array}{c}\text { Conducted } \\
\text { attack }\end{array}$ & Honduras & State & $\begin{array}{l}\text { Two launches of the Honduran navy } \\
\text { attacked a Nicaraguan coastguard } \\
\text { vessel in waters under Nicaraguan } \\
\text { jurisdiction. The coastguard vessel } \\
\text { repelled the "unwarranted attack, } \\
\text { hitting one of the attacking launches } \\
\text { with a missile." The same day, two } \\
\text { Honduran coastguard vessels } \\
\text { "attacked" two Nicaraguan fishing } \\
\text { vessels. The following day, two } \\
\text { Honduran launches and two } \\
\text { coastguard vessels "attacked two } \\
\text { Nicaraguan fishing boats" and three } \\
\text { Honduran aircraff "airirraft machine- } \\
\text { gunned and fired rockets" at the } \\
\text { vessels. "These latest acts of } \\
\text { aggression and flagrant violation of } \\
\text { Nicaraguan sovereignty are further } \\
\text { evidence of the total absence of any } \\
\text { real desire for peace on the part of the } \\
\text { Honduran Government in spite of its } \\
\text { repeated representations to that } \\
\text { effect." }\end{array}$ & $\begin{array}{l}\text { None } \\
\text { identified }\end{array}$ & None identified & $\begin{array}{l}\text { None } \\
\text { identified }\end{array}$ & $\begin{array}{l}\text { None } \\
\text { identified }\end{array}$ & \begin{tabular}{|l||} 
http: \\
//www.un. \\
org/en/ga/ \\
search/vie \\
w_doc. \\
asp? \\
symbol=s/ \\
16200
\end{tabular} & \begin{tabular}{|l} 
http://www. \\
un. \\
org/en/ga/se \\
arch/view_do \\
casp? \\
symbol=s/162 \\
oo\&lang=s
\end{tabular} & $\begin{array}{l}\text { hitps: } \\
\text { //perma. } \\
\text { cc///C28- } \\
\text { w2aw }\end{array}$ \\
\hline 213 & 1983.12.15 & 1983.12.16 & $\mathrm{S} / 16221$ & Honduras & $\begin{array}{l}\text { Honduras, } \\
\text { Nicaragua }\end{array}$ & \begin{tabular}{|c} 
Implied \\
assertion of \\
"individual" \\
self-defense
\end{tabular} & $\begin{array}{c}\text { Conducted } \\
\text { attack }\end{array}$ & Nicaragua & State & 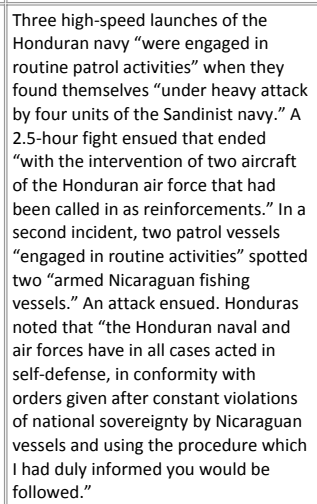 & $\begin{array}{l}\text { None } \\
\text { identified }\end{array}$ & None identified & $\begin{array}{l}\text { None } \\
\text { identified }\end{array}$ & \begin{tabular}{|l} 
None \\
identified
\end{tabular} & \begin{tabular}{|l||} 
http: \\
//www.un. \\
organ/gal \\
search/vie \\
w_doc. \\
asp? \\
symbol=s/ \\
16221
\end{tabular} & $\begin{array}{l}\text { http://www. } \\
\text { un. } \\
\text { org/en/ga/se } \\
\text { arch/view_do } \\
\text { c.asp? } \\
\text { symbol=s/162 } \\
\text { 21\&Lang=s }\end{array}$ & $\begin{array}{l}\text { hitps: } \\
\text { //perma. } \\
\text { cc/6T2- } \\
\text { unLI }\end{array}$ \\
\hline
\end{tabular}


VI. HLS PILAC Catalogue of Apparent “Article 51 Communications”

\begin{tabular}{|c|c|c|c|c|c|c|c|c|c|c|c|c|c|c|c|c|c|}
\hline $\begin{array}{l}\text { Chron. } \\
\text { Order }\end{array}$ & $\begin{array}{l}\text { Date of } \\
\text { Comm. }\end{array}$ & \begin{tabular}{|c} 
Date of \\
UNsc \\
Document
\end{tabular} & | UNSC Symbol & \begin{tabular}{||c} 
Member \\
State(s) That \\
Submitted \\
the Comm.
\end{tabular} & \begin{tabular}{|c} 
Expressly \\
Mentioned UN \\
Members (\& \\
Colonial \\
Holdings \& \\
Protectorates, \\
if any)
\end{tabular} & \begin{tabular}{|c} 
Express or \\
Implied \\
Assertion of \\
Individual, \\
Collective, or \\
Both Self- \\
defense \\
\end{tabular} & \begin{tabular}{|c} 
Nature of \\
the Alleged \\
Threat
\end{tabular} & \begin{tabular}{|l|} 
Expressly Alleged \\
Author(s) of the \\
Threat (ff Any \\
Indicated)
\end{tabular} & \begin{tabular}{|c|} 
Nature of the \\
Alleged \\
Author(s) of \\
the Threat (If \\
Any \\
Indicated) \\
\end{tabular} & $\begin{array}{l}\text { Summary of Alleged Self-defense } \\
\text { Grounds }\end{array}$ & \begin{tabular}{|c|} 
UNsc \\
Meeting(s) \\
(if Any) at \\
Which the \\
Comm. was \\
Raised
\end{tabular} & $\begin{array}{l}\text { Responsive Act (If Any) by the } \\
\text { UNSC }\end{array}$ & \begin{tabular}{||c} 
UN \\
Repertory \\
Inclusion?
\end{tabular} & $\begin{array}{c}\text { UNSC } \\
\text { Repertoire } \\
\text { Inclusion? }\end{array}$ & \begin{tabular}{|l} 
URL to an \\
English \\
Text
\end{tabular} & \begin{tabular}{||c||} 
URL to Non- \\
English \\
Original \\
Text (ff Any)
\end{tabular} & \begin{tabular}{|l} 
Perma.cc \\
URL
\end{tabular} \\
\hline 214 & 1984.02.23 & 1984.02.24 & $s / 16362$ & Iraq & Iraq, Iran & $\begin{array}{c}\text { Implied } \\
\text { assertion of } \\
\text { "individual" } \\
\text { self-defense }\end{array}$ & $\begin{array}{c}\text { Conducted } \\
\text { attack }\end{array}$ & Iran & State & \begin{tabular}{|l} 
Iran launched an offensive "with the \\
aim of penetrating Iraq's international \\
frontiers and occupying Iraqi towns \\
and villages." rraqi forces "repulsed \\
the aggressors and crushed their \\
attack" though "large scale battles \\
remain in progress on [Iraq's] eastern \\
borders." Iraq states that it will \\
continue to take measures to "protect \\
its sovereignty, its security and the \\
lives of its citizens" and will use \\
"whatever effective deterrent means \\
to crush the aggression".
\end{tabular} & $\begin{array}{l}\text { None } \\
\text { identified }\end{array}$ & None identified & Article 98 & $\begin{array}{l}\text { None } \\
\text { identified }\end{array}$ & $\begin{array}{l}\text { http: } \\
\text { //www.un. } \\
\text { org/en/ga/ } \\
\text { search/vie } \\
\text { w_doc. } \\
\text { asp? } \\
\text { symbol=s/ } \\
16362\end{array}$ & \begin{tabular}{|l||} 
http://www. \\
un. \\
org/en/ga/se \\
arch//iew_do \\
c.asp? \\
symbol=s/163 \\
62\&Lang=A
\end{tabular} & \begin{tabular}{|l} 
https: \\
//perma. \\
cc/303L- \\
GVJP
\end{tabular} \\
\hline 215 & 1984.07.13 & 1984.07.16 & $\mathrm{s} / 16671$ & Israel & Israel, Lebanon & $\begin{array}{c}\text { Implied } \\
\text { assertion of } \\
\text { "individual" } \\
\text { self-defense }\end{array}$ & $\begin{array}{l}\text { Threat of } \\
\text { attack }\end{array}$ & \begin{tabular}{|l} 
"[P]ersons closely \\
connected with an \\
imminent threat to \\
Israel's security"
\end{tabular} & $\begin{array}{l}\text { Non-state } \\
\text { actors }\end{array}$ & $\begin{array}{l}\text { Israel seized a ship traveling to Beirut } \\
\text { "consequent to strong indications that } \\
\text { the ship carried persons closely } \\
\text { connected with an imminent threat to } \\
\text { Israel's security." Two passengers } \\
\text { "strongly suspected of involvement in } \\
\text { terrorist activity and plans" were } \\
\text { detained while the boat, its crew, and } \\
\text { the rest of the passengers were } \\
\text { allowed to continue on. "Israel is } \\
\text { consequently fully justified in having } \\
\text { exercised its inherent right to self- } \\
\text { defence." }\end{array}$ & $\begin{array}{l}\text { None } \\
\text { identified }\end{array}$ & None identified & $\begin{array}{l}\text { None } \\
\text { identified }\end{array}$ & $\begin{array}{l}\text { None } \\
\text { identified }\end{array}$ & $\begin{array}{l}\text { http: } \\
\text { //www.un. } \\
\text { org/en/ga/ } \\
\text { search/vie } \\
\text { w_doc. } \\
\text { asp? } \\
\text { symbol=s/ } \\
16671\end{array}$ & & \begin{tabular}{|l} 
https: \\
//perma. \\
c/3JJI- \\
6G92
\end{tabular} \\
\hline 216 & 1985.01.24 & 1985.01.25 & $\mathrm{S} / 16908$ & China & $\begin{array}{l}\text { China, } \\
\text { Vietnam, } \\
\text { Kampuchea } \\
\text { [Cambodia] }\end{array}$ & $\begin{array}{c}\text { Implied } \\
\text { assertion of } \\
\text { "individual" } \\
\text { self-defense }\end{array}$ & $\begin{array}{c}\text { Conducted } \\
\text { attack }\end{array}$ & Vietnam & State & \begin{tabular}{|l} 
Vietnamese troops have "intensified \\
their military provocations and armed \\
incursions into China's Yunnan and \\
Guangxi border areas" in the past two \\
months. China states that Vietnam \\
fired 137,000 shells of various types \\
and launched more than 40 sneak \\
raids against Chinese territory since \\
last November [1984t]. Vietnam has \\
fired at Chinese villages and towns, \\
kidnapped Chinese civilians, and sent \\
"spies and agents across the border" \\
into China to "carry out \\
reconnaissance and subterfuge \\
activities.". Vietnam introduced a \\
"smokescreen" with the Spring \\
Festival ceasefire while "step[ing] up \\
their military attacks." China was \\
"forced to counterattack in self- \\
defense."
\end{tabular} & $\begin{array}{l}\text { None } \\
\text { identified }\end{array}$ & None identified & $\begin{array}{l}\text { None } \\
\text { identified }\end{array}$ & $\begin{array}{l}\text { None } \\
\text { identified }\end{array}$ & $\begin{array}{l}\text { http: } \\
\text { //www.un. } \\
\text { org/en/ga/ } \\
\text { search/vie } \\
\text { w_doc. } \\
\text { asp? } \\
\text { symbol=s/ } \\
16908\end{array}$ & \begin{tabular}{|l|} 
http://www. \\
un. \\
org/en/ga/se \\
arch/view_do \\
casp? \\
symbol=s/169 \\
o8\&lang=c
\end{tabular} & \begin{tabular}{|l} 
https: \\
//perma. \\
cc/FDR \\
H6CM
\end{tabular} \\
\hline 217 & 1985.03.11 & 1985.03.12 & $S / 17023$ & China & $\begin{array}{l}\text { China, } \\
\text { Vietnam, } \\
\text { Kampuchea } \\
\text { [Cambodia], } \\
\text { Thailand }\end{array}$ & $\begin{array}{c}\text { Implied } \\
\text { assertion of } \\
\text { "individual" } \\
\text { self-defense }\end{array}$ & $\begin{array}{c}\text { Conducted } \\
\text { attack }\end{array}$ & Vietnam & State & \begin{tabular}{|l} 
Vietnamese troops have "frantically \\
bombarded border villages and towns \\
inside China, willfully shot and \\
kidnapped peaceable Chinese border \\
inhabitants, and dispatched secret \\
agents and other armed personnel..to \\
conduct sabotage against production." \\
This caused Chinese frontier troops \\
"to engage in restricted and necessary \\
counter-attacks." China also \\
condems "acts of aggression" by \\
Vietnam in Thailand and states that \\
China supports Thailand and \\
Kampuchea [Cambodia] in "their just \\
struggle against Vietnamese \\
aggression."
\end{tabular} & \begin{tabular}{|l} 
None \\
identified
\end{tabular} & None identified & \begin{tabular}{|l} 
None \\
identified
\end{tabular} & \begin{tabular}{|l} 
None \\
identified
\end{tabular} & $\begin{array}{l}\text { http: } \\
\text { //www.un. } \\
\text { org/en/ga/ } \\
\text { search/vie } \\
\text { w_doc. } \\
\text { asp? } \\
\text { symbol=S/ } \\
17023\end{array}$ & \begin{tabular}{|l||} 
http://www. \\
un. \\
org/en/ga/se \\
arch/view_do \\
cassp? \\
symbol=s/170 \\
23\&Llang=c
\end{tabular} & \begin{tabular}{|l} 
https: \\
//perma. \\
cc/9SPR- \\
UN23
\end{tabular} \\
\hline
\end{tabular}


VI. HLS PILAC Catalogue of Apparent “Article 51 Communications”

\begin{tabular}{|c|c|c|c|c|c|c|c|c|c|c|c|c|c|c|c|c|c|}
\hline $\begin{array}{l}\text { Chron. } \\
\text { Order }\end{array}$ & $\begin{array}{l}\text { Date of } \\
\text { comm. }\end{array}$ & \begin{tabular}{|c} 
Date of \\
UNsC \\
Document
\end{tabular} & UNSC Symbol & \begin{tabular}{||c} 
Member \\
State(s) That \\
Submitted \\
the Comm.
\end{tabular} & \begin{tabular}{|c|} 
Expressly \\
Mentioned UN \\
Members (\& \\
Colonial \\
Holdings \& \\
Protectorates, \\
if any) \\
\end{tabular} & \begin{tabular}{|c|} 
Express or \\
Implied \\
Assertion of \\
Individual, \\
Collective, or \\
Both Self- \\
defense
\end{tabular} & \begin{tabular}{|c} 
Nature of \\
the Alleged \\
Threat
\end{tabular} & $\begin{array}{l}\text { Expressly Alleged } \\
\text { Author(s) of the } \\
\text { Threat (ff Any } \\
\text { Indicated) }\end{array}$ & \begin{tabular}{|l|} 
Nature of the \\
Alleged \\
Author(s) of \\
the Threat (If \\
Any \\
Indicated)
\end{tabular} & $\begin{array}{l}\text { Summary of Alleged Self-defense } \\
\text { Grounds }\end{array}$ & $\begin{array}{l}\text { UNsc } \\
\text { Meeting(s) } \\
\text { (if Any) at } \\
\text { Which the } \\
\text { Comm. was } \\
\text { Raised }\end{array}$ & $\begin{array}{l}\text { Responsive Act (If Any) by the } \\
\text { UNSC }\end{array}$ & \begin{tabular}{||c} 
UN \\
Repertory \\
Inclusion?
\end{tabular} & \begin{tabular}{|c|} 
UNSC \\
Repertoire \\
Inclusion?
\end{tabular} & \begin{tabular}{|c||} 
URL to an \\
English \\
Text
\end{tabular} & \begin{tabular}{||c||} 
URL to Non- \\
English \\
Original \\
Text (ff Any)
\end{tabular} & $\begin{array}{l}\text { Perma.cc } \\
\text { URL }\end{array}$ \\
\hline 218 & 1985.04.04 & 1985.04.05 & $S / 17084$ & Iran & Iran, Iraq & $\begin{array}{c}\text { Implied } \\
\text { assertion of } \\
\text { "individual" } \\
\text { self-defense }\end{array}$ & $\begin{array}{c}\text { Conducted } \\
\text { attack }\end{array}$ & Iraq & State & $\begin{array}{l}\text { Iran responds to the "pressure being } \\
\text { mounted to impose a negotiated } \\
\text { settlement" between Iran and Iraq. } \\
\text { Iran considers the Security Council to } \\
\text { have acted with bias towards Iraq by } \\
\text { refusing to speak against Iraq's } \\
\text { "imposed war of aggression." Iran } \\
\text { points to Iraqi destruction of Iranian } \\
\text { oil wells in the Persian Gulf, Iraqi use } \\
\text { of chemical weapons, and attacks on } \\
\text { civilians, none of which, it says, the } \\
\text { Security Council responded to. }\end{array}$ & $\begin{array}{l}\text { None } \\
\text { identified }\end{array}$ & None identified & $\begin{array}{l}\text { None } \\
\text { identified }\end{array}$ & \begin{tabular}{|l} 
None \\
identified
\end{tabular} & \begin{tabular}{|l||} 
http: \\
//www.un. \\
org///nngal \\
search/vie \\
w_doc. \\
asp? \\
symbol=s/ \\
symos4
\end{tabular} & & $\begin{array}{l}\text { https: } \\
\text { //perma. } \\
\text { cc//922- } \\
\text { veNM }\end{array}$ \\
\hline 219 & 1985.09.10 & 1985.09.10 & $s / 17450$ & Iraq & Iraq, Iran & $\begin{array}{c}\text { Implied } \\
\text { assertion of } \\
\text { "individual" } \\
\text { self-defense }\end{array}$ & $\begin{array}{c}\text { Conducted } \\
\text { attack }\end{array}$ & Iran & State & $\begin{array}{l}\text { Iran "launched a new hostile action } \\
\text { against Iraqi territory ... in the } \\
\text { northern border area in an attempt to } \\
\text { violate raa's's sovereignty and occupy } \\
\text { its territory by force...." }\end{array}$ & $\begin{array}{l}\text { None } \\
\text { identified }\end{array}$ & None identified & $\begin{array}{l}\text { None } \\
\text { identified }\end{array}$ & Article 51 & \begin{tabular}{|l||} 
http: \\
//www.un. \\
org///nngal \\
search/vie \\
w_doc. \\
asp? \\
symbol=s/ \\
17450 \\
1750
\end{tabular} & Not available & 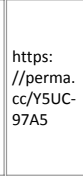 \\
\hline 220 & 1985.09.14 & 1985.09.16 & $s / 17466$ & Honduras & $\begin{array}{l}\text { Honduras, } \\
\text { Nicaragua }\end{array}$ & $\begin{array}{c}\text { Implied } \\
\text { assertion of } \\
\text { "individual" } \\
\text { self-defense }\end{array}$ & $\begin{array}{c}\text { Conducted } \\
\text { attack }\end{array}$ & Nicaragua & State & $\begin{array}{l}\text { Honduras lists a number of "further } \\
\text { acts of aggression committed by the } \\
\text { Sandinista Army" against Honduras. } \\
\text { The acts include launching mortar } \\
\text { shells, firing on border patrols and } \\
\text { villages, and confrontations between } \\
\text { the two States' air forces. This } \\
\text { situation "has forced the Honduran } \\
\text { government to exercise its inherent } \\
\text { right of self-defense." }\end{array}$ & $\begin{array}{l}\text { None } \\
\text { identified }\end{array}$ & None identified & $\begin{array}{l}\text { None } \\
\text { identified }\end{array}$ & $\begin{array}{l}\text { None } \\
\text { identified }\end{array}$ & 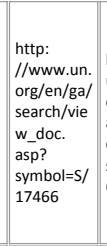 & $\begin{array}{l}\text { http://www. } \\
\text { un. } \\
\text { org/en/ga/se } \\
\text { arch/view_do } \\
\text { c.asp? } \\
\text { symbol=s/174 } \\
\text { 66\&lang=s }\end{array}$ & \begin{tabular}{|l} 
hitps: \\
//perma. \\
cc/DCMB- \\
23FG
\end{tabular} \\
\hline 221 & 1985.10.02 & 1985.10.02 & $\mathrm{S} / \mathrm{PV} .2611$ & Israel & $\begin{array}{l}\text { Israel, Tunisia, } \\
\text { Egypt, } \\
\text { Lebanon, } \\
\text { Uganda, } \\
\text { Cyprus, France, } \\
\text { India, South } \\
\text { Korea, United } \\
\text { States, Soviet } \\
\text { Union }\end{array}$ & $\begin{array}{c}\text { Implied } \\
\text { assertion of } \\
\text { "individual" } \\
\text { self-defense }\end{array}$ & $\begin{array}{c}\text { Conducted } \\
\text { attack }\end{array}$ & $\begin{array}{l}\text { PLO (Palestine } \\
\text { Liberation } \\
\text { Organization) }\end{array}$ & $\begin{array}{c}\text { Non-state } \\
\text { actors }\end{array}$ & 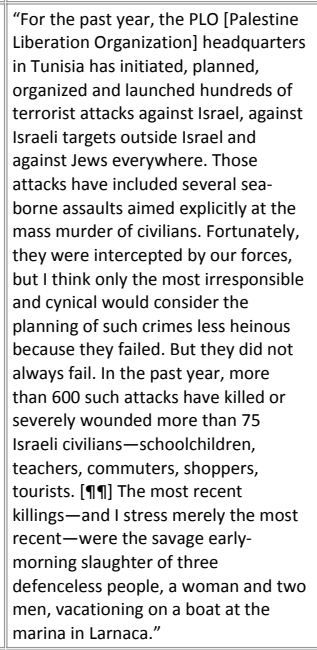 & $\begin{array}{l}\text { S/PV.2611 } \\
\text { (2611th); } \\
\text { S/PV.2615 } \\
\text { (2615th) }\end{array}$ & $\begin{array}{l}\text { S/RES/573(1985), OPs 1-2: "1. } \\
\text { Condemns vigorously the act } \\
\text { of armed aggression } \\
\text { perpetrated by Israel against } \\
\text { Tunisian territory in flagrant } \\
\text { violation of the Charter of the } \\
\text { United Nations, international } \\
\text { law and norms of conduct; } \\
\text { 2. Demands that Israel refrain } \\
\text { from perpetrating such acts of } \\
\text { aggression or from threatening } \\
\text { to do so" (14-0-1). }\end{array}$ & $\begin{array}{l}\text { None } \\
\text { identified }\end{array}$ & $\begin{array}{l}\text { Articles 2(4), } \\
31,32,35, \\
39, \text { and 51; } \\
\text { Consideratio } \\
\text { nof } \\
\text { Questions } \\
\text { under the } \\
\text { Council's } \\
\text { Responsibilit } \\
\text { y for the } \\
\text { Maintenanc } \\
\text { e of } \\
\text { International } \\
\text { Peace and } \\
\text { Security }\end{array}$ & \begin{tabular}{|l||} 
https: \\
//documen \\
ts-dds-ny. \\
un. \\
org/doc/U \\
NDOC/GEN \\
NDLC/500/ \\
No/pdf/NL \\
80/0000. \\
pdf? \\
OpenElem \\
ent
\end{tabular} & & 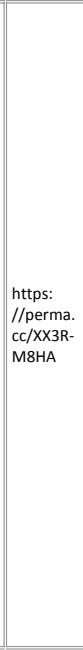 \\
\hline
\end{tabular}


VI. HLS PILAC Catalogue of Apparent “Article 51 Communications”

\begin{tabular}{|c|c|c|c|c|c|c|c|c|c|c|c|c|c|c|c|c|c|}
\hline $\begin{array}{l}\text { Chron. } \\
\text { Order }\end{array}$ & $\begin{array}{l}\text { Date of } \\
\text { comm. }\end{array}$ & \begin{tabular}{|c} 
Date of \\
UNsc \\
Document
\end{tabular} & UNSC Symbol & \begin{tabular}{||c} 
Member \\
State(s) That \\
Submitted \\
the Comm.
\end{tabular} & \begin{tabular}{|c|} 
Expressly \\
Mentioned UN \\
Members (\& \\
Colonial \\
Holdings \& \\
Protectorates, \\
if any) \\
\end{tabular} & \begin{tabular}{||c|} 
Express or \\
Implied \\
Assertion of \\
Individual, \\
Collective, or \\
Both Self- \\
defense \\
\end{tabular} & \begin{tabular}{|c} 
Nature of \\
the Alleged \\
Threat
\end{tabular} & $\begin{array}{l}\text { Expressly Alleged } \\
\text { Author(s) of the } \\
\text { Threat (If Any } \\
\text { Indicated) }\end{array}$ & \begin{tabular}{|c|} 
Nature of the \\
Alleged \\
Author(s) of \\
the Threat (If \\
Any \\
Indicated) \\
\end{tabular} & $\begin{array}{l}\text { Summary of Alleged Self-defense } \\
\text { Grounds }\end{array}$ & \begin{tabular}{|c|} 
UNSC \\
Meeting(s) \\
(If Any) at \\
Which the \\
Comm. was \\
Raised \\
\end{tabular} & $\begin{array}{l}\text { Responsive Act (If Any) by the } \\
\text { UNSC }\end{array}$ & $\begin{array}{l}\text { UN } \\
\text { Repertory } \\
\text { Inclusion? }\end{array}$ & \begin{tabular}{|c||} 
UNSC \\
Repertoire \\
Inclusion?
\end{tabular} & \begin{tabular}{|l|} 
URL to an \\
English \\
Text
\end{tabular} & \begin{tabular}{||c||} 
URL to Non- \\
English \\
Original \\
Tert (ff Any)
\end{tabular} & $\begin{array}{l}\text { Perma.cc } \\
\text { URL }\end{array}$ \\
\hline 222 & 1985.10.21 & 1985.10.22 & $\mathrm{s} / 17586$ & South Africa & $\begin{array}{l}\text { South Africa, } \\
\text { Botswana }\end{array}$ & \begin{tabular}{|c} 
Implied \\
assertion of \\
"individual" \\
self-defense
\end{tabular} & $\begin{array}{l}\text { Imminent } \\
\text { attack }\end{array}$ & Not indicated & Not indicated & $\begin{array}{l}\text { South Africa rejects Security Council } \\
\text { resolution } 572 \text {, which required it to } \\
\text { pay compensation to Botswana, and } \\
\text { the resolution's inferences that South } \\
\text { Africa carried out an unprovoked act } \\
\text { of aggression against Botswana. South } \\
\text { Africa asserts that "terrorist groups } \\
\text { established in and operating from } \\
\text { Bottwanan" are not refugees and that } \\
\text { it exercised its inherent right to self- } \\
\text { defense by acting to "curtail further } \\
\text { imminent acts of violence in South } \\
\text { Africa." }\end{array}$ & $\begin{array}{l}\text { None } \\
\text { identified }\end{array}$ & None identified & $\begin{array}{l}\text { None } \\
\text { identified }\end{array}$ & \begin{tabular}{|l||} 
Consideratio \\
n of \\
Questions \\
under the \\
Council's \\
Responsibilit \\
y for the \\
Maintenanc \\
e of \\
International \\
Peace and \\
Security \\
\end{tabular} & \begin{tabular}{|l||} 
http: \\
//www.un. \\
org/en/ga/ \\
search/vie \\
w_doc. \\
asp? \\
symbol=s/ \\
17586
\end{tabular} & & $\begin{array}{l}\text { https: } \\
\text { //perma. } \\
\text { cc/RM8B- } \\
\text { S25V }\end{array}$ \\
\hline 223 & 1985.12.26 & 1985.12.27 & $\mathrm{S} / 17698$ & Israel & $\begin{array}{c}\text { Israel, } \\
\text { Lebanon, Syria }\end{array}$ & $\begin{array}{l}\text { Implied } \\
\text { assertion of } \\
\text { "individual" } \\
\text { self-defense }\end{array}$ & $\begin{array}{c}\text { Conducted } \\
\text { attack }\end{array}$ & $\begin{array}{l}\text { "[T]errorist } \\
\text { elements in } \\
\text { Lebanon" }\end{array}$ & $\begin{array}{c}\text { Non-state } \\
\text { actors }\end{array}$ & $\begin{array}{l}\text { Israel counters allegations made } \\
\text { against it, stating that "Israel's activity } \\
\text { along the Lebanese-lsraeli border is } \\
\text { carried out entirely in self-defense." } \\
\text { Israel claims that, between June } 1985 \\
\text { and the issuance of the complaint, } \\
\text { "790 attacks and attempted attacks } \\
\text { have been carried out by terrorist } \\
\text { elements in Lebanon against targets in } \\
\text { southern Lebanon and strael." In the } \\
\text { same period, } 280 \text { rockets were } \\
\text { launched from Lebanon towards Israel } \\
\text { and } 495 \text { acts of infiltration and } \\
\text { sabotage were carried out by } \\
\text { terrorists. }\end{array}$ & $\begin{array}{l}\text { None } \\
\text { identified }\end{array}$ & None identified & $\begin{array}{l}\text { None } \\
\text { identified }\end{array}$ & $\begin{array}{l}\text { None } \\
\text { identified }\end{array}$ & \begin{tabular}{|l||} 
http: \\
//www.un. \\
org/en/ga/ \\
search/vie \\
w_doc. \\
asp? \\
symbol=s/ \\
17698
\end{tabular} & & $\begin{array}{l}\text { https: } \\
\text { //perma. } \\
\text { cc/A2P- } \\
\text { 8NDS }\end{array}$ \\
\hline 224 & 1986.02.11 & 1986.02.11 & $S / 17816$ & China & $\begin{array}{l}\text { China, } \\
\text { Kampuchea } \\
\text { [Cambodia], } \\
\text { Vietnam, } \\
\text { Thailand }\end{array}$ & $\begin{array}{l}\text { Implied } \\
\text { assertion of } \\
\text { "individual" } \\
\text { self-defense }\end{array}$ & $\begin{array}{c}\text { Conducted } \\
\text { attack }\end{array}$ & Vietnam & State & $\begin{array}{l}\text { China calls attention to the } \\
\text { "Vietnamese authorities' intensified } \\
\text { aggression against Kampuchea } \\
\text { [Cambodial and their creating tension } \\
\text { along the Sino-Vietnamese border.... } \\
\text { At present, the Vietnamese } \\
\text { authorities are sending more troops to } \\
\text { the Sino-Vietnamese border areas in } \\
\text { an attempt to provoke new military } \\
\text { conflicts." }\end{array}$ & $\begin{array}{l}\text { None } \\
\text { identified }\end{array}$ & None identified & $\begin{array}{l}\text { None } \\
\text { identified }\end{array}$ & $\begin{array}{l}\text { None } \\
\text { identified }\end{array}$ & \begin{tabular}{|l||} 
http: \\
//www.un. \\
org/en/ga/ \\
search/vie \\
w_doc. \\
asp? \\
symbol=s/ \\
17816
\end{tabular} & $\begin{array}{l}\text { http://www. } \\
\text { un. } \\
\text { org/en/ga/se } \\
\text { arch/view_do } \\
\text { ca.ap? } \\
\text { symbol=s/178 } \\
16 \& \text { Lang=c }\end{array}$ & $\begin{array}{l}\text { https: } \\
\text { //perma. } \\
\text { cc/F78c- } \\
45 \mathrm{M} 4\end{array}$ \\
\hline 225 & 1986.02.18 & 1986.02.18 & $S / 17837$ & Chad & $\begin{array}{l}\text { Chad, Libya, } \\
\text { France }\end{array}$ & $\begin{array}{l}\text { Implied } \\
\text { assertion of } \\
\text { "collective" } \\
\text { self-defense }\end{array}$ & $\begin{array}{c}\text { Conducted } \\
\text { attack }\end{array}$ & Libya & State & \begin{tabular}{|l} 
Chad states "the very serious war \\
situation that Libya has once again \\
imposed on Chad ... [andd ill-advised \\
actsof flagrant and overt military \\
aggression against Chad...." Chad \\
requested military intervention of \\
France to repel the Libyan attack; \\
Chad also points to how, "[p]ersisting \\
in its aggressive conduct, Libya this \\
morning bombed the civilian airport at \\
Ndjamena."
\end{tabular} & $\begin{array}{l}\text { None } \\
\text { identified }\end{array}$ & None identified & $\begin{array}{l}\text { None } \\
\text { identified }\end{array}$ & $\begin{array}{l}\text { None } \\
\text { identified }\end{array}$ & \begin{tabular}{|l||} 
http: \\
//www.un. \\
organ/ga/ \\
search/vie \\
w_doc. \\
asp? \\
symbol=s/ \\
17837
\end{tabular} & $\begin{array}{l}\text { http://www. } \\
\text { un. } \\
\text { org/en/ga/se } \\
\text { arch/view_do } \\
\text { ca.ap? } \\
\text { symbol=s/178 } \\
\text { 37\&Llang=F }\end{array}$ & $\begin{array}{l}\text { https: } \\
\text { //perma. } \\
\text { cc/D332- } \\
\text { BCU2 }\end{array}$ \\
\hline 226 & 1986.03 .25 & 1986.03.25 & $S / 17938$ & $\begin{array}{l}\text { United } \\
\text { States }\end{array}$ & $\begin{array}{c}\text { United States, } \\
\text { Libya }\end{array}$ & $\begin{array}{l}\text { Implied } \\
\text { assertion of } \\
\text { "individual" } \\
\text { self-defense }\end{array}$ & $\begin{array}{c}\text { Conducted } \\
\text { attack }\end{array}$ & Libya & State & $\begin{array}{l}\text { Libya launched several missiles against } \\
\text { American naval units: "United States } \\
\text { forces have exercised their right of } \\
\text { self-defence by responding to hostile } \\
\text { Libyan military attacks in international } \\
\text { waters in the Gulf of Sidra." }\end{array}$ & $\begin{array}{l}\text { S/PV.2668 } \\
\text { (2668th) }\end{array}$ & None identified & $\begin{array}{l}\text { None } \\
\text { identified }\end{array}$ & Article 51 & \begin{tabular}{|l|} 
http: \\
//www.un. \\
org//en/gal \\
search/vie \\
w_doc. \\
asp? \\
symbol=s/ \\
17938
\end{tabular} & & $\begin{array}{l}\text { https: } \\
\text { //perma. } \\
\text { cc/wUaa- } \\
\text { UDAX }\end{array}$ \\
\hline 227 & 1986.04.12 & 1986.04.12 & $S / 17983$ & Libya & $\begin{array}{l}\text { Libya, United } \\
\text { States, Soviet } \\
\text { Union, Malta }\end{array}$ & $\begin{array}{c}\text { Implied } \\
\text { assertion of } \\
\text { "individual" } \\
\text { self-defense }\end{array}$ & $\begin{array}{l}\text { Threat of } \\
\text { attack }\end{array}$ & United States & State & $\begin{array}{l}\text { Libya states that "United States } \\
\text { aircratt-carriers and other United } \\
\text { States naval units are now proceeding } \\
\text { towards the Libyan coast for the } \\
\text { purpose of staging military aggression } \\
\text { against the Socialist People's Libyan } \\
\text { Arab Jamahiriya...." }\end{array}$ & $\begin{array}{l}\text { S/PV.2672 } \\
\text { (2672nd); } \\
\text { S/PV.2675 } \\
\text { (2675th) }\end{array}$ & None identified & $\begin{array}{l}\text { None } \\
\text { identified }\end{array}$ & Article 51 & \begin{tabular}{|l|} 
http: \\
//www.un. \\
org//en/gal \\
search/vie \\
w_doc. \\
asp? \\
symbol=s/ \\
17983 \\
1798
\end{tabular} & $\begin{array}{l}\text { http://www. } \\
\text { un. } \\
\text { org/en/ga/se } \\
\text { arch//iew_do } \\
\text { c.asp? } \\
\text { symbol=s/179 } \\
\text { 83\&Lang=A }\end{array}$ & $\begin{array}{l}\text { https: } \\
\text { //perma. } \\
\text { cc/6FEs- } \\
\text { DJUB }\end{array}$ \\
\hline
\end{tabular}


VI. HLS PILAC Catalogue of Apparent “Article 51 Communications”

\begin{tabular}{|c|c|c|c|c|c|c|c|c|c|c|c|c|c|c|c|c|c|}
\hline $\begin{array}{l}\text { Chron. } \\
\text { Order }\end{array}$ & $\begin{array}{l}\text { Date of } \\
\text { Comm. }\end{array}$ & \begin{tabular}{|c} 
Date of \\
UNsC \\
Document
\end{tabular} & | UNSC Symbol & \begin{tabular}{|l} 
Member \\
State(s) That \\
Submitted \\
the Comm.
\end{tabular} & \begin{tabular}{|c|} 
Expressly \\
Mentioned UN \\
Members (\& \\
Colonial \\
Holdings \& \\
Protectorates, \\
if any) \\
\end{tabular} & \begin{tabular}{|l} 
Express or \\
Implied \\
Assertion of \\
Individual, \\
Collective, or \\
Both Self- \\
defense
\end{tabular} & \begin{tabular}{|c} 
Nature of \\
the Alleged \\
Threat
\end{tabular} & $\begin{array}{l}\text { Expressly Alleged } \\
\text { Author(s) of the } \\
\text { Threat (If Any } \\
\text { Indicated) }\end{array}$ & \begin{tabular}{|c|} 
Nature of the \\
Alleged \\
Author(s) of \\
the Threat (If \\
Any \\
Indicated)
\end{tabular} & $\begin{array}{l}\text { Summary of Alleged Self-defense } \\
\text { Grounds }\end{array}$ & $\begin{array}{l}\text { UNsc } \\
\text { Meeting(s) } \\
\text { (if Any) at } \\
\text { Which the } \\
\text { Comm. was } \\
\text { Raised }\end{array}$ & $\begin{array}{l}\text { Responsive Act (If Any) by the } \\
\text { UNSC }\end{array}$ & \begin{tabular}{||c} 
UN \\
Repertory \\
Inclusion?
\end{tabular} & $\begin{array}{c}\text { UNSC } \\
\text { Repertoire } \\
\text { Inclusion? }\end{array}$ & \begin{tabular}{|c||} 
URL to an \\
English \\
Text
\end{tabular} & \begin{tabular}{||c||} 
URL to Non- \\
English \\
Original \\
Text (ff Any)
\end{tabular} & \begin{tabular}{|l} 
Perma.cc \\
URL
\end{tabular} \\
\hline 228 & 1986.04.14 & 1986.04.14 & $\mathrm{s} / 17990$ & $\begin{array}{l}\text { United } \\
\text { States }\end{array}$ & \begin{tabular}{|l} 
Libya, United \\
States, \\
Germany
\end{tabular} & $\begin{array}{l}\text { Implied } \\
\text { assertion of } \\
\text { "individual" } \\
\text { self-defense }\end{array}$ & $\begin{array}{l}\text { Conducted } \\
\text { attack and } \\
\text { threat of } \\
\text { attack }\end{array}$ & Libya & State & $\begin{array}{l}\text { The United States states that it has } \\
\text { exercised the right to self-defense by } \\
\text { "responding to an ongoing pattern of } \\
\text { attacks by the Government of Libya" } \\
\text { as Liby a "has openly targeted } \\
\text { American citizens and U.S. } \\
\text { installations. The most recent instance } \\
\text { was in West Berlin on April 5, [1986,] } \\
\text { where Libya was directly responsible } \\
\text { for a bombing...." The United States } \\
\text { states that it has taken care in } \\
\text { "restricting its military response to } \\
\text { terrorist-related targets". }\end{array}$ & $\begin{array}{l}\text { S/PV.2674 } \\
\text { (2674th); } \\
\text { S/PV.2840 } \\
\text { (2840th) }\end{array}$ & None identified & $\begin{array}{l}\text { None } \\
\text { identified }\end{array}$ & $\begin{array}{l}\text { Articles 2(4), } \\
33 \text {, and 51 }\end{array}$ & 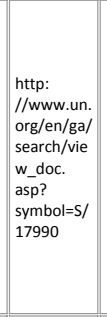 & & $\begin{array}{l}\text { https: } \\
\text { //perma. } \\
\text { cc/32UX- } \\
\text { VM3L }\end{array}$ \\
\hline 229 & 1986.05.19 & 1986.05.19 & $\mathrm{s} / 18067$ & Botswana & $\begin{array}{l}\text { Botswana, } \\
\text { South Africa }\end{array}$ & $\begin{array}{l}\text { Implied } \\
\text { assertion of } \\
\text { "individual" } \\
\text { self-defense }\end{array}$ & $\begin{array}{c}\text { Conducted } \\
\text { attack }\end{array}$ & South Africa & State & $\begin{array}{l}\text { "“... [H]elicopters of the South African } \\
\text { Defence Force started firing at the } \\
\text { Botswana Defence Force Barracks at } \\
\text { Mogoditshane. There was a } \\
\text { simultaneous attack bb ground forces } \\
\text { supported by the helicopters on a } \\
\text { civilian housing complex in } \\
\text { Mogoditshane." }\end{array}$ & $\begin{array}{l}\text { S/PV. } 2684 \\
\text { (2684th) }\end{array}$ & None identified & $\begin{array}{l}\text { None } \\
\text { identified }\end{array}$ & \begin{tabular}{|l|} 
Consideratio \\
n of \\
Questions \\
under the \\
Council's \\
Responsibilit \\
y for the \\
Maintenanc \\
e of \\
International \\
Peace and \\
Security \\
\end{tabular} & \begin{tabular}{|l||} 
https: \\
//documen \\
ts-dds-ny. \\
un. \\
org/doc/U/U \\
NDOC/GEN \\
/N866/183/ \\
25/im/N8 \\
65385. \\
pdf? \\
OpenElem \\
ent
\end{tabular} & & $\begin{array}{l}\text { https: } \\
\text { //perma. } \\
\text { c/ } 3 \text { MMP- } \\
\text { K2AQ }\end{array}$ \\
\hline 230 & 1987.02.27 & 1987.02.27 & $\mathrm{S} / 18728$ & Iran & Iran, Iraq & $\begin{array}{l}\text { Implied } \\
\text { assertion of } \\
\text { "individual" } \\
\text { self-defense }\end{array}$ & $\begin{array}{c}\text { Conducted } \\
\text { attack }\end{array}$ & Iraq & State & \begin{tabular}{|l} 
Iraq conducted "an unprecedented \\
series of aerial and missile attacks \\
within the past few weeks which have \\
claimed the precious lives of more \\
than 4,000 civilians and wounded \\
more than 10,000 others.". Iran states \\
that Iraq has started a war of \\
aggression by directing attacks against \\
"very populous areas" and declaring \\
"the intention to use the massive \\
attacks and deliberate massacre of \\
innocent civilians as a Part \\
thicl of \\
their war effort and a tactic within \\
their overall aggressive war strategy."
\end{tabular} & $\begin{array}{l}\text { None } \\
\text { identified }\end{array}$ & None identified & $\begin{array}{l}\text { None } \\
\text { identified }\end{array}$ & $\begin{array}{l}\text { None } \\
\text { identified }\end{array}$ & \begin{tabular}{l|l||} 
http: \\
//wwww.un. \\
org/en/ga/ \\
search/vie \\
w_doc. \\
asp? \\
symbol=s/ \\
18728 \\
\end{tabular} & & \begin{tabular}{|l} 
https: \\
//perma. \\
c/UWD7- \\
T/PY
\end{tabular} \\
\hline 231 & 1987.08.11 & 1987.08.11 & $\mathrm{s} / 19030$ & Chad & Chad, Libya & $\begin{array}{c}\text { Implied } \\
\text { assertion of } \\
\text { "individual" } \\
\text { self-defense }\end{array}$ & $\begin{array}{c}\text { Conducted } \\
\text { attack }\end{array}$ & Libya & State & $\begin{array}{l}\text { On August 8, 1987, "Libyan forces } \\
\text { attacked the positions of the Chadian } \\
\text { National Armed Forces (FANT) in } \\
\text { Tibesti, at Bardaĩ and Umchi." }\end{array}$ & $\begin{array}{l}\text { None } \\
\text { identified }\end{array}$ & None identified & $\begin{array}{l}\text { None } \\
\text { identified }\end{array}$ & $\begin{array}{l}\text { None } \\
\text { identified }\end{array}$ & \begin{tabular}{|l|} 
http: \\
I/www.un. \\
org///nngal \\
search/vie \\
w_doc. \\
asp? \\
symbol=s/ \\
19030 \\
\end{tabular} & $\begin{array}{l}\text { hetp://www. } \\
\text { un. } \\
\text { org/en/ga/se } \\
\text { arch/view_do } \\
\text { c.asp? } \\
\text { symbol=s/190 } \\
\text { 30\&lang=F } \\
\end{array}$ & \begin{tabular}{|l} 
https: \\
//perma. \\
c/6eDT- \\
55AL
\end{tabular} \\
\hline 232 & 1987.09.03 & 1987.09.04 & s/19106 & Libya & $\begin{array}{l}\text { Libya, France, } \\
\text { Chad, United } \\
\text { States }\end{array}$ & $\begin{array}{l}\text { Implied } \\
\text { assertion of } \\
\text { "individual" } \\
\text { self-defense }\end{array}$ & $\begin{array}{c}\text { Conducted } \\
\text { attack }\end{array}$ & Chad & State & $\begin{array}{l}\text { Libya informed the Council of "military } \\
\text { aggression - supported and } \\
\text { instigated by the colonial and imperial } \\
\text { 1st [sic] Powers - which was carried } \\
\text { out by Habre's forces against the } \\
\text { southern frontier of the Jamahiriya." }\end{array}$ & $\begin{array}{l}\text { None } \\
\text { identified }\end{array}$ & None identified & \begin{tabular}{|l} 
one \\
identified
\end{tabular} & $\begin{array}{l}\text { None } \\
\text { identified }\end{array}$ & \begin{tabular}{|l|} 
http: \\
//www.un. \\
org//nn/gal \\
search/vie \\
w_doc. \\
asp? \\
symbol=s/ \\
19106
\end{tabular} & $\begin{array}{l}\text { http://www. } \\
\text { un. } \\
\text { org/en/ga/se } \\
\text { arch/view_do } \\
\text { c.asp? } \\
\text { symbol=s/191 } \\
\text { ob\&lang=A }\end{array}$ & $\begin{array}{l}\text { https: } \\
\text { //perma. } \\
\text { cc/9uUk- } \\
\text { 3/SU }\end{array}$ \\
\hline
\end{tabular}


VI. HLS PILAC Catalogue of Apparent “Article 51 Communications”

\begin{tabular}{|c|c|c|c|c|c|c|c|c|c|c|c|c|c|c|c|c|c|}
\hline $\begin{array}{l}\text { Chron. } \\
\text { Order }\end{array}$ & $\begin{array}{l}\text { Date of } \\
\text { Comm. }\end{array}$ & $\begin{array}{c}\text { Date of } \\
\text { UNsC } \\
\text { Document }\end{array}$ & UNSC Symbol & \begin{tabular}{||c} 
Member \\
State(s) That \\
Submitted \\
the Comm.
\end{tabular} & \begin{tabular}{|c|} 
Expressly \\
Mentioned UN \\
Members (\& \\
Colonial \\
Holdings \& \\
Protectorates, \\
if any) \\
\end{tabular} & \begin{tabular}{||c|} 
Express or \\
Implied \\
Assertion of \\
Individual, \\
Collective, or \\
Both Self- \\
defense \\
\end{tabular} & \begin{tabular}{|c} 
Nature of \\
the Alleged \\
Threat
\end{tabular} & $\begin{array}{l}\text { Expressly Alleged } \\
\text { Author(s) of the } \\
\text { Threat (If Any } \\
\text { Indicated) }\end{array}$ & \begin{tabular}{|c|} 
Nature of the \\
Alleged \\
Author(s) of \\
the Threat (If \\
Any \\
Indicated) \\
\end{tabular} & $\begin{array}{l}\text { Summary of Alleged Self-defense } \\
\text { Grounds }\end{array}$ & \begin{tabular}{|c|} 
UNSC \\
Meeting(s) \\
(If Any) at \\
Which the \\
Comm. was \\
Raised \\
\end{tabular} & $\begin{array}{l}\text { Responsive Act (ff Any) by the } \\
\text { UNSC }\end{array}$ & \begin{tabular}{|l} 
UN \\
Repertory \\
Inclusion?
\end{tabular} & \begin{tabular}{|} 
UNsC \\
Repertoire \\
Inclusion?
\end{tabular} & \begin{tabular}{|l||} 
URL to an \\
English \\
Text
\end{tabular} & \begin{tabular}{||c||} 
URL to Non- \\
English \\
Original \\
Text (ff Any)
\end{tabular} & \begin{tabular}{|c} 
Perma.cc \\
URL
\end{tabular} \\
\hline 233 & 1987.09.08 & 1987.09.08 & $\mathrm{s} / 19112$ & Libya & $\begin{array}{l}\text { Libya, Chad, } \\
\text { France, United } \\
\text { States }\end{array}$ & $\begin{array}{c}\text { Implied } \\
\text { assertion of } \\
\text { "individual" } \\
\text { self-defense }\end{array}$ & $\begin{array}{c}\text { Conducted } \\
\text { attack }\end{array}$ & Chad & State & 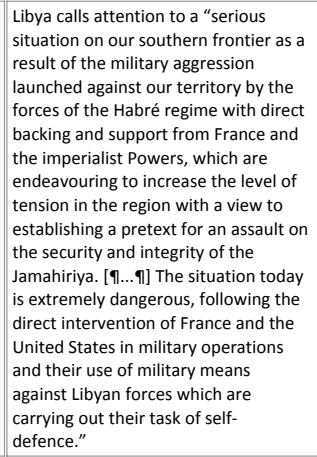 & $\begin{array}{l}\text { None } \\
\text { identified }\end{array}$ & None identified & $\begin{array}{l}\text { None } \\
\text { identified }\end{array}$ & $\begin{array}{l}\text { None } \\
\text { identified }\end{array}$ & \begin{tabular}{|l||} 
http: \\
//www.un. \\
org/en/ga/ \\
search/vie \\
w_doc. \\
asp? \\
symbol=s/ \\
19112
\end{tabular} & \begin{tabular}{|l|} 
http://www. \\
un. \\
org/en/ga/se \\
arch/view_do \\
casp? \\
symbol=s/191 \\
12\&lang=A
\end{tabular} & \begin{tabular}{|l} 
https: \\
//perma. \\
cc/GAFT- \\
MNKT
\end{tabular} \\
\hline 234 & 1987.09.14 & 1987.09.15 & $\mathrm{S} / 19136$ & Chad & $\begin{array}{l}\text { Chad, France, } \\
\text { Libya }\end{array}$ & $\begin{array}{l}\text { Implied } \\
\text { assertion of } \\
\text { "collective" } \\
\text { self-defense }\end{array}$ & $\begin{array}{c}\text { Conducted } \\
\text { attack }\end{array}$ & Libya & State & \begin{tabular}{|l} 
Chad states that "ilin fact, by repelling \\
the savage Libyan hordes' attack on \\
Ounianga Kebir, , FANT chased the \\
invaders as far as the Ma'tanas as Sara \\
base, which is the bridgehead whence \\
bombers take off daily on their evil \\
mission to Chad. Chad therefore \\
merely availed itself of its right to self- \\
defence and its right of pursuit."
\end{tabular} & $\begin{array}{l}\text { None } \\
\text { identified }\end{array}$ & None identified & $\begin{array}{l}\text { None } \\
\text { identified }\end{array}$ & $\begin{array}{l}\text { None } \\
\text { identified }\end{array}$ & \begin{tabular}{|l||} 
http: \\
|/www.un. \\
org/en/ga/ \\
search/vie \\
w_doc. \\
asp? \\
symbol=s/ \\
19136
\end{tabular} & \begin{tabular}{|l|} 
http://www. \\
un. \\
org/en/ga/se \\
arch/view_do \\
casp? \\
symbol=s/191 \\
36\&lang=F
\end{tabular} & $\begin{array}{l}\text { hitps: } \\
\text { //perma. } \\
\text { cc//9526- } \\
\text { EkgG }\end{array}$ \\
\hline 235 & 1987.09.22 & 1987.09.22 & $\mathrm{s} / 19149$ & $\begin{array}{l}\text { United } \\
\text { States }\end{array}$ & \begin{tabular}{|l} 
United States, \\
Iran, Bahrain
\end{tabular} & $\begin{array}{c}\text { Implied } \\
\text { assertion of } \\
\text { "individual" } \\
\text { self-defense }\end{array}$ & $\begin{array}{l}\text { Indirect } \\
\text { attack }\end{array}$ & Iran & State & $\begin{array}{l}\text { Iranian ship laying mines in shipping } \\
\text { lanes used by the Unitied States: "[S]ix } \\
\text { mines were laid before the United } \\
\text { States took measures to cause the } \\
\text { Iranian craft to cease this hostile use } \\
\text { of force. Ten additional mines were } \\
\text { discovered on [b]oard the Iranian } \\
\text { vessel." }\end{array}$ & $\begin{array}{l}\text { None } \\
\text { identified }\end{array}$ & None identified & $\begin{array}{l}\text { None } \\
\text { identified }\end{array}$ & Article 51 & \begin{tabular}{|l||} 
http: \\
//www.un. \\
org/en/ga/ \\
search/vie \\
w_doc. \\
asp? \\
symbol=s/ \\
19149 \\
\end{tabular} & & $\begin{array}{l}\text { hitps: } \\
\text { //perma. } \\
\text { cc//PHFB- } \\
\text { 9PE2 }\end{array}$ \\
\hline 236 & 1987.09.23 & 1987.09.25 & $\mathrm{s} / 19151$ & Chad & $\begin{array}{l}\text { Chad, Libya, } \\
\text { France, United } \\
\text { States }\end{array}$ & $\begin{array}{c}\text { Implied } \\
\text { assertion of } \\
\text { "individual" } \\
\text { self-defense }\end{array}$ & \begin{tabular}{|l} 
Conducted \\
attack and \\
threat of \\
attack
\end{tabular} & Libya & State & \begin{tabular}{|l} 
Chad asserts that Libya is "seeking to \\
justify in advance the new aggression \\
which it is preparing against Chad \\
going so far in its diversionary tactics \\
as to attribute some kind of \\
responsibility to France and to the \\
United States," while Chad is \\
"attacked, occupied and threatened ... \\
merely defending itself."
\end{tabular} & $\begin{array}{l}\text { None } \\
\text { identified }\end{array}$ & None identified & $\begin{array}{l}\text { None } \\
\text { identified }\end{array}$ & $\begin{array}{l}\text { None } \\
\text { identified }\end{array}$ & \begin{tabular}{|l||} 
http: \\
//www.un. \\
org/en/ga/ \\
search/vie \\
w_doc. \\
asp? \\
symbol=s/ \\
19151
\end{tabular} & \begin{tabular}{|l|} 
http://www. \\
un. \\
org/en/ga/se \\
arch//iew_do \\
c.asp? \\
symbol=s/191 \\
51\&Lang=F
\end{tabular} & \begin{tabular}{|l} 
https: \\
//perma. \\
cc//7772- \\
p95w
\end{tabular} \\
\hline 237 & 1987.10.09 & 1987.10.09 & $\mathrm{s} / 19194$ & $\begin{array}{l}\text { United } \\
\text { States }\end{array}$ & $\begin{array}{l}\text { United States, } \\
\text { Iran }\end{array}$ & $\begin{array}{l}\text { Implied } \\
\text { assertion of } \\
\text { "individual" } \\
\text { self-defense }\end{array}$ & $\begin{array}{c}\text { Conducted } \\
\text { attack }\end{array}$ & Iran & State & $\begin{array}{l}\text { U.S. aircraft were attacked by Iranian } \\
\text { forces: “... Iranian patrol craft [flired } \\
\text { on a United States helicopter on } \\
\text { routine nighttime patrol over } \\
\text { international waters of the Persian } \\
\text { Gulf. United States helicopters } \\
\text { returned fire, sinking one of the } \\
\text { Iranian craft.” }\end{array}$ & $\begin{array}{l}\text { None } \\
\text { identified }\end{array}$ & None identified & $\begin{array}{l}\text { None } \\
\text { identified }\end{array}$ & Article 51 & \begin{tabular}{|l||} 
http: \\
//www.un. \\
org//nn/ga/ \\
search/vie \\
w_doc. \\
asp? \\
symbol=s/ \\
19194 \\
\end{tabular} & & \begin{tabular}{|l} 
https: \\
//perma. \\
c/4kMM3- \\
YL5X
\end{tabular} \\
\hline 238 & 1987.10.19 & 1987.10.19 & $\mathrm{s} / 19219$ & $\begin{array}{l}\text { United } \\
\text { States }\end{array}$ & $\begin{array}{l}\text { United States, } \\
\text { Iran, Iraq, } \\
\text { Kuwait }\end{array}$ & $\begin{array}{c}\text { Implied } \\
\text { assertion of } \\
\text { "individual" } \\
\text { self-defense }\end{array}$ & $\begin{array}{c}\text { Conducted } \\
\text { attack }\end{array}$ & Iran & State & \begin{tabular}{|l} 
"[A] Silkworm missile fired by Iranian \\
forces from Iranian-occupied lraqi \\
territory struck the Sea Isle City, a \\
United States flag vessel, in the \\
territorial waters of Kuwait.... These \\
actions are, moreover, only the latest \\
in a series of unlawful armed attacks \\
by Iranian forces against the United \\
States, including laying mines in \\
international waters...."
\end{tabular} & $\begin{array}{l}\text { None } \\
\text { identified }\end{array}$ & None identified & $\begin{array}{l}\text { None } \\
\text { identified }\end{array}$ & $\begin{array}{l}\text { None } \\
\text { identified }\end{array}$ & \begin{tabular}{|l||} 
http: \\
//www.un. \\
org/en/ga/ \\
search/vie \\
w_doc. \\
asp? \\
symbol=s/ \\
19219
\end{tabular} & & \begin{tabular}{|l} 
https: \\
//perma. \\
c/ClCG2- \\
G425
\end{tabular} \\
\hline
\end{tabular}


VI. HLS PILAC Catalogue of Apparent “Article 51 Communications”

\begin{tabular}{|c|c|c|c|c|c|c|c|c|c|c|c|c|c|c|c|c|c|}
\hline $\begin{array}{l}\text { Chron. } \\
\text { Order }\end{array}$ & $\begin{array}{l}\text { Date of } \\
\text { comm. }\end{array}$ & $\begin{array}{c}\text { Date of } \\
\text { UNsC } \\
\text { Document }\end{array}$ & UNSC Symbol & \begin{tabular}{|l} 
Member \\
State(s) That \\
Submitted \\
the Comm.
\end{tabular} & \begin{tabular}{||c||} 
Expressly \\
Mentioned UN \\
Members (\& \\
Colonial \\
Holdings \& \\
Protectorates, \\
if any) \\
\end{tabular} & \begin{tabular}{|c} 
Express or \\
Implied \\
Assertion of \\
Individual, \\
Collective, or \\
Both Self- \\
defense \\
\end{tabular} & \begin{tabular}{|l}
$\begin{array}{c}\text { Nature of } \\
\text { the Alleged } \\
\text { Threat }\end{array}$
\end{tabular} & $\begin{array}{l}\text { Expressly Alleged } \\
\text { Author(s) of the } \\
\text { Threat (If Any } \\
\text { Indicated) }\end{array}$ & \begin{tabular}{|c} 
Nature of the \\
Alleged \\
Author(s) of \\
the Threat (If \\
Any \\
Indicated)
\end{tabular} & $\begin{array}{l}\text { Summary of Alleged Self-defense } \\
\text { Grounds }\end{array}$ & \begin{tabular}{|c} 
UNSC \\
Meeting(s) \\
(If Any) at \\
Which the \\
Comm. was \\
Raised
\end{tabular} & $\begin{array}{l}\text { Responsive Act (If Any) by the } \\
\text { UNSC }\end{array}$ & $\begin{array}{l}\text { UN } \\
\text { Repertory } \\
\text { Inclusion? }\end{array}$ & $\begin{array}{c}\text { UNSC } \\
\text { Repertoire } \\
\text { Inclusion? }\end{array}$ & $\begin{array}{l}\text { URL to an } \\
\text { English } \\
\text { Text }\end{array}$ & \begin{tabular}{|l} 
URL to Non- \\
English \\
Original \\
Text (ff Any)
\end{tabular} & \begin{tabular}{|l} 
Perma.cc \\
URL
\end{tabular} \\
\hline 239 & 1987.10.20 & 1987.10.21 & $\mathrm{s} / 19224$ & Iran & $\begin{array}{l}\text { Iran, United } \\
\text { States }\end{array}$ & $\begin{array}{c}\text { Implied } \\
\text { assertion of } \\
\text { "individual" } \\
\text { self-defense }\end{array}$ & $\begin{array}{c}\text { Conducted } \\
\text { attack }\end{array}$ & United States & State & \begin{tabular}{|l} 
"[T]he naval forces of the United \\
States, illegitimately stationed in the \\
Persian Gulf, attacked two Iranian oil \\
platforms - Resalat and Reshadat - \\
injuring a large number of civilian \\
technical employees and inflicting \\
heavy damages." Iran describes a \\
series of "aggressive acts [that the \\
United States] has carried out in the \\
past month," stating that "the \\
international community and \\
particularly the United Nations \\
Security Council remained silent."
\end{tabular} & \begin{tabular}{|l} 
None \\
identified
\end{tabular} & None identified & $\begin{array}{l}\text { None } \\
\text { identified }\end{array}$ & Article 51 & $\begin{array}{l}\text { http: } \\
\text { //www.un. } \\
\text { org/en/ga/ } \\
\text { search/vie } \\
\text { w_doc. } \\
\text { asp? } \\
\text { symbol=s/ } \\
19224\end{array}$ & & \begin{tabular}{|l} 
https: \\
//perma. \\
c/ScFF5- \\
WA3G
\end{tabular} \\
\hline 240 & 1987.11.10 & 1987.11.10 & $\mathrm{s} / 19261$ & Chad & \begin{tabular}{|} 
Chad, Libya, \\
United States, \\
Syria, Lebanon, \\
Yemen
\end{tabular} & $\begin{array}{l}\text { Implied } \\
\text { assertion of } \\
\text { "collective" } \\
\text { self-defense }\end{array}$ & $\begin{array}{c}\text { Conducted } \\
\text { attack }\end{array}$ & Libya & State & $\begin{array}{l}\text { Chad is "the victim of aggression and } \\
\text { occupation". }\end{array}$ & $\begin{array}{l}\text { None } \\
\text { identified }\end{array}$ & None identified & $\begin{array}{l}\text { None } \\
\text { identified }\end{array}$ & $\begin{array}{l}\text { None } \\
\text { identified }\end{array}$ & $\begin{array}{l}\text { http: } \\
\text { //www.un. } \\
\text { org/en//ga/ } \\
\text { search/vie } \\
\text { w_doc. } \\
\text { asp? } \\
\text { spybol=S/ } \\
19261\end{array}$ & $\begin{array}{l}\text { http://www. } \\
\text { un. } \\
\text { org/en/ga/se } \\
\text { arch/view_do } \\
\text { c.asp? } \\
\text { symbol=s/192 } \\
\text { 618lang=F }\end{array}$ & $\begin{array}{l}\text { https: } \\
\text { //perma. } \\
\text { cc/HGSF- } \\
\text { S2N8 }\end{array}$ \\
\hline 241 & 1988.02.10 & 1988.02.12 & s/19498 & Laos & Laos, Thailand & $\begin{array}{l}\text { Implied } \\
\text { assertion of } \\
\text { "individual" } \\
\text { self-defense }\end{array}$ & $\begin{array}{c}\text { Conducted } \\
\text { attack and } \\
\text { imminent } \\
\text { attack }\end{array}$ & Thailand & State & $\begin{array}{l}\text { Thailand conducted a military attack } \\
\text { against Laos during which “military } \\
\text { troops pounded Lao positions with } \\
\text { heavy artillery." Laos states that the } \\
\text { Thai Minister of Defense stated that } \\
\text { "he would be readjusting military } \\
\text { tactics with the aim of launching still } \\
\text { more violent tattacks against the } \\
\text { positions of the Loo forces." Laos } \\
\text { considers those statements to indicate } \\
\text { that "new large-scale attacks are } \\
\text { imminent." }\end{array}$ & $\begin{array}{l}\text { None } \\
\text { identified }\end{array}$ & None identified & $\begin{array}{l}\text { None } \\
\text { identified }\end{array}$ & $\begin{array}{l}\text { None } \\
\text { identified }\end{array}$ & $\begin{array}{l}\text { http: } \\
\text { //www.un. } \\
\text { org/en/ga/ } \\
\text { search/vie } \\
\text { w_doc. } \\
\text { asp? } \\
\text { symbol=s/ } \\
19498\end{array}$ & \begin{tabular}{|l} 
http://www. \\
un. \\
org/en/ga/se \\
arch/view_do \\
c.asp? \\
symbol=s/194 \\
98\&Lang=F
\end{tabular} & $\begin{array}{l}\text { https: } \\
\text { //perma. } \\
\text { cc/ry25- } \\
\text { Z7KD }\end{array}$ \\
\hline 242 & 1988.02.12 & 1988.02.16 & S/19504 & Thailand & Thailand, Laos & $\begin{array}{c}\text { Express } \\
\text { assertion of } \\
\text { "individual" } \\
\text { self-defense }\end{array}$ & $\begin{array}{c}\text { Conducted } \\
\text { attack }\end{array}$ & Laos & State & $\begin{array}{l}\text { Thailand claims that, “on } 31 \text { May } \\
\text { 1987, } 15 \text { Laotian soldiers intruded into } \\
\text { Thai territory at Amphoe Chart } \\
\text { Trakarn, Phitsanulok Province, killing } \\
\text { an innocent Thai labourer and } \\
\text { destroying three tractors owned by a } \\
\text { Thai private company." Thailand also } \\
\text { claims that taos sent trooos into } \\
\text { Thailand, for planting a large number } \\
\text { of land mines and occupying Hill } \\
\text { 1428." }\end{array}$ & \begin{tabular}{|l} 
None \\
identified
\end{tabular} & None identified & $\begin{array}{l}\text { None } \\
\text { identified }\end{array}$ & \begin{tabular}{|l} 
None \\
identified
\end{tabular} & $\begin{array}{l}\text { http: } \\
\text { //www.un. } \\
\text { org/en/ga/ } \\
\text { search/vie } \\
\text { w_doc. } \\
\text { asp? } \\
\text { symbol=s/ } \\
19504\end{array}$ & & $\begin{array}{l}\text { https: } \\
\text { //perma. } \\
\text { c/ZZAA8- } \\
\text { H6D3 }\end{array}$ \\
\hline 243 & 1988.03.05 & 1988.03.05 & $\mathrm{s} / 19583$ & Iraq & Iraq, Iran & $\begin{array}{c}\text { Implied } \\
\text { assertion of } \\
\text { "individual" } \\
\text { self-defense }\end{array}$ & \begin{tabular}{|c} 
Conducted \\
attack
\end{tabular} & Iran & State & $\begin{array}{l}\text { Iraq claims that "it was the Iranian } \\
\text { regime which began the hostilities by } \\
\text { bombarding towns and exclusively } \\
\text { residential sectors." }\end{array}$ & $\begin{array}{l}\text { None } \\
\text { identified }\end{array}$ & None identified & $\begin{array}{l}\text { None } \\
\text { identified }\end{array}$ & $\begin{array}{l}\text { None } \\
\text { identified }\end{array}$ & $\begin{array}{l}\text { http: } \\
\text { //www.un. } \\
\text { org/en//ga/ } \\
\text { search//vie } \\
\text { w_doc. } \\
\text { asp? } \\
\text { symbol=S/ } \\
19583\end{array}$ & $\left\{\begin{array}{l}\text { http://www. } \\
\text { un. } \\
\text { org/en/ga/se } \\
\text { archh/view_do } \\
\text { c.asp? } \\
\text { symbol=s/195 } \\
\text { 83\&lang=A }\end{array}\right.$ & $\begin{array}{l}\text { https: } \\
\text { //perma. } \\
\text { cc/SSZL- } \\
\text { P2LR }\end{array}$ \\
\hline 244 & 1988.03.11 & 1988.03.11 & $\mathrm{s} / 19603$ & Iran & Iran, Iraq & $\begin{array}{l}\text { Implied } \\
\text { assertion of } \\
\text { "individual" } \\
\text { self-defense }\end{array}$ & $\begin{array}{c}\text { Conducted } \\
\text { attack }\end{array}$ & Iraq & State & \begin{tabular}{|l} 
Iran claims that Iraq conducted \\
"attacks against purely civilian areas," \\
that the attacks "were most intensive \\
during Friday congregational prayers," \\
and that the "escalation and \\
continuation of these attacks since 2 \\
February 1988 is only a continuation \\
of the lraqi policy of barbarism and \\
total disregard for the most \\
universally recognized rules of \\
international law governing the \\
conduct of armed hostilities."
\end{tabular} & \begin{tabular}{|l} 
None \\
identified
\end{tabular} & None identified & \begin{tabular}{|l} 
None \\
identified
\end{tabular} & \begin{tabular}{|l} 
None \\
identified
\end{tabular} & $\begin{array}{l}\text { http: } \\
\text { //www.un. } \\
\text { org/en/ga/ } \\
\text { search/vie } \\
\text { w_doc. } \\
\text { asp? } \\
\text { symbol=s/ } \\
19603\end{array}$ & & \begin{tabular}{|l} 
https: \\
//perma. \\
cc/gzEQ- \\
SJPD
\end{tabular} \\
\hline
\end{tabular}


VI. HLS PILAC Catalogue of Apparent “Article 51 Communications”

\begin{tabular}{|c|c|c|c|c|c|c|c|c|c|c|c|c|c|c|c|c|c|}
\hline $\begin{array}{c}\text { Chron. } \\
\text { Order }\end{array}$ & $\begin{array}{l}\text { Date of } \\
\text { Comm. }\end{array}$ & $\begin{array}{l}\text { Date of } \\
\text { UNsC } \\
\text { Document }\end{array}$ & UNSC Symbol & \begin{tabular}{||c} 
Member \\
State(s) That \\
Submitted \\
the Comm.
\end{tabular} & \begin{tabular}{|c||} 
Expressly \\
Mentioned UN \\
Members (\& \\
Colonial \\
Holdings \& \\
Protectorates, \\
if any) \\
\end{tabular} & \begin{tabular}{|l|} 
Express or \\
Implied \\
Assertion of \\
Individual, \\
Collective, or \\
Both Self- \\
defense \\
\end{tabular} & \begin{tabular}{|l}
$\begin{array}{c}\text { Nature of } \\
\text { the Alleged } \\
\text { Threat }\end{array}$
\end{tabular} & $\begin{array}{l}\text { Expressly Alleged } \\
\text { Author(s) of the } \\
\text { Threat (If Any } \\
\text { Indicated) }\end{array}$ & \begin{tabular}{|c|} 
Nature of the \\
Alleged \\
Author(s) of \\
the Threat (If \\
Any \\
Indicated)
\end{tabular} & $\begin{array}{l}\text { Summary of Alleged Self-defense } \\
\text { Grounds }\end{array}$ & \begin{tabular}{|c|} 
UNSC \\
Meeting(s) \\
(If Any) at \\
Which the \\
Comm. was \\
Raised \\
\end{tabular} & $\begin{array}{l}\text { Responsive Act (If Any) by the } \\
\text { UNSC }\end{array}$ & \begin{tabular}{|l} 
UN \\
Repertory \\
Inclusion?
\end{tabular} & \begin{tabular}{|c} 
UNsC \\
Repertoire \\
Inclusion?
\end{tabular} & \begin{tabular}{|l|} 
URL to an \\
English \\
Text
\end{tabular} & \begin{tabular}{||c||} 
URL to Non- \\
English \\
Original \\
Text (ff Any)
\end{tabular} & $\begin{array}{l}\text { Perma.cc } \\
\text { URL }\end{array}$ \\
\hline 245 & 1988.03.14 & 1988.03.15 & S/19619 & Iran & Iran, Iraq & $\begin{array}{l}\text { Implied } \\
\text { assertion of } \\
\text { "individual" } \\
\text { self-defense }\end{array}$ & $\begin{array}{c}\text { Conducted } \\
\text { attack }\end{array}$ & Iraq & State & \begin{tabular}{|l} 
"TThe Iraqi regime resumed its \\
attacks against neutral shipping in the \\
Persian Gulf last week and once again \\
resorted to the use of chemical \\
weapons against civilians ... the Iraqi \\
régime resumed its missile attacks \\
against non-military and residential \\
quarters."
\end{tabular} & $\begin{array}{l}\text { None } \\
\text { identified }\end{array}$ & None identified & $\begin{array}{l}\text { None } \\
\text { identified }\end{array}$ & $\begin{array}{l}\text { None } \\
\text { identified }\end{array}$ & \begin{tabular}{|l|} 
http: \\
//www.un. \\
org/en/ga/ \\
search/vie \\
W_doc. \\
asp? \\
symbol=s/ \\
19619 \\
\end{tabular} & & $\begin{array}{l}\text { hitps: } \\
\text { //perma. } \\
\text { cc/8NW7- } \\
\text { ZGA2 }\end{array}$ \\
\hline 246 & 1988.03.16 & 1988.03.16 & S/19634 & Vietnam & Vietnam, China & $\begin{array}{l}\text { Implied } \\
\text { assertion of } \\
\text { "individual" } \\
\text { self-defense }\end{array}$ & $\begin{array}{c}\text { Conducted } \\
\text { attack }\end{array}$ & China & State & $\begin{array}{l}\text { Vietnam is concerned about China's } \\
\text { violation of Vietnamese waters and } \\
\text { that China “overtly opened fire at two } \\
\text { Vietnamese freighters" and considers } \\
\text { it a violation of Vietnam's territorial } \\
\text { sovereignty and an act of "armed } \\
\text { provocation." }\end{array}$ & $\begin{array}{l}\text { None } \\
\text { identified }\end{array}$ & None identified & $\begin{array}{l}\text { None } \\
\text { identified }\end{array}$ & $\begin{array}{l}\text { None } \\
\text { identified }\end{array}$ & \begin{tabular}{|l||} 
http: \\
//www.un. \\
org/en/ga/ \\
search/vie \\
w_doc. \\
asp? \\
symbol=s/ \\
19634 \\
1963
\end{tabular} & & \begin{tabular}{|l} 
hitps: \\
$/ / / p e r m a$. \\
cc/4R2RG- \\
$6 \mathrm{MGM}$
\end{tabular} \\
\hline 247 & 1988.04.18 & 1988.04.18 & S/19791 & $\begin{array}{l}\text { United } \\
\text { States }\end{array}$ & $\begin{array}{c}\text { United States, } \\
\text { Iran }\end{array}$ & $\begin{array}{l}\text { Implied } \\
\text { assertion of } \\
\text { "individual" } \\
\text { self-defense }\end{array}$ & $\begin{array}{c}\text { Conducted } \\
\text { attack }\end{array}$ & Iran & State & 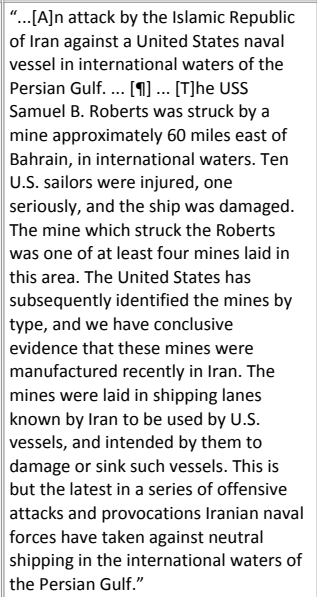 & $\begin{array}{l}\text { None } \\
\text { identified }\end{array}$ & None identified & $\begin{array}{l}\text { None } \\
\text { identified }\end{array}$ & $\begin{array}{l}\text { None } \\
\text { identified }\end{array}$ & \begin{tabular}{|l||} 
http: \\
|/www.un. \\
org/en/ga/ \\
search/vie \\
w_doc. \\
asp? \\
symbol=s/ \\
19791
\end{tabular} & & $\begin{array}{l}\text { https: } \\
\text { //perma. } \\
\text { cc } \\
\text { TESSUW- }\end{array}$ \\
\hline 248 & 1988.07.06 & 1988.07.06 & S/19989 & $\begin{array}{l}\text { United } \\
\text { States }\end{array}$ & $\begin{array}{l}\text { United States, } \\
\text { Iran }\end{array}$ & $\begin{array}{l}\text { Implied } \\
\text { assertion of } \\
\text { "individual" } \\
\text { self-defense }\end{array}$ & $\begin{array}{c}\text { Conducted } \\
\text { attack }\end{array}$ & Iran & State & $\begin{array}{l}\text { A group of Iranian patrol craft fired on } \\
\text { a US helicopter operating in } \\
\text { international waters of the Persian } \\
\text { Gulf. Too US naval vessels were } \\
\text { approaching a group of Iranian small } \\
\text { boats, some of which turned and } \\
\text { began "closing in on" the US warships, } \\
\text { which, in turn opened fire on the } \\
\text { small boats, sinking two and damaging } \\
\text { a third. }\end{array}$ & $\begin{array}{l}\text { S/PV.2818 } \\
\text { (2818th) }\end{array}$ & None identified & $\begin{array}{l}\text { None } \\
\text { identified }\end{array}$ & Article 51 & \begin{tabular}{|l||} 
http: \\
|/www.un. \\
org/en/ga/ \\
search/vie \\
w_doc. \\
asp? \\
symbol=s/ \\
19989
\end{tabular} & & $\begin{array}{l}\text { https: } \\
/ / / p e r m a . \\
\text { cc/N268- } \\
\text { EGG8 }\end{array}$ \\
\hline 249 & 1989.01.04 & 1989.01.04 & $\mathrm{s} / 20366$ & $\begin{array}{l}\text { United } \\
\text { States }\end{array}$ & \begin{tabular}{|c} 
United States, \\
Libya
\end{tabular} & $\begin{array}{l}\text { Implied } \\
\text { assertion of } \\
\text { "individual" } \\
\text { self-defense }\end{array}$ & \begin{tabular}{|c} 
Conducted \\
attack
\end{tabular} & Libya & State & $\begin{array}{l}\text { U.S. aircraft were participating in a } \\
\text { peaceful training operations over } \\
\text { international waters in the } \\
\text { Mediterranean Sea when two Libyan } \\
\text { aircraft approached them "in a hostile } \\
\text { manner." The US aircraft attempted to } \\
\text { take evasive measures and disengage; } \\
\text { they then fired upon and shot down } \\
\text { the Libyan aircraft. }\end{array}$ & $\begin{array}{l}\text { S/PV. } 2835 \\
\text { (2835th); } \\
\text { S/PV.22836 } \\
\text { (2836th) }\end{array}$ & None identified & $\begin{array}{l}\text { None } \\
\text { identified }\end{array}$ & \begin{tabular}{|l|} 
Article 51; \\
Consideratio \\
n of \\
Questions \\
under the \\
Council's \\
Responsibilit \\
y for the \\
Maintenanc \\
e of \\
International \\
Peace and \\
Security
\end{tabular} & \begin{tabular}{|l||} 
http: \\
|/www.un. \\
org/en/ga/ \\
search/vie \\
w_doc. \\
asp? \\
symbol=s/ \\
20366
\end{tabular} & & $\begin{array}{l}\text { https: } \\
\text { //perma. } \\
\text { cc//Juvk- } \\
\text { TKVD }\end{array}$ \\
\hline
\end{tabular}


VI. HLS PILAC Catalogue of Apparent “Article 51 Communications”

\begin{tabular}{|c|c|c|c|c|c|c|c|c|c|c|c|c|c|c|c|c|c|}
\hline $\begin{array}{l}\text { Chron. } \\
\text { Order }\end{array}$ & $\begin{array}{l}\text { Date of } \\
\text { Comm. }\end{array}$ & $\begin{array}{c}\text { Date of } \\
\text { UNsC } \\
\text { Document }\end{array}$ & UNSC Symbol & \begin{tabular}{|l} 
Member \\
State(s) That \\
Submitted \\
the Comm.
\end{tabular} & \begin{tabular}{||c||} 
Expressly \\
Mentioned UN \\
Members (\& \\
Colonial \\
Holdings \& \\
Protectorates, \\
if any) \\
\end{tabular} & \begin{tabular}{|c|} 
Express or \\
Implied \\
Assertion of \\
Individual, \\
Collective, or \\
Both Self- \\
defense \\
\end{tabular} & \begin{tabular}{|l}
$\begin{array}{c}\text { Nature of } \\
\text { the Alleged } \\
\text { Threat }\end{array}$
\end{tabular} & $\begin{array}{l}\text { Expressly Alleged } \\
\text { Author(s) of the } \\
\text { Threat (If Any } \\
\text { Indicated) }\end{array}$ & \begin{tabular}{|c|} 
Nature of the \\
Alleged \\
Author(s) of \\
the Threat (If \\
Any \\
Indicated) \\
\end{tabular} & $\begin{array}{l}\text { Summary of Alleged Self-defense } \\
\text { Grounds }\end{array}$ & $\begin{array}{l}\text { UNSC } \\
\text { Meeting(s) } \\
\text { (ff Any) at } \\
\text { Which the } \\
\text { Comm. was } \\
\text { Raised }\end{array}$ & $\begin{array}{l}\text { Responsive Act (ff Any) by the } \\
\text { UNSC }\end{array}$ & \begin{tabular}{|l} 
UN \\
Repertory \\
Inclusion?
\end{tabular} & $\begin{array}{c}\text { UNSC } \\
\text { Repertoire } \\
\text { Inclusion? }\end{array}$ & $\begin{array}{l}\text { URL to an } \\
\text { English } \\
\text { Text }\end{array}$ & \begin{tabular}{|c} 
URL to Non- \\
English \\
Original \\
Tert (If Any)
\end{tabular} & Perma.cc \\
\hline 250 & 1989.12.20 & 1989.12.20 & $\mathrm{s} / 21035$ & $\begin{array}{l}\text { United } \\
\text { States }\end{array}$ & $\begin{array}{c}\text { United States, } \\
\text { Panama }\end{array}$ & $\begin{array}{l}\text { Implied } \\
\text { assertion of } \\
\text { "individual" } \\
\text { self-defense }\end{array}$ & $\begin{array}{c}\text { Conducted } \\
\text { attack }\end{array}$ & Panama & State & $\begin{array}{l}\text { Manuel Noriega declared a state of } \\
\text { war with the United States and his } \\
\text { forces attacked "lawfully present } \\
\text { American personnel" in Panama, } \\
\text { killing one. The US took action in self- } \\
\text { defense after consultation with the } \\
\text { "demorctatically-elected leaders of } \\
\text { Panama" and after exhausting "every } \\
\text { available diplomatic means" to resolve } \\
\text { disputes with Noriega. }\end{array}$ & $\begin{array}{l}\text { S/PV.2899 } \\
\text { (2899th) }\end{array}$ & None identified & $\begin{array}{l}\text { None } \\
\text { identified }\end{array}$ & $\begin{array}{l}\text { Article 51; } \\
\text { Consideratio } \\
\text { n of } \\
\text { Questions } \\
\text { under the } \\
\text { Council's } \\
\text { Responsibilit } \\
\text { y for the } \\
\text { Maintenanc } \\
\text { e of } \\
\text { International } \\
\text { Peace and } \\
\text { Security } \\
\end{array}$ & $\begin{array}{l}\text { http: } \\
\text { //www.un. } \\
\text { org/en/ga/ } \\
\text { search/vie } \\
\text { w_doc. } \\
\text { asp? } \\
\text { symbol=s/ } \\
21035\end{array}$ & & $\begin{array}{l}\text { https: } \\
\text { //perma. } \\
\text { cc//W23C- } \\
\text { AGX3 }\end{array}$ \\
\hline 251 & 1990.05.14 & 1990.05.15 & $s / 21295$ & Chad & $\begin{array}{l}\text { Chad, Libya, } \\
\text { Sudan }\end{array}$ & $\begin{array}{l}\text { Implied } \\
\text { assertion of } \\
\text { "individual" } \\
\text { self-defense }\end{array}$ & $\begin{array}{c}\text { Conducted } \\
\text { attack }\end{array}$ & Libya, Sudan & States & $\begin{array}{l}\text { Chad responds to a statement made } \\
\text { by Libya four days earlier. Chad states } \\
\text { its actions were "self-defence } \\
\text { triggered by an unmistakable Libyan } \\
\text { attack for which there is irrefutable } \\
\text { evidence." }\end{array}$ & $\begin{array}{l}\text { None } \\
\text { identified }\end{array}$ & None identified & $\begin{array}{l}\text { None } \\
\text { identified }\end{array}$ & $\begin{array}{l}\text { None } \\
\text { identified }\end{array}$ & $\begin{array}{l}\text { http: } \\
\text { //www.un. } \\
\text { org/en//ga/ } \\
\text { search/vie } \\
\text { w_doc. } \\
\text { asp? } \\
\text { spybol=S/ } \\
\text { 21295 }\end{array}$ & $\left\{\begin{array}{l}\text { http://www. } \\
\text { un. } \\
\text { org/en/ga/se } \\
\text { arch//iew_do } \\
\text { c.asp? } \\
\text { symbl=s/212 } \\
\text { 95\&Lang=F }\end{array}\right.$ & $\begin{array}{l}\text { https: } \\
\text { //perma. } \\
\text { cc/XJ37- } \\
7 \text { FN8 }\end{array}$ \\
\hline 252 & 1990.05.23 & 1990.05.24 & $\mathrm{s} / 21333$ & Chad & $\begin{array}{l}\text { Chad, Libya, } \\
\text { Sudan }\end{array}$ & $\begin{array}{l}\text { Implied } \\
\text { assertion of } \\
\text { "individual" } \\
\text { self-defense }\end{array}$ & $\begin{array}{c}\text { Conducted } \\
\text { attack }\end{array}$ & Libya & State & $\begin{array}{l}\text { Chad captured a Libyan military } \\
\text { convoy "in the course of [] action } \\
\text { taken in self-defencen" " fater a Libyan } \\
\text { attack from the Darfur region. }\end{array}$ & $\begin{array}{l}\text { None } \\
\text { identified }\end{array}$ & None identified & $\begin{array}{l}\text { None } \\
\text { identified }\end{array}$ & \begin{tabular}{|l} 
None \\
identified
\end{tabular} & $\begin{array}{l}\text { http: } \\
\text { //wwww.un. } \\
\text { org/en/ga/ } \\
\text { search//ie } \\
\text { w_doc. } \\
\text { asp? } \\
\text { symbol=S/ } \\
\text { 21333 }\end{array}$ & $\begin{array}{l}\text { hettp://www. } \\
\text { un. } \\
\text { org/en/ga/se } \\
\text { arrh//view_do } \\
\text { c.asp? } \\
\text { symbol=s/213 } \\
\text { 33\&Llang=F }\end{array}$ & $\begin{array}{l}\text { https: } \\
\text { //perma. } \\
\text { cc/9uJ2- } \\
\text { UM7F }\end{array}$ \\
\hline 253 & 1990.08.09 & 1990.08.10 & $s / 21492$ & $\begin{array}{l}\text { United } \\
\text { States }\end{array}$ & $\begin{array}{c}\text { United States, } \\
\text { Kuwait, Saudi } \\
\text { Arabia, Iraq }\end{array}$ & \begin{tabular}{|c|} 
Express \\
assertion of \\
"individual" \\
self-defense \\
and express \\
assertion of \\
"collective" \\
self-defense
\end{tabular} & $\begin{array}{c}\text { Conducted } \\
\text { attack }\end{array}$ & Iraq & State & $\begin{array}{l}\text { Iraq attacked and occupied Kuwait } \\
\text { and then made statements that } \\
\text { threatened states neighboring Kuwait, } \\
\text { including Saudi Arabia. The Us } \\
\text { characterized "Iraq's invasion and the } \\
\text { continued occupation of Kuwait" as } \\
\text { concerning "the entire community of } \\
\text { nations" and the Us deployed forces } \\
\text { to the "Persian Gulf region" "in } \\
\text { response to developments and } \\
\text { requests from Governments in the } \\
\text { region", such as Kuwait and Saudi } \\
\text { Arabia, for assistance. }\end{array}$ & $\begin{array}{l}\text { S/PV.2937 } \\
\text { (2937th) }\end{array}$ & 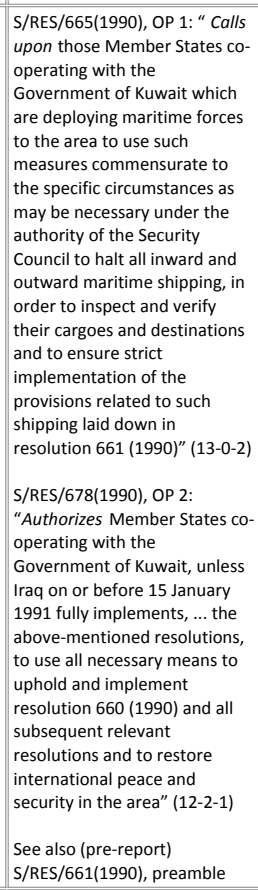 & $\begin{array}{l}\text { None } \\
\text { identified }\end{array}$ & Article 51 & $\begin{array}{l}\text { http: } \\
\text { /twww.un. } \\
\text { org/en/ga/ } \\
\text { search/vie } \\
\text { w_doc. } \\
\text { asp? } \\
\text { symbol=s/ } \\
21492\end{array}$ & & $\begin{array}{l}\text { https: } \\
\text { //perma. } \\
\text { cc/SVus- } \\
\text { 8ARS }\end{array}$ \\
\hline
\end{tabular}


VI. HLS PILAC Catalogue of Apparent “Article 51 Communications”

\begin{tabular}{|c|c|c|c|c|c|c|c|c|c|c|c|c|c|c|c|c|c|}
\hline $\begin{array}{l}\text { Chron. } \\
\text { Order }\end{array}$ & $\begin{array}{l}\text { Date of } \\
\text { Comm. }\end{array}$ & $\begin{array}{c}\text { Date of } \\
\text { UNSC } \\
\text { Document }\end{array}$ & UNSC Symbol & \begin{tabular}{||c} 
Member \\
State(s) That \\
Submitted \\
the Comm.
\end{tabular} & \begin{tabular}{||c||} 
Expressly \\
Mentioned UN \\
Members (\& \\
Colonial \\
Holdings \& \\
Protectorates, \\
if any) \\
\end{tabular} & \begin{tabular}{|c} 
Express or \\
Implied \\
Assertion of \\
Individual, \\
Collective, or \\
Both Self- \\
defense
\end{tabular} & $\begin{array}{l}\text { Nature of } \\
\text { the Alleged } \\
\text { Threat }\end{array}$ & $\begin{array}{l}\text { Expressly Alleged } \\
\text { Author(s) of the } \\
\text { Threat (If Any } \\
\text { Indicated) }\end{array}$ & \begin{tabular}{|l|} 
Nature of the \\
Alleged \\
Author(s) of \\
the Threat (If \\
Any \\
Indicated)
\end{tabular} & $\begin{array}{l}\text { Summary of Alleged Self-defense } \\
\text { Grounds }\end{array}$ & $\begin{array}{l}\text { UNSC } \\
\text { Meeting(s) } \\
\text { (If Any) at } \\
\text { Which the } \\
\text { Comm. was } \\
\text { Raised }\end{array}$ & $\begin{array}{l}\text { Responsive Act (If Any) by the } \\
\text { UNSC }\end{array}$ & $\begin{array}{c}\text { UN } \\
\text { Repertory } \\
\text { Inclusion? }\end{array}$ & \begin{tabular}{|c} 
UNSC \\
Repertoire \\
Inclusion?
\end{tabular} & \begin{tabular}{|c} 
URL to an \\
English \\
Text
\end{tabular} & \begin{tabular}{||c||} 
URL to Non- \\
English \\
Original \\
Text (ff Any)
\end{tabular} & \begin{tabular}{|l} 
Perma.cc \\
URL
\end{tabular} \\
\hline 254 & 1990.08.12 & 1990.08.13 & $s / 21498$ & Kuwait & Kuwait, Iraq & \begin{tabular}{|c|} 
Express \\
assertion of \\
"individual" \\
self-defense \\
and express \\
assertion of \\
"collective" \\
self-defense
\end{tabular} & $\begin{array}{c}\text { Conducted } \\
\text { attack }\end{array}$ & Iraq & State & \begin{tabular}{|l} 
In response to Iraq's attacks and \\
occupation of it, Kuwait informed the \\
UN Security Council of Iraq's requests \\
to other (unnamed) nations to help \\
with implementation of Security \\
Council Resolution 661 .
\end{tabular} & $\begin{array}{l}\text { None } \\
\text { identified }\end{array}$ & 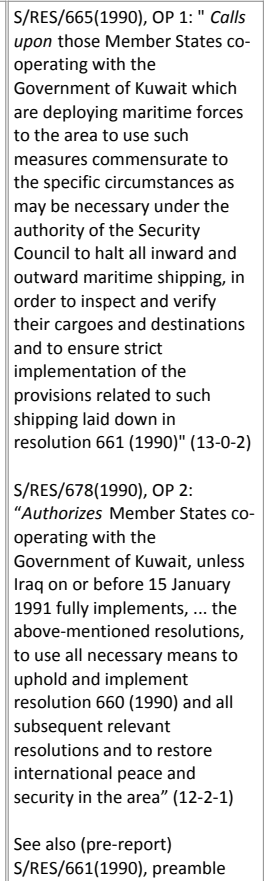 & $\begin{array}{l}\text { None } \\
\text { identified }\end{array}$ & Article 51 & $\begin{array}{l}\text { lntp: } \\
\text { //wwww.un. } \\
\text { org/en//gal } \\
\text { search/vie } \\
\text { ww doc. } \\
\text { asp? } \\
\text { symbol=s/ } \\
\text { 21498 }\end{array}$ & & \begin{tabular}{|l} 
https: \\
//perma. \\
cc/9QPP- \\
XC32
\end{tabular} \\
\hline
\end{tabular}


VI. HLS PILAC Catalogue of Apparent “Article 51 Communications”

\begin{tabular}{|c|c|c|c|c|c|c|c|c|c|c|c|c|c|c|c|c|c|}
\hline $\begin{array}{l}\text { Chron. } \\
\text { Order }\end{array}$ & $\begin{array}{l}\text { Date of } \\
\text { Comm. }\end{array}$ & $\begin{array}{c}\text { Date of } \\
\text { UNSC } \\
\text { Document }\end{array}$ & UNSC Symbol & \begin{tabular}{||c} 
Member \\
State(s) That \\
Submitted \\
the Comm.
\end{tabular} & \begin{tabular}{|c|} 
Expressly \\
Mentioned UN \\
Members (\& \\
Colonial \\
Holdings \& \\
Protectorates, \\
if any) \\
\end{tabular} & \begin{tabular}{|c|} 
Express or \\
Implied \\
Assertion of \\
Individual, \\
Collective, or \\
Both Self- \\
defense \\
\end{tabular} & $\begin{array}{l}\text { Nature of } \\
\text { the Alleged } \\
\text { Threat }\end{array}$ & $\begin{array}{l}\text { Expressly Alleged } \\
\text { Author(s) of the } \\
\text { Threat (If Any } \\
\text { Indicated) }\end{array}$ & \begin{tabular}{|l|} 
Nature of the \\
Alleged \\
Author(s) of \\
the Threat (If \\
Any \\
Indicated)
\end{tabular} & $\begin{array}{l}\text { Summary of Alleged Self-defense } \\
\text { Grounds }\end{array}$ & \begin{tabular}{|c} 
UNSC \\
Meeting(s) \\
(If Any) at \\
Which the \\
Comm. was \\
Raised
\end{tabular} & $\begin{array}{l}\text { Responsive Act (If Any) by the } \\
\text { UNSC }\end{array}$ & $\begin{array}{c}\text { UN } \\
\text { Repertory } \\
\text { Inclusion? }\end{array}$ & \begin{tabular}{|c} 
UNSC \\
Repertoire \\
Inclusion?
\end{tabular} & \begin{tabular}{|c} 
URL to an \\
English \\
Text
\end{tabular} & \begin{tabular}{||c||} 
URL to Non- \\
English \\
Original \\
Text (ff Any)
\end{tabular} & \begin{tabular}{|l} 
Perma.cc \\
URL
\end{tabular} \\
\hline 255 & 1990.08.13 & 1990.08.13 & $\mathrm{s} / 21501$ & $\begin{array}{l}\text { United } \\
\text { Kingdom }\end{array}$ & $\begin{array}{c}\text { United } \\
\text { Kingdom, } \\
\text { Saudi Arabia, } \\
\text { Kuwait, } \\
\text { Bahrain, Oman }\end{array}$ & \begin{tabular}{|l|} 
Express \\
assertion of \\
"individual" \\
self-defense \\
and express \\
assertion of \\
"collective" \\
self-defense
\end{tabular} & $\begin{array}{c}\text { Conducted } \\
\text { attack }\end{array}$ & Iraq & State & $\begin{array}{l}\text { The United Kingdom announces the } \\
\text { deployment of troops to "the Gulf" "in } \\
\text { response to developments and } \\
\text { requests from Governments in the } \\
\text { region, including requests from } \\
\text { Kuwait, Saudi Arabia and Bahrain for } \\
\text { assistance and by agreement with } \\
\text { Oman." }\end{array}$ & $\begin{array}{l}\text { None } \\
\text { identified }\end{array}$ & 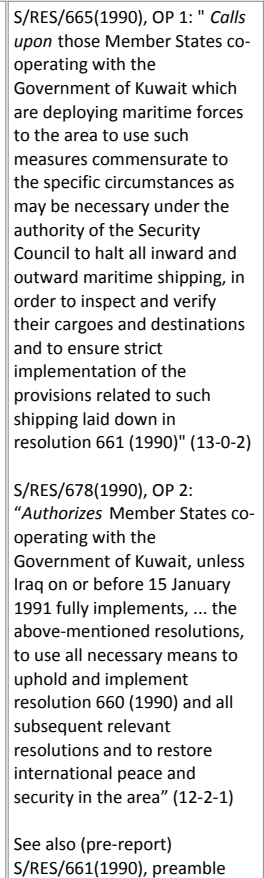 & \begin{tabular}{|l} 
None \\
identified
\end{tabular} & Article 51 & 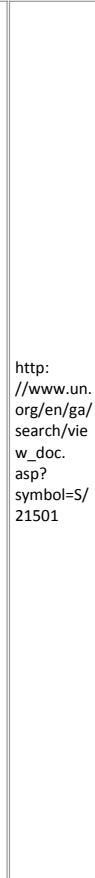 & & \begin{tabular}{|l} 
https: \\
//perma. \\
cc/W2DH- \\
FFEB
\end{tabular} \\
\hline
\end{tabular}


VI. HLS PILAC Catalogue of Apparent “Article 51 Communications”

\begin{tabular}{|c|c|c|c|c|c|c|c|c|c|c|c|c|c|c|c|c|c|}
\hline $\begin{array}{l}\text { Chron. } \\
\text { Order }\end{array}$ & $\begin{array}{l}\text { Date of } \\
\text { Comm. }\end{array}$ & $\begin{array}{l}\text { Date of } \\
\text { UNSC } \\
\text { Document }\end{array}$ & UNSC Symbol & \begin{tabular}{||c||} 
Member \\
State(s) That \\
Submitted \\
the Comm.
\end{tabular} & \begin{tabular}{|c} 
Expressly \\
Mentioned UN \\
Members (\& \\
Colonial \\
Holdings \& \\
Protectorates, \\
if any)
\end{tabular} & \begin{tabular}{|c|} 
Express or \\
Implied \\
Assertion of \\
Individual, \\
Collective, or \\
Both Self- \\
defense \\
\end{tabular} & $\begin{array}{c}\text { Nature of } \\
\text { the Alleged } \\
\text { Threat }\end{array}$ & $\begin{array}{l}\text { Expressly Alleged } \\
\text { Author(s) of the } \\
\text { Threat (If Any } \\
\text { Indicated) }\end{array}$ & \begin{tabular}{|c} 
Nature of the \\
Alleged \\
Author(s) of \\
the Threat (If \\
Any \\
Indicated)
\end{tabular} & $\begin{array}{l}\text { Summary of Alleged Self-defense } \\
\text { Grounds }\end{array}$ & $\begin{array}{l}\text { UNsC } \\
\text { Meeting(s) } \\
\text { (If Any) at } \\
\text { Which the } \\
\text { Comm. was } \\
\text { Raised }\end{array}$ & $\begin{array}{l}\text { Responsive Act (If Any) by the } \\
\text { UNSC }\end{array}$ & $\begin{array}{l}\text { UN } \\
\text { Repertory } \\
\text { Inclusion? }\end{array}$ & $\begin{array}{c}\text { UNSC } \\
\text { Repertoire } \\
\text { Inclusion? }\end{array}$ & \begin{tabular}{|c|} 
URL to an \\
English \\
Text
\end{tabular} & \begin{tabular}{||c||} 
URL to Non- \\
English \\
Original \\
Text (If Any)
\end{tabular} & \begin{tabular}{|l} 
Perma.cc \\
URL
\end{tabular} \\
\hline 256 & 1990.08.16 & 1990.08.16 & $\mathrm{s} / 21537$ & $\begin{array}{l}\text { United } \\
\text { States }\end{array}$ & $\begin{array}{l}\text { United States, } \\
\text { Kuwait, Iraq }\end{array}$ & $\begin{array}{l}\text { Express } \\
\text { assertion of } \\
\text { "individual" } \\
\text { self-defense } \\
\text { and express } \\
\text { assertion of } \\
\text { "collective" } \\
\text { self-defense }\end{array}$ & $\begin{array}{c}\text { Conducted } \\
\text { attack }\end{array}$ & Iraq & State & $\begin{array}{l}\text { The United States is working with } \\
\text { Kuwait to "intercept vessels seeking to } \\
\text { engage in trade with Iraq or Kuwait in } \\
\text { violation of the mandatory sanctions } \\
\text { imposed in Security Council resolution } \\
661 . "\end{array}$ & \begin{tabular}{|l} 
None \\
identified
\end{tabular} & 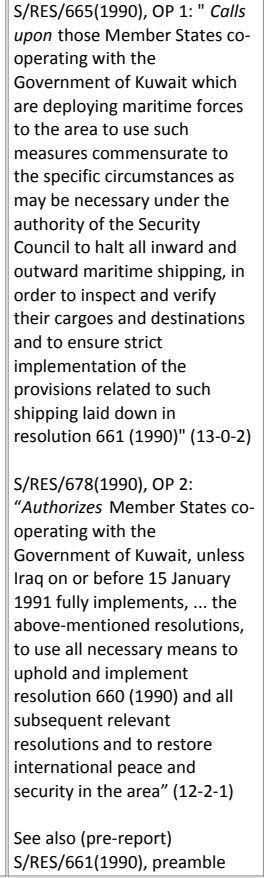 & $\begin{array}{l}\text { None } \\
\text { identified }\end{array}$ & Article 51 & $\begin{array}{l}\text { http: } \\
\text { h/www.un. } \\
\text { org///an/gal } \\
\text { search//vie } \\
\text { w_doc. } \\
\text { asp? } \\
\text { spmbol=s/ } \\
\text { 21537 }\end{array}$ & & $\begin{array}{l}\text { https: } \\
\text { //perma. } \\
\text { cc/9HWV- } \\
\text { V6UQ }\end{array}$ \\
\hline
\end{tabular}


VI. HLS PILAC Catalogue of Apparent “Article 51 Communications”

\begin{tabular}{|c|c|c|c|c|c|c|c|c|c|c|c|c|c|c|c|c|c|}
\hline $\begin{array}{l}\text { Chron. } \\
\text { Order }\end{array}$ & $\begin{array}{l}\text { Date of } \\
\text { Comm. }\end{array}$ & $\begin{array}{c}\text { Date of } \\
\text { UNSC } \\
\text { Document }\end{array}$ & | UNSC Symbol & \begin{tabular}{|c} 
Member \\
State(s) That \\
Submitted \\
the Comm.
\end{tabular} & \begin{tabular}{|c|} 
Expressly \\
Mentioned UN \\
Members (\& \\
Colonial \\
Holdings \& \\
Protectorates, \\
if any) \\
\end{tabular} & \begin{tabular}{|l} 
Express or \\
Implied \\
Assertion of \\
Individual, \\
Collective, or \\
Both Self- \\
defense
\end{tabular} & \begin{tabular}{|l} 
Nature of \\
the Alleged \\
Threat
\end{tabular} & $\begin{array}{l}\text { Expressly Alleged } \\
\text { Author(s) of the } \\
\text { Threat (If Any } \\
\text { Indicated) }\end{array}$ & $\begin{array}{c}\text { Nature of the } \\
\text { Alleged } \\
\text { Author(s) of } \\
\text { the Threat (If } \\
\text { Any } \\
\text { Indicated) }\end{array}$ & $\begin{array}{l}\text { Summary of Alleged Self-defense } \\
\text { Grounds }\end{array}$ & $\begin{array}{l}\text { UNSC } \\
\text { Meeting(s) } \\
\text { (If Any) at } \\
\text { Which the } \\
\text { Comm. was } \\
\text { Raised }\end{array}$ & $\begin{array}{l}\text { Responsive Act (If Any) by the } \\
\text { UNSC }\end{array}$ & $\begin{array}{c}\text { UN } \\
\text { Repertory } \\
\text { Inclusion? }\end{array}$ & \begin{tabular}{|c} 
UNSC \\
Repertoire \\
Inclusion?
\end{tabular} & \begin{tabular}{|l} 
URL to an \\
English \\
Text
\end{tabular} & \begin{tabular}{||c||} 
URL to Non- \\
English \\
Original \\
Text (ff Any)
\end{tabular} & \begin{tabular}{|l} 
Perma.cc \\
URL
\end{tabular} \\
\hline 257 & 1990.08.17 & 1990.08.17 & $\mathrm{s} / 21554$ & Saudi Arabia & \begin{tabular}{|l} 
Saudi Arabia, \\
Kuwait, Iraq
\end{tabular} & $\begin{array}{l}\text { Implied } \\
\text { assertion of } \\
\text { "individual"s } \\
\text { elf-defense } \\
\text { and implied } \\
\text { assertion of } \\
\text { "collective" } \\
\text { self-defense }\end{array}$ & $\begin{array}{l}\text { Conducted } \\
\text { attack }\end{array}$ & Iraq & State & $\begin{array}{l}\text { Saudi Arabia exercised its "legitimate } \\
\text { right" of self-defense following several } \\
\text { actions by Iraq, including placing } \\
\text { "large military forces in combat } \\
\text { formation near the border between } \\
\text { Kuwait and Saudi Arabia"; Saudi } \\
\text { Arabia "welcomed the forces of } \\
\text { fraternal and other friendly States } \\
\text { which expressed their willingness to } \\
\text { support the Saudi Arabian armed } \\
\text { forces in the defence of the Kingdom". }\end{array}$ & $\begin{array}{l}\text { S/PV.2938 } \\
\text { (2938th) }\end{array}$ & $\begin{array}{l}\text { S/RES/665(1990), OP 1: "Calls } \\
\text { upon those Member States co- } \\
\text { operating with the } \\
\text { Government of Kuwait which } \\
\text { are deploying maritime forces } \\
\text { to the area to use such } \\
\text { measures commensurate to } \\
\text { the specific circumstances as } \\
\text { may be necessary under the } \\
\text { authority of the Security } \\
\text { Council to halt all inward and } \\
\text { outward maritime shipping, in } \\
\text { order to inspect and verify } \\
\text { their cargees and destinations } \\
\text { and to ensure strict } \\
\text { implementation of the } \\
\text { provisions related to such } \\
\text { shipping laid down in } \\
\text { resolution 661 (1990)" (13-0-2) } \\
\text { S/RES/678(1990), OP 2: } \\
\text { "Authorizes Member States co- } \\
\text { operating with the } \\
\text { Government of Kuwait, unless } \\
\text { Iraq on or before 15 January } \\
1991 \text { fully implements, ,..the } \\
\text { above-mentioned resolutions, } \\
\text { to use all necessary means to } \\
\text { uphold and implement } \\
\text { resolution } 660(1990) \text { and all } \\
\text { subsequent relevant } \\
\text { resolutions and to restore } \\
\text { international peace and } \\
\text { security in the area" (12-2-1) } \\
\text { See also (pre-report) } \\
\text { S/RES/661(1990), preamble }\end{array}$ & $\begin{array}{l}\text { None } \\
\text { identified }\end{array}$ & Article 51 & 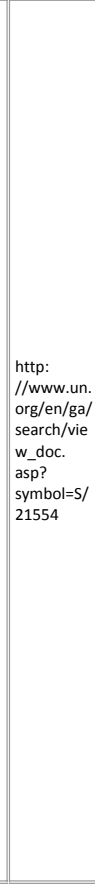 & $\begin{array}{l}\text { http://www. } \\
\text { un. } \\
\text { org/en/ga/se } \\
\text { arch//view_do } \\
\text { c.asp? } \\
\text { symbol=s/215 } \\
\text { 54andlang=A }\end{array}$ & $\begin{array}{l}\text { https: } \\
\text { //perma. } \\
\text { cc/FW6M- } \\
\text { TAGC }\end{array}$ \\
\hline 258 & 1991.01.17 & 1991.01.17 & $\mathrm{s} / 22094$ & Kuwait & Kuwait, Iraq & $\begin{array}{l}\text { Implied } \\
\text { assertion of } \\
\text { "individual" } \\
\text { self-defense }\end{array}$ & \begin{tabular}{|c} 
Conducted \\
attack
\end{tabular} & Iraq & State & \begin{tabular}{|l} 
Iraq had not removed its forces \\
occupying Kuwait by the deadline set \\
in Security Council resolution 678, so \\
Kuwait announced it was exercising its \\
right to self-deferse to recover its \\
territories, with "forces of fraternal \\
and friendly States which are equally \\
determined to end the obdurate Iraqi \\
occupation".
\end{tabular} & \begin{tabular}{|l} 
None \\
identified
\end{tabular} & None identified & $\begin{array}{l}\text { None } \\
\text { identified }\end{array}$ & \begin{tabular}{|l} 
None \\
identified
\end{tabular} & $\begin{array}{l}\text { http: } \\
\text { //www.un. } \\
\text { org/en/ga/ } \\
\text { search/vie } \\
\text { w_doc. } \\
\text { asp? } \\
\text { symbol=s/ } \\
\text { 22094 }\end{array}$ & $\begin{array}{l}\text { http://www. } \\
\text { un. } \\
\text { org/en/ga/se } \\
\text { arch/view_do } \\
\text { c.asp? } \\
\text { symbol=s/220 } \\
\text { 94\&Llang=A }\end{array}$ & \begin{tabular}{|l} 
https: \\
//perma. \\
cc/KCG2- \\
2U3J
\end{tabular} \\
\hline 259 & 1991.01.17 & 1991.01.18 & $s / 22113$ & Egypt & \begin{tabular}{|l} 
Egypt, Iraq, \\
Kuwait, Saudi \\
Arabia, United \\
States, United \\
Arab Emirates
\end{tabular} & $\begin{array}{l}\text { Implied } \\
\text { assertion of } \\
\text { "individual" } \\
\text { self-defense } \\
\text { and implied } \\
\text { assertion of } \\
\text { "collective" } \\
\text { self-defense } \\
\end{array}$ & $\begin{array}{c}\text { Conducted } \\
\text { attack }\end{array}$ & Iraq & State & \begin{tabular}{|l} 
Egypt announced its military action \\
against Iraq along with a coalition of \\
other States, in order to free Kuwait \\
from Iraqi occupation after Iraq \\
rejected diplomatic outreaches.
\end{tabular} & $\begin{array}{l}\text { None } \\
\text { identified }\end{array}$ & None identified & $\begin{array}{l}\text { None } \\
\text { identified }\end{array}$ & Article 51 & $\begin{array}{l}\text { http: } \\
\text { //wwww.un. } \\
\text { org/en/ga/ } \\
\text { search/vie } \\
\text { w_doc. } \\
\text { asp? } \\
\text { symbol=S/ } \\
22113 \\
\end{array}$ & $\begin{array}{l}\text { http://www. } \\
\text { un. } \\
\text { org/en/ga/se } \\
\text { arch/view_do } \\
\text { c.asp? } \\
\text { symbol=s/221 } \\
\text { 13\&Lang=A }\end{array}$ & \begin{tabular}{|l} 
https: \\
//perma. \\
cc/3FF2- \\
HJHS
\end{tabular} \\
\hline
\end{tabular}


VI. HLS PILAC Catalogue of Apparent “Article 51 Communications”

\begin{tabular}{|c|c|c|c|c|c|c|c|c|c|c|c|c|c|c|c|c|c|}
\hline $\begin{array}{l}\text { Chron. } \\
\text { Order }\end{array}$ & $\begin{array}{l}\text { Date of } \\
\text { comm. }\end{array}$ & \begin{tabular}{|c} 
Date of \\
UNsc \\
Document
\end{tabular} & UNSC Symbol & \begin{tabular}{||c} 
Member \\
State(s) That \\
Submitted \\
the Comm.
\end{tabular} & \begin{tabular}{|c||} 
Expressly \\
Mentioned UN \\
Members (\& \\
Colonial \\
Holdings \& \\
Protectorates, \\
if any) \\
\end{tabular} & \begin{tabular}{||c|} 
Express or \\
Implied \\
Assertion of \\
Individual, \\
Collective, or \\
Both Self- \\
defense \\
\end{tabular} & \begin{tabular}{|c} 
Nature of \\
the Alleged \\
Threat
\end{tabular} & \begin{tabular}{|l} 
Expressly Alleged \\
Author(s) of the \\
Threat (If Any \\
Indicated)
\end{tabular} & \begin{tabular}{|c} 
Nature of the \\
Alleged \\
Author(s) of \\
the Threat (If \\
Any \\
Indicated)
\end{tabular} & $\begin{array}{l}\text { Summary of Alleged Self-defense } \\
\text { Grounds }\end{array}$ & \begin{tabular}{||c|} 
UNSC \\
Meeting(s) \\
(If Any) at \\
Which the \\
Comm. was \\
Raised \\
\end{tabular} & $\begin{array}{l}\text { Responsive Act (If Any) by the } \\
\text { UNSC }\end{array}$ & \begin{tabular}{|l} 
UN \\
Repertory \\
Inclusion?
\end{tabular} & $\begin{array}{c}\text { UNSC } \\
\text { Repertoire } \\
\text { Inclusion? }\end{array}$ & \begin{tabular}{|l||} 
URL to an \\
English \\
Text
\end{tabular} & \begin{tabular}{||c||} 
URL to Non- \\
English \\
Original \\
Tert (ff Any)
\end{tabular} & \begin{tabular}{|l} 
Perma.cc \\
URL
\end{tabular} \\
\hline 260 & 1993.05.25 & 1993.05.26 & $\mathrm{S} / 25843$ & Iran & Iran, Iraq & $\begin{array}{c}\text { Implied } \\
\text { assertion of } \\
\text { "individual" } \\
\text { self-defense }\end{array}$ & $\begin{array}{c}\text { Conducted } \\
\text { attack }\end{array}$ & \begin{tabular}{|l} 
"AAlrmed and \\
organized terrorist \\
mercenaries" \\
funded, trained, \\
etc. by Iraq"
\end{tabular} & $\begin{array}{l}\text { Non-state } \\
\text { actors }\end{array}$ & $\begin{array}{l}\text { "IAlrmed and organized terrorist } \\
\text { mercenaries ... whose headquarters } \\
\text { and military bases are located in Iraq } \\
\text { where military training, financial and } \\
\text { logistical support and intelligence } \\
\text { services are provided to them" have } \\
\text { "perpetrated terrorist activities inside } \\
\text { Iran." Iran conducted an air raid } \\
\text { against the terrorists' military bases in } \\
\text { Iraq, "without prejudice to Iran's } \\
\text { policy of respecting the sovereignty } \\
\text { and territorial integrity of Iraq." }\end{array}$ & $\begin{array}{l}\text { None } \\
\text { identified }\end{array}$ & None identified & $\begin{array}{l}\text { None } \\
\text { identified }\end{array}$ & Article 51 & \begin{tabular}{|l||} 
http: \\
//www.un. \\
org/en/ga/ \\
search/vie \\
w_doc. \\
asp? \\
symbol=s/ \\
25843
\end{tabular} & & $\begin{array}{l}\text { https: } \\
\text { //perma. } \\
\text { cc/56DC- } \\
\text { J7zQ }\end{array}$ \\
\hline 261 & 1993.06.26 & 1993.06.26 & $\mathrm{S} / 26003$ & $\begin{array}{l}\text { United } \\
\text { States }\end{array}$ & $\begin{array}{l}\text { United States, } \\
\text { Iraq }\end{array}$ & \begin{tabular}{|c} 
Implied \\
assertion \\
"individual" \\
self-defense
\end{tabular} & \begin{tabular}{|c} 
Conducted \\
attack and \\
threat of \\
attack
\end{tabular} & Iraq & State & $\begin{array}{l}\text { The US states that the Iraqi } \\
\text { government attempted to murder } \\
\text { President GGorge Bush and continues } \\
\text { to be a threat to US nationals. In } \\
\text { response, because the US did not } \\
\text { believe diplomatic measures would } \\
\text { work, it planned to "strik[e] at an Iraqi } \\
\text { military and intelligence target that is } \\
\text { involved in such attacks." }\end{array}$ & $\begin{array}{l}\text { S/PV. } 3245 \\
\text { (3245th) }\end{array}$ & None identified & $\begin{array}{l}\text { None } \\
\text { identified }\end{array}$ & \begin{tabular}{|l|} 
Article 2(4); \\
Chapter III \\
(no \\
particular \\
article); \\
Article 51; \\
Chapter VIII \\
(no \\
particular \\
article) \\
\end{tabular} & \begin{tabular}{|l||} 
http: \\
|/www.un. \\
org/en/ga/ \\
search/vie \\
w_doc. \\
asp? \\
symbol=s/ \\
26003
\end{tabular} & & $\begin{array}{l}\text { https: } \\
\text { //perma. } \\
\text { cc/4VMJ- } \\
\text { MGWN }\end{array}$ \\
\hline 262 & 1993.07.06 & 1993.07.06 & $\mathrm{s} / 26044$ & Armenia & $\begin{array}{l}\text { Armenia, } \\
\text { Azerbaijan }\end{array}$ & \begin{tabular}{|c|} 
Implied \\
assertion of \\
"individual" \\
self-defense
\end{tabular} & $\begin{array}{c}\text { Conducted } \\
\text { attack }\end{array}$ & Azerbaijan & State & $\begin{array}{l}\text { "On the morning of } 4 \text { July, units of the } \\
\text { Azerbaijani army, supported by } \\
\text { military aircraft and artillery, initiated } \\
\text { a large-scale offensive along the full } \\
\text { eastern front of the Republic of } \\
\text { Nagorny-Karabagh. The city of } \\
\text { Stepanakert itself was hit by five } \\
\text { missiles. The self-defence ermy of the } \\
\text { Republic of Nagorny-Karabagh, } \\
\text { exercising its right to self-defence, was } \\
\text { able to stop the offensive and force } \\
\text { the enemy to retreat." }\end{array}$ & $\begin{array}{l}\text { None } \\
\text { identified }\end{array}$ & None identified & $\begin{array}{l}\text { None } \\
\text { identified }\end{array}$ & $\begin{array}{l}\text { None } \\
\text { identified }\end{array}$ & \begin{tabular}{|l||} 
http: \\
|/www.un. \\
org/en/ga/ \\
search/vie \\
w_doc. \\
asp? \\
symbol=s/ \\
26044
\end{tabular} & & \begin{tabular}{|l} 
https: \\
//perma. \\
cc/P2203- \\
3HCC
\end{tabular} \\
\hline 263 & 1993.07.26 & 1993.07.26 & $s / 26152$ & Israel & Israel, Lebanon & \begin{tabular}{|l}
\multicolumn{1}{|c}{ Implied } \\
assertion of \\
"individual"s \\
elf-defense
\end{tabular} & $\begin{array}{c}\text { Conducted } \\
\text { attack }\end{array}$ & \begin{tabular}{|l} 
Hezbollah and \\
"other terrorist \\
organizations" \\
(including the \\
Popular r ront for \\
the Liberation of \\
Palestine)
\end{tabular} & $\begin{array}{l}\text { Non-state } \\
\text { actors }\end{array}$ & $\begin{array}{l}\text { Hezbollah conducting attacks against } \\
\text { Israeli towns: "Hezbollah's 'strategy' } \\
\text { has included the repeated firing of } \\
\text { Katyusha rockets against towns and } \\
\text { villages in northern Israel as well as } \\
\text { attacks upon IDF units with rockets, } \\
\text { bombs and gunfire.... Israel is } \\
\text { exercising its legitimate right of self- } \\
\text { defence so as to restore adequate } \\
\text { security along our northern border." }\end{array}$ & $\begin{array}{l}\text { None } \\
\text { identified }\end{array}$ & None identified & $\begin{array}{l}\text { None } \\
\text { identified }\end{array}$ & $\begin{array}{l}\text { None } \\
\text { identified }\end{array}$ & \begin{tabular}{|l||} 
http: \\
|/www.un. \\
org/en/ga/ \\
search/vie \\
w_doc. \\
asp? \\
symbol=s/ \\
26152
\end{tabular} & & $\begin{array}{l}\text { https: } \\
\text { //perma. } \\
\text { cc/EgLC- } \\
\text { H9XL }\end{array}$ \\
\hline 264 & 1993.08.03 & 1993.08.03 & $s / 26232$ & $\begin{array}{l}\text { Bosnia and } \\
\text { Herzegovina }\end{array}$ & $\begin{array}{l}\text { Bosnia and } \\
\text { Herzegovina }\end{array}$ & \begin{tabular}{|c|} 
Implied \\
assertion of \\
"individual" \\
self-defense
\end{tabular} & $\begin{array}{c}\text { Conducted } \\
\text { attack }\end{array}$ & $\begin{array}{l}\text { Not indicated ("the } \\
\text { aggressor forces") }\end{array}$ & Not indicated & $\begin{array}{l}\text { "[A]ggressor forces" launching attacks } \\
\text { against towns: “tthe aggressor forces } \\
\text { launched repeated attacks against the } \\
\text { towns of Brcko, Maglaj, Tesanj, Olovo, } \\
\text { and upon the mountains around the } \\
\text { capital of our State, Sarajevo." }\end{array}$ & $\begin{array}{l}\text { S/PV.3269 } \\
\text { (3269th) }\end{array}$ & $\begin{array}{l}\text { S/RES/859(1993) OPs 2-3: “2. } \\
\text { Calls for an immediate } \\
\text { ceasefire and cessation of } \\
\text { hostilities throughout the } \\
\text { Republic of Bosnia and } \\
\text { Herzegovina as essential for } \\
\text { achieving a just and equitable } \\
\text { political solution to the conflict } \\
\text { in Bosnnia and Herzegovina } \\
\text { through peaceful negotiations; } \\
\text { 3. Demands that all concerned } \\
\text { facilitate the unhindered flow } \\
\text { of humanitarian assistance, } \\
\text { including the provision of food, } \\
\text { water, electricity, fuel and } \\
\text { communications, in particular } \\
\text { to the safe arases in Bosnia and } \\
\text { Herzegovina" (adopted } \\
\text { unanimously) }\end{array}$ & $\begin{array}{l}\text { None } \\
\text { identified }\end{array}$ & \begin{tabular}{|l} 
Chapter VIII \\
(no \\
particular \\
article)
\end{tabular} & \begin{tabular}{|l||} 
http: \\
|/www.un. \\
org/en/ga/ \\
search/vie \\
w_doc. \\
asp? \\
symbol=s/ \\
26232
\end{tabular} & & $\begin{array}{l}\text { https: } \\
\text { //perma. } \\
\text { cc/ERY7- } \\
\text { GEGF }\end{array}$ \\
\hline
\end{tabular}


VI. HLS PILAC Catalogue of Apparent “Article 51 Communications”

\begin{tabular}{|c|c|c|c|c|c|c|c|c|c|c|c|c|c|c|c|c|c|}
\hline $\begin{array}{l}\text { Chron. } \\
\text { Order }\end{array}$ & $\begin{array}{l}\text { Date of } \\
\text { Comm. }\end{array}$ & \begin{tabular}{|c} 
Date of \\
UNsc \\
Document
\end{tabular} & UNSC Symbol & \begin{tabular}{|c} 
Member \\
State(s) That \\
Submitted \\
the Comm.
\end{tabular} & \begin{tabular}{|c|} 
Expressly \\
Mentioned UN \\
Members (\& \\
Colonial \\
Holdings \& \\
Protectorates, \\
if any) \\
\end{tabular} & \begin{tabular}{|l} 
Express or \\
Implied \\
Assertion of \\
Individual, \\
Collective, or \\
Both Self- \\
defense
\end{tabular} & \begin{tabular}{|c} 
Nature of \\
the Alleged \\
Threat
\end{tabular} & $\begin{array}{l}\text { Expressly Alleged } \\
\text { Author(s) of the } \\
\text { Threat (If Any } \\
\text { Indicated) }\end{array}$ & $\begin{array}{l}\text { Nature of the } \\
\text { Alleged } \\
\text { Author(s) of } \\
\text { the Threat (If } \\
\text { Any } \\
\text { Indicated) }\end{array}$ & $\begin{array}{l}\text { Summary of Alleged Self-defense } \\
\text { Grounds }\end{array}$ & \begin{tabular}{|c||} 
UNsC \\
Meeting(s) \\
(If Any) at \\
Which the \\
Comm. was \\
Raised \\
\end{tabular} & $\begin{array}{l}\text { Responsive Act (If Any) by the } \\
\text { UNSC }\end{array}$ & $\begin{array}{l}\text { UN } \\
\text { Repertory } \\
\text { Inclusion? }\end{array}$ & \begin{tabular}{|c|} 
UNSC \\
Repertoire \\
Inclusion?
\end{tabular} & \begin{tabular}{|c} 
URL to an \\
English \\
Text
\end{tabular} & \begin{tabular}{|l} 
URL to Non- \\
English \\
Original \\
Text (lf Any)
\end{tabular} & $\begin{array}{l}\text { Perma.cc } \\
\text { URL }\end{array}$ \\
\hline 265 & 1993.08.10 & 1993.08.11 & $\mathrm{s} / 26290$ & $\begin{array}{l}\text { Kazakhstan, } \\
\text { Kyrgyzstan, } \\
\text { Russia, } \\
\text { Tajikistan }\end{array}$ & $\begin{array}{l}\text { Kazakhstan, } \\
\text { Kyrgyzstan, } \\
\text { Russia, } \\
\text { Tajikistan, } \\
\text { Afghaninstan, } \\
\text { Uzbekistan }\end{array}$ & $\begin{array}{l}\text { Implied } \\
\text { assertion of } \\
\text { "individual" } \\
\text { self-defense } \\
\text { and implied } \\
\text { assertion of } \\
\text { "collective" } \\
\text { self-defense }\end{array}$ & $\begin{array}{c}\text { Conducted } \\
\text { attack and } \\
\text { threat of } \\
\text { attack }\end{array}$ & $\begin{array}{l}\text { "[F]lighters from } \\
\text { the Tajik } \\
\text { opposition and } \\
\text { individual Afghan } \\
\text { armed grousp that } \\
\text { support them" }\end{array}$ & $\begin{array}{c}\text { Non-state } \\
\text { actors }\end{array}$ & \begin{tabular}{|l} 
"The matter [i.e., the serious \\
aggravation of the situation on the \\
Tajik-Afghan frontier] has led to large- \\
scale attacks against the territory of \\
the Republic of Tajikistan.... Recently, \\
specific military operations have been \\
undertaken aimed at breaching the \\
frontier and stirring up armed conflict \\
in Tajikistan. As a result of shelling and \\
attacks by fighters from the Tajik \\
opposition and individual Afghan \\
armed groups that support them, \\
there has been an increasing number \\
of victims among the peaceful \\
population and our soldiers taking \\
part in defending the State frontier of \\
Tajikistan are dying."
\end{tabular} & $\begin{array}{l}\text { S/PV.3266 } \\
\text { (3266th) }\end{array}$ & $\begin{array}{l}\text { Presidential Statement } \\
\text { S/26341: "The Council } \\
\text { expresses its deep concern at } \\
\text { the continuing violence and } \\
\text { armed conflict in Tajeikistan, at } \\
\text { athe escalating crisis along the } \\
\text { Tajik-Afghan border, and at the } \\
\text { risk of the conflict threatening } \\
\text { the peace and stability of } \\
\text { Central Asia and beyond. } \\
\text { The Council stresses the urgent } \\
\text { need for the e essation of all } \\
\text { hostile actions on the Tajik- } \\
\text { Afghan border..." }\end{array}$ & $\begin{array}{l}\text { None } \\
\text { identified }\end{array}$ & \begin{tabular}{|l} 
Chapter VIII \\
(no \\
particular \\
article)
\end{tabular} & \begin{tabular}{l|l|} 
http: \\
//www.un. \\
org//enga/ \\
search/vie \\
w_doc. \\
a_p? \\
symbol=s/ \\
26290
\end{tabular} & $\begin{array}{l}\text { http://www. } \\
\text { un: } \\
\text { org/en/ga/se } \\
\text { arch/view_do } \\
\text { c.asp? } \\
\text { symbol=s/262 } \\
\text { gorlang=R }\end{array}$ & $\begin{array}{l}\text { hitps: } \\
\text { //perma. } \\
\text { cc/pFT2- } \\
\text { 828Y }\end{array}$ \\
\hline 266 & 1993.08.18 & 1993.08.18 & $\mathrm{s} / 26328$ & Armenia & $\begin{array}{l}\text { Armenia, } \\
\text { Azerbaijan }\end{array}$ & $\begin{array}{c}\text { Implied } \\
\text { assertion of } \\
\text { "individual" } \\
\text { self-defense }\end{array}$ & $\begin{array}{c}\text { Conducted } \\
\text { attack }\end{array}$ & Azerbaijan & State & $\begin{array}{l}\text { Attack by Azerbaijani armed forces on } \\
\text { the "Republic of Nagorny Karabakh": } \\
\text { "Recent intensification of the attacks } \\
\text { of the Azerbaijani armed forces on the } \\
\text { defence positions of the Republic of } \\
\text { Nagorny Karabakh, the aerial } \\
\text { bombings of the civilian population, } \\
\text { the continuing Azerbaijani violations } \\
\text { of United Nations resolutions and of } \\
\text { the cease-fire agreements between } \\
\text { Nagorny Karabakh and Azerbaijan." }\end{array}$ & $\begin{array}{l}\text { S/PV.3264 } \\
\text { (3264th) }\end{array}$ & $\begin{array}{l}\text { Presidential Statement } \\
\text { S/26326: "The Security Council } \\
\text { expresses its serious concern } \\
\text { at the deterioration of } \\
\text { relations between the Republic } \\
\text { of Armenia and the Azerbaiji } \\
\text { Republic and at the tensions } \\
\text { between them. The Council } \\
\text { calls upon the Government of } \\
\text { Armenia to use its influence to } \\
\text { achieve compliance by the } \\
\text { Armenians of the Nagorny } \\
\text { Karabakh region of Azerbaijan } \\
\text { with Council resolutions 822 } \\
\text { (1993) and } 853 \text { (1993)." }\end{array}$ & $\begin{array}{l}\text { None } \\
\text { identified }\end{array}$ & \begin{tabular}{|l} 
Chapter VIII \\
(no \\
particular \\
article)
\end{tabular} & \begin{tabular}{|l||} 
http: \\
//www.un. \\
org//enga/ \\
search/vie \\
w_doc. \\
a_p? \\
symbol=s/ \\
26328
\end{tabular} & & $\begin{array}{l}\text { hitps: } \\
\text { //perma. } \\
\text { cc//33T- } \\
\text { ATSC }\end{array}$ \\
\hline 267 & 1993.11.03 & 1993.11.08 & $s / 26710$ & Kuwait & Kuwait, Iraq & $\begin{array}{l}\text { Implied } \\
\text { assertion of } \\
\text { "individual" } \\
\text { self-defense }\end{array}$ & $\begin{array}{c}\text { Conducted } \\
\text { attack }\end{array}$ & Iraq & State & \begin{tabular}{|l} 
Iraqi personnel, in Kuwait, took \\
Kuwaiti officials hostage: "alalt that \\
moment, one of the Kuwaiti officials, \\
acting in self-defence, opened fire on \\
the aggressors using one of their \\
weapons, wounding three of the \\
Iraqis."
\end{tabular} & $\begin{array}{l}\text { None } \\
\text { identified }\end{array}$ & None identified & $\begin{array}{l}\text { None } \\
\text { identified }\end{array}$ & $\begin{array}{l}\text { None } \\
\text { identified }\end{array}$ & \begin{tabular}{|l|} 
http: \\
//www.un. \\
org//nn//ai \\
search/vie \\
w_doc. \\
asp? \\
symbol=s/ \\
26710 \\
26710
\end{tabular} & Not available & $\begin{array}{l}\text { hitps: } \\
\text { //perma. } \\
\text { cc/263s- } \\
\text { gाTw }\end{array}$ \\
\hline 268 & 1994.08.01 & 1994.08.01 & S/1994/915 & Israel & $\begin{array}{c}\text { Israel, } \\
\text { Lebanon, } \\
\text { United States, } \\
\text { Jordan, Iran }\end{array}$ & \begin{tabular}{|c} 
Implied \\
assertion of \\
"individual" \\
self-defense
\end{tabular} & $\begin{array}{c}\text { Conducted } \\
\text { attack }\end{array}$ & $\begin{array}{l}\text { "A]rmed members } \\
\text { of the Hezbollah } \\
\text { and other terrorist } \\
\text { organizations" }\end{array}$ & $\begin{array}{c}\text { Non-state } \\
\text { actors }\end{array}$ & $\begin{array}{l}\text { Attacks by terrorist organizations } \\
\text { emanating from Lebanese territory: } \\
\text { "armed members of the Hezbollah } \\
\text { and other terrorist organizations } \\
\text { function with impunity in Lebanon, } \\
\text { equipped with mortars and Katyysha } \\
\text { missiles, and are free to plan and carry } \\
\text { out attacks and shellings both in } \\
\text { northern Israel and Lebanon.... All of } \\
\text { the above occur without any serious } \\
\text { attempt by the Government of } \\
\text { Lebanon to act effectively in order to } \\
\text { prevent such activities." }\end{array}$ & \begin{tabular}{|l||} 
S/PV.3495 \\
(3495th): \\
report not \\
expressly \\
discussed but \\
S/1994/915 \\
was \\
mentioned in \\
letter \\
S/1995/58, \\
which was \\
expressly \\
discussed \\
\end{tabular} & $\begin{array}{l}\text { S/RES/974(1995) OP 2: } \\
\text { "Reiterates its tstrong support } \\
\text { for the territorial integrity, } \\
\text { sovereignty and independence } \\
\text { of Lebanon within its } \\
\text { internationally recognized } \\
\text { boundaries;" (adopted } \\
\text { unanimously) }\end{array}$ & $\begin{array}{l}\text { None } \\
\text { identified }\end{array}$ & \begin{tabular}{|l} 
Chapter VIII \\
(no \\
particular \\
article)
\end{tabular} & \begin{tabular}{|l||} 
http: \\
//www.un. \\
org//nen//gai \\
search/vie \\
w_doc. \\
asp? \\
symbol=s/ \\
1994/915
\end{tabular} & & $\begin{array}{l}\text { hitps: } \\
\text { ///perma. } \\
\text { cc/RALF- } \\
\text { ADLP }\end{array}$ \\
\hline
\end{tabular}


VI. HLS PILAC Catalogue of Apparent “Article 51 Communications”

\begin{tabular}{|c|c|c|c|c|c|c|c|c|c|c|c|c|c|c|c|c|c|}
\hline $\begin{array}{l}\text { Chron. } \\
\text { Order }\end{array}$ & $\begin{array}{l}\text { Date of } \\
\text { Comm. }\end{array}$ & $\begin{array}{c}\text { Date of } \\
\text { UNsC } \\
\text { Document }\end{array}$ & UNSC Symbol & $\begin{array}{l}\text { Member } \\
\text { State(s) That } \\
\text { Submitted } \\
\text { the Comm. }\end{array}$ & \begin{tabular}{|c|} 
Expressly \\
Mentioned UN \\
Members (\& \\
Colonial \\
Holdings \& \\
Protectorates, \\
if any) \\
\end{tabular} & \begin{tabular}{||c|} 
Express or \\
Implied \\
Assertion of \\
Individual, \\
Collective, or \\
Both Self- \\
defense \\
\end{tabular} & \begin{tabular}{|c}
$\begin{array}{c}\text { Nature of } \\
\text { the Alleged } \\
\text { Threat }\end{array}$
\end{tabular} & $\begin{array}{l}\text { Expressly Alleged } \\
\text { Author(s) of the } \\
\text { Threat (If Any } \\
\text { Indicated) }\end{array}$ & \begin{tabular}{|c} 
Nature of the \\
Alleged \\
Author(s) of \\
the Threat (If \\
Any (I) \\
Indicated)
\end{tabular} & $\begin{array}{l}\text { Summary of Alleged Self-defense } \\
\text { Grounds }\end{array}$ & \begin{tabular}{|c|} 
UNsc \\
Meeting(s) \\
(If Any) at \\
Which the \\
Comm. was \\
Raised
\end{tabular} & $\begin{array}{l}\text { Responsive Act (If Any) by the } \\
\text { UNSC }\end{array}$ & $\begin{array}{l}\text { UN } \\
\text { Repertory } \\
\text { Inclusion? }\end{array}$ & \begin{tabular}{|c|} 
UNSC \\
Repertoire \\
Inclusion?
\end{tabular} & \begin{tabular}{|l|} 
URL to an \\
English \\
Text
\end{tabular} & \begin{tabular}{||c} 
URL to Non- \\
English \\
Original \\
Text (ff Any)
\end{tabular} & $\begin{array}{l}\text { Perma.cc } \\
\text { URL }\end{array}$ \\
\hline 269 & 1994.08.01 & 1994.08.02 & S/1994/917 & Yugoslavia & $\begin{array}{l}\text { Yugoslavia, } \\
\text { Albania }\end{array}$ & $\begin{array}{l}\text { Implied } \\
\text { assertion of } \\
\text { "individual" } \\
\text { self-defense }\end{array}$ & $\begin{array}{c}\text { Conducted } \\
\text { attack }\end{array}$ & $\begin{array}{l}\text { Albania and } \\
\text { "illegally armed } \\
\text { persons and } \\
\text { terrorist groups" }\end{array}$ & $\begin{array}{l}\text { State and } \\
\text { non-state } \\
\text { actors }\end{array}$ & \begin{tabular}{|l} 
Border provocations by Albanian \\
persons and terrorist groups, in \\
addition to statements by the \\
Albanian President questioning the \\
territorial integrity of Yugoslavia: \\
"policy of a systematic provocation of \\
incidents on the Yugossala-llabanian \\
border, with ever more frequent \\
attempts to infiltrate illegally armed \\
persons and terrorist groups from \\
Albania into Yugoslavia... In self- \\
defence and acting according to the \\
rules of the border service, the \\
Yugoslav patrol returned fire and in \\
consequence the two terrorists lost \\
their lives."
\end{tabular} & $\begin{array}{l}\text { None } \\
\text { identified }\end{array}$ & None identified & $\begin{array}{l}\text { None } \\
\text { identified }\end{array}$ & $\begin{array}{l}\text { None } \\
\text { identified }\end{array}$ & \begin{tabular}{l||} 
http: \\
|/www.un. \\
org/en/ga/ \\
search/vie \\
w_doc. \\
asp? \\
symbol=s/ \\
1994/917
\end{tabular} & & $\begin{array}{l}\text { https: } \\
\text { ///perma. } \\
\text { cc/Ylkg2- } \\
\text { DCNS }\end{array}$ \\
\hline 270 & 1994.08.24 & 1994.08.24 & S/1994/992 & Tajikistan & $\begin{array}{c}\text { Tajikistan, } \\
\text { Afghanistan, } \\
\text { Russia }\end{array}$ & \begin{tabular}{|c} 
Implied \\
assertion of \\
"individual" \\
self-defense
\end{tabular} & $\begin{array}{c}\text { Conducted } \\
\text { attack }\end{array}$ & $\begin{array}{l}\text { "Armed units from } \\
\text { the intransigent } \\
\text { wing of the } \\
\text { opposition" and } \\
\text { mercenaries }\end{array}$ & $\begin{array}{l}\text { Non-state } \\
\text { actors }\end{array}$ & $\begin{array}{l}\text { "After having carried out initial } \\
\text { artillery fire on } 17 \text { and } 18 \text { August, an } \\
\text { armed group from the Tajik } \\
\text { opposition, numbering some } 200 \\
\text { people, and supported by foreign } \\
\text { mercenaries, approached what is } \\
\text { called the Kulyab front to launch } \\
\text { military operations, the aim being to } \\
\text { seize a frontier post. At the same } \\
\text { time, this group carried out direct } \\
\text { shelling on a wide front, of troop } \\
\text { emplacements and frontier posts." }\end{array}$ & $\begin{array}{l}\text { None } \\
\text { identified }\end{array}$ & None identified & $\begin{array}{l}\text { None } \\
\text { identified }\end{array}$ & $\begin{array}{l}\text { None } \\
\text { identified }\end{array}$ & \begin{tabular}{l||} 
http: \\
//www.un. \\
ory/en/ga/ \\
search/vie \\
w_doc. \\
asp? \\
symbol=s/ \\
1994/992
\end{tabular} & \begin{tabular}{|l||} 
http://www. \\
un. \\
org/en/ga/se \\
arch/view_do \\
c.asp? \\
symbol=s/199 \\
4/992\&Lang= \\
R
\end{tabular} & $\begin{array}{l}\text { https: } \\
\text { //perma. } \\
\text { ccl/C8xV- } \\
\text { V7LM }\end{array}$ \\
\hline 271 & 1994.08.31 & 1994.08.31 & $\mathrm{S} / 1994 / 1015$ & Tajikistan & $\begin{array}{l}\text { Tajikistan, } \\
\text { Russia, } \\
\text { Afghanistan, } \\
\text { Algeria, Sudan }\end{array}$ & $\begin{array}{l}\text { Implied } \\
\text { assertion of } \\
\text { "collective" } \\
\text { self-defense }\end{array}$ & $\begin{array}{c}\text { Conducted } \\
\text { attack }\end{array}$ & $\begin{array}{l}\text { The "armed } \\
\text { opposition" }\end{array}$ & $\begin{array}{c}\text { Non-state } \\
\text { actors }\end{array}$ & 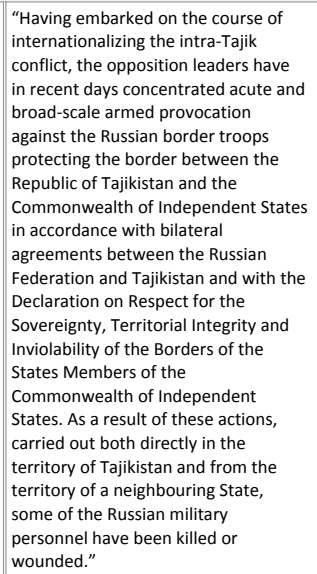 & $\begin{array}{l}\text { None } \\
\text { identified }\end{array}$ & None identified & $\begin{array}{l}\text { None } \\
\text { identified }\end{array}$ & $\begin{array}{l}\text { None } \\
\text { identified }\end{array}$ & \begin{tabular}{l||} 
http: \\
//www.un. \\
org/en/ga/ \\
search/vie \\
w_doc. \\
asp? \\
symbol=S/ \\
1994/1015
\end{tabular} & \begin{tabular}{|l|} 
http://www. \\
un. \\
org/en/ga/se \\
arch/view_do \\
c.asp? \\
symbol=s/199 \\
4/1015\&Lang \\
$=$ =R
\end{tabular} & $\begin{array}{l}\text { https: } \\
\text { ///perma. } \\
\text { cclussy- } \\
\text { G73K }\end{array}$ \\
\hline 272 & 1994.11.09 & 1994.11.10 & S/1994/1273 & Iran & Iran, Iraq & $\begin{array}{l}\text { Implied } \\
\text { assertion of } \\
\text { "individual" } \\
\text { self-defense }\end{array}$ & $\begin{array}{l}\text { Conducted } \\
\text { attack }\end{array}$ & $\begin{array}{l}\text { "T]Jerrorist } \\
\text { groups" }\end{array}$ & $\begin{array}{c}\text { Non-state } \\
\text { actors }\end{array}$ & $\begin{array}{l}\text { "Over the past weeks, these terrorist } \\
\text { groups have intensified their bombing } \\
\text { campaigns and armed attacks against } \\
\text { civilians and oil installations in the } \\
\text { Islamic Republic of Iran resulting in } \\
\text { the martyrdom of a number of franian } \\
\text { nationals and material damages." }\end{array}$ & $\begin{array}{l}\text { None } \\
\text { identified }\end{array}$ & None identified & $\begin{array}{l}\text { None } \\
\text { identified }\end{array}$ & $\begin{array}{l}\text { None } \\
\text { identified }\end{array}$ & \begin{tabular}{|l||} 
http: \\
//www.un. \\
org/en/ga/ \\
search/vie \\
w_doc. \\
asp? \\
symbol=s/ \\
1994/1273 \\
\end{tabular} & & $\begin{array}{l}\text { hitps: } \\
\text { ///perma. } \\
\text { cc//DSp- } \\
\text { NaYg }\end{array}$ \\
\hline
\end{tabular}


VI. HLS PILAC Catalogue of Apparent “Article 51 Communications”

\begin{tabular}{|c|c|c|c|c|c|c|c|c|c|c|c|c|c|c|c|c|c|}
\hline $\begin{array}{c}\text { Chron. } \\
\text { Order }\end{array}$ & $\begin{array}{l}\text { Date of } \\
\text { Comm. }\end{array}$ & $\begin{array}{c}\text { Date of } \\
\text { UNsc } \\
\text { Document }\end{array}$ & UNSC Symbol & \begin{tabular}{|c} 
Member \\
State(s) That \\
Submitted \\
the Comm.
\end{tabular} & \begin{tabular}{|c} 
Expressly \\
Mentioned UN \\
Members (\& \\
Colonial \\
Holdings \& \\
Protectorates, \\
if any)
\end{tabular} & \begin{tabular}{|c|} 
Express or \\
Implied \\
Assertion of \\
Individual, \\
Collective, or \\
Both Self- \\
defense
\end{tabular} & $\begin{array}{c}\text { Nature of } \\
\text { the Alleged } \\
\text { Threat }\end{array}$ & \begin{tabular}{|l} 
Expressly Alleged \\
Author(s) of the \\
Threat (If Any \\
Indicated)
\end{tabular} & \begin{tabular}{|l|} 
Nature of the \\
Alleged \\
Author(s) of \\
the Threat (If \\
Any \\
Indicated)
\end{tabular} & $\begin{array}{l}\text { Summary of Alleged Self-defense } \\
\text { Grounds }\end{array}$ & \begin{tabular}{|l} 
UNsc \\
Meeting(s) \\
(If Any) at \\
Which the \\
Comm. was \\
Raised
\end{tabular} & $\begin{array}{l}\text { Responsive Act (If Any) by the } \\
\text { UNSC }\end{array}$ & \begin{tabular}{|l} 
UN \\
Repertory \\
Inclusion?
\end{tabular} & $\begin{array}{c}\text { UNSC } \\
\text { Repertoire } \\
\text { Inclusion? }\end{array}$ & $\begin{array}{l}\text { URL to an } \\
\text { English } \\
\text { Text }\end{array}$ & $\begin{array}{l}\text { URL to Non- } \\
\text { English } \\
\text { Original } \\
\text { Text (If Any) }\end{array}$ & $\begin{array}{l}\text { Perma.cc } \\
\text { URL }\end{array}$ \\
\hline 273 & 1995.01.27 & 1995.01.28 & $\mathrm{S} / 1995 / 87$ & Ecuador & $\begin{array}{l}\text { Ecuador, Peru, } \\
\text { Bolivia, United } \\
\text { States, Brazil, } \\
\text { Argentina, } \\
\text { Chile }\end{array}$ & $\begin{array}{l}\text { Implied } \\
\text { assertion of } \\
\text { "individual" } \\
\text { self-defense }\end{array}$ & $\begin{array}{c}\text { Conducted } \\
\text { attack }\end{array}$ & Peru & State & $\begin{array}{l}\text { ".... Peru launched military operations } \\
\text { against Ecuadorian army positions } \\
\text { located in Ecuadorian territory." }\end{array}$ & $\begin{array}{l}\text { None } \\
\text { identified }\end{array}$ & None identified & $\begin{array}{l}\text { None } \\
\text { identified }\end{array}$ & $\begin{array}{l}\text { None } \\
\text { identified }\end{array}$ & $\begin{array}{l}\text { http: } \\
\text { //www.un. } \\
\text { org/en//ga/ } \\
\text { search/vie } \\
\text { w_doc. } \\
\text { asp? } \\
\text { spybol=S/ } \\
\text { 1995/87 }\end{array}$ & \begin{tabular}{|l||} 
http://www. \\
un. \\
org/en/ga/se \\
arch/view_do \\
c.asp? \\
symbol=S/199 \\
5/87\&Lang=S
\end{tabular} & $\begin{array}{l}\text { https: } \\
\text { //perma. } \\
\text { cc/8X7A- } \\
\text { JSAE }\end{array}$ \\
\hline 274 & 1995.01.27 & 1995.01.28 & $\mathrm{S} / 1995 / 88$ & Ecuador & $\begin{array}{l}\text { Ecuador, Peru, } \\
\text { Bolivia, United } \\
\text { States, Brazil, } \\
\text { Argentina, } \\
\text { Chile }\end{array}$ & $\begin{array}{l}\text { Implied } \\
\text { assertion of } \\
\text { "individual" } \\
\text { self-defense }\end{array}$ & $\begin{array}{c}\text { Conducted } \\
\text { attack }\end{array}$ & Peru & State & $\begin{array}{l}\text { Peruvian army conducting operations } \\
\text { against Ecuador (same general } \\
\text { complaint as set out in } S / 1995 / 87, \text { but } \\
\text { with more detail in this } \\
\text { communication). }\end{array}$ & $\begin{array}{l}\text { None } \\
\text { identified }\end{array}$ & None identified & $\begin{array}{l}\text { None } \\
\text { identified }\end{array}$ & Article 51 & $\begin{array}{l}\text { http: } \\
\text { //wwww.un. } \\
\text { org/en/ga/ } \\
\text { search//ie } \\
\text { w_doc. } \\
\text { asp? } \\
\text { symbol=S/ } \\
\text { 1995/88 }\end{array}$ & $\begin{array}{l}\text { http://www. } \\
\text { un. } \\
\text { org/en/ga/se } \\
\text { arch//iew_do } \\
\text { c.asp? } \\
\text { symbol=s/199 } \\
\text { 5//88\&Lang=s }\end{array}$ & $\begin{array}{l}\text { https: } \\
\text { //perma. } \\
\text { cc/SJK6- } \\
\text { 5EB7 }\end{array}$ \\
\hline 275 & 1995.07.24 & 1995.07.24 & S/1995/605 & Turkey & $\begin{array}{l}\text { Turkey, Libya, } \\
\text { Iraq }\end{array}$ & $\begin{array}{l}\text { Implied } \\
\text { assertion of } \\
\text { "individual" } \\
\text { self-defense }\end{array}$ & $\begin{array}{c}\text { Conducted } \\
\text { attack }\end{array}$ & \begin{tabular}{|l} 
"AA] terrorist \\
organization based \\
and operating from \\
a neighbouring \\
country"
\end{tabular} & $\begin{array}{c}\text { Non-state } \\
\text { actors }\end{array}$ & \begin{tabular}{|l} 
"As Iraq has not been able to exercise \\
its authority over the northern part of \\
its country since 1991 for reasons well \\
known, Turkey cannot ask the \\
Government of Iraq to fuffil its \\
obligation, under international law, to \\
prevent the use of fits territory for the \\
staging of terrorist acts against \\
Turkey. Under these circumstances, \\
Turkey's resorting to legitimate \\
measures which are imperative to its \\
own security cannot be regarded as a \\
violation of Iraq's sovereignty. No \\
country could be expected to stand \\
idle when its own territorial integrity \\
is incessantly threatened by blatant \\
cross-border attacks of a terrorist \\
organization based and operating \\
from a neighbouring country, if that \\
country is unable to put an end to \\
such attacks."
\end{tabular} & $\begin{array}{l}\text { None } \\
\text { identified }\end{array}$ & None identified & $\begin{array}{l}\text { None } \\
\text { identified }\end{array}$ & $\begin{array}{l}\text { None } \\
\text { identified }\end{array}$ & $\begin{array}{l}\text { http: } \\
\text { //wwww.un. } \\
\text { org/en/ga/ } \\
\text { search//vie } \\
\text { w_doc. } \\
\text { asp? } \\
\text { symbol=S/ } \\
\text { 1995/605 }\end{array}$ & & $\begin{array}{l}\text { https: } \\
\text { //perma. } \\
\text { cc/3YLL- } \\
\text { 7SYE }\end{array}$ \\
\hline
\end{tabular}


VI. HLS PILAC Catalogue of Apparent “Article 51 Communications”

\begin{tabular}{|c|c|c|c|c|c|c|c|c|c|c|c|c|c|c|c|c|c|}
\hline $\begin{array}{c}\text { Chron. } \\
\text { Order }\end{array}$ & $\begin{array}{l}\text { Date of } \\
\text { Comm. }\end{array}$ & $\begin{array}{l}\text { Date of } \\
\text { UNSC } \\
\text { Document }\end{array}$ & UNSC Symbol & \begin{tabular}{||c} 
Member \\
State(s) That \\
Submitted \\
the Comm.
\end{tabular} & \begin{tabular}{|c||} 
Expressly \\
Mentioned UN \\
Members (\& \\
Colonial \\
Holdings \& \\
Protectorates, \\
if any) \\
\end{tabular} & \begin{tabular}{||c|} 
Express or \\
Implied \\
Assertion of \\
Individual, \\
Collective, or \\
Both Self- \\
defense \\
\end{tabular} & \begin{tabular}{|l} 
Nature of \\
the Alleged \\
Threat
\end{tabular} & $\begin{array}{l}\text { Expressly Alleged } \\
\text { Author(s) of the } \\
\text { Threat (If Any } \\
\text { Indicated) }\end{array}$ & \begin{tabular}{|c} 
Nature of the \\
Alleged \\
Author(s) of \\
the Threat (If \\
Any \\
Indicated)
\end{tabular} & $\begin{array}{l}\text { Summary of Alleged Self-defense } \\
\text { Grounds }\end{array}$ & $\begin{array}{c}\text { UNSC } \\
\text { Meeting(s) } \\
\text { (If Any) at } \\
\text { Which the } \\
\text { Comm. was } \\
\text { Raised }\end{array}$ & $\begin{array}{l}\text { Responsive Act (If Any) by the } \\
\text { UNSC }\end{array}$ & \begin{tabular}{|l} 
UN \\
Repertory \\
Inclusion?
\end{tabular} & $\begin{array}{l}\text { UNsC } \\
\text { Repertoire } \\
\text { Inclusion? }\end{array}$ & \begin{tabular}{|l|} 
URL to an \\
English \\
Text
\end{tabular} & \begin{tabular}{||c||} 
URL to Non- \\
English \\
Original \\
Text (ff Any)
\end{tabular} & $\begin{array}{l}\text { Perma.cc } \\
\text { URL }\end{array}$ \\
\hline 276 & 1995.08.04 & 1995.08 .04 & S/1995/647 & Croatia & $\begin{array}{c}\text { Croatia, Bosnia } \\
\text { and } \\
\text { Herzegovina, } \\
\text { Yugoslavia }\end{array}$ & $\begin{array}{l}\text { Implied } \\
\text { assertion of } \\
\text { "collective" } \\
\text { self-defense }\end{array}$ & \begin{tabular}{|c} 
Conducted \\
attack
\end{tabular} & $\begin{array}{l}\text { Yugoslavia, } \\
\text { Bosnian Serbs and } \\
\text { Croatian Serb rebel } \\
\text { forces }\end{array}$ & $\begin{array}{l}\text { State and } \\
\text { non-state } \\
\text { actors }\end{array}$ & 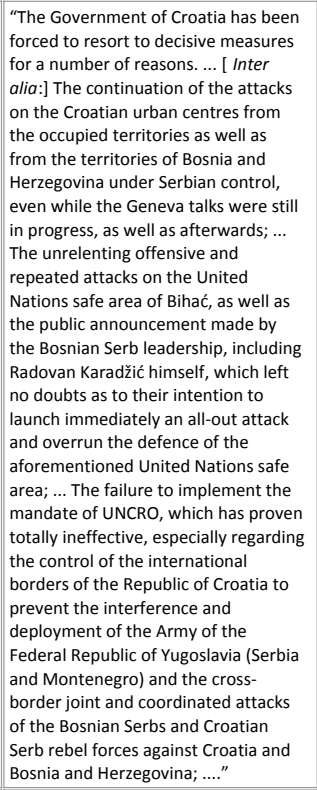 & $\begin{array}{l}\text { S/PV.3561 } \\
\text { (3561st) }\end{array}$ & $\begin{array}{l}\text { S/PRST/1995/38: "The Security } \\
\text { Council is deeply concerned at } \\
\text { the resumption of hostilities in } \\
\text { and around the Republic of } \\
\text { Croatia. The Council recalls the } \\
\text { statement by its President of } 3 \\
\text { Augusts } 19955 \text {. It strongly } \\
\text { deplores the decision by the } \\
\text { Croatian Government to } \\
\text { launch a broad military } \\
\text { offensive, thereby } \\
\text { nuacceptably escalating the } \\
\text { conflict, with the risk of further } \\
\text { consequent attacks by } \\
\text { whatever rarty, and demands } \\
\text { that all military action cease } \\
\text { immediately and that there be } \\
\text { full compliance with all Council } \\
\text { resolutions including } \\
\text { resolution } 994 \text { (1995)." }\end{array}$ & $\begin{array}{l}\text { None } \\
\text { identified }\end{array}$ & $\begin{array}{l}\text { Article 2(4); } \\
\text { Chapter VIII } \\
\text { (no } \\
\text { particular } \\
\text { article) }\end{array}$ & \begin{tabular}{|l||} 
http: \\
|/www.un. \\
org/en/ga/ \\
search/vie \\
w_doc. \\
asp? \\
symbol=s/ \\
1995/647
\end{tabular} & & \begin{tabular}{|l} 
https: \\
//perma. \\
cr/69VH- \\
A663
\end{tabular} \\
\hline 277 & 1996.07.29 & 1996.07.29 & S/1996/602 & Iran & Iran, Iraq & $\begin{array}{l}\text { Implied } \\
\text { assertion of } \\
\text { "individual" } \\
\text { self-defense }\end{array}$ & $\begin{array}{c}\text { Conducted } \\
\text { attack }\end{array}$ & $\begin{array}{l}\text { "[T]errorist armed } \\
\text { groups" }\end{array}$ & $\begin{array}{l}\text { Non-state } \\
\text { actors }\end{array}$ & $\begin{array}{l}\text { Terrorist groups attacking from Iraqi } \\
\text { territory, while lraq remains unable to } \\
\text { control its territory: "transsborder } \\
\text { armed attacks and sabotage } \\
\text { operations by terrorist groups against } \\
\text { Iranian border towns, originating from } \\
\text { Iraqi territory, have been intensified } \\
\text { and escalated." }\end{array}$ & $\begin{array}{l}\text { None } \\
\text { identified }\end{array}$ & None identified & $\begin{array}{l}\text { None } \\
\text { identified }\end{array}$ & Article 51 & \begin{tabular}{|l||} 
http: \\
//www.un. \\
org/en/ga/ \\
search/vie \\
w_doc. \\
asp? \\
symbol=s/ \\
$1996 / 602$ \\
\end{tabular} & & \begin{tabular}{|l} 
https: \\
//perma. \\
cc/TRR3- \\
JV2P
\end{tabular} \\
\hline 278 & 1996.12.04 & 1996.12.05 & S/1996/1007 & Sudan & Sudan, Eritrea & $\begin{array}{l}\text { Implied } \\
\text { assertion of } \\
\text { "individual" } \\
\text { self-defense }\end{array}$ & \begin{tabular}{|c} 
Conducted \\
attack
\end{tabular} & $\begin{array}{l}\text { Eritrea and the } \\
\text { Sudanese National } \\
\text { Alliance and other } \\
\text { "terrorist groups" }\end{array}$ & $\begin{array}{l}\text { State and } \\
\text { non-state } \\
\text { actors }\end{array}$ & 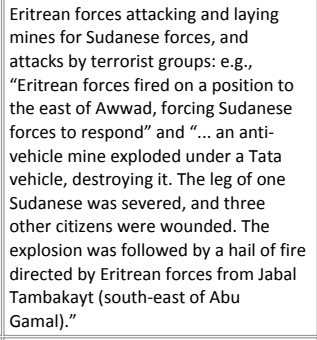 & $\begin{array}{l}\text { None } \\
\text { identified }\end{array}$ & None identified & $\begin{array}{l}\text { None } \\
\text { identified }\end{array}$ & $\begin{array}{l}\text { None } \\
\text { identified }\end{array}$ & \begin{tabular}{|l||} 
http: \\
|/www.un. \\
org/en/ga/ \\
search/vie \\
w_doc. \\
asp? \\
symbol=s/ \\
$1996 / 1007$
\end{tabular} & & \begin{tabular}{|l} 
https: \\
//perma. \\
c/FAQ4Y- \\
F/J3
\end{tabular} \\
\hline 279 & 1997.10.02 & 1997.10.02 & S/1997/768 & Iran & Iran, Iraq & $\begin{array}{l}\text { Implied } \\
\text { assertion of } \\
\text { "individual" } \\
\text { self-defense }\end{array}$ & \begin{tabular}{|c} 
Conducted \\
attack
\end{tabular} & $\begin{array}{l}\text { Iraq and "two } \\
\text { heavily-armed } \\
\text { groups belonging } \\
\text { to an Iranian } \\
\text { terrorist } \\
\text { organization based } \\
\text { in Iraq" } \\
\end{array}$ & $\begin{array}{c}\text { State and } \\
\text { non-state } \\
\text { actors }\end{array}$ & $\begin{array}{l}\text { Groups belonging to an Iranian } \\
\text { terrorist organization in Iraq crossed } \\
\text { the border and attacked Iran. }\end{array}$ & \begin{tabular}{|l} 
None \\
identified
\end{tabular} & None identified & $\begin{array}{l}\text { None } \\
\text { identified }\end{array}$ & Article 51 & \begin{tabular}{|l|} 
http: \\
|/www.un. \\
org/en/ga/ \\
search/vie \\
w_doc. \\
asp? \\
symbol=s/ \\
1997/768 \\
\end{tabular} & & \begin{tabular}{|l} 
https: \\
//perma. \\
cc/9HD4- \\
C8A6
\end{tabular} \\
\hline
\end{tabular}


VI. HLS PILAC Catalogue of Apparent “Article 51 Communications”

\begin{tabular}{|c|c|c|c|c|c|c|c|c|c|c|c|c|c|c|c|c|c|}
\hline $\begin{array}{l}\text { Chron. } \\
\text { Order }\end{array}$ & $\begin{array}{l}\text { Date of } \\
\text { Comm. }\end{array}$ & $\begin{array}{c}\text { Date of } \\
\text { UNsc } \\
\text { Document }\end{array}$ & UNSC Symbol & \begin{tabular}{||c} 
Member \\
State(s) That \\
Submitted \\
the Comm.
\end{tabular} & \begin{tabular}{||c||} 
Expressly \\
Mentioned UN \\
Members (\& \\
Colonial \\
Holdings \& \\
Protectorates, \\
if any) \\
\end{tabular} & \begin{tabular}{|l} 
Express or \\
Implied \\
Assertion of \\
Individual, \\
Collective, or \\
Both Self- \\
defense
\end{tabular} & \begin{tabular}{|c} 
Nature of \\
the Alleged \\
Threat
\end{tabular} & \begin{tabular}{|l|} 
Expressly Alleged \\
Author(s) of the \\
Threat (ff Any \\
Indicated)
\end{tabular} & $\begin{array}{l}\text { Nature of the } \\
\text { Alleged } \\
\text { Author(s) of } \\
\text { the Threat (If } \\
\text { Any } \\
\text { Indicated) }\end{array}$ & $\begin{array}{l}\text { Summary of Alleged Self-defense } \\
\text { Grounds }\end{array}$ & \begin{tabular}{|l} 
UNsc \\
Meeting(s) \\
(If Any) at \\
Which the \\
Comm. was \\
Raised
\end{tabular} & $\begin{array}{l}\text { Responsive Act (If Any) by the } \\
\text { UNSC }\end{array}$ & $\begin{array}{l}\text { UN } \\
\text { Repertory } \\
\text { Inclusion? }\end{array}$ & $\begin{array}{c}\text { UNSC } \\
\text { Repertoire } \\
\text { Inclusion? }\end{array}$ & $\begin{array}{l}\text { URL to an } \\
\text { English } \\
\text { Text }\end{array}$ & \begin{tabular}{||c||} 
URL to Non- \\
English \\
Original \\
Text (ff Any)
\end{tabular} & $\begin{array}{l}\text { Perma.cc } \\
\text { URL }\end{array}$ \\
\hline 280 & 1997.11.03 & 1997.11.05 & S/1997/850 & Tanzania & $\begin{array}{r}\text { Tanzania, } \\
\text { Burundi }\end{array}$ & $\begin{array}{l}\text { Implied } \\
\text { assertion of } \\
\text { "individual" } \\
\text { self-defense }\end{array}$ & $\begin{array}{c}\text { Conducted } \\
\text { attack }\end{array}$ & Burundi & State & $\begin{array}{l}\text { “[T]he Burundian army ... attacked the } \\
\text { Kiteule detachment of the Tanzanian } \\
\text { People's Defence Forces situated at } \\
\text { Kagunga by light arms in the early } \\
\text { morning of } 27 \text { October 1997." }\end{array}$ & $\begin{array}{l}\text { None } \\
\text { identified }\end{array}$ & None identified & $\begin{array}{l}\text { None } \\
\text { identified }\end{array}$ & Article 51 & $\begin{array}{l}\text { http: } \\
\text { //www.un. } \\
\text { org/en//ga/ } \\
\text { search/vie } \\
\text { w_doc. } \\
\text { asp? } \\
\text { spybol=S/ } \\
\text { 1997/850 } \\
\end{array}$ & & $\begin{array}{l}\text { hitps: } \\
\text { //perma. } \\
\text { cc//8883-- } \\
\text { xP54 }\end{array}$ \\
\hline 281 & 1998.06.05 & 1998.06.05 & S/1998/474 & Ethiopia & $\begin{array}{c}\text { Ethiopia, } \\
\text { Eritrea }\end{array}$ & $\begin{array}{l}\text { Implied } \\
\text { assertion of } \\
\text { "individual" } \\
\text { self-defense }\end{array}$ & $\begin{array}{c}\text { Conducted } \\
\text { attack }\end{array}$ & Eritrea & State & $\begin{array}{l}\text { "The authorities in Eritrea have today } \\
\ldots \text { carried out an air attack on Mekelle, } \\
\text { wounding five persons...." }\end{array}$ & $\begin{array}{l}\text { None } \\
\text { identified }\end{array}$ & None identified & $\begin{array}{l}\text { None } \\
\text { identified }\end{array}$ & Article 51 & $\begin{array}{l}\text { http: } \\
\text { //wwww.un. } \\
\text { org/en/ga/ } \\
\text { search//ie } \\
\text { w_doc. } \\
\text { asp? } \\
\text { symbol=S/ } \\
\text { 1998/474 }\end{array}$ & & $\begin{array}{l}\text { hitps: } \\
\text { //Terma. } \\
\text { ccl/8PDS- } \\
\text { EKgE }\end{array}$ \\
\hline 282 & 1998.08.20 & 1998.08.20 & $\mathrm{S} / 1998 / 780$ & $\begin{array}{l}\text { United } \\
\text { States }\end{array}$ & $\begin{array}{c}\text { United States, } \\
\text { Sudan, } \\
\text { Afghanistan }\end{array}$ & $\begin{array}{c}\text { Implied } \\
\text { assertion of } \\
\text { "individual" } \\
\text { self-defense }\end{array}$ & $\begin{array}{c}\text { Conducted } \\
\text { attack }\end{array}$ & $\begin{array}{l}\text { "IT]he organization } \\
\text { of Usama Bin } \\
\text { Ladin" }\end{array}$ & $\begin{array}{l}\text { Non-state } \\
\text { actors }\end{array}$ & $\begin{array}{l}\text { "A] series of armed attacks against } \\
\text { United States embassies and United } \\
\text { States nationals": "the organization of } \\
\text { Usama Bin Ladin is responsible for the } \\
\text { devastating bombings on } 7 \text { August } \\
\text { 1998 of the United States embassies } \\
\text { in Nairobi and Dar Es Salaamb...." }\end{array}$ & $\begin{array}{l}\text { None } \\
\text { identified }\end{array}$ & None identified & $\begin{array}{l}\text { None } \\
\text { identified }\end{array}$ & Article 51 & $\begin{array}{l}\text { http: } \\
\text { //www.un. } \\
\text { org/en/ga/ } \\
\text { search/vie } \\
\text { w_doc. } \\
\text { asp? } \\
\text { symbol=S/ } \\
1998 / 780 \\
\end{array}$ & & $\begin{array}{l}\text { hitps: } \\
\text { //Terma. } \\
\text { cc/NBBS- } \\
\text { BIZP }\end{array}$ \\
\hline 283 & 1998.08.31 & 1998.09.02 & S/1998/827 & $\begin{array}{l}\text { Democratic } \\
\text { Republic of } \\
\text { the Congo }\end{array}$ & \begin{tabular}{|c|} 
Democratic \\
Republic of the \\
Congo, \\
Rwanda, \\
Uganda
\end{tabular} & $\begin{array}{c}\text { Implied } \\
\text { assertion of } \\
\text { "individual" } \\
\text { self-defense }\end{array}$ & $\begin{array}{c}\text { Conducted } \\
\text { attack }\end{array}$ & $\begin{array}{l}\text { Rwanda and } \\
\text { Uganda }\end{array}$ & States & $\begin{array}{l}\text { "[S]ince } 3 \text { August 1998, it [the DRC] } \\
\text { has been the object of an aggression } \\
\text { by the regular armies of Rwanda and } \\
\text { Uganda in its provinces of North Kivu, } \\
\text { South Kivu and Lower Congo and in its } \\
\text { Eastern province." }\end{array}$ & \begin{tabular}{|l} 
None \\
identified
\end{tabular} & None identified & $\begin{array}{l}\text { None } \\
\text { identified }\end{array}$ & $\begin{array}{l}\text { Articles 2(4), } \\
35, \& 51\end{array}$ & $\begin{array}{l}\text { http: } \\
\text { //wwww.un. } \\
\text { org/en/ga/ } \\
\text { search/vie } \\
\text { w_doc. } \\
\text { asp? } \\
\text { symbol=S/ } \\
\text { 1998/827 }\end{array}$ & \begin{tabular}{|l|} 
http://www. \\
un. \\
org/en/ga/se \\
arch/view_do \\
c.asp? \\
symbol=S/199 \\
8/827\&Lang= \\
F
\end{tabular} & \begin{tabular}{|l} 
hitps: \\
//perma. \\
cc//XBS4- \\
iJGN
\end{tabular} \\
\hline 284 & 1998.09.23 & 1998.09.25 & S/1998/891 & Zimbabwe & \begin{tabular}{|c|} 
Zimbabwe, \\
Democratic \\
Republic of the \\
Congo, \\
Rwanda, \\
Uganda, \\
Angola, \\
Namibia, South \\
Africa, \\
Lesotho, \\
Botswana
\end{tabular} & $\begin{array}{l}\text { Implied } \\
\text { assertion of } \\
\text { "collective" } \\
\text { self-defense }\end{array}$ & $\begin{array}{c}\text { Conducted } \\
\text { attack }\end{array}$ & $\begin{array}{l}\text { Rwanda and } \\
\text { Uganda }\end{array}$ & States & $\begin{array}{l}\text { "President Kabila, after realizing that } \\
\text { he could not contain the foreign } \\
\text { invaders alone, aappealed for } \\
\text { assistance from the member countries } \\
\text { of the Southern African Development } \\
\text { Community (SADC)... The } \\
\text { involvement by Zimbabwe, Angola } \\
\text { and Namibia came as a result of the } \\
\text { appeal by the internationally } \\
\text { recognized Government of the } \\
\text { Democratic Republic of the Congo, a } \\
\text { member State of SADC. The } \\
\text { involvement, ..., ought to be } \\
\text { understood for what it really is, a } \\
\text { regional commitment to assist } \\
\text { brothers and sisters to repel } \\
\text { aggressors." }\end{array}$ & $\begin{array}{l}\text { None } \\
\text { identified }\end{array}$ & None identified & $\begin{array}{l}\text { None } \\
\text { identified }\end{array}$ & $\begin{array}{l}\text { None } \\
\text { identified }\end{array}$ & $\begin{array}{l}\text { http: } \\
\text { //www.un. } \\
\text { org/en/ga/ } \\
\text { search/vie } \\
\text { w_doc. } \\
\text { asp? } \\
\text { spybol=S/ } \\
\text { 1998/891 }\end{array}$ & & \begin{tabular}{|l} 
hitps: \\
//perma. \\
cc//L7L- \\
usE7
\end{tabular} \\
\hline 285 & 1998.10.08 & 1998.10.08 & S/1998/934 & Iran & Iran & 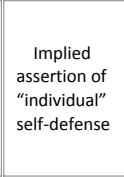 & $\begin{array}{c}\text { Conducted } \\
\text { attack }\end{array}$ & $\begin{array}{l}\text { "TThhe Taliban } \\
\text { militia" }\end{array}$ & $\begin{array}{l}\text { Non-state } \\
\text { actors }\end{array}$ & \begin{tabular}{|l} 
Attack on Iran by Taliban militia: “... \\
the Taliban militia launched an attack, \\
using mortar and Dush-K, against the \\
territory of the Islamic Republic of Iran \\
between the Ibrahim Khani and \\
Konden Souz border posts in \\
Khorassan Province."
\end{tabular} & $\begin{array}{l}\text { None } \\
\text { identified }\end{array}$ & None identified & $\begin{array}{l}\text { None } \\
\text { identified }\end{array}$ & $\begin{array}{l}\text { None } \\
\text { identified }\end{array}$ & $\begin{array}{l}\text { http: } \\
\text { //www.un. } \\
\text { org/en/ga/ } \\
\text { search/vie } \\
\text { w_doc. } \\
\text { asp? } \\
\text { spybol=S/ } \\
\text { 1998/934 }\end{array}$ & & $\begin{array}{l}\text { hitps: } \\
\text { //perma. } \\
\text { cc//6655- } \\
\text { 3N3M }\end{array}$ \\
\hline
\end{tabular}


VI. HLS PILAC Catalogue of Apparent “Article 51 Communications”

\begin{tabular}{|c|c|c|c|c|c|c|c|c|c|c|c|c|c|c|c|c|c|}
\hline $\begin{array}{l}\text { Chron. } \\
\text { Order }\end{array}$ & $\begin{array}{l}\text { Date of } \\
\text { comm. }\end{array}$ & $\begin{array}{c}\text { Date of } \\
\text { UNsc } \\
\text { Document }\end{array}$ & UNSC Symbol & \begin{tabular}{||c} 
Member \\
State(s) That \\
Submitted \\
the Comm.
\end{tabular} & \begin{tabular}{|c|} 
Expressly \\
Mentioned UN \\
Members (\& \\
Colonial \\
Holdings \& \\
Protectorates, \\
if any) \\
\end{tabular} & \begin{tabular}{||c|} 
Express or \\
Implied \\
Assertion of \\
Individual, \\
Collective, or \\
Both Self- \\
defense
\end{tabular} & \begin{tabular}{|l} 
Nature of \\
the Alleged \\
Threat
\end{tabular} & $\begin{array}{l}\text { Expressly Alleged } \\
\text { Author(s) of the } \\
\text { Threat (If Any } \\
\text { Indicated) }\end{array}$ & \begin{tabular}{|l} 
Nature of the \\
Alleged \\
Author(s) of \\
the Threat (If \\
Any \\
Indicated)
\end{tabular} & $\begin{array}{l}\text { Summary of Alleged Self-defense } \\
\text { Grounds }\end{array}$ & $\begin{array}{l}\text { UNSC } \\
\text { Meeting(s) } \\
\text { (If Any) at } \\
\text { Which the } \\
\text { Comm. was } \\
\text { Raised }\end{array}$ & $\begin{array}{l}\text { Responsive Act (If Any) by the } \\
\text { UNSC }\end{array}$ & $\begin{array}{l}\text { UN } \\
\text { Repertory } \\
\text { Inclusion? }\end{array}$ & $\begin{array}{l}\text { UNSC } \\
\text { Repertoire } \\
\text { Inclusion? }\end{array}$ & \begin{tabular}{|l|l|} 
URL to an \\
English \\
Text
\end{tabular} & \begin{tabular}{||c||} 
URL to Non- \\
English \\
Original \\
Text (ff Any)
\end{tabular} & $\begin{array}{l}\text { Perma.cc } \\
\text { URL }\end{array}$ \\
\hline 286 & 1998.12.21 & 1998.12.21 & s/1998/1205 & Eritrea & \begin{tabular}{|} 
Eritrea, \\
Ethiopia, \\
Sudan, Burkina \\
Faso, Italy, \\
Yemen
\end{tabular} & 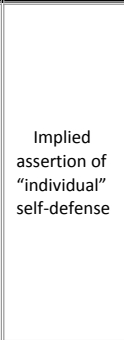 & $\begin{array}{c}\text { Conducted } \\
\text { attack }\end{array}$ & Ethiopia & State & \begin{tabular}{|l} 
“... Ethiopia, believing in its might as a \\
big country and choosing the use of \\
force, declared war on Eritrea on the \\
morrow of the fighting. Concurrently, \\
it stopped using Eritrean ports, cut air \\
and telecommunication links and \\
deployed almost all its army along the \\
Eritrean borders, including in areas \\
where there were no border incidents. \\
Two weeks later it launched the \\
ground war and on 5 June [1998], it \\
further escalated the border conflict \\
by bombing the Eritrear capital \\
Asmara."
\end{tabular} & $\begin{array}{l}\text { None } \\
\text { identified }\end{array}$ & None identified & $\begin{array}{l}\text { None } \\
\text { identified }\end{array}$ & Article 51 & \begin{tabular}{|l||} 
http: \\
//www.un. \\
org/en/ga/ \\
search/vie \\
w_doc. \\
asp? \\
symbol=s/ \\
$1998 / 1205$
\end{tabular} & & $\begin{array}{l}\text { https: } \\
\text { //perma. } \\
\text { cc/Bg99- } \\
\text { 3VCW }\end{array}$ \\
\hline 287 & 1999.01.09 & 1999.01.11 & $\mathrm{s} / 1999 / 29$ & Iraq & $\begin{array}{l}\text { Iraq, Saudi } \\
\text { Arabia }\end{array}$ & 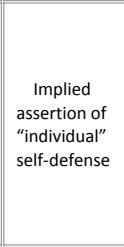 & $\begin{array}{c}\text { Conducted } \\
\text { attack }\end{array}$ & Saudi Arabia & State & \begin{tabular}{|l} 
"[T]he incident took place ... after an \\
Iraqi patrol attached to the customs \\
police in the Iraqi Governorate of \\
Najaf had observed three Saudi \\
armoured cars in the restricted area \\
between the two control posts of \\
Lisiyah and Hakim, one kilometre \\
inside Iraqi territory. The Saudi cars \\
opened fire on the Iraqi patrol as soon \\
as they were observed, ...."
\end{tabular} & $\begin{array}{l}\text { None } \\
\text { identified }\end{array}$ & None identified & $\begin{array}{l}\text { None } \\
\text { identified }\end{array}$ & Article 51 & \begin{tabular}{|l||} 
http: \\
|/www.un. \\
org/en/ga/ \\
search/vie \\
w_doc. \\
asp? \\
symbol=s/ \\
$1999 / 29$
\end{tabular} & $\begin{array}{l}\text { http://www. } \\
\text { un. } \\
\text { org/en/ga/se } \\
\text { arch/view_do } \\
\text { casp? } \\
\text { symbol=s/199 } \\
\text { 9/29\&lang=A }\end{array}$ & $\begin{array}{l}\text { https: } \\
\text { //perma. } \\
\text { cc//3W87- } \\
\text { FFUU }\end{array}$ \\
\hline 288 & 1999.01.23 & 1999.01.25 & $S / 1999 / 72$ & Iraq & $\begin{array}{l}\text { Iraq, United } \\
\text { States, United } \\
\text { Kingdom }\end{array}$ & $\begin{array}{c}\text { Implied } \\
\text { assertion of } \\
\text { "individual" } \\
\text { self-defense }\end{array}$ & $\begin{array}{c}\text { Conducted } \\
\text { attack }\end{array}$ & $\begin{array}{l}\text { United States and } \\
\text { United Kingdom }\end{array}$ & States & $\begin{array}{l}\text { "UViolations of Iraq's airspace by } \\
\text { United States and British aircraft } \\
\text { continued between } 1 \text { and } 15 \text { January } \\
1999 \text {... the aircraft in question carried } \\
\text { out reconnaissance and engaged in } \\
\text { acts of provocation." }\end{array}$ & $\begin{array}{l}\text { None } \\
\text { identified }\end{array}$ & None identified & $\begin{array}{l}\text { None } \\
\text { identified }\end{array}$ & Article 51 & \begin{tabular}{|l||} 
http: \\
//www.un. \\
org/en/ga/ \\
search/vie \\
w_doc. \\
asp? \\
symbol=s/ \\
1999/72 \\
\end{tabular} & \begin{tabular}{|l||} 
http://www. \\
un. \\
org/en/ga/se \\
arch/view_do \\
c.asp? \\
symbol=S/199 \\
9/72\&Lang=A \\
\end{tabular} & $\begin{array}{l}\text { https: } \\
\text { //perma. } \\
\text { cc/P3RB- } \\
\text { RYaF }\end{array}$ \\
\hline 289 & 1999.02.10 & 1999.02.10 & S/1999/134 & Ethiopia & $\begin{array}{l}\text { Ethiopia, } \\
\text { Eritrea, United } \\
\text { States, Rwanda }\end{array}$ & $\begin{array}{c}\text { Implied } \\
\text { assertion of } \\
\text { "individual" } \\
\text { self-defense }\end{array}$ & $\begin{array}{c}\text { Conducted } \\
\text { attack }\end{array}$ & Eritrea & State & \begin{tabular}{|l} 
"The final Eritrean response to the \\
OAU peace plan came on 6 February \\
1999, after already having violated the \\
air strike moratorium the previous \\
day, when Eritrea mounted a large- \\
scale militiry offensive on the Badme- \\
Shiraro front, thus imposing war on \\
Ethiopia ...."
\end{tabular} & $\begin{array}{l}\text { None } \\
\text { identified }\end{array}$ & None identified & $\begin{array}{l}\text { None } \\
\text { identified }\end{array}$ & Article 51 & \begin{tabular}{|l||} 
http: \\
//www.un. \\
org/en/ga/ \\
search/vie \\
wdoc. \\
asp? \\
symbol=s/ \\
sygg/134 \\
\end{tabular} & & \begin{tabular}{|l} 
https: \\
//perma. \\
cc/ZNNS- \\
R886
\end{tabular} \\
\hline 290 & 1999.02.17 & 1999.02.17 & $\mathrm{S} / 1999 / 162$ & Ethiopia & $\begin{array}{l}\text { Ethiopia, } \\
\text { Eritrea }\end{array}$ & $\begin{array}{l}\text { Implied } \\
\text { assertion of } \\
\text { "individual" } \\
\text { self-defense }\end{array}$ & $\begin{array}{c}\text { Conducted } \\
\text { attack }\end{array}$ & Eritrea & State & \begin{tabular}{|l} 
"TThe Eritrean regime launched a \\
large-scale military action, including \\
the aerial bombing of the town of \\
Adigrat, on 4, 5 and 6 February [1999] \\
while the Special Envoy of the \\
Secretary-General was in the region to \\
persuade Eritrea to accept the OAU \\
Framework Agreement."
\end{tabular} & $\begin{array}{l}\text { None } \\
\text { identified }\end{array}$ & None identified & \begin{tabular}{|l} 
None \\
identified
\end{tabular} & Article 51 & \begin{tabular}{|l||} 
http: \\
//www.un. \\
org/en/ga/ \\
search/vie \\
wdoc. \\
asp? \\
symbol=s/ \\
1999/162 \\
\end{tabular} & & $\begin{array}{l}\text { https: } \\
\text { //perma. } \\
\text { cc/C5NW- } \\
\text { WY59 }\end{array}$ \\
\hline 291 & 1999.03.08 & 1999.03.08 & S/1999/246 & Ethiopia & $\begin{array}{l}\text { Ethiopia, } \\
\text { Eritrea }\end{array}$ & \begin{tabular}{|c|} 
Implied \\
assertion of \\
"individual" \\
self-defense
\end{tabular} & $\begin{array}{c}\text { Conducted } \\
\text { attack }\end{array}$ & Eritrea & State & $\begin{array}{l}\text { Eritrean forces continue to occupy } \\
\text { Ethiopian territory: e.g.,."[i]t is true } \\
\text { that the Eritrean occupying forces } \\
\text { have, with great sacrifice, been driven } \\
\text { out of Badme. But large chunks of } \\
\text { Ethiopian territory in the Zalambessa- } \\
\text { Aiga, Bada-Bure and Egala regions still } \\
\text { remain under Eritrean occupation. } \\
\text { What the Eritrean intentions are in } \\
\text { these occupied areas is made crystal } \\
\text { clear by the frantic efforts being made } \\
\text { to build and reinforce fortifications." }\end{array}$ & $\begin{array}{l}\text { None } \\
\text { identified }\end{array}$ & None identified & $\begin{array}{l}\text { None } \\
\text { identified }\end{array}$ & Article 51 & \begin{tabular}{|l||}
$\mid$ http: \\
|/www.un. \\
org/en/ga/ \\
search/vie \\
w_doc. \\
asp? \\
symbol=s/ \\
1999/246
\end{tabular} & & $\begin{array}{l}\text { https: } \\
\text { //perma. } \\
\text { cc/UAA3- } \\
\text { KSTD }\end{array}$ \\
\hline
\end{tabular}


VI. HLS PILAC Catalogue of Apparent “Article 51 Communications”

\begin{tabular}{|c|c|c|c|c|c|c|c|c|c|c|c|c|c|c|c|c|c|}
\hline $\begin{array}{l}\text { Chron. } \\
\text { Order }\end{array}$ & $\begin{array}{l}\text { Date of } \\
\text { Comm. }\end{array}$ & $\begin{array}{c}\text { Date of } \\
\text { UNsC } \\
\text { Document }\end{array}$ & UNSC Symbol & \begin{tabular}{|l} 
Member \\
State(s) That \\
Submitted \\
the Comm.
\end{tabular} & \begin{tabular}{|c||} 
Expressly \\
Mentioned UN \\
Members (\& \\
Colonial \\
Holdings \& \\
Protectorates, \\
if any) \\
\end{tabular} & \begin{tabular}{||c|} 
Express or \\
Implied \\
Assertion of \\
Individual, \\
Collective, or \\
Both Self- \\
defense \\
\end{tabular} & \begin{tabular}{|l}
$\begin{array}{c}\text { Nature of } \\
\text { the Alleged } \\
\text { Threat }\end{array}$
\end{tabular} & $\begin{array}{l}\text { Expressly Alleged } \\
\text { Author(s) of the } \\
\text { Threat (If Any } \\
\text { Indicated) }\end{array}$ & \begin{tabular}{|c} 
Nature of the \\
Alleged \\
Author(s) of \\
the Threat (If \\
Any \\
Indicated)
\end{tabular} & $\begin{array}{l}\text { Summary of Alleged Self-defense } \\
\text { Grounds }\end{array}$ & \begin{tabular}{|c|} 
UNSC \\
Meeting(s) \\
(If Any) at \\
Which the \\
Comm. was \\
Raised \\
\end{tabular} & $\begin{array}{l}\text { Responsive Act (ff Any) by the } \\
\text { UNSC }\end{array}$ & $\begin{array}{l}\text { UN } \\
\text { Repertory } \\
\text { Inclusion? }\end{array}$ & \begin{tabular}{|} 
UNsC \\
Repertoire \\
Inclusion?
\end{tabular} & \begin{tabular}{|l||} 
URL to an \\
English \\
Text
\end{tabular} & \begin{tabular}{||c||} 
URL to Non- \\
English \\
Original \\
Text (ff Any)
\end{tabular} & $\begin{array}{l}\text { Perma.cc } \\
\text { URL }\end{array}$ \\
\hline 292 & 1999.03.22 & 1999.03.24 & S/1999/304* & Eritrea & \begin{tabular}{|} 
Eritrea, \\
Ethiopia, \\
United States, \\
Sudan
\end{tabular} & $\begin{array}{l}\text { Implied } \\
\text { assertion of } \\
\text { "individual" } \\
\text { self-defense }\end{array}$ & $\begin{array}{c}\text { Conducted } \\
\text { attack }\end{array}$ & Ethiopia & State & \begin{tabular}{|l} 
Ethiopian attacks on Eritrean officials \\
in Badme: "Ethiopia's efforts to \\
redraw the international boundary in \\
Badme culminated in its attack of 6 \\
May 1998 . On that date, about 60 \\
Ethiopian army troops completely \\
encicicled a group of 10 Eritrean \\
officers who were present in the \\
Badme region and opened fire. Four \\
were killed and three wounded. This \\
initial attack further led to spiralling \\
clashes in the subsequent days, with \\
both sides bringing in reinforcements \\
and a final showdown on 12 May 1998 \\
in which Ethiopian troops were driven \\
out of Badme."
\end{tabular} & $\begin{array}{l}\text { None } \\
\text { identified }\end{array}$ & None identified & $\begin{array}{l}\text { None } \\
\text { identified }\end{array}$ & $\begin{array}{l}\text { Articles 2(4) } \\
\& 51\end{array}$ & \begin{tabular}{|l||} 
http: \\
|/www.un. \\
org/en/ga/ \\
search/vie \\
w_doc. \\
asp? \\
symbol=s/ \\
1999/304
\end{tabular} & & \begin{tabular}{|l} 
https: \\
//perma. \\
cc/M9Q5- \\
TATR
\end{tabular} \\
\hline 293 & 1999.06.20 & 1999.06.21 & S/1999/699 & Iraq & \begin{tabular}{|} 
Iraq, United \\
States, United \\
Kingdom, \\
Saudi Arabia, \\
Kuwait, Turkey
\end{tabular} & $\begin{array}{l}\text { Implied } \\
\text { assertion of } \\
\text { "individual" } \\
\text { self-defense }\end{array}$ & $\begin{array}{c}\text { Conducted } \\
\text { attack }\end{array}$ & $\begin{array}{l}\text { United States, } \\
\text { United Kingdom, } \\
\text { Saudi Arabia, } \\
\text { Kuwait, Turkey }\end{array}$ & States & $\begin{array}{l}\text { "VV]iolations of Iraq's airspace by } \\
\text { United States and British aircraft } \\
\text { based in Saudi Arabia, Kuwait and } \\
\text { Turkey continued between } 8 \text { and } 15 \\
\text { June } 1999 \text {... the aircraft in question } \\
\text { engaged in acts of aggression, } \\
\text { reconnaissance activities and acts of } \\
\text { provocation, ....” }\end{array}$ & $\begin{array}{l}\text { None } \\
\text { identified }\end{array}$ & None identified & $\begin{array}{l}\text { None } \\
\text { identified }\end{array}$ & Article 51 & \begin{tabular}{|l|} 
http: \\
//www.un. \\
orge//gnal \\
search/vie \\
w_doc. \\
asp? \\
symbol=s/ \\
1999/699 \\
\end{tabular} & \begin{tabular}{l|} 
http://www. \\
un. \\
org/en/ga/se \\
arch/view_do \\
c.asp? \\
symbol=S/199 \\
9/699\&Lang= \\
A
\end{tabular} & $\begin{array}{l}\text { https: } \\
\text { //perma. } \\
\text { cc/PNA4- } \\
\text { Z4VA }\end{array}$ \\
\hline 294 & 1999.06.28 & 1999.06.29 & S/1999/733 & \begin{tabular}{|l|} 
Democratic \\
Republic of \\
the Congo
\end{tabular} & \begin{tabular}{|l} 
Democratic \\
Republic of the \\
Congo, \\
Uganda, \\
Rwanda, \\
Burundi, \\
Angola, \\
Zimbabwe, \\
Namibia
\end{tabular} & $\begin{array}{l}\text { Express } \\
\text { assertion of } \\
\text { "collective" } \\
\text { self-defense }\end{array}$ & $\begin{array}{c}\text { Conducted } \\
\text { attack }\end{array}$ & $\begin{array}{l}\text { Uganda, Rwanda, } \\
\text { and Burundi }\end{array}$ & States & $\begin{array}{l}\text { Armed aggression by Rwanda, } \\
\text { Uganda, and Burundi. }\end{array}$ & $\begin{array}{l}\text { None } \\
\text { identified }\end{array}$ & None identified & $\begin{array}{l}\text { None } \\
\text { identified }\end{array}$ & $\begin{array}{l}\text { Articles 51- } \\
54\end{array}$ & \begin{tabular}{|l||} 
http: \\
|/www.un. \\
org/en/ga/ \\
search/vie \\
w_doc. \\
asp? \\
symbol=s/ \\
1999/733
\end{tabular} & \begin{tabular}{|l|} 
http://www. \\
un. \\
org/en/ga/se \\
arch/view_do \\
c.asp? \\
symbol=S/199 \\
//733\&Lang= \\
F
\end{tabular} & \begin{tabular}{|l} 
https: \\
//perma. \\
c/660az- \\
ESS7
\end{tabular} \\
\hline 295 & 1999.07.12 & 1999.07.12 & S/1999/772 & Iraq & \begin{tabular}{|} 
Iraq, United \\
States, United \\
Kingdom, \\
Saudi Arabia, \\
Kuwait, Turkey
\end{tabular} & $\begin{array}{l}\text { Implied } \\
\text { assertion of } \\
\text { "individual" } \\
\text { self-defense }\end{array}$ & $\begin{array}{c}\text { Conducted } \\
\text { attack }\end{array}$ & $\begin{array}{l}\text { United States, } \\
\text { United Kingdom, } \\
\text { Saudi Arabia, } \\
\text { Kuwait, Turkey }\end{array}$ & States & {$\left[\begin{array}{l}\text { “VV]iolations of Iraq's airspace by } \\
\text { United States and British aircraft } \\
\text { based in Saudi Arabia, Kuwait and } \\
\text { Turkey continued between } 1 \text { and } 8 \\
\text { July } 1999 \text {... the aircraft in question } \\
\text { engaged in acts of aggression, } \\
\text { reconnaissance activities and acts of } \\
\text { provocation”. }\end{array}\right.$} & $\begin{array}{l}\text { None } \\
\text { identified }\end{array}$ & None identified & $\begin{array}{l}\text { None } \\
\text { identified }\end{array}$ & Article 51 & \begin{tabular}{|l||} 
http: \\
//www.un. \\
org/en/ga/ \\
search/vie \\
w_doc. \\
asp? \\
symbol=s/ \\
1999/772 \\
\end{tabular} & \begin{tabular}{l|} 
http://www. \\
un. \\
org/en/ga/se \\
arch/view_do \\
c.asp? \\
symbol=s/199 \\
9/7722LLang= \\
A
\end{tabular} & $\begin{array}{l}\text { https: } \\
\text { //perma. } \\
\text { cc/KGM7- } \\
\text { FVRZ }\end{array}$ \\
\hline 296 & 1999.07.12 & 1999.07.12 & S/1999/781 & Iran & Iran, Iraq & $\begin{array}{l}\text { Implied } \\
\text { assertion of } \\
\text { "individual" } \\
\text { self-defense }\end{array}$ & $\begin{array}{c}\text { Conducted } \\
\text { attack }\end{array}$ & $\begin{array}{l}\text { Iraq and "terrorist } \\
\text { organization" }\end{array}$ & $\begin{array}{l}\text { State and } \\
\text { non-state } \\
\text { actors }\end{array}$ & $\begin{array}{l}\text { Terrorist organization conducting } \\
\text { attacks against Iran, with support of } \\
\text { Iraq. }\end{array}$ & $\begin{array}{l}\text { None } \\
\text { identified }\end{array}$ & None identified & $\begin{array}{l}\text { None } \\
\text { identified }\end{array}$ & Article 51 & \begin{tabular}{|l||} 
http: \\
//www.un. \\
org/en/ga/ \\
search/vie \\
w_doc. \\
asp? \\
symbol=s/ \\
1999/781 \\
\end{tabular} & & \begin{tabular}{|l} 
https: \\
//perma. \\
cc/8s53- \\
9UVT
\end{tabular} \\
\hline 297 & 1999.08.10 & 1999.08.10 & S/1999/870 & Iraq & \begin{tabular}{|} 
Iraq, United \\
States, United \\
Kingdom, \\
Saudi Arabia, \\
Kuwait, Turkey
\end{tabular} & $\begin{array}{l}\text { Implied } \\
\text { assertion of } \\
\text { "individual" } \\
\text { self-defense }\end{array}$ & \begin{tabular}{|c} 
Conducted \\
attack
\end{tabular} & $\begin{array}{l}\text { United States, } \\
\text { United Kingdom, } \\
\text { Saudi Arabia, } \\
\text { Kuwait, Turkey }\end{array}$ & States & \begin{tabular}{|l} 
"[B]etween 1 and 7 August 1999, \\
United States and British aircraft, \\
taking off from their bases in Saudi \\
Arabiai, Kuwait and Turkey, continued \\
to violate Iraqi airspace, carrying out \\
acts of aggression, observation and \\
provocation.... These acts continue to \\
cause hundreds of deaths and injuries \\
among the civilian population and \\
material damage to private and public \\
property."
\end{tabular} & \begin{tabular}{|l} 
None \\
identified
\end{tabular} & None identified & $\begin{array}{l}\text { None } \\
\text { identified }\end{array}$ & Article 51 & \begin{tabular}{|l||} 
http: \\
|/www.un. \\
org/en/ga/ \\
search/vie \\
w_doc. \\
asp? \\
symbol=s/ \\
1999/870
\end{tabular} & \begin{tabular}{|l|} 
http://www. \\
un. \\
org/en/ga/se \\
arch/view_do \\
c.asp? \\
symbol=s/199 \\
9/870\&Lang= \\
A
\end{tabular} & $\begin{array}{l}\text { https: } \\
\text { //perma. } \\
\text { cc/NFFK- } \\
\text { HNBW }\end{array}$ \\
\hline
\end{tabular}


VI. HLS PILAC Catalogue of Apparent “Article 51 Communications”

\begin{tabular}{|c|c|c|c|c|c|c|c|c|c|c|c|c|c|c|c|c|c|}
\hline $\begin{array}{l}\text { Chron. } \\
\text { Order }\end{array}$ & $\begin{array}{l}\text { Date of } \\
\text { Comm. }\end{array}$ & $\begin{array}{c}\text { Date of } \\
\text { UNsC } \\
\text { Document }\end{array}$ & UNSC Symbol & \begin{tabular}{||c} 
Member \\
State(s) That \\
Submitted \\
the Comm.
\end{tabular} & \begin{tabular}{|c||} 
Expressly \\
Mentioned UN \\
Members (\& \\
Colonial \\
Holdings \& \\
Protectorates, \\
if any) \\
\end{tabular} & \begin{tabular}{|c|} 
Express or \\
Implied \\
Assertion of \\
Individual, \\
Collective, or \\
Both Self- \\
defense \\
\end{tabular} & \begin{tabular}{|l}
$\begin{array}{c}\text { Nature of } \\
\text { the Alleged } \\
\text { Threat }\end{array}$
\end{tabular} & \begin{tabular}{|l} 
Expressly Alleged \\
Author(s) of the \\
Threat (If Any \\
Indicated)
\end{tabular} & \begin{tabular}{|c|} 
Nature of the \\
Alleged \\
Author(s) of \\
the Threat (If \\
Any \\
Indicated)
\end{tabular} & $\begin{array}{l}\text { Summary of Alleged Self-defense } \\
\text { Grounds }\end{array}$ & $\begin{array}{c}\text { UNSC } \\
\text { Meeting(s) } \\
\text { (If Any) at } \\
\text { Which the } \\
\text { Comm. was } \\
\text { Raised }\end{array}$ & $\begin{array}{l}\text { Responsive Act (If Any) by the } \\
\text { UNSC }\end{array}$ & $\begin{array}{l}\text { UN } \\
\text { Repertory } \\
\text { Inclusion? }\end{array}$ & $\begin{array}{c}\text { UNSC } \\
\text { Repertoire } \\
\text { Inclusion? }\end{array}$ & $\begin{array}{l}\text { URL to an } \\
\text { English } \\
\text { Text }\end{array}$ & \begin{tabular}{|l||} 
URL to Non- \\
English \\
Original \\
Text (ff Any)
\end{tabular} & $\begin{array}{l}\text { Perma.cc } \\
\text { URL }\end{array}$ \\
\hline 298 & 1999.10.03 & 1999.10.04 & S/1999/1022 & Iraq & \begin{tabular}{|} 
Iraq, United \\
States, United \\
Kingdom, \\
Saudi Arabia, \\
Kuwait, Turkey
\end{tabular} & $\begin{array}{c}\text { Implied } \\
\text { assertion of } \\
\text { "individual" } \\
\text { self-defense }\end{array}$ & $\begin{array}{c}\text { Conducted } \\
\text { attack }\end{array}$ & \begin{tabular}{|l} 
United States, \\
United Kingdom, \\
Saudi AAabia, \\
Kuwait, Turkey
\end{tabular} & States & \begin{tabular}{|l} 
"Vliolations of Iraq's airspace by \\
United States and British aircraft \\
based in Saudi Arabia, Kuwait and \\
Turkey continued between 22 and 30 \\
September 1999 and ... the aircraft in \\
question engaged in acts of \\
aggression, reconnaissance activities \\
and acts of provocation ...."
\end{tabular} & $\begin{array}{l}\text { None } \\
\text { identified }\end{array}$ & None identified & $\begin{array}{l}\text { None } \\
\text { identified }\end{array}$ & Article 51 & $\begin{array}{l}\text { http: } \\
\text { //www.un. } \\
\text { org/en/ga/ } \\
\text { search/vie } \\
\text { w_doc. } \\
\text { asp? } \\
\text { symbol=s/ } \\
1999 / 1022 \\
\end{array}$ & \begin{tabular}{|l|} 
http://www. \\
un. \\
org/en/ga/se \\
arch/view_do \\
c.asp? \\
symbol=S/199 \\
9/1022\&Lang \\
$=$ A \\
\end{tabular} & $\begin{array}{l}\text { hitps: } \\
\text { //perma. } \\
\text { cc/XW3A- } \\
\text { TGNH }\end{array}$ \\
\hline 299 & 2000.01.03 & 2000.01.04 & $S / 2000 / 1$ & Iraq & \begin{tabular}{|} 
Iraq, United \\
States, United \\
Kingdom, \\
Saudi Arabia, \\
Kuwait, Turkey
\end{tabular} & $\begin{array}{l}\text { Implied } \\
\text { assertion of } \\
\text { "individual" } \\
\text { self-defense }\end{array}$ & $\begin{array}{c}\text { Conducted } \\
\text { attack }\end{array}$ & $\begin{array}{l}\text { United States, } \\
\text { United Kingdom, } \\
\text { Saudi Arabia, } \\
\text { Kuwait, Turkey }\end{array}$ & States & $\begin{array}{l}\text { "VV]iolations of Iraq's airspace by } \\
\text { United States and British aircraft } \\
\text { based in Saudi Arabia, Kuwait and } \\
\text { Turkey continued between } 16 \text { and } 31 \\
\text { December } 1999 \text {... the aircraft in } \\
\text { question engaged in acts of } \\
\text { aggression, reconnaissance activities } \\
\text { and acts of provocation ...." }\end{array}$ & $\begin{array}{l}\text { None } \\
\text { identified }\end{array}$ & None identified & $\begin{array}{l}\text { None } \\
\text { identified }\end{array}$ & $\begin{array}{l}\text { None } \\
\text { identified }\end{array}$ & $\begin{array}{l}\text { http: } \\
\text { //www.un. } \\
\text { org/en/ga/ } \\
\text { search/vie } \\
\text { w_doc. } \\
\text { asp? } \\
\text { symbol=S/ } \\
\text { 2000/1 }\end{array}$ & \begin{tabular}{|l} 
http://www. \\
un. \\
org/en/ga/se \\
arch/view_do \\
c.asp? \\
symbol=s/200 \\
o/18lang=A
\end{tabular} & \begin{tabular}{|l} 
hitps: \\
//perma. \\
cc/ITWBC- \\
YRY7
\end{tabular} \\
\hline 300 & 2000.01.23 & 2000.01.25 & $\mathrm{S} / 2000 / 48$ & Pakistan & | Pakistan, India & $\begin{array}{c}\text { Implied } \\
\text { assertion of } \\
\text { "individual" } \\
\text { self-defense }\end{array}$ & $\begin{array}{c}\text { Conducted } \\
\text { attack }\end{array}$ & India & State & $\begin{array}{l}\text { "Indian forces crossed the line of } \\
\text { control in the Iftikharabad subsector } \\
\text { in the Chamb area and launched a } \\
\text { company-strength attack on a small } \\
\text { and long existing Pakistani post } \\
\text { between the two channels of the Tawi } \\
\text { river. This act of flagrant aggression } \\
\text { was preceded by intense Indian } \\
\text { mortar fire, which damaged the } \\
\text { bunkers of the Pakistani post." }\end{array}$ & $\begin{array}{l}\text { None } \\
\text { identified }\end{array}$ & None identified & $\begin{array}{l}\text { None } \\
\text { identified }\end{array}$ & Article 51 & $\begin{array}{l}\text { http: } \\
\text { //www.un. } \\
\text { org/en/ga/ } \\
\text { search/vie } \\
\text { w_doc. } \\
\text { asp? } \\
\text { symbol=s/ } \\
\text { 2000/48 }\end{array}$ & & \begin{tabular}{|l} 
hitps: \\
///perma. \\
ccl/PD88- \\
g28H
\end{tabular} \\
\hline 301 & 2000.02.03 & 2000.02.04 & $\mathrm{s} / 2000 / 85$ & Iraq & \begin{tabular}{|} 
Iraq, United \\
States, United \\
Kingdom, \\
Saudi Arabia, \\
Kuwait, Turkey
\end{tabular} & $\begin{array}{c}\text { Implied } \\
\text { assertion of } \\
\text { "individual" } \\
\text { self-defense }\end{array}$ & $\begin{array}{c}\text { Conducted } \\
\text { attack }\end{array}$ & $\begin{array}{l}\text { United States, } \\
\text { United Kingdom, } \\
\text { Saudi Arabia, } \\
\text { Kuwait, Turkey }\end{array}$ & States & \begin{tabular}{|l} 
"VV]jolations of Iraq's airspace by \\
United States and British aircraft \\
based in Saudi Arabia, Kuwait and \\
Turkey continued between 24 and 31 \\
January 2000 ... the aircraft in \\
question engaged in acts of \\
aggression, reconnaissance activities \\
and acts of provocation ...."
\end{tabular} & \begin{tabular}{|l} 
None \\
identified
\end{tabular} & None identified & $\begin{array}{l}\text { None } \\
\text { identified }\end{array}$ & Article 51 & $\begin{array}{l}\text { http: } \\
\text { //www.un. } \\
\text { org/en/ga/ } \\
\text { search/vie } \\
\text { w_doc. } \\
\text { asp? } \\
\text { symbol=s/ } \\
\text { 2000/85 }\end{array}$ & \begin{tabular}{|l} 
http://www. \\
un. \\
org//en/ga/se \\
arch/view_do \\
c.asp? \\
symbol=s/200 \\
0/85\&Lang=A
\end{tabular} & 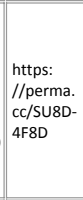 \\
\hline 302 & 2000.02.10 & 2000.02.10 & $\mathrm{S} / 2000 / 104$ & Iraq & \begin{tabular}{|} 
Iraq, United \\
States, United \\
Kingdom, \\
Saudi Arabia, \\
Kuwait, Turkey
\end{tabular} & $\begin{array}{c}\text { Implied } \\
\text { assertion of } \\
\text { "individual" } \\
\text { self-defense }\end{array}$ & $\begin{array}{c}\text { Conducted } \\
\text { attack }\end{array}$ & $\begin{array}{l}\text { United States, } \\
\text { United Kingdom, } \\
\text { Saudi Arabia, } \\
\text { Kuwait, Turkey }\end{array}$ & States & {$\left[\begin{array}{l}\text { “VV]iolations of Iraq's airspace by } \\
\text { United States and British aircraft } \\
\text { based in Saudi Arabia, Kuwait and } \\
\text { Turkey continued between } 1 \text { and } 7 \\
\text { February } 2000 \text { and ... the aircraft in } \\
\text { question engaged in acts of } \\
\text { aggression, reconnaissance activities } \\
\text { and acts of provocation ....” }\end{array}\right.$} & \begin{tabular}{|l} 
None \\
identified
\end{tabular} & None identified & $\begin{array}{l}\text { None } \\
\text { identified }\end{array}$ & Article 51 & $\begin{array}{l}\text { http: } \\
\text { //wwww.un. } \\
\text { org/en/ga/ } \\
\text { search/vie } \\
\text { w_doc. } \\
\text { asp? } \\
\text { symbol=s/ } \\
\text { 2000/104 } \\
\end{array}$ & \begin{tabular}{|l|} 
http://www. \\
un. \\
org/en/ga/se \\
arch/view_do \\
c.asp? \\
symbol=S/200 \\
0/104\&Lang= \\
A
\end{tabular} & \begin{tabular}{|l} 
https: \\
//perma. \\
cc/A662- \\
4MSE
\end{tabular} \\
\hline 303 & 2000.02.16 & 2000.02.18 & $\mathrm{S} / 2000 / 134$ & Iraq & \begin{tabular}{|} 
Iraq, United \\
States, United \\
Kingdom, \\
Saudi Arabia, \\
Kuwait, Turkey
\end{tabular} & \begin{tabular}{|l} 
Implied \\
assertion of \\
"individual" \\
self-defense
\end{tabular} & $\begin{array}{c}\text { Conducted } \\
\text { attack }\end{array}$ & $\begin{array}{l}\text { United States, } \\
\text { United Kingdom, } \\
\text { Saudi Arabia, } \\
\text { Kuwait, Turkey }\end{array}$ & States & \begin{tabular}{|l} 
"[V]iolations of Iraq's airspace by \\
United States and British aircraft \\
based in Saudi Arabia, Kuwait and \\
Turkey continued between 8 and 14 \\
February 2000 ... the aircraft in \\
question engaged in acts of \\
aggression, reconnaissance activities \\
and acts of provocation ....."
\end{tabular} & $\begin{array}{l}\text { None } \\
\text { identified }\end{array}$ & None identified & $\begin{array}{l}\text { None } \\
\text { identified }\end{array}$ & Article 51 & $\begin{array}{l}\text { http: } \\
\text { //www.un. } \\
\text { org/en/ga/ } \\
\text { search/vie } \\
\text { w_doc. } \\
\text { asp? } \\
\text { symbol=S/ } \\
\text { 2000/134 }\end{array}$ & \begin{tabular}{|l||} 
http://www. \\
un. \\
org/en/ga/se \\
arch/view_do \\
c.asp? \\
symbol=s/200 \\
O/134\&Lang= \\
A
\end{tabular} & $\begin{array}{l}\text { hitps: } \\
\text { //perma. } \\
\text { cc/7AuL- } \\
\text { N9QY }\end{array}$ \\
\hline
\end{tabular}


VI. HLS PILAC Catalogue of Apparent “Article 51 Communications”

\begin{tabular}{|c|c|c|c|c|c|c|c|c|c|c|c|c|c|c|c|c|c|}
\hline $\begin{array}{l}\text { Chron. } \\
\text { Order }\end{array}$ & $\begin{array}{l}\text { Date of } \\
\text { Comm. }\end{array}$ & $\begin{array}{c}\text { Date of } \\
\text { UNSC } \\
\text { Document }\end{array}$ & UNSC Symbol & \begin{tabular}{|c} 
Member \\
State(s) That \\
Submitted \\
the Comm.
\end{tabular} & \begin{tabular}{|c|} 
Expressly \\
Mentioned UN \\
Members (\& \\
Colonial \\
Holdings \& \\
Protectorates, \\
if any) \\
\end{tabular} & \begin{tabular}{|c|} 
Express or \\
Implied \\
Assertion of \\
Individual, \\
Collective, or \\
Both Self- \\
defense \\
\end{tabular} & \begin{tabular}{|l} 
Nature of \\
the Alleged \\
Threat
\end{tabular} & $\begin{array}{l}\text { Expressly Alleged } \\
\text { Author(s) of the } \\
\text { Threat (If Any } \\
\text { Indicated) }\end{array}$ & \begin{tabular}{|c} 
Nature of the \\
Alleged \\
Author(s) of \\
the Threat (If \\
Any (f) \\
Indicated)
\end{tabular} & $\begin{array}{l}\text { Summary of Alleged Self-defense } \\
\text { Grounds }\end{array}$ & $\begin{array}{c}\text { UNsc } \\
\text { Meeting(s) } \\
\text { (If Any) at } \\
\text { Which the } \\
\text { Commm was } \\
\text { Raised }\end{array}$ & $\begin{array}{l}\text { Responsive Act (ff Any) by the } \\
\text { UNSC }\end{array}$ & $\begin{array}{c}\text { UN } \\
\text { Repertory } \\
\text { Inclusion? }\end{array}$ & \begin{tabular}{|c} 
UNSC \\
Repertoire \\
Inclusion?
\end{tabular} & \begin{tabular}{|l} 
URL to an \\
English \\
Text
\end{tabular} & \begin{tabular}{||c||} 
URL to Non- \\
English \\
Original \\
Text (ff Any)
\end{tabular} & $\begin{array}{l}\text { Perma.cc } \\
\text { URL }\end{array}$ \\
\hline 304 & 2000.02.28 & 2000.02.29 & $\mathrm{S} / 2000 / 159$ & Iraq & \begin{tabular}{|l} 
Iraq, United \\
States, United \\
Kingdom, \\
Saudi Arabia, \\
Kuwait, Turkey
\end{tabular} & $\begin{array}{c}\text { Implied } \\
\text { assertion of } \\
\text { "individual" } \\
\text { self-defense }\end{array}$ & $\begin{array}{c}\text { Conducted } \\
\text { attack }\end{array}$ & $\begin{array}{l}\text { United States, } \\
\text { United Kingdom, } \\
\text { Saudi irabia, } \\
\text { Kuwait, Turkey }\end{array}$ & States & $\begin{array}{l}\text { “... United States and British aircraft } \\
\text { have been continuing their armed } \\
\text { sorties against northern and southern } \\
\text { Iraq ... they have bombed Iraqi civilian } \\
\text { installations, causing further suffering } \\
\text { to civilians and killing and terrorizing } \\
\text { them.”. }\end{array}$ & $\begin{array}{l}\text { None } \\
\text { identified }\end{array}$ & 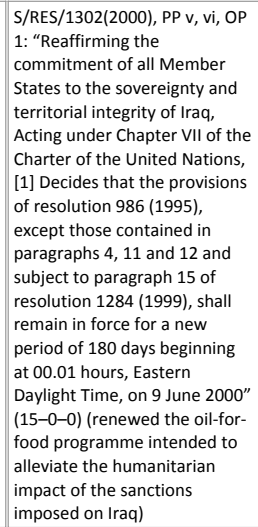 & $\begin{array}{l}\text { None } \\
\text { identified }\end{array}$ & Article 51 & $\begin{array}{l}\text { http: } \\
\text { //www.un. } \\
\text { org/en/ga/ } \\
\text { search/vie } \\
\text { w_doc. } \\
\text { asp? } \\
\text { symbol=s/ } \\
\text { 2000/159 }\end{array}$ & $\begin{array}{l}\text { http://www. } \\
\text { un. } \\
\text { org/en/ga/se } \\
\text { arch/view_do } \\
\text { c.asp? } \\
\text { symbol=S/200 } \\
\text { O/159\&Lang= } \\
\text { A }\end{array}$ & $\begin{array}{l}\text { hitps: } \\
\text { //perma. } \\
\text { cc/U7zP- } \\
\text { 8HZZ }\end{array}$ \\
\hline 305 & 2000.03.06 & 2000.03.07 & $\mathrm{S} / 2000 / 191$ & Iraq & $\begin{array}{l}\text { Iraq, United } \\
\text { States, United } \\
\text { Kingdom, } \\
\text { Saudi Arabia, } \\
\text { Kuwait, Turkey }\end{array}$ & $\begin{array}{c}\text { Implied } \\
\text { assertion of } \\
\text { "individual" } \\
\text { self-defense }\end{array}$ & $\begin{array}{c}\text { Conducted } \\
\text { attack }\end{array}$ & $\begin{array}{l}\text { United States, } \\
\text { United Kingdom, } \\
\text { Saadi irabia, } \\
\text { Kuwait, Turkey }\end{array}$ & States & $\begin{array}{l}\text { "BB]etween } 22 \text { and } 29 \text { February 2000, } \\
\text { United States and British military } \\
\text { aircraft, taking off from their bases in } \\
\text { Saudi AArabia, Kuwait and Turkey, } \\
\text { continued to violate Iraqi airspace, } \\
\text { carrying out a total of } 165 \text { aerial } \\
\text { sorties, of which } 87 \text { were from Saudi } \\
\text { Arabia, } 26 \text { from Kuwait and } 52 \text { from } \\
\text { Turkey." }\end{array}$ & \begin{tabular}{|l} 
None \\
identified
\end{tabular} & None identified & $\begin{array}{l}\text { None } \\
\text { identified }\end{array}$ & Article 51 & $\begin{array}{l}\text { http: } \\
\text { /twww.un. } \\
\text { org/en/ga/ } \\
\text { search/vie } \\
\text { w_doc. } \\
\text { asp? } \\
\text { symbol=s/ } \\
\text { 2000/191 }\end{array}$ & \begin{tabular}{|l} 
http://www. \\
un. \\
org/en/ga/se \\
arch/view_do \\
c.asp? \\
symbol=S/200 \\
O/191\&Lang= \\
A
\end{tabular} & $\begin{array}{l}\text { https: } \\
\text { //perma. } \\
\text { cc///RKG- } \\
\text { YDFU }\end{array}$ \\
\hline 306 & 2000.03.27 & 2000.03.28 & $\mathrm{S} / 2000 / 259$ & Iraq & \begin{tabular}{|l} 
Iraq, United \\
States, United \\
Kingdom, \\
Saudi Arabia, \\
Kuwait, Turkey
\end{tabular} & \begin{tabular}{|l} 
Implied \\
assertion of \\
"individual" \\
self-defense
\end{tabular} & $\begin{array}{c}\text { Conducted } \\
\text { attack }\end{array}$ & $\begin{array}{l}\text { United States, } \\
\text { United Kingdom, } \\
\text { Saudi Arabia, } \\
\text { Kuwait, Turkey }\end{array}$ & States & \begin{tabular}{|l} 
"[B]etween 8 and 21 March 2000, \\
United States and British military \\
airraft, taking off from their bases in \\
Saudi Arabia, Kuwait and Turkes, \\
continued to violate Iraqi airspace, \\
carrying out a total of 382 aerial \\
sorties, of which 238 were from Saudi \\
Arabia, 68 from Kuwait and 76 from \\
Turkey, killing one civilian and \\
wounding 14 others."
\end{tabular} & \begin{tabular}{|l} 
None \\
identified
\end{tabular} & None identified & \begin{tabular}{|l} 
None \\
identified
\end{tabular} & Article 51 & $\begin{array}{l}\text { http: } \\
\text { //www.un. } \\
\text { org/en/ga/ } \\
\text { search/vie } \\
\text { w_doc. } \\
\text { asp? } \\
\text { symbol=s/ } \\
\text { 2000/259 }\end{array}$ & $\begin{array}{l}\text { http: //www. } \\
\text { un. } \\
\text { org/en/ga/se } \\
\text { arch/view_do } \\
\text { c.asp? } \\
\text { symbol=s/200 } \\
0 / 259 \& L a n g= \\
\text { A }\end{array}$ & $\begin{array}{l}\text { https: } \\
\text { //perma. } \\
\text { cc//77V- } \\
\text { URC2 }\end{array}$ \\
\hline 307 & 2000.04.04 & 2000.04.06 & $\mathrm{S} / 2000 / 291$ & Iraq & \begin{tabular}{|l} 
Iraq, United \\
States, United \\
Kingdom, \\
Saudi Arabia, \\
Kuwait, Turkey
\end{tabular} & $\begin{array}{c}\text { Implied } \\
\text { assertion of } \\
\text { "individual" } \\
\text { self-defense }\end{array}$ & $\begin{array}{c}\text { Conducted } \\
\text { attack }\end{array}$ & $\begin{array}{l}\text { United States, } \\
\text { United Kingdom, } \\
\text { Saudi Arabia, } \\
\text { Kuwait, Turkey }\end{array}$ & States & $\begin{array}{l}\text { ".... United States and British warplanes } \\
\text { based in Saudi Arabia, Kuwait and } \\
\text { Turkey have continued to violate the } \\
\text { airspace of the Republic of Iraq and } \\
\text { carried out } 331 \text { sorties in the period } \\
\text { from } 22 \text { to } 31 \text { March } 2000 \text {. One } \\
\text { hundred and thirty-nine of these } \\
\text { sorties were from Saudi Arabia, } 70 \\
\text { were from Kuwait and } 122 \text { were from } \\
\text { Turkey...." }\end{array}$ & \begin{tabular}{|l} 
None \\
identified
\end{tabular} & None identified & $\mid \begin{array}{l}\text { None } \\
\text { identified }\end{array}$ & Article 51 & $\begin{array}{l}\text { http: } \\
\text { //www.un. } \\
\text { org/en/ga/ } \\
\text { search/vie } \\
\text { w_doc. } \\
\text { asp? } \\
\text { symbol=s/ } \\
\text { 2000/291 }\end{array}$ & $\begin{array}{l}\text { http://www. } \\
\text { un. } \\
\text { org/en/ga/se } \\
\text { arch/view_do } \\
\text { c.asp? } \\
\text { symbol=S/200 } \\
\text { O/291\&Lang= } \\
\text { A }\end{array}$ & \begin{tabular}{|l} 
https: \\
$/ / / p e r m a$. \\
cc//775u- \\
4/BG
\end{tabular} \\
\hline
\end{tabular}


VI. HLS PILAC Catalogue of Apparent “Article 51 Communications”

\begin{tabular}{|c|c|c|c|c|c|c|c|c|c|c|c|c|c|c|c|c|c|}
\hline $\begin{array}{l}\text { Chron. } \\
\text { Order }\end{array}$ & $\begin{array}{l}\text { Date of } \\
\text { Comm. }\end{array}$ & $\begin{array}{c}\text { Date of } \\
\text { UNsc } \\
\text { Document }\end{array}$ & UNSC Symbol & \begin{tabular}{||c} 
Member \\
State(s) That \\
Submitted \\
the Comm.
\end{tabular} & \begin{tabular}{|c|} 
Expressly \\
Mentioned UN \\
Members (\& \\
Colonial \\
Holdings \& \\
Protectorates, \\
if any) \\
\end{tabular} & \begin{tabular}{|l} 
Express or \\
Implied \\
Assertion of \\
Individual, \\
Collective, or \\
Both Self- \\
defense
\end{tabular} & \begin{tabular}{|l} 
Nature of \\
the Alleged \\
Threat
\end{tabular} & $\begin{array}{l}\text { Expressly Alleged } \\
\text { Author(s) of the } \\
\text { Threat (If Any } \\
\text { Indicated) }\end{array}$ & \begin{tabular}{|l|} 
Nature of the \\
Alleged \\
Author(s) of \\
the Threat (If \\
Any \\
Indicated)
\end{tabular} & $\begin{array}{l}\text { Summary of Alleged Self-defense } \\
\text { Grounds }\end{array}$ & \begin{tabular}{|c|} 
UNsc \\
Meeting(s) \\
(if Any) at \\
Which the \\
Comm. was \\
Raised
\end{tabular} & $\begin{array}{l}\text { Responsive Act (If Any) by the } \\
\text { UNSC }\end{array}$ & \begin{tabular}{||c} 
UN \\
Repertory \\
Inclusion?
\end{tabular} & \begin{tabular}{|c|} 
UNSC \\
Repertoire \\
Inclusion?
\end{tabular} & \begin{tabular}{|l|l|} 
URL to an \\
English \\
Text
\end{tabular} & \begin{tabular}{||c||} 
URL to Non- \\
English \\
Original \\
Text (ff Any)
\end{tabular} & $\begin{array}{c}\text { Perma.cc } \\
\text { URL }\end{array}$ \\
\hline 308 & 2000.04.07 & 2000.04.10 & S/2000/296 & Ethiopia & $\begin{array}{l}\text { Ethiopia, } \\
\text { Eritrea }\end{array}$ & $\begin{array}{c}\text { Implied } \\
\text { assertion of } \\
\text { "individual" } \\
\text { self-defense }\end{array}$ & $\begin{array}{c}\text { Conducted } \\
\text { attack }\end{array}$ & Eritrea & State & \begin{tabular}{|l} 
"[T]he crisis started with the \\
unprovoked aggression by Eritrea \\
against Ethiopia on 12 May 1998 and \\
the occupation of Ethiopian sovereign \\
territory by Eritrea. This was the \\
culmination of the Eritrean pattern of \\
aggressive behaviour towards its \\
neighbours since its inception as new \\
State. With the exception of the \\
liberation of the biggest chunk of \\
Ethiopian territory - Badme - -... - \\
that is, Eritrean aggression against \\
Ethiopia continues by virtue of the \\
fact there are Ethiopian territories \\
along the entire common border still \\
under Eritrean occupation.”
\end{tabular} & $\begin{array}{l}\text { None } \\
\text { identified }\end{array}$ & None identified & Article 24 & $\begin{array}{l}\text { Articles } 24 \text { \& } \\
51\end{array}$ & \begin{tabular}{|l||} 
http: \\
//www.un. \\
org/en/ga/ \\
search/vie \\
w_doc. \\
asp? \\
symbol=s/ \\
2000/296
\end{tabular} & & $\begin{array}{l}\text { litps: } \\
\text { ///perma. } \\
\text { cc//7PVy- } \\
429 \mathrm{~W}\end{array}$ \\
\hline 309 & 2000.04.11 & 2000.04.13 & $\mathrm{S} / 2000 / 308$ & Iraq & $\begin{array}{l}\text { Iraq, United } \\
\text { States, United } \\
\text { Kingdom, } \\
\text { Saudi Arabia, } \\
\text { Kuwait, Turkey }\end{array}$ & $\begin{array}{c}\text { Implied } \\
\text { assertion of } \\
\text { "individual" } \\
\text { self-defense }\end{array}$ & $\begin{array}{c}\text { Conducted } \\
\text { attack }\end{array}$ & $\begin{array}{l}\text { United States, } \\
\text { United Kingdom, } \\
\text { Saudi Arabia,, } \\
\text { Kuwait, Turkey }\end{array}$ & States & $\begin{array}{l}\text { “...United States and British warplanes } \\
\text { based in Saudi Arabia, Kuwait and } \\
\text { Turkey have continued to violate the } \\
\text { airspace of the Republic of Iraq and } \\
\text { carried out } 202 \text { sorties in the period } \\
\text { from } 1 \text { to } 7 \text { April } 2000 \text {. Eighty-two of } \\
\text { these sorties were from Saudi Arabia, } \\
62 \text { were from Kunait and } 58 \text { were } \\
\text { from Turkey, as shown hereunder, } \\
\text { and } 14 \text { people were killed and } 19 \\
\text { were injured as a result.". }\end{array}$ & $\begin{array}{l}\text { None } \\
\text { identified }\end{array}$ & None identified & $\begin{array}{l}\text { None } \\
\text { identified }\end{array}$ & Article 51 & \begin{tabular}{|l||} 
http: \\
//www.un. \\
org/en/ga/ \\
search/vie \\
w_doc. \\
asp? \\
symbol=s/ \\
2000/308
\end{tabular} & \begin{tabular}{|l|} 
http://www. \\
un. \\
org/en/ga/se \\
arch/view_do \\
c.asp? \\
symbol=S/200 \\
o/308\&Lang= \\
A
\end{tabular} & $\begin{array}{l}\text { hitps: } \\
\text { //perma. } \\
\text { ccluAk8- } \\
\text { zTT2 }\end{array}$ \\
\hline 310 & 2000.04.19 & 2000.04.24 & $\mathrm{S} / 2000 / 341$ & Iraq & $\begin{array}{l}\text { Iraq, United } \\
\text { States, United } \\
\text { Kingdom, } \\
\text { Saudi Arabia, } \\
\text { Kuwait, Turkey }\end{array}$ & $\begin{array}{c}\text { Implied } \\
\text { assertion of } \\
\text { "individual" } \\
\text { self-defense }\end{array}$ & $\begin{array}{c}\text { Conducted } \\
\text { attack }\end{array}$ & $\begin{array}{l}\text { United States, } \\
\text { United Kingdom, } \\
\text { Saudi Arabia,, } \\
\text { Kuwait, Turkey }\end{array}$ & States & $\begin{array}{l}\text { "... United States and British aircraft } \\
\text { have been continuing their violation of } \\
\text { the airspace of the Republic of Iraq } \\
\text { from their bases in Saudi Arabia, } \\
\text { Kuwait and Turkey. They carried out } \\
184 \text { sorties during the period from } 8 \\
\text { to } 1 \text { Appril } 2000, \text {, t8 of these from } \\
\text { Saudi Arabia, } 52 \text { from Kuwait and } 54 \\
\text { from Turkey." }\end{array}$ & $\begin{array}{l}\text { None } \\
\text { identified }\end{array}$ & None identified & $\begin{array}{l}\text { None } \\
\text { identified }\end{array}$ & Article 51 & \begin{tabular}{|l||} 
\\
$\mid$ http: \\
//www.un. \\
org/en/ga/ \\
search/vie \\
w_doc. \\
asp? \\
symbol=s/ \\
2000/341
\end{tabular} & \begin{tabular}{|l|} 
http://www. \\
un. \\
org/en/ga/se \\
arch/view_do \\
c.asp? \\
symbol=S/200 \\
O/341\&Lang= \\
A
\end{tabular} & $\begin{array}{l}\text { hitps: } \\
\text { //perma. } \\
\text { cc/7LIZ- } \\
\text { TPDS }\end{array}$ \\
\hline 311 & 2000.05.03 & 2000.05.04 & $\mathrm{S} / 2000 / 383$ & Iraq & $\begin{array}{l}\text { Iraq, United } \\
\text { States, United } \\
\text { Kingdom, } \\
\text { Saudi Arabia, } \\
\text { Kuwait, Turkey }\end{array}$ & $\begin{array}{c}\text { Implied } \\
\text { assertion of } \\
\text { "individual" } \\
\text { self-defense }\end{array}$ & $\begin{array}{c}\text { Conducted } \\
\text { attack }\end{array}$ & $\begin{array}{l}\text { United States, } \\
\text { United Kingdom, } \\
\text { Saudi Arabia, } \\
\text { Kuwait, Turkey }\end{array}$ & States & $\begin{array}{l}\text { "[Clontinuing overt aggression by the } \\
\text { United States of America and the } \\
\text { United Kingdom against Iraq. During } \\
\text { the period from } 16 \text { to } 28 \text { April 2000, } \\
\text { United States and British military } \\
\text { aircraft carried out a total of } 289 \\
\text { hostite sorties, including } 154 \text { from } \\
\text { Saudi Arabia, } 77 \text { from Kuwait and } 58 \\
\text { from Turkey." }\end{array}$ & \begin{tabular}{|l} 
None \\
identified
\end{tabular} & None identified & \begin{tabular}{|l} 
None \\
identified
\end{tabular} & Article 51 & \begin{tabular}{|l||} 
http: \\
//www.un. \\
org/en/ga/ \\
search/vie \\
w_doc. \\
asp? \\
symbol=s/ \\
2000/383
\end{tabular} & \begin{tabular}{|l|} 
http://www. \\
un. \\
org/en/ga/se \\
arch/view_do \\
c.asp? \\
symbol=s/200 \\
O/383\&Lang= \\
A
\end{tabular} & $\begin{array}{l}\text { hitps: } \\
\text { //perma. } \\
\text { cc/6AAM- } \\
\text { Y2P8 }\end{array}$ \\
\hline 312 & 2000.05.15 & 2000.05.17 & S/2000/439 & Iraq & $\begin{array}{l}\text { Iraq, United } \\
\text { States, United } \\
\text { Kingdom, } \\
\text { Saudi Arabia, } \\
\text { Kuwait, Turkey }\end{array}$ & 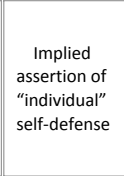 & $\begin{array}{c}\text { Conducted } \\
\text { attack }\end{array}$ & $\begin{array}{l}\text { United States, } \\
\text { United Kingdom, } \\
\text { Saudi Arabia,, } \\
\text { Kuwait, Turkey }\end{array}$ & States & \begin{tabular}{|l} 
"[O]ngoing United States and British \\
aggression against Iraq... United \\
States and British aircraft carried out \\
200 sorties in the period from 29 April \\
to 7 May 2000 in which they bombed \\
civilian installations in the country, \\
wounding three citizens."
\end{tabular} & $\begin{array}{l}\text { None } \\
\text { identified }\end{array}$ & None identified & $\begin{array}{l}\text { None } \\
\text { identified }\end{array}$ & Article 51 & \begin{tabular}{|l||} 
http: \\
//www.un. \\
org/en/ga/ \\
search/vie \\
w_doc. \\
asp? \\
symbol=s/ \\
2000/439 \\
\end{tabular} & \begin{tabular}{|l||} 
http://www. \\
un. \\
org/en/ga/se \\
arch/view_do \\
c.asp? \\
symbol=S/200 \\
O/439\&Lang= \\
A \\
\end{tabular} & \begin{tabular}{|l} 
hitps: \\
///perma. \\
cc//as4- \\
NGE3
\end{tabular} \\
\hline 313 & 2000.05.19 & 2000.05.24 & $S / 2000 / 471$ & Iraq & $\begin{array}{l}\text { Iraq, United } \\
\text { States, United } \\
\text { Kingdom, } \\
\text { Saudi Arabia, } \\
\text { Kuwait, Turkey }\end{array}$ & $\begin{array}{c}\text { Implied } \\
\text { assertion of } \\
\text { "individual" } \\
\text { self-defense }\end{array}$ & $\begin{array}{c}\text { Conducted } \\
\text { attack }\end{array}$ & $\begin{array}{l}\text { United States, } \\
\text { United Kingdom, } \\
\text { Saudi Arabia, } \\
\text { Kuwait, Turkey }\end{array}$ & States & $\begin{array}{l}\text { "[O]ngoing wanton aggression by } \\
\text { United States and British aircraft } \\
\text { against Iraq, inasmuch as in the period } \\
\text { from } 8 \text { to } 15 \text { May } 2000 \text { they carried } \\
\text { out } 202 \text { sorties, } 90 \text { of them from Saudi } \\
\text { Arabia, } 34 \text { from Kuwait and } 78 \text { from } \\
\text { Turkey...." }\end{array}$ & $\begin{array}{l}\text { None } \\
\text { identified }\end{array}$ & None identified & $\begin{array}{l}\text { None } \\
\text { identified }\end{array}$ & Article 51 & \begin{tabular}{|l|} 
http: \\
//www.un. \\
org//en/ga/ \\
search/vie \\
w_doc. \\
asp? \\
symbol=s/ \\
2000/471 \\
\end{tabular} & \begin{tabular}{|l||} 
http://www. \\
un. \\
org/en/ga/se \\
arch/view_do \\
c.asp? \\
symbol=S/200 \\
O/471\&Lang= \\
A
\end{tabular} & \begin{tabular}{|l} 
hitps: \\
///perma. \\
cc//122B- \\
ACR5
\end{tabular} \\
\hline
\end{tabular}


VI. HLS PILAC Catalogue of Apparent “Article 51 Communications”

\begin{tabular}{|c|c|c|c|c|c|c|c|c|c|c|c|c|c|c|c|c|c|}
\hline $\begin{array}{l}\text { Chron. } \\
\text { Order }\end{array}$ & $\begin{array}{l}\text { Date of } \\
\text { Comm. }\end{array}$ & $\begin{array}{c}\text { Date of } \\
\text { UNSC } \\
\text { Document }\end{array}$ & UNSC Symbol & \begin{tabular}{||c} 
Member \\
State(s) That \\
Submitted \\
the Commm.
\end{tabular} & \begin{tabular}{|c||} 
Expressly \\
Mentioned UN \\
Members (\& \\
Colonial \\
Holdings \& \\
Protectorates, \\
if any) \\
\end{tabular} & \begin{tabular}{|l} 
Express or \\
Implied \\
Assertion of \\
Individual, \\
Collective, or \\
Both Self- \\
defense \\
\end{tabular} & \begin{tabular}{|c} 
Nature of \\
the Alleged \\
Threat
\end{tabular} & $\begin{array}{l}\text { Expressly Alleged } \\
\text { Author(s) of the } \\
\text { Threat (If Any } \\
\text { Indicated) }\end{array}$ & \begin{tabular}{|c|} 
Nature of the \\
Alleged \\
Author(s) of \\
the Threat (If \\
Any \\
Indicated)
\end{tabular} & $\begin{array}{l}\text { Summary of Alleged Self-defense } \\
\text { Grounds }\end{array}$ & \begin{tabular}{|l} 
UNSC \\
Meeting(s) \\
(If Any) at \\
Which the \\
Comm. was \\
Raised \\
\end{tabular} & $\begin{array}{l}\text { Responsive Act (If Any) by the } \\
\text { UNSC }\end{array}$ & \begin{tabular}{|l} 
UN \\
Repertory \\
Inclusion?
\end{tabular} & \begin{tabular}{|c} 
UNsC \\
Repertoire \\
Inclusion?
\end{tabular} & \begin{tabular}{|l} 
URL to an \\
English \\
Text
\end{tabular} & \begin{tabular}{|c||} 
URL to Non- \\
English \\
Original \\
Tert (ff Any)
\end{tabular} & $\begin{array}{c}\text { Perma.cc } \\
\text { URL }\end{array}$ \\
\hline 314 & 2000.05.27 & 2000.05.31 & S/2000/507 & Iraq & \begin{tabular}{|c|} 
Iraq, United \\
States, United \\
Kingdom, \\
Saudi Arabia, \\
Kuwait, Turkey
\end{tabular} & $\begin{array}{l}\text { Implied } \\
\text { assertion of } \\
\text { "individual" } \\
\text { self-defense }\end{array}$ & $\begin{array}{c}\text { Conducted } \\
\text { attack }\end{array}$ & $\begin{array}{l}\text { United States, } \\
\text { United Kingdom, } \\
\text { Saudi irabia, } \\
\text { Kuwait, Turkey }\end{array}$ & States & $\begin{array}{l}\text { "[O]ngoing United States and British } \\
\text { aggression against raq in the so-called } \\
\text { no-flight zones... in the period from } \\
15 \text { to } 22 \text { May } 2000 \text { United States and } \\
\text { British aircraft carried out } 152 \text { sorties } \\
\text { in the course of which they bombed } \\
\text { civilian installations in Iraq, killing one } \\
\text { child, wounding } 11 \text { civilian citizens and } \\
\text { killing and injuring large numbers of } \\
\text { livestock.". }\end{array}$ & $\begin{array}{l}\text { None } \\
\text { identified }\end{array}$ & None identified & $\begin{array}{l}\text { None } \\
\text { identified }\end{array}$ & Article 51 & $\begin{array}{l}\text { http: } \\
\text { //www.un. } \\
\text { org/en/ga/ } \\
\text { search/vie } \\
\text { w_doc. } \\
\text { asp? } \\
\text { symbol=s/ } \\
\text { 2000/507 }\end{array}$ & \begin{tabular}{|l|} 
http: //www. \\
un. \\
org/en/ga/se \\
arch/view_do \\
c.asp? \\
symbol=s/200 \\
O/507\&Lang= \\
A
\end{tabular} & $\begin{array}{l}\text { https: } \\
\text { //cerma. } \\
\text { cc/7DrM- } \\
\text { DQMC }\end{array}$ \\
\hline 315 & 2000.06 .02 & 2000.06 .02 & S/2000/523 & Ethiopia & $\begin{array}{l}\text { Ethiopia, } \\
\text { Eritrea }\end{array}$ & $\begin{array}{l}\text { Implied } \\
\text { assertion of } \\
\text { "individual" } \\
\text { self-defense }\end{array}$ & $\begin{array}{c}\text { Conducted } \\
\text { attack }\end{array}$ & Eritrea & State & \begin{tabular}{|l} 
"The long-standing intransigent \\
position of Eritrea frustrated the \\
peace efforts of the Organization of \\
African Unity (OAU), most recently the \\
proximity talks that were held in \\
Aggiers from 29 April to 5 May 2000. \\
[q] Following the collapse of the \\
proximity talks in Algiers, ...."
\end{tabular} & $\begin{array}{l}\text { None } \\
\text { identified }\end{array}$ & None identified & $\begin{array}{l}\text { None } \\
\text { identified }\end{array}$ & Article 51 & $\begin{array}{l}\text { http: } \\
\text { //www.un. } \\
\text { org/en/ga/ } \\
\text { search/vie } \\
\text { w_doc. } \\
\text { asp? } \\
\text { symbol=S/ } \\
\text { 2000/523 }\end{array}$ & & $\begin{array}{l}\text { hetps: } \\
\text { //perma. } \\
\text { cc//974B- } \\
563 Q\end{array}$ \\
\hline 316 & 2000.06.05 & 2000.06.06 & $\mathrm{S} / 2000 / 540$ & Iraq & \begin{tabular}{|c|} 
Iraq, United \\
States, United \\
Kingdom, \\
Saudi Arabia, \\
Kuwait, Turkey
\end{tabular} & $\begin{array}{l}\text { Implied } \\
\text { assertion of } \\
\text { "individual" } \\
\text { self-defense }\end{array}$ & $\begin{array}{c}\text { Conducted } \\
\text { attack }\end{array}$ & $\begin{array}{l}\text { United States, } \\
\text { United Kingdom, } \\
\text { Saadi irabia, } \\
\text { Kuwait, Turkey }\end{array}$ & States & \begin{tabular}{|l} 
"[O]ngoing wanton aggression by \\
United States and British aircraft in \\
the unlawful no-flight zones ... in the \\
period from 23 to 31 May 2000 they \\
carried out 234 sorties, 78 o f them \\
from Saudi Arabia, 44 from Kuwait \\
and 92 from Turkey."
\end{tabular} & $\begin{array}{l}\text { None } \\
\text { identified }\end{array}$ & None identified & $\begin{array}{l}\text { None } \\
\text { identified }\end{array}$ & Article 51 & $\begin{array}{l}\text { http: } \\
\text { /twww.un. } \\
\text { org/en/ga/ } \\
\text { search/vie } \\
\text { w_doc. } \\
\text { asp? } \\
\text { symbol=s/ } \\
\text { 2000/540 }\end{array}$ & $\begin{array}{l}\text { http://www. } \\
\text { un. } \\
\text { org/en/ga/se } \\
\text { arch/view_do } \\
\text { c.asp? } \\
\text { symbol=S/200 } \\
\text { O/540\&Lang= } \\
\text { A } \\
\end{array}$ & $\begin{array}{l}\text { https: } \\
\text { //perma. } \\
\text { cc/NX2A- } \\
\text { S76Q }\end{array}$ \\
\hline 317 & 2000.06.12 & 2000.06 .14 & S/2000/571 & Iraq & \begin{tabular}{|c|} 
Iraq, United \\
States, United \\
Kingdom, \\
Saudi Arabia, \\
Kuwait, Turkey
\end{tabular} & $\begin{array}{l}\text { Implied } \\
\text { assertion of } \\
\text { "individual" } \\
\text { self-defense }\end{array}$ & $\begin{array}{c}\text { Conducted } \\
\text { attack }\end{array}$ & $\begin{array}{l}\text { United States, } \\
\text { United Kingdom, } \\
\text { Saudi Arabia, } \\
\text { Kuwait, Turkey }\end{array}$ & States & $\begin{array}{l}\text { "OOlngoing wanton aggression by } \\
\text { United States and British aircraft in } \\
\text { the unlawful no-flight zones ... in the } \\
\text { period from } 1 \text { to } 8 \text { June } 2000 \text { they } \\
\text { carried out } 242 \text { sorties, } 82 \text { of them } \\
\text { from Saudi Arabia, } 48 \text { from Kuwait } \\
\text { and } 112 \text { from Turkey." }\end{array}$ & $\begin{array}{l}\text { None } \\
\text { identified }\end{array}$ & None identified & $\begin{array}{l}\text { None } \\
\text { identified }\end{array}$ & Article 51 & $\begin{array}{l}\text { http: } \\
\text { //www.un. } \\
\text { org/en/ga/ } \\
\text { search/vie } \\
\text { w_doc. } \\
\text { ass? } \\
\text { symbol=s/ } \\
\text { 2000/571 } \\
\end{array}$ & \begin{tabular}{|l|} 
http://www. \\
un. \\
org/en/ga/se \\
arch/view_do \\
c.asp? \\
symbol=S/200 \\
//571\&Lang= \\
A \\
\end{tabular} & $\begin{array}{l}\text { https: } \\
\text { //cerma. } \\
\text { cc/CD34- } \\
\text { F2V7 }\end{array}$ \\
\hline 318 & 2000.06.15 & 2000.06.17 & S/2000/596 & Uganda & \begin{tabular}{|c|} 
Uganda, \\
Rwanda, \\
Democratic \\
Republic of the \\
Congo
\end{tabular} & $\begin{array}{l}\text { Implied } \\
\text { assertion of } \\
\text { "individual" } \\
\text { self-defense }\end{array}$ & $\begin{array}{c}\text { Conducted } \\
\text { attack }\end{array}$ & Rwanda & State & 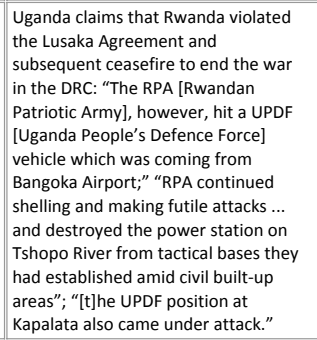 & $\begin{array}{l}\text { None } \\
\text { identified }\end{array}$ & None identified & $\begin{array}{l}\text { None } \\
\text { identified }\end{array}$ & Article 51 & $\begin{array}{l}\text { http: } \\
\text { //www.un. } \\
\text { org/en/ga/ } \\
\text { search/vie } \\
\text { w_doc. } \\
\text { asp? } \\
\text { symbol=s/ } \\
\text { 2000/596 }\end{array}$ & & \begin{tabular}{|l} 
https: \\
//perma. \\
cc/399L- \\
w7PA
\end{tabular} \\
\hline 319 & 2000.06 .20 & 2000.06.22 & S/2000/614 & Iraq & \begin{tabular}{||c|} 
Iraq, United \\
States, United \\
Kingdom, \\
Saudi Arabia, \\
Kuwait, Turkey
\end{tabular} & $\begin{array}{l}\text { Implied } \\
\text { assertion of } \\
\text { "individual" } \\
\text { self-defense }\end{array}$ & $\begin{array}{c}\text { Conducted } \\
\text { attack }\end{array}$ & $\begin{array}{l}\text { United States, } \\
\text { United Kingdom, } \\
\text { Saudi Arabaia, } \\
\text { Kuwait, Turkey }\end{array}$ & States & $\begin{array}{l}\text { "OO]ngoing wanton aggression by } \\
\text { United States and British aircraft in } \\
\text { the unlawful no-flight zones ... in the } \\
\text { period from } 9 \text { to } 16 \text { June } 2000 \text { they } \\
\text { carried out } 196 \text { sorties, } 62 \text { of them } \\
\text { from Saudi Arabia, } 34 \text { from Kuwait } \\
\text { and } 100 \text { from Turkey." }\end{array}$ & $\begin{array}{l}\text { None } \\
\text { identified }\end{array}$ & None identified & $\begin{array}{l}\text { None } \\
\text { identified }\end{array}$ & Article 51 & $\begin{array}{l}\text { http: } \\
\text { //wwww.un. } \\
\text { org/en/ga/ } \\
\text { search//vie } \\
\text { w_doc. } \\
\text { asp? } \\
\text { symbol=S/ } \\
\text { 2000/614 }\end{array}$ & \begin{tabular}{|l|} 
http://www. \\
un. \\
org/en/ga/se \\
arch/view_do \\
c.asp? \\
symbol=S/200 \\
O/614\&Lang= \\
A
\end{tabular} & $\begin{array}{l}\text { https: } \\
\text { //perma. } \\
\text { cc/S8UU- } \\
\text { JERU } \\
\end{array}$ \\
\hline 320 & 2000.06.26 & 2000.06.27 & S/2000/628 & Iraq & \begin{tabular}{|c|} 
Iraq, United \\
States, United \\
Kingdom, \\
Saudi Arabia, \\
Kuwait, Turkey
\end{tabular} & $\begin{array}{l}\text { Implied } \\
\text { assertion of } \\
\text { "individual" } \\
\text { self-defense }\end{array}$ & $\begin{array}{c}\text { Conducted } \\
\text { attack }\end{array}$ & $\begin{array}{l}\text { United States, } \\
\text { United Kingdom, } \\
\text { Saadi irabia, } \\
\text { Kuwait, Turkey }\end{array}$ & States & $\begin{array}{l}\text { "[O]ngoing wanton aggression by } \\
\text { United States and British aircraft in } \\
\text { the unlawful no-flight zones ... in the } \\
\text { period from } 17 \text { to } 23 \text { June } 2000 \text { they } \\
\text { carried out } 178 \text { sorties, } 66 \text { of them } \\
\text { from Saudi Arabia, } 38 \text { from Kuwait } \\
\text { and } 74 \text { from Turkey. Three citizens } \\
\text { were injured in these attacks, during } \\
\text { which the aircraft released a total of } \\
\text { seven heat flares." }\end{array}$ & \begin{tabular}{|l} 
None \\
identified
\end{tabular} & None identified & \begin{tabular}{|l} 
None \\
identified
\end{tabular} & Article 51 & $\begin{array}{l}\text { http: } \\
\text { //www.un. } \\
\text { org/en/ga/ } \\
\text { search/vie } \\
\text { w_doc. } \\
\text { asp? } \\
\text { symbol=s/ } \\
\text { 2000/628 }\end{array}$ & \begin{tabular}{|l||} 
http://www. \\
un. \\
org/en/ga/se \\
arch/view_do \\
c.asp? \\
symbol=s/200 \\
O/628\&Lang= \\
A
\end{tabular} & $\begin{array}{l}\text { https: } \\
\text { //perma. } \\
\text { cc/8k778- } \\
\text { 4VJM }\end{array}$ \\
\hline
\end{tabular}


VI. HLS PILAC Catalogue of Apparent “Article 51 Communications”

\begin{tabular}{|c|c|c|c|c|c|c|c|c|c|c|c|c|c|c|c|c|c|}
\hline $\begin{array}{l}\text { Chron. } \\
\text { Order }\end{array}$ & $\begin{array}{l}\text { Date of } \\
\text { Comm. }\end{array}$ & $\begin{array}{c}\text { Date of } \\
\text { UNSC } \\
\text { Document }\end{array}$ & UNSC Symbol & \begin{tabular}{||c} 
Member \\
State(s) That \\
Submitted \\
the Comm.
\end{tabular} & \begin{tabular}{|c||} 
Expressly \\
Mentioned UN \\
Members (\& \\
Colonial \\
Holdings \& \\
Protectorates, \\
if any) \\
\end{tabular} & \begin{tabular}{|c|} 
Express or \\
Implied \\
Assertion of \\
Individual, \\
Collective, or \\
Both Self- \\
defense \\
\end{tabular} & \begin{tabular}{|l} 
Nature of \\
the Alleged \\
Threat
\end{tabular} & \begin{tabular}{|l} 
Expressly Alleged \\
Author(s) of the \\
Threat (If Any \\
Indicated)
\end{tabular} & \begin{tabular}{|c|} 
Nature of the \\
Alleged \\
Author(s) of \\
the Threat (If \\
Any \\
Indicated)
\end{tabular} & $\begin{array}{l}\text { Summary of Alleged Self-defense } \\
\text { Grounds }\end{array}$ & \begin{tabular}{|c|} 
UNSC \\
Meeting(s) \\
(If Any) at \\
Which the \\
Comm. was \\
Raised \\
\end{tabular} & $\begin{array}{l}\text { Responsive Act (ff Any) by the } \\
\text { UNSC }\end{array}$ & \begin{tabular}{|c} 
UN \\
Repertory \\
Inclusion?
\end{tabular} & \begin{tabular}{|c|} 
UNSC \\
Repertoire \\
Inclusion?
\end{tabular} & \begin{tabular}{|c|} 
URL to an \\
English \\
Text
\end{tabular} & \begin{tabular}{|l||} 
URL to Non- \\
English \\
Original \\
Text (ff Any)
\end{tabular} & $\begin{array}{l}\text { Perma.cc } \\
\text { URL }\end{array}$ \\
\hline 321 & 2000.07.04 & 2000.07.06 & s/2000/652 & Iraq & \begin{tabular}{|} 
Iraq, United \\
States, United \\
Kingdom, \\
Saudi Arabia, \\
Kuwait, Turkey
\end{tabular} & \begin{tabular}{|c|} 
Implied \\
assertion of \\
"individual" \\
self-defense
\end{tabular} & $\begin{array}{c}\text { Conducted } \\
\text { attack }\end{array}$ & $\begin{array}{l}\text { United States, } \\
\text { United Kingdom, } \\
\text { Saadi Arabia, } \\
\text { Kuwait, Turkey }\end{array}$ & States & \begin{tabular}{|l} 
"[O]ngoing wanton aggression by \\
United States and British aircraft in \\
the unlawful no-flight tones... in the \\
period from 24 to 30 June 2000 they \\
carried out 126 sorties, 84 of them \\
from Saudi Arabia, 10 from Kuwait \\
and 32 from Turkey, in which they \\
targeted civilian and services-related \\
installations, killing one Iraqi woman \\
and injuring three other civilians."
\end{tabular} & $\begin{array}{l}\text { None } \\
\text { identified }\end{array}$ & None identified & \begin{tabular}{|l} 
None \\
identified
\end{tabular} & Article 51 & $\begin{array}{l}\text { http: } \\
\text { /twww.un. } \\
\text { org/en/ga/ } \\
\text { search/vie } \\
\text { w_doc. } \\
\text { asp? } \\
\text { symbol=s/ } \\
\text { 2000/652 }\end{array}$ & \begin{tabular}{|l|} 
http: //www. \\
un. \\
org/en/ga/se \\
arch/view_do \\
c.asp? \\
symbol=s/200 \\
O/652\&Lang= \\
A
\end{tabular} & \begin{tabular}{|l} 
https: \\
//perma. \\
cc/DD8B- \\
L29K
\end{tabular} \\
\hline 322 & 2000.07.12 & 2000.07.14 & S/2000/694 & Iraq & \begin{tabular}{|} 
Iraq, United \\
States, United \\
Kingdom, \\
Saudi Arabia, \\
Kuwait, Turkey
\end{tabular} & \begin{tabular}{|c|} 
Implied \\
assertion of \\
"individual" \\
self-defense
\end{tabular} & $\begin{array}{c}\text { Conducted } \\
\text { attack }\end{array}$ & \begin{tabular}{|l} 
United States, \\
United Kingdom, \\
Saudi AAabia, \\
Kuwait, Turkey
\end{tabular} & States & \begin{tabular}{|l} 
"OO]ngoing wanton aggression against \\
Iraq by United States and British \\
aircraft in the unlawful no-flight zones \\
$\ldots$ in the period from 1 to 8 July 2000 \\
they carried out 146 sorties, 62 of \\
them from Saudi AArabia, 46 from \\
Kuwait and 38 from Turkey."
\end{tabular} & $\begin{array}{l}\text { None } \\
\text { identified }\end{array}$ & None identified & $\begin{array}{l}\text { None } \\
\text { identified }\end{array}$ & Article 51 & $\begin{array}{l}\text { http: } \\
\text { //www.un. } \\
\text { org/en/ga/ } \\
\text { search/vie } \\
\text { w_doc. } \\
\text { asp? } \\
\text { spybol=S/ } \\
\text { 2000/694 }\end{array}$ & \begin{tabular}{|l||} 
http://www. \\
un. \\
org/en/ga/se \\
arch/view_do \\
c.asp? \\
symbol=S/200 \\
O/694\&Lang= \\
A
\end{tabular} & \begin{tabular}{|l} 
https: \\
//perma. \\
cc/TT4S- \\
HLFT
\end{tabular} \\
\hline 323 & 2000.07.22 & 2000.08.08 & S/2000/735 & Iraq & \begin{tabular}{|} 
Iraq, United \\
States, United \\
Kingdom, \\
Saudi Arabia, \\
Kuwait, Turkey
\end{tabular} & \begin{tabular}{|c|} 
Implied \\
assertion of \\
"individual" \\
self-defense
\end{tabular} & $\begin{array}{c}\text { Conducted } \\
\text { attack }\end{array}$ & \begin{tabular}{|l} 
United States, \\
United Kingdom, \\
Saudi AAabia, \\
Kuwait, Turkey
\end{tabular} & States & $\begin{array}{l}\text { "IO]ngoing wanton aggression against } \\
\text { Iraq by United States and British } \\
\text { aircraft in the unlawful no-flight zones } \\
\text {... in the period from } 9 \text { to } 16 \text { July } 2000 \\
\text { they carried out } 172 \text { sorties, } 66 \text { of } \\
\text { them from Saudi Arabia, } 60 \text { from } \\
\text { Kuwait and } 46 \text { from Turkey." }\end{array}$ & $\begin{array}{l}\text { None } \\
\text { identified }\end{array}$ & None identified & $\begin{array}{l}\text { None } \\
\text { identified }\end{array}$ & Article 51 & $\begin{array}{l}\text { http: } \\
\text { //wwww.un. } \\
\text { org/en/ga/ } \\
\text { search/vie } \\
\text { w_doc. } \\
\text { asp? } \\
\text { symbol=S/ } \\
\text { 2000/735 }\end{array}$ & \begin{tabular}{|l|} 
http://www. \\
un. \\
org/en/ga/se \\
arch/view_do \\
c.asp? \\
symbol=S/200 \\
O/735\&Lang= \\
A
\end{tabular} & \begin{tabular}{|l} 
https: \\
//perma. \\
cc/6EQS- \\
K8UL
\end{tabular} \\
\hline 327 & 2000.07.22 & 2000.08.08 & S/2000/776 & Iraq & \begin{tabular}{|} 
Iraq, United \\
States, United \\
Kingdom, \\
Saudi Arabia, \\
Kuwait, Turkey
\end{tabular} & \begin{tabular}{|c|} 
Implied \\
assertion of \\
"individual" \\
self-defense
\end{tabular} & $\begin{array}{c}\text { Conducted } \\
\text { attack }\end{array}$ & $\begin{array}{l}\text { United States, } \\
\text { United Kingdom, } \\
\text { Saudi Arabia, } \\
\text { Kuwait, Turkey }\end{array}$ & States & \begin{tabular}{|l} 
"OO]ngoing wanton aggression against \\
Iraq by United States and British \\
aircraft in the unlawful no-flight zones \\
$\ldots$ in the period from 9 to 16 July 2000 \\
they carried out 172 sorties, 66 of \\
them from Saudi A Aabia,a, 60 from \\
Kuwait and 46 from Turkey."
\end{tabular} & $\begin{array}{l}\text { None } \\
\text { identified }\end{array}$ & None identified & $\begin{array}{l}\text { None } \\
\text { identified }\end{array}$ & Article 51 & $\begin{array}{l}\text { http: } \\
\text { //www.un. } \\
\text { org/en/ga/ } \\
\text { search/vie } \\
\text { w_doc. } \\
\text { asp? } \\
\text { symbol=s/ } \\
\text { 2000/776 } \\
\end{array}$ & \begin{tabular}{|l||} 
http://www. \\
un. \\
org/en/ga/se \\
arch/view_do \\
c.asp? \\
symbol=S/200 \\
//776\&Lang= \\
A \\
\end{tabular} & $\begin{array}{l}\text { https: } \\
\text { //perma. } \\
\text { cc/N3w3- } \\
\text { 36NN }\end{array}$ \\
\hline 324 & 2000.07.30 & 2000.08.01 & $S / 2000 / 754$ & Iraq & \begin{tabular}{|} 
Iraq, United \\
States, United \\
Kingdom, \\
Saudi Arabia, \\
Kuwait, Turkey
\end{tabular} & $\begin{array}{c}\text { Implied } \\
\text { assertion of } \\
\text { "individual" } \\
\text { self-defense }\end{array}$ & $\begin{array}{c}\text { Conducted } \\
\text { attack }\end{array}$ & $\begin{array}{l}\text { United States, } \\
\text { United Kingdom, } \\
\text { Saudi Arabia, } \\
\text { Kuwait, Turkey }\end{array}$ & States & $\begin{array}{l}\text { "IO]ngoing wanton aggression against } \\
\text { Iraq by United States and British } \\
\text { aircraft in the unlawful no-flight zones } \\
\text {... in the period from } 17 \text { to } 23 \text { July } \\
2000 \text { they carried out } 132 \text { sorties, } 62 \\
\text { of them from Saudi Arabia, } 28 \text { from } \\
\text { Kuwait and } 42 \text { from Turkey." }\end{array}$ & $\begin{array}{l}\text { None } \\
\text { identified }\end{array}$ & None identified & $\begin{array}{l}\text { None } \\
\text { identified }\end{array}$ & Article 51 & $\begin{array}{l}\text { http: } \\
\text { //www.un. } \\
\text { org/en/ga/ } \\
\text { search/vie } \\
\text { w_doc. } \\
\text { asp? } \\
\text { symbol=S/ } \\
\text { 2000/754 }\end{array}$ & \begin{tabular}{|l||} 
http://www. \\
un. \\
org/en/ga/se \\
arch/view_do \\
c.asp? \\
symbol=S/200 \\
O/754\&Lang= \\
A
\end{tabular} & $\begin{array}{l}\text { https: } \\
\text { //perma. } \\
\text { cc/T/812- } \\
255 \mathrm{~K}\end{array}$ \\
\hline 325 & 2000.08 .05 & 2000.08.07 & $S / 2000 / 774$ & Iraq & \begin{tabular}{|} 
Iraq, United \\
States, United \\
Kingdom, \\
Saudi Arabia, \\
Kuwait, Turkey
\end{tabular} & $\begin{array}{c}\text { Implied } \\
\text { assertion of } \\
\text { "individual" } \\
\text { self-defense }\end{array}$ & $\begin{array}{c}\text { Conducted } \\
\text { attack }\end{array}$ & $\begin{array}{l}\text { United States, } \\
\text { United Kingdom, } \\
\text { Saudi Arabia, } \\
\text { Kuwait, Turkey }\end{array}$ & States & $\begin{array}{l}\text { "O]ngoing wanton aggression against } \\
\text { Iraq by United States and British } \\
\text { aircraft in the unlawful no-flight zones } \\
\ldots . . \text { in the period from } 24 \text { to } 30 \text { July } \\
2000 \text { they carried out } 220 \text { sorties, } 106 \\
\text { of them from Saudi Arabia, } 66 \text { from } \\
\text { Kuwait and } 48 \text { from Turkey." }\end{array}$ & $\begin{array}{l}\text { None } \\
\text { identified }\end{array}$ & None identified & $\begin{array}{l}\text { None } \\
\text { identified }\end{array}$ & Article 51 & $\begin{array}{l}\text { http: } \\
\text { //www.un. } \\
\text { org/en//ga/ } \\
\text { search/vie } \\
\text { w_doc. } \\
\text { asp? } \\
\text { spybol=S/ } \\
\text { 2000/774 }\end{array}$ & \begin{tabular}{|l|} 
http://www. \\
un. \\
org/en/ga/se \\
arch/view_do \\
c.asp? \\
symbol=S/200 \\
0/774\&Lang= \\
A \\
\end{tabular} & $\begin{array}{l}\text { https: } \\
\text { //perma. } \\
\text { cc/TNA3- } \\
\text { GUTZ }\end{array}$ \\
\hline 326 & 2000.08.05 & 2000.08.08 & S/2000/775 & Iraq & \begin{tabular}{|} 
Iraq, United \\
States, United \\
Kingdom, \\
Saudi Arabia, \\
Kuwait, Turkey
\end{tabular} & \begin{tabular}{|c|} 
Implied \\
assertion of \\
"individual" \\
self-defense
\end{tabular} & $\begin{array}{c}\text { Conducted } \\
\text { attack }\end{array}$ & $\begin{array}{l}\text { United States, } \\
\text { United Kingdom, } \\
\text { Saudi Arabia, } \\
\text { Kuwait, Turkey }\end{array}$ & States & \begin{tabular}{|l} 
"OO]ngoing wanton aggression against \\
Iraq by United States and British \\
aircraft in the unlawful no-flight zones \\
... in the period from 24 to 30 July \\
2000 they carried out 220 sorties, 106 \\
of them from Saudi Arabia, 66 from \\
Kuwait and 48 from Turkey."
\end{tabular} & \begin{tabular}{|l} 
None \\
identified
\end{tabular} & None identified & $\begin{array}{l}\text { None } \\
\text { identified }\end{array}$ & Article 51 & $\begin{array}{l}\text { http: } \\
\text { //www.un. } \\
\text { org/en/ga/ } \\
\text { search/vie } \\
\text { w_doc. } \\
\text { asp? } \\
\text { spybol=S/ } \\
\text { 2000/775 }\end{array}$ & \begin{tabular}{|l|} 
http://www. \\
un. \\
org/en/ga/se \\
arch/view_do \\
c.asp? \\
symbol=S/200 \\
O/775\&Lang= \\
A
\end{tabular} & \begin{tabular}{|l} 
https: \\
//perma. \\
cc/6V3s- \\
E7RS
\end{tabular} \\
\hline 328 & 2000.08.12 & 2000.08.14 & S/2000/795 & Iraq & \begin{tabular}{|} 
Iraq, United \\
States, United \\
Kingdom, \\
Saudi Arabia, \\
Kuwait, Turkey
\end{tabular} & \begin{tabular}{|c|} 
Implied \\
assertion of \\
"individual" \\
self-defense
\end{tabular} & $\begin{array}{l}\text { Conducted } \\
\text { attack }\end{array}$ & $\begin{array}{l}\text { United States, } \\
\text { United Kingdom, } \\
\text { Saudi Arabia, } \\
\text { Kuwait, Turkey }\end{array}$ & States & \begin{tabular}{|l} 
"IO]ngoing wanton aggression against \\
Iraq by United States and British \\
aircraft in the unlawful no-flight \\
zones. During the period from 31 July \\
to 7 August 2000, these aircraft \\
carried out 240 aggressive sorties, 154 \\
of them from Saudi Arabia,, 66 from \\
Kuwait and 30 from Turkey."
\end{tabular} & $\begin{array}{l}\text { None } \\
\text { identified }\end{array}$ & None identified & $\begin{array}{l}\text { None } \\
\text { identified }\end{array}$ & Article 51 & $\begin{array}{l}\text { http: } \\
\text { //www.un. } \\
\text { org/en/ga/ } \\
\text { search/vie } \\
\text { w_doc. } \\
\text { asp? } \\
\text { symbol=s/ } \\
\text { 2000/795 }\end{array}$ & \begin{tabular}{|l|} 
http: //www. \\
un. \\
org/en/ga/se \\
arch/view_do \\
c.asp? \\
symbol=S/200 \\
O/795\&Lang= \\
A
\end{tabular} & $\begin{array}{l}\text { https: } \\
\text { //perma. } \\
\text { cc/A2RP- } \\
\text { B/46 }\end{array}$ \\
\hline
\end{tabular}


VI. HLS PILAC Catalogue of Apparent “Article 51 Communications”

\begin{tabular}{|c|c|c|c|c|c|c|c|c|c|c|c|c|c|c|c|c|c|}
\hline $\begin{array}{l}\text { Chron. } \\
\text { Order }\end{array}$ & $\begin{array}{l}\text { Date of } \\
\text { Comm. }\end{array}$ & \begin{tabular}{|c} 
Date of \\
UNsc \\
Document
\end{tabular} & UNSC Symbol & \begin{tabular}{||c} 
Member \\
State(s) That \\
Submitted \\
the Comm.
\end{tabular} & \begin{tabular}{|c|} 
Expressly \\
Mentioned UN \\
Members (\& \\
Colonial \\
Holdings \& \\
Protectorates, \\
if any) \\
\end{tabular} & \begin{tabular}{|c|} 
Express or \\
Implied \\
Assertion of \\
Individual, \\
Collective, or \\
Both Self- \\
defense
\end{tabular} & \begin{tabular}{|c} 
Nature of \\
the Alleged \\
Threat
\end{tabular} & $\begin{array}{l}\text { Expressly Alleged } \\
\text { Author(s) of the } \\
\text { Threat (If Any } \\
\text { Indicated) }\end{array}$ & \begin{tabular}{|c|} 
Nature of the \\
Alleged \\
Author(s) of \\
the Threat (If \\
Any \\
Indicated) \\
\end{tabular} & $\begin{array}{l}\text { Summary of Alleged Self-defense } \\
\text { Grounds }\end{array}$ & \begin{tabular}{|c|} 
UNsc \\
Meeting(s) \\
(if Any) at \\
Which the \\
Comm. was \\
Raised
\end{tabular} & $\begin{array}{l}\text { Responsive Act (If Any) by the } \\
\text { UNSC }\end{array}$ & $\begin{array}{l}\text { UN } \\
\text { Repertory } \\
\text { Inclusion? }\end{array}$ & $\begin{array}{c}\text { UNSC } \\
\text { Repertoire } \\
\text { Inclusion? }\end{array}$ & \begin{tabular}{|l} 
URL to an \\
English \\
Text
\end{tabular} & \begin{tabular}{|c||} 
URL to Non- \\
English \\
Original \\
Text (ff Any)
\end{tabular} & $\begin{array}{l}\text { Perma.cc } \\
\text { URL }\end{array}$ \\
\hline 329 & 2000.08 .12 & 2000.08.15 & S/2000/802 & Iraq & $\begin{array}{l}\text { Iraq, United } \\
\text { States, United } \\
\text { Kingdom, } \\
\text { Saudi Arabia, } \\
\text { Kuwait, Turkey }\end{array}$ & $\begin{array}{c}\text { Implied } \\
\text { assertion of } \\
\text { "individual" } \\
\text { self-defense }\end{array}$ & $\begin{array}{c}\text { Conducted } \\
\text { attack }\end{array}$ & $\begin{array}{l}\text { United States, } \\
\text { United Kingdom, } \\
\text { Saudi irabia, } \\
\text { Kuwait, Turkey }\end{array}$ & States & \begin{tabular}{|l} 
"IO]ngoing wanton aggression against \\
Iraq by United States and British \\
aircraft in the unlawful no-flight \\
zones. During the period from 31 July \\
to 7 August 2000, these aircraft \\
carried out 240 aggressive sorties, 154 \\
of them from Saudi Arabia, 66 from \\
Kuwait and 30 from Turkey."
\end{tabular} & $\begin{array}{l}\text { None } \\
\text { identified }\end{array}$ & None identified & $\begin{array}{l}\text { None } \\
\text { identified }\end{array}$ & Article 51 & $\begin{array}{l}\text { http: } \\
\text { //www.un. } \\
\text { org/en/ga/ } \\
\text { search/vie } \\
\text { w_doc. } \\
\text { asp? } \\
\text { symbol=S/ } \\
\text { 2000/802 }\end{array}$ & Not available & $\begin{array}{l}\text { https: } \\
\text { //perma. } \\
\text { cc/NYY3- } \\
\text { LFHB }\end{array}$ \\
\hline 330 & 2000.08.19 & 2000.08.22 & $\mathrm{S} / 2000 / 820$ & Iraq & $\begin{array}{l}\text { Iraq, United } \\
\text { States, United } \\
\text { Kingdom, } \\
\text { Saudi Arabia, } \\
\text { Kuwait, Turkey }\end{array}$ & $\begin{array}{c}\text { Implied } \\
\text { assertion of } \\
\text { "individual" } \\
\text { self-defense }\end{array}$ & $\begin{array}{c}\text { Conducted } \\
\text { attack }\end{array}$ & $\begin{array}{l}\text { United States, } \\
\text { United Kingdom, } \\
\text { Saudi Arabia, } \\
\text { Kuwait, Turkey }\end{array}$ & States & $\begin{array}{l}\text { "OO]ngoing wanton aggression against } \\
\text { Iraq by United States and British } \\
\text { aircraft in the unlawful no-fly zones. } \\
\text { During the period from } 8 \text { to } 15 \text { August } \\
\text { 2000, these aircraft carried out } 216 \\
\text { aggressive sorties, } 124 \text { of them from } \\
\text { Saudi Arabia, } 48 \text { from Kuwait and } 44 \\
\text { from Turkey, killing two innocent } \\
\text { civilians, injuring a further } 23 \text { and } \\
\text { destroying civilian residential buildings } \\
\text { and important civilian installations } \\
\text { including grain warehouses." }\end{array}$ & $\begin{array}{l}\text { None } \\
\text { identified }\end{array}$ & None identified & $\begin{array}{l}\text { None } \\
\text { identified }\end{array}$ & Article 51 & $\begin{array}{l}\text { http: } \\
\text { //www.un. } \\
\text { org/en/ga/ } \\
\text { search/vie } \\
\text { w_doc. } \\
\text { asp? } \\
\text { symbol=s/ } \\
\text { 2000/820 }\end{array}$ & $\begin{array}{l}\text { http://www. } \\
\text { un. } \\
\text { org/en/ga/se } \\
\text { arch/view_do } \\
\text { c.asp? } \\
\text { symbol=S/200 } \\
\text { 0/820\&Lang= } \\
\text { A }\end{array}$ & $\begin{array}{l}\text { https: } \\
\text { //perma. } \\
\text { cc//4C6- } \\
\text { TGCZ }\end{array}$ \\
\hline 331 & 2000.08.19 & 2000.08.23 & $\mathrm{S} / 2000 / 826$ & Iraq & $\begin{array}{l}\text { Iraq, United } \\
\text { States, United } \\
\text { Kingdom, } \\
\text { Saudi Arabia, } \\
\text { Kuwait, Turkey }\end{array}$ & $\begin{array}{c}\text { Implied } \\
\text { assertion of } \\
\text { "individual" } \\
\text { self-defense }\end{array}$ & $\begin{array}{c}\text { Conducted } \\
\text { attack }\end{array}$ & $\begin{array}{l}\text { United States, } \\
\text { United Kingdom, } \\
\text { Saudi Arabia, } \\
\text { Kuwait, Turkey }\end{array}$ & States & $\begin{array}{l}\text { "OO]ngoing wanton aggression against } \\
\text { Iraq by United States and British } \\
\text { aircraft in the unlawful no-fly zones. } \\
\text { During the period from } 8 \text { to } 15 \text { August } \\
\text { 2000, these aircraft carried out } 216 \\
\text { aggressive sorties, } 124 \text { of them from } \\
\text { Saudi Arabia, } 48 \text { from Kuwait and } 44 \\
\text { from Turkey, killing two innocent } \\
\text { civilians, injuring a further } 23 \text { and } \\
\text { destroying civilian residential buildings } \\
\text { and important civilian installations } \\
\text { including grain warehouses." }\end{array}$ & $\begin{array}{l}\text { None } \\
\text { identified }\end{array}$ & None identified & $\begin{array}{l}\text { None } \\
\text { identified }\end{array}$ & Article 51 & $\begin{array}{l}\text { http: } \\
\text { //www.un. } \\
\text { org/en/ga/ } \\
\text { search/vie } \\
\text { w_doc. } \\
\text { ass? } \\
\text { symbol=s/ } \\
\text { 2000/826 }\end{array}$ & \begin{tabular}{|l||} 
http://www. \\
un. \\
org/en/ga/se \\
arch/view_do \\
c.asp? \\
symbol=s/200 \\
O/826\&Lang= \\
A
\end{tabular} & $\begin{array}{l}\text { hitps: } \\
\text { //Tperma. } \\
\text { cc//1X2N- } \\
\text { YZYY }\end{array}$ \\
\hline 332 & 2000.09.02 & 2000.09.06 & $\mathrm{S} / 2000 / 848$ & Iraq & $\begin{array}{l}\text { Iraq, United } \\
\text { States, United } \\
\text { Kingdom, } \\
\text { Saudi Arabia, } \\
\text { Kuwait, Turkey }\end{array}$ & $\begin{array}{c}\text { Implied } \\
\text { assertion of } \\
\text { "individual" } \\
\text { self-defense }\end{array}$ & $\begin{array}{c}\text { Conducted } \\
\text { attack }\end{array}$ & $\begin{array}{l}\text { United States, } \\
\text { United Kingdom, } \\
\text { Saudi Arabia, } \\
\text { Kuwait, Turkey }\end{array}$ & States & $\begin{array}{l}\text { "OO]ngoing wanton aggression against } \\
\text { Iraq by Unitied States and British } \\
\text { aircraft in the unlawful no-flight zones } \\
\text {... in the period from } 16 \text { to } 23 \text { August } \\
2000 \text { they carried out } 228 \text { sorties, } 74 \\
\text { of them from Saudi Arabia, } 74 \text { from } \\
\text { Kuwait and } 90 \text { from Turkey." } \\
\end{array}$ & $\begin{array}{l}\text { None } \\
\text { identified }\end{array}$ & None identified & $\begin{array}{l}\text { None } \\
\text { identified }\end{array}$ & Article 51 & $\begin{array}{l}\text { http: } \\
\text { //www.un. } \\
\text { org/en//ga/ } \\
\text { search/vie } \\
\text { w_doc. } \\
\text { asp? } \\
\text { symbol=S/ } \\
\text { 2000/848 } \\
\end{array}$ & \begin{tabular}{|l|} 
http://www. \\
un. \\
org/en/ga/se \\
arch/view_do \\
c.asp? \\
symbol=S/200 \\
o/848\&Lang= \\
A \\
\end{tabular} & $\begin{array}{l}\text { https: } \\
\text { //perma. } \\
\text { cc/50aT- } \\
\text { GX72 }\end{array}$ \\
\hline 333 & 2000.09.02 & 2000.09.06 & S/2000/849 & Iraq & $\begin{array}{l}\text { Iraq, United } \\
\text { States, United } \\
\text { Kingdom, } \\
\text { Saudi Arabia, } \\
\text { Kuwait, Turkey }\end{array}$ & $\begin{array}{c}\text { Implied } \\
\text { assertion of } \\
\text { "individual" } \\
\text { self-defense }\end{array}$ & $\begin{array}{c}\text { Conducted } \\
\text { attack }\end{array}$ & $\begin{array}{l}\text { United States, } \\
\text { United Kingdom, } \\
\text { Saudi Arabia, } \\
\text { Kuwait, Turkey }\end{array}$ & States & \begin{tabular}{|l} 
"OO]ngoing wanton aggression against \\
Iraq by United States and British \\
aircraft in the unlawful no-flight zones \\
$\ldots$ in the period from 16 to 23 August \\
2000 they carried out 228 sorties, 74 \\
of them from Saudi Arabia, 74 from \\
Kuwait and 90 from Turkey."
\end{tabular} & $\begin{array}{l}\text { None } \\
\text { identified }\end{array}$ & None identified & $\begin{array}{l}\text { None } \\
\text { identified }\end{array}$ & Article 51 & $\begin{array}{l}\text { http: } \\
\text { //www.un. } \\
\text { org/en//ga/ } \\
\text { search/vie } \\
\text { w_doc. } \\
\text { ass? } \\
\text { symbol=s/ } \\
\text { 2000/849 }\end{array}$ & \begin{tabular}{|l|} 
http://www. \\
un. \\
org/en/ga/se \\
arch/view_do \\
c.asp? \\
symbol=S/200 \\
o/849\&Lang= \\
A
\end{tabular} & $\begin{array}{l}\text { https: } \\
\text { //perma. } \\
\text { cc//9928- } \\
\text { 95x4 }\end{array}$ \\
\hline 334 & 2000.09.04 & 2000.09.07 & $\mathrm{S} / 2000 / 850$ & Iraq & $\begin{array}{l}\text { Iraq, United } \\
\text { States, United } \\
\text { Kingdom, } \\
\text { Saudi Arabia, } \\
\text { Kuwait, Turkey }\end{array}$ & $\begin{array}{c}\text { Implied } \\
\text { assertion of } \\
\text { "individual" } \\
\text { self-defense }\end{array}$ & $\begin{array}{c}\text { Conducted } \\
\text { attack }\end{array}$ & $\begin{array}{l}\text { United States, } \\
\text { United Kingdom, } \\
\text { Saudi Arabia, } \\
\text { Kuwait, Turkey }\end{array}$ & States & \begin{tabular}{|l} 
"IO]ngoing wanton aggression against \\
Iraq by United States and British \\
aircraft in the unlawful no-flight zones \\
. in the period from 24 to 31 August \\
2000 they carried out 272 sorties, 156 \\
of them from Saudi Arabia, 48 from \\
Kuwait and 68 from Turkey. One \\
civilian was killld and 16 others, \\
including a child, were wounded. \\
Eleven heat flares were also dropped \\
in cultivated areas in northern Iraq."
\end{tabular} & $\begin{array}{l}\text { None } \\
\text { identified }\end{array}$ & None identified & $\begin{array}{l}\text { None } \\
\text { identified }\end{array}$ & Article 51 & $\begin{array}{l}\text { http: } \\
\text { //www.un. } \\
\text { org/en/ga/ } \\
\text { search/vie } \\
\text { w_doc. } \\
\text { asp? } \\
\text { symbol=s/ } \\
\text { 2000/850 }\end{array}$ & \begin{tabular}{|l||} 
http://www. \\
un. \\
org/en/ga/se \\
arch/view_do \\
c.asp? \\
symbol=s/200 \\
o/850\&Lang= \\
A
\end{tabular} & 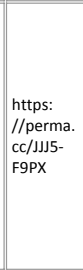 \\
\hline
\end{tabular}


VI. HLS PILAC Catalogue of Apparent “Article 51 Communications”

\begin{tabular}{|c|c|c|c|c|c|c|c|c|c|c|c|c|c|c|c|c|c|}
\hline $\begin{array}{l}\text { Chron. } \\
\text { Order }\end{array}$ & $\begin{array}{l}\text { Date of } \\
\text { Comm. }\end{array}$ & $\begin{array}{c}\text { Date of } \\
\text { UNsc } \\
\text { Document }\end{array}$ & UNSC Symbol & \begin{tabular}{||c} 
Member \\
State(s) That \\
Submitted \\
the Comm.
\end{tabular} & \begin{tabular}{|l} 
Expressly \\
Mentioned UN \\
Members (\& \\
Colonial \\
Holdings \& \\
Protectorates, \\
if any)
\end{tabular} & \begin{tabular}{|l} 
Express or \\
Implied \\
Assertion of \\
Individual, \\
Collective, or \\
Both Self- \\
defense
\end{tabular} & $\begin{array}{c}\text { Nature of } \\
\text { the Alleged } \\
\text { Threat }\end{array}$ & $\begin{array}{l}\text { Expressly Alleged } \\
\text { Author(s) of the } \\
\text { Threat (If Any } \\
\text { Indicated) }\end{array}$ & \begin{tabular}{|l} 
Nature of the \\
Alleged \\
Author(s) of \\
the Threat (If \\
Any \\
Indicated)
\end{tabular} & $\begin{array}{l}\text { Summary of Alleged Self-defense } \\
\text { Grounds }\end{array}$ & $\begin{array}{c}\text { UNSC } \\
\text { Meeting(s) } \\
\text { (If Any) at } \\
\text { Which the } \\
\text { Comm. was } \\
\text { Raised }\end{array}$ & $\begin{array}{l}\text { Responsive Act (If Any) by the } \\
\text { UNSC }\end{array}$ & \begin{tabular}{||c} 
UN \\
Repertory \\
Inclusion?
\end{tabular} & \begin{tabular}{|c|} 
UNSC \\
Repertoire \\
Inclusion?
\end{tabular} & \begin{tabular}{|c} 
URL to an \\
English \\
Text
\end{tabular} & \begin{tabular}{|c||} 
URL to Non- \\
English \\
Original \\
Text (ff Any)
\end{tabular} & $\begin{array}{c}\text { Perma.cc } \\
\text { URL }\end{array}$ \\
\hline 335 & 2000.09.04 & 2000.09.07 & S/2000/851 & Iraq & $\begin{array}{l}\text { Iraq, United } \\
\text { States, United } \\
\text { Kingdom, } \\
\text { Saudi Arabia, } \\
\text { Kuwait, Turkey }\end{array}$ & $\begin{array}{c}\text { Implied } \\
\text { assertion of } \\
\text { "individual" } \\
\text { self-defense }\end{array}$ & $\begin{array}{c}\text { Conducted } \\
\text { attack }\end{array}$ & $\begin{array}{l}\text { United States, } \\
\text { United Kingdom, } \\
\text { Saudi Arabia,, } \\
\text { Kuwait, Turkey }\end{array}$ & States & \begin{tabular}{|l} 
"IO]ngoing wanton aggression against \\
Iraq by United States and British \\
aircraft in the unlawful no-flight zones \\
.. in the period from 24 to 31 August \\
2000 they carried out 272 sorties, 156 \\
of them from Saudi Arabia, 48 from \\
Kuwwait and 68 from Turkey. One \\
civilian was killld and 16 others, \\
including a child, were wounded. \\
Eleven heat flares were also dropped \\
in cultivated areas in northern Iraq."
\end{tabular} & $\begin{array}{l}\text { None } \\
\text { identified }\end{array}$ & None identified & $\begin{array}{l}\text { None } \\
\text { identified }\end{array}$ & Article 51 & \begin{tabular}{|l||} 
http: \\
//www.un. \\
org//nen/// \\
search/vie \\
w_doc. \\
asp? \\
symbol=s/ \\
2000/851
\end{tabular} & \begin{tabular}{|l||} 
http://www. \\
un. \\
org/en/ga/se \\
arch/view_do \\
c.asp? \\
symbol=s/200 \\
o/851\&Lang= \\
A
\end{tabular} & $\begin{array}{l}\text { hitps: } \\
\text { ///perma. } \\
\text { cc//X34H- } \\
\text { 7wDY }\end{array}$ \\
\hline 336 & 2000.09.21 & 2000.09.22 & S/2000/895 & Iraq & $\begin{array}{l}\text { Iraq, United } \\
\text { States, United } \\
\text { Kingdom, } \\
\text { Saudi Arabia, } \\
\text { Kuwait, Turkey }\end{array}$ & $\begin{array}{c}\text { Implied } \\
\text { assertion of } \\
\text { "individual" } \\
\text { self-defense }\end{array}$ & $\begin{array}{c}\text { Conducted } \\
\text { attack }\end{array}$ & $\begin{array}{l}\text { United States, } \\
\text { United Kingdom, } \\
\text { Saudi Arabia, } \\
\text { Kuwait, Turkey }\end{array}$ & States & $\begin{array}{l}\text { "[O]ngoing wanton aggression against } \\
\text { Iraq by United States and British } \\
\text { airraft in the unlawful no-flight zones } \\
\text {... in the period from } 1 \text { to } 8 \text { September } \\
2000 \text { they carried out } 278 \text { sorties, } 174 \\
\text { of them from Saudi Arabia, } 8 \text { from } \\
\text { Kuwait and } 16 \text { from Turkey." }\end{array}$ & $\begin{array}{l}\text { None } \\
\text { identified }\end{array}$ & None identified & $\begin{array}{l}\text { None } \\
\text { identified }\end{array}$ & Article 51 & \begin{tabular}{|l|} 
http: \\
h/www.un. \\
org/en/ga/ \\
search/vie \\
w_doc. \\
asp? \\
spmbol=s/ \\
2000/895 \\
\end{tabular} & \begin{tabular}{|l|} 
http://www. \\
un. \\
org/en/ga/se \\
arch/view_do \\
c.asp? \\
symbol=S/200 \\
O/895\&Lang= \\
A
\end{tabular} & \begin{tabular}{|l} 
hitps: \\
//perma. \\
cc/6VWC- \\
ATgB
\end{tabular} \\
\hline 337 & 2000.09.28 & 2000.09.29 & S/2000/924 & Iraq & $\begin{array}{l}\text { Iraq, United } \\
\text { States, United } \\
\text { Kingdom, } \\
\text { Saudi Arabia, } \\
\text { Kuwait, Turkey }\end{array}$ & $\begin{array}{c}\text { Implied } \\
\text { assertion of } \\
\text { "individual" } \\
\text { self-defense }\end{array}$ & $\begin{array}{c}\text { Conducted } \\
\text { attack }\end{array}$ & $\begin{array}{l}\text { United States, } \\
\text { United Kingdom, } \\
\text { Saudi Arabia,, } \\
\text { Kuwait, Turkey }\end{array}$ & States & $\begin{array}{l}\text { "[O]ngoing wanton aggression against } \\
\text { Iraq by United States and British } \\
\text { airraft in the unlawfulu no-fly zones. } \\
\text { During the period from } 9 \text { to } 23 \\
\text { September } 2000, \text { these aircraft carried } \\
\text { out } 629 \text { aggressive sorties, } 367 \text { of } \\
\text { them from Saudi Arabia, } 102 \text { from } \\
\text { Kuwait and } 160 \text { from Turkey." }\end{array}$ & $\begin{array}{l}\text { None } \\
\text { identified }\end{array}$ & None identified & $\begin{array}{l}\text { None } \\
\text { identified }\end{array}$ & Article 51 & \begin{tabular}{|l||} 
http: \\
//www.un. \\
org//enga/ \\
search/vie \\
w_doc. \\
a_p? \\
symbol=s/ \\
2000/924
\end{tabular} & \begin{tabular}{|l||} 
http://www. \\
un. \\
org/en/ga/se \\
arch/view_do \\
c.asp? \\
symbol=s/200 \\
O/g24\&Lang= \\
A
\end{tabular} & \begin{tabular}{|l} 
hitps: \\
///perma. \\
cc/17DT- \\
D38D
\end{tabular} \\
\hline 338 & 2000.10 .05 & 2000.10.06 & S/2000/968 & Iraq & $\begin{array}{l}\text { Iraq, United } \\
\text { States, United } \\
\text { Kingdom, } \\
\text { Saudi Arabia, } \\
\text { Kuwait, Turkey }\end{array}$ & $\begin{array}{l}\text { Implied } \\
\text { assertion of } \\
\text { "individual" } \\
\text { self-defense }\end{array}$ & $\begin{array}{c}\text { Conducted } \\
\text { attack }\end{array}$ & $\begin{array}{l}\text { United States, } \\
\text { United Kingdom, } \\
\text { Saudi Arabia,, } \\
\text { Kuwait, Turkey }\end{array}$ & States & $\begin{array}{l}\text { "[O]ngoing wanton aggression against } \\
\text { Iraq by United States and British } \\
\text { aircraft in the unlawful no-flight zones } \\
\text {... in the period from } 24 \text { to } 30 \\
\text { September } 2000 \text { they carried out } 298 \\
\text { sorties, } 174 \text { of them from Saudi } \\
\text { Arabia, } 58 \text { from Kuwait and } 66 \text { from } \\
\text { Turkey." }\end{array}$ & $\begin{array}{l}\text { None } \\
\text { identified }\end{array}$ & None identified & $\begin{array}{l}\text { None } \\
\text { identified }\end{array}$ & Article 51 & \begin{tabular}{|l||} 
http: \\
//www.un. \\
org//en/ga/ \\
search/vie \\
w_doc. \\
asp? \\
symbol=s/ \\
2000/968 \\
\end{tabular} & $\begin{array}{l}\text { http://www. } \\
\text { un.: } \\
\text { org/en/ga/se } \\
\text { arch/view_do } \\
\text { c.asp? } \\
\text { symbol=s/2oo } \\
\text { 0/968\&Lang= } \\
\text { A }\end{array}$ & $\begin{array}{l}\text { litps: } \\
\text { //perma. } \\
\text { cc/2PLT- } \\
\text { TZHA }\end{array}$ \\
\hline 339 & 2000.10.11 & 2000.10.17 & S/2000/997 & Iraq & $\begin{array}{l}\text { Iraq, United } \\
\text { States, United } \\
\text { Kingdom, } \\
\text { Saudi Arabia, } \\
\text { Kuwait, Turkey }\end{array}$ & $\begin{array}{l}\text { Implied } \\
\text { assertion of } \\
\text { "individual" } \\
\text { self-defense }\end{array}$ & $\begin{array}{c}\text { Conducted } \\
\text { attack }\end{array}$ & $\begin{array}{l}\text { United States, } \\
\text { United Kingdom, } \\
\text { Saudi Arabia,, } \\
\text { Kuwait, Turkey }\end{array}$ & States & $\begin{array}{l}\text { "[O]ngoing wanton aggression against } \\
\text { Iraq by United States and British } \\
\text { aircraft in the unlawful no-flight zones } \\
\text {... in the period from } 1 \text { to } 8 \text { October } \\
2000 \text { they carried out } 268 \text { sorties, } 124 \\
\text { of them from Saudi Arabia, } 78 \text { from } \\
\text { Kuwait and } 66 \text { from Turkey." }\end{array}$ & $\begin{array}{l}\text { None } \\
\text { identified }\end{array}$ & None identified & $\begin{array}{l}\text { None } \\
\text { identified }\end{array}$ & Article 51 & \begin{tabular}{|l|} 
http: \\
1/www.un. \\
org/en/ga/ \\
search/vie \\
w_doc. \\
asp? \\
spmbol=s/ \\
2000/997 \\
\end{tabular} & $\begin{array}{l}\text { http://www. } \\
\text { un. } \\
\text { org/en/ga/se } \\
\text { arch/view_do } \\
\text { c.asp? } \\
\text { symbol=S/200 } \\
\text { 0/997\&Lang= } \\
\text { A }\end{array}$ & \begin{tabular}{|l} 
litps: \\
//perma. \\
cc//AG65- \\
W45E
\end{tabular} \\
\hline 340 & 2000.10 .22 & 2000.10.23 & $\mathrm{S} / 2000 / 1012$ & Iraq & $\begin{array}{l}\text { Iraq, United } \\
\text { States, United } \\
\text { Kingdom, } \\
\text { Saudi Arabia, } \\
\text { Kuwait, Turkey }\end{array}$ & \begin{tabular}{|l}
\multicolumn{1}{|c}{ Implied } \\
assertion of \\
"individual" \\
self-defense
\end{tabular} & $\begin{array}{c}\text { Conducted } \\
\text { attack }\end{array}$ & $\begin{array}{l}\text { United States, } \\
\text { United Kingdom, } \\
\text { Saudi Arabia,, } \\
\text { Kuwait, Turkey }\end{array}$ & States & $\begin{array}{l}\text { "IO]ngoing wanton aggression against } \\
\text { Iraq by United States and British } \\
\text { aircraft in the unlawful no-flight zones } \\
\text {... in the period from } 9 \text { to } 15 \text { October } \\
2000 \text { they carried out } 198 \text { sorties, } 90 \\
\text { of them from Saudi Arabia, } 78 \text { from } \\
\text { Kuwait and } 30 \text { from Turkey." }\end{array}$ & $\begin{array}{l}\text { None } \\
\text { identified }\end{array}$ & None identified & $\begin{array}{l}\text { None } \\
\text { identified }\end{array}$ & Article 51 & \begin{tabular}{|l|} 
http: \\
//www.un. \\
org/en///ai \\
search/vie \\
w_doc. \\
asp? \\
symbol=s/ \\
2000/1012
\end{tabular} & \begin{tabular}{|l|} 
http://www. \\
un. \\
org/en/ga/se \\
arch/view_do \\
c.asp? \\
symbol=S/200 \\
0/1012\&Lang \\
$=$ A
\end{tabular} & $\begin{array}{l}\text { litps: } \\
\text { ///perma. } \\
\text { cc/foget- } \\
\text { xGNM }\end{array}$ \\
\hline 341 & 2000.11 .05 & 2000.11.06 & S/2000/1069 & Iraq & $\begin{array}{l}\text { Iraq, United } \\
\text { States, United } \\
\text { Kingdom, } \\
\text { Saudi Arabia, } \\
\text { Kuwait, Turkey }\end{array}$ & $\begin{array}{l}\text { Implied } \\
\text { assertion of } \\
\text { "individual" } \\
\text { self-defense }\end{array}$ & $\begin{array}{c}\text { Conducted } \\
\text { attack }\end{array}$ & $\begin{array}{l}\text { United States, } \\
\text { United Kingdom, } \\
\text { Saudi Arabia,, } \\
\text { Kuwait, Turkey }\end{array}$ & States & $\begin{array}{l}\text { "IO]ngoing wanton aggression against } \\
\text { Iraq by United States and British } \\
\text { aircraft in the unlawful no-flight zones } \\
\text { and to the fact that in the period from } \\
24 \text { to } 31 \text { October } 2000 \text { they carried } \\
\text { out } 428 \text { sorties, } 262 \text { of them from } \\
\text { Saudi Arabia, } 8 \text { from Kuwait and } 82 \\
\text { from Turkey." }\end{array}$ & $\begin{array}{l}\text { None } \\
\text { identified }\end{array}$ & None identified & $\begin{array}{l}\text { None } \\
\text { identified }\end{array}$ & Articles 51 & \begin{tabular}{|l|} 
http: \\
//www.un. \\
org/en///aa/ \\
search/vie \\
w_doc. \\
asp? \\
symbol=s/ \\
2000/1069 \\
\end{tabular} & $\begin{array}{l}\text { http://www. } \\
\text { un. } \\
\text { org/en/ga/se } \\
\text { arch/view_do } \\
\text { c.asp? } \\
\text { symbol=S/200 } \\
0 / 1069 \& L a n g \\
\text { =A }\end{array}$ & \begin{tabular}{|l} 
hitps: \\
//perma. \\
cc//856D- \\
65ME
\end{tabular} \\
\hline
\end{tabular}


VI. HLS PILAC Catalogue of Apparent “Article 51 Communications”

\begin{tabular}{|c|c|c|c|c|c|c|c|c|c|c|c|c|c|c|c|c|c|}
\hline $\begin{array}{l}\text { Chron. } \\
\text { Order }\end{array}$ & $\begin{array}{l}\text { Date of } \\
\text { Comm. }\end{array}$ & $\begin{array}{c}\text { Date of } \\
\text { UNSC } \\
\text { Document }\end{array}$ & UNSC Symbol & \begin{tabular}{|c} 
Member \\
State(s) That \\
Submitted \\
the Comm.
\end{tabular} & \begin{tabular}{|c||} 
Expressly \\
Mentioned UN \\
Members (\& \\
Colonial \\
Holdings \& \\
Protectorates, \\
if any) \\
\end{tabular} & \begin{tabular}{|c|} 
Express or \\
Implied \\
Assertion of \\
Individual, \\
Collective, or \\
Both Self- \\
defense \\
\end{tabular} & \begin{tabular}{|c} 
Nature of \\
the Alleged \\
Threat
\end{tabular} & $\begin{array}{l}\text { Expressly Alleged } \\
\text { Author(s) of the } \\
\text { Threat (If Any } \\
\text { Indicated) }\end{array}$ & \begin{tabular}{|c|} 
Nature of the \\
Alleged \\
Author(s) of \\
the Threat (If \\
Any \\
Indicated) \\
\end{tabular} & $\begin{array}{l}\text { Summary of Alleged Self-defense } \\
\text { Grounds }\end{array}$ & \begin{tabular}{|c} 
UNSC \\
Meeting(s) \\
(If Any) at \\
Which the \\
Comm. was \\
Raised
\end{tabular} & $\begin{array}{l}\text { Responsive Act (If Any) by the } \\
\text { UNSC }\end{array}$ & \begin{tabular}{|l} 
UN \\
Repertory \\
Inclusion?
\end{tabular} & \begin{tabular}{|c} 
UNSC \\
Repertoire \\
Inclusion?
\end{tabular} & \begin{tabular}{|c|} 
URL to an \\
English \\
Text
\end{tabular} & \begin{tabular}{|c} 
URL to Non- \\
English \\
Original \\
Text (If Any)
\end{tabular} & \begin{tabular}{|l} 
Perma.cc \\
URL
\end{tabular} \\
\hline 342 & 2000.11.27 & 2000.11.28 & $S / 2000 / 1128$ & Iraq & \begin{tabular}{|} 
Iraq, United \\
States, United \\
Kingdom, \\
Saudi Arabia, \\
Kuwait, Turkey
\end{tabular} & $\begin{array}{c}\text { Implied } \\
\text { assertion of } \\
\text { "individual" } \\
\text { self-defense }\end{array}$ & $\begin{array}{c}\text { Conducted } \\
\text { attack }\end{array}$ & $\begin{array}{l}\text { United States, } \\
\text { United Kingdom, } \\
\text { Saudi irabia, } \\
\text { Kuwait, Turkey }\end{array}$ & States & $\begin{array}{l}\text { "[O]ngoing wanton aggression against } \\
\text { Iraq by United States and British } \\
\text { aircraft in the unlawful no-flight zones } \\
\text {... in the period from } 1 \text { to } 14 \\
\text { November } 2000 \text { they carried out } 561 \\
\text { sorties, } 285 \text { of them from Saudi } \\
\text { Arabia, } 104 \text { from Kuwait and } 172 \text { from } \\
\text { Turkey." }\end{array}$ & $\begin{array}{l}\text { None } \\
\text { identified }\end{array}$ & None identified & $\begin{array}{l}\text { None } \\
\text { identified }\end{array}$ & $\begin{array}{l}\text { Article 39, } \\
51\end{array}$ & \begin{tabular}{|l||} 
http: \\
//www.un. \\
org//en/ga/ \\
search/vie \\
w_doc. \\
asp? \\
spybol=s/ \\
2000/1128 \\
\end{tabular} & \begin{tabular}{|l||} 
http://www. \\
un. \\
org/en/ga/se \\
arch/view_do \\
c.asp? \\
symbol=s/200 \\
O/1128\&Lang \\
=A
\end{tabular} & $\begin{array}{l}\text { https: } \\
\text { //perma. } \\
\text { cc/EWWS- } \\
\text { NYG3 }\end{array}$ \\
\hline 343 & 2000.12.03 & 2000.12.06 & S/2000/1155 & Iraq & \begin{tabular}{|} 
Iraq, United \\
States, United \\
Kingdom, \\
Saudi Arabia, \\
Kuwait, Turkey
\end{tabular} & $\begin{array}{c}\text { Implied } \\
\text { assertion of } \\
\text { "individual" } \\
\text { self-defense }\end{array}$ & $\begin{array}{c}\text { Conducted } \\
\text { attack }\end{array}$ & $\begin{array}{l}\text { United States, } \\
\text { United Kingdom, } \\
\text { Saudi Arabia, } \\
\text { Kuwait, Turkey }\end{array}$ & States & $\begin{array}{l}\text { "IO]ngoing wanton aggression against } \\
\text { Iraq by United States and British } \\
\text { aircraft in the unlawful no-flight zones } \\
\ldots \text { in the period from } 15 \text { to } 25 \\
\text { November } 2000 \text { they carried out } 314 \\
\text { sorties, } 134 \text { of them from Saudi } \\
\text { Arabia, } 62 \text { from Kuwait and } 118 \text { from } \\
\text { Turkey." }\end{array}$ & $\begin{array}{l}\text { None } \\
\text { identified }\end{array}$ & None identified & $\begin{array}{l}\text { None } \\
\text { identified }\end{array}$ & $\begin{array}{l}\text { Article 39, } \\
51\end{array}$ & \begin{tabular}{|l||} 
http: \\
//www.un. \\
org//en/ga/ \\
search/vie \\
w_doc. \\
asp? \\
spmbol=s/ \\
2000/1155 \\
200
\end{tabular} & $\begin{array}{l}\text { http://www. } \\
\text { un. } \\
\text { org/en/ga/se } \\
\text { arch/view_do } \\
\text { c.asp? } \\
\text { symbol=S/200 } \\
\text { O/1155\&Lang } \\
\text { =A }\end{array}$ & \begin{tabular}{|l} 
https: \\
//perma. \\
cc/20D3D- \\
K5V3
\end{tabular} \\
\hline 344 & 2000.12.07 & 2000.12.07 & $\mathrm{S} / 2000 / 1165$ & Iraq & \begin{tabular}{|} 
Iraq, United \\
States, United \\
Kingdom, \\
Saudi Arabia, \\
Kuwait, Turkey
\end{tabular} & $\begin{array}{c}\text { Implied } \\
\text { assertion of } \\
\text { "individual" } \\
\text { self-defense }\end{array}$ & $\begin{array}{c}\text { Conducted } \\
\text { attack }\end{array}$ & $\begin{array}{l}\text { United States, } \\
\text { United Kingdom, } \\
\text { Saudi irabia, } \\
\text { Kuwait, Turkey }\end{array}$ & States & $\begin{array}{l}\text { "[O]ngoing wanton aggression against } \\
\text { Iraq by United States and British } \\
\text { aircraft in the unlawful no-flight zones } \\
\text {... in the period from } 26 \text { November to } \\
2 \text { December } 2000 \text { they carried out } 212 \\
\text { sorties, } 100 \text { of them from Saudi } \\
\text { Arabia, } 74 \text { from Kuwait and } 38 \text { from } \\
\text { Turkey." }\end{array}$ & $\begin{array}{l}\text { None } \\
\text { identified }\end{array}$ & None identified & $\begin{array}{l}\text { None } \\
\text { identified }\end{array}$ & $\begin{array}{l}\text { Article 39, } \\
51\end{array}$ & \begin{tabular}{|l||} 
http: \\
//www.un. \\
org//en/ga/ \\
search/vie \\
w_doc. \\
asp? \\
spmbol=s/ \\
2000/1165 \\
\end{tabular} & \begin{tabular}{|l|} 
http://www. \\
un. \\
org/en/ga/se \\
arch/view_do \\
c.asp? \\
symbol=S/200 \\
O/1165\&Lang \\
=A
\end{tabular} & $\begin{array}{l}\text { https: } \\
\text { //perma. } \\
\text { cc/8MD2- } \\
\text { JAGA }\end{array}$ \\
\hline 345 & 2000.12.17 & 2000.12.19 & $\mathrm{S} / 2000 / 1208$ & Iraq & \begin{tabular}{|} 
Iraq, United \\
States, United \\
Kingdom, \\
Saudi Arabia, \\
Kuwait, Turkey
\end{tabular} & $\begin{array}{c}\text { Implied } \\
\text { assertion of } \\
\text { "individual" } \\
\text { self-defense }\end{array}$ & $\begin{array}{c}\text { Conducted } \\
\text { attack }\end{array}$ & $\begin{array}{l}\text { United States, } \\
\text { United Kingdom, } \\
\text { Saudi Arabia, } \\
\text { Kuwait, Turkey }\end{array}$ & States & $\begin{array}{l}\text { "IO]ngoing wanton aggression against } \\
\text { Iraq by United States and British } \\
\text { aircraft in the unlawful no-flight zones } \\
\text {... in the period from } 3 \text { to } 10 \\
\text { December } 2000 \text { they carried out } 287 \\
\text { sorties, } 135 \text { of them from Saudi } \\
\text { Arabia, } 70 \text { from Kuwait and } 82 \text { from } \\
\text { Turkey." }\end{array}$ & $\begin{array}{l}\text { None } \\
\text { identified }\end{array}$ & None identified & $\begin{array}{l}\text { None } \\
\text { identified }\end{array}$ & $\begin{array}{l}\text { Article 39, } \\
51\end{array}$ & \begin{tabular}{|l||} 
http: \\
//www.un. \\
org//en/ga/ \\
search/vie \\
w_doc. \\
asp? \\
symbol=s/ \\
2000/1208 \\
\end{tabular} & \begin{tabular}{|l||} 
http://www. \\
un. \\
org/en/ga/se \\
arch/view_do \\
c.asp? \\
symbol=S/200 \\
O/1208\&Lang \\
=A
\end{tabular} & \begin{tabular}{|l} 
https: \\
//perma. \\
c/UYYG- \\
AK79
\end{tabular} \\
\hline 346 & 2000.12.21 & 2000.12.22 & S/2000/1229 & Iraq & \begin{tabular}{|} 
Iraq, United \\
States, United \\
Kingdom, \\
Saudi Arabia, \\
Kuwait, Turkey
\end{tabular} & $\begin{array}{c}\text { Implied } \\
\text { assertion of } \\
\text { "individual" } \\
\text { self-defense }\end{array}$ & $\begin{array}{c}\text { Conducted } \\
\text { attack }\end{array}$ & $\begin{array}{l}\text { United States, } \\
\text { United Kingdom, } \\
\text { Saudi Arabia,, } \\
\text { Kuwait, Turkey }\end{array}$ & States & $\begin{array}{l}\text { "IO]ngoing wanton aggression against } \\
\text { Iraq by United States and British } \\
\text { aircraft in the unlawful no-fly zones. } \\
\text { During the period from } 11 \text { to } 17 \\
\text { December 2000, these aircraft carried } \\
\text { out } 194 \text { aggressive sorties, } 78 \text { of them } \\
\text { from Saudi Arabia, } 6 \text { from Kuwait } \\
\text { and } 50 \text { from Turkey." }\end{array}$ & \begin{tabular}{|l} 
None \\
identified
\end{tabular} & None identified & $\begin{array}{l}\text { None } \\
\text { identified }\end{array}$ & $\begin{array}{l}\text { Article 39, } \\
51\end{array}$ & \begin{tabular}{|l||} 
http: \\
//www.un. \\
org//en/ga/ \\
search/vie \\
w_doc. \\
asp? \\
spmbol=s/ \\
2000/1229 \\
\end{tabular} & \begin{tabular}{|l|} 
http: //www. \\
un. \\
org/en/ga/se \\
arch/view_do \\
c.asp? \\
symbol=S/200 \\
O/1229\&Lang \\
=A
\end{tabular} & $\begin{array}{l}\text { https: } \\
\text { //perma. } \\
\text { cc/UuW2- } \\
\text { 8TMV }\end{array}$ \\
\hline 347 & 2000.12.26 & 2000.12.29 & $\mathrm{S} / 2000 / 1248$ & Iraq & \begin{tabular}{|} 
Iraq, United \\
States, United \\
Kingdom, \\
Saudi Arabia, \\
Kuwait, Turkey
\end{tabular} & $\begin{array}{c}\text { Implied } \\
\text { assertion of } \\
\text { "individual" } \\
\text { self-defense }\end{array}$ & $\begin{array}{c}\text { Conducted } \\
\text { attack }\end{array}$ & $\begin{array}{l}\text { United States, } \\
\text { United Kingdom, } \\
\text { Saudi Arabia,, } \\
\text { Kuwait, Turkey }\end{array}$ & States & \begin{tabular}{|l} 
"IO]ngoing wanton aggression against \\
Iraq by United States and British \\
aircraft in the unlawfulu no-flight \\
zones. During the period from 18 to \\
23 December 2000 , these aircraft \\
carried out 212 aggressive sorties, 100 \\
of them from Saudi Arabia, 60 from \\
Kuwait and 52 from Turkey."
\end{tabular} & $\begin{array}{l}\text { None } \\
\text { identified }\end{array}$ & None identified & $\begin{array}{l}\text { None } \\
\text { identified }\end{array}$ & $\begin{array}{l}\text { Article 39, } \\
51\end{array}$ & \begin{tabular}{|l||} 
http: \\
//www.un. \\
org//en/ga/ \\
search/vie \\
w_doc. \\
asp? \\
symbol=s/ \\
2000/1248 \\
\end{tabular} & $\begin{array}{l}\text { http://www. } \\
\text { un. } \\
\text { org/en/ga/se } \\
\text { arch/view_do } \\
\text { c.asp? } \\
\text { symbol=s/200 } \\
\text { 0/1248\&Lang } \\
=\text { A }\end{array}$ & \begin{tabular}{|l} 
https: \\
//perma. \\
c/3CYN- \\
RE53
\end{tabular} \\
\hline 348 & 2001.01.11 & 2001.01.15 & $s / 2001 / 37$ & Iraq & \begin{tabular}{|} 
Iraq, United \\
States, United \\
Kingdom, \\
Saudi Arabia, \\
Kuwait, Turkey
\end{tabular} & $\begin{array}{c}\text { Implied } \\
\text { assertion of } \\
\text { "individual" } \\
\text { self-defense }\end{array}$ & $\begin{array}{c}\text { Conducted } \\
\text { attack }\end{array}$ & $\begin{array}{l}\text { United States, } \\
\text { United Kingdom, } \\
\text { Saudi Arabia, } \\
\text { Kuwait, Turkey }\end{array}$ & States & $\begin{array}{l}\text { "[O]ngoing wanton aggression against } \\
\text { Iraq by United States and British } \\
\text { aircraft in the unlawful no-flight zones } \\
\text {... in the period from } 1 \text { to } 6 \text { January } \\
2001 \text { they carried out } 137 \text { sorties, } 72 \\
\text { of them from Saudi Arabia, } 47 \text { from } \\
\text { Kuwait and } 18 \text { from Turkey." }\end{array}$ & \begin{tabular}{|l} 
None \\
identified
\end{tabular} & None identified & \begin{tabular}{|l} 
None \\
identified
\end{tabular} & $\begin{array}{l}\text { Article 39, } \\
51\end{array}$ & \begin{tabular}{|l||} 
http: \\
//www.un. \\
org//en/ga/ \\
search/vie \\
w_doc. \\
asp? \\
symbol=s/ \\
2001/37 \\
\end{tabular} & \begin{tabular}{|l||} 
http://www. \\
un. \\
org/en/ga/se \\
arch/view_do \\
c.asp? \\
symbol=S/200 \\
$1 / 37 \&$ Lang=A \\
\end{tabular} & $\begin{array}{l}\text { https: } \\
\text { //perma. } \\
\text { cc/9558- } \\
\text { 4YuN }\end{array}$ \\
\hline 349 & 2001.01.23 & 2001.01.24 & $S / 2001 / 79$ & Iraq & \begin{tabular}{|} 
Iraq, United \\
States, United \\
Kingdom, \\
Saudi Arabia, \\
Kuwait, Turkey
\end{tabular} & $\begin{array}{c}\text { Implied } \\
\text { assertion of } \\
\text { "individual" } \\
\text { self-defense }\end{array}$ & $\begin{array}{c}\text { Conducted } \\
\text { attack }\end{array}$ & $\begin{array}{l}\text { United States, } \\
\text { United Kingdom, } \\
\text { Saudi Arabia, } \\
\text { Kuwait, Turkey }\end{array}$ & States & \begin{tabular}{|l} 
"OO]ngoing wanton aggression against \\
Iraq by United States and British \\
aircraft in the unlawful no-flight zones \\
$\ldots$ in the period from 8 to 16 January \\
2001 they carried out 185 sorties, 64 \\
of them from Saudi Arabia, 73 from \\
Kuwait and 48 from Turkey."
\end{tabular} & \begin{tabular}{|l} 
None \\
identified
\end{tabular} & None identified & \begin{tabular}{|l} 
None \\
identified
\end{tabular} & $\begin{array}{l}\text { Article 39, } \\
51\end{array}$ & \begin{tabular}{|l||} 
http: \\
//www.un. \\
org//nen/ga/ \\
search/vie \\
w_doc. \\
asp? \\
symbol=s/ \\
2001/79 \\
\end{tabular} & \begin{tabular}{|l||} 
http://www. \\
un. \\
org/en/ga/se \\
arch/view_do \\
c.asp? \\
symbol=S/200 \\
$1 / 79 \& L$ Lang=A \\
\end{tabular} & \begin{tabular}{|l} 
https: \\
//perma. \\
cc/44EM- \\
2895
\end{tabular} \\
\hline
\end{tabular}


VI. HLS PILAC Catalogue of Apparent “Article 51 Communications”

\begin{tabular}{|c|c|c|c|c|c|c|c|c|c|c|c|c|c|c|c|c|c|}
\hline $\begin{array}{l}\text { Chron. } \\
\text { Order }\end{array}$ & $\begin{array}{l}\text { Date of } \\
\text { comm. }\end{array}$ & \begin{tabular}{|c} 
Date of \\
UNsc \\
Document
\end{tabular} & UNSC Symbol & \begin{tabular}{|c} 
Member \\
State(s) That \\
Submitted \\
the Comm.
\end{tabular} & \begin{tabular}{|c||} 
Expressly \\
Mentioned UN \\
Members (\& \\
Colonial \\
Holdings \& \\
Protectorates, \\
if any) \\
\end{tabular} & \begin{tabular}{||c|} 
Express or \\
Implied \\
Assertion of \\
Individual, \\
Collective, or \\
Both Self- \\
defense \\
\end{tabular} & \begin{tabular}{|c} 
Nature of \\
the Alleged \\
Threat
\end{tabular} & $\begin{array}{l}\text { Expressly Alleged } \\
\text { Author(s) of the } \\
\text { Threat (If Any } \\
\text { Indicated) }\end{array}$ & \begin{tabular}{|c|} 
Nature of the \\
Alleged \\
Author(s) of \\
the Threat (If \\
Any \\
Indicated)
\end{tabular} & $\begin{array}{l}\text { Summary of Alleged Self-defense } \\
\text { Grounds }\end{array}$ & \begin{tabular}{|c|} 
UNsc \\
Meeting(s) \\
(if Any) at \\
Which the \\
Comm. was \\
Raised
\end{tabular} & $\begin{array}{l}\text { Responsive Act (If Any) by the } \\
\text { UNSC }\end{array}$ & $\begin{array}{l}\text { UN } \\
\text { Repertory } \\
\text { Inclusion? }\end{array}$ & $\begin{array}{c}\text { UNSC } \\
\text { Repertoire } \\
\text { Inclusion? }\end{array}$ & \begin{tabular}{|c||} 
URL to an \\
English \\
Text
\end{tabular} & \begin{tabular}{||c||} 
URL to Non- \\
English \\
Original \\
Tert (ff Any)
\end{tabular} & \begin{tabular}{|l} 
Perma.cc \\
URL
\end{tabular} \\
\hline 350 & 2001.02.05 & 2001.02.07 & S/2001/116 & Iraq & \begin{tabular}{|} 
Iraq, United \\
States, United \\
Kingdom, \\
Saudi Arabia, \\
Kuwait, Turkey
\end{tabular} & $\begin{array}{l}\text { Implied } \\
\text { assertion of } \\
\text { "individual" } \\
\text { self-defense }\end{array}$ & $\begin{array}{c}\text { Conducted } \\
\text { attack }\end{array}$ & $\begin{array}{l}\text { United States, } \\
\text { United Kingdom, } \\
\text { Saudi Arabia, } \\
\text { Kuwait, Turkey }\end{array}$ & States & $\begin{array}{l}\text { "IO]ngoing wanton aggression against } \\
\text { Iraq by United States and British } \\
\text { aircraft in the unlawful no-flight zones } \\
\ldots \text { in the period from } 17 \text { to } 25 \text { January } \\
2001 \text { they carried out } 215 \text { sorties, } 87 \\
\text { of them from Saudi Arabia, } 80 \text { from } \\
\text { Kuwait and } 88 \text { from Turkey." }\end{array}$ & $\begin{array}{l}\text { None } \\
\text { identified }\end{array}$ & None identified & $\begin{array}{l}\text { None } \\
\text { identified }\end{array}$ & $\begin{array}{l}\text { Article 39, } \\
51\end{array}$ & \begin{tabular}{|l||} 
http: \\
//www.un. \\
org//nn/gal \\
search/vie \\
w_doc. \\
asp? \\
symbol=s/ \\
2001/116 \\
\end{tabular} & \begin{tabular}{|l||} 
http://www. \\
un. \\
org/en/ga/se \\
arch/view_do \\
c.asp? \\
symbol=S/200 \\
$1 / 116 \& L$ Lang= \\
A \\
\end{tabular} & $\begin{array}{l}\text { https: } \\
\text { //perma. } \\
\text { cc/ADU9- } \\
\text { SSUH }\end{array}$ \\
\hline 351 & 2001.02.06 & 2001.02.09 & $\mathrm{S} / 2001 / 122$ & Iraq & \begin{tabular}{|} 
Iraq, United \\
States, United \\
Kingdom, \\
Saudi Arabia, \\
Kuwait, Turkey
\end{tabular} & 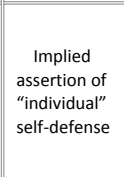 & $\begin{array}{c}\text { Conducted } \\
\text { attack }\end{array}$ & $\begin{array}{l}\text { United States, } \\
\text { United Kingdom, } \\
\text { Saudi Arabia, } \\
\text { Kuwait, Turkey }\end{array}$ & States & $\begin{array}{l}\text { "[O]ngoing wanton aggression against } \\
\text { Iraq by United States and British } \\
\text { airraft in the unlawful no-flight zones } \\
\text {... in the period from } 26 \text { January to } 1 \\
\text { February } 2001 \text { they carried out } 145 \\
\text { sorties, } 52 \text { of them from Saudi Arabia, } \\
35 \text { from Kuwait and } 58 \text { from Turkey." }\end{array}$ & $\begin{array}{l}\text { None } \\
\text { identified }\end{array}$ & None identified & $\begin{array}{l}\text { None } \\
\text { identified }\end{array}$ & $\begin{array}{l}\text { Article 39, } \\
51\end{array}$ & \begin{tabular}{|l||} 
http: \\
//www.un. \\
org/en/ga/ \\
search/vie \\
w_doc. \\
asp? \\
symbol=s/ \\
2001/122 \\
\end{tabular} & \begin{tabular}{|l||} 
http://www. \\
un. \\
org/en/ga/se \\
arch/view_do \\
c.asp? \\
symbol=S/200 \\
1/122\&Lang= \\
A
\end{tabular} & $\begin{array}{l}\text { https: } \\
\text { //perma. } \\
\text { cc/X3MT- } \\
\text { P6X9 }\end{array}$ \\
\hline 352 & 2001.02.14 & 2001.02.15 & S/2001/141 & Iraq & \begin{tabular}{|} 
Iraq, United \\
States, United \\
Kingdom, \\
Saudi Arabia, \\
Kuwait, Turkey
\end{tabular} & \begin{tabular}{|c} 
Implied \\
assertion of \\
"individual" \\
self-defense
\end{tabular} & $\begin{array}{c}\text { Conducted } \\
\text { attack }\end{array}$ & $\begin{array}{l}\text { United States, } \\
\text { United Kingdom, } \\
\text { Saudi Arabia, } \\
\text { Kuwait, Turkey }\end{array}$ & States & $\begin{array}{l}\text { "[O]ngoing wanton aggression against } \\
\text { Iraq by United States and British } \\
\text { airraft in the unlawfulu no-flight zones } \\
\text { and to the fact that in the period from } \\
2 \text { to } 6 \text { February } 2001 \text { they carried out } \\
167 \text { sorties, } 88 \text { of them from Saudi } \\
\text { Arabia, } 45 \text { from Kuwait and } 34 \text { from } \\
\text { Turkey." }\end{array}$ & $\begin{array}{l}\text { None } \\
\text { identified }\end{array}$ & None identified & $\begin{array}{l}\text { None } \\
\text { identified }\end{array}$ & $\begin{array}{l}\text { Article 39, } \\
51\end{array}$ & \begin{tabular}{|l||} 
http: \\
//www.un. \\
org//en/gal \\
search/vie \\
w_doc. \\
asp? \\
symbol=s/ \\
2001/141 \\
2001
\end{tabular} & \begin{tabular}{|l|} 
http://www. \\
un. \\
org/en/ga/se \\
arch/view_do \\
c.asp? \\
symbol=s/200 \\
$1 / 141 \& L$ Lang= \\
A
\end{tabular} & $\begin{array}{l}\text { https: } \\
\text { //perma. } \\
\text { cc/GEA2- } \\
\text { GR3J }\end{array}$ \\
\hline 353 & 2001.02.20 & 2001.02.22 & S/2001/161 & Iraq & \begin{tabular}{|} 
Iraq, United \\
States, United \\
Kingdom, \\
Saudi Arabia, \\
Kuwait, Turkey
\end{tabular} & $\begin{array}{c}\text { Implied } \\
\text { assertion of } \\
\text { "individual" } \\
\text { self-defense }\end{array}$ & $\begin{array}{c}\text { Conducted } \\
\text { attack }\end{array}$ & $\begin{array}{l}\text { United States, } \\
\text { United Kingdom, } \\
\text { Saudi Arabia, } \\
\text { Kuwait, Turkey }\end{array}$ & States & $\begin{array}{l}\text { "[O]ngoing wanton aggression against } \\
\text { Iraq by United States and British } \\
\text { airraft in the unlawful no-flight zones } \\
\text {... in the period from } 7 \text { to } 15 \text { February } \\
2001 \text { they carried out } 291 \text { sorties, } 99 \\
\text { of them from Saudi Arabia, } 128 \text { from } \\
\text { Kuwait and } 64 \text { from Turkey." }\end{array}$ & $\begin{array}{l}\text { None } \\
\text { identified }\end{array}$ & None identified & $\begin{array}{l}\text { None } \\
\text { identified }\end{array}$ & $\begin{array}{l}\text { Article 39, } \\
51\end{array}$ & \begin{tabular}{|l|} 
http: \\
//www.un. \\
org/en/ga/ \\
search/vie \\
w_doc. \\
asp? \\
symbol=s/ \\
2001/161 \\
\end{tabular} & \begin{tabular}{|l||} 
http://www. \\
un. \\
org/en/ga/se \\
arch/view_do \\
c.asp? \\
symbol=S/200 \\
$1 / 161 \&$ Lang= \\
A
\end{tabular} & $\begin{array}{l}\text { https: } \\
\text { //perma. } \\
\text { cc/G999- } \\
\text { XB92 }\end{array}$ \\
\hline 354 & 2001.02.25 & 2001.02.26 & $\mathrm{S} / 2001 / 168$ & Iraq & \begin{tabular}{|} 
Iraq, United \\
States, United \\
Kingdom, \\
Saudi Arabia, \\
Kuwait, Turkey
\end{tabular} & \begin{tabular}{|c|} 
Implied \\
assertion of \\
"individual" \\
self-defense
\end{tabular} & $\begin{array}{c}\text { Conducted } \\
\text { attack }\end{array}$ & $\begin{array}{l}\text { United States, } \\
\text { United Kingdom, } \\
\text { Saudi Arabia,, } \\
\text { Kuwait, Turkey }\end{array}$ & States & $\begin{array}{l}\text { "O]ngoing wanton aggression against } \\
\text { Iraq by United States and British } \\
\text { aircraft in the unlawful no-flight zones } \\
\ldots \text { in the period from } 16 \text { to } 22 \\
\text { February } 2001 \text { they carried out } 209 \\
\text { sorties, } 97 \text { of them from Saudi Arabia, } \\
58 \text { from Kuwait and } 54 \text { from Turkey." }\end{array}$ & \begin{tabular}{|l} 
None \\
identified
\end{tabular} & None identified & $\begin{array}{l}\text { None } \\
\text { identified }\end{array}$ & $\begin{array}{l}\text { Article 39, } \\
51\end{array}$ & \begin{tabular}{|l|} 
http: \\
//www.un. \\
org//n/gal \\
search/vie \\
w_doc. \\
asp? \\
symbol=s/ \\
2001/168 \\
\end{tabular} & \begin{tabular}{|l|} 
http://www. \\
un. \\
org/en/ga/se \\
arch/view_do \\
c.asp? \\
symbol=S/200 \\
$1 / 168 \& L a n g=$ \\
A \\
\end{tabular} & $\begin{array}{l}\text { https: } \\
\text { //perma. } \\
\text { cc/LQQu7- } \\
\text { X5E2 }\end{array}$ \\
\hline 355 & 2001.03.14 & 2001.03.15 & S/2001/227 & Iraq & \begin{tabular}{|} 
Iraq, United \\
States, United \\
Kingdom, \\
Saudi Arabia, \\
Kuwait, Turkey
\end{tabular} & \begin{tabular}{|c|} 
Implied \\
assertion of \\
"individual" \\
self-defense
\end{tabular} & $\begin{array}{c}\text { Conducted } \\
\text { attack }\end{array}$ & $\begin{array}{l}\text { United States, } \\
\text { United Kingdom, } \\
\text { Saudi Arabia, } \\
\text { Kuwait, Turkey }\end{array}$ & States & $\begin{array}{l}\text { "[O]ngoing wanton aggression against } \\
\text { Iraq by United States and British } \\
\text { aircraft in the unlawful no-flight zones } \\
\text {... in the period from } 23 \text { to } 27 \\
\text { February } 2001 \text { they carried out } 143 \\
\text { sorties, } 66 \text { of them from Saudi Arabia } \\
\text { and } 77 \text { from Kuwait." }\end{array}$ & \begin{tabular}{|l} 
None \\
identified
\end{tabular} & None identified & $\begin{array}{l}\text { None } \\
\text { identified }\end{array}$ & $\begin{array}{l}\text { Article 39, } \\
51\end{array}$ & \begin{tabular}{|l||} 
http: \\
//www.un. \\
org/en/ga/ \\
search/vie \\
w_doc. \\
asp? \\
symbol=s/ \\
2001/227 \\
\end{tabular} & \begin{tabular}{|l||} 
http://www. \\
un. \\
org/en/ga/se \\
arch/view_do \\
c.asp? \\
symbol=S/200 \\
1/227\&Lang= \\
A
\end{tabular} & $\begin{array}{l}\text { hetps: } \\
\text { //perma. } \\
\text { cc/4/4T- } \\
\text { UB2G }\end{array}$ \\
\hline 356 & 2001.03.20 & 2001.03.20 & $\mathrm{S} / 2001 / 248$ & Iraq & \begin{tabular}{|} 
Iraq, United \\
States, United \\
Kingdom, \\
Saudi Arabia, \\
Kuwait, Turkey
\end{tabular} & $\begin{array}{l}\text { Implied } \\
\text { assertion of } \\
\text { "individual" } \\
\text { self-defense }\end{array}$ & $\begin{array}{c}\text { Conducted } \\
\text { attack }\end{array}$ & $\begin{array}{l}\text { United States, } \\
\text { United Kingdom, } \\
\text { Saudi Arabia, } \\
\text { Kuwait, Turkey }\end{array}$ & States & \begin{tabular}{|l} 
"OO]ngoing wanton aggression against \\
Iraq by United States and British \\
aircraft in the unlawful no-flight zones \\
... in the period from 1 to 6 March \\
2001 they carried out 233 sorties, 109 \\
of them from Saudi Arabia, 75 from \\
Kuwait and 49 from Turkey."
\end{tabular} & $\begin{array}{l}\text { None } \\
\text { identified }\end{array}$ & None identified & $\begin{array}{l}\text { None } \\
\text { identified }\end{array}$ & $\begin{array}{l}\text { Article 39, } \\
51\end{array}$ & \begin{tabular}{|l||} 
http: \\
I/www.un. \\
org//nn/ga/ \\
search/pie \\
w_doc. \\
asp? \\
symbol=s/ \\
2001/248 \\
\end{tabular} & \begin{tabular}{|l||} 
http://www. \\
un. \\
org/en/ga/se \\
arch/view_do \\
c.asp? \\
symbol=S/200 \\
$1 / 248 \& L$ Lang= \\
A
\end{tabular} & $\begin{array}{l}\text { https: } \\
\text { //perma. } \\
\text { cc/8EBN- } \\
\text { XHYK }\end{array}$ \\
\hline 357 & 2001.03.28 & 2001.03.30 & S/2001/297 & Iraq & \begin{tabular}{|l} 
Iraq, United \\
States, United \\
Kingdom, \\
Saudi Arabia, \\
Kuwait, Turkey
\end{tabular} & $\begin{array}{l}\text { Implied } \\
\text { assertion of } \\
\text { "individual" } \\
\text { self-defense }\end{array}$ & $\begin{array}{c}\text { Conducted } \\
\text { attack }\end{array}$ & $\begin{array}{l}\text { United States, } \\
\text { United Kingdom, } \\
\text { Saudi Arabia, } \\
\text { Kuwait, Turkey }\end{array}$ & States & $\begin{array}{l}\text { "IO]ngoing wanton aggression against } \\
\text { Iraq by United States and British } \\
\text { aircraft in the unlawful no-flight zones } \\
\text {... in the period from } 6 \text { to } 18 \text { March } \\
2001 \text { they carried out } 230 \text { sorties, } 108 \\
\text { of them from Saudi Arabia, } 106 \text { from } \\
\text { Kuwait and } 16 \text { from Turkey." }\end{array}$ & \begin{tabular}{|l} 
None \\
identified
\end{tabular} & None identified & $\begin{array}{l}\text { None } \\
\text { identified }\end{array}$ & $\begin{array}{l}\text { Article 39, } \\
51\end{array}$ & \begin{tabular}{|l|} 
http: \\
//www.un. \\
org//nn/gal \\
search/vie \\
w_doc. \\
asp? \\
symbol=s/ \\
2001/297 \\
\end{tabular} & \begin{tabular}{|l||} 
http://www. \\
un. \\
org/en/ga/se \\
arch/view_do \\
c.asp? \\
symbol=S/200 \\
1/297\&Lang= \\
A
\end{tabular} & $\begin{array}{l}\text { https: } \\
\text { //perma. } \\
\text { cc//Y2BC- } \\
\text { HM8N }\end{array}$ \\
\hline
\end{tabular}


VI. HLS PILAC Catalogue of Apparent “Article 51 Communications”

\begin{tabular}{|c|c|c|c|c|c|c|c|c|c|c|c|c|c|c|c|c|c|}
\hline $\begin{array}{c}\text { Chron. } \\
\text { Order }\end{array}$ & $\begin{array}{l}\text { Date of } \\
\text { comm. }\end{array}$ & $\begin{array}{l}\text { Date of } \\
\text { UNsC } \\
\text { Document }\end{array}$ & UNSC Symbol & \begin{tabular}{||c} 
Member \\
State(s) That \\
Submitted \\
the Comm.
\end{tabular} & \begin{tabular}{||c||} 
Expressly \\
Mentioned UN \\
Members (\& \\
Colonial \\
Holdings \& \\
Protectorates, \\
if any) \\
\end{tabular} & \begin{tabular}{|c|} 
Express or \\
Implied \\
Assertion of \\
Individual, \\
Collective, or \\
Both Self- \\
defense \\
\end{tabular} & \begin{tabular}{|l} 
Nature of \\
the Alleged \\
Threat
\end{tabular} & $\begin{array}{l}\text { Expressly Alleged } \\
\text { Author(s) of the } \\
\text { Threat (If Any } \\
\text { Indicated) }\end{array}$ & \begin{tabular}{|c} 
Nature of the \\
Alleged \\
Author(s) of \\
the Threat (If \\
Any \\
Indicated)
\end{tabular} & $\begin{array}{l}\text { Summary of Alleged Self-defense } \\
\text { Grounds }\end{array}$ & $\begin{array}{l}\text { UNsC } \\
\text { Meeting(s) } \\
\text { (If Any) at } \\
\text { Which the } \\
\text { Comm. was } \\
\text { Raised }\end{array}$ & $\begin{array}{l}\text { Responsive Act (If Any) by the } \\
\text { UNSC }\end{array}$ & \begin{tabular}{|l} 
UN \\
Repertory \\
Inclusion?
\end{tabular} & \begin{tabular}{|c} 
UNSC \\
Repertoire \\
Inclusion?
\end{tabular} & $\begin{array}{l}\text { URL to an } \\
\text { English } \\
\text { Text }\end{array}$ & \begin{tabular}{||c||} 
URL to Non- \\
English \\
Original \\
Text (ff Any)
\end{tabular} & $\begin{array}{l}\text { Perma.cc } \\
\text { URL }\end{array}$ \\
\hline 358 & 2001.04.01 & 2001.04.03 & S/2001/316 & Iraq & \begin{tabular}{||l|} 
Iraq, United \\
States, United \\
Kingdom, \\
Saudi Arabia, \\
Kuwait, Turkey
\end{tabular} & $\begin{array}{c}\text { Implied } \\
\text { assertion of } \\
\text { "individual" } \\
\text { self-defense }\end{array}$ & $\begin{array}{c}\text { Conducted } \\
\text { attack }\end{array}$ & $\begin{array}{l}\text { United States, } \\
\text { United Kingdom, } \\
\text { Saudi irabia, } \\
\text { Kuwait, Turkey }\end{array}$ & States & \begin{tabular}{|l} 
"OO]ngoing wanton aggression against \\
Iraq by Unitied States and British \\
aircraft in the unlawful no-flight zones \\
... in the period from 19 to 26 March \\
2001 they carried out 190 sorties, 62 \\
of them from Saudi Arabia, 27 from \\
Kuwait and 56 from Turkey."
\end{tabular} & $\begin{array}{l}\text { None } \\
\text { identified }\end{array}$ & None identified & $\begin{array}{l}\text { None } \\
\text { identified }\end{array}$ & $\begin{array}{l}\text { Articles 39, } \\
51\end{array}$ & $\begin{array}{l}\text { http: } \\
\text { //wwww.un. } \\
\text { org/en//ga/ } \\
\text { search/vie } \\
\text { w_doc. } \\
\text { asp? } \\
\text { spybol=s/ } \\
\text { 2001/316 }\end{array}$ & \begin{tabular}{|l||} 
http://www. \\
un. \\
org/en/ga/se \\
arch/view_do \\
c.asp? \\
symbol=S/200 \\
1/316\&Lang= \\
A
\end{tabular} & $\begin{array}{l}\text { hitps: } \\
\text { //perma. } \\
\text { cc/BKGJ- } \\
\text { vJXY }\end{array}$ \\
\hline 359 & 2001.04.13 & 2001.04.17 & S/2001/370 & Iraq & \begin{tabular}{|l|} 
Iraq, United \\
States, United \\
Kingdom, \\
Russia, China, \\
France
\end{tabular} & $\begin{array}{c}\text { Implied } \\
\text { assertion of } \\
\text { "individual" } \\
\text { self-defense }\end{array}$ & \begin{tabular}{|c} 
Conducted \\
attack and \\
threat of \\
attack
\end{tabular} & $\begin{array}{l}\text { United Kingdom, } \\
\text { United States }\end{array}$ & States & $\begin{array}{l}\text { “...Iraq's valiant sons are engaging the } \\
\text { United States and British aircraft that } \\
\text { violate Iraqi airspace using the 'no- } \\
\text { flight zones' as a pretext and bomb } \\
\text { civilian areas in a unilateral use of } \\
\text { armed force that is in violation of the } \\
\text { Charter of the United Nations." The } \\
\text { United States and United Kingdom are } \\
\text { also dropping leaflets, "cautioning the } \\
\text { Iraqi armed forces against engaging } \\
\text { the attacking United States and British } \\
\text { aircraft and threatening to destroy } \\
\text { sites that orient their radar systems or } \\
\text { from which fire is directed in order to } \\
\text { oppose these aircraft." }\end{array}$ & \begin{tabular}{|l} 
None \\
identified
\end{tabular} & None identified & $\begin{array}{l}\text { None } \\
\text { identified }\end{array}$ & \begin{tabular}{|l} 
None \\
identified
\end{tabular} & $\begin{array}{l}\text { http: } \\
\text { /twww.un. } \\
\text { org/en/ga/ } \\
\text { search/vie } \\
\text { w_doc. } \\
\text { asp? } \\
\text { symbol=s/ } \\
\text { 2001/370 }\end{array}$ & \begin{tabular}{|l|} 
http: //www. \\
un. \\
org/en/ga/se \\
arch/view_do \\
c.asp? \\
symbol=S/200 \\
1/370\&Lang= \\
A
\end{tabular} & \begin{tabular}{|l} 
hitps: \\
//perma. \\
cc/Tr8P- \\
HA9K
\end{tabular} \\
\hline 360 & 2001.04.15 & 2001.04.18 & S/2001/369 & Iraq & \begin{tabular}{||l|} 
Iraq, United \\
States, United \\
Kingdom, \\
Saudi Arabia, \\
Kuwait, Turkey
\end{tabular} & $\begin{array}{c}\text { Implied } \\
\text { assertion of } \\
\text { "individual" } \\
\text { self-defense }\end{array}$ & \begin{tabular}{|c} 
Conducted \\
attack
\end{tabular} & $\begin{array}{l}\text { United States, } \\
\text { United Kingdom, } \\
\text { Saadi irabia, } \\
\text { Kuwait, Turkey }\end{array}$ & States & $\begin{array}{l}\text { ".... United States and British warplanes } \\
\text { based in Saudi Arabia and Kunwait have } \\
\text { continued to violate the airspace of } \\
\text { the Republic of Iraq. They carried out } \\
299 \text { sorties in the period from } 27 \\
\text { March to } 6 \text { April } 2001,97 \text { of them } \\
\text { from Saudi Arabia, } 110 \text { from Kuwait } \\
\text { and } 92 \text { from Turkey." }\end{array}$ & \begin{tabular}{|l} 
None \\
identified
\end{tabular} & None identified & $\begin{array}{l}\text { None } \\
\text { identified }\end{array}$ & $\begin{array}{l}\text { Articles } 39 \text { \& } \\
51\end{array}$ & $\begin{array}{l}\text { http: } \\
\text { //www.un. } \\
\text { org/en/ga/ } \\
\text { search/vie } \\
\text { w_doc. } \\
\text { asp? } \\
\text { symbol=S/ } \\
\text { 2001/369 }\end{array}$ & \begin{tabular}{l|} 
http://www. \\
un. \\
org/en/ga/se \\
arch/view_do \\
casp? \\
symbol=S/200 \\
1/369\&Lang= \\
A
\end{tabular} & \begin{tabular}{|l} 
https: \\
//perma. \\
cc/plpge- \\
GJNW
\end{tabular} \\
\hline 361 & 2001.04.16 & 2001.04.16 & S/2001/362 & Syria & $\begin{array}{l}\text { Syria, Israel, } \\
\text { Lebanon }\end{array}$ & \begin{tabular}{|c} 
Implied \\
assertion of \\
"individual" \\
self-defense
\end{tabular} & $\begin{array}{c}\text { Conducted } \\
\text { attack }\end{array}$ & Israel & State & $\begin{array}{l}\text { "...lsraeli formations violated } \\
\text { Lebanese airspace and bombed one of } \\
\text { our positions in Lebanese territory." }\end{array}$ & $\begin{array}{l}\text { None } \\
\text { identified }\end{array}$ & None identified & $\begin{array}{l}\text { None } \\
\text { identified }\end{array}$ & \begin{tabular}{|l} 
None \\
identified
\end{tabular} & $\begin{array}{l}\text { http: } \\
\text { //wwww.un. } \\
\text { org/en/ga/ } \\
\text { search/vie } \\
\text { w_doc. } \\
\text { asp? } \\
\text { symbol=S/ } \\
\text { 2001/362 }\end{array}$ & \begin{tabular}{|l||} 
http://www. \\
un. \\
org/en/ga/se \\
arch/view_do \\
c.asp? \\
symbol=S/200 \\
1/362\&Lang= \\
A
\end{tabular} & $\begin{array}{l}\text { hitps: } \\
\text { //perma. } \\
\text { cc/5625- } \\
\text { 3YHS }\end{array}$ \\
\hline 362 & 2001.04.19 & 2001.04.18 & S/2001/381 & Iran & Iran, Iraq & $\begin{array}{c}\text { Implied } \\
\text { assertion of } \\
\text { "individual" } \\
\text { self-defense }\end{array}$ & $\begin{array}{c}\text { Conducted } \\
\text { attack }\end{array}$ & $\begin{array}{l}\text { "MKO terrorist } \\
\text { organization based } \\
\text { in Iraq" }\end{array}$ & $\begin{array}{c}\text { Non-state } \\
\text { actors }\end{array}$ & $\begin{array}{l}\text { “.... [N]umerous operations by the MKO } \\
\text { terrorist organization from its bases } \\
\text { inside the territory of Iraq against the } \\
\text { Islamic Republic of Iran resulting in } \\
\text { human and material losses over the } \\
\text { last several months, ,...” }\end{array}$ & \begin{tabular}{|l} 
None \\
identified
\end{tabular} & None identified & $\begin{array}{l}\text { None } \\
\text { identified }\end{array}$ & Article 51 & $\begin{array}{l}\text { http: } \\
\text { //www.un. } \\
\text { org/en/ga/ } \\
\text { search/vie } \\
\text { w_doc. } \\
\text { asp? } \\
\text { symbol=s/ } \\
\text { 2001/381 }\end{array}$ & & $\begin{array}{l}\text { hitps: } \\
\text { //perma. } \\
\text { cc//RRDD- } \\
\text { YAAZ }\end{array}$ \\
\hline 363 & 2001.05.14 & 2001.05.15 & S/2001/484 & Iraq & \begin{tabular}{|l|} 
Iraq, United \\
Kingdom, \\
United States, \\
Saudi Arabia, \\
Kuwait, Turkey
\end{tabular} & $\begin{array}{c}\text { Implied } \\
\text { assertion of } \\
\text { "individual" } \\
\text { self-defense }\end{array}$ & $\begin{array}{c}\text { Conducted } \\
\text { attack }\end{array}$ & $\begin{array}{l}\text { United States, } \\
\text { United Kingdom, } \\
\text { Saadi Arabia, } \\
\text { Kuwait, Turkey }\end{array}$ & States & \begin{tabular}{|l} 
"OO]ngoing wanton aggression against \\
Iraq by United States and British \\
aircraft in the unlawful no-flight zones \\
... in the period from 16 to 22 April \\
2001 they carried out 225 sorties, 77 \\
of them from Saudi Arabia, 70 from \\
Kuwait and 78 from Turkey."
\end{tabular} & \begin{tabular}{|l} 
None \\
identified
\end{tabular} & None identified & \begin{tabular}{|l} 
None \\
identified
\end{tabular} & Article 51 & $\begin{array}{l}\text { http: } \\
\text { //www.un. } \\
\text { org/en/ga/ } \\
\text { search/vie } \\
\text { w_doc. } \\
\text { asp? } \\
\text { symbol=s/ } \\
\text { 2001/484 } \\
\end{array}$ & \begin{tabular}{|l|} 
http://www. \\
un. \\
org/en/ga/se \\
arch/view_do \\
c.asp? \\
symbol=S/200 \\
$1 / 484 \& L a n g=$ \\
A \\
\end{tabular} & $\begin{array}{l}\text { hitps: } \\
\text { //perma. } \\
\text { cc//ECLB- } \\
\text { FR9S }\end{array}$ \\
\hline 364 & 2001.05.26 & 2001.05.31 & S/2001/536 & Iraq & \begin{tabular}{||l|} 
Iraq, United \\
States, United \\
Kingdom, \\
Saudi Arabia, \\
Kuwait, Turkey
\end{tabular} & \begin{tabular}{|l} 
Implied \\
assertion of \\
"individual" \\
self-defense
\end{tabular} & $\begin{array}{c}\text { Conducted } \\
\text { attack }\end{array}$ & $\begin{array}{l}\text { United States, } \\
\text { United Kingdom, } \\
\text { Saudi Arabaia, } \\
\text { Kuwait, Turkey }\end{array}$ & States & $\begin{array}{l}\text { "OO]ngoing wanton aggression against } \\
\text { Iraq by United States and British } \\
\text { aircraft in the unlawful no-flight zones } \\
\text {... in the period from } 23 \text { April to } 3 \text { May } \\
2001 \text { they carried out } 241 \text { sorties, }, 0 \\
\text { of them from Saudi Arabia, } 107 \text { from } \\
\text { Kuwait and } 44 \text { from Turkey." } \\
\end{array}$ & $\begin{array}{l}\text { None } \\
\text { identified }\end{array}$ & None identified & $\begin{array}{l}\text { None } \\
\text { identified }\end{array}$ & \begin{tabular}{|l} 
Articles $39 \&$ \\
51
\end{tabular} & $\begin{array}{l}\text { http: } \\
\text { //www.un. } \\
\text { org/en/ga/ } \\
\text { search/vie } \\
\text { w_doc. } \\
\text { asp? } \\
\text { symbol=s/ } \\
\text { 2001/536 } \\
\end{array}$ & \begin{tabular}{|l||} 
http://www. \\
un. \\
org/en/ga/se \\
arch/view_do \\
c.asp? \\
symbol=S/200 \\
1/536\&Lang= \\
A \\
\end{tabular} & $\begin{array}{l}\text { hitps: } \\
\text { //perma. } \\
\text { cc/T33D- } \\
\text { DT6B }\end{array}$ \\
\hline
\end{tabular}


VI. HLS PILAC Catalogue of Apparent “Article 51 Communications”

\begin{tabular}{|c|c|c|c|c|c|c|c|c|c|c|c|c|c|c|c|c|c|}
\hline $\begin{array}{l}\text { Chron. } \\
\text { Order }\end{array}$ & $\begin{array}{l}\text { Date of } \\
\text { Comm. }\end{array}$ & $\begin{array}{l}\text { Date of } \\
\text { UNsC } \\
\text { Document }\end{array}$ & UNSC Symbol & \begin{tabular}{||c|} 
Member \\
State(s) That \\
Submitted \\
the Comm.
\end{tabular} & \begin{tabular}{|c||} 
Expressly \\
Mentioned UN \\
Members (\& \\
Colonial \\
Holdings \& \\
Protectorates, \\
if any) \\
\end{tabular} & \begin{tabular}{||c|} 
Express or \\
Implied \\
Assertion of \\
Individual, \\
Collective, or \\
Both Self- \\
defense \\
\end{tabular} & \begin{tabular}{|l} 
Nature of \\
the Alleged \\
Threat
\end{tabular} & $\begin{array}{l}\text { Expressly Alleged } \\
\text { Author(s) of the } \\
\text { Threat (If Any } \\
\text { Indicated) }\end{array}$ & \begin{tabular}{|c} 
Nature of the \\
Alleged \\
Author(s) of \\
the Threat (If \\
Any \\
Indicated)
\end{tabular} & $\begin{array}{l}\text { Summary of Alleged Self-defense } \\
\text { Grounds }\end{array}$ & \begin{tabular}{||c} 
UNSC \\
Meeting(s) \\
(If Any) at \\
Which the \\
Comm. was \\
Raised
\end{tabular} & $\begin{array}{l}\text { Responsive Act (If Any) by the } \\
\text { UNSC }\end{array}$ & $\begin{array}{l}\text { UN } \\
\text { Repertory } \\
\text { Inclusion? }\end{array}$ & \begin{tabular}{|c} 
UNSC \\
Repertoire \\
Inclusion?
\end{tabular} & \begin{tabular}{|l|} 
URL to an \\
English \\
Text
\end{tabular} & \begin{tabular}{||c||} 
URL to Non- \\
English \\
Original \\
Text (ff Any)
\end{tabular} & \begin{tabular}{|l} 
Perma.cc \\
URL
\end{tabular} \\
\hline 365 & 2001.06.17 & 2001.06.21 & $\mathrm{S} / 2001 / 620$ & Iraq & \begin{tabular}{|} 
Iraq, United \\
States, United \\
Kingdom, \\
Saudi Arabia, \\
Kuwait, Turkey
\end{tabular} & $\begin{array}{l}\text { Implied } \\
\text { assertion of } \\
\text { "individual" } \\
\text { self-defense }\end{array}$ & $\begin{array}{c}\text { Conducted } \\
\text { attack }\end{array}$ & $\begin{array}{l}\text { United States, } \\
\text { United Kingdom, } \\
\text { Saudi Arabia, } \\
\text { Kuwait, Turkey }\end{array}$ & States & \begin{tabular}{|l} 
"IO]ngoing wanton aggression against \\
Iraq by United States and British \\
aircraft in the unlawful no-flight zones \\
$\ldots$ in the period from 5 to 25 May 2001 \\
they carried out 424 sorties, 134 of \\
them from Saudi Arabia, 160 from \\
Kuwait and 130 from Turkey.”
\end{tabular} & $\begin{array}{l}\text { None } \\
\text { identified }\end{array}$ & None identified & $\begin{array}{l}\text { None } \\
\text { identified }\end{array}$ & \begin{tabular}{|l|} 
Articles $39 \&$ \\
51
\end{tabular} & \begin{tabular}{|l||} 
http: \\
//www.un. \\
orge//ga/ \\
search/vie \\
w_doc. \\
asp? \\
symbol=s/ \\
2001/620 \\
\end{tabular} & \begin{tabular}{|l||} 
http://www. \\
un. \\
org/en/ga/se \\
arch/view_do \\
c.asp? \\
symbol=S/200 \\
$1 / 620 \& L$ Lang= \\
A
\end{tabular} & \begin{tabular}{|l} 
https: \\
//perma. \\
cr/2JS22- \\
QDK3
\end{tabular} \\
\hline 366 & 2001.06.24 & 2001.06.26 & $\mathrm{S} / 2001 / 638$ & Iraq & \begin{tabular}{|l|} 
Iraq, United \\
States, United \\
Kingdom, \\
Saudi Arabia, \\
Kuwait, Turkey
\end{tabular} & $\begin{array}{l}\text { Implied } \\
\text { assertion of } \\
\text { "individual" } \\
\text { self-defense }\end{array}$ & $\begin{array}{c}\text { Conducted } \\
\text { attack }\end{array}$ & $\begin{array}{l}\text { United States, } \\
\text { United Kingdom, } \\
\text { Saudi Arabia, } \\
\text { Kuwait, Turkey }\end{array}$ & States & \begin{tabular}{|l} 
"[O]ngoing wanton aggression against \\
Iraq by United States and British \\
aircraft in the unlawful no-flight zones \\
... in the period from 26 May to 11 \\
June 2001 they carried out 388 \\
sorties, 128 of them from Saudi \\
Arabia, 136 from Kuwait and 124 from \\
Turkey"
\end{tabular} & $\begin{array}{l}\text { None } \\
\text { identified }\end{array}$ & None identified & $\begin{array}{l}\text { None } \\
\text { identified }\end{array}$ & \begin{tabular}{|l} 
Articles $39 \&$ \\
51
\end{tabular} & \begin{tabular}{|l||} 
http: \\
//www.un. \\
org/en/ga/ \\
search/vie \\
wdoc. \\
asp? \\
symbol=s/ \\
2001/638 \\
\end{tabular} & \begin{tabular}{|l|} 
http: //www. \\
un. \\
org/en/ga/se \\
arch/view_do \\
c.asp? \\
symbol=s/200 \\
$1 / 638 \& L a n g=$ \\
A
\end{tabular} & $\begin{array}{l}\text { https: } \\
\text { ///perma. } \\
\text { c/KAFL- } \\
\text { PEX3 }\end{array}$ \\
\hline 367 & 2001.06.28 & 2001.07.02 & $\mathrm{S} / 2001 / 650$ & Iraq & \begin{tabular}{|} 
Iraq, United \\
States, United \\
Kingdom, \\
Saudi Arabia, \\
Kuwait, Turkey
\end{tabular} & $\begin{array}{l}\text { Implied } \\
\text { assertion of } \\
\text { "individual" } \\
\text { self-defense }\end{array}$ & $\begin{array}{c}\text { Conducted } \\
\text { attack }\end{array}$ & $\begin{array}{l}\text { United States, } \\
\text { United Kingdom, } \\
\text { Saudi Arabia, } \\
\text { Kuwait, Turkey }\end{array}$ & States & $\begin{array}{l}\text { "OO]ngoing wanton aggression against } \\
\text { Iraq by United States and British } \\
\text { aircraft in the unlawful no-flight zones } \\
\text {... in the period from } 12 \text { to } 21 \text { June } \\
2001 \text { they carried out } 350 \text { sorties, } 88 \\
\text { of them from Saudiarabia, } 130 \text { from } \\
\text { Kuwait and } 132 \text { from Turkey." }\end{array}$ & $\begin{array}{l}\text { None } \\
\text { identified }\end{array}$ & None identified & $\begin{array}{l}\text { None } \\
\text { identified }\end{array}$ & \begin{tabular}{|l} 
Articles $39 \&$ \\
51
\end{tabular} & \begin{tabular}{|l|} 
http: \\
//www.un. \\
org//en/ga/ \\
search/vie \\
w_doc. \\
asp? \\
symbol=s/ \\
2001/650 \\
201/6
\end{tabular} & \begin{tabular}{|l||} 
http://www. \\
un. \\
org/en/ga/se \\
arch/view_do \\
c.asp? \\
symbol=S/200 \\
1/650\&Lang= \\
A
\end{tabular} & $\begin{array}{l}\text { https: } \\
\text { //perma. } \\
\text { cc/7/FSH- } \\
\text { W2NU }\end{array}$ \\
\hline 368 & 2001.07.12 & 2001.07.13 & S/2001/692 & Iraq & \begin{tabular}{|l|} 
Iraq, United \\
States, United \\
Kingdom, \\
Saudi Arabia, \\
Kuwait, Turkey
\end{tabular} & $\begin{array}{l}\text { Implied } \\
\text { assertion of } \\
\text { "individual" } \\
\text { self-defense }\end{array}$ & $\begin{array}{c}\text { Conducted } \\
\text { attack }\end{array}$ & $\begin{array}{l}\text { United States, } \\
\text { United Kingdom, } \\
\text { Saudi Arabia, } \\
\text { Kuwait, Turkey }\end{array}$ & States & $\begin{array}{l}\text { "OO]ngoing wanton aggression against } \\
\text { Iraq by United States and British } \\
\text { aircraft in the unlawful no-flight zones } \\
\text {... in the period from } 22 \text { to } 30 \text { June } \\
2001 \text { they carried out } 275 \text { sorties, } 91 \\
\text { of them from Saudid Arabia, } 116 \text { from } \\
\text { Kuwait and } 68 \text { from Turkey." }\end{array}$ & $\begin{array}{l}\text { None } \\
\text { identified }\end{array}$ & None identified & $\begin{array}{l}\text { None } \\
\text { identified }\end{array}$ & \begin{tabular}{|l|} 
Articles $39 \&$ \\
51
\end{tabular} & \begin{tabular}{|l|} 
http: \\
//www.un. \\
orge//gnal \\
search/vie \\
w_doc. \\
asp? \\
symbol=s/ \\
2001/692 \\
\end{tabular} & \begin{tabular}{|l||} 
http://www. \\
un. \\
org/en/ga/se \\
arch/view_do \\
c.asp? \\
symbol=S/200 \\
$1 / 692 \& L$ Lang= \\
A
\end{tabular} & $\begin{array}{l}\text { https: } \\
\text { //perma. } \\
\text { cc/PVMM- } \\
\text { WGUL }\end{array}$ \\
\hline 369 & 2001.07.18 & 2001.07.18 & S/2001/709 & $\begin{array}{l}\text { Democratic } \\
\text { Republic of } \\
\text { the Congo }\end{array}$ & \begin{tabular}{|c|} 
Democratic \\
Republic of the \\
Congo, \\
Rwanda, \\
Uganda
\end{tabular} & $\begin{array}{l}\text { Implied } \\
\text { assertion of } \\
\text { "individual" } \\
\text { self-defense }\end{array}$ & $\begin{array}{c}\text { Conducted } \\
\text { attack }\end{array}$ & $\begin{array}{l}\text { Rwanda and } \\
\text { Uganda }\end{array}$ & States & $\begin{array}{l}\text { Rwanda and Uganda refuse to } \\
\text { withdraw their troops from Congolese } \\
\text { territory. }\end{array}$ & \begin{tabular}{|l|}
.PV/4361 \\
(4361st); S. \\
PV/4634 \\
(4634th) \\
(general \\
subject \\
matter \\
discussed) \\
\end{tabular} & None identified & $\begin{array}{l}\text { None } \\
\text { identified }\end{array}$ & Article 51 & \begin{tabular}{|l||} 
http: \\
//www.un. \\
org/en/ga/ \\
search/vie \\
wdoc. \\
asp? \\
symbol=s/ \\
2001/709 \\
\end{tabular} & \begin{tabular}{|l|} 
http://www. \\
un. \\
org/en/ga/se \\
arch/view_do \\
c.asp? \\
symbol=s/200 \\
1/709\&Lang= \\
F
\end{tabular} & $\begin{array}{l}\text { https: } \\
\text { //perma. } \\
\text { cc/5BT6- } \\
\text { J6DK }\end{array}$ \\
\hline 370 & 2001.10.07 & 2001.10.07 & S/2001/946 & $\begin{array}{l}\text { United } \\
\text { States }\end{array}$ & \begin{tabular}{|l} 
United States, \\
Afghanistan
\end{tabular} & $\begin{array}{l}\text { Express } \\
\text { assertion of } \\
\text { "individual" } \\
\text { self-defense } \\
\text { and express } \\
\text { assertion of } \\
\text { "collective" } \\
\text { self-defense }\end{array}$ & $\begin{array}{c}\text { Conducted } \\
\text { attack and } \\
\text { threat of } \\
\text { attack }\end{array}$ & $\begin{array}{l}\text { Afghanistan (at } \\
\text { least insofar as } \\
\text { "Taliban regime" } \\
\text { conduct is } \\
\text { attributable to } \\
\text { Afghanistan) and } \\
\text { "Al-Qaeda } \\
\text { organization" }\end{array}$ & $\begin{array}{c}\text { State and } \\
\text { non-state } \\
\text { actors }\end{array}$ & \begin{tabular}{|l} 
"[A]rmed attacks that were carried \\
out against the United States on 11 \\
September 2001. " "The attacks on 11 \\
September 2001 and the ongoing \\
threat to the United States and its \\
nationals posed by the Al-Qaeda \\
organization have been made possible \\
by the decision of the Taliban regime \\
to allow the parts of Afghanistan that \\
it controls to be used by this \\
organization as a base of operation."
\end{tabular} & $\begin{array}{l}\text { S.PV/4414 } \\
\text { (4414th) }\end{array}$ & None identified & $\begin{array}{l}\text { None } \\
\text { identified }\end{array}$ & Article 51 & \begin{tabular}{|l||} 
http: \\
|/www.un. \\
org/en/ga/ \\
search/vie \\
w_doc. \\
asp? \\
symbol=s/ \\
2001/946
\end{tabular} & & \begin{tabular}{|l} 
https: \\
//perma. \\
cc/9RF8- \\
5FCE
\end{tabular} \\
\hline 371 & 2001.10.07 & 2001.10.07 & S/2001/947 & $\begin{array}{l}\text { United } \\
\text { Kingdom }\end{array}$ & \begin{tabular}{|c|} 
United \\
Kingdom, \\
United States, \\
Afghanistan
\end{tabular} & $\begin{array}{l}\text { Express } \\
\text { assertion of } \\
\text { "individual" } \\
\text { self-defense } \\
\text { and express } \\
\text { assertion of } \\
\text { "collective" } \\
\text { self-defense }\end{array}$ & $\begin{array}{c}\text { Conducted } \\
\text { attack and } \\
\text { threat of } \\
\text { armed } \\
\text { attack }\end{array}$ & $\begin{array}{l}\text { "Usama Bin Laden' } \\
\text { s Al-Qaeda } \\
\text { terrorist } \\
\text { organization and } \\
\text { the Taliban regime } \\
\text { that is supporting } \\
\text { it" }\end{array}$ & $\begin{array}{l}\text { State and } \\
\text { non-state } \\
\text { actors }\end{array}$ & $\begin{array}{l}\text { "[T]he terrorist outrage of } 11 \\
\text { September" and "the continuing } \\
\text { threat of attacks from the same } \\
\text { source." }\end{array}$ & $\begin{array}{l}\text { S.PV/4414 } \\
\text { (4414th) }\end{array}$ & None identified & $\begin{array}{l}\text { None } \\
\text { identified }\end{array}$ & Article 51 & \begin{tabular}{|l||} 
http: \\
//www.un. \\
org/en/ga/ \\
search/vie \\
w_doc. \\
asp? \\
symbol=s/ \\
2001/947
\end{tabular} & & $\begin{array}{l}\text { https: } \\
\text { //perma. } \\
\text { cc/KgF2- } \\
\text { DQLZ }\end{array}$ \\
\hline
\end{tabular}


VI. HLS PILAC Catalogue of Apparent “Article 51 Communications”

\begin{tabular}{|c|c|c|c|c|c|c|c|c|c|c|c|c|c|c|c|c|c|}
\hline $\begin{array}{l}\text { Chron. } \\
\text { Order }\end{array}$ & $\begin{array}{l}\text { Date of } \\
\text { Comm. }\end{array}$ & $\begin{array}{l}\text { Date of } \\
\text { UNsC } \\
\text { Document }\end{array}$ & UNSC Symbol & \begin{tabular}{||c} 
Member \\
State(s) That \\
Submitted \\
the Comm.
\end{tabular} & \begin{tabular}{|c} 
Expressly \\
Mentioned UN \\
Members (\& \\
Colonial \\
Holdings \& \\
Protectorates, \\
if any)
\end{tabular} & \begin{tabular}{|c|} 
Express or \\
Implied \\
Assertion of \\
Individual, \\
Collective, or \\
Both Self- \\
defense
\end{tabular} & \begin{tabular}{|l} 
Nature of \\
the Alleged \\
Threat
\end{tabular} & $\begin{array}{l}\text { Expressly Alleged } \\
\text { Author(s) of the } \\
\text { Threat (If Any } \\
\text { Indicated) }\end{array}$ & \begin{tabular}{|c} 
Nature of the \\
Alleged \\
Author(s) of \\
the Threat (If \\
Any \\
Indicated)
\end{tabular} & $\begin{array}{l}\text { Summary of Alleged Self-defense } \\
\text { Grounds }\end{array}$ & $\begin{array}{l}\text { UNsC } \\
\text { Meeting(s) } \\
\text { (If Any) at } \\
\text { Which the } \\
\text { Comm. was } \\
\text { Raised }\end{array}$ & $\begin{array}{l}\text { Responsive Act (If Any) by the } \\
\text { UNSC }\end{array}$ & $\begin{array}{l}\text { UN } \\
\text { Repertory } \\
\text { Inclusion? }\end{array}$ & $\begin{array}{l}\text { UNSC } \\
\text { Repertoire } \\
\text { Inclusion? }\end{array}$ & \begin{tabular}{|c||} 
URL to an \\
English \\
Text
\end{tabular} & \begin{tabular}{||c||} 
URL to Non- \\
English \\
Original \\
Text (ff Any)
\end{tabular} & \begin{tabular}{|l} 
Perma.cc \\
URL
\end{tabular} \\
\hline 372 & 2001.10.24 & 2001.10.24 & $S / 2001 / 1005$ & Canada & \begin{tabular}{|l} 
Canada, \\
United States, \\
Afghanistan
\end{tabular} & $\begin{array}{l}\text { Express } \\
\text { assertion of } \\
\text { "individual" } \\
\text { self-defense } \\
\text { and express } \\
\text { assertion of } \\
\text { "collective" } \\
\text { self-defense }\end{array}$ & $\begin{array}{c}\text { Conducted } \\
\text { attack }\end{array}$ & $\begin{array}{l}\text { Express assertion } \\
\text { of "individual" self- } \\
\text { defense and } \\
\text { express assertion } \\
\text { of "collective" self- } \\
\text { defense }\end{array}$ & $\begin{array}{c}\text { State and } \\
\text { non-state } \\
\text { actors }\end{array}$ & $\begin{array}{l}\text { The "armed attacks in the United } \\
\text { States on } 11 \text { September 2001. Those } \\
\text { attacks, ..., resulted in the deaths of } \\
\text { thousands of citizens from many } \\
\text { countries, including Canada." }\end{array}$ & $\begin{array}{l}\text { S.PV/4414 } \\
\text { (4414th) }\end{array}$ & None identified & $\begin{array}{l}\text { None } \\
\text { identified }\end{array}$ & Article 51 & \begin{tabular}{|l||} 
http: \\
//www.un. \\
org///nngal \\
search/vie \\
w_doc. \\
asp? \\
symbol=s/ \\
2001/1005 \\
2001
\end{tabular} & & \begin{tabular}{|l} 
https: \\
//perma. \\
c/RVBG- \\
62QB
\end{tabular} \\
\hline 373 & 2001.11.23 & 2001.11.23 & S/2001/1103 & France & $\begin{array}{l}\text { France, United } \\
\text { States }\end{array}$ & $\begin{array}{l}\text { Implied } \\
\text { assertion of } \\
\text { "collective" } \\
\text { self-defense }\end{array}$ & $\begin{array}{c}\text { Conducted } \\
\text { attack }\end{array}$ & Not indicated & Not indicated & $\begin{array}{l}\text { "[T]he terrorist attacks perpetrated in } \\
\text { the United States of A America on } 11 \\
\text { September 2001,...." }\end{array}$ & $\begin{array}{l}\text { None } \\
\text { identified }\end{array}$ & None identified & $\begin{array}{l}\text { None } \\
\text { identified }\end{array}$ & Article 51 & \begin{tabular}{|l|} 
http: \\
//www.un. \\
org///nngal \\
search/vie \\
w_doc. \\
asp? \\
symbol=s/ \\
2001/1103 \\
\end{tabular} & \begin{tabular}{|l||} 
http://www. \\
un. \\
org/en/ga/se \\
arch/view_do \\
c.asp? \\
symbol=S/200 \\
1/11103\&Lang \\
=F
\end{tabular} & \begin{tabular}{|l} 
https: \\
//perma. \\
c/7WWZQ- \\
EV68
\end{tabular} \\
\hline 374 & 2001.11.23 & 2001.11.23 & $\mathrm{S} / 2001 / 1104$ & Australia & $\begin{array}{l}\text { Australia, New } \\
\text { Zealand, } \\
\text { United States }\end{array}$ & 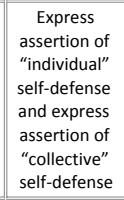 & $\begin{array}{c}\text { Conducted } \\
\text { attack }\end{array}$ & Not indicated & Not indicated & $\begin{array}{l}\text { "TThhe armed attacks against the } \\
\text { United States of America on } 11 \\
\text { September 2001." }\end{array}$ & \begin{tabular}{|l} 
None \\
identified
\end{tabular} & None identified & $\begin{array}{l}\text { None } \\
\text { identified }\end{array}$ & Article 51 & \begin{tabular}{|l||} 
http: \\
//www.un. \\
org//nn/ga/ \\
search/pie \\
w_doc. \\
asp? \\
symbol=s/ \\
2001/1104 \\
\end{tabular} & & \begin{tabular}{|l} 
https: \\
//perma. \\
c/4/4UV- \\
WREW
\end{tabular} \\
\hline 375 & 2001.11.29 & 2001.11.29 & S/2001/1127 & Germany & Germany & \begin{tabular}{|c} 
Express \\
assertion of \\
"individual" \\
self-defense \\
and express \\
assertion of \\
"collective" \\
self-defense
\end{tabular} & $\begin{array}{c}\text { Conducted } \\
\text { attack }\end{array}$ & $\begin{array}{l}\text { "[T]he terrorist } \\
\text { network of Bin } \\
\text { Laden, Al-Qaida, } \\
\text { and those } \\
\text { harbouring and } \\
\text { supporting it" }\end{array}$ & $\begin{array}{c}\text { State and } \\
\text { non-state } \\
\text { actors }\end{array}$ & $\begin{array}{l}\text { "TThe armed attacks that were } \\
\text { carried out against the United States } \\
\text { on } 11 \text { September 2001." }\end{array}$ & $\begin{array}{l}\text { None } \\
\text { identified }\end{array}$ & None identified & $\begin{array}{l}\text { None } \\
\text { identified }\end{array}$ & Article 51 & \begin{tabular}{|l||} 
http: \\
//www.un. \\
org/en/ga/ \\
search/vie \\
w_doc. \\
asp? \\
symbol=s/ \\
2001/1127 \\
\end{tabular} & & \begin{tabular}{|l} 
https: \\
//perma. \\
cc/93CR- \\
DPRU
\end{tabular} \\
\hline 376 & 2001.12.06 & 2001.12.06 & S/2001/1171 & $\begin{array}{c}\text { The } \\
\text { Netherlands }\end{array}$ & $\begin{array}{l}\text { The } \\
\text { Netherlands, } \\
\text { United States }\end{array}$ & \begin{tabular}{|c} 
Express \\
assertion of \\
"individual" \\
self-defense \\
and express \\
assertion of \\
"collective" \\
self-defense \\
\end{tabular} & $\begin{array}{c}\text { Conducted } \\
\text { attack }\end{array}$ & Not indicated & Not indicated & $\begin{array}{l}\text { "[T]he armed attacks against the } \\
\text { United States of America on } 11 \\
\text { September 2001." }\end{array}$ & $\begin{array}{l}\text { None } \\
\text { identified }\end{array}$ & None identified & $\begin{array}{l}\text { None } \\
\text { identified }\end{array}$ & Article 51 & \begin{tabular}{|l||} 
http: \\
//www.un. \\
org/en/ga/ \\
search/vie \\
w_doc. \\
asp? \\
symbol=s/ \\
2001/1171 \\
\end{tabular} & & \begin{tabular}{|l} 
https: \\
//perma. \\
cc/FA2- \\
DCBX
\end{tabular} \\
\hline 377 & 2001.12.17 & 2001.12.18 & S/2001/1193 & New Zealand & \begin{tabular}{|l} 
New Zealand, \\
United States
\end{tabular} & $\begin{array}{l}\text { Express } \\
\text { assertion of } \\
\text { "individual" } \\
\text { self-defense } \\
\text { and express } \\
\text { assertion of } \\
\text { "collective" } \\
\text { self-defense }\end{array}$ & $\begin{array}{c}\text { Conducted } \\
\text { attack }\end{array}$ & $\begin{array}{l}\text { Afghanistan (as } \\
\text { least insofar as } \\
\text { conduct of "the } \\
\text { Taliban" is } \\
\text { attributable to it) } \\
\text { and "ssama bin } \\
\text { Laden and the } \\
\text { Qaeda terrorist } \\
\text { organization" }\end{array}$ & $\begin{array}{c}\text { State and } \\
\text { non-state } \\
\text { actors }\end{array}$ & $\begin{array}{l}\text { "[T]he terrorist attacks in the United } \\
\text { States of America on } 11 \text { September } \\
\text { 2001." }\end{array}$ & $\begin{array}{l}\text { None } \\
\text { identified }\end{array}$ & None identified & $\begin{array}{l}\text { None } \\
\text { identified }\end{array}$ & Article 51 & \begin{tabular}{|l||} 
http: \\
//www.un. \\
orge/en/ga/ \\
search/vie \\
w_doc. \\
asp? \\
spmbol=s/ \\
2001/1193
\end{tabular} & & $\begin{array}{l}\text { https: } \\
\text { //perma. } \\
\text { cc/9gzX- } \\
\text { Q5FP }\end{array}$ \\
\hline 378 & 2001.12.27 & 2001.12.27 & S/2001/1275 & Poland & \begin{tabular}{|l} 
Poland, \\
Afghanistan, \\
United States
\end{tabular} & \begin{tabular}{|l|} 
Express \\
assertion of \\
"individual" \\
self-defense \\
and express \\
assertion of \\
"collective" \\
self-defense
\end{tabular} & $\begin{array}{c}\text { Conducted } \\
\text { attack }\end{array}$ & "[T]he terrorists" & Not indicated & $\begin{array}{l}\text { "[T]he terrorist attacks of } 11 \\
\text { September 2001". }\end{array}$ & $\begin{array}{l}\text { None } \\
\text { identified }\end{array}$ & None identified & $\begin{array}{l}\text { None } \\
\text { identified }\end{array}$ & $\begin{array}{l}\text { None } \\
\text { identified }\end{array}$ & \begin{tabular}{|l||} 
http: \\
//wwww.un \\
org/en/ga/ \\
search/vie \\
w_doc. \\
asp? \\
symbol=s/ \\
2001/1275 \\
\end{tabular} & \begin{tabular}{|l||} 
http:://www. \\
un. \\
org/en/ga/se \\
arch/view_do \\
c.casp? \\
symbol=S/200 \\
1/1275\&Lang \\
=F
\end{tabular} & $\begin{array}{l}\text { https: } \\
\text { //perma. } \\
\text { cc/MD2B- } \\
5893\end{array}$ \\
\hline
\end{tabular}


VI. HLS PILAC Catalogue of Apparent “Article 51 Communications”

\begin{tabular}{|c|c|c|c|c|c|c|c|c|c|c|c|c|c|c|c|c|c|}
\hline $\begin{array}{l}\text { Chron. } \\
\text { Order }\end{array}$ & $\begin{array}{l}\text { Date of } \\
\text { comm. }\end{array}$ & $\begin{array}{l}\text { Date of } \\
\text { UNsc } \\
\text { Document }\end{array}$ & UNSC Symbol & $\begin{array}{l}\text { Member } \\
\text { State(s) That } \\
\text { Submitted } \\
\text { the Comm. }\end{array}$ & \begin{tabular}{|c|} 
Expressly \\
Mentioned UN \\
Members (\& \\
Colonial \\
Holdings \& \\
Protectorates, \\
if any) \\
\end{tabular} & \begin{tabular}{||c|} 
Express or \\
Implied \\
Assertion of \\
Individual, \\
Collective, or \\
Both Self- \\
defense \\
\end{tabular} & \begin{tabular}{|c}
$\begin{array}{c}\text { Nature of } \\
\text { the Alleged } \\
\text { Threat }\end{array}$ \\
To
\end{tabular} & $\begin{array}{l}\text { Expressly Alleged } \\
\text { Author(s) of the } \\
\text { Threat (If Any } \\
\text { Indicated) }\end{array}$ & \begin{tabular}{|c|} 
Nature of the \\
Alleged \\
Author(s) of \\
the Threat (If \\
Any \\
Indicated)
\end{tabular} & $\begin{array}{l}\text { Summary of Alleged Self-defense } \\
\text { Grounds }\end{array}$ & \begin{tabular}{|c|} 
UNSC \\
Meeting(s) \\
(If Any) at \\
Which the \\
Comm. was \\
Raised \\
\end{tabular} & $\begin{array}{l}\text { Responsive Act (If Any) by the } \\
\text { UNSC }\end{array}$ & $\begin{array}{l}\text { UN } \\
\text { Repertory } \\
\text { Inclusion? }\end{array}$ & \begin{tabular}{|c|} 
UNSC \\
Repertoire \\
Inclusion?
\end{tabular} & \begin{tabular}{|l|} 
URL to an \\
English \\
Text
\end{tabular} & \begin{tabular}{||c} 
URL to Non- \\
English \\
Original \\
Text (ff Any)
\end{tabular} & \begin{tabular}{|l} 
Perma.cc \\
URL
\end{tabular} \\
\hline 379 & 2002.02.25 & 2002.02.26 & S/2002/198 & $\begin{array}{l}\text { Democratic } \\
\text { Republic of } \\
\text { the Congo }\end{array}$ & \begin{tabular}{|} 
Democratic \\
Republic of the \\
Congo, \\
Rwanda
\end{tabular} & $\begin{array}{l}\text { Implied } \\
\text { assertion of } \\
\text { "individual" } \\
\text { self-defense }\end{array}$ & $\begin{array}{c}\text { Conducted } \\
\text { attack }\end{array}$ & $\begin{array}{c}\text { Rwanda and the } \\
\text { Rassemblement } \\
\text { congolais pour la } \\
\text { démocratie (RCD- } \\
\text { Goma) }\end{array}$ & $\begin{array}{c}\text { States and } \\
\text { non-state } \\
\text { actors }\end{array}$ & $\begin{array}{l}\text { "At a moment when the inter- } \\
\text { Congolese dialogue is opening in Sun } \\
\text { City, troops of the Rwandan Patriotic } \\
\text { Arry (RPA), supported by those of the } \\
\text { Rassemblement congolais pour la } \\
\text { démocratie (RCD-Goma), flagrantly } \\
\text { violated the ceasefirie by attacking } \\
\text { troops based in Muliro, in the vicinity } \\
\text { of Lake Tanganyika. [ף] RPA deployed } \\
\text { three battalions of its forces stationed } \\
\text { in Kamamba for these clashes, ...." }\end{array}$ & \begin{tabular}{|l} 
S.PV/4634 \\
(4634th) \\
(subject \\
matter \\
discussed)
\end{tabular} & None identified & $\begin{array}{l}\text { None } \\
\text { identified }\end{array}$ & Article 51 & \begin{tabular}{l||} 
http: \\
//www.un. \\
org/en/ga/ \\
search/vie \\
w_doc. \\
asp? \\
symbol=s/ \\
2002/198
\end{tabular} & \begin{tabular}{|l|} 
http://www. \\
un. \\
org/en/ga/se \\
arch/view_do \\
c.asp? \\
symbol=s/200 \\
2/1988\&Lang= \\
F
\end{tabular} & \begin{tabular}{|l} 
https: \\
//perma. \\
cc/G2FD- \\
K52L
\end{tabular} \\
\hline 380 & 2002.02.28 & 2002.03.01 & $S / 2002 / 217$ & \begin{tabular}{|l} 
Democratic \\
Republic of \\
the Congo
\end{tabular} & $\begin{array}{c}\text { Democratic } \\
\text { Republic of the } \\
\text { Congo, } \\
\text { Rwanda }\end{array}$ & \begin{tabular}{|c} 
Implied \\
assertion of \\
"individual" \\
self-defense
\end{tabular} & $\begin{array}{c}\text { Conducted } \\
\text { attack }\end{array}$ & $\begin{array}{l}\text { Rwanda and } \\
\text { "elements of the } \\
\text { Rassemblement } \\
\text { congolais pour la } \\
\text { démocratie (RCD- } \\
\text { Goma)" }\end{array}$ & $\begin{array}{c}\text { State and } \\
\text { non-state } \\
\text { actors }\end{array}$ & $\begin{array}{l}\text { "“Thhe attack against the garrison of } \\
\text { the Congolese armed forces at Muliro, } \\
\text { in Katanga province, on the night of } 22 \\
\text { to } 23 \text { February } 2002 \text { launched by units } \\
\text { of the Rwandan armed forces and } \\
\text { elements of the Rassemblement } \\
\text { congolais pour la démocratie (RCD- } \\
\text { Goma) in violation of the current } \\
\text { ceasefire." }\end{array}$ & \begin{tabular}{|l} 
S.PV/4634 \\
(4634th) \\
(subject \\
matter \\
discussed)
\end{tabular} & None identified & $\begin{array}{l}\text { None } \\
\text { identified }\end{array}$ & Article 51 & \begin{tabular}{l||} 
http: \\
|/www.un. \\
org/en/ga/ \\
search/vie \\
w_doc. \\
asp? \\
symbol=s/ \\
2002/217
\end{tabular} & \begin{tabular}{|l||} 
http://www. \\
un. \\
org/en/ga/se \\
arch/view_do \\
c.asp? \\
symbol=s/200 \\
2/217\&\&Lang= \\
F
\end{tabular} & $\begin{array}{l}\text { https: } \\
\text { //perma. } \\
\text { c/AUUL- } \\
\text { D3HD }\end{array}$ \\
\hline 381 & 2002.03.15 & 2002.03.15 & $S / 2002 / 275$ & Poland & $\begin{array}{l}\text { Poland, United } \\
\text { States }\end{array}$ & \begin{tabular}{|l|}
\multicolumn{1}{|c|}{ Express } \\
assertion of \\
"individual" \\
self-defense \\
and express \\
assertion of \\
"collective" \\
self-defense \\
\end{tabular} & $\begin{array}{c}\text { Conducted } \\
\text { attack }\end{array}$ & $\begin{array}{l}\text { "IT]he terrorist } \\
\text { network } \\
\text { responsible for the } \\
\text { attacks" }\end{array}$ & $\begin{array}{l}\text { Non-state } \\
\text { actors }\end{array}$ & $\begin{array}{l}\text { "TThe terrorist attacks perpetrated in } \\
\text { the United States of America...." }\end{array}$ & $\begin{array}{l}\text { None } \\
\text { identified }\end{array}$ & None identified & $\begin{array}{l}\text { None } \\
\text { identified }\end{array}$ & Article 51 & \begin{tabular}{l||} 
http: \\
//www.un. \\
org/en/ga/ \\
search/vie \\
wdoc. \\
asp? \\
symbol=s/ \\
2002/275 \\
\end{tabular} & & \begin{tabular}{|l} 
https: \\
//perma. \\
cc/DJ7T- \\
U3QR
\end{tabular} \\
\hline 382 & 2002.03.20 & 2002.03.26 & $\mathrm{S} / 2002 / 310$ & Liberia & Liberia & \begin{tabular}{|c|} 
Implied \\
assertion of \\
"individual" \\
self-defense
\end{tabular} & $\begin{array}{c}\text { Conducted } \\
\text { attack }\end{array}$ & Not indicated & Not indicated & $\begin{array}{l}\text { "[P]ersistent armed attacks against its } \\
\text { [that is, Liberian] territory." }\end{array}$ & $\begin{array}{l}\text { S/PV. } 4405 \\
\text { (4405th) }\end{array}$ & None identified & $\begin{array}{l}\text { None } \\
\text { identified }\end{array}$ & Article 51 & \begin{tabular}{|l||} 
http: \\
//www.un. \\
org/en/ga/ \\
search/vie \\
w_doc. \\
asp? \\
symbol=s/ \\
2002/310 \\
\end{tabular} & & $\begin{array}{l}\text { https: } \\
\text { //perma. } \\
\text { cc/ZMMW- } \\
\text { WAQW }\end{array}$ \\
\hline 383 & 2002.04.15 & 2002.04.15 & $S / 2002 / 420$ & Rwanda & $\begin{array}{c}\text { Rwanda, } \\
\text { Democratic } \\
\text { Republic of the } \\
\text { Congo }\end{array}$ & \begin{tabular}{|c} 
Implied \\
assertion of \\
"individual" \\
self-defense
\end{tabular} & $\begin{array}{c}\text { Conducted } \\
\text { attack }\end{array}$ & $\begin{array}{l}\text { Democratic } \\
\text { Republic of Congo } \\
\text { and "ex-Forces } \\
\text { armées rwandaises } \\
\text { (ex-FAR) and } \\
\text { Interahamwe } \\
\text { militias" }\end{array}$ & $\begin{array}{l}\text { State and } \\
\text { non-state } \\
\text { actors }\end{array}$ & \begin{tabular}{|l} 
Rwanda draws attention to certain \\
"underlying causes which led" it "to \\
intervene militarily in the Democratic \\
Republic of the Congo", apparently \\
includicg the DRC's refusal to comply \\
with UN Security Council resolutions \\
requesting that Member States \\
distance themselves "from the ex- \\
Forces armées rwandaises (ex-FAR) \\
and Interahamwe militias, the \\
planners and perpetrators of the \\
genocide in Rwanda."
\end{tabular} & $\begin{array}{l}\text { S/PV.4532 } \\
\text { (4532nd); } \\
\text { S/PV.4634 } \\
\text { (4634th) }\end{array}$ & None identified & $\begin{array}{l}\text { None } \\
\text { identified }\end{array}$ & Article 51 & \begin{tabular}{l||} 
http: \\
//www.un. \\
org/en/ga/ \\
search/vie \\
w_doc. \\
asp? \\
symbol=s/ \\
2002/420
\end{tabular} & \begin{tabular}{|l|} 
http://www. \\
un. \\
org/en/ga/se \\
arch/view_do \\
c.asp? \\
symbol=s/200 \\
2/420\&Lang= \\
F
\end{tabular} & $\begin{array}{l}\text { https: } \\
\text { //perma. } \\
\text { c/VGGG6- } \\
\text { X6RE }\end{array}$ \\
\hline
\end{tabular}


VI. HLS PILAC Catalogue of Apparent “Article 51 Communications”

\begin{tabular}{|c|c|c|c|c|c|c|c|c|c|c|c|c|c|c|c|c|c|}
\hline $\begin{array}{l}\text { Chron. } \\
\text { Order }\end{array}$ & $\begin{array}{l}\text { Date of } \\
\text { comm. }\end{array}$ & $\begin{array}{c}\text { Date of } \\
\text { UNsC } \\
\text { Document }\end{array}$ & UNSC Symbol & \begin{tabular}{||c} 
Member \\
State(s) That \\
Submitted \\
the Comm.
\end{tabular} & \begin{tabular}{|c|} 
Expressly \\
Mentioned UN \\
Members (\& \\
Colonial \\
Holdings \& \\
Protectorates, \\
if any) \\
\end{tabular} & \begin{tabular}{|c|} 
Express or \\
Implied \\
Assertion of \\
Individual, \\
Collective, or \\
Both Self- \\
defense \\
\end{tabular} & \begin{tabular}{|l}
$\begin{array}{c}\text { Nature of } \\
\text { the Alleged } \\
\text { Threat }\end{array}$
\end{tabular} & $\begin{array}{l}\text { Expressly Alleged } \\
\text { Author(s) of the } \\
\text { Threat (If Any } \\
\text { Indicated) }\end{array}$ & \begin{tabular}{|c} 
Nature of the \\
Alleged \\
Author(s) of \\
the Threat (If \\
Any \\
Indicated)
\end{tabular} & $\begin{array}{l}\text { Summary of Alleged Self-defense } \\
\text { Grounds }\end{array}$ & $\begin{array}{l}\text { UNsC } \\
\text { Meeting(s) } \\
\text { (If Any) at } \\
\text { Which the } \\
\text { Comm. was } \\
\text { Raised }\end{array}$ & $\begin{array}{l}\text { Responsive Act (If Any) by the } \\
\text { UNSC }\end{array}$ & $\begin{array}{l}\text { UN } \\
\text { Repertory } \\
\text { Inclusion? }\end{array}$ & \begin{tabular}{|} 
UNSC \\
Repertoire \\
Inclusion?
\end{tabular} & \begin{tabular}{|c||} 
URL to an \\
English \\
Text
\end{tabular} & \begin{tabular}{||c||} 
URL to Non- \\
English \\
Original \\
Text (ff Any)
\end{tabular} & $\begin{array}{l}\text { Perma.cc } \\
\text { URL }\end{array}$ \\
\hline 384 & 2003.03.21 & 2003.03.21 & S/2003/351 & $\begin{array}{l}\text { United } \\
\text { States }\end{array}$ & $\begin{array}{l}\text { United States, } \\
\text { Iraq }\end{array}$ & $\begin{array}{l}\text { Implied } \\
\text { assertion of } \\
\text { "individual" } \\
\text { self defense } \\
\text { and implied } \\
\text { assertion of } \\
\text { "collective" } \\
\text { self-defense }\end{array}$ & $\begin{array}{l}\text { Threat of } \\
\text { attack }\end{array}$ & Iraq & State & $\begin{array}{l}\text { "Iraq repeatedly has refused, over a } \\
\text { protracted period of time, to respond } \\
\text { to diplomatic overtures, economic } \\
\text { sanctions and other peaceful means, } \\
\text { designed to help bring about Iraqi } \\
\text { compliance with hits obligations to } \\
\text { disarm and to permit full inspection of } \\
\text { its weapons of mass destruction and } \\
\text { related programmes. The actions that } \\
\text { coalition forces are undertaking are an } \\
\text { appropriate response. They are } \\
\text { necessary steps to defend the United } \\
\text { States and the international } \\
\text { community from the threat posed by } \\
\text { Iraq and to restore international } \\
\text { peace and security in the area. Further } \\
\text { delay would simply allow Iraq q to } \\
\text { continue its unlawful and threatening } \\
\text { conduct.". }\end{array}$ & $\begin{array}{l}\text { None } \\
\text { identified }\end{array}$ & None identified & $\begin{array}{l}\text { None } \\
\text { identified }\end{array}$ & $\begin{array}{l}\text { None } \\
\text { identified }\end{array}$ & 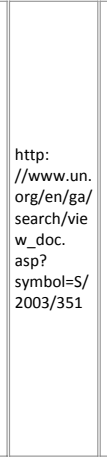 & & $\begin{array}{l}\text { hitps: } \\
\text { //perma. } \\
\text { cc//972- } \\
\text { A88L }\end{array}$ \\
\hline 385 & 2003.04.28 & 2003.04.26 & S/2003/510 & Cote d'Ivoire & $\begin{array}{l}\text { Cote d'Ivoire, } \\
\text { France }\end{array}$ & $\begin{array}{l}\text { Implied } \\
\text { assertion of } \\
\text { "individual" } \\
\text { self-defense }\end{array}$ & $\begin{array}{c}\text { Conducted } \\
\text { attack }\end{array}$ & "[R]ebel forces" & $\begin{array}{l}\text { Non-state } \\
\text { actors }\end{array}$ & \begin{tabular}{|l} 
Inter alia, "numerous atrocities and \\
flagrant violations of the Linas- \\
Marcoussis Agreement, in particular \\
the ceasefire, which are endangering \\
the peace process."
\end{tabular} & $\begin{array}{l}\text { None } \\
\text { identified }\end{array}$ & None identified & \begin{tabular}{|l} 
None \\
identified
\end{tabular} & Article 51 & \begin{tabular}{|l|} 
http: \\
//www.un. \\
org//nn/gal \\
search/vie \\
w_doc. \\
asp? \\
symbol=s/ \\
2003/s10 \\
\end{tabular} & \begin{tabular}{|l||} 
http://www. \\
un. \\
org/en/ga/se \\
arch/view_do \\
c.asp? \\
symbol=S/200 \\
3/510\&Lang= \\
$\mathrm{F}$
\end{tabular} & $\begin{array}{l}\text { https: } \\
\text { //Perma. } \\
\text { cc/8/5R- } \\
\text { YTKV }\end{array}$ \\
\hline 386 & 2004.06.08 & 2004.06.08 & S/2004/465 & Israel & $\begin{array}{c}\text { Israel, } \\
\text { Lebanon, Syria, } \\
\text { Iran }\end{array}$ & $\begin{array}{c}\text { Implied } \\
\text { assertion of } \\
\text { "individual" } \\
\text { self-defense }\end{array}$ & $\begin{array}{c}\text { Conducted } \\
\text { attack }\end{array}$ & $\begin{array}{l}\text { Hezbollah and } \\
\text { Ahmed Jibril's } \\
\text { Popular Front for } \\
\text { the Liberation of } \\
\text { Palestine (PFLP) }\end{array}$ & $\begin{array}{c}\text { Non-state } \\
\text { actors }\end{array}$ & \begin{tabular}{|l} 
“[T]he latest violations of the Blue \\
Line from Lebanese territory”: “six \\
$107-m m$ missiles were fired from \\
Lebanese territory at an Israeli naval \\
vessel.... Israeli aircraft responded to \\
these attacks by measured defensive \\
action....; etc.
\end{tabular} & $\begin{array}{l}\text { S/PV.5012 } \\
\text { (5012th) }\end{array}$ & $\begin{array}{l}\text { S/RES/1553(2004), OP 3-4: } \\
\text { "3. Reiterates its strong } \\
\text { support for the territorial } \\
\text { integrity, sovereignty and } \\
\text { political independence of } \\
\text { Lebanon within its } \\
\text { internationally recognized } \\
\text { boundaries; } \\
\text { 4. Encourages the Government } \\
\text { of Lebanon to continue efforts } \\
\text { to ensure the return of its } \\
\text { effective authority throughout } \\
\text { the south, including the } \\
\text { deployment of Lebanese } \\
\text { armed forces, stresses the } \\
\text { importance of the Government } \\
\text { of Lebanon continuing to } \\
\text { extend these measures and } \\
\text { calls on the Government of } \\
\text { Lebanon to do its utmost to } \\
\text { ensure a calm environment } \\
\text { throughout the south, } \\
\text { including along the Blue Line;"; }\end{array}$ & $\begin{array}{l}\text { None } \\
\text { identified }\end{array}$ & $\begin{array}{l}\text { Chapter IV; } \\
\text { Chapter V }\end{array}$ & 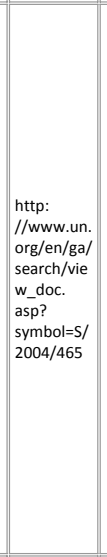 & & 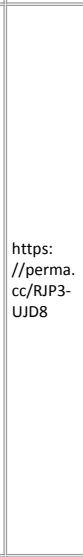 \\
\hline 387 & 2005.09.26 & 2005.09.26 & S/2005/609 & Israel & Israel & $\begin{array}{c}\text { Implied } \\
\text { assertion of } \\
\text { "individual" } \\
\text { self-defense }\end{array}$ & $\begin{array}{c}\text { Conducted } \\
\text { attack }\end{array}$ & $\begin{array}{l}\text { "TThhe terrorist } \\
\text { organization } \\
\text { Hamas" }\end{array}$ & $\begin{array}{c}\text { Non-state } \\
\text { actors }\end{array}$ & $\begin{array}{l}\text { ".... Hamas showered more than } 40 \\
\text { Kassam artillery rockets onto the } \\
\text { Israeli town of Sderot and elsewhere } \\
\text { in the Negev, wounding five persons, } \\
\text { two moderately, causing extensive } \\
\text { damage and forcing inhabitants of the } \\
\text { region to seek bomb shelters and } \\
\text { reinforced rooms.” }\end{array}$ & \begin{tabular}{|l} 
None \\
identified
\end{tabular} & None identified & $\begin{array}{l}\text { None } \\
\text { identified }\end{array}$ & Article 51 & \begin{tabular}{l|l||} 
http: \\
//www..un. \\
org/enn/ga/ \\
search/vie \\
w_doc. \\
asp? \\
symbol=s/ \\
2005/609
\end{tabular} & & $\begin{array}{l}\text { hitps: } \\
\text { ///perma. } \\
\text { cc//6KPN- } \\
\text { WLZz }\end{array}$ \\
\hline 388 & 2005.12.05 & 2005.12.05 & S/2005/756 & Israel & Israel & $\begin{array}{c}\text { Implied } \\
\text { assertion of } \\
\text { "individual" } \\
\text { self-defense }\end{array}$ & $\begin{array}{c}\text { Conducted } \\
\text { attack }\end{array}$ & $\begin{array}{l}\text { "[A]l-Aqsa Martyrs } \\
\text { Brigade" }\end{array}$ & $\begin{array}{c}\text { Non-state } \\
\text { actors }\end{array}$ & $\begin{array}{l}\text { "[P]ersistent armed attacks against its } \\
\text { [that is, Liberian] territory." }\end{array}$ & $\begin{array}{l}\text { None } \\
\text { identified }\end{array}$ & None identified & \begin{tabular}{|l} 
None \\
identified
\end{tabular} & Article 51 & \begin{tabular}{|l||} 
http: \\
I/www.un. \\
org///nh/ga/ \\
search//vie \\
w_doc. \\
asp? \\
symbol=s/ \\
2005/756 \\
\end{tabular} & & $\begin{array}{l}\text { hitps: } \\
\text { ///perma. } \\
\text { cc/Nuks- } \\
\text { GVTS }\end{array}$ \\
\hline
\end{tabular}


VI. HLS PILAC Catalogue of Apparent “Article 51 Communications”

\begin{tabular}{|c|c|c|c|c|c|c|c|c|c|c|c|c|c|c|c|c|c|}
\hline $\begin{array}{l}\text { Chron. } \\
\text { Order }\end{array}$ & $\begin{array}{l}\text { Date of } \\
\text { Comm. }\end{array}$ & $\begin{array}{c}\text { Date of } \\
\text { UNsc } \\
\text { Document }\end{array}$ & UNSC Symbol & \begin{tabular}{|c} 
Member \\
State(s) That \\
Submitted \\
the Comm.
\end{tabular} & \begin{tabular}{||c||} 
Expressly \\
Mentioned UN \\
Members (\& \\
Colonial \\
Holdings \& \\
Protectorates, \\
if any) \\
\end{tabular} & \begin{tabular}{|c|} 
Express or \\
Implied \\
Assertion of \\
Individual, \\
Collective, or \\
Both Self- \\
defense
\end{tabular} & \begin{tabular}{|c} 
Nature of \\
the Alleged \\
Threat
\end{tabular} & $\begin{array}{l}\text { Expressly Alleged } \\
\text { Author(s) of the } \\
\text { Threat (If Any } \\
\text { Indicated) }\end{array}$ & \begin{tabular}{|c|} 
Nature of the \\
Alleged \\
Author(s) of \\
the Threat (If \\
Any \\
Indicated) \\
\end{tabular} & $\begin{array}{l}\text { Summary of Alleged Self-defense } \\
\text { Grounds }\end{array}$ & \begin{tabular}{|c|} 
UNsc \\
Meeting(s) \\
(if Any) at \\
Which the \\
Comm. was \\
Raised
\end{tabular} & $\begin{array}{l}\text { Responsive Act (If Any) by the } \\
\text { UNSC }\end{array}$ & $\begin{array}{l}\text { UN } \\
\text { Repertory } \\
\text { Inclusion? }\end{array}$ & $\begin{array}{c}\text { UNSC } \\
\text { Repertoire } \\
\text { Inclusion? }\end{array}$ & \begin{tabular}{|c||} 
URL to an \\
English \\
Text
\end{tabular} & \begin{tabular}{||c||} 
URL to Non- \\
English \\
OOrinal \\
Text (ff Any)
\end{tabular} & \begin{tabular}{|l} 
Perma.cc \\
URL
\end{tabular} \\
\hline 389 & 2007.02.08 & 2007.02.08 & $s / 2007 / 69$ & Israel & Israel, Lebanon & $\begin{array}{l}\text { Implied } \\
\text { assertion of } \\
\text { "individual" } \\
\text { self-defense }\end{array}$ & $\begin{array}{c}\text { Conducted } \\
\text { attack }\end{array}$ & Lebanon & State & $\begin{array}{l}\text { "...Israeli soldiers were fired on by the } \\
\text { Lebanese Army. In response, the Israel } \\
\text { Defense Forces returned fire." }\end{array}$ & \begin{tabular}{|l} 
None \\
identified
\end{tabular} & None identified & $\begin{array}{l}\text { None } \\
\text { identified }\end{array}$ & \begin{tabular}{|l} 
None \\
identified
\end{tabular} & \begin{tabular}{|l||} 
http: \\
t/www.un. \\
org//nn/ga/ \\
search/vie \\
w_doc. \\
asp?? \\
symbol=s/ \\
2007/6s \\
\end{tabular} & & \begin{tabular}{|l} 
https: \\
//perma. \\
cc/TUZ7- \\
3ANG
\end{tabular} \\
\hline 390 & 2008.01.15 & 2008.01.15 & $\mathrm{s} / 2008 / 21$ & Chad & Chad, Sudan & $\begin{array}{l}\text { Implied } \\
\text { assertion of } \\
\text { "individual" } \\
\text { self-defense }\end{array}$ & $\begin{array}{c}\text { Conducted } \\
\text { attack }\end{array}$ & Sudan & State & \begin{tabular}{|l} 
"Alcts of aggression and \\
destabilization committed by the \\
Sudan against Chad; .... [ף] ... [T]he \\
Sudanese Government has never \\
stopped organizing and arming hostile \\
groups in its territory for the purpose \\
of destabilizing Chad, not to mention \\
the collateral effects, with thousands \\
of Darfur refugees and Chadian \\
displaced persons in eastern Chad. \\
The Sudan is determined and secretly \\
plotting to use every possible means \\
to install a compliant regime in $\mathrm{N}^{\prime}$ \\
Djamena prior to the deployment of \\
the European Union operation \\
(EUFO) and to resolve its internal \\
crisis in Darfur by making Chad a \\
victim.”
\end{tabular} & $\begin{array}{l}\text { None } \\
\text { identified }\end{array}$ & None identified & $\begin{array}{l}\text { None } \\
\text { identified }\end{array}$ & Article 51 & 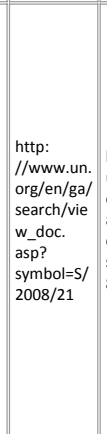 & $\begin{array}{l}\text { http://www. } \\
\text { un. } \\
\text { org/en/ga/se } \\
\text { arch/view_do } \\
\text { casp? } \\
\text { symbol=s/200 } \\
\text { 8/218Llang=F }\end{array}$ & $\begin{array}{l}\text { https: } \\
\text { //perma. } \\
\text { c/D7LK- } \\
\text { PF65 }\end{array}$ \\
\hline 391 & 2008.08.09 & 2008.08.09 & $\mathrm{S} / 2008 / 544$ & Georgia & Georgia, Russia & $\begin{array}{c}\text { Implied } \\
\text { assertion of } \\
\text { "individual" } \\
\text { self-defense }\end{array}$ & $\begin{array}{c}\text { Conducted } \\
\text { attack }\end{array}$ & Russia & State & $\begin{array}{l}\text { The President of Georgia declared, } \\
\text { and the Parliament approved, a state } \\
\text { of war within the territory of Georgia } \\
\text { following "military aggression of the } \\
\text { Russian Federation against Georgia on } \\
\text { August } 8,2008 \text { that continue as for } \\
\text { today. A s a result of invasion, civilian } \\
\text { objects, hospitals, residential sites and } \\
\text { critical infrastructure have been } \\
\text { bombed throughout the country } \\
\text { causing casualties among civilian } \\
\text { population and destruction of } \\
\text { property." }\end{array}$ & $\begin{array}{l}\text { None } \\
\text { identified }\end{array}$ & None identified & $\begin{array}{l}\text { None } \\
\text { identified }\end{array}$ & $\begin{array}{l}\text { None } \\
\text { identified }\end{array}$ & \begin{tabular}{|l||} 
http: \\
//www.un. \\
org///nnga/ \\
search//vie \\
w_doc. \\
asp? \\
symbol=s/ \\
2008/544 \\
200/
\end{tabular} & & \begin{tabular}{|l} 
https: \\
//perma. \\
cc/PEM3- \\
NHEN
\end{tabular} \\
\hline 392 & 2008.08.11 & 2008.08.11 & $\mathrm{S} / 2008 / 545$ & Russia & Russia, Georgia & $\begin{array}{c}\text { Implied } \\
\text { assertion of } \\
\text { "individual" } \\
\text { self-defense }\end{array}$ & $\begin{array}{c}\text { Conducted } \\
\text { attack }\end{array}$ & Georgia & State & $\begin{array}{l}\text { "...Georgian forces, in violation of the } \\
\text { existing agreemements on ceasefire in } \\
\text { the zone of Georgian-Ossetian } \\
\text { conflict, launched a military operation } \\
\text { in South Ossetia. The first hours of the } \\
\text { operation inflicted considerable } \\
\text { destruction on the city of Tshinval; } \\
\text { about } 1,500 \text { peaceful civilians, most of } \\
\text { them Russian citizens, lost their lives. } \\
\text { A targeted massive assault was } \\
\text { launched on the Russian } \\
\text { peacekeeping contingent which is part } \\
\text { of the Joint Peacekeeping Forces. The } \\
\text { Russian peacekeepers sustained } \\
\text { casualties." }\end{array}$ & $\begin{array}{l}\text { S/PV.5969 } \\
\text { (5969th) }\end{array}$ & None identified & $\begin{array}{l}\text { None } \\
\text { identified }\end{array}$ & $\begin{array}{l}\text { None } \\
\text { identified }\end{array}$ & \begin{tabular}{|l||} 
http: \\
//www.un. \\
org///nnga/ \\
search/vie \\
w_doc. \\
asp? \\
symbol=s/ \\
2008/545 \\
200/
\end{tabular} & & \begin{tabular}{|l} 
https: \\
//perma. \\
cc/GL5L- \\
5XE9
\end{tabular} \\
\hline 393 & 2008.10.15 & 2008.10.15 & $\mathrm{S} / 2008 / 653$ & Cambodia & $\begin{array}{l}\text { Cambodia, } \\
\text { Thailand }\end{array}$ & $\begin{array}{l}\text { Implied } \\
\text { assertion of } \\
\text { "individual" } \\
\text { self-defense }\end{array}$ & $\begin{array}{c}\text { Conducted } \\
\text { attack }\end{array}$ & Thailand & State & $\begin{array}{l}\text { Thai troops "returned to the same } \\
\text { location [Veal Intry area, in } \\
\text { Cambodian territoryl and fired guns } \\
\text { on Cambodian soldiers, ...." }\end{array}$ & \begin{tabular}{|l} 
None \\
identified
\end{tabular} & None identified & $\begin{array}{l}\text { None } \\
\text { identified }\end{array}$ & Article 51 & \begin{tabular}{|l|} 
http: \\
//www.un. \\
org/en/ga/ \\
search/vie \\
w_doc. \\
asp? \\
symbol=s/ \\
2008/653 \\
\end{tabular} & & $\begin{array}{l}\text { https: } \\
\text { //perma. } \\
\text { cc/H3MB- } \\
\text { 6R97 }\end{array}$ \\
\hline
\end{tabular}


VI. HLS PILAC Catalogue of Apparent “Article 51 Communications”

\begin{tabular}{|c|c|c|c|c|c|c|c|c|c|c|c|c|c|c|c|c|c|}
\hline \begin{tabular}{l|} 
Chron. \\
Order
\end{tabular} & $\begin{array}{l}\text { Date of } \\
\text { Comm. }\end{array}$ & $\begin{array}{c}\text { Date of } \\
\text { UNsC } \\
\text { Document }\end{array}$ & UNSC Symbol & \begin{tabular}{||c} 
Member \\
State(s) That \\
Submitted \\
the Comm.
\end{tabular} & \begin{tabular}{|c||} 
Expressly \\
Mentioned UN \\
Members (\& \\
Colonial \\
Holdings \& \\
Protectorates, \\
if any) \\
\end{tabular} & \begin{tabular}{|l|} 
Express or \\
Implied \\
Assertion of \\
Individual, \\
Collective, or \\
Both Self- \\
defense \\
\end{tabular} & $\begin{array}{c}\text { Nature of } \\
\text { the Alleged } \\
\text { Threat }\end{array}$ & $\begin{array}{l}\text { Expressly Alleged } \\
\text { Author(s) of the } \\
\text { Threat (If Any } \\
\text { Indicated) }\end{array}$ & \begin{tabular}{|c} 
Nature of the \\
Alleged \\
Author(s) of \\
the Threat (If \\
Any \\
Indicated)
\end{tabular} & $\begin{array}{l}\text { Summary of Alleged Self-defense } \\
\text { Grounds }\end{array}$ & $\begin{array}{l}\text { UNsC } \\
\text { Meeting(s) } \\
\text { (If Any) at } \\
\text { Which the } \\
\text { Comm. was } \\
\text { Raised }\end{array}$ & $\begin{array}{l}\text { Responsive Act (If Any) by the } \\
\text { UNSC }\end{array}$ & \begin{tabular}{|l} 
UN \\
Repertory \\
Inclusion?
\end{tabular} & $\begin{array}{c}\text { UNSC } \\
\text { Repertoire } \\
\text { Inclusion? }\end{array}$ & \begin{tabular}{|l|} 
URL to an \\
English \\
Text
\end{tabular} & \begin{tabular}{||c||} 
URL to Non- \\
English \\
Original \\
Text (ff Any)
\end{tabular} & \begin{tabular}{|l} 
Perma.cc \\
URL
\end{tabular} \\
\hline 394 & 2008.10.16 & 2008.10.17 & S/2008/657 & Thailand & $\begin{array}{l}\text { Thailand, } \\
\text { Cambodia }\end{array}$ & $\begin{array}{c}\text { Implied } \\
\text { assertion of } \\
\text { "individual" } \\
\text { self-defense }\end{array}$ & $\begin{array}{l}\text { Conducted } \\
\text { attack }\end{array}$ & Cambodia & State & \begin{tabular}{|l} 
"[W]hile conducting a routine patrol \\
near the area called Phu Ma Khua in \\
Thai territory, Thai soldiers came \\
under hostile attack by Cambodian \\
soldiers using rocket-propelled \\
grenades and sub-machine guns. At \\
the same time, around the area near \\
Pha Mor I Dang in Thai territory, \\
another group of Cambodian soldiers \\
also opened fire - using recoilless \\
guns, rocket-propelled grenades, \\
mortars and rifles - on Thai soldiers. \\
... While the first incident went on for \\
5 minutes, the second incident lasted \\
about 35 minutes."
\end{tabular} & $\begin{array}{l}\text { None } \\
\text { identified }\end{array}$ & None identified & $\begin{array}{l}\text { None } \\
\text { identified }\end{array}$ & $\begin{array}{l}\text { Articles 2(4) } \\
\& 51\end{array}$ & \begin{tabular}{|l||} 
http: \\
|/www.un. \\
org/en/ga/ \\
search/vie \\
w_doc. \\
asp? \\
symbol=s/ \\
2008/657
\end{tabular} & & \begin{tabular}{|l} 
https: \\
//perma. \\
c/g/93J-- \\
6RUB
\end{tabular} \\
\hline 395 & 2008.12.27 & 2008.12.27 & S/2008/816 & Israel & Israel, Egypt & $\begin{array}{l}\text { Implied } \\
\text { assertion of } \\
\text { "individual" } \\
\text { self-defense }\end{array}$ & $\begin{array}{l}\text { Conducted } \\
\text { attack }\end{array}$ & $\begin{array}{l}\text { "Hamas and other } \\
\text { terrorist } \\
\text { organizations" }\end{array}$ & $\begin{array}{l}\text { Non-state } \\
\text { actors }\end{array}$ & \begin{tabular}{|l} 
"OO]ngoing terrorist attacks originating \\
from the Gaza Strip .... In] In the past \\
two months alone, more than 400 \\
rockets and 200 mortar shells were \\
fired at Israeli civilian communities. \\
These deliberate attacks against \\
civilians have intensified lately...."
\end{tabular} & $\begin{array}{l}\text { None } \\
\text { identified }\end{array}$ & None identified & $\begin{array}{l}\text { None } \\
\text { identified }\end{array}$ & $\begin{array}{l}\text { None } \\
\text { identified }\end{array}$ & \begin{tabular}{|l|} 
http: \\
//www.un. \\
orge//gan \\
search/vie \\
w_doc. \\
asp? \\
symbol=s/ \\
2008/816 \\
\end{tabular} & & \begin{tabular}{|l} 
https: \\
//perma. \\
c/5YSPB- \\
2AY2
\end{tabular} \\
\hline 396 & 2009.01.04 & 2009.01.06 & $S / 2009 / 6$ & Israel & Israel, Egypt & $\begin{array}{l}\text { Implied } \\
\text { assertion of } \\
\text { "individual" } \\
\text { self-defense }\end{array}$ & $\begin{array}{c}\text { Conducted } \\
\text { attack }\end{array}$ & Hamas & $\begin{array}{c}\text { Non-state } \\
\text { actors }\end{array}$ & $\begin{array}{l}\text { “.....Hamas' continuous terrorist } \\
\text { attacks, } \text {... [T]he State of Israel was } \\
\text { compelled to resort to this defensive } \\
\text { military operation after a long period } \\
\text { during which its citizens were } \\
\text { subjected to deliberate terrorist } \\
\text { attacks.” }\end{array}$ & $\begin{array}{l}\text { None } \\
\text { identified }\end{array}$ & None identified & $\begin{array}{l}\text { None } \\
\text { identified }\end{array}$ & \begin{tabular}{|l} 
None \\
identified
\end{tabular} & \begin{tabular}{|l|} 
http: \\
//www.un. \\
organ/ga/ \\
search/vie \\
w_doc. \\
asp? \\
symbol=s/ \\
2009/6 \\
\end{tabular} & & \begin{tabular}{|l} 
https: \\
//perma. \\
cc/7754- \\
C26U
\end{tabular} \\
\hline 397 & 2009.10.26 & 2009.10.29 & S/2009/563 & Israel & Israel, Lebanon & $\begin{array}{l}\text { Implied } \\
\text { assertion of } \\
\text { "individual" } \\
\text { self-defense }\end{array}$ & $\begin{array}{c}\text { Conducted } \\
\text { attack }\end{array}$ & Not indicated & Not indicated & $\begin{array}{l}\text { "[A] 107-millimetre rocket was fired } \\
\text { from Lebanon and struck the area of } \\
\text { the city of Kiryat Shmona in northern } \\
\text { Israel. Thankfully, the rocket landed in } \\
\text { an open area and no injuries or } \\
\text { serious damage has been reported." }\end{array}$ & $\begin{array}{l}\text { None } \\
\text { identified }\end{array}$ & None identified & $\begin{array}{l}\text { None } \\
\text { identified }\end{array}$ & $\begin{array}{l}\text { None } \\
\text { identified }\end{array}$ & \begin{tabular}{|l||} 
http: \\
//www.un. \\
org/en/ga/ \\
search/vie \\
w_doc. \\
asp? \\
symbol=s/ \\
2009/563 \\
\end{tabular} & & \begin{tabular}{|l} 
https: \\
//perma. \\
c/FFEQ- \\
8RVE
\end{tabular} \\
\hline 398 & 2010.01.12 & 2010.01.13 & $S / 2010 / 21$ & Israel & Israel & $\begin{array}{l}\text { Implied } \\
\text { assertion of } \\
\text { "individual" } \\
\text { self-defense }\end{array}$ & $\begin{array}{c}\text { Conducted } \\
\text { attack }\end{array}$ & "[T]errorists" & $\begin{array}{c}\text { Non-state } \\
\text { actors }\end{array}$ & 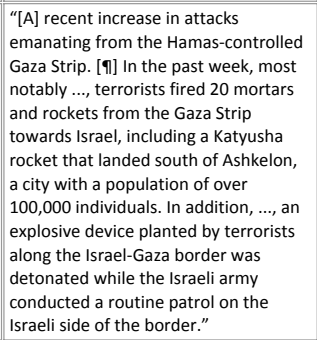 & $\begin{array}{l}\text { None } \\
\text { identified }\end{array}$ & None identified & $\begin{array}{l}\text { None } \\
\text { identified }\end{array}$ & Article 51 & \begin{tabular}{|l||} 
http: \\
//www.un. \\
org/en/ga/ \\
search/vie \\
w_doc. \\
asp? \\
symbol=s/ \\
2010/21
\end{tabular} & & $\begin{array}{l}\text { https: } \\
\text { //perma. } \\
\text { cc/MJE4- } \\
\text { HGR8 }\end{array}$ \\
\hline 399 & 2010.08.03 & 2010.08.03 & S/2010/415 & Israel & Israel, Lebanon & $\begin{array}{l}\text { Implied } \\
\text { assertion of } \\
\text { "individual" } \\
\text { self-defense }\end{array}$ & $\begin{array}{c}\text { Conducted } \\
\text { attack }\end{array}$ & Lebanon & State & \begin{tabular}{|l} 
“... Lebanese Armed Forces (LAF) \\
positions opened fire at the Israel \\
Defense forces, killing Battalion \\
Commander Lieutenant Colonel Dov \\
Harari and critically wounding a \\
company commander. Shortly \\
thereafter, ..., the Lebanese Armed \\
Forces launched a secondary attack at \\
Israel with rocket propelled \\
grenades.”
\end{tabular} & $\begin{array}{l}\text { None } \\
\text { identified }\end{array}$ & None identified & $\begin{array}{l}\text { None } \\
\text { identified }\end{array}$ & $\begin{array}{l}\text { None } \\
\text { identified }\end{array}$ & \begin{tabular}{|l||} 
http: \\
|/www.un. \\
org/en/ga/ \\
search/vie \\
w_doc. \\
asp? \\
symbol=s/ \\
2010/415
\end{tabular} & & \begin{tabular}{|l} 
https: \\
//perma. \\
cc/TV3P- \\
DZJV
\end{tabular} \\
\hline
\end{tabular}


VI. HLS PILAC Catalogue of Apparent “Article 51 Communications”

\begin{tabular}{|c|c|c|c|c|c|c|c|c|c|c|c|c|c|c|c|c|c|}
\hline $\begin{array}{c}\text { Chron. } \\
\text { Order }\end{array}$ & $\begin{array}{l}\text { Date of } \\
\text { Comm. }\end{array}$ & $\begin{array}{c}\text { Date of } \\
\text { UNSC } \\
\text { Document }\end{array}$ & UNSC Symbol & \begin{tabular}{||c} 
Member \\
State(s) That \\
Submitted \\
the Comm.
\end{tabular} & \begin{tabular}{|c} 
Expressly \\
Mentioned UN \\
Members (\& \\
Colonial \\
Holdings \& \\
Protectorates, \\
if any)
\end{tabular} & \begin{tabular}{||c|} 
Express or \\
Implied \\
Assertion of \\
Individual, \\
Collective, or \\
Both Self- \\
defense \\
\end{tabular} & \begin{tabular}{|l} 
Nature of \\
the Alleged \\
Threat
\end{tabular} & $\begin{array}{l}\text { Expressly Alleged } \\
\text { Author(s) of the } \\
\text { Threat (If Any } \\
\text { Indicated) }\end{array}$ & \begin{tabular}{|c} 
Nature of the \\
Alleged \\
Author(s) of \\
the Threat (If \\
Any \\
Indicated)
\end{tabular} & $\begin{array}{l}\text { Summary of Alleged Self-defense } \\
\text { Grounds }\end{array}$ & \begin{tabular}{|c} 
UNSC \\
Meeting(s) \\
(If Any) at \\
Which the \\
Comm. was \\
Raised \\
\end{tabular} & $\begin{array}{l}\text { Responsive Act (If Any) by the } \\
\text { UNSC }\end{array}$ & $\begin{array}{l}\text { UN } \\
\text { Repertory } \\
\text { Inclusion? }\end{array}$ & \begin{tabular}{|c|} 
UNSC \\
Repertoire \\
Inclusion?
\end{tabular} & \begin{tabular}{|c|} 
URL to an \\
English \\
Text
\end{tabular} & \begin{tabular}{||c||} 
URL to Non- \\
English \\
Original \\
Text (ff Any)
\end{tabular} & $\begin{array}{l}\text { Perma.cc } \\
\text { URL }\end{array}$ \\
\hline 400 & 2011.02.05 & 2011.02.07 & $\mathrm{S} / 2011 / 56$ & Cambodia & $\begin{array}{l}\text { Cambodia, } \\
\text { Thailand }\end{array}$ & \begin{tabular}{|l} 
Implied \\
assertion of \\
"individual" \\
self-defense
\end{tabular} & $\begin{array}{c}\text { Conducted } \\
\text { attack }\end{array}$ & Thailand & State & \begin{tabular}{|l} 
"[A]pproximately 300 Thai troops \\
entered Cambodian territory and \\
attacked Cambodian troops at three \\
locations, .... This aggression by Thai \\
armed forces was also followed by \\
firing of many $130 \mathrm{~mm}$ and $155 \mathrm{~mm}$ \\
artilllery shells, which reached as far as \\
about $20 \mathrm{~km}$ inside Cambodian \\
territory. The attack caused much \\
serious damage to the Temple of \\
Preah Vihear, a World Heritege site, as \\
well as death and injury of more than \\
10 Cambodian troops and villagers. [ף] \\
Again, ..., Thai armed forces fired a \\
number of $105 \mathrm{~mm}$ artillery shells at \\
Phnom Trap hill, which lasted for \\
about 20 minutes."
\end{tabular} & $\begin{array}{l}\text { S/PV.6480 } \\
\text { (6480th) }\end{array}$ & None identified & $\begin{array}{l}\text { None } \\
\text { identified }\end{array}$ & $\begin{array}{l}\text { Articles 2(4) } \\
\& 94\end{array}$ & \begin{tabular}{|l||} 
http: \\
//www.un. \\
org/en/ga/ \\
search/vie \\
w_doc. \\
asp? \\
symbol=S/ \\
2011/56
\end{tabular} & & \begin{tabular}{|l} 
https: \\
//perma. \\
cp/6UTJ- \\
LVBK
\end{tabular} \\
\hline 401 & 2011.02.05 & 2011.02.07 & $S / 2011 / 57$ & Thailand & $\begin{array}{l}\text { Thailand, } \\
\text { Cambodia }\end{array}$ & $\begin{array}{l}\text { Implied } \\
\text { assertion of } \\
\text { "individual" } \\
\text { self-defense }\end{array}$ & $\begin{array}{c}\text { Conducted } \\
\text { attack }\end{array}$ & Cambodia & State & 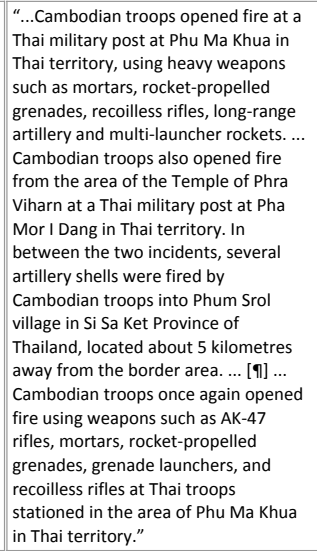 & $\begin{array}{l}\text { S/PV.6480 } \\
\text { (6480th) }\end{array}$ & None identified & $\begin{array}{l}\text { None } \\
\text { identified }\end{array}$ & Article 51 & \begin{tabular}{|l||} 
http: \\
|/www.un. \\
org/en/ga/ \\
search/vie \\
w_doc. \\
asp? \\
symbol=s/ \\
2011/57
\end{tabular} & & $\begin{array}{l}\text { https: } \\
\text { //perma. } \\
\text { cc/ASFM- } \\
\text { DQKK }\end{array}$ \\
\hline 402 & 2011.04.22 & 2011.04.22 & $\mathrm{S} / 2011 / 265$ & Thailand & $\begin{array}{l}\text { Thailand, } \\
\text { Cambodia }\end{array}$ & $\begin{array}{l}\text { Implied } \\
\text { assertion of } \\
\text { "individual" } \\
\text { self-defense }\end{array}$ & $\begin{array}{l}\text { Conducted } \\
\text { attack }\end{array}$ & Cambodia & State & $\begin{array}{l}\text { "[U]nprovoked armed attacks by } \\
\text { Cambodian troops on Thai territory in } \\
\text { the area of Ta Kwai temple and along } \\
\text { the Thai-Cambodian border near } \\
\text { Tamuen temples, in Surin Province, } \\
\text {...." }\end{array}$ & \begin{tabular}{|l} 
None \\
identified
\end{tabular} & None identified & $\begin{array}{l}\text { None } \\
\text { identified }\end{array}$ & Article 51 & \begin{tabular}{|l|} 
http: \\
//www.un. \\
org//nn/ga/ \\
search/vie \\
w_doc. \\
asp? \\
symbol=s/ \\
2011/265 \\
\end{tabular} & & \begin{tabular}{|l} 
https: \\
//perma. \\
cc/74F9- \\
PHA7
\end{tabular} \\
\hline 403 & 2012.04.23 & 2012.04.23 & S/2012/252 & Sudan & $\begin{array}{l}\text { Sudan, South } \\
\text { Sudan }\end{array}$ & $\begin{array}{l}\text { Implied } \\
\text { assertion of } \\
\text { "individual" } \\
\text { self-defense }\end{array}$ & \begin{tabular}{|c} 
Conducted \\
attack
\end{tabular} & South Sudan & State & \begin{tabular}{|l} 
"TThe unlawful occupation by the \\
Government of the Republic of South \\
Sudan of the Sudanese town of Heglig, \\
...." In addition to the refusal by the \\
President of South Sudan to withdraw \\
therefrom, "the Government of Sudan \\
has evidence in the form of a recorded \\
telephone conversation ..., between \\
the Governor of Unity State in South \\
Sudan, General Taaban Deng, and \\
Fadeel, South Sudan's commander in \\
Heglig, where General Taaban Deng is \\
giving clear orders to their \\
commander to burn all the oil facilities \\
in Heglig."
\end{tabular} & $\begin{array}{l}\text { None } \\
\text { identified }\end{array}$ & None identified & $\begin{array}{l}\text { None } \\
\text { identified }\end{array}$ & $\begin{array}{l}\text { Articles 51, } \\
35\end{array}$ & \begin{tabular}{|l||} 
http: \\
|/www.un. \\
org/en/ga/ \\
search/vie \\
w_doc. \\
asp? \\
symbol=s/ \\
2012/252 \\
\end{tabular} & & \begin{tabular}{|l} 
https: \\
//perma. \\
cc/YTZ4- \\
ALDH
\end{tabular} \\
\hline
\end{tabular}


VI. HLS PILAC Catalogue of Apparent “Article 51 Communications”

\begin{tabular}{|c|c|c|c|c|c|c|c|c|c|c|c|c|c|c|c|c|c|}
\hline $\begin{array}{c}\text { Chron. } \\
\text { Order }\end{array}$ & $\begin{array}{l}\text { Date of } \\
\text { comm. }\end{array}$ & $\begin{array}{l}\text { Date of } \\
\text { UNsc } \\
\text { Document }\end{array}$ & UNSC Symbol & \begin{tabular}{|c} 
Member \\
State(s) That \\
Submitted \\
the Comm.
\end{tabular} & \begin{tabular}{|c|} 
Expressly \\
Mentioned UN \\
Members (\& \\
Colonial \\
Holdings \& \\
Protectorates, \\
if any) \\
\end{tabular} & \begin{tabular}{|l|} 
Express or \\
Implied \\
Assertion of \\
Individual, \\
Collective, or \\
Both Self- \\
defense \\
\end{tabular} & $\begin{array}{c}\text { Nature of } \\
\text { the Alleged } \\
\text { Threat }\end{array}$ & $\begin{array}{l}\text { Expressly Alleged } \\
\text { Author(s) of the } \\
\text { Threat (If Any } \\
\text { Indicated) }\end{array}$ & \begin{tabular}{|c||} 
Nature of the \\
Alleged \\
Author(s) of \\
the Threat (If \\
Any \\
Andicated)
\end{tabular} & $\begin{array}{l}\text { Summary of Alleged Self-defense } \\
\text { Grounds }\end{array}$ & \begin{tabular}{|c|} 
UNsc \\
Meeting(s) \\
(if Any) at \\
Which the \\
Comm. was \\
Raised
\end{tabular} & $\begin{array}{l}\text { Responsive Act (If Any) by the } \\
\text { UNSC }\end{array}$ & $\begin{array}{l}\text { UN } \\
\text { Repertory } \\
\text { Inclusion? }\end{array}$ & $\begin{array}{c}\text { UNSC } \\
\text { Repertoire } \\
\text { Inclusion? }\end{array}$ & \begin{tabular}{|l|} 
URL to an \\
English \\
Text
\end{tabular} & \begin{tabular}{||c||} 
URL to Non- \\
English \\
Original \\
Text (ff Any)
\end{tabular} & $\begin{array}{l}\text { Perma.cc } \\
\text { URL }\end{array}$ \\
\hline 404 & 2013.05.21 & 2013.05.21 & $\mathrm{S} / 2013 / 303$ & Syria & Syria, Israel & $\begin{array}{c}\text { Implied } \\
\text { assertion of } \\
\text { "individual" } \\
\text { self-defense }\end{array}$ & $\begin{array}{c}\text { Conducted } \\
\text { attack }\end{array}$ & Israel & State & $\begin{array}{l}\text { "AAln Israeli vehicle crossed the } \\
\text { ceasefire line.... The presence of } \\
\text { armed terrorist groups in that village } \\
\text { led the Syrian armed forces to target } \\
\text { the above-mentioned Israeli vehicle. } \\
\text { Israel also launched two infrared } \\
\text { homing missics ... in the occupied } \\
\text { Syrian Golan towards the territory of } \\
\text { the Syrian Arab Republic." }\end{array}$ & $\begin{array}{l}\text { None } \\
\text { identified }\end{array}$ & None identified & $\begin{array}{l}\text { None } \\
\text { identified }\end{array}$ & Article 51 & \begin{tabular}{|l||} 
http: \\
//www.un. \\
org/en/ga/ \\
search/vie \\
w_doc. \\
asp? \\
symbol=s/ \\
2013/303
\end{tabular} & \begin{tabular}{|l|} 
http://www. \\
un. \\
org/en/ga/se \\
arch/view_do \\
c.asp? \\
symbol=s/201 \\
3/303\&Lang= \\
A
\end{tabular} & $\begin{array}{l}\text { https: } \\
\text { //perma. } \\
\text { ccl/frRg- } \\
\text { FWZM }\end{array}$ \\
\hline 405 & 2014.06.17 & 2014.06.18 & $\mathrm{S} / 2014 / 417$ & $\begin{array}{l}\text { United } \\
\text { States }\end{array}$ & \begin{tabular}{|l} 
United States, \\
Libya
\end{tabular} & $\begin{array}{c}\text { Implied } \\
\text { assertion of } \\
\text { "individual" } \\
\text { self-defense }\end{array}$ & $\begin{array}{l}\text { Conducted } \\
\text { attack and } \\
\text { threat of } \\
\text { attack }\end{array}$ & $\begin{array}{l}\text { Ahmed Abu } \\
\text { Khattalah/Ansar al- } \\
\text { Sharia-Benghazi }\end{array}$ & $\begin{array}{l}\text { Non-state } \\
\text { actors }\end{array}$ & 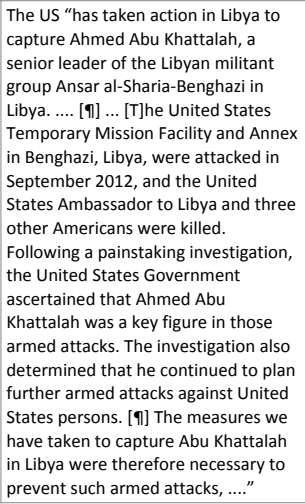 & $\begin{array}{l}\text { None } \\
\text { identified }\end{array}$ & None identified & $\begin{array}{l}\text { None } \\
\text { identified }\end{array}$ & Article 51 & \begin{tabular}{|l||} 
http: \\
|/www.un. \\
org/en/ga/ \\
search/vie \\
w_doc. \\
asp? \\
symbol=s/ \\
2014/417
\end{tabular} & & $\begin{array}{l}\text { https: } \\
\text { //perma. } \\
\text { cc/58878- } \\
\text { s283 }\end{array}$ \\
\hline
\end{tabular}


VI. HLS PILAC Catalogue of Apparent “Article 51 Communications”

\begin{tabular}{|c|c|c|c|c|c|c|c|c|c|c|c|c|c|c|c|c|c|}
\hline $\begin{array}{l}\text { Chron. } \\
\text { Order }\end{array}$ & $\begin{array}{l}\text { Date of } \\
\text { Comm. }\end{array}$ & $\begin{array}{c}\text { Date of } \\
\text { UNSC } \\
\text { Document }\end{array}$ & UNSC Symbol & $\begin{array}{c}\text { Member } \\
\text { State(s) That } \\
\text { Submitted } \\
\text { the Comm. }\end{array}$ & \begin{tabular}{|c} 
Expressly \\
Mentioned UN \\
Members (\& \\
Colonial \\
Holdings \& \\
Protectorates, \\
if any)
\end{tabular} & \begin{tabular}{|c} 
Express or \\
Implied \\
Assertion of \\
Individual, \\
Collective, or \\
Both Self- \\
defense
\end{tabular} & \begin{tabular}{|l} 
Nature of \\
the Alleged \\
Threat
\end{tabular} & \begin{tabular}{|l} 
Expressly Alleged \\
Author(s) of the \\
Threat (If any \\
Indicated)
\end{tabular} & \begin{tabular}{|c|} 
Nature of the \\
Alleged \\
Author(s) of \\
the Threat (If \\
Any \\
Indicated)
\end{tabular} & $\begin{array}{l}\text { Summary of Alleged Self-defense } \\
\text { Grounds }\end{array}$ & \begin{tabular}{|c} 
UNSC \\
Meeting(s) \\
(If Any) at \\
Which the \\
Comm. was \\
Raised
\end{tabular} & $\begin{array}{l}\text { Responsive Act (If Any) by the } \\
\text { UNSC }\end{array}$ & $\begin{array}{c}\text { UN } \\
\text { Repertory } \\
\text { Inclusion? }\end{array}$ & $\begin{array}{c}\text { UNSC } \\
\text { Repertoire } \\
\text { Inclusion? }\end{array}$ & \begin{tabular}{|c|} 
URL to an \\
English \\
Text
\end{tabular} & \begin{tabular}{||c||} 
URL to Non- \\
English \\
Original \\
Text (If Any)
\end{tabular} & $\begin{array}{l}\text { Perma.cc } \\
\text { URL }\end{array}$ \\
\hline 406 & 2014.09.23 & 2014.09.23 & S/2014/695 & $\begin{array}{l}\text { United } \\
\text { States }\end{array}$ & $\begin{array}{l}\text { United States, } \\
\text { Iraq, Syria }\end{array}$ & \begin{tabular}{|c|} 
Express \\
assertion of \\
"individual" \\
self-defense \\
and express \\
assertion of \\
"collective" \\
self-defense
\end{tabular} & $\begin{array}{c}\text { Conducted } \\
\text { attack and } \\
\text { threat of } \\
\text { attack }\end{array}$ & $\begin{array}{l}\text { The Islamic State in } \\
\text { Iraq and the Levant } \\
\text { (IIIL) (IISI) "and } \\
\text { other terrorist } \\
\text { groups in Syria", } \\
\text { including "al-Qaida } \\
\text { elements in Syria } \\
\text { known as the } \\
\text { Khorasan Group" }\end{array}$ & $\begin{array}{c}\text { Non-state } \\
\text { actors }\end{array}$ & 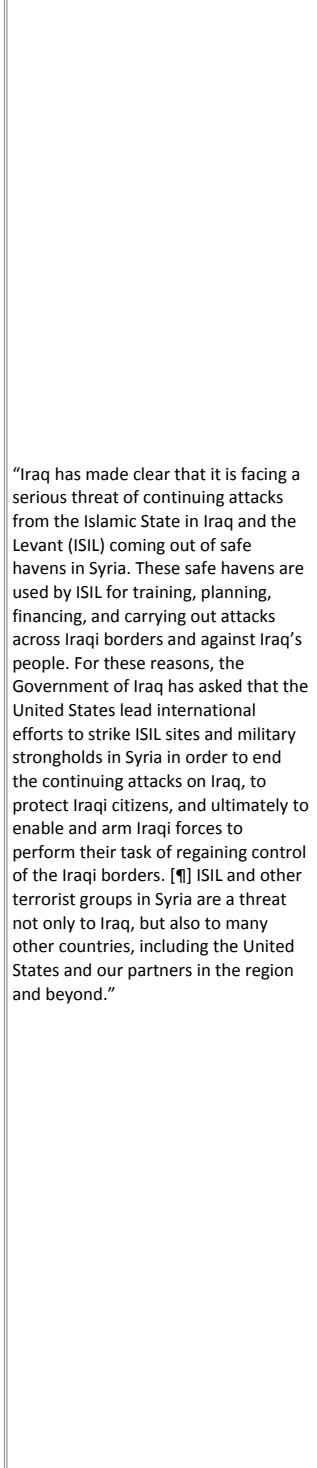 & $\begin{array}{l}\text { None } \\
\text { identified }\end{array}$ & 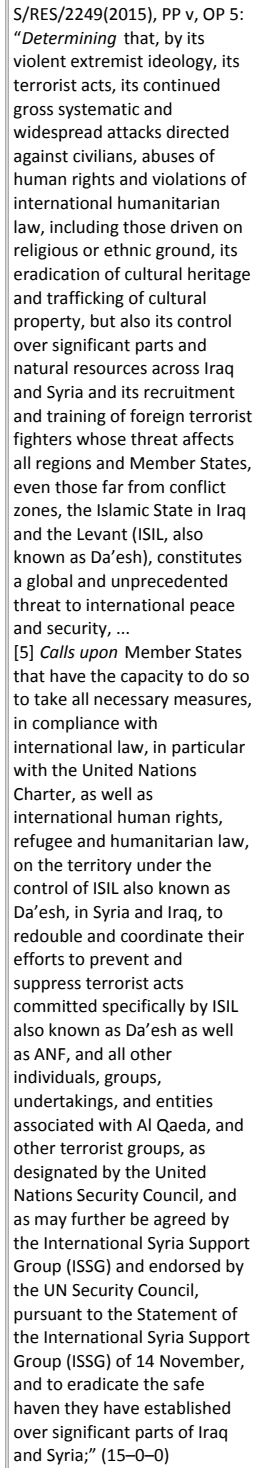 & \begin{tabular}{|l} 
None \\
identified
\end{tabular} & Article 51 & \begin{tabular}{|l||} 
http: \\
//www.un. \\
org//en/ga/ \\
search/vie \\
w_doc. \\
asp? \\
symbol=s/ \\
2014/695 \\
\end{tabular} & & $\begin{array}{l}\text { hitps: } \\
\text { //perma. } \\
\text { cc//D80G- } \\
\text { juDa }\end{array}$ \\
\hline
\end{tabular}


VI. HLS PILAC Catalogue of Apparent “Article 51 Communications”

\begin{tabular}{|c|c|c|c|c|c|c|c|c|c|c|c|c|c|c|c|c|c|}
\hline $\begin{array}{l}\text { Chron. } \\
\text { Order }\end{array}$ & $\begin{array}{l}\text { Date of } \\
\text { Comm. }\end{array}$ & $\begin{array}{c}\text { Date of } \\
\text { UNsC } \\
\text { Document }\end{array}$ & UNSC Symbol & \begin{tabular}{|c} 
Member \\
State(s) That \\
Submitted \\
the Comm.
\end{tabular} & \begin{tabular}{||c|} 
Expressly \\
Mentioned UN \\
Members (\& \\
Colonial \\
Holdings \& \\
Protectorates, \\
if any) \\
\end{tabular} & \begin{tabular}{|c|} 
Express or \\
Implied \\
Assertion of \\
Individual, \\
Collective, or \\
Both Self- \\
defense \\
\end{tabular} & \begin{tabular}{|l}
$\begin{array}{c}\text { Nature of } \\
\text { the Alleged } \\
\text { Threat }\end{array}$
\end{tabular} & $\begin{array}{l}\text { Expressly Alleged } \\
\text { Author(s) of the } \\
\text { Threat (ff Any } \\
\text { Indicated) }\end{array}$ & $\begin{array}{c}\text { Nature of the } \\
\text { Alleged } \\
\text { Author(s) of } \\
\text { the Threat (ff } \\
\text { Any } \\
\text { Indicated) }\end{array}$ & $\begin{array}{l}\text { Summary of Alleged Self-defense } \\
\text { Grounds }\end{array}$ & \begin{tabular}{||c} 
UNSC \\
Meeting(s) \\
(If Any) at \\
Which the \\
Comm. was \\
Raised
\end{tabular} & $\begin{array}{l}\text { Responsive Act (If Any) by the } \\
\text { UNSC }\end{array}$ & $\begin{array}{l}\text { UN } \\
\text { Repertory } \\
\text { Inclusion? }\end{array}$ & \begin{tabular}{|c|} 
UNSC \\
Repertoire \\
Inclusion?
\end{tabular} & $\begin{array}{l}\text { URL to an } \\
\text { English } \\
\text { Text }\end{array}$ & \begin{tabular}{||c||} 
URL to Non- \\
English \\
Original \\
Text (ff Any)
\end{tabular} & $\begin{array}{c}\text { Perma.cc } \\
\text { URL }\end{array}$ \\
\hline 407 & 2014.10.11 & 2014.10.13 & $S / 2014 / 730$ & Pakistan & Pakistan, India & \begin{tabular}{|c} 
Implied \\
assertion of \\
"individual" \\
self-defense
\end{tabular} & $\begin{array}{c}\text { Conducted } \\
\text { attack }\end{array}$ & India & State & \begin{tabular}{|l} 
India conducted "deliberate and \\
unprovoked violations of the ceasefire \\
agreement"." India has now escalated \\
the situation along the line of control \\
in Jammu and Kashmir and the \\
working boundary. Persistent shelling \\
and firing by Indian forces has resulted \\
in heavy civilian casualties on the \\
Pakistan side."
\end{tabular} & $\begin{array}{l}\text { None } \\
\text { identified }\end{array}$ & None identified & $\begin{array}{l}\text { None } \\
\text { identified }\end{array}$ & Article 51 & $\begin{array}{l}\text { http: } \\
\text { //www.un. } \\
\text { org/en/ga/ } \\
\text { search/vie } \\
\text { w_doc. } \\
\text { asp? } \\
\text { symbol=s/ } \\
\text { 2014/730 }\end{array}$ & & \begin{tabular}{|l} 
https: \\
//perma. \\
cc/Nz8s- \\
MCT8
\end{tabular} \\
\hline
\end{tabular}


VI. HLS PILAC Catalogue of Apparent “Article 51 Communications”

\begin{tabular}{|c|c|c|c|c|c|c|c|c|c|c|c|c|c|c|c|c|c|}
\hline $\begin{array}{l}\text { Chron. } \\
\text { Order }\end{array}$ & $\begin{array}{l}\text { Date of } \\
\text { Comm. }\end{array}$ & $\begin{array}{c}\text { Date of } \\
\text { UNSC } \\
\text { Document }\end{array}$ & UNSC Symbol & $\begin{array}{c}\text { Member } \\
\text { State(s) That } \\
\text { Submitted } \\
\text { the Comm. }\end{array}$ & \begin{tabular}{|c} 
Expressly \\
Mentioned UN \\
Members (\& \\
Colonial \\
Holdings \& \\
Protectorates, \\
if any)
\end{tabular} & \begin{tabular}{|c|} 
Express or \\
Implied \\
Assertion of \\
Individual, \\
Collective, or \\
Both Self- \\
defense
\end{tabular} & \begin{tabular}{|c} 
Nature of \\
the Alleged \\
Threat
\end{tabular} & \begin{tabular}{|l|} 
Expressly Alleged \\
Author(s) of the \\
Threat (If Any \\
Indicated)
\end{tabular} & \begin{tabular}{|c} 
Nature of the \\
Alleged \\
Author(s) of \\
the Threat (If \\
Any \\
Indicated)
\end{tabular} & $\begin{array}{l}\text { Summary of Alleged Self-defense } \\
\text { Grounds }\end{array}$ & \begin{tabular}{|c} 
UNSC \\
Meeting(s) \\
(If Any) at \\
Which the \\
Comm. was \\
Raised
\end{tabular} & $\begin{array}{l}\text { Responsive Act (If Any) by the } \\
\text { UNSC }\end{array}$ & $\begin{array}{l}\text { UN } \\
\text { Repertory } \\
\text { Inclusion? }\end{array}$ & $\begin{array}{c}\text { UNSC } \\
\text { Repertoire } \\
\text { Inclusion? }\end{array}$ & \begin{tabular}{|c|} 
URL to an \\
English \\
Text
\end{tabular} & \begin{tabular}{||c||} 
URL to Non- \\
English \\
Original \\
Text (If Any)
\end{tabular} & $\begin{array}{l}\text { Perma.cc } \\
\text { URL }\end{array}$ \\
\hline 408 & 2014.11.25 & 2014.11.26 & $S / 2014 / 851$ & $\begin{array}{l}\text { United } \\
\text { Kingdom }\end{array}$ & $\begin{array}{c}\text { United } \\
\text { Kingdom, Iraq, } \\
\text { United States, } \\
\text { Syria }\end{array}$ & $\begin{array}{l}\text { Express } \\
\text { assertion of } \\
\text { "collective" } \\
\text { self-defense }\end{array}$ & $\begin{array}{c}\text { Conducted } \\
\text { attack }\end{array}$ & $\begin{array}{l}\text { Islamic State in } \\
\text { Iraq and the elevant } \\
\text { (ISIL) [IISS] }\end{array}$ & $\begin{array}{c}\begin{array}{c}\text { Non-state } \\
\text { actors }\end{array} \\
\text {. }\end{array}$ & $\begin{array}{l}\text { The United Kingdom "is taking } \\
\text { measures in support of the collective } \\
\text { self-defence of Iraq as part of } \\
\text { international efforts led by the United } \\
\text { States. [f]] These measures are in } \\
\text { response to the request by the } \\
\text { Government of Iraq for assistance in } \\
\text { confronting the attack by the Islamic } \\
\text { State in Iraq and the Levant (IIL) on } \\
\text { Iraq, ...." }\end{array}$ & $\begin{array}{l}\text { None } \\
\text { identified }\end{array}$ & 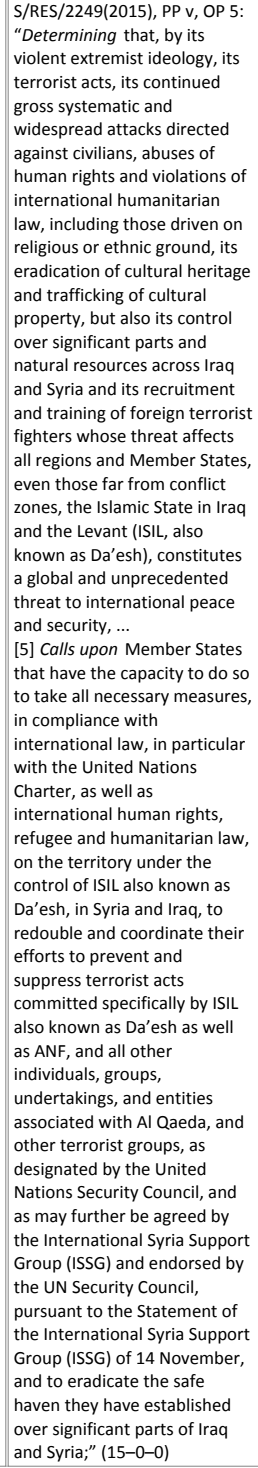 & $\begin{array}{l}\text { None } \\
\text { identified }\end{array}$ & Article 51 & \begin{tabular}{|l|}
$\mid$ httpp: \\
//www.un. \\
org//engal \\
search/vie \\
w_doc. \\
ass? \\
spmbol=s/ \\
2014/851
\end{tabular} & & $\begin{array}{l}\text { https: } \\
\text { //perma. } \\
\text { cc//ZFKK- } \\
\text { HSQL }\end{array}$ \\
\hline
\end{tabular}


VI. HLS PILAC Catalogue of Apparent “Article 51 Communications”

\begin{tabular}{|c|c|c|c|c|c|c|c|c|c|c|c|c|c|c|c|c|c|}
\hline $\begin{array}{l}\text { Chron. } \\
\text { Order }\end{array}$ & $\begin{array}{l}\text { Date of } \\
\text { Comm. }\end{array}$ & $\begin{array}{c}\text { Date of } \\
\text { UNsc } \\
\text { Document }\end{array}$ & UNSC Symbol & \begin{tabular}{c||c|} 
Member \\
State(s) That \\
Submitted \\
the Comm.
\end{tabular} & \begin{tabular}{|c|} 
Expressly \\
Mentioned UN \\
Members (\& \\
Colonial \\
Holdings \& \\
Protectorates, \\
if any) \\
\end{tabular} & \begin{tabular}{|l} 
Express or \\
Implied \\
Assertion of \\
Individual, \\
Collective, or \\
Both Self- \\
defense
\end{tabular} & $\begin{array}{c}\text { Nature of } \\
\text { the Alleged } \\
\text { Threat }\end{array}$ & $\begin{array}{l}\text { Expressly Alleged } \\
\text { Author(s) of the } \\
\text { Threat (If Any } \\
\text { Indicated) }\end{array}$ & \begin{tabular}{|l|} 
Nature of the \\
Alleged \\
Author(s) of \\
the Threat (If \\
Any \\
Indicated)
\end{tabular} & $\begin{array}{l}\text { Summary of Alleged Self-defense } \\
\text { Grounds }\end{array}$ & $\begin{array}{c}\text { UNsc } \\
\text { Meeting(s) } \\
\text { (If Any) at } \\
\text { Which the } \\
\text { Comm was } \\
\text { Raised }\end{array}$ & $\begin{array}{l}\text { Responsive Act (If Any) by the } \\
\text { UNSC }\end{array}$ & \begin{tabular}{|c|} 
UN \\
Repertory \\
Inclusion?
\end{tabular} & $\begin{array}{l}\text { UNSC } \\
\text { Repertoire } \\
\text { Inclusion? }\end{array}$ & \begin{tabular}{|c||} 
URL to an \\
English \\
Text
\end{tabular} & \begin{tabular}{|l} 
URL to Non- \\
English \\
Original \\
Text (If Any)
\end{tabular} & $\begin{array}{l}\text { Perma.cc } \\
\text { URL }\end{array}$ \\
\hline 409 & 2015.02.22 & 2015.02.23 & S/2015/127 & Turkey & $\begin{array}{l}\text { Turkey, Syria, } \\
\text { France }\end{array}$ & $\begin{array}{c}\text { Implied } \\
\text { assertion of } \\
\text { "individual" } \\
\text { self-defense }\end{array}$ & \begin{tabular}{|l} 
Imminent \\
attack
\end{tabular} & $\begin{array}{l}\text { "[T]he terrorist } \\
\text { organization Deash } \\
\text { [sic] [IISIS]" }\end{array}$ & $\begin{array}{c}\text { Non-state } \\
\text { actors }\end{array}$ & $\begin{array}{l}\text { "Facing an imminent threat from the } \\
\text { terrorist organization Deash [sic], the } \\
\text { Turkish armed forces conducted a } \\
\text { military operation for the relocation of } \\
\text { the Süleyman Saat Memorial Outpost, } \\
\text { a 10-acre area of land of Turkish } \\
\text { territory inside Syria." }\end{array}$ & \begin{tabular}{|l} 
None \\
identified
\end{tabular} & 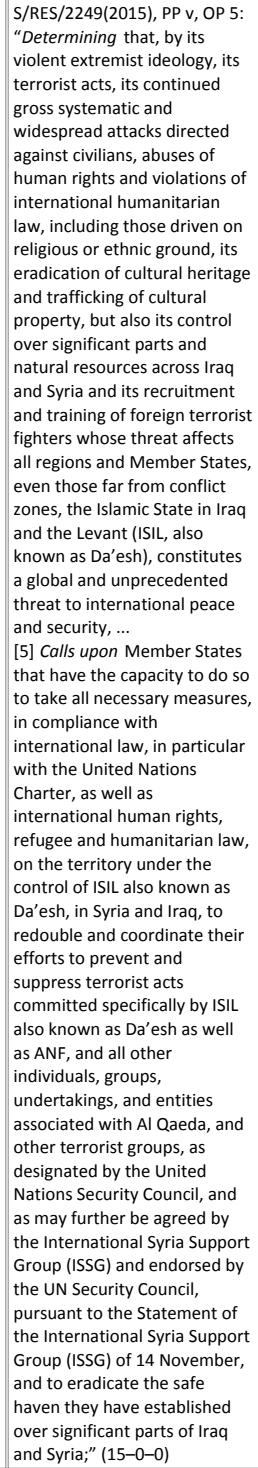 & $\begin{array}{l}\text { None } \\
\text { identified }\end{array}$ & Article 51 & 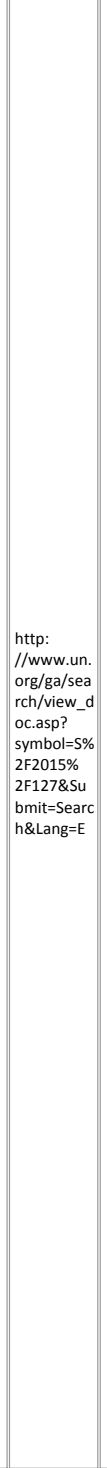 & & $\begin{array}{l} \\
\text { https: } \\
\text { /perma. } \\
\text { cc/M2WA- } \\
\text { M64N }\end{array}$ \\
\hline
\end{tabular}


VI. HLS PILAC Catalogue of Apparent “Article 51 Communications”

\begin{tabular}{|c|c|c|c|c|c|c|c|c|c|c|c|c|c|c|c|c|c|}
\hline $\mid \begin{array}{c}\text { Chron. } \\
\text { Order }\end{array}$ & $\begin{array}{l}\text { Date of } \\
\text { Comm. }\end{array}$ & $\begin{array}{l}\text { Date of } \\
\text { UNSC } \\
\text { Document }\end{array}$ & UNSC Symbol & \begin{tabular}{||c||} 
Member \\
State(s) That \\
Submitted \\
the Comm.
\end{tabular} & \begin{tabular}{|c||} 
Expressly \\
Mentioned UN \\
Members (\& \\
Colonial \\
Holdings \& \\
Protectorates, \\
if any) \\
\end{tabular} & \begin{tabular}{|c|} 
Express or \\
Implied \\
Assertion of \\
Individual, \\
Collective, or \\
Both Self- \\
defense \\
\end{tabular} & $\begin{array}{l}\text { Nature of } \\
\text { the Alleged } \\
\text { Threat }\end{array}$ & $\begin{array}{l}\text { Expressly Alleged } \\
\text { Author(s) of the } \\
\text { Threat (If Any } \\
\text { Indicated) }\end{array}$ & \begin{tabular}{|c|} 
Nature of the \\
Alleged \\
Author(s) of \\
the Threat (If \\
Any \\
Indicated)
\end{tabular} & $\begin{array}{l}\text { Summary of Alleged Self-defense } \\
\text { Grounds }\end{array}$ & $\begin{array}{c}\text { UNSC } \\
\text { Meeting(s) } \\
\text { (If Any) at } \\
\text { Which the } \\
\text { Comm. was } \\
\text { Raised }\end{array}$ & $\begin{array}{l}\text { Responsive Act (ff Any) by the } \\
\text { UNSC }\end{array}$ & $\begin{array}{l}\text { UN } \\
\text { Repertory } \\
\text { Inclusion? }\end{array}$ & \begin{tabular}{|c|} 
UNSC \\
Repertoire \\
Inclusion?
\end{tabular} & \begin{tabular}{|c|} 
URL to an \\
English \\
Text
\end{tabular} & \begin{tabular}{||c||} 
URL to Non- \\
English \\
Original \\
Text (If Any)
\end{tabular} & \begin{tabular}{|l} 
Perma.cc \\
URL
\end{tabular} \\
\hline 410 & 2015.03.26 & 2015.03.27 & S/2015/217 & $\begin{array}{c}\text { Bahrain, } \\
\text { Qatar, Saudi } \\
\text { Arabia, } \\
\text { United Arab } \\
\text { Emirates, } \\
\text { Kuwait }\end{array}$ & \begin{tabular}{|c|} 
Bahrain, Qatar, \\
Saudi Arabia, \\
United Arab \\
Emirates, \\
Kuwait, Yemen
\end{tabular} & $\begin{array}{l}\text { Implied } \\
\text { assertion of } \\
\text { "collective" } \\
\text { self-defense }\end{array}$ & $\begin{array}{l}\text { Conducted } \\
\text { attack and } \\
\text { threat of } \\
\text { attack }\end{array}$ & Houthi militias & $\begin{array}{c}\text { Non-state } \\
\text { actors }\end{array}$ & 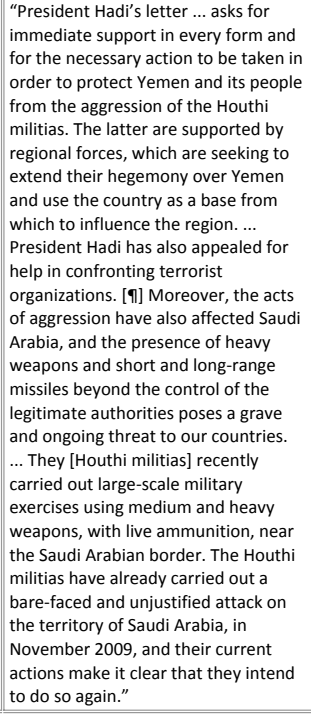 & $\begin{array}{l}\text { None } \\
\text { identified }\end{array}$ & None identified & $\begin{array}{l}\text { None } \\
\text { identified }\end{array}$ & Article 51 & \begin{tabular}{|l||} 
http: \\
|/www.un. \\
org/en/ga/ \\
search/vie \\
w_doc. \\
asp? \\
symbol=s/ \\
2015/217
\end{tabular} & \begin{tabular}{|l||} 
http://www. \\
un. \\
org/en/ga/se \\
arch/view_do \\
c.asp? \\
symbol=S/201 \\
$5 / 217 \&$ Lang= \\
A
\end{tabular} & $\begin{array}{l}\text { hitps: } \\
\text { //perma. } \\
\text { cc/8uU2- } \\
\text { 934V }\end{array}$ \\
\hline
\end{tabular}


VI. HLS PILAC Catalogue of Apparent “Article 51 Communications”

\begin{tabular}{|c|c|c|c|c|c|c|c|c|c|c|c|c|c|c|c|c|c|}
\hline $\begin{array}{l}\text { Chron. } \\
\text { Order }\end{array}$ & $\begin{array}{l}\text { Date of } \\
\text { Comm. }\end{array}$ & $\begin{array}{c}\text { Date of } \\
\text { UNSC } \\
\text { Document }\end{array}$ & | UNSC Symbol & \begin{tabular}{|l} 
Member \\
State(s) That \\
Submitted \\
the Comm.
\end{tabular} & \begin{tabular}{||c|} 
Expressly \\
Mentioned UN \\
Members (\& \\
Colonial \\
Holdings \& \\
Protectorates, \\
if any) \\
\end{tabular} & \begin{tabular}{|c|} 
Express or \\
Implied \\
Assertion of \\
Individual, \\
Collective, or \\
Both Self- \\
defense \\
\end{tabular} & \begin{tabular}{|l} 
Nature of \\
the Alleged \\
Threat
\end{tabular} & $\begin{array}{l}\text { Expressly Alleged } \\
\text { Author(s) of the } \\
\text { Threat (ff Any } \\
\text { Indicated) }\end{array}$ & \begin{tabular}{|l} 
Nature of the \\
Alleged \\
Author(s) of \\
the Threat (If \\
Any \\
Indicated)
\end{tabular} & $\begin{array}{l}\text { Summary of Alleged Self-defense } \\
\text { Grounds }\end{array}$ & \begin{tabular}{|c} 
UNSC \\
Meeting(s) \\
(If Any) at \\
Which the \\
Comm. was \\
Raised
\end{tabular} & $\begin{array}{l}\text { Responsive Act (If Any) by the } \\
\text { UNSC }\end{array}$ & \begin{tabular}{|l|} 
UN \\
Repertory \\
Inclusion?
\end{tabular} & $\begin{array}{l}\text { UNSC } \\
\text { Repertoire } \\
\text { Inclusion? }\end{array}$ & $\begin{array}{l}\text { URL to an } \\
\text { English } \\
\text { Text }\end{array}$ & \begin{tabular}{|c|} 
URL to Non- \\
English \\
Orignal \\
Text (If Any)
\end{tabular} & $\begin{array}{c}\text { Perma.cc } \\
\text { URL }\end{array}$ \\
\hline 411 & 2015.03.31 & 2015.03.31 & $\mathrm{S} / 2015 / 221$ & Canada & $\begin{array}{l}\text { Canada, Iraq, } \\
\text { Syria, United } \\
\text { States }\end{array}$ & $\begin{array}{l}\text { Express } \\
\text { assertion of } \\
\text { "collective" } \\
\text { self-defense }\end{array}$ & $\begin{array}{c}\text { Conducted } \\
\text { attack and } \\
\text { threat of } \\
\text { attack }\end{array}$ & ISIL [ISIS] & $\begin{array}{c}\begin{array}{c}\text { Non-state } \\
\text { actors }\end{array} \\
\text {. }\end{array}$ & $\begin{array}{l}\text { Persisting "serious threat of } \\
\text { continuing attacks from Islamic State } \\
\text { in Iraq and the Levant (IILI) emanating } \\
\text { from safe havens in Syria." }\end{array}$ & \begin{tabular}{|l} 
None \\
identified
\end{tabular} & 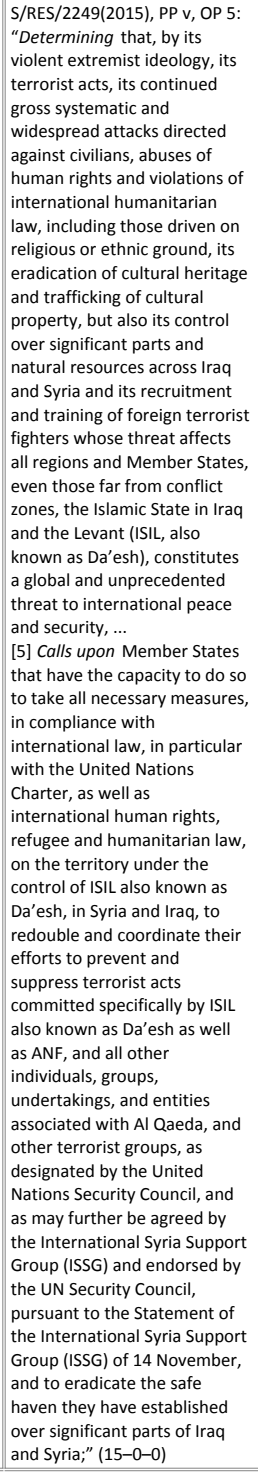 & \begin{tabular}{|l} 
None \\
identified
\end{tabular} & Article 51 & $\begin{array}{l}\text { http: } \\
\text { //www.un. } \\
\text { org/en/ga/ } \\
\text { search/vie } \\
\text { w_doc. } \\
\text { asp? } \\
\text { symbol=s/ } \\
\text { 2015/221 }\end{array}$ & \begin{tabular}{|l} 
http://www. \\
un. \\
org/en/ga/se \\
arch/view_do \\
c.asp? \\
symbol=S/201 \\
5/221\&Lang= \\
F
\end{tabular} & $\begin{array}{l}\text { https: } \\
\text { //perma. } \\
\text { cc/LWTT- } \\
\text { DZ4Z }\end{array}$ \\
\hline
\end{tabular}


VI. HLS PILAC Catalogue of Apparent “Article 51 Communications”

\begin{tabular}{|c|c|c|c|c|c|c|c|c|c|c|c|c|c|c|c|c|c|}
\hline $\begin{array}{l}\text { Chron. } \\
\text { Order }\end{array}$ & $\begin{array}{l}\text { Date of } \\
\text { Comm. }\end{array}$ & $\begin{array}{c}\text { Date of } \\
\text { UNSC } \\
\text { Document }\end{array}$ & UNSC Symbol & \begin{tabular}{||c} 
Member \\
State(s) That \\
Submitted \\
the Comm.
\end{tabular} & \begin{tabular}{|c|} 
Expressly \\
Mentioned UN \\
Members (\& \\
Colonial \\
Holdings \& \\
Protectorates, \\
if any) \\
\end{tabular} & \begin{tabular}{|c|} 
Express or \\
Implied \\
Assertion of \\
Individual, \\
Collective, or \\
Both Self- \\
defense \\
\end{tabular} & \begin{tabular}{|l} 
Nature of \\
the Alleged \\
Threat
\end{tabular} & $\begin{array}{l}\text { Expressly Alleged } \\
\text { Author(s) of the } \\
\text { Threat (ff Any } \\
\text { Indicated) }\end{array}$ & \begin{tabular}{|c|} 
Nature of the \\
Alleged \\
Author(s) of \\
the Threat (If \\
Any \\
Indicated)
\end{tabular} & $\begin{array}{l}\text { Summary of Alleged Self-defense } \\
\text { Grounds }\end{array}$ & \begin{tabular}{|c} 
UNSC \\
Meeting(s) \\
(If Any) at \\
Which the \\
Comm. was \\
Raised
\end{tabular} & $\begin{array}{l}\text { Responsive Act (If Any) by the } \\
\text { UNSC }\end{array}$ & $\begin{array}{c}\text { UN } \\
\text { Repertory } \\
\text { Inclusion? }\end{array}$ & $\begin{array}{c}\text { UNSC } \\
\text { Repertoire } \\
\text { Inclusion? }\end{array}$ & \begin{tabular}{|c||} 
URL to an \\
English \\
Text
\end{tabular} & \begin{tabular}{||c||} 
URL to Non- \\
English \\
Original \\
Text (If Any)
\end{tabular} & \begin{tabular}{|c} 
Perma.cc \\
URL
\end{tabular} \\
\hline 412 & 2015.07.24 & 2015.07.24 & S/2015/563 & Turkey & Turkey, Syria & \begin{tabular}{|l|} 
Express \\
assertion of \\
"individual" \\
self-defense \\
and express \\
assertion of \\
"collective" \\
self-defense
\end{tabular} & $\begin{array}{c}\text { Conducted } \\
\text { attack and } \\
\text { threat of } \\
\text { attack }\end{array}$ & Daesh [IISIS] & $\begin{array}{c}\begin{array}{c}\text { Non-state } \\
\text { actors }\end{array} \\
\text {. }\end{array}$ & $\begin{array}{l}\text { "The terrorist attack that took the } \\
\text { lives of } 32 \text { Turkish citizens in Suruc.... } \\
\text { reaffirms that Turkey is under a clear } \\
\text { and imminent threat of continuing } \\
\text { attack from Daesh. Most recently, ..., } \\
\text { Daesh attacked the border military } \\
\text { post in Elbeyli and killed a Turkish } \\
\text { soldier." }\end{array}$ & \begin{tabular}{|l} 
None \\
identified
\end{tabular} & 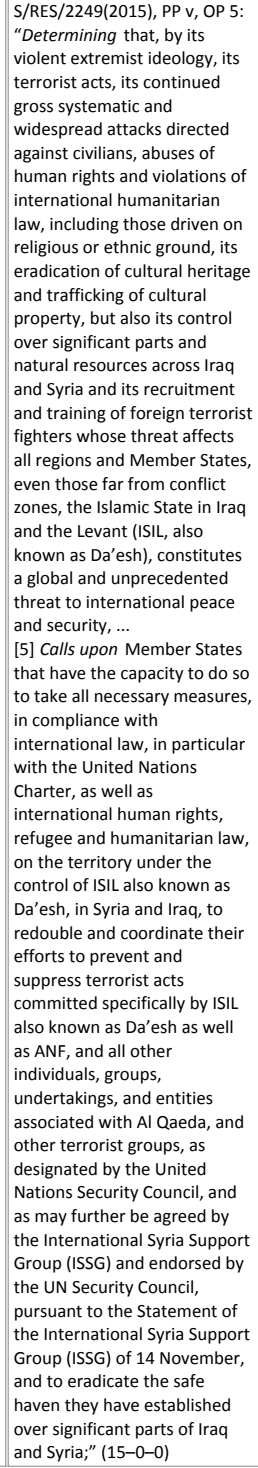 & \begin{tabular}{|l} 
None \\
identified
\end{tabular} & Article 51 & 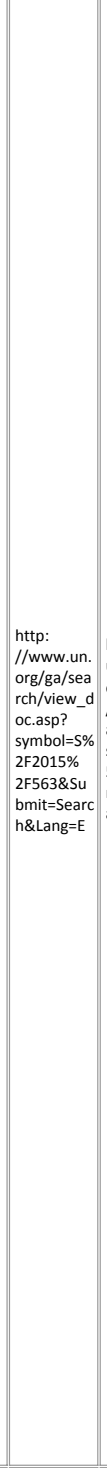 & $\begin{array}{l}\text { http://www. } \\
\text { un. } \\
\text { org/ga/search } \\
\text { /view_doc. } \\
\text { asp? } \\
\text { symbol=s/201 } \\
5 / 5638 \text { refere } \\
\text { r//english/\&L } \\
\text { ang=F }\end{array}$ & $\begin{array}{l}\text { https: } \\
\text { //perma. } \\
\text { ccl/HN2S- } \\
\text { HRK4 }\end{array}$ \\
\hline
\end{tabular}


VI. HLS PILAC Catalogue of Apparent “Article 51 Communications”

\begin{tabular}{|c|c|c|c|c|c|c|c|c|c|c|c|c|c|c|c|c|c|}
\hline $\begin{array}{l}\text { Chron. } \\
\text { Order }\end{array}$ & $\begin{array}{l}\text { Date of } \\
\text { Comm. }\end{array}$ & $\begin{array}{c}\text { Date of } \\
\text { UNSC } \\
\text { Document }\end{array}$ & UNSC Symbol & $\begin{array}{c}\text { Member } \\
\text { State(s) That } \\
\text { Submitted } \\
\text { the Comm. }\end{array}$ & \begin{tabular}{|c} 
Expressly \\
Mentioned UN \\
Members (\& \\
Colonial \\
Holdings \& \\
Protectorates, \\
if any)
\end{tabular} & \begin{tabular}{|c} 
Express or \\
Implied \\
Assertion of \\
Individual, \\
Collective, or \\
Both Self- \\
defense \\
\end{tabular} & \begin{tabular}{|l}
$\begin{array}{c}\text { Nature of } \\
\text { the Alleged } \\
\text { Threat }\end{array}$
\end{tabular} & \begin{tabular}{|l|} 
Expressly Alleged \\
Author(s) of the \\
Threat (If Any \\
Indicated)
\end{tabular} & \begin{tabular}{|c} 
Nature of the \\
Alleged \\
Author(s) of \\
the Threat (If \\
Any \\
Indicated)
\end{tabular} & $\begin{array}{l}\text { Summary of Alleged Self-defense } \\
\text { Grounds }\end{array}$ & $\begin{array}{l}\text { UNSC } \\
\text { Meeting(s) } \\
\text { (If Any) at } \\
\text { Which the } \\
\text { Comm. was } \\
\text { Raised }\end{array}$ & $\begin{array}{l}\text { Responsive Act (If Any) by the } \\
\text { UNSC }\end{array}$ & $\begin{array}{c}\text { UN } \\
\text { Repertory } \\
\text { Inclusion? }\end{array}$ & $\begin{array}{c}\text { UNSC } \\
\text { Repertoire } \\
\text { Inclusion? }\end{array}$ & \begin{tabular}{|c||} 
URL to an \\
English \\
Text
\end{tabular} & \begin{tabular}{||c||} 
URL to Non- \\
English \\
Original \\
Text (If Any)
\end{tabular} & $\begin{array}{l}\text { Perma.cc } \\
\text { URL }\end{array}$ \\
\hline 413 & 2015.09.07 & 2015.09.08 & S/2015/688 & $\begin{array}{l}\text { United } \\
\text { Kingdom }\end{array}$ & $\begin{array}{l}\text { United } \\
\text { Kingdom, } \\
\text { Syria, Iraq }\end{array}$ & \begin{tabular}{|c|} 
Express \\
assertion of \\
"individual" \\
self-defense \\
and express \\
assertion of \\
"collective" \\
self-defense
\end{tabular} & \begin{tabular}{|c} 
Conducted \\
attack and \\
imminent \\
attack
\end{tabular} & $\begin{array}{l}\text { Islamic State in } \\
\text { Iraq and the elevant } \\
\text { (ISIL) [IISS] }\end{array}$ & $\begin{array}{c}\begin{array}{c}\text { Non-state } \\
\text { actors }\end{array} \\
\text {. }\end{array}$ & $\begin{array}{l}\text { UK armed forces “carried out a } \\
\text { precision air strike against an IIIL } \\
\text { vehicle in which a target known to be } \\
\text { actively engaged in planning and } \\
\text { directing imminent armed attacks } \\
\text { against the United Kingdom was } \\
\text { travelling." }\end{array}$ & $\begin{array}{l}\text { None } \\
\text { identified }\end{array}$ & 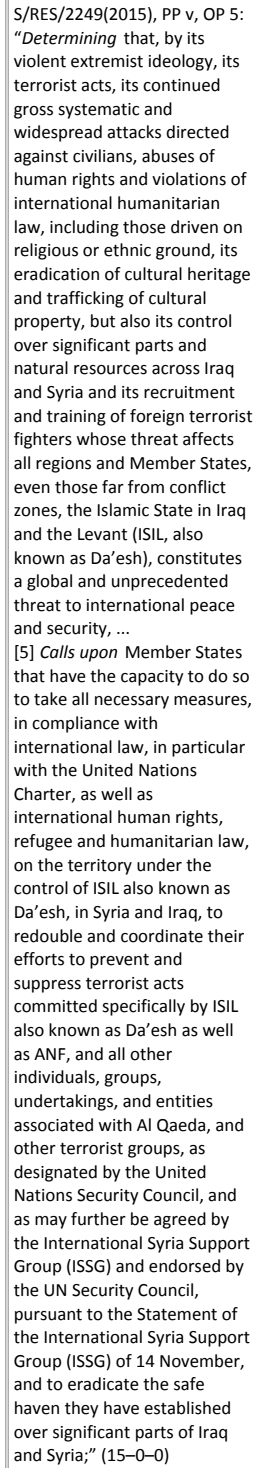 & \begin{tabular}{|l} 
None \\
identified
\end{tabular} & Article 51 & 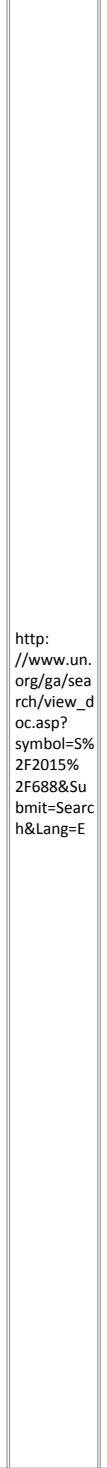 & & $\begin{array}{l}\text { https: } \\
\text { //perma. } \\
\text { cc/W5BZZ- } \\
8 B 6 \mathrm{~V}\end{array}$ \\
\hline
\end{tabular}


VI. HLS PILAC Catalogue of Apparent “Article 51 Communications”

\begin{tabular}{|c|c|c|c|c|c|c|c|c|c|c|c|c|c|c|c|c|c|}
\hline $\begin{array}{l}\text { Chron. } \\
\text { Order }\end{array}$ & $\begin{array}{l}\text { Date of } \\
\text { Comm. }\end{array}$ & $\begin{array}{c}\text { Date of } \\
\text { UNSC } \\
\text { Document }\end{array}$ & UNSC Symbol & $\begin{array}{c}\text { Member } \\
\text { State(s) That } \\
\text { Submitted } \\
\text { the Comm. }\end{array}$ & \begin{tabular}{|c} 
Expressly \\
Mentioned UN \\
Members (\& \\
Colonial \\
Holdings \& \\
Protectorates, \\
if any)
\end{tabular} & \begin{tabular}{|c|} 
Express or \\
Implied \\
Assertion of \\
Individual, \\
Collective, or \\
Both Self- \\
defense
\end{tabular} & \begin{tabular}{|c} 
Nature of \\
the Alleged \\
Threat
\end{tabular} & \begin{tabular}{|l|} 
Expressly Alleged \\
Author(s) of the \\
Threat (If Any \\
Indicated)
\end{tabular} & \begin{tabular}{|c} 
Nature of the \\
Alleged \\
Author(s) of \\
the Threat (If \\
Any (f) \\
Indicated)
\end{tabular} & $\begin{array}{l}\text { Summary of Alleged Self-defense } \\
\text { Grounds }\end{array}$ & \begin{tabular}{|c} 
UNSC \\
Meeting(s) \\
(If Any) at \\
Which the \\
Comm. was \\
Raised
\end{tabular} & $\begin{array}{l}\text { Responsive Act (If Any) by the } \\
\text { UNSC }\end{array}$ & $\begin{array}{l}\text { UN } \\
\text { Repertory } \\
\text { Inclusion? }\end{array}$ & $\begin{array}{c}\text { UNSC } \\
\text { Repertoire } \\
\text { Inclusion? }\end{array}$ & \begin{tabular}{|c||} 
URL to an \\
English \\
Text
\end{tabular} & \begin{tabular}{||c||} 
URL to Non- \\
English \\
Original \\
Text (If Any)
\end{tabular} & $\begin{array}{c}\text { Perma.cc } \\
\text { URL }\end{array}$ \\
\hline 414 & 2015.09.08 & 2015.09.09 & $\mathrm{S} / 2015 / 745$ & France & $\begin{array}{c}\text { France, Syria, } \\
\text { Iraq }\end{array}$ & $\begin{array}{l}\text { Implied } \\
\text { assertion of } \\
\text { "individual" } \\
\text { self-defense } \\
\text { and implied } \\
\text { assertion of } \\
\text { "collective" } \\
\text { self-defense }\end{array}$ & $\begin{array}{c}\text { Conducted } \\
\text { attack }\end{array}$ & $\begin{array}{l}\text { Islamic State in } \\
\text { Iraq and the elevant } \\
\text { (ISIL) [IISS] }\end{array}$ & $\begin{array}{c}\begin{array}{c}\text { Non-state } \\
\text { actors }\end{array} \\
\text {. }\end{array}$ & $\begin{array}{l}\text { "[A]ttacks carried out by ISIL from the } \\
\text { territory of the Syrian Arab Republic." }\end{array}$ & $\begin{array}{l}\text { None } \\
\text { identified }\end{array}$ & 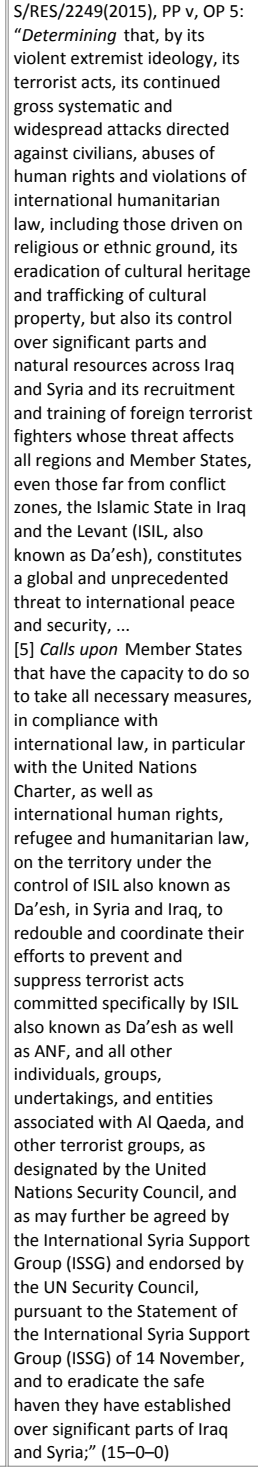 & \begin{tabular}{|l} 
None \\
identified
\end{tabular} & Article 51 & 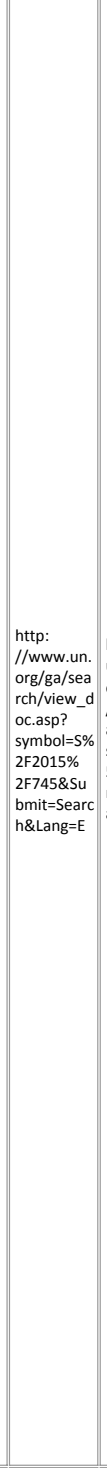 & $\begin{array}{l}\text { http://www. } \\
\text { un. } \\
\text { org/ga/search } \\
\text { /view_doc. } \\
\text { ass? } \\
\text { symbol=s/201 } \\
5 / 7458 \text { refere } \\
\text { r/lenglish/\&L } \\
\text { ang=F }\end{array}$ & \begin{tabular}{|l} 
hetps: \\
//perma. \\
cc J/J42- \\
FV9P
\end{tabular} \\
\hline
\end{tabular}


VI. HLS PILAC Catalogue of Apparent “Article 51 Communications”

\begin{tabular}{|c|c|c|c|c|c|c|c|c|c|c|c|c|c|c|c|c|c|}
\hline $\begin{array}{l}\text { Chron. } \\
\text { Order }\end{array}$ & $\begin{array}{l}\text { Date of } \\
\text { Comm. }\end{array}$ & $\begin{array}{c}\text { Date of } \\
\text { UNSC } \\
\text { Document }\end{array}$ & UNSC Symbol & \begin{tabular}{||c} 
Member \\
State(s) That \\
Submitted \\
the Comm.
\end{tabular} & \begin{tabular}{|c} 
Expressly \\
Mentioned UN \\
Members (\& \\
Colonial \\
Holdings \& \\
Protectorates, \\
if any)
\end{tabular} & \begin{tabular}{|c|} 
Express or \\
Implied \\
Assertion of \\
Individual, \\
Collective, or \\
Both Self- \\
defense
\end{tabular} & \begin{tabular}{|c} 
Nature of \\
the Alleged \\
Threat
\end{tabular} & \begin{tabular}{|l|} 
Expressly Alleged \\
Author(s) of the \\
Threat (If Any \\
Indicated)
\end{tabular} & \begin{tabular}{|c} 
Nature of the \\
Alleged \\
Author(s) of \\
the Threat (If \\
Any (f) \\
Indicated)
\end{tabular} & $\begin{array}{l}\text { Summary of Alleged Self-defense } \\
\text { Grounds }\end{array}$ & \begin{tabular}{|c} 
UNSC \\
Meeting(s) \\
(If Any) at \\
Which the \\
Comm. was \\
Raised
\end{tabular} & $\begin{array}{l}\text { Responsive Act (If Any) by the } \\
\text { UNSC }\end{array}$ & $\begin{array}{l}\text { UN } \\
\text { Repertory } \\
\text { Inclusion? }\end{array}$ & $\begin{array}{c}\text { UNSC } \\
\text { Repertoire } \\
\text { Inclusion? }\end{array}$ & \begin{tabular}{|c|} 
URL to an \\
English \\
Text
\end{tabular} & \begin{tabular}{||c||} 
URL to Non- \\
English \\
Original \\
Text (If Any)
\end{tabular} & $\begin{array}{l}\text { Perma.cc } \\
\text { URL }\end{array}$ \\
\hline 415 & 2015.09.09 & 2015.09.09 & S/2015/693 & Australia & $\begin{array}{l}\text { Australia, Iraq, } \\
\text { United States, } \\
\text { Syria }\end{array}$ & $\begin{array}{l}\text { Express } \\
\text { assertion of } \\
\text { "collective" } \\
\text { self-defense }\end{array}$ & $\begin{array}{c}\text { Conducted } \\
\text { attack }\end{array}$ & $\begin{array}{l}\text { Islamic State in } \\
\text { Iraq and the elevant } \\
\text { (ISIL) [IISS] }\end{array}$ & $\begin{array}{c}\begin{array}{c}\text { Non-state } \\
\text { actors }\end{array} \\
\text {. }\end{array}$ & 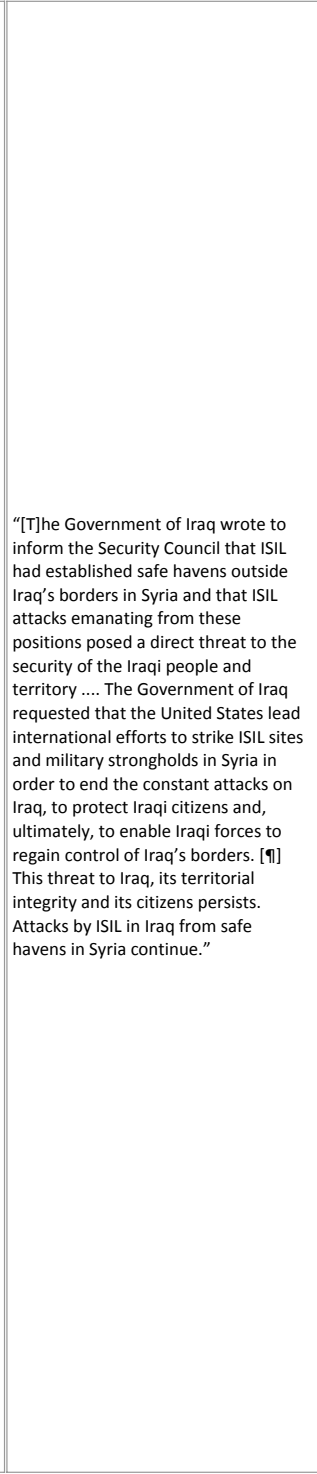 & \begin{tabular}{|l} 
None \\
identified
\end{tabular} & 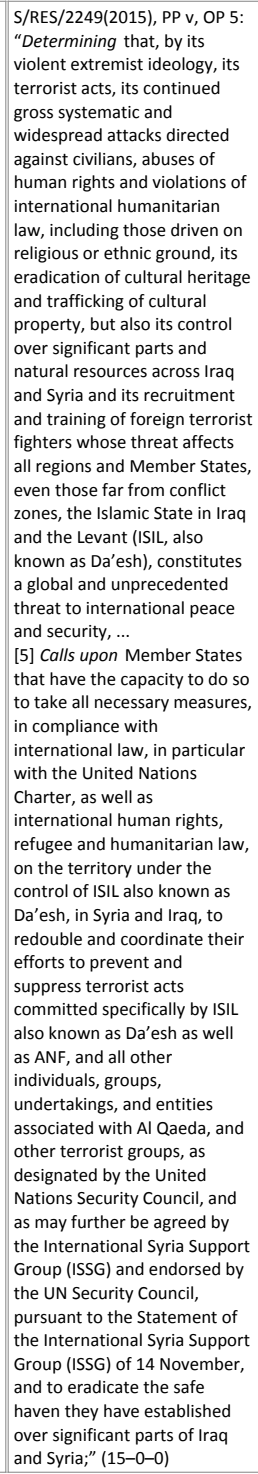 & \begin{tabular}{|l} 
None \\
identified
\end{tabular} & Article 51 & \begin{tabular}{|l|}
$\mid$ httpp: \\
//www.un. \\
org//eng/gal \\
search/vie \\
w_doc. \\
ass? \\
spmbol=s/ \\
2015/693
\end{tabular} & & $\begin{array}{l}\text { https: } \\
\text { //perma. } \\
\text { cc//2DVV- } \\
\text { NGP4 }\end{array}$ \\
\hline
\end{tabular}


VI. HLS PILAC Catalogue of Apparent “Article 51 Communications”

\begin{tabular}{|c|c|c|c|c|c|c|c|c|c|c|c|c|c|c|c|c|c|}
\hline $\begin{array}{l}\text { Chron. } \\
\text { Order }\end{array}$ & $\begin{array}{l}\text { Date of } \\
\text { Comm. }\end{array}$ & $\begin{array}{l}\text { Date of } \\
\text { UNsC } \\
\text { Document }\end{array}$ & | UNSC Symbol & \begin{tabular}{||c} 
Member \\
State(s) That \\
Submitted \\
the Comm.
\end{tabular} & \begin{tabular}{||c||} 
Expressly \\
Mentioned UN \\
Members (\& \\
Colonial \\
Holdings \& \\
Protectorates, \\
if any) \\
\end{tabular} & \begin{tabular}{|c|} 
Express or \\
Implied \\
Assertion of \\
Individual, \\
Collective, or \\
Both Self- \\
defense
\end{tabular} & \begin{tabular}{|c} 
Nature of \\
the Alleged \\
Threat
\end{tabular} & \begin{tabular}{|l} 
Expressly Alleged \\
Author(s) of the \\
Threat (ff Any \\
Indicated)
\end{tabular} & \begin{tabular}{|c|} 
Nature of the \\
Alleged \\
Author(s) of \\
the Threat (If \\
Any \\
Indicated) \\
\end{tabular} & $\begin{array}{l}\text { Summary of Alleged Self-defense } \\
\text { Grounds }\end{array}$ & \begin{tabular}{|c|} 
UNsc \\
Meeting(s) \\
(if Any) at \\
Which the \\
Comm. was \\
Raised
\end{tabular} & $\begin{array}{l}\text { Responsive Act (If Any) by the } \\
\text { UNSC }\end{array}$ & \begin{tabular}{|l} 
UN \\
Repertory \\
Inclusion?
\end{tabular} & $\begin{array}{l}\text { UNSC } \\
\text { Repertoire } \\
\text { Inclusion? }\end{array}$ & \begin{tabular}{|c||} 
URL to an \\
English \\
Text
\end{tabular} & \begin{tabular}{||c||} 
URL to Non- \\
English \\
Original \\
Text (ff Any)
\end{tabular} & $\begin{array}{l}\text { Perma.cc } \\
\text { URL }\end{array}$ \\
\hline 416 & 2015.12.03 & 2015.12.03 & S/2015/928 & $\begin{array}{l}\text { United } \\
\text { Kingdom }\end{array}$ & \begin{tabular}{|c|} 
United \\
Kingdom, Syria
\end{tabular} & 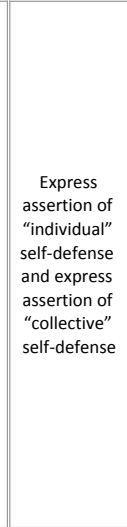 & $\begin{array}{l}\text { Conducted } \\
\text { attack and } \\
\text { threat of } \\
\text { attack }\end{array}$ & Not indicated & $\begin{array}{c}\text { Non-state } \\
\text { actors }\end{array}$ & 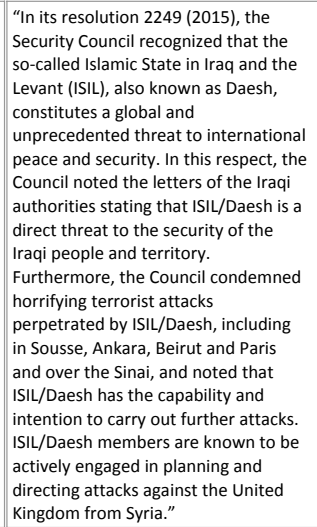 & $\begin{array}{l}\text { None } \\
\text { identified }\end{array}$ & None identified & $\begin{array}{l}\text { None } \\
\text { identified }\end{array}$ & Article 51 & 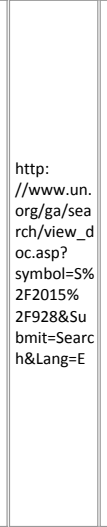 & & \begin{tabular}{|l} 
hitps: \\
//perma. \\
cc/sp7s- \\
6MF5
\end{tabular} \\
\hline 417 & 2015.12.10 & 2015.12.10 & S/2015/946 & Germany & $\begin{array}{l}\text { Germany, } \\
\text { Syria, Iraq, } \\
\text { France }\end{array}$ & $\begin{array}{l}\text { Express } \\
\text { assertion of } \\
\text { "collective" } \\
\text { self-defense }\end{array}$ & $\begin{array}{c}\text { Conducted } \\
\text { attack }\end{array}$ & \begin{tabular}{|c} 
"TThe terrorist \\
organization \\
Islamic State in \\
Iraq and the Levant \\
(ISLL) [ISIS]"
\end{tabular} & $\begin{array}{l}\text { Non-state } \\
\text { actors }\end{array}$ & $\begin{array}{l}\text { "The Security Council has confirmed in } \\
\text { its resolution } 2249 \text { (2015) of } 20 \\
\text { November } 2015 \text { that ISIL 'constitutes } \\
\text { a global and unprecedented threat to } \\
\text { international peace and security' and } \\
\text { has called upon Member States to } \\
\text { eradicate the safe haven that ISIL has } \\
\text { established in significant parts of Iraq } \\
\text { and the Syrian Arab Republic. IILL has } \\
\text { carried out, and continues to carry } \\
\text { out, armed attacks against Iraq, } \\
\text { France, and other States." }\end{array}$ & $\begin{array}{l}\text { None } \\
\text { identified }\end{array}$ & None identified & $\begin{array}{l}\text { None } \\
\text { identified }\end{array}$ & Article 51 & \begin{tabular}{|l||} 
http: \\
//www.un. \\
org///nn/gal \\
search/vie \\
w_doc. \\
wasp? \\
symbol=s/ \\
2015/946
\end{tabular} & & $\begin{array}{l}\text { https: } \\
\text { //perma. } \\
\text { cc//4PRR- } \\
\text { PQKL }\end{array}$ \\
\hline 418 & 2016.01.11 & 2016.01.13 & $\mathrm{s} / 2016 / 34$ & Denmark & $\begin{array}{l}\text { Denmark, Iraq, } \\
\text { Syria, United } \\
\text { States }\end{array}$ & $\begin{array}{l}\text { Express } \\
\text { assertion of } \\
\text { "collective" } \\
\text { self-defense }\end{array}$ & $\begin{array}{c}\text { Conducted } \\
\text { attack }\end{array}$ & $\begin{array}{l}\text { Islamic State in } \\
\text { Iraq and the Levant } \\
\text { (ISLL, also known as } \\
\text { Da'esh [ISIS]) }\end{array}$ & $\begin{array}{c}\text { Non-state } \\
\text { actors }\end{array}$ & 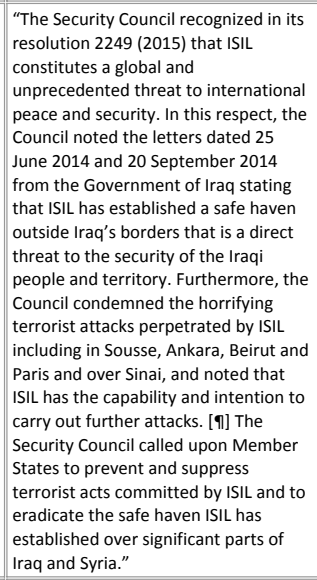 & \begin{tabular}{|l} 
None \\
identified
\end{tabular} & None identified & $\begin{array}{l}\text { None } \\
\text { identified }\end{array}$ & Article 51 & \begin{tabular}{|l||} 
http: \\
//www.un. \\
org//nn/ga/ \\
search/vie \\
w_doc. \\
asp? \\
symbol=s/ \\
2016/34
\end{tabular} & & $\begin{array}{l}\text { hitps: } \\
\text { //perma. } \\
\text { cc/82zP- } \\
\text { cE33 }\end{array}$ \\
\hline 419 & 2016.01.21 & 2016.01.22 & $S / 2016 / 63$ & Azerbaijan & $\begin{array}{l}\text { Azerbaijan, } \\
\text { Armenia }\end{array}$ & $\begin{array}{l}\text { Implied } \\
\text { assertion of } \\
\text { "individual" } \\
\text { self-defense }\end{array}$ & $\begin{array}{c}\text { Conducted } \\
\text { attack }\end{array}$ & Armenia & State & $\begin{array}{l}\text { Armenia's ongoing aggression, use of } \\
\text { force, ceasefire violations, and } \\
\text { occupation. }\end{array}$ & \begin{tabular}{|l} 
None \\
identified
\end{tabular} & None identified & $\begin{array}{l}\text { None } \\
\text { identified }\end{array}$ & Article 51 & \begin{tabular}{|l|} 
http: \\
//www.un. \\
org/en/ga/ \\
search/vie \\
w_doc. \\
asp? \\
symbol=s/ \\
2016/63 \\
\end{tabular} & & \begin{tabular}{|l} 
hitps: \\
///perma. \\
cc/7PYR- \\
RYLN
\end{tabular} \\
\hline
\end{tabular}


VI. HLS PILAC Catalogue of Apparent “Article 51 Communications”

\begin{tabular}{|c|c|c|c|c|c|c|c|c|c|c|c|c|c|c|c|c|c|}
\hline $\begin{array}{l}\text { Chron. } \\
\text { Order }\end{array}$ & $\begin{array}{l}\text { Date of } \\
\text { Comm. }\end{array}$ & \begin{tabular}{|c} 
Date of \\
UNsc \\
Document
\end{tabular} & UNSC Symbol & \begin{tabular}{||c} 
Member \\
State(s) That \\
Submitted \\
the Comm.
\end{tabular} & \begin{tabular}{|c|} 
Expressly \\
Mentioned UN \\
Members (\& \\
Colonial \\
Holdings \& \\
Protectorates, \\
if any) \\
\end{tabular} & \begin{tabular}{|c|} 
Express or \\
Implied \\
Assertion of \\
Individual, \\
Collective, or \\
Both Self- \\
defense \\
\end{tabular} & \begin{tabular}{|c} 
Nature of \\
the Alleged \\
Threat
\end{tabular} & \begin{tabular}{|l} 
Expressly Alleged \\
Author(s) of the \\
Threat (ff Any \\
Indicated)
\end{tabular} & \begin{tabular}{|c|} 
Nature of the \\
Alleged \\
Author(s) of \\
the Threat (If \\
Any \\
Indicated) \\
\end{tabular} & $\begin{array}{l}\text { Summary of Alleged Self-defense } \\
\text { Grounds }\end{array}$ & \begin{tabular}{|c|} 
UNsc \\
Meeting(s) \\
(if Any) at \\
Which the \\
Comm. was \\
Raised
\end{tabular} & $\begin{array}{l}\text { Responsive Act (If Any) by the } \\
\text { UNSC }\end{array}$ & $\begin{array}{l}\text { UN } \\
\text { Repertory } \\
\text { Inclusion? }\end{array}$ & \begin{tabular}{|c|} 
UNSC \\
Repertoire \\
Inclusion?
\end{tabular} & \begin{tabular}{|l} 
URL to an \\
English \\
Text
\end{tabular} & \begin{tabular}{|c} 
URL to Non- \\
English \\
Original \\
Text (If Any)
\end{tabular} & $\begin{array}{l}\text { Perma.cc } \\
\text { URL }\end{array}$ \\
\hline 420 & 2016.02.10 & 2016.02.10 & S/2016/132 & $\begin{array}{l}\text { The } \\
\text { Netherlands }\end{array}$ & $\begin{array}{l}\text { The } \\
\text { Netherlands, } \\
\text { Syria, Iraq, } \\
\text { United States }\end{array}$ & $\begin{array}{l}\text { Express } \\
\text { assertion of } \\
\text { "collective" } \\
\text { self-defense }\end{array}$ & $\begin{array}{c}\text { Conducted } \\
\text { attack }\end{array}$ & $\begin{array}{l}\text { "[S]o-called Islamic } \\
\text { State in Iraq and } \\
\text { the Levant (ISLL, } \\
\text { also known as Da' } \\
\text { esh [IISIS)" }\end{array}$ & $\begin{array}{c}\text { Non-state } \\
\text { actors }\end{array}$ & 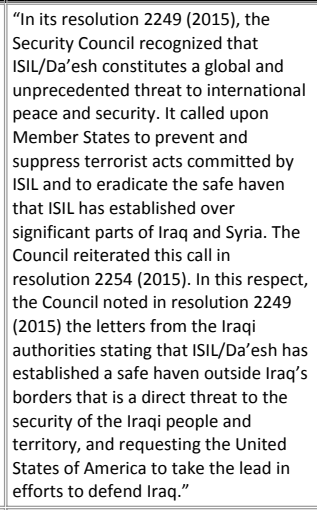 & $\begin{array}{l}\text { None } \\
\text { identified }\end{array}$ & None identified & $\begin{array}{l}\text { None } \\
\text { identified }\end{array}$ & Article 51 & $\begin{array}{l}\text { http: } \\
\text { //www.un. } \\
\text { org/en/ga/ } \\
\text { search/vie } \\
\text { w_doc. } \\
\text { asp? } \\
\text { symbol=s/ } \\
\text { 2016/132 }\end{array}$ & & $\begin{array}{l}\text { hitps: } \\
\text { //perma. } \\
\text { ccl/7CRQ- } \\
\text { FGSG }\end{array}$ \\
\hline 421 & 2016.02.19 & 2016.02.19 & S/2016/163 & Turkey & Turkey, Syria & $\begin{array}{c}\text { Implied } \\
\text { assertion of } \\
\text { "individual" } \\
\text { self-defense }\end{array}$ & $\begin{array}{c}\text { Conducted } \\
\text { attack }\end{array}$ & $\begin{array}{l}\text { Syria, "PYD/YPG", } \\
\text { and "PKK" }\end{array}$ & $\begin{array}{c}\text { State and } \\
\text { non-state } \\
\text { actors }\end{array}$ & $\begin{array}{l}\text { "We have been facing national } \\
\text { security threats and attacks } \\
\text { emanating from Syria since the start } \\
\text { of the crisis, including from terrorist } \\
\text { organizations therein. These threats } \\
\text { have gained new dimensions and } \\
\text { changed over time, and have always } \\
\text { dramatically increased." }\end{array}$ & $\begin{array}{l}\text { None } \\
\text { identified }\end{array}$ & None identified & $\begin{array}{l}\text { None } \\
\text { identified }\end{array}$ & Article 51 & $\begin{array}{l}\text { http: } \\
\text { //www.un. } \\
\text { org/en/ga/ } \\
\text { search/vie } \\
\text { w_doc. } \\
\text { asp? } \\
\text { symbol=S/ } \\
\text { 2016/163 }\end{array}$ & & \begin{tabular}{|l} 
hitps: \\
//perma. \\
cc//A8MB- \\
4/37
\end{tabular} \\
\hline 422 & 2016.06.03 & 2016.06.03 & $\mathrm{S} / 2016 / 513$ & Norway & Norway, Syria & $\begin{array}{l}\text { Express } \\
\text { assertion of } \\
\text { "collective" } \\
\text { self-defense }\end{array}$ & $\begin{array}{c}\text { Conducted } \\
\text { attack }\end{array}$ & \begin{tabular}{|c} 
"[T]he terrorist \\
organization \\
Islamic State in \\
IIaq and the Levant \\
(IILL, alaso known as \\
Da'esh [ISISI)"
\end{tabular} & $\begin{array}{c}\text { Non-state } \\
\text { actors }\end{array}$ & 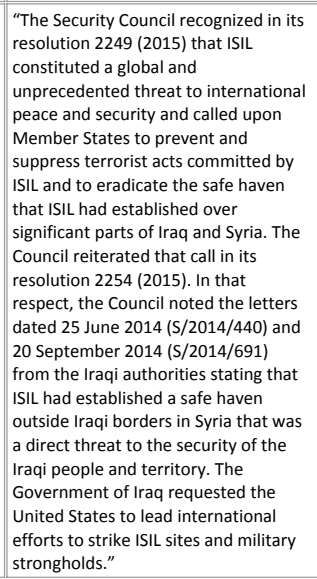 & $\begin{array}{l}\text { None } \\
\text { identified }\end{array}$ & None identified & $\begin{array}{l}\text { None } \\
\text { identified }\end{array}$ & Article 51 & $\begin{array}{l}\text { http: } \\
\text { //www.un. } \\
\text { org/en/ga/ } \\
\text { search/vie } \\
\text { w_doc. } \\
\text { asp? } \\
\text { symbol=s/ } \\
\text { 2016/513 }\end{array}$ & & $\begin{array}{l}\text { https: } \\
\text { //perma. } \\
\text { cc/DAU2- } \\
\text { 6B9B }\end{array}$ \\
\hline
\end{tabular}


VI. HLS PILAC Catalogue of Apparent “Article 51 Communications”

\begin{tabular}{|c|c|c|c|c|c|c|c|c|c|c|c|c|c|c|c|c|c|}
\hline $\begin{array}{c}\text { Chron. } \\
\text { Order }\end{array}$ & $\begin{array}{l}\text { Date of } \\
\text { Comm. }\end{array}$ & $\begin{array}{l}\text { Date of } \\
\text { UNsC } \\
\text { Document }\end{array}$ & UNSC Symbol & \begin{tabular}{|c} 
Member \\
State(s) That \\
Submitted \\
the Comm.
\end{tabular} & \begin{tabular}{|c|} 
Expressly \\
Mentioned UN \\
Members (\& \\
Colonial \\
Holdings \& \\
Protectorates, \\
if any) \\
\end{tabular} & \begin{tabular}{||c|} 
Express or \\
Implied \\
Assertion of \\
Individual, \\
Collective, or \\
Both Self- \\
defense \\
\end{tabular} & \begin{tabular}{|c}
$\begin{array}{c}\text { Nature of } \\
\text { the Alleged } \\
\text { Threat }\end{array}$
\end{tabular} & $\begin{array}{l}\text { Expressly Alleged } \\
\text { Author(s) of the } \\
\text { Threat (If Any } \\
\text { Indicated) }\end{array}$ & \begin{tabular}{|c|} 
Nature of the \\
Alleged \\
Author(s) of \\
the Threat (If \\
Any \\
Indicated)
\end{tabular} & $\begin{array}{l}\text { Summary of Alleged Self-defense } \\
\text { Grounds }\end{array}$ & \begin{tabular}{|c|} 
UNSC \\
Meeting(s) \\
(If Any) at \\
Which the \\
Comm. was \\
Raised \\
\end{tabular} & $\begin{array}{l}\text { Responsive Act (If Any) by the } \\
\text { UNSC }\end{array}$ & $\begin{array}{c}\text { UN } \\
\text { Repertory } \\
\text { Inclusion? }\end{array}$ & \begin{tabular}{|c} 
UNSC \\
Repertoire \\
Inclusion?
\end{tabular} & \begin{tabular}{|l||} 
URL to an \\
English \\
Text
\end{tabular} & \begin{tabular}{||c} 
URL to Non- \\
English \\
Original \\
Text (ff Any)
\end{tabular} & \begin{tabular}{|c|} 
Perma.cc \\
URL
\end{tabular} \\
\hline 423 & 2016.06.07 & 2016.06.09 & $\mathrm{S} / 2016 / 523$ & Belgium & $\begin{array}{l}\text { Belgium, Syria, } \\
\text { Iraq }\end{array}$ & $\begin{array}{l}\text { Express } \\
\text { assertion of } \\
\text { "collective" } \\
\text { self-defense }\end{array}$ & $\begin{array}{c}\text { Conducted } \\
\text { attack }\end{array}$ & $\begin{array}{l}\text { "[T]he terrorist } \\
\text { organization } \\
\text { 'Islamic State in } \\
\text { Iraq and the } \\
\text { Levant' (ISLL, also } \\
\text { known as Da'esh } \\
\text { [IISIS]" }\end{array}$ & $\begin{array}{c}\text { Non-state } \\
\text { actors }\end{array}$ & \begin{tabular}{|l} 
"The Security Council determined in \\
its resolution 2249 (2015) of 20 \\
November 2015 that ISLL constituted a \\
global and unprecedented threat to \\
international peace and security and it \\
called upon Member States to \\
eradicate the safe haven that ISIL had \\
established over significant parts of \\
Iraq and Syria. In that respect, the \\
Security Council noted the letters \\
dated 25 June 2014 (S/2014/440) and \\
20 September 2014 (S/2014/691) \\
from the Government of Iraq stating \\
that ISIL had established a safe haven \\
outside of the borders of Iraq that was \\
a direct threat to the security of the \\
Iraqi people and territory."
\end{tabular} & $\begin{array}{l}\text { None } \\
\text { identified }\end{array}$ & None identified & $\begin{array}{l}\text { None } \\
\text { identified }\end{array}$ & Article 51 & \begin{tabular}{l||} 
http: \\
//www.un. \\
org/en/ga/ \\
search/vie \\
w_doc. \\
asp? \\
symbol=S/ \\
2016/523
\end{tabular} & & \begin{tabular}{|l|} 
https: \\
//perma. \\
cc/5DFM- \\
XGXV
\end{tabular} \\
\hline 424 & 2016.08.24 & 2016.08.25 & S/2016/739 & Turkey & Turkey, Syria & $\begin{array}{c}\text { Implied } \\
\text { assertion of } \\
\text { "individual" } \\
\text { self-defense }\end{array}$ & $\begin{array}{c}\text { Conducted } \\
\text { attack }\end{array}$ & $\begin{array}{l}\text { "DEASH [sic] [IISI] } \\
\text { terrorists" }\end{array}$ & $\begin{array}{c}\text { Non-state } \\
\text { actors }\end{array}$ & 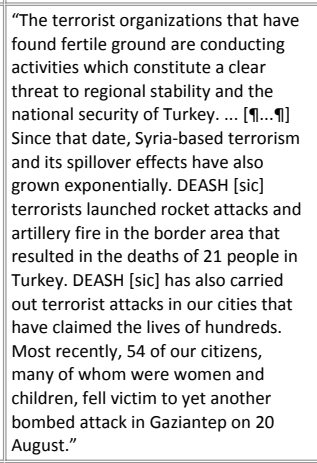 & $\begin{array}{l}\text { None } \\
\text { identified }\end{array}$ & None identified & $\begin{array}{l}\text { None } \\
\text { identified }\end{array}$ & Article 51 & \begin{tabular}{l||} 
http: \\
//www.un. \\
org/en/ga/ \\
search/vie \\
w_doc. \\
asp? \\
symbol=S/ \\
2016/739
\end{tabular} & & 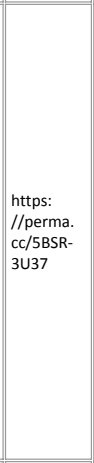 \\
\hline 425 & 2017.02.08 & 2017.02.13 & $S / 2017 / 124$ & Turkey & Turkey, Syria & \begin{tabular}{|c}
$\quad$ Implied \\
assertion of \\
"individual" \\
self-defense
\end{tabular} & $\begin{array}{c}\text { Conducted } \\
\text { attack }\end{array}$ & “Deash [sic] [IIIS]" & $\begin{array}{c}\text { Non-state } \\
\text { actors }\end{array}$ & \begin{tabular}{|l} 
"“...Deash [sic] ... has been directly and \\
deliberately targeting Turkey ...."
\end{tabular} & $\begin{array}{l}\text { None } \\
\text { identified }\end{array}$ & None identified & $\begin{array}{l}\text { None } \\
\text { identified }\end{array}$ & Article 51 & \begin{tabular}{|l||} 
http: \\
//www.un. \\
org//en/ga/ \\
search/vie \\
w_doc. \\
asp? \\
symbol=s/ \\
2017/124 \\
\end{tabular} & & \begin{tabular}{|l|} 
https: \\
//perma. \\
cc/aHLg- \\
TTDM
\end{tabular} \\
\hline 426 & 2017.03.17 & 2017.03.21 & S/2017/227 & Syria & Syria, Israel & $\begin{array}{c}\text { Implied } \\
\text { assertion of } \\
\text { "individual" } \\
\text { self-defense }\end{array}$ & $\begin{array}{c}\text { Conducted } \\
\text { attack }\end{array}$ & Israel & State & $\begin{array}{l}\text { "IT]his morning, four Israeli aircraft } \\
\text { violated Syrian airspace via Lebanese } \\
\text { territory in the Burayjarae. They } \\
\text { attacked one of the Syrian military } \\
\text { posts in the vicinity of the city of } \\
\text { Tadmur (Palmyra) in the eastern Homs } \\
\text { countryside." }\end{array}$ & $\begin{array}{l}\text { None } \\
\text { identified }\end{array}$ & None identified & $\begin{array}{l}\text { None } \\
\text { identified }\end{array}$ & Article 51 & \begin{tabular}{|l||} 
http: \\
//www.un. \\
org//en/ga/ \\
search/vie \\
w_doc. \\
asp? \\
symbol=s/ \\
2017/227 \\
\end{tabular} & & \begin{tabular}{|l||} 
htps: \\
//perma. \\
cc/WMMU- \\
HWFM
\end{tabular} \\
\hline 427 & 2017.03.24 & 2017.03.27 & $\mathrm{S} / 2017 / 256$ & Turkey & Turkey, Syria & \begin{tabular}{|c} 
Implied \\
assertion of \\
"individual" \\
self-defense
\end{tabular} & $\begin{array}{c}\text { Conducted } \\
\text { attack }\end{array}$ & "DEASH [sic] [ISIS]" & $\begin{array}{c}\text { Non-state } \\
\text { actors }\end{array}$ & $\begin{array}{l}\text { “... DEASH [sic] ... has been directly } \\
\text { and deliberately targeting Turkey ...." }\end{array}$ & $\begin{array}{l}\text { None } \\
\text { identified }\end{array}$ & None identified & \begin{tabular}{|l} 
None \\
identified
\end{tabular} & Article 51 & \begin{tabular}{|l||} 
http: \\
//www.un. \\
orga/en/ga/ \\
search/vie \\
w_doc. \\
asp? \\
symbol=s/ \\
2017/256 \\
\end{tabular} & & \begin{tabular}{|l|} 
https: \\
//perma. \\
cc/EASS- \\
A2E2
\end{tabular} \\
\hline
\end{tabular}


VI. HLS PILAC Catalogue of Apparent “Article 51 Communications”

\begin{tabular}{|c|c|c|c|c|c|c|c|c|c|c|c|c|c|c|c|c|c|}
\hline $\begin{array}{c}\text { Chron. } \\
\text { Order }\end{array}$ & $\begin{array}{l}\text { Date of } \\
\text { comm. }\end{array}$ & $\begin{array}{c}\text { Date of } \\
\text { UNSC } \\
\text { Document }\end{array}$ & UNSC Symbol & \begin{tabular}{||c} 
Member \\
State(s) That \\
Submitted \\
the Comm.
\end{tabular} & \begin{tabular}{|c} 
Expressly \\
Mentioned UN \\
Members (\& \\
Colonial \\
Holdings \& \\
Protectorates, \\
if any)
\end{tabular} & \begin{tabular}{|c|} 
Express or \\
Implied \\
Assertion of \\
Individual, \\
Collective, or \\
Both Self- \\
defense
\end{tabular} & \begin{tabular}{|l}
$\begin{array}{c}\text { Nature of } \\
\text { the Alleged } \\
\text { Threat }\end{array}$
\end{tabular} & \begin{tabular}{|l|} 
Expressly Alleged \\
Author(s) of the \\
Threat (If Any \\
Indicated)
\end{tabular} & \begin{tabular}{|c} 
Nature of the \\
Alleged \\
Author(s) of \\
the Threat (If \\
Any \\
Indicated)
\end{tabular} & $\begin{array}{l}\text { Summary of Alleged Self-defense } \\
\text { Grounds }\end{array}$ & $\begin{array}{l}\text { UNsC } \\
\text { Meeting(s) } \\
\text { (If Any) at } \\
\text { Which the } \\
\text { Comm. was } \\
\text { Raised }\end{array}$ & $\begin{array}{l}\text { Responsive Act (If Any) by the } \\
\text { UNSC }\end{array}$ & $\begin{array}{l}\text { UN } \\
\text { Repertory } \\
\text { Inclusion? }\end{array}$ & \begin{tabular}{|} 
UNSC \\
Repertoire \\
Inclusion?
\end{tabular} & \begin{tabular}{|l} 
URL to an \\
English \\
Text
\end{tabular} & \begin{tabular}{|c|} 
URL to Non- \\
English \\
Original \\
Tert (If Any)
\end{tabular} & $\begin{array}{l}\text { Perma.cc } \\
\text { URL }\end{array}$ \\
\hline 428 & 2017.04.25 & 2017.04.25 & $\mathrm{S} / 2017 / 350$ & Turkey & Turkey, Syria & $\begin{array}{l}\text { Implied } \\
\text { assertion of } \\
\text { "individual" } \\
\text { self-defense }\end{array}$ & $\begin{array}{l}\text { Conducted } \\
\text { attack }\end{array}$ & \begin{tabular}{|l} 
"The PKK terrorist \\
organization and \\
its affiliates"
\end{tabular} & $\begin{array}{c}\text { Non-state } \\
\text { actors }\end{array}$ & 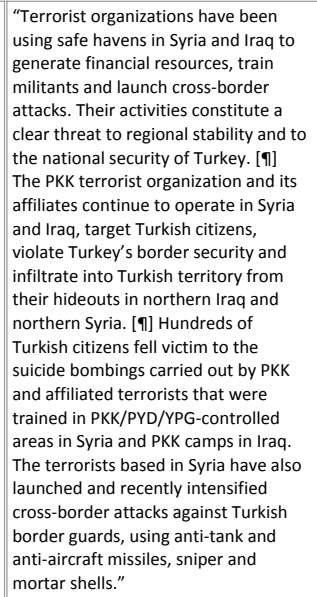 & $\begin{array}{l}\text { None } \\
\text { identified }\end{array}$ & None identified & $\begin{array}{l}\text { None } \\
\text { identified }\end{array}$ & Article 51 & $\begin{array}{l}\text { http: } \\
\text { //www.un. } \\
\text { org/en/ga/ } \\
\text { search/vie } \\
\text { w_doc. } \\
\text { asp? } \\
\text { symbol=s/ } \\
\text { 2017/350 }\end{array}$ & & $\begin{array}{l}\text { hitps: } \\
\text { //perma. } \\
\text { cc/DSSL- } \\
\text { 43WP }\end{array}$ \\
\hline 429 & 2017.05.27 & 2017.06.01 & S/2017/456 & Egypt & Egypt, Libya & $\begin{array}{c}\text { Implied } \\
\text { assertion of } \\
\text { "individual" } \\
\text { self-defense }\end{array}$ & \begin{tabular}{|c} 
Conducted \\
attack
\end{tabular} & $\begin{array}{l}\text { "[T]errorist } \\
\text { organizations in } \\
\text { Libya" }\end{array}$ & $\begin{array}{c}\begin{array}{c}\text { Non-state } \\
\text { actors }\end{array} \\
\text {. }\end{array}$ & \begin{tabular}{|l} 
"This action is being taken in the light \\
of intelligence indicating that the \\
organizations carried out a series of \\
armed terrorist attacks within \\
Egyptian territory, attacks that \\
originated on Libyyan territory. Most \\
recently, on 26 May 2017, they \\
targeted innocent Egyptian civilians in \\
the town of Minya, in southern Egypt. \\
That incident constitutes an attack on \\
the sovereignty and territorial \\
integrity of Egypt."
\end{tabular} & \begin{tabular}{|l} 
None \\
identified
\end{tabular} & None identified & $\begin{array}{l}\text { None } \\
\text { identified }\end{array}$ & Article 51 & $\begin{array}{l}\text { http: } \\
\text { //www.un. } \\
\text { org/en/ga/ } \\
\text { search/vie } \\
\text { w_doc. } \\
\text { asp? } \\
\text { symbol=s/ } \\
\text { 2017/456 }\end{array}$ & $\begin{array}{l}\text { http://www. } \\
\text { un. } \\
\text { org/en/ga/se } \\
\text { arch/view_do } \\
\text { c.asp? } \\
\text { symbol=S/201 } \\
\text { 7/456\&Lang= } \\
\text { A }\end{array}$ & $\begin{array}{l}\text { https: } \\
\text { //perma. } \\
\text { cc/HSA3- } \\
\text { xsKW }\end{array}$ \\
\hline 430 & 2018.01.20 & 2018.01.22 & $\mathrm{s} / 2018 / 53$ & Turkey & Turkey, Syria & $\begin{array}{l}\text { Implied } \\
\text { assertion of } \\
\text { "individual" } \\
\text { self-defense }\end{array}$ & $\begin{array}{c}\text { Conducted } \\
\text { attack and } \\
\text { threat of } \\
\text { attack }\end{array}$ & \begin{tabular}{|l} 
"[T]he \\
PKK/KCK/PYD/YPG \\
terrorist \\
organization" and \\
"Deash [sic] [IISI]"
\end{tabular} & $\begin{array}{c}\text { Non-state } \\
\text { actors }\end{array}$ & \begin{tabular}{|l} 
“[T]he threat of terrorism from Syria \\
targeting our borders has not ended. \\
The recent increase in rocket attacks \\
and harassment fire directed at Hatay \\
and Kilis provinces of Turkey from the \\
Afrin region of Syria, which is under \\
the control of the PKK/KK//PYD//PPG \\
terrorist organization, has resulted in \\
the deaths of many civilians and \\
soldiers and has left many more \\
wounded. [n] The risk of Deash \\
elements infiltrating Turkey via this \\
area and targeting the security of \\
Turkey as well as the European \\
countries is also heightened owing to \\
the recent movements of Deash [sic] \\
terrorists coming into the Afrin region \\
from other parts of Syrria."
\end{tabular} & $\begin{array}{l}\text { None } \\
\text { identified }\end{array}$ & None identified & $\begin{array}{l}\text { None } \\
\text { identified }\end{array}$ & $\begin{array}{l}\text { Not } \\
\text { Released }\end{array}$ & $\begin{array}{l}\text { http: } \\
\text { //www.un. } \\
\text { org/en/ga/ } \\
\text { search/vie } \\
\text { w_doc. } \\
\text { asp? } \\
\text { symbol=s/ } \\
\text { 2018/53 }\end{array}$ & & $\begin{array}{l}\text { hitps: } \\
\text { //perma. } \\
\text { cc/EZAA- } \\
\text { Y8XY }\end{array}$ \\
\hline 431 & 2018.02.20 & 2018.02.26 & $\mathrm{S} / 2018 / 141$ & Syria & $\begin{array}{l}\text { Syria, Israel, } \\
\text { United States }\end{array}$ & $\begin{array}{l}\text { Implied } \\
\text { assertion of } \\
\text { "individual" } \\
\text { self-defense }\end{array}$ & \begin{tabular}{|c} 
Conducted \\
attack
\end{tabular} & Israel & State & $\begin{array}{l}\text { "...Israeli warplanes penetrated the } \\
\text { airspace of the Syrian Arab Republic } \\
\text { and struck a number of sites in the } \\
\text { central and southern parts of the } \\
\text { country." }\end{array}$ & $\begin{array}{l}\text { None } \\
\text { identified }\end{array}$ & None identified & \begin{tabular}{|l} 
None \\
identified
\end{tabular} & $\begin{array}{l}\text { Not } \\
\text { Released }\end{array}$ & $\begin{array}{l}\text { http: } \\
\text { //www.un. } \\
\text { org/en/ga/ } \\
\text { search/vie } \\
\text { w_doc. } \\
\text { asp? } \\
\text { symbol=s/ } \\
\text { 2018/141 }\end{array}$ & $\begin{array}{l}\text { http://www. } \\
\text { un. } \\
\text { org/en/ga/se } \\
\text { arch/view_do } \\
\text { c.asp? } \\
\text { symbol=S/201 } \\
\text { 8/1414Lang= } \\
\text { A }\end{array}$ & $\begin{array}{l}\text { https: } \\
\text { //perma. } \\
\text { cc } \\
\text { gFTQ } \\
\text { 9FT- }\end{array}$ \\
\hline
\end{tabular}


VI. HLS PILAC Catalogue of Apparent “Article 51 Communications”

\begin{tabular}{|c|c|c|c|c|c|c|c|c|c|c|c|c|c|c|c|c|c|}
\hline $\begin{array}{l}\text { Chron. } \\
\text { Order }\end{array}$ & $\begin{array}{l}\text { Date of } \\
\text { Comm. }\end{array}$ & $\begin{array}{c}\text { Date of } \\
\text { UNSC } \\
\text { Document }\end{array}$ & UNSC Symbol & \begin{tabular}{|c} 
Member \\
State(s) That \\
Submitted \\
the Comm.
\end{tabular} & \begin{tabular}{||c|} 
Expressly \\
Mentioned UN \\
Members (\& \\
Colonial \\
Holdings \& \\
Protectorates, \\
if any)
\end{tabular} & \begin{tabular}{||c|} 
Express or \\
Implied \\
Assertion of \\
Individual, \\
Collective, or \\
Both Self- \\
defense \\
\end{tabular} & $\begin{array}{l}\text { Nature of } \\
\text { the Alleged } \\
\text { Threat }\end{array}$ & $\begin{array}{l}\text { Expressly Alleged } \\
\text { Author(s) of the } \\
\text { Threat (If Any } \\
\text { Indicated) }\end{array}$ & \begin{tabular}{|} 
Nature of the \\
Alleged \\
Author(s) of \\
the Threat (If \\
Any \\
Indicated)
\end{tabular} & $\begin{array}{l}\text { Summary of Alleged Self-defense } \\
\text { Grounds }\end{array}$ & $\begin{array}{l}\text { UNSC } \\
\text { Meeting(s) } \\
\text { (If Any) at } \\
\text { Which the } \\
\text { Comm. was } \\
\text { Raised }\end{array}$ & $\begin{array}{l}\text { Responsive Act (If Any) by the } \\
\text { UNSC }\end{array}$ & \begin{tabular}{|l} 
UN \\
Repertory \\
Inclusion?
\end{tabular} & \begin{tabular}{|l} 
UNSC \\
Repertoire \\
Inclusion?
\end{tabular} & \begin{tabular}{|c|} 
URL to an \\
English \\
Text
\end{tabular} & \begin{tabular}{||c||} 
URL to Non- \\
English \\
Original \\
Text (ff Any)
\end{tabular} & $\begin{array}{c}\text { Perma.cc } \\
\text { URL }\end{array}$ \\
\hline 432 & 2018.10.03 & 2018.10.03 & $\mathrm{S} / 2018 / 891$ & Iran & $\begin{array}{l}\text { Iran, United } \\
\text { Kingdom, } \\
\text { Saudi Arabia, } \\
\text { Syria }\end{array}$ & $\begin{array}{c}\text { Implied } \\
\text { assertion of } \\
\text { "individual" } \\
\text { self-defense }\end{array}$ & $\begin{array}{c}\text { Conducted } \\
\text { attack }\end{array}$ & $\begin{array}{c}\text { Saudi Arabia, "al- } \\
\text { Ahvaziya terrorist } \\
\text { group" and Daesh } \\
\text { [IISI] }\end{array}$ & $\begin{array}{c}\text { State and } \\
\text { non-state } \\
\text { actors }\end{array}$ & 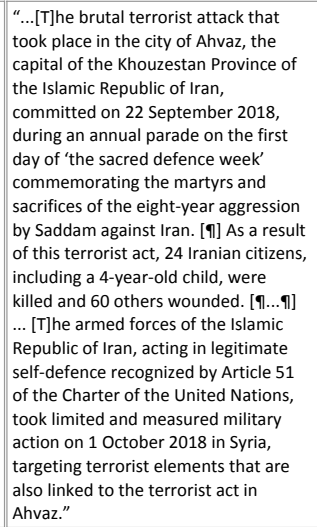 & $\begin{array}{l}\text { None } \\
\text { identified }\end{array}$ & None identified & $\begin{array}{l}\text { None } \\
\text { identified }\end{array}$ & $\begin{array}{l}\text { Not } \\
\text { Released }\end{array}$ & \begin{tabular}{|l||} 
http: \\
//www.un. \\
org//en/ga/ \\
search/vie \\
w_doc. \\
asp? \\
symbol=s/ \\
2018/891
\end{tabular} & & $\begin{array}{l}\text { hitps: } \\
\text { ///perma. } \\
\text { cc//BHGG- } \\
\text { AH66 }\end{array}$ \\
\hline 433 & 2018.11.13 & 2018.11.15 & $\mathrm{s} / 2018 / 1022$ & Turkey & Turkey, Iraq & $\begin{array}{c}\text { Implied } \\
\text { assertion of } \\
\text { "individual" } \\
\text { self-defense }\end{array}$ & $\begin{array}{c}\text { Conducted } \\
\text { attack }\end{array}$ & "[T]errorists" & $\begin{array}{c}\text { Non-state } \\
\text { actors }\end{array}$ & 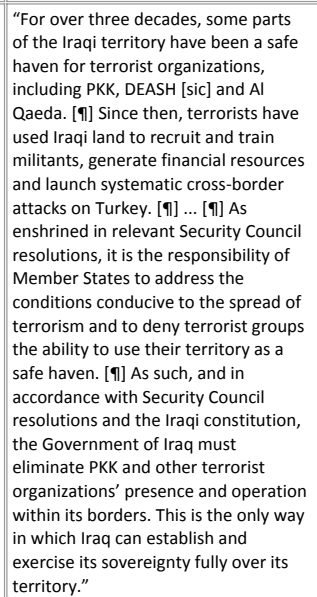 & \begin{tabular}{|l} 
None \\
identified
\end{tabular} & None identified & $\begin{array}{l}\text { None } \\
\text { identified }\end{array}$ & \begin{tabular}{|l} 
Not \\
Released
\end{tabular} & \begin{tabular}{|l||} 
http: \\
//www.un. \\
org//nen//gai \\
search/vie \\
w_doc. \\
asp? \\
symbol=s/ \\
2018/1022
\end{tabular} & & $\begin{array}{l}\text { hitps: } \\
\text { ///perma. } \\
\text { cc/35PN- } \\
\text { FYPP }\end{array}$ \\
\hline
\end{tabular}




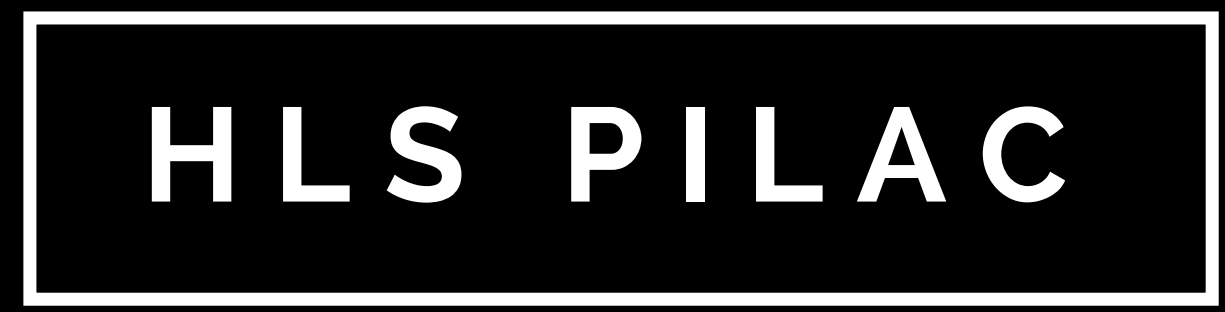

PILAC.LAW.HARVARD.EDU 